Universidade de São Paulo

Instituto de Física

Instituto de Química

Instituto de Biociências

Faculdade de Educação

Anike Araujo Arnaud

\title{
A construção do conteúdo de reações redox em livros didáticos da educação básica
}


Anike Araujo Arnaud

\section{A construção do conteúdo de reações redox em livros didáticos da educação básica}

Dissertação de Mestrado apresentada ao Instituto de Física, ao Instituto de Química, ao Instituto de Biociências e à Faculdade de Educação da Universidade de São Paulo para a obtenção do título de Mestre em Ciências.

Área de concentração: Ensino de Química

ORIENTADORA: Profa. Dra. Carmen Fernandez

São Paulo - SP

2019 


\section{FICHA CATALOGRÁFICA}

\section{Preparada pelo Serviço de Biblioteca e Informação do Instituto de Física da Universidade de São Paulo}

Arnaud, Anike Araujo

A construção do conteúdo de reações redox em livros didáticos da educação básica. São Paulo, 2019.

Dissertação (Mestrado) - Universidade de São Paulo. Faculdade de Educação, Instituto de Física, Instituto de Química e Instituto de Biociências.

Orientador: Profa. Dra. Carmen Fernandez

Área de Concentração: Ensino de Química.

Unitermos: 1. Química - Estudo e ensino; 2. PNLD; 3. Oxirredução; 4. Concepções alternativas. 


\section{$[\ldots]$}

A gente já passou por tudo

Qual seria a graça da vida sem você aqui?

Pra ser o meu porto seguro

$\mathrm{O}$ presente que a vida me deu logo que eu nasci

Não é sobre tudo que o seu dinheiro é capaz de comprar E sim sobre cada momento que juntas pudemos passar Contigo aprendi que o mais importante é ser do que ter $\mathrm{E}$ pelo que eu me tornei só tenho a te agradecer

Você me segurou no colo

Sorriu e entendeu realmente o que era amar

E eu desde o primeiro dia

Tão pequena, já soube que em ti podia confiar...

Para Maria de Fatima, minha luz. 


\section{AGRADECIMENTOS}

À mulher fundamental em toda e qualquer caminhada que eu faça, mãe. Pelas vezes que se preocupou pelo adiantado da hora, pelo lar que constrói todos os dias, pelas vezes em que me mandou sentar e estudar enquanto cuidava de nós, sobretudo pelo amor.

À minha primeira mãe acadêmica, Leila, que me incentivou a seguir esse caminho e me ensinou que a docência vai sempre valer a pena. Sei que eu cheguei com aquela frase pronta de que seria 'Pós-Doutora em Química Petrolífera' e no primeiro ano da licenciatura você me disse: "Calma, tem muito pela frente ainda", e teve até demais! Obrigada por nunca ter me abandonado.

À minha orientadora maravilhosa de mestrado, Carmen, por acreditar comigo que era possível e me indicar o caminho para fazê-lo. Sei que tive muitos projetos, de mestrado, de doutorado e de vida, ao invés de me achar uma doida e desistir de mim, você fez o que faz com excelência, me orientou! Eu jamais seria mestra sem ti.

Aos colegas do PEQuim que riram comigo, se estressaram comigo, ficaram loucos comigo, leram as 300 páginas e discutiram cada virgula da qualificação, almoçavam salada comigo, ficavam conversando sobre amenidades, coisas sérias e o futuro da educação no país. Lu, Pablo, Andreia, especialmente, que nossos caminhos nos concedam muitas discussões sobre a função da ponte salina e qual emprego seguir na vida.

Ao professor Rodrigo de Andrade que me explicou, no auge dos meus 15 anos, o que era mestrado e plantou a sementinha aqui dentro. As professoras e professores Andrea, Daniele, Toshio, Célia, Karen, Zé Maria e Luciana por me ensinarem que esse amor imensurável pela química nunca diminui. As professoras e professor Maria Eunice, Daisy, Elba, Daniele, Ivã, Lúcia e Valéria por serem brilhantes na profissão e ensinarem pelo exemplo.

A todos os membros da CPGI cujas discussões me fizeram crescer, não só como mestre, e me fizeram entender a importância da Representação Discente.

Aos alunos que acompanhei durante as monitorias. Cada relato, relatório e conversa que presenciei constituíram-me como docente, como aprendiz e como mestre, muito obrigada.

Aos amigos que o mestrado me presenteou: os loucos da Física: Rechi, Roger, Walter, Mari, Érica, Seu Antônio; os doidos da Química: Thaiara, Caian, Matheus; e os malucos da Bio: Natalia, Helena, Gabriel. Pelas discussões que me tornaram, de fato, 
mestre em Ensino de Ciências. Nós discordamos tanto quanto concordamos e esse foi meu combustível pra crescer sempre mais.

Aos 665 km que separam Ponta Grossa e São Paulo que me ensinaram que amizades verdadeiras podem resistir a eles. Minha Celli que colocava meus dois pés no chão e segurava a minha mão quando eu queria abraçar o mundo e sabia que eu não daria conta, Rubia com quem eu fui ao bar pela primeira, segunda e outras vezes, obrigada por deixar minha vida mais leve e Gisi, minha grande garota que agora mora perto, mas, nada é realmente perto em São Paulo, né? Apesar de tudo, nunca desistiu da gente, obrigada. Por fim, ao Clube da Luluzinha por estar comigo, na alegria e na tristeza.

Aos meus filhos, Flavio e Livia, não concebidos por mim, mas de igual amor. Quando vocês forem grandes o suficiente pra ler esta dissertação eu provavelmente vou ser a chorona relembrando que fui a primeira a dar um livro aos dois. Não dá pra descrever o quanto eu amo vocês.

À minha nova família que perdoa minha ausência sempre: Sonia, Israel, Aline, Débora, Renan, Tamires, Yandra, Julio, Ronaldo... Principalmente a Yasmin, que agora é meu maior motivo pra compreender, mudar e lutar pela educação. Em breve estarei lendo pra você e sendo a madrinha que não desgruda por nada, vamos crescer juntas também no doutorado.

Ao Bauman que me dava forças ao final de um dia cansativo pra seguir em frente. Nós nunca conhecemos o amor verdadeiro até sermos amadas por um animal.

À FAPESP que acreditou junto comigo nesse projeto, me fornecendo a bolsa (cujo processo é 2017/12951-0, vinculado ao projeto 2013/07937-8).

A todos os que torceram por mim, vibraram com minhas conquistas, ajudaram na construção dessa dissertação e, sobretudo, a quem disse que eu não conseguiria.

A Tolkien, Howling, Doyle e Martin. 
Tem que resolver essa coisa. Tem que mudar a educação para estancar essa sangria. Rapaz, a solução mais fácil é botar mais educação.

Num acordo, mais educação, a nível nacional.

Com o governo, com tudo.

Com tudo, aí parava tudo.

É. Dá asas pra pensar, pronto. 


\section{RESUMO}

ARNAUD, A. A. A construção do conteúdo de reações redox em livros didáticos da educação básica. 2019. 271f. Dissertação (mestrado) apresentada ao Instituto de Física, Instituto de Química, Instituto de Biociências e à Faculdade de Educação, Universidade de São Paulo, São Paulo, 2019.

O livro didático figura no contexto brasileiro como um dos recursos didáticos mais presentes na escolarização básica. Isso se deve, também, pelas ações do Programa Nacional do Livro Didático que seleciona e distribui livros em todo o território nacional. Este recurso pode auxiliar o trabalho do professor em sala de aula, sobretudo nos conceitos químicos considerados difíceis de ensinar e aprender, como é o caso do conteúdo de oxirredução. Nesse sentido, realizou-se a investigação com o intuito de responder à questão: Como o conteúdo de reações redox é construído ao longo dos livros didáticos da educação básica e quais as possíveis influências nas concepções alternativas relatadas na literatura? Para responder a esta questão escolheu-se como metodologia de pesquisa a Análise de Conteúdo Temático Categorial e realizou-se três análises principais. A primeira análise consistiu em identificar nos livros didáticos de ciências do ensino fundamental I e II, e de química do ensino médio, temas pertinentes às reações redox e descrever como esse conteúdo é construído ao longo da educação básica. A segunda análise buscou compreender quais os modelos redox estão sendo utilizados na abordagem deste conteúdo, principalmente na definição destas reações. Os resultados destas duas análises permitiram inferir que a forma como os exemplos de reações redox está presente nos livros de ciências, e o modelo redox utilizado na definição destas reações, podem estar influenciando nas concepções alternativas mais relatadas na literatura. Em virtude disso, realizou-se outra análise nos livros de química do ensino médio para verificar se estes fornecem suporte ao professor no processo de ensino-aprendizagem e confronto à estas concepções. Para esta terceira análise utilizou-se o instrumento de avaliação da qualidade do livro didático criado pelo projeto 2061 que investiga a presença de setes aspectos, considerados essenciais ao trabalho do professor. Apesar das análises indicarem que a abordagem do conteúdo presente nestes livros pode causar confusão conceitual e influenciar as concepções alternativas dos alunos, apenas uma coleção de química no nível médio aborda o conteúdo de forma a auxiliar o professor no confronto destas concepções, apresentando reações redox sem a presença do oxigênio, colocando sempre as reações de oxidação e redução juntas, e discutindo a importância da eletronegatividade nos processos. Devido a isso, conclui-se a importância de novos trabalhos que investiguem o uso destes livros em sala de aula e ressaltem a importância de conhecer e trabalhar as concepções alternativas dos alunos.

Palavras chave: PNLD, oxirredução, concepções alternativas. 


\section{ABSTRACT}

ARNAUD, A. A. Analysis of the construction of the content of redox reactions in basic education textbooks. 2019. 271f. Dissertation (master's degree) presented to the Institute of Physics, Institute of Chemistry, Institute of Biosciences and Faculty of Education, University of São Paulo, São Paulo, 2019.

The textbook appears in the Brazilian context as one of the most present didactic resources in basic education. This is due to the actions of the National Textbook Program that selects and distributes books throughout the national territory. This resource can help the work of the teacher in the classroom, especially in the chemical concepts considered difficult to teach and to learn. It is the case of redox reactions content. In this sense, this investigation was carried out in order to answer the question: How is the content of redox reactions constructed throughout the textbooks of basic education and what are the possible influences on the alternative conceptions reported in the literature? In order to answer this question, the Categorical Thematic Content Analysis was chosen as the research methodology and three main analyzes were carried out. The first analysis consisted of identifying topics relevant to the redox reactions in the textbooks of elementary and middle school and high school chemistry, and describing how this content is constructed throughout basic education. The second analysis sought to understand which redox models are being used to approach this content, mainly in the definition of these reactions. The results of these two analyzes allowed us to infer that the way in which the redox reactions are present in the science books and the redox model used in the definition of these reactions may be influencing the alternative conceptions most reported in the literature. As a result, another analysis was carried out in the high school chemistry books to verify if they provide support to the teacher in the teaching-learning process and in the confrontation with these conceptions. For this third analysis was used the instrument of evaluation of the quality of the textbook created by project 2061 that investigates the presence of seven aspects, considered essential to the work of the teacher Although the analyzes indicate that the approach of the content present in these books can cause conceptual confusion and influence the alternative conceptions of the students, it was realized that only one of the collections of textbooks for high school level approaches the content in order to help the teacher in the confrontation of these conceptions. In order to do it, this collection presents redox reactions without the presence of oxygen, always placing the oxidation and reduction reactions together, and discussing the importance of electronegativity in the processes. Due to this, we conclude the importance of new research that investigate the use of these books in the classroom and emphasize the importance of knowing and working the students' alternative conceptions.

Keyword: PNLD, redox reactions, misconceptions. 


\section{LISTA DE FIGURAS}

Figura 1 - Exemplo do uso do modelo de oxigênio $\quad 62$

$\begin{array}{ll}\text { Figura } 2 \text { - Esquema resumo dos aspectos metodológicos } & 81\end{array}$

Figura 3 - Tema Respiração no livro 2 da coleção PB 95

Figura 4 - Tema fotossíntese no livro 3 da coleção PB 95

Figura 5 - Tema fotossíntese no livro 3 da coleção PA 96

Figura 6 - Tema fotossíntese no livro 3 da coleção LC 97

Figura 7 - Tema fotossíntese no livro 4 da coleção LC 185

Figura 8 - Tema Pilhas no livro 4 da coleção PB 98

Figura 9 - O tema Fotossíntese no livro 1 da coleção TL 100

Figura 10 - O tema Respiração Celular no livro 1 da coleção TL. 101

Figura 11 - O tema Fotossíntese no livro 2 da coleção IC. 102

Figura 12 - O tema Fotossíntese no livro 2 da coleção IC 102

Figura 13 - O tema Respiração Celular no livro 2 da coleção IC 103

Figura 14 - O tema Respiração Celular no livro 3 da coleção IC 105

Figura 15 - O tema Escurecimento da Maçã no livro 3 da coleção IC 105

Figura 16 - O tema Eletrólise no livro 4 da coleção TL 107

Figura 17 - O tema Ferrugem no livro 4 da coleção TL 108

Figura 18 - O tema Ferrugem no livro 4 da coleção AR. 108

Figura 19 - O tema Pilhas e Baterias no livro 4 da coleção IC. 110

Figura 20 - O tema Pilhas e Baterias no livro 4 da coleção TL. 110

Figura 21 - O tema Pilhas e Baterias no livro 4 da coleção AR 110

Figura 22 - O tema Pilhas e Baterias no livro 4 da coleção TL 112

Figura 23 - Nuvem de palavras referentes ao conteúdo de reações redox 115

Figura 24 - O tema Pilhas e Baterias no livro 1 da coleção MR 145

Figura 25 - O tema Combustão no livro 1 da coleção VV 146

Figura 26 - O tema Pilhas e Baterias no livro 2 da coleção CP 147

Figura 27 e 28 - O tema Pilhas e Baterias no livro 2 da coleção MR 148

Figura 29 - O tema Escurecimento da Maçã no livro 2 da coleção MM 148

Figura 30 - O tema Fermentação no livro 2 da coleção SP 149

Figura 31 - O tema Ferrugem no livro 2 da coleção VV 150

Figura 32 - O tema Fermentação no livro 3 da coleção QC 151

Figura 33 - O tema Lentes Fotossensíveis no livro 3 da coleção QC 152

Figura 34 - O tema Bafômetro no livro 3 da coleção MR 153

Figuras 35 e 36 - A contextualização presente no livro 3 da coleção SP 153

Figura 37 - A evolução do tema Fotossíntese ao longo dos livros de educação básica 171

Figura 38 - A evolução do tema Respiração Celular ao longo dos livros de educação básica 173

Figura 39 - A evolução do tema Pilhas e Baterias ao longo dos livros de educação básica 174

Figura 40 - A evolução do tema Oxirredução ao longo dos livros de educação básica. 175 
Figura 41 - Linha de evolução dos temas redox em livros da educação básica

Figura 42 - Semirreações de oxidação e redução

Figura 43 - Representação da pilha na coleção CP

Figura 44 - Representação esquemática presente na coleção CP

Figura 45 - Esquema de representação de uma pilha na coleção MR

Figura 46 - Representação esquemática presente na coleção MR

Figura 47 - Representação da pilha de Daniell na coleção MM

Figura 48 - Representação esquemática ' 1 ' presente na coleção MM

Figura 49 - Representação esquemática '2' presente na coleção MM

Figura 50 - Representação esquemática ' 3 ' presente na coleção MM

Figura 51 - Semirreações de oxidação e redução na formação do $\mathrm{NaCl}$

Figura 52 - Representação esquemática ' 1 ' presente na coleção QC

Figura 53 - Representação esquemática '2' presente na coleção QC

Figura 54 - Semirreações de oxidação e redução na coleção SP

Figura 55 - Representação da Pilha de Daniell na coleção SP

Figura 56 - Representação esquemática ' 1 ' presente na coleção SP

Figura 57 - Representação esquemática '2' presente na coleção SP

Figura 58 - Representação esquemática ' 3 ' presente na coleção SP

Figura 59 - Representação esquemática '4' presente na coleção SP

Figura 60 - Representação esquemática ' 5 ' presente na coleção SP

Figura 61 - A Pilha de Daniell na coleção VV

Figura 62 - Representação esquemática ' 1 ' presente na coleção VV

Figura 63 - Representação esquemática '2' presente na coleção VV

Figura 64 - Representação esquemática ' 3 ' presente na coleção VV

Figura 65 - Representação esquemática '4' presente na coleção VV 


\section{LISTA DE TABELAS}

Tabela 1 - Páginas dos livros correspondentes à abordagem das reações redox

Tabela 2 - Relação de páginas e do conteúdo redox 


\section{LISTA DE QUADROS}

Quadro 1 - As principais funções dos LD nas práticas pedagógicas 52

Quadro 2 - Os modelos redox descritos na literatura 66

Quadro 3 - Principais concepções/equívocos/dificuldades dos alunos referentes aos conceitos de oxirredução e eletroquímica 69

Quadro 4 - Coleções aprovadas no PNLD 83

Quadro 5 - Descritores das coleções aprovadas no PNLD 83

Quadro 6 - Categorias provenientes do Projeto 2061

Quadro 7 - A distribuição dos temas Redox nas coleções investigadas ao longo do

ensino fundamental

Quadro 8 - O conteúdo redox na coleção QC

Quadro 9 - O conteúdo redox na coleção SP

Quadro 10 - O conteúdo redox na coleção VV

Quadro 11 - O conteúdo redox na coleção MM

Quadro 12 - O conteúdo redox na coleção CP

Quadro 13 - O conteúdo redox na coleção MR

Quadro 14 - A distribuição dos temas Redox ao longo do ensino básico

Quadro 15 - As categorias do projeto 2061 presentes nas coleções brasileiras 
LISTA DE SIGLAS

$\begin{array}{ll}\text { AAAS } & \text { American Association for the Advancement of Science } \\ \text { ANPED } & \text { Associação Nacional de Pós-Graduação e Pesquisa em Educação } \\ \text { CAPES } & \text { Coordenação de Aperfeiçoamento do Ensino Superior } \\ \text { CONAMA } & \text { Conselho Nacional do Meio Ambiente } \\ \text { ENDIPE } & \text { Encontro Nacional de Didática e Prática de Ensino } \\ \text { ENPEC } & \text { Encontro Nacional de Pesquisa em Educação em Ciências } \\ \text { FNDE } & \text { Fundo Nacional de Desenvolvimento da Educação } \\ \text { IUPAC } & \text { International Union of Pure and Applied Chemistry } \\ \text { LIVRES } & \text { Livros Escolares } \\ \text { MANES } & \text { Manuais Escolares } \\ \text { MEC } & \text { Ministério da Educação e Cultura } \\ \text { Pibid } & \text { Programa Institucional de Bolsas de Iniciação à Docência } \\ \text { PNAE } & \text { Programa Nacional de Alimentação Escolar } \\ \text { PNBE } & \text { Programa Nacional de Biblioteca da Escola } \\ \text { PNLD } & \text { Programa Nacional do Livro Didático } \\ \text { SCIELO } & \text { Scientific Eletronic Library } \\ \text { USP } & \text { Universidade de São Paulo } \\ & \end{array}$




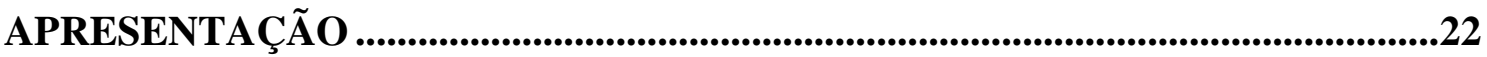

1. INTRODUÇÃO ...............................................................................................24

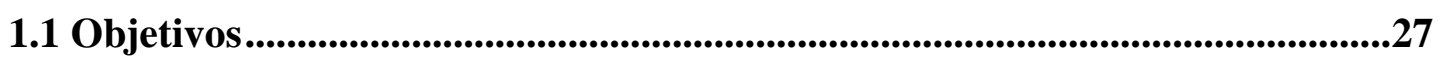

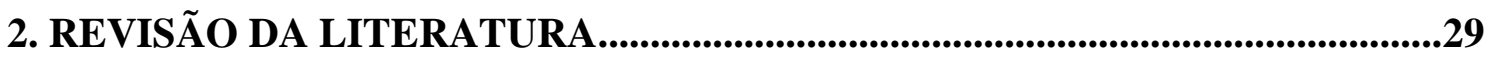

2.1 Reações redox e os livros didáticos nas pesquisas brasileiras ...........................33

3. FUNDAMENTAÇÃO TEÓRICA........................................................................43

3.1 Sobre o livro didático ...............................................................................................43

3.1.1. Função e uso do livro didático .............................................................48

3.2 As reaçỗes redox .....................................................................................................54

3.2.1. O conceito redox ……………………………………………....54

3.2.2. A eletroquímica ..............................................................................5

3.2.3. Modelos de reações redox.................................................................59

3.2.4. Concepções alternativas no ensino de reações redox.............................68

3.3. O Projeto 2061 ....................................................................................................74

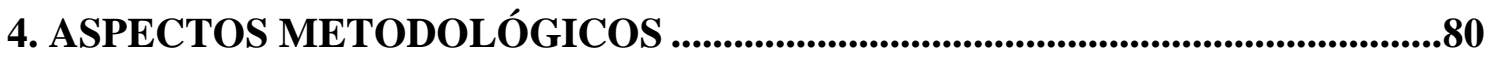

4.1. Etapa de preparação das informações ......................................................82

4.2. Etapa de unitarização ……………………………………………….....8

4.3. Etapa de categorização ..........................................................................89

4.4. Etapa de descrição.............................................................................91

4.5. Etapa de interpretação ………………………………………………....92

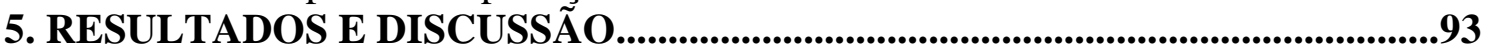

5.1. A evolução das reações redox nos livros didáticos.............................................93

5.1.1. Distribuição dos temas ao longo do ensino fundamental......................112

5.2. Apresentação das coleções de química do PNLD 2018 ...................................115

5.2.1. Os capítulos para ensino de reações redox..........................................117

5.2.2. Diferenças e semelhanças das coleções de química...............................140

5.2.3 Dos conceitos redox apresentados ......................................................142

5.2.4. Os temas de oxirredução presentes nas coleções de ensino médio.....144

5.3. Os modelos redox nos livros didáticos brasileiros ..........................................156

5.3.1. Os modelos redox mais utilizados ....................................................162

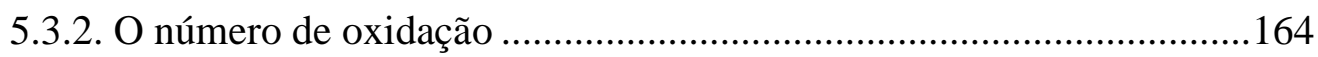

5.3.3. Consequências do uso dos modelos no ensino de redox......................167

5.4. A evolução do conteúdo de reações redox nos livros didáticos da educação básica.....................................................................................................................170

5.5. Os livros didáticos como suporte ao processo de aprendizagem..................179

5.5.1 Coleções brasileiras e o ensino de reações redox ................................225

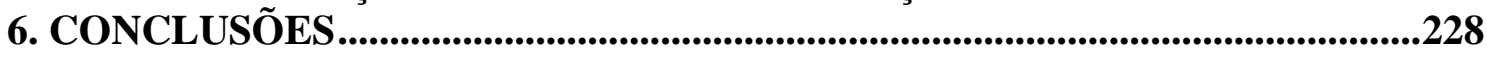

7. REFERÊNCIAS...............................................................................................228

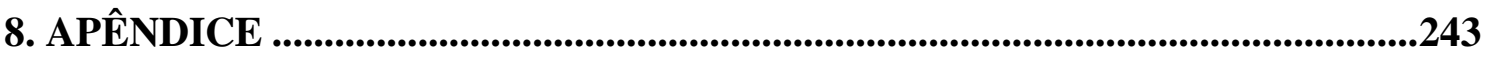

9. ANEXO............................................................................................................................261 


\section{APRESENTAÇ̃̃O}

Os professores que tive ao longo da minha vida escolar gostam de afirmar que sou professora desde que aprendi a falar. Eu era a criança agitada que terminava a tarefa e corria conversar com o coleguinha, não adiantava, não dava para ficar parada. Alguns professores aproveitavam a oportunidade e me colocavam para ensinar aqueles que não estavam compreendendo, ou os tímidos, ou os que também não ficavam parados.

Optei nos anos finais da educação básica por cursar o técnico em química muito devido às aulas de ciências maravilhosas que tive no fundamental. $\mathrm{O}$ amor pela química decorreu das séries assistidas, dos livros lidos e sobretudo das aulas experimentais apaixonantes que tive ao longo do curso.

Seguir a carreira acadêmica sempre foi o meu objetivo, ainda no ensino técnico em química integrado, e os excelentes exemplos de professores que tive durante a licenciatura, em Ponta Grossa no Paraná, me incentivaram a prosseguir mesmo ao mostrar as dificuldades que enfrentaria no caminho.

A licenciatura em química eu iniciei em março de 2013 e a concluí quatro anos depois em fevereiro de 2017, no mesmo mês em que me matriculei no mestrado no Programa Interunidades em Ensino de Ciências na Universidade de São Paulo. Sou grata pela oportunidade em aprimorar meus conhecimentos da docência antes de mergulhar na carreira e me tornar uma professora melhor a cada discussão que participei durante o mestrado.

O interesse em analisar livros didáticos da educação básica inicia-se com meu ingresso no Grupo de Pesquisa em Ensino de Química - PEQuim- sob orientação da Prof. ${ }^{\text {a }}$ Dra. Carmen Fernandez. O grupo de pesquisa tem como foco principal investigar o Conhecimento Pedagógico de Conteúdo (PCK) de professores de química, que trata do conhecimento que diferencia um docente de química de um químico especialista. Outro objetivo do grupo é também a análise dos diversos contextos que permeiam o ensino de reações redox, são diversos os sujeitos de pesquisa investigados, desde professores ingressantes na carreira, pibidianos ${ }^{1}$, professores experientes de ensino básico e superior. Apesar das diversas publicações do grupo, poucas são aquelas que têm como objeto de pesquisa os livros didáticos e nenhuma, até então, analisava os livros didáticos de ciências do ensino fundamental.

\footnotetext{
${ }^{1}$ Participantes do Programa Institucional de Bolsas de Iniciação à Docência
} 
Aliando-se aos interesses do PEQuim estão os meus como professora iniciante na carreira. $\mathrm{O}$ contato que tive na docência foi em sua totalidade mediado pela participação no Programa Institucional de Bolsas de Iniciação à Docência (Pibid) e pela disciplina de estágio supervisionado nos últimos anos da graduação. Das vezes que assumi a frente da sala de aula, corri em busca de "salvação" nos livros didáticos. No Pibid, ainda nos primeiros anos da licenciatura, o livro didático me ajudou a suprir o pouco conhecimento do currículo do ensino básico que eu tinha, já que as disciplinas pedagógicas deste conhecimento seriam ministradas no final da graduação. Já nas 100 horas de regência do estágio supervisionado, os livros me ajudaram a transpor aquilo que aprendi na universidade para aquilo que se ensina no ensino básico. Os livros sempre estiveram presentes na minha formação, mas tive poucas oportunidades para analisar criticamente seu conteúdo.

A transposição de alguns conteúdos pode ocasionar diversas concepções alternativas nos discentes, são inúmeras as pesquisas que descrevem os erros conceituais, analogias incorretas e imagens incoerentes presentes nos livros didáticos. Compreendo ainda que muitas destas concepções podem advir de outros momentos da vida escolar do estudante. Um conteúdo mal aprendido nos anos iniciais do ensino fundamental ocasiona dificuldades de entendimento no ensino médio e contribui para tornar a disciplina de química ainda mais difícil aos olhos dos alunos. Assim, elenca-se os livros de ciências do ensino fundamental como objeto de pesquisa para tentar compreender como vai surgindo o conteúdo redox em exemplos e processos ainda sem formalização. Já no ensino médio a formalização se inicia quando o aluno entra em contato com os elétrons, as reações de oxidação, de redução, os potenciais e pilhas. Assim, pretende-se analisar como se dá a construção do conhecimento de processos redox nos materiais curriculares da educação básica, do fundamental ao ensino médio.

Como mestranda do Programa de Pós-Graduação Interunidades em Ensino de Ciências (PIEC) me preocupo nesta investigação em entender como os livros didáticos de ciências e de química abordam o conteúdo de reações redox para indagar se e como eles influenciam as concepções alternativas descritas na literatura. Como licenciada em química e apaixonada pela docência busco, implicitamente, revelar aos professores as possíveis limitações do instrumento utilizado em sala de aula para que juntos, pesquisa e ensino, consigamos melhorar a docência no ensino básico. 


\section{INTRODUÇÃO}

O livro didático (LD) assume um papel central no processo de ensinoaprendizagem à medida que influencia a prática pedagógica do professor (LOPES, 1992), as atividades escolares dos alunos (MEGID NETO; FRACALANZA, 2003) e, por vezes, orienta o currículo escolar.

Nesse sentido, ele pode servir como simplificador do trabalho docente já que determina os conteúdos, as atividades e muitas vezes a abordagem a ser utilizada pelo professor (CÁSSIO et al., 2012).

Devido ao papel que vêm exercendo nas salas de aulas brasileiras houve um crescente aumento no número de pesquisas cujo tema é livro didático. Essas pesquisas são destacadas nos diversos mapeamentos realizados (MARPICA; LOGAREZZI, 2010, FRANCISCO; QUEIROZ, 2010, FERNANDES; GOUVÊA, 2011, LEITE et al., 2011, EMMEL; ARAÚJO, 2012, MOREIRA, 2012; MAIA; VILLANI, 2013, PEDREIRA; CARNEIRO, 2017; SCHIMER; SAUERWEIN, 2017).

Os levantamentos realizados ampliam as discussões sobre os temas e objetivos de pesquisa quando se trata do LD. Mais que isso, também assumem, ressaltam e enfatizam a importância desse recurso didático em todos os níveis de ensino e aprendizagem. Destaca-se também outras iniciativas que ampliam e divulgam as discussões sobre o LD. Um exemplo claro disso é o Projeto LIVRES.

O LIVRES 2 é um banco de dados de LIVRos EScolares brasileiros. Esse banco de dados faz parte do projeto temático "Educação e Memória: organização de acervos de livros didáticos (2004-2007)". Nele é disponibilizado o acesso a livros didáticos das diversas disciplinas escolares brasileiras, do século XIX até os dias atuais. O LIVRES reúne obras de diversas bibliotecas do país, e é alimentado e ampliado constantemente pelas pesquisas de uma equipe de especialistas da área, que analisam o livro didático em suas diferentes vertentes. Atualmente diversos pesquisadores, de diversas instituições de ensino, inclusive estrangeiras, participam e alimentam o projeto com as publicações da área.

A importância do LD no processo de ensino e aprendizagem, sobretudo na disciplina de química, também é destacada por diversos autores, em diferentes temáticas: a) conceitos químicos (SCHNETZLER,1981, FERREIRA; JUSTI, 2004), b) políticas educacionais brasileiras (MORTIMER, 1988); c) uso de analogias (MONTEIRO; JUSTI,

\footnotetext{
${ }^{2}$ Acesso em: http://www2.fe.usp.br:8080/livres/
} 
2000) e d) aspectos pedagógicos (MÓL et al., 2005). Dentre estas publicações destacamse, também, as que analisam o conteúdo de reações redox, foco deste estudo: Sanger e Greenbowe (1999), Vitz (2002), Boulabiar et al. (2004), Mendonça, Campos e Jófili (2004), Österlund, Berg e Ekborg (2010), Shibley et al. (2010), Reis, Goes e Fernandez, (2016a, 2016b), Goes, Nogueira e Fernandez, (2018).

Estas pesquisas sugerem que nos livros há presença de linguagem inadequada, distorções conceituais, coexistência de diferentes modelos redox que não são discutidos com os alunos, excesso de analogias de senso comum e propostas experimentais impossíveis de serem reproduzidas (ÖSTERLUND, BERG, EKBORG, 2010; BOCANEGRA, 2010; FONTES, LOURENÇO, MESSEDER et al., 2012). A presença desses aspectos possivelmente dificulta a compreensão de conceitos e podem gerar concepções alternativas nos estudantes.

As dificuldades de compreensão dos conceitos relacionados às reações redox podem sugerir uma lacuna no ensino de química à medida que se considera de grande importância a aprendizagem desse conteúdo. Conforme apontam Ocotero et al. (2015), as reações de oxirredução ocorrem em um grande número de casos em nossas vidas e são tão comuns que, muitas vezes, passam sem que se percebam ou se reflitam sobre elas. Tais reações regulam o comportamento de muitos compostos químicos presentes nos ecossistemas, e participam de muitos processos de vital importância, como a respiração em animais, a fotossíntese em vegetais ou a fermentação em bactérias.

Esta importância é também afirmada por Nogueira, Goes e Fernandez (2017) no trabalho de estado da arte sobre ensino de reações redox nos principais eventos na área de educação no Brasil. Os dados permitiram concluir que a produção sobre o tema é maior na região Sudeste; a experimentação é a estratégia de ensino mais adotada para o ensino das reações redox principalmente as de caráter demonstrativo; e não se têm publicações sobre o tema no nível fundamental de ensino, em compensação são amplamente contempladas no ensino médio, o que, segundo as autoras:

[...] se contradiz com o fato de a literatura também apontar que as reações redox geralmente não são trabalhadas neste nível de ensino e de que muitos docentes não ministram esse conteúdo em sala de aula, por não terem conhecimento desse conteúdo da eletroquímica (NOGUEIRA, GOES, FERNANDEZ, 2017, p. 429).

Destaca-se que, em virtude da importância associada ao ensino das reações redox, inúmeras pesquisas buscaram catalogar: 
A. Estratégias de ensino e atividades práticas envolvendo processos redox e/ou eletroquímica (HUDDLE, WHITE, ROGERS, 2000; NIAZ, CHACÓN, 2003; SESEN, TARHAN, 2013; NOGUEIRA, GOES, FERNANDEZ, 2017).

B. Ensino-aprendizagem de processos redox e/ou eletroquímica com foco no aluno, incluindo trabalhos sobre concepções alternativas (GARNETT, TREAGUST, 1990; 1992a; 1992b; BARRAL et al., 1992; RINGNES, 1995; SANGER, GREENBOWE, 1997a; 1997b; 2000; NIAZ, 2002; SCHMIDT, MAROHN, HARRISON, 2007; LEE, 2007; BARKE, HAZARI, YITBAREK, 2009).

C. Ensino-aprendizagem de processos redox e/ou eletroquímica com foco no professor (de JONG, ACAMPO, VERDONK, 1995; ÖSKAYA, 2002; de JONG, TREAGUST, 2002; AHTEE, ASUNTA, PALM, 2002).

D. PCK de professores sobre processos redox e/ou eletroquímica (HUME, 2010; AYDIN, 2012; AYDIN, BOZ, 2013; FREIRE, FERNANDEZ, 2014).

E. Processos redox e/ou eletroquímica em livros didáticos de Química (SANGER, GREENBOWE, 1999; MENDONÇA, CAMPOS, JÓFILI, 2004; ÖSTERLUND, BERG, EKBORG, 2010).

Assim, uma vez que se considera o livro didático como um dos recursos didáticos centrais no sistema de ensino brasileiro, esta investigação destina-se, portanto, a todas as escolas de educação básica que recebem e utilizam os livros didáticos. Por conseguinte, a divulgação dos resultados desta pesquisa alcança inúmeros professores de química e de ciências atuantes no ensino fundamental e médio das escolas brasileiras.

Em virtude do exposto, objetivou-se verificar a construção do conteúdo de reações redox nos livros didáticos do ensino básico. Nesta pesquisa, busca-se inferir a possível influência destas abordagens nas concepções alternativas dos alunos que são relatadas na literatura. Utiliza-se, para isso, três diferentes análises em livros didáticos de ciências do ensino fundamental e de química no ensino médio. O texto é estruturado em sete tópicos principais, a saber: introdução, revisão de literatura, fundamentação teórica, pressupostos metodológicos, resultados e discussão, conclusões e implicações do estudo.

Inicialmente apresenta-se uma breve introdução sobre a investigação. Busca-se destacar qual a direção que as pesquisas em livros didáticos vêm tomando, e ainda, a importância da pesquisa sobre o conteúdo redox. Na introdução também são delimitados os objetivos que norteiam a pesquisa.

No segundo tópico apresenta-se uma revisão de literatura que aponta as publicações da área de ensino de ciências divulgadas em três meios de pesquisa: artigos 
de periódicos, atas de eventos nacionais e banco de teses e dissertações. Tais publicações são relatadas de acordo com o objetivo de investigação dos autores.

No terceiro tópico é apresentada a fundamentação teórica na qual se baseia a pesquisa. São traçadas considerações gerais acerca do livro didático, como por exemplo, as funções que os LD assumem no contexto brasileiro. As definiçõos, concepções e modelos das reações redox também são esmiuçadas nesse tópico, que é finalizado tratando do Projeto 2061 em que se baseia uma das análises.

No quarto tópico, busca-se delinear quais os pressupostos metodológicos que foram seguidos nas análises posteriormente apresentadas. Assumindo a análise de conteúdo como principal referencial metodológico, destacam-se as etapas de preparação das informações, unitarização, categorização, descrição e interpretação de acordo com Moraes (1999).

O quinto tópico apresenta os resultados obtidos e as discussões finais. Esse tópico é subdividido em cada uma das análises realizadas e, portanto, apresenta em sua primeira parte os resultados da investigação que buscou identificar os temas pertinentes às reações redox em livros de ensino fundamental. Na segunda parte faz-se uma breve apresentação dos livros didáticos analisados, destacando como o conteúdo de reações redox e eletroquímica está presente nas coleções analisadas e quais os temas pertinentes aparecem nos livros de química do ensino médio. A terceira parte detalha quais os modelos de reações redox estão presentes nos LD tecendo-se considerações sobre qual a alternativa mais adequada para o ensino redox e as consequências do uso desses modelos no ensino. A quarta parte deste tópico apresenta a interpretação dos resultados obtidos e que explicam as possíveis influências da abordagem do conteúdo nas concepções alternativas dos alunos. A quinta e última parte traz os resultados da análise em que se buscou identificar se as coleções aprovadas fornecem suporte ao ensino de reações redox e confronto das concepções mais relatadas na literatura.

No sexto tópico apresenta-se as conclusões do estudo. No sétimo tópico são descritas possíveis implicações desse estudo tanto para o ensino, quanto outras perguntas que surgiram no estudo realizado. Além disso, os tópicos de referências, apêndice e anexo findam esta dissertação.

\subsection{Objetivos}

A pesquisa tem como objetivo principal responder à questão de pesquisa: como os conceitos de reações redox vão sendo construídos nos textos dos livros didáticos de 
ciências do ensino fundamental I e II e de química do ensino médio? E como esses textos podem se relacionar às concepções alternativas dos estudantes relatadas na literatura?

Assim, pretende-se descrever e analisar a evolução do conteúdo de reações redox nos livros didáticos de educação básica brasileira avaliados pelo PNLD 2016, 2017 e 2018. Para tanto, serão desenvolvidos os seguintes objetivos específicos:

I. Identificar os temas pertinentes ao conteúdo de reações redox em livros didáticos de ciências aprovados pelo PNLD para o ensino fundamental I e II.

II. Analisar como os livros didáticos de química, aprovados no PNLD do ensino médio, abordam os conceitos de oxirredução.

III. Relacionar as concepções dos alunos e a apresentação do conteúdo de reações redox nos livros didáticos da educação básica.

IV. Inferir se, e como, a abordagem utilizada nos livros didáticos, para os conceitos de oxirredução, pode influenciar as concepções alternativas dos alunos relatadas na literatura. 


\section{REVISÃO DA LITERATURA}

Sanger e Greenbowe (1999) motivados em relacionar as concepções alternativas referentes ao conteúdo de eletroquímica e os textos do LD de química, analisaram 10 livros de ensino superior e classificaram as afirmações que poderiam ser fonte de concepções errôneas.

$\mathrm{Na}$ análise, as afirmações de que "o ânodo está sempre à esquerda" seja em representações simbólicas das células ou em desenhos esquemáticos, "o cálculo de potenciais celulares tem de usar o método aditivo", podem sugerir aos estudantes que os potenciais de meia-célula têm significados isolados, quando na verdade só há significado na diferença de potencial. As afirmações: "fluxo de elétrons em solução aquosa" sem a presença de uma ponte salina, "O movimento do cátion na solução não gera corrente elétrica" mas somente o movimento de ânions, desconsiderar a "carga eletrônica dos eletrodos", "reações envolvendo eletrodos inertes" desconsiderando a possibilidade de que eles reajam e não explicando as características que os tornam inertes, "previsão de produtos de eletrólise" utilizando unicamente potenciais de redução padrão, são considerados exemplos presentes nos LD que podem ser fontes de erros conceituais, e consequentemente levar a concepções alternativas.

Os autores, Sanger e Greenbowe (1999), produzem uma lista de sugestões a serem consideradas quando no uso dos materiais didáticos analisados ou ainda na criação de novos livros, os itens da lista são: a) evitar simplificações nas representações utilizadas; b) evitar o uso de declarações breves em favor das descrições dos processos que estão ocorrendo; c) utilizar o método de diferenças de potenciais e não método aditivo no cálculo de potenciais de redução; d) evitar argumentos simplistas na previsão de fluxo de íons e elétrons e, e) considerar sempre as possíveis semirreações ocorrentes na previsão de produtos.

No contexto francês e tunisiano, Boulabiar e colaboradores (2004), investigaram a apresentação da pilha de Daniell em livros didáticos. A principal motivação do estudo é o paradoxo da importância histórica da pilha de Daniell e o fato de nenhum dispositivo existente hoje se parecer com a célula presente nos livros.

Os resultados de Boulabiar et al. (2004) apontam que entre os anos de 1840 e 1934, as pilhas de Volta e de Daniell não são abordadas em livros didáticos de química, apenas nos de física. Nesses livros, a pilha da Volta ocupa um lugar central servindo para introdução de conceitos e abordagem descritiva da natureza eletrostática, enquanto que a 
pilha de Daniell é utilizada para introdução das reações químicas. Os autores acrescentam que esse fator é relacionado ao pouco conhecimento sobre dissociação iônica, reações de oxidação e redução e elétrons, existente na época. No período de 1934 a 1966, a pilha de Daniell é apresentada entre as células não polarizáveis nos livros de física, mencionandose as equações globais, porém, sem referência aos elétrons.

As células eletroquímicas começam a aparecer tanto nos livros de física quanto nos de química, entre os anos de 1966 e 1977. Nos livros didáticos de física, as células de Daniell servem de introdução à interpretação eletrônica, enquanto que nos livros de química utiliza-se um novo modelo da pilha de Daniell para introdução das semirreações e pares redox.

A partir de 1977 utiliza-se esse novo modelo das pilhas, composto por duas meiascélulas separadas, na abordagem eletroquímica. Nos livros didáticos tunisianos a única célula apresentada é a de Daniell. Com o advento desse modelo foi necessário a inclusão de um dispositivo, a ponte salina, para garantir a ligação elétrica entre os dois compartimentos. Os autores enfatizam que: "Este tipo de célula nunca foi usado fora das salas de aula, e seus status seria descrito como um artefato pedagógico" (BOULABIAR, et al., p. 755, 2004, tradução nossa)

A utilização desse novo dispositivo, a ponte salina, não é acompanhada de explicação sobre a transferência iônica através da ponte, e quando aparece explicação, utiliza-se apenas movimentos aniônicos. A constituição da ponte e suas principais funções, como a redução do potencial de junção liquida, também é pouco abordada.

Os autores concluem que o modelo de ensino da célula de Daniell, utilizado amplamente em livros franceses e tunisianos, difere notavelmente de qualquer tipo de célula já construída. Além disso, esse modelo com ênfase nas reações redox nas meiascélulas, não ajuda os alunos a compreenderem a célula como um sistema. O modelo ainda pode ser a principal fonte de equívocos sobre a condução iônica, pois negligencia a condução na ponte salina. (BOULABIAR, et al., 2004)

Os autores apontam que trabalhar com dois modelos de condução iônica - na ponte salina e na célula, utilizar simulações para visualização dos níveis macro e microscópicos, e conscientizar os alunos sobre suas concepções alternativas, é um bom caminho para superar as limitações do modelo da pilha de Daniell. (BOULABIAR, et al., 2004)

No ensino de reações redox há ainda a possibilidade de uso de diversos modelos explicativos, a coexistência desses modelos pode ser confundida por professores, alunos 
e autores de LD (ÖSTERLUND, BERG, EKBORG, 2010). Buscando investigar como os LD utilizam e/ou modificam os diversos modelos de explicação das reações redox em diferentes áreas da química, se são fornecidas explicações do uso desses diferentes modelos e ainda como os livros abordam várias dificuldades de aprendizagem sobre os processos redox identificados na literatura, os autores Österlund, Berg e Ekborg analisaram quatro livros suecos e dois de língua inglesa identificando os modelos encontrados.

Os principais resultados obtidos descrevem que todos os livros representam os quatro modelos redox, sendo que eles são muito similares dentro da química inorgânica e orgânica. Os resultados também separam o modelo utilizado nos diferentes campos da química. Na inorgânica utiliza-se modelos de número de elétrons e oxidação, na orgânica utiliza-se frequentemente os modelos de oxigênio e de hidrogênio, e na bioquímica as representações alternativas são mais usadas. Este estudo mostrou que os livros didáticos, em grande parte, não forneceram qualquer justificativa para a mudança de modelos dentro e entre áreas temáticas, não explicando o porquê para um determinado contexto utilizase um modelo e não outro. (ÖSTERLUND, BERG, EKBORG, 2010).

Baseando-se em uma série de concepções alternativas descritas na literatura Österlund, Berg e Ekborg (2010) analisaram também se os livros didáticos consideram estas dificuldades na formulação dos conteúdos. Nesta análise, encontraram poucas informações que levam em consideração as dificuldades dos estudantes. Assim, os autores expõem exemplos de como os vários modelos redox podem ser utilizados para explicar um mesmo fenômeno, salientando que o motivo da escolha de cada modelo deve ser claro ao aluno para que os mesmos superem as dificuldades descritas.

Ainda discutindo sobre o uso desses diferentes modelos no ensino das reações redox, Vitz (2002) compara as definições mais utilizadas para reações redox, apontando o modelo de mudança no número de oxidação como o mais correto para o ensino. $\mathrm{O}$ autor discute também o quanto a definição da IUPAC precisa ser revista, pois pode ser fonte de confusão àquele professor inexperiente, e sobretudo, nos alunos, já que a definição é baseada em regras arbitrárias.

Vitz (2002) também critica a definição dada nos livros didáticos para as reações de oxirredução. A principal definição dos livros é em termos da transferência eletrônica, essa definição não abrange todas as reações redox e não auxilia o aluno na distinção dos mecanismos redox. Segundo o autor, essas definições são baseadas na IUPAC e leitores experientes não as aplicam de forma literal, entretanto, os alunos se beneficiariam com 
definições mais cuidadosamente escritas e que envolvam a mudança no número de oxidação.

O uso do modelo da mudança no número de oxidação, nos livros didáticos, promoveria uma visão mais unificada na química orgânica e inorgânica e permitiria um conceito mais realista de estrutura eletrônica (VITZ, 2002).

Mendonça, Campos e Jófili (2004) analisaram livros do terceiro ano do ensino médio, os livros de orgânica, e destacam que poucos deles fazem revisão do conceito de oxidação anteriormente ao ensino das reações em orgânica. Um único livro relaciona o conceito de oxidação ao número de oxidação do carbono, e somente dois livros apresentam que as reações de oxidação ocorrem sem a necessidade da presença de oxigênio.

Os autores ainda apontam que nenhum dos livros apresentam conteúdo contextualizado envolvendo aspectos ambientais, sociais, econômicos e políticos, eles somente citam reações que ocorrem no dia-a-dia. Por isso os livros seriam pouco adequados ao ensino, já que contribuem para confusão conceitual dos alunos e também dos professores (MENDONÇA; CAMPOS; JÓFILI, 2004).

Ainda no contexto das reações redox em química orgânica, Shibley e colaboradores (2010) fazem uma breve discussão sobre a abordagem em 11 livros didáticos. Os autores enfatizam que os livros mencionam a transferência eletrônica, mas em geral, descrevem a oxidação como diminuição ou aumento nos átomos de oxigênio, nitrogênio ou halogênio. Outras abordagens mais aprofundadas descrevem o número de oxidação dos átomos de carbono, com cálculos que requerem a carga formal.

Outra conclusão importante apresentada por Shibley et al. (2010) é que, apesar de a maioria dos livros admitir que os conceitos de oxidação e redução, em termos da transferência eletrônica, terem pouco significado em química orgânica, várias páginas são utilizadas na determinação de agentes oxidados e reduzidos.

Essa parte da literatura apresentada descreve as produções sobre a presença do conteúdo de oxirredução nos livros didáticos em contexto internacional. Contudo, no contexto brasileiro os livros didáticos são um recurso bastante presente nas salas de aulas, uma vez que se tem um programa nacional para seleção, compra e distribuição dos mesmos. Devido a isso, realizou-se uma pesquisa na literatura da área de ensino de ciências e química, buscando apresentar as publicações que considerem o contexto nacional. As publicações são apresentadas na sessão seguinte. 


\title{
2.1. Reações redox e os livros didáticos nas pesquisas brasileiras
}

As publicações que tem como objetivo investigar o conteúdo de oxirredução em livros didáticos são apresentadas, em contexto brasileiro, em vários meios de divulgação. Por isso, selecionou-se publicações dos principais eventos nacionais ${ }^{3}$, artigos de periódicos ${ }^{4}$, teses e dissertações da área de ensino de ciências e química ${ }^{5,6}$. As publicações estão relatadas de acordo com a seção do livro analisada:

I. Nos textos escritos:

I.i Contextualização

Em A abordagem CTS em livros didáticos de química: uma análise do conteúdo Pilhas, Santos e Aires (2016) investigaram como a abordagem CTS (Ciência, Tecnologia e Sociedade) é contemplada nas coleções didáticas de química aprovadas pelos PNLD de 2008, 2012 e 2015. Os autores descrevem considerações sobre a importância da abordagem CTS e interdisciplinar na formação crítica e cidadã do aluno, e utilizam 5 critérios que "são enfrentamentos à transmissão do conhecimento científico sem uma abordagem CTS” (SANTOS e AIRES, 2016, pág. 6). Os critérios são:

\begin{abstract}
A) Evita tratar a construção do conhecimento científico como um conjunto de etapas padronizadas realizadas pontualmente por um cientista; B) Contextualiza historicamente o processo de produção do conhecimento científico; C) Aborda a aplicação do conhecimento científico pela sociedade em seu cotidiano e os impactos (positivos e/ou negativos) sobre ela; D) Aborda o conhecimento científico como base ao desenvolvimento tecnológico, que melhora as condições de vida; e E) Aborda os impactos ambientais relacionados à utilização de pilhas e baterias pela sociedade, bem como alternativas para sua minimização.
\end{abstract}

A investigação resultou nas seguintes conclusões: primeiro, o aspecto positivo de inserção dessa abordagem em todas as coleções que vem crescendo cada vez mais; segundo, os critérios A, B e D foram os que menos apareceram, e em virtude disso os livros careceriam, segundo os autores, de uma abordagem epistemológica por meio dos aspectos históricos da construção do conhecimento científico; terceiro, apesar da abordagem CTS ter sido considerada satisfatória, os textos aparecem em boxes separados do texto principal, nesse aspecto os autores apontam que esse fator pode causar desinteresse dos professores e alunos pelas informações escritas. (SANTOS e AIRES, 2016).

\footnotetext{
${ }^{3}$ Percorreu-se as atas dos eventos: Encontro Nacional de Pesquisa em Educação em Ciências (ENPEC); Encontro Nacional de Ensino de Química (ENEQ); Simpósio Brasileiro de Educação Química (SIMPEQUI); Congresso Brasileiro de Química (CBQ) e Reunião Anual da Sociedade Brasileira de Química (RASBQ).

${ }^{4}$ Acesso ao portal de periódicos da CAPES: http://www-periodicos-capes-gov-br.ez67.periodicos.capes.gov.br/

${ }^{5}$ Acesso a plataforma da Biblioteca Digital Brasileira de Teses e Dissertações: http://bdtd.ibict.br/vufind/

${ }^{6}$ Acesso a plataforma de teses e dissertações da Universidade de São Paulo: http://www.teses.usp.br/
} 
Outra análise que buscava compreender a noção de contextualização presente nos LD é descrita em A contextualização do conteúdo de eletroquímica: um olhar para o livro didático e para concepções de professores de química. A análise dos livros permeou três seções principais: textos complementares (cuja noção de contextualização é utilizada apenas para despertar interesse no leitor ou tomar decisões frente às questões ambientais), atividades experimentais (basicamente a construção de uma pilha utilizando-se itens simples ou a representação das reações químicas presentes no fenômeno da corrente elétrica) e exercícios (onde não há indício de contextualização). (SILVA, SILVA, 2016).

\title{
I.ii. Obstáculos epistemológicos
}

Ao pesquisar os aspectos ligados à previsão da ocorrência de reações redox, presença de obstáculos epistemológicos e a visão de ciência presentes nos livros, o autor de Aspectos conceituais e epistemológicos do tema eletroquímica nos livros didáticos de Química aprovados pelo Programa Nacional do Livro Didático para o Ensino Médio PNLEM (2007), enfatiza que:

\begin{abstract}
as matrizes teóricas para entendimento dos conceitos provêm da física; os autores dos livros utilizam imagens e analogias próximas ao senso comum; encontrou-se obstáculos realistas e verbalistas; o conceito não é desenvolvido segundo o domínio teórico necessário; cálculos utilizam regras e tabelas; e ainda a visão de ciência presente define o conhecimento como acabado não sendo vinculado à história da sua construção. Esses resultados permitem corroborar para distorcer as explicações e dificultar o entendimento pelo aluno (BOCANEGRA, 2010).
\end{abstract}

Outros autores também utilizam o referencial de Bachelard para analisar os obstáculos epistemológicos presentes nos LD e assim afirmam que:

os livros LD1, LD5 e o LD6 embora tratem o conceito de número de oxidação nos seus textos, não deixam claro que a oxidação não ocorre apenas pela perda e ganho de elétrons e também que o oxigênio deve estar presente. (SANTOS et al., 2010, p.1)

Os autores ainda apontam que há presença de obstáculos animistas e substancialistas pois, "aparece uma figura em que o metal parece perder massa" e "ao analisar a definição de oxidação, que pode variar entre a visão macroscópica — perda de massa - e a visão microscópica — perda de elétrons" (SANTOS et al., 2010) em Uma análise dos livros didáticos de química usando a epistemologia de Bachelard a partir dos conceitos de oxidação e redução. No entanto, não descrevem o porquê essas afirmações são consideradas como obstáculos epistemológicos.

Por fim os autores exprimem que:

Embora o conceito atual de oxidação envolva simplesmente a perda de elétrons de uma espécie, a maioria dos livros didáticos de química não propõe uma uniformidade (SANTOS et al., 2010, p. 1). 


\title{
I.iii. História da ciência
}

São preconizados pelos documentos oficiais de ensino a inserção de elementos da história da ciência no ensino de conceitos químicos, dessa forma os autores de História da Ciência nos Livros Didáticos de Química: Eletroquímica como Objeto de Investigação utilizaram um processo hermenêutico como metodologia de análise, estabelecendo quatro categorias principais. Na categoria "Histórias anedóticas" descreve-se que

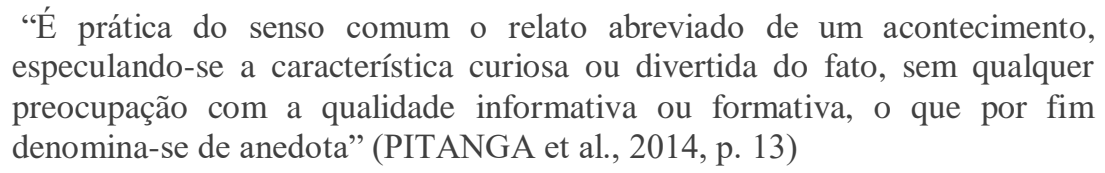
especulando-se a característica curiosa ou divertida do fato, sem qualquer preocupação com a qualidade informativa ou formativa, o que por fim denomina-se de anedota" (PITANGA et al., 2014, p. 13)

Trechos de três livros apresentaram concepções simplórias e inocentes sobre as atividades dos cientistas e sobre eles próprios. Isso implica no aumento da ideia de que o conhecimento científico é dependente da ação de gênios isolados.

Para a categoria "Linearidade", descreve-se que:

\begin{abstract}
"A linearidade é uma característica humana de desenvolver uma visão contínua da história. Acredita-se, dessa forma, que tudo está determinado, pronto e será sempre dessa forma, não mudará a não ser dentro de um processo contínuo, gradativo" (PITANGA et al., 2014, p. 14)
\end{abstract}

Ela é presente em todos os livros analisados, com uma abordagem linear e cumulativa de episódios históricos. Implica na crença de que o conhecimento é uma verdade absoluta, definitiva que dispensa novos conceitos.

$\mathrm{Na}$ categoria Consensualidade, tem-se que “[...] o processo de construção científica é permeado por ideias antagônicas e descontínuas, que geram as discussões, levando ao amadurecimento e à consolidação das proposições" (PITANGA et al., 2014, p. 14). Foram encontrados trechos de três livros que abordam que o trabalho desenvolvido por um pesquisador é incorreto enquanto outro, o correto, é enfatizado. Isso pode fornecer uma visão de que o LD é sempre exato, levando ao não questionamento do conteúdo presente nos LD.

Por fim, a categoria "Ausência do Contexto Histórico mais Amplo" coloca que "O ser humano, gregário por natureza, vive em sociedade, evolui como consequência da atividade coletiva de construção cultural e é influenciado por tudo e todos ao seu entorno." (PITANGA et al., 2014, p. 15). Na análise, encontrou-se que um único livro apresenta a influência política da época. Os autores concluem que a falta dessa concepção incapacita os episódios históricos de promoverem a discussão sobre o contexto específico da natureza da ciência. 
Outras categorias foram definidas a posteriori, como a narrativa histórica errônea, apresentações desconectadas e subutilização do recurso. A discussão dos resultados permitiu a conclusão de que a história da ciência está sendo subutilizada, numa visão ingênua deste importante recurso, visto que os professores e alunos não identificam facilmente concepções historiográficas errôneas, acumulativas e simplificadas (PITANGA et al., 2014).

A abordagem da história da ciência nos livros didáticos também foi alvo de pesquisa em A pilha de Volta em livros didáticos de química: algumas considerações, mas, como o próprio título sugere, o objetivo foi investigar um texto de um livro sobre a invenção de Alessandro Volta. Os autores apresentam o trecho investigado junto aos seguintes resultados: menciona-se no livro a "refutação de ideias" que pode desenvolver uma visão empírico-indutivista da ciência nos alunos, já que apresenta que um único fator, nesse caso a invenção da pilha de Volta, foi capaz de refutar as ideias dos seus precursores, o que não ocorre de fato. Além disso, o trecho destacado apresenta dados históricos incorretos, demonstrando que os autores dos livros em questão não realizaram consultas a fontes atualizadas. A conclusão dos autores aponta como a abordagem histórica muitas vezes sugere visões simplistas da ciência, e que em solução a isso deveria haver mais interação entre os educadores e os historiadores da ciência. (VIDAL, PORTO, 2009)

\section{I.iv. As pilhas e baterias}

Em sua monografia Martins (2015) investigou a Abordagem da problemática do descarte de pilhas e baterias nos livros didáticos de química do PNLD 2015 para o conteúdo de eletroquímica. Após tecer diversas considerações sobre a importância da educação ambiental e a abordagem CTSA (Ciência, Tecnologia, Sociedade e Ambiente), a autora define como objetivo do seu estudo identificar se a problemática é contemplada nos livros, se o enfoque adotado pelos autores das coleções é CTSA, se os conceitos são relacionados com questões do cotidiano e se os livros se relacionam à educação ambiental. Os resultados encontrados pela autora ressaltam que todas as coleções abordam a problemática, mas com ênfases diferentes. Das coleções analisadas, segundo a autora, uma apresenta o conteúdo descontextualizado e outra não contempla o preconizado pelos PCN e documentos orientadores. Porém, ela destaca que os livros que se caracterizam com abordagens construtivistas cumprem bem tal perspectiva de ensino. Nesse sentido, um único livro "apresentou toda a parte criteriosa que supomos ser essencial para entender a estrutura de pilhas e baterias bem como do impacto do mau 
descarte no meio ambiente para toda a sociedade conforme recomendada pelos documentos oficiais" (MARTINS, 2015, p. 28).

O trabalho O funcionamento da pilha de Daniell em três livros didáticos de química apresentou os dados de uma análise que buscava identificar a presença dos tópicos: (1) informações sobre o aspecto histórico da descoberta e construção da radioatividade, (2) a relação do conteúdo com o cotidiano dos alunos, (3) a interdisciplinaridade, principalmente com a disciplina de Física e (4) os enfoques com a questão ambiental. Na conclusão dos autores todos os livros apresentaram todos os aspectos listados. (SILVA et al., 2017)

A dificuldade em realizar-se a transposição didática é destacada por Machado e Santos (2009) em: Da pilha de Daniell ao eletrodo de vidro no livro de Análise Química Instrumental: Uma abordagem didática?. Neste trabalho, os autores investigaram como se dá a relação entre os conteúdos da eletroquímica e potenciometria, em um livro de química analítica do ensino superior. Motivados pela dificuldade de compreensão do conteúdo, por alunos do ensino técnico, os autores fazem uma análise da relação entre a abordagem da pilha de Daniell e os eletrodos no livro escolhido. Dessa investigação, Machado e Santos (2009) concluem que, de acordo com a abordagem presente, um estudante não conseguiria estabelecer nenhuma relação entre os dispositivos, o livro apresentaria ainda alguns desafios como: a forte influência do paradigma cartesiano e do modelo da racionalidade técnica, e dificuldades na realização de transposições didáticas e de processos de didatização adequados. Os autores apontam ainda outra importante conclusão:

Neste sentido, alguns desafios se colocam para a pesquisa, tais como a necessidade de: i) desenvolver ações investigativas que aprofundem a crítica ao livro superior indo além dos conteúdos e se estendendo também ao campo didático da obra; ii) ações propositivas que valorizem o uso de ferramentas didáticas no aperfeiçoamento desse livro, tendo em vista a melhoria do processo de ensino-aprendizagem. (MACHADO, SANTOS, 2009, p.1)

I.v. A eletrólise

Em Eletrodo de hidrogênio - O que há nos livros didáticos além de $E^{\theta}=0 \mathrm{~V}$ ? os autores apresentam dados de uma pesquisa realizada com alunos de uma disciplina em que as dificuldades apresentadas pelos respondentes justificaram "uma busca na literatura para verificar como esses conteúdos são tratados nos textos didáticos" (OLIVEIRA et al., 2007). Os autores descreveram que foram consultados livros de química introdutórios, sites da internet e textos de físico-química, porém não especificam quais foram as fontes nem quais os critérios de busca. A conclusão levantada pelos autores é: “o eletrodo de 
hidrogênio é tratado de forma superficial e às vezes até incorreta nos livros introdutórios. A situação melhora nos textos mais avançados" (OLIVEIRA et al., 2007).

Posteriormente, numa publicação que leva o mesmo nome do resumo anterior, Eletrodo de hidrogênio - $O$ que há nos livros didáticos além de $E^{\theta}=0$ ?, os autores apresentam mais resultados sobre o estudo realizado. $\mathrm{O}$ artigo inicia-se descrevendo a atividade que motivou a pesquisa e descreve os documentos pesquisados, sendo 21 livros de química geral do ensino superior. Os autores buscaram responder às questões: "O que é eletrodo de hidrogênio? Há um esquema do eletrodo? Por que $\mathrm{E}^{\theta}=O$ ? O que significa potencial-padrão? Como as variações de concentração e de pressão afetam o potencial do eletrodo? Qual é a expressão da equação de Nernst para o eletrodo?” (OLIVEIRA, et al., 2015, pág. 1065). Os principais resultados encontrados são que, apesar de bem trabalhados os conceitos de eletrodo de hidrogênio e a adoção do mesmo como referência, os livros não seguem as recomendações da IUPAC para os valores de pressão e temperatura; é definida concentração molar unitária e não atividade unitária, o que seria o mais adequado para esse nível de ensino; pouco aborda-se como as variações de concentração e de pressão afetam o potencial do eletrodo; e ainda, a equação de Nernst nem sempre é aplicada ao eletrodo de hidrogênio ou mesmo a outros eletrodos envolvendo fase gasosa. As conclusões permanecem as mesmas do resumo anterior (OLIVEIRA et al., 2007).

Os conceitos referentes ao conteúdo de eletrólise foi alvo de pesquisa de dois outros trabalhos: Análise do conceito de Eletrólise nos livros didáticos de Química do PNLD-2015 e periódicos nacionais e $O$ conceito de Eletrólise nos livros didáticos de Química do PNLD-2015; ambos dos mesmos autores. No primeiro, Martins et al. (2016a) analisaram as partes referentes ao conteúdo de eletrólise das quatro coleções de química aprovadas pelo PNLD 2015, além disso fazem parte do escopo de análise, artigos de periódicos e teses e dissertações da plataforma CAPES. Os autores são enfáticos ao afirmar que "o conceito de Eletrólise é pouco explorado, apresentado de modo descontextualizado e na maioria das vezes classificado como não relevante ao ensino de Química.” (MARTINS et al., 2016a, pág. 7). Ainda, não foram observadas diferenças significativas em relação à abordagem escolhida pelos autores dos livros didáticos analisados, à medida que os exemplos mencionados e as propostas de atividades experimentais frequentemente são as mesmas. No segundo, os mesmos resultados são apresentados, porém de forma resumida por tratar-se de um resumo de uma única página. 


\section{I.vi Outros}

Os autores do resumo: Avaliação dos conteúdos de eletroquímica em livros didáticos para o ensino médio, investigaram todo o conteúdo de eletroquímica em cinco livros didáticos. Como conclusão da análise os autores destacam que deve haver uma reformulação do conteúdo apresentado como, por exemplo, maior sugestão de leituras complementares.

No resumo Reações redox e livros didáticos: um mapeamento do conteúdo de oxirredução em livros de química para o ensino médio, as autoras realizaram uma análise quantitativa do conteúdo redox nos cadernos do estado de São Paulo e também nos livros didáticos de química do ensino médio aprovados no PNLD 2015. A análise aprofundouse em todas as páginas que se referiam direta ou indiretamente ao conteúdo de reações redox nos três livros das coleções e promoveu as seguintes conclusões:

\section{[...] conclui-se que apenas duas coleções abordam esse conteúdo ao longo dos três anos do Ensino Médio, com retomada e aprofundamento dos conceitos. Três coleções abordam o conteúdo de forma concentrada o que pode ser um indício das possíveis dificuldades em relação a esse conteúdo pela falta de conexão com outros temas da Química. (REIS, GOES, FERNANDEZ, 2016a, p.1)}

A abordagem presente nos livros didáticos do ensino médio foi comparada a do ensino superior em $O$ papel dos íons nas transformações químicas em solução segundo os livros didáticos: Protagonista?. Baseando-se nas respostas obtidas em uma questão sobre reações redox, os autores objetivaram compreender como esse conceito é apresentado nos livros didáticos do ensino médio. Dessa análise concluíram que se utiliza a classificação do esquema clássico na classificação das reações químicas. Os autores então fizeram uma comparação com a abordagem presente nos livros de ensino superior e destacam que estes apresentam os íons como protagonistas nas reações químicas contendo capítulos específicos sobre "reações em fase aquosa". Em virtude desses resultados os autores concluem que:

Isso nos convida a pensar que a transposição didática, feita pelos autores de livros, por vezes leva à supersimplificação dos conceitos, o que sem dúvida coopera com uma construção debilitada e incoerente dos significados pelos alunos. (CORDEIRO, et al. 2010, p. 1)

\section{Exercícios}

Em Cálculo da ddp: uma análise dos conceitos presentes nos livros didáticos, o enfoque era nos exercícios presentes no livro didático. Os autores apontam que só há dois tipos de abordagens na apresentação deste tópico, uso de uma simples equação ou discussão empregando-se as semirreações de cada processo. Quando utilizada apenas 
uma dessas abordagens haveria dificuldade na aprendizagem deste tópico pelos alunos (MOREIRA, MOREIRA, TRETIN, 2008).

\section{Experimentos}

Um importante aspecto a ser considerado no ensino das reações redox são os experimentos. Considerando isso, os autores do artigo A representação experimental da pilha de Daniell nos livros didáticos: um erro questionado, buscaram nos LD quais as possibilidades experimentais existentes nos livros didáticos, para construção de uma pilha de Daniell. Os resultados indicam que há uma abordagem principal, mas duas possibilidades, em uma utiliza-se uma lâmpada para verificar a passagem de corrente e na segunda um voltímetro. No entanto, os autores observaram que a abordagem indicada não traz os mesmos resultados descritos no livro, em virtude disso eles propõem uma outra possibilidade na qual é utilizada uma lâmpada de LED (FONTES, LOURENÇO, MESSEDER, 2012).

Martins et al. (2016b) analisaram o conteúdo de eletrólise apresentado nas quatro coleções aprovadas pelo PNLD 2015. Na investigação foi verificado que há poucas sugestões de atividades práticas; em virtude disso é proposta a utilização de materiais alternativos como: baterias, eletrodos e soluções de cloreto de sódio ou iodeto de potássio. Os autores ainda ressaltam que "a abordagem do conceito investigado nos LDQs [Livros Didáticos de Química] são frequentemente a mesma tanto os materiais utilizados quanto na estrutura física dos experimentos" (MARTINS, et al., 2016b, p.5)

\section{Imagens}

Em Imagens na comunicação do conhecimento em livros didáticos de química e física: uma análise à luz da semiótica peirceana, a autora faz uma análise referente ao conteúdo de 'pilhas e baterias' em livros de física e química. Os resultados da investigação apontam que há uma distinção entre a abordagem dos livros de química (que descrevem as células eletroquímicas como aparatos que geram energia elétrica por meio de reações químicas) e dos livros de física (que colocam termos genéricos como circuitos elétricos).

Quanto às imagens nos livros de química foram categorizadas em 'laboratório e experimentação' e 'cotidiano'. As fotografias foram utilizadas para representar situações do cotidiano e referem-se a situações experimentais. A função delas seria a de exemplificação e contextualização dos assuntos trabalhados, e de representação dos aparatos necessários à experimentação (JOAQUIM, 2017, p. 99-100). 
O esquema do eletrodo de hidrogênio apresentado em livros de ensino superior para as disciplinas de química geral e físico-química, e em páginas da internet, foi objeto de pesquisa do ensaio Eletrodo de hidrogênio - O que há nos livros didáticos além de $E^{\theta}$ $=0$ ?. Os esquemas apresentaram-se problemáticos, segundo os autores, pois $30 \%$ dos livros de química geral, $20 \%$ dos de físico-química e $46 \%$ dos sites pesquisados trazem dispositivos considerados absurdos e que não se assemelham aos eletrodos utilizados (OLIVEIRA et al. 2015). Nesse sentido, poderiam ocasionar erros e confusões conceituais.

Em A representação do conteúdo de oxirredução por meio de imagens nos livros didáticos de química para o Ensino Médio, as autoras buscaram conhecer como as imagens nos livros didáticos, aprovados no PNLD 2015, apresentam os três níveis representacionais da química (macroscópico, microscópico e simbólico). Nessa investigação foi perceptível que:

[...] a maioria das ilustrações é de nível macroscópico, estando presente em todas as coleções analisadas, e há pouca representação no nível submicroscópico, aparecendo apenas na combinação entre os níveis, ou seja, quando as ilustrações abordavam duas ou mais representações simultaneamente. Nenhuma das coleções apresenta uma ilustração que contenha apenas a representação no nível submicroscópico. (REIS, GOES, FERNANDEZ, 2016b, p. 1)

As autoras ainda destacam que, como apenas dois níveis de representação são priorizados, pode-se acarretar dificuldades de compreensão do conteúdo pelos alunos, já descritas na literatura. (REIS, GOES, FERNANDEZ, 2016b, p.1)

As publicações destacadas analisaram livros de química do ensino médio e do ensino superior. Em sua maioria os livros analisados foram os do segundo ano geralmente intitulados como 'físico-química'. Uma publicação analisou livros de orgânica e uma, livros de física. Quanto aos livros de ensino superior analisou-se os livros de química geral, considerados introdutórios, de físico-química e de química analítica, porém esse nível de ensino é pouco explorado se comparado ao nível médio.

O objetivo dos autores era entender como é feita a apresentação do conteúdo, das imagens, experimentos e exercícios de reações redox, como são realizados os cálculos referentes a este tópico e se há a presença de aspectos epistemológicos, metodológicos e da história da ciência.

É perceptível que o conteúdo de eletrólise foi o foco de mais trabalhos. A investigação dos exercícios propostos nos livros é foco de apenas um trabalho, enquanto que o conteúdo de todo o capítulo e sua distribuição é abordado em dois trabalhos. 
Os LD investigados compreendiam o período de 2008 a 2015, ou seja, fizeram parte de três editais do PNLD para o ensino médio. Em geral, eles apresentavam conteúdo descontextualizado, imagens e analogias de forma abusiva, obstáculos epistemológicos, equações simplificadas, exercícios que se preocupam com a utilização de fórmulas e experimentos que se realizados não levam aos mesmos resultados descritos nos LD.

Quanto à visão de ciência presente nos livros analisados, em geral, o conhecimento científico é visto como uma verdade absoluta, pronto, acabado, feito por gênios com suas regras próprias. Tal visão não se assemelha ao processo de pesquisa científica presente na comunidade acadêmica e pode levar o aluno a não se identificar com a carreira.

Uma grande parcela dos livros analisados apresentou confusão/distorção conceitual que pode dificultar a compreensão de conceito e, portanto, comprometem a qualidade do LD e a aprendizagem dos conceitos científicos. Um artigo ainda exprime a confusão conceitual presente nos próprios autores do trabalho, de início há a afirmação de que os LD seriam considerados de baixa qualidade por não apresentarem a informação de que uma reação de oxidação não ocorre apenas pela perda e ganho de elétrons, no entanto, ao concluir o trabalho os autores afirmam que o conceito de oxidação seria justamente a perda de elétrons de uma espécie.

Na revisão de literatura realizada não foram encontradas publicações que têm como objeto de investigação o LD de ciências utilizado no ensino fundamental, nem de biologia no ensino médio apesar de haver inúmeras reações redox envolvidas na aprendizagem destas disciplinas. Também não foram encontrados trabalhos que se preocupam com a presença dos modelos de reações redox. 


\title{
3. FUNDAMENTAÇÃO TEÓRICA
}

\section{Um país se faz com homens e livros.}

Monteiro Lobato

\subsection{Sobre o livro didático}

\begin{abstract}
O livro, que registra as ideias, crenças e costumes de um povo, transmitindo o conhecimento para outras gerações há de ser considerado a forma mais antiga de documentação. A história do livro é, portanto, intimamente ligada à história da humanidade (HASLAM, 2007).
\end{abstract}

Cotidianamente nos deparamos com diversos tipos de livros nas prateleiras das livrarias e, sobretudo, nas salas de aulas brasileiras. Choppin caracteriza os livros didáticos como:

[... "utilitários da sala de aula", ou seja, obras produzidas com o objetivo de auxiliar no ensino de uma determinada disciplina, por meio da apresentação de um conjunto extenso de conteúdos do currículo, de acordo com uma progressão, sob a forma de unidades ou lições, e por meio de uma organização que favorecem tanto usos coletivos (em sala de aula), quanto individuais (em casa ou em sala de aula) (CHOPPIN, 1992, p. 16, apud ROJO, 2005, p. 35).

A importância de tal ferramenta é apontada por Bittencourt (2004):

Por ser um objeto de 'múltiplas facetas', o livro didático é pesquisado enquanto produto cultural; como mercadoria ligada ao mundo editorial e dentro da lógica do mercado capitalista; como suporte de conhecimentos e de métodos de ensino das diversas disciplinas e matérias escolares; e, ainda, como veículo de valores, ideológicos ou culturais. (BITTENCOURT, 2004, p.1).

Além disso, em países com situação educacional precária, o livro pode determinar “conteúdos e condicionar estratégias de ensino, marcando, pois, de forma decisiva, o que se ensina e como se ensina o que se ensina" (LAJOLO, 1996, p. 3). O conteúdo do livro favorece ao aluno o acesso "ao conhecimento cientificamente elaborado, historicamente construído pelo homem, porém, reorganizado, reestruturado em saber escolar e que deve ser mediado pelo professor no decorrer do processo ensino-aprendizagem" (BAGANHA, 2010, p. 21). A organização desses conteúdos coloca o LD como um recurso de grande importância na construção de saberes e, por isso, este recurso tornou-se objeto de estudo de inúmeras pesquisas, legitimando o papel destes na educação escolar.

Marpica e Logarezzi (2010) realizaram um levantamento das publicações que analisam o tema educação ambiental nos livros didáticos. A descentralização das pesquisas do campo foi a principal conclusão dos autores. As pesquisas espalhadas pelo Brasil desencontram-se da centralização da produção dos livros didáticos, que ocorrem principalmente no estado de São Paulo. Apesar de não terem sido encontradas pesquisas 
nos estados do norte do país, de acordo com os critérios de seleção, as publicações estão espalhadas por território nacional. A centralização da produção num único estado é destacada de forma negativa à medida que, segundo os autores, ocorre uma marginalização de certos contextos regionais brasileiros. Os mapeamentos realizados por Emmel e Araujo (2012) e Maia e Villani (2013) coadunam com esses resultados obtidos.

Os autores, Marpica e Logarezzi (2010) ainda destacam o fato de que as publicações tecem inúmeras críticas ao conteúdo dos livros, suas abordagens, entre outros. Entretanto:

[...] não foram encontradas produções de caráter propositivo ao uso e à produção de livros didáticos, ou seja, se as falhas e lacunas dos livros didáticos são conhecidas, é importante que se faça uso desse conhecimento para se propor e sugerir materiais de melhor qualidade, exercendo a produção acadêmica o papel de ir além de denúncias e constatações. (MARPICA; LOGAREZZI, 2010, p. 126)

Além disso, destaca-se o fato de que, dentre as publicações que investigaram a temática educação ambiental, nenhuma analisou livros de química do ensino médio. Na medida em que se considera a importância da interdisciplinaridade, que é também orientada pelos documentos oficiais de ensino, existe uma lacuna nas pesquisas da área nos livros de química.

Os mesmos resultados foram encontrados por Francisco e Queiroz (2010) que analisaram as produções acadêmicas sobre os livros didáticos de 16 cursos de pósgraduação da área de ensino de ciências e matemática (área 46 da CAPES). Os autores acrescentam, também, a necessidade de ampliar as pesquisas da área, reconhecendo que outras temáticas são importantes, como: a investigação do uso real do livro pelo professor em sala de aula; como os professores associam os diferentes recursos didáticos (textos de divulgação científica, Wikipédia etc.) e, ainda, se no contexto atual há predominância na utilização do livro didático ou de outros materiais alternativos. (FRANCISCO; QUEIROZ, 2010).

Fernandes e Gouvêa (2011) levantaram os trabalhos publicados em 9 revistas da área de ensino de ciências, totalizando 50 artigos. A conclusão principal foi a expressiva porcentagem de trabalhos que analisam os conceitos presentes no livro didático com viés histórico.

Leite e colaboradores (2011) observam que muitos dos conteúdos presentes nos livros são desatualizados, não esclarecedores e muitas vezes errados; são utilizadas analogias como se fossem a verdadeira explicação para o fenômeno; os autores dos LD não promovem uma abordagem interdisciplinar e uma construção de procedimentos que 
permitam coletar, organizar e interpretar dados. Leite et al. (2011) também ressaltam que muitas vezes os professores podem não possuir formação adequada para reconhecer os erros conceituais e que, pelo contrário, utilizam os conteúdos presentes nos livros didáticos como fonte de consulta e aprendizado.

Dos mapeamentos realizados, o mais extenso, que considerou o maior número de publicações, foi produzido por Moreira (2012). As conclusões da autora referem-se às temáticas abordadas nas pesquisas e são bastante contempladas as questões de gênero, de etnia e mais recentemente a produção, indústria e circulação do livro didático. A autora conclui que:

[...] esse mesmo mapeamento nos permite evidenciar a carência de grupos de trabalhos dedicados a escrever uma história geral da literatura escolar no Brasil. Ainda não dispomos de um censo dos livros didáticos produzidos no país, de inventários das obras disponíveis, da evolução dos marcos legislativo e regulamentário, das edições escolares, da sociologia dos autores, da evolução da estrutura produtiva, da análise de sua difusão e de sua recepção, etc. (MOREIRA, 2012, p. 141).

Destaca-se que nenhuma das publicações consideradas no mapeamento realizado por Moreira (2012) abordava o livro de química, ressaltando a necessidade de pesquisas no campo da história da educação sobre a disciplina de química.

Emmel e Araujo (2012) realizaram um levantamento sobre as publicações, no período de 1999 a 2010, que tinham como foco de pesquisa o livro didático. A não participação de professores da educação básica como autores das publicações e a porcentagem baixíssima de publicações que analisam os livros didáticos da educação infantil e Educação de Jovens e Adultos (EJA) são conclusões importantes desse trabalho.

No levantamento realizado por Pedreira e Carneiro (2017) o objeto de estudo foram as publicações que investigavam os livros de biologia. As temáticas encontradas permitiram concluir que nos livros didáticos de biologia há fragmentação e simplificação de conteúdo, estereótipos e as assimetrias do gênero. Assim, outro aspecto importante que cabe destacar é a necessidade de reformulação dos $\mathrm{LD}$ em busca de uma abordagem de temas mais modernos.

No trabalho "Livros didáticos em publicações na área de ensino: contribuições para análise e escolha", Schirmer e Saurwein (2017) apontam diversas contribuições para a pesquisa na área de ensino de ciências, como por exemplo, quanto às publicações que ilustram as percepções dos alunos sobre o uso do LD:

Os resultados alcançados pelos autores podem, por um lado, apresentar aos professores resultados gerais sobre as visões dos alunos em contextos diversificados e em alguma medida generalizáveis. Por outro lado, tomar ciência das visões dos alunos sobre o LD, sua presença e seu uso na escola 
podem contribuir para o professor pensar, a partir dessas pesquisas, nas necessidades de seus próprios alunos. (SCHIRMER; SAUERWEIN, 2017, p. 30)

Quanto às publicações que ilustram as práticas dos professores que consideram o LD, Schirmer e Sauerwein $(2017$, p. 31) acrescentam que "as práticas são bastante semelhantes ao que acontecia antes do PNLD, onde os livros serviam como subsídio ao trabalho docente e de estudo aos alunos sem uma maior articulação no trabalho em sala de aula."

Além disso, os autores apontam que há uma grande variedade de critérios adotados na escolha do LD. Isso demonstra uma falta de consenso quanto aos critérios e os resultados pouco falam sobre o que os professores realmente pensam sobre eles. Outra conclusão destacada é de que:

[...] percebe-se que, em relação à escolha e uso de LD, ainda predominam pesquisas do tipo diagnóstico. O baixo número de propostas efetivas de investigações sobre práticas formativas relacionadas aos processos de análise, escolha e uso de LD pode ser associado a certo descompasso entre a pesquisa e a prática educacional, já diagnosticada na área de pesquisa em Ensino e Educação. (SCHIRMER, SAUERWEIN, 2017, p. 34)

Em suas conclusões finais os autores destacam o descompasso existente entre as duas pesquisas predominantes sobre os LD. Há uma diversidade de pesquisas sobre: análise, escolha e uso do LD e aspectos conceituais e metodológicos. Mas elas "não conversam entre si", ou seja, é necessário que haja um movimento de unificação entre esses dois tipos de pesquisas em busca de melhoras no processo de escolha, no uso deste recurso e nas relações que se estabelecem por meio dele. (SCHIRMER; SAUERWEIN, 2017).

O expressivo número de mapeamentos realizados sobre as produções acadêmicas, que têm como enfoque a análise de temas pertinentes ao LD, permite depreender algumas conclusões. Primeiramente, destaca-se que o número de publicações tem aumentado após o ano de 2004, o histórico do PNLD pode trazer indícios do motivo desse aumento à medida que em 2003 é publicada a Resolução CD FNDE nº. 38, de 15/10/2003, que institui o Programa Nacional do Livro Didático para o Ensino Médio (PNLEM). Segundo, há um baixíssimo número de produções acadêmicas cujo foco de pesquisa seja o livro didático do ensino superior, esta conclusão já é apontada por Francisco e Queiroz (2011), que constataram que nenhuma das publicações atendiam esse nível de ensino:

Este fato é preocupante, pois no Ensino Superior se dá a formação de bacharéis e licenciandos que irão disseminar os conhecimentos e concepções sobre a natureza da Química na sociedade. Persiste assim o questionamento em relação aos LD nos cursos de graduação, não somente em relação a erros conceituais 
que porventura neles existam, mas também quanto à sua atualidade; (FRANCISCO, QUEIROZ, 2011, p. 8)

Outra conclusão importante é a baixíssima produção na região Norte do país. A centralização das produções acadêmicas é na região Sudeste, lideradas pela USP em quase todos os mapeamentos realizados. Nesse sentido é importante destacar que a maior parte das editoras participantes do PNLD também se concentram nessa região. O aumento na produção da região Norte é de suma importância uma vez que elementos como a regionalização podem não estar sendo considerados nos LD.

Salienta-se também que a produção, circulação, avaliação e utilização deste recurso envolve diferentes esferas como editoras, programas oficiais, professores, alunos e a sociedade como um todo. Portanto, ocorrem embates nos interesses da aplicabilidade do LD na educação (BUNZEN, 2007).

Porém, não se pode esquecer que o LD é um objeto, um material estático e que só se pode exigir dele se sua estrutura e seus limites forem compreendidos. Além disso, diante da importância atribuída a esse recurso didático, destaca-se ser necessário aprimorar o padrão de qualidade daqueles adotados na rede pública da educação básica. Nesse intuito, o PNLD assume um papel de relevância no sistema educacional brasileiro.

O PNLD é um programa federal que têm por objetivo equipar as escolas de ensino fundamental, médio e EJA com livros didáticos e acervos de obras literárias, didáticas e pedagógicas. Ao todo são 12 etapas de funcionamento do programa que levam até a escolha de quais coleções serão utilizadas nas escolas brasileiras.

Além disso, o PNLD é um dos programas do governo brasileiro que mais está presente nas escolas. Ele é um programa mantido e organizado pelo Fundo Nacional de Desenvolvimento da Educação (FNDE). Em termos de valores financeiros destinados aos programas de assistência escolar, o PNLD é o segundo maior, estando atrás apenas do Programa Nacional de Alimentação Escolar (PNAE), conhecido popularmente como merenda escolar. Somente no ano de 2017 o FNDE destinou R\$ 1.246.729.168,56 para aquisição de 144.743.355 exemplares de livros ao ensino fundamental e médio.

A aquisição dos livros pelo PNLD beneficia anualmente 40 milhões de estudantes, em 140 mil escolas de todo o Brasil. Dessa forma, as pesquisas que tem como objetivo analisar os LDs alcançam diretamente a grande maioria dos alunos da educação básica.

No entanto, a implementação de políticas públicas nacionais não acresce resultados significativos, se na escolha do livro o professor não considerar que: 
nas necessidades e possibilidades que lhe são características, o contexto real de vida dos alunos (NÚÑEZ, 2003, p.3).

Além disso, os professores devem estar atentos ao que os documentos oficiais de ensino determinam para o conteúdo do LD, mas estes são formulados segundo as tendências e concepções pedagógicas de cada autor e editora. Ainda, com o aumento significativo da sua produção, há no mercado mais opções que demandam mais trabalho na escolha do material realmente adequado ao contexto dos alunos.

A escolha dos livros exige, portanto, competências e saberes além dos conhecimentos de docência, pois, conforme aponta Silva (2015, p.46), essa seleção:

\section{[...] se relaciona diretamente com a formação inicial e formação continuada do docente, pois para estar apto a selecionar um LD com maior criticidade e eficácia, o professor necessita de uma orientação prévia e estudos sobre os avanços científicos relacionados ao seu objeto de ensino.}

Apesar disso, Silva e Marques (2016) apontam que o conteúdo contido no PNLD é de conhecimento de poucos professores. As autoras afirmam que a maioria dos professores não acompanham as diversas pesquisas e discussões que vêm estabelecendo o LD nos campos político, social e educativo.

Silva (2015) acrescenta que os professores têm de reconhecer a importância dos documentos legais ao adotar os LD, para isso, deve-se repensar as práticas pedagógicas, assim como a compreensão da relevância do processo de seleção dos LD.

\subsubsection{Função e uso do livro didático}

Mesmo ao longo de tantas transformações na sociedade, o LD cumpre diversas funções no processo de ensino-aprendizagem. Os usos variam para cada professor, há aqueles que os utilizam de forma complementar ao ensino (quando se busca diferentes exercícios e imagens); ou como instrumentos para gestão das aulas, do planejamento escolar, e do currículo. Diversas pesquisas apontam quais os principais usos e papéis que este importante instrumento ocupa no espaço escolar.

Segundo Seguin (1989) os LD apresentam-se aos professores como uma coleção de conhecimentos organizados, estabelecendo o roteiro de trabalho anual e diário ao constituir as atividades na sala de aula, e ainda ocupa os alunos durante horas extraclasse.

Para Gerard e Roegiers (1998) os LD podem ter seis funções essenciais: transmissão de conhecimentos; desenvolvimento de capacidades e de competências; consolidação das aquisições de aprendizagem; avaliações das aquisições; ajuda na integração das aquisições; e educação social e cultural. Em suma, o LD contém 
referências didáticas e de conteúdo para o professor que procura completar as suas informações científicas e pedagógicas.

Na França, Metoudi e Duchauffour (2001, apud JUNIOR; REGNIER, 2008) apontam que os professores utilizam o livro didático como complemento do curso ministrado ou para a resolução de exercícios.

Textos didáticos podem construir "de diferentes modos a relação entre os alunos e os objetos de conhecimento, entre os professores e seus alunos, entre o professor e sua prática de ensino" (BATISTA, 2002, p. 566). Desta forma, eles servem como organizador do trabalho de ensino do professor; complemento ao aprendizado do aluno; referência às atividades escolares; instrumento de consulta ou de acesso a documentos textuais e iconográficos.

O LD, ao reunir o conteúdo em unidades/capítulos, atua como suporte ao conhecimento e na preparação de aulas, além de auxiliar o aluno. Desta forma, WUO (2002) afirma que o mesmo atua como um mediador entre o saber científico, que seria a referência, e a matéria transposta didaticamente para o ensino em sala de aula. Este autor ainda afirma que:

Com um caráter disciplinante, e conforme a "lógica" que o orientou, o livro didático organiza os dados, ordena as atividades pedagógicas, pode sugerir atividades complementares, apresentar soluções variadas e estimuladoras que favoreçam uma aprendizagem mais criativa, trazendo situações do cotidiano, explicações de fenômenos interessantes, apresentação de tópicos mais avançados, resolução de problemas mais elaborados, etc. (WUO, 2002, p.164).

Gerard e Roegiers (2003, apud JUNIOR; REGNIER, 2008) abordam quatro funções complementares para os livros didáticos: (i) formação científica e geral que oferece aos professores o saber propriamente dito; (ii) formação pedagógica na sugestão de diferentes metodologias de trabalho; (iii) ajuda na gestão de um curso fornecendo numerosos instrumentos que permitem melhorar a aprendizagem; e (iv) ajuda à avaliação, ao permitir explicitar os erros e de propor vias de melhoria.

Megid Neto e Fracalanza (2003) investigaram o uso que professores alegavam fazer do LD em suas práticas, concluindo que os mesmos os fazem de acordo com três diferentes funções. Em (i) planejamento, os professores utilizam várias coleções didáticas para elaborar o planejamento anual ou preparar aulas ao longo do ano letivo. Em (ii) recurso de apoio, são utilizados textos, exercícios, outras atividades, imagens, fotos, desenhos, gráficos em atividades de ensino-aprendizagem em sala de aula ou extraescolares. E por fim (iii) fonte bibliográfica, em complemento à sua formação ou em pesquisas escolares realizadas pelos alunos. 
Bittencourt (2004) destaca a importância deste recurso como um instrumento de tradição escolar.

Choppin (2004), além de diferenciar os conceitos de manual escolar e livro didático relaciona quatro funções específicas do livro didático. A primeira função, referencial (curricular ou programática), indica que o livro se constitui num fiel tradutor dos programas de ensino e depositário dos conhecimentos, técnicas ou habilidades que sejam consideradas necessárias para se transmitir a outras gerações. A segunda função, instrumental, propõe métodos para resolução de problemas; aquisição de habilidades, exercícios para facilitar a memorização dos conhecimentos e etc. Na terceira função, ideológica e cultural, o livro é considerado "vetor essencial da língua, da cultura e dos valores das classes dirigentes" e instrumento para a construção da identidade. E na quarta função, documental, o livro é instrumento para armazenamento de documentos textuais, literais ou icônicos possíveis de desenvolver o senso crítico dos alunos.

O LD assume diferentes funções como, por exemplo, direcionador do currículo; material de apoio ao professor/aluno; fonte de informação e de pesquisa; organização dos métodos de ensino, e mediador entre os diferentes saberes que constituem os conteúdos escolares. (SELLES, FERREIRA, 2004).

No contexto do ensino de matemática, Assude e Maolinas (2005) abordam que utilizando o livro didático, o professor possui uma quádrupla aprendizagem: elementos a serem ensinados; elementos lógicos subjacentes, atividades e suporte à condução da aprendizagem dos alunos, correlato à função de currículo apontada por outros autores.

Bruillard (2005) e Silva Junior (2005) apontam que o LD se constitui como um recurso que pode fornecer ajuda teórica, base de sugestões pedagógicas, informações científicas em geral, formação pedagógica ligada à disciplina, gestão das lições, e ajuda na avaliação das aquisições. Os autores ainda afirmam que, em geral, este uso é presente quando o professor não se sente especialista na disciplina abordada na classe.

Para Santos e Carneiro (2006) os LD podem assumir essencialmente três grandes funções: (i) de informação, (ii) de estruturação e organização da aprendizagem e, finalmente, (iii) a função de guia do aluno no processo de apreensão do mundo exterior (que pode induzir uma atividade livre e criativa ou a simples imitação de modelos de apreensão do real).

Junior e Regnier (2008) analisaram as funções e o uso do LD de matemática no contexto brasileiro e francês, segundo os autores o LD também assume três funções: (i) ferramenta de utilização didática/profissional, onde o livro atua como um recurso na 
preparação das aulas, avaliações e condução da aprendizagem; (ii) formação complementar, o LD seria o currículo praticado/a ser seguido pelos professores, fonte de informações científicas para auto formação, e por último (iii) formação profissional, o LD como um instrumento que o professor pode contar buscando tratar as consequências de uma formação inicial deficiente.

O livro didático cumpre também o papel de apresentar os saberes a serem ensinados de forma organizada, diferente da produção acadêmica, permitindo às novas gerações a comunicação com o conhecimento científico. (BAGANHA, 2010)

Segundo Quesado (2012), o LD ao fornecer orientação ao professor e ao aluno nas diversas organizações do ensino, é considerado como um referencial para a construção do currículo escolar.

Figueiredo (2017) pesquisando as ações de uma professora frente ao uso de um LD, afirma que no contexto analisado ele teve papel de "norteador da prática pedagógica", ocupando um lugar de destaque, pois as atividades foram pensadas e dirigidas de acordo com os propósitos do LD, mesmo em atividades complementares os exemplares assumiam o papel de material de apoio e consulta.

Em suma, as pesquisas mostram que os LD podem assumir diferentes funções, no quadro 1 são resumidas aquelas apontadas no texto. 
Quadro 1 - As principais funções dos LD nas práticas pedagógicas

\begin{tabular}{|c|c|}
\hline Função & Fonte \\
\hline Norteador da prática pedagógica & Figueiredo (2017) \\
\hline Referencial para currículo escolar & Quesado (2012) \\
\hline Apresentar o conhecimento cientifico & Baganha (2010) \\
\hline Formação profissional & \multirow{3}{*}{$\begin{array}{l}\text { Silva Junior e Regnier } \\
\text { (2008) }\end{array}$} \\
\hline Formação complementar & \\
\hline Ferramenta de utilização didática/profissional & \\
\hline Informação & \multirow{3}{*}{$\begin{array}{l}\text { Santos e Carneiro } \\
(2006)\end{array}$} \\
\hline Estruturação e organização da aprendizagem & \\
\hline Guia do aluno no processo de apreensão do mundo exterior & \\
\hline Base de sugestões pedagógicas & $\begin{array}{l}\text { Bruillard }(2005) \\
\text { Silva Junior }(2005)\end{array}$ \\
\hline O que ensinar, como ensinar & $\begin{array}{l}\text { Assude \& Maolinas } \\
(2005)\end{array}$ \\
\hline $\begin{array}{l}\text { Direcionador do currículo, material de apoio/informação, } \\
\text { organizador de métodos e mediador dos saberes escolares }\end{array}$ & $\begin{array}{l}\text { Selles e } \quad \text { Ferreira } \\
(2004)\end{array}$ \\
\hline Referencial & \multirow[t]{4}{*}{ Choppin (2004) } \\
\hline Instrumental & \\
\hline Ideológica e cultural & \\
\hline Documental & \\
\hline Comunicação, produção e transmissão de conhecimentos & \multirow{4}{*}{$\begin{array}{l}\text { Bittencourt (2004) } \\
\text { Fracalanza e Megi } \\
\text { Neto (2003) }\end{array}$} \\
\hline Planejamento & \\
\hline Recurso de apoio & \\
\hline Fonte bibliográfica & \\
\hline Mediador entre o saber científico e aquele a ser ensinado & \multirow{3}{*}{$\begin{array}{l}\text { Wuo (2002) } \\
\text { Batista (2002) } \\
\text { Metoudi } \\
\text { Duchauffour (2001) }\end{array}$} \\
\hline Construidor de relações no ambiente escolar, & \\
\hline Complemento às aulas & \\
\hline Transmissão de conhecimentos & \multirow{6}{*}{$\begin{array}{l}\text { Gerard e Roegiers } \\
(1998)\end{array}$} \\
\hline Desenvolvimento de capacidades e de competências & \\
\hline Consolidação das aquisições de aprendizagem & \\
\hline Avaliações das aquisições & \\
\hline Ajuda na integração das aquisições & \\
\hline Educação social e cultural & \\
\hline
\end{tabular}

São numerosos os usos relacionados no quadro 1, porém, uma leitura mais apurada permite agrupá-los em algumas funções principais, nas quais todas as apontadas pelos pesquisadores encaixam-se, são elas:

I. Currículo: o LD é entendido como um exemplar do currículo que se pretende implantar no espaço escolar, ele pode ser determinado pelos documentos orientadores de ensino no domínio público, ou ainda pela concepção pedagógica de colégios particulares que transmitem às páginas dos $\mathrm{LD}$ o que deve ser ensinado e como ensinar, nesse sentido o livro orienta os métodos de ensino, a forma que se avalia, e os objetivos de aprendizagem ao longo de um capítulo ou ano. A noção de currículo nesses casos é de aplicação dos conteúdos determinados oficialmente.

II. Referencial do conhecimento: o conteúdo apresentado no LD pode significar o "conhecimento pronto e acabado da ciência" transposto didaticamente, no qual o 
professor respalda-se no intento de diminuir deficiências da sua formação ou um recurso de pesquisa extraclasse aos alunos.

III. Recurso de apoio: o professor não o utiliza da primeira à última página ao longo do ano letivo, mas sim em momentos pontuais. São usados exercícios, imagens, propostas de atividades diferenciadas e diferentes avaliações em mudança da prática escolar.

IV. Instrumento cultural: quando se compreende que nas páginas do LD é apresentado o "mundo externo" ao aluno, aquele do qual se quer ensinar/aprender. Nesse sentido ele pode ser um "vetor essencial da língua, da cultura e dos valores das classes dirigentes" (CHOPPIN, 2004, p. 553), e auxilia no desenvolvimento de habilidades e competências.

Especificamente sobre o uso dos livros de ciências e de química, Schnetzler (2010, p. 159) comenta:

[...] os professores de Ciências/Química geralmente atuam como transmissores mecânicos de conteúdos de livros didáticos, não se envolvendo com práticas inovadoras e repassando aos alunos fatos, informações, conceitos de maneira assistemática e descontextualizada histórica e socialmente.

Os professores o fazem assim desconsiderando que o livro de ciências é constituído como representante da comunidade científica no contexto escolar. Representar a comunidade científica é trazer para a sala de aula as ciências naturais para que o aluno compreenda e explique o mundo em que vive. (NÚÑEZ et al., 2003).

Nesse processo, Núñez e colaboradores (2003, p.3) ainda complementam que:

É nele que as ciências devem dialogar com outros tipos de saberes, como uma obra aberta, problematizadora da realidade, que dialoga com a razão para o pensamento criativo. Nele a Ciência se deve apresentar como uma referência fruto da construção humana, sócio historicamente contextualizada, na dinâmica do processo que lhe caracteriza como construção, e não como um produto fechado, como racionalidade objetiva única que mutila o pensamento das crianças.

O conhecimento apresentado aos professores e seus alunos pelos LD de Ciências "situa-se entre uma versão adaptada do produto final da atividade científica e uma versão livre dos métodos de produção do conhecimento científico" (FRACALANZA; MEGID NETO, 2003, p. 154). Nesse sentido, o conteúdo apresentado, infelizmente, coloca o conhecimento cientifico como produto acabado, verdade absoluta que não se vincula ao contexto histórico e sociocultural e, portanto, é elaborado por pessoas privilegiadas isentas de ideologias e interesses políticos e econômicos (AMARAL; MEGID NETO, 1997) e mais, realçam o método empírico-indutivo em detrimento da apresentação da 
diversidade de métodos na construção histórica do conhecimento científico. (PRETTO, 1985; FRACALANZA, 1993; BRASIL, 1994; AMARAL et al. 1999).

Em uma constatação também alarmante, Fracalanza e Megid Neto (2003) destacam o fato de que, mesmo havendo todas as pesquisas e processos de avaliação da qualidade dos LD, ocorre uma padronização dos LD utilizados, e salvo raras exceções, apresentam conteúdos idênticos, com sequências e exemplos bastante semelhantes e atividades/sugestões similares. Os autores apontam então algumas alternativas e possiblidades para minimizar as consequências do uso de tais livros, classificados pelos autores como de baixa qualidade: a) Investimento na divulgação dos diversos estudos e pesquisas disponíveis, para que as discussões sobre as deficiências dos LD sejam aprofundadas e assim a produção de novos recursos (ou diferentes maneiras de uso dos recursos disponíveis) sejam estimuladas; b) Produção de livros paradidáticos e c) Reedição de projetos curriculares de ensino, levando-se em consideração os inúmeros projetos alternativos existentes.

\subsection{As reações redox}

Dans la nature, rien n'est créé, rien n'est perdu, tout est transformé.

Antoine Laurent de Lavoisier

\subsubsection{O conceito redox}

As reações redox são uma classe de reações químicas versáteis e muito presentes no cotidiano. Fazem parte desta classe a combustão, a ferrugem, a fotossíntese, o metabolismo de alimentos, a extração e corrosão de metais, a respiração celular, a queima de combustíveis fósseis, a produção de ATP, o processo de revestimento de objetos com metais, as pilhas e baterias que movimentam os brinquedos e eletrônicos, entre outros. $\mathrm{O}$ nome 'redox' refere-se à associação das reações de REDução e OXidação, o mesmo acontece nas formas oxirredução e óxido-redução. Do ponto de vista químico as reações de oxidação e redução são governadas por um único processo, a transferência de elétrons:

A transferência de elétrons de uma espécie para outra é hoje reconhecida como a etapa essencial da oxidação e os químicos definem oxidação como sendo a perda de elétrons, desconsiderando as espécies para as quais os elétrons migram.

[...] Em uma redução, um átomo ganha elétrons de outra espécie. Sempre que a carga diminui, dizemos que houve redução. A mesma regra se aplica se a carga é negativa. (ATKINS e JONES, p. 98, 2012) 
Redox refere-se à associação das reações de oxidação e redução, pois, como o processo envolve ganho ou perda de elétrons sempre que uma espécie se oxida, outra tem que reduzir. Os elétrons são partículas que não podem "sumir" ao longo de um processo, por isso ambas as reações de oxidação e redução tem que ocorrer simultaneamente.

Ganhar ou perder elétrons tem um efeito direto na densidade eletrônica do átomo, íon ou molécula que participa da reação, isso acarreta numa diferença do número de oxidação da espécie entre o começo e final do processo. O número de oxidação é, portanto, a carga elétrica que o elemento adquire quando faz uma ligação iônica ou a carga parcial $(\delta)$ que o elemento adquire quando faz uma ligação covalente, que irá depender da eletronegatividade do elemento. Para uma reação de oxidação há aumento no número de oxidação, enquanto que numa redução ocorre a diminuição do número de oxidação. (ATKINS e PAULA, 2008)

Outro conceito importante a destacar são os agentes que participam da reação. Como a reação redox é um processo simultâneo, ao se reduzir, ou seja, aceitar os elétrons liberados na reação, uma espécie promove a oxidação da outra e, portanto, é chamada agente oxidante. Dessa forma o agente redutor fornece os elétrons da reação enquanto ele mesmo é oxidado. A identificação do redutor ou oxidante ocorre pela comparação entre o número de oxidação antes e depois da reação.

A compreensão de todos esses termos é muito importante para que o aluno consiga entender o processo e também possa compreender e efetuar o balanceamento de uma reação de oxirredução. $\mathrm{O}$ balanceamento pode ser realizado por vários métodos como o método de tentativa, o uso de semirreações, o balanceamento do número de oxidação, entre outros.

\subsubsection{A eletroquímica}

O estudo do modo como ocorrem as reações de transferência eletrônica e a produção de eletricidade por meio delas abrange o ramo da química denominado Eletroquímica. No nível básico o conteúdo de eletroquímica é dividido nos temas de pilhas e baterias e eletrólise.

O tema pilhas e baterias inicia o conteúdo de eletroquímica introduzindo os conceitos de cátodo e ânodo, potencial-padrão de redução, circuito elétrico e força eletromotriz. Esses conceitos são importantes para diferenciar o processo químico envolvido nas pilhas e na eletrólise, esta diferença tem a ver com a espontaneidade do processo. 
A pilha mais frequentemente abordada no nível básico é a pilha galvânica, que é uma célula eletroquímica que produz eletricidade como resultado de uma reação espontânea ocorrendo dentro dela. Uma célula eletroquímica é um dispositivo onde produz-se um fluxo de elétrons através de um circuito por intermédio de uma reação espontânea, ela é constituída por:

Dois eletrodos, ou condutores metálicos, em contato com um eletrólito, um
condutor iônico (que pode ser uma solução, um líquido ou um sólido). Um
eletrodo e o eletrólito com que está em contato constituem o compartimento
eletródico. Os dois eletrodos podem partilhar o mesmo compartimento. [...] Se
os eletrólitos forem diferentes, os dois compartimentos podem ser unidos por
uma ponte salina, que é um tubo contendo uma solução concentrada de
eletrólito. A ponte salina completa o circuito elétrico e possibilita a operação
da célula. (SHRIVER, ATKINS, 2003, p.192)

Os processos de redução e oxidação que resultam na reação numa célula eletroquímica ocorrem espacialmente separados, ou seja, em compartimentos diferentes para que a corrente elétrica produzida possa ser aproveitada. No avanço de uma reação de oxidação, os elétrons liberados em um eletrodo deslocam-se através do circuito externo entrando na célula por meio do outro eletrodo. A entrada no outro eletrodo permite que ocorra a reação de redução. O eletrodo onde ocorre a oxidação é chamado de ânodo, enquanto que o eletrodo onde ocorre a redução chama-se cátodo.

As espécies que sofrem redução retiram elétrons do eletrodo metálico, esse eletrodo fica então com excesso de carga positiva. Já as espécies que sofrem oxidação transferem elétrons para o ânodo, deixando o eletrodo com excesso de carga negativa. Por isso em uma pilha galvânica o cátodo tem um potencial elétrico mais elevado que o ânodo.

O potencial elétrico, para física, é uma grandeza que descreve o campo elétrico gerado por uma carga. Nesse sentido, o potencial elétrico seria a quantidade necessária de trabalho para mover uma carga unitária de um ponto a outro contra um campo elétrico. Na química o alto potencial de célula caracteriza a capacidade que a reação tem de "empurrar" e "puxar" elétrons. O potencial da célula tem relação com a energia livre de Gibbs (que mede a espontaneidade) de uma reação e a diferença de potencial produzida por ela. (ATKINS e PAULA, 2012)

Quando se tem o potencial máximo que pode ser produzido pelo trabalho máximo de não expansão, tem-se uma diferença de potencial de célula. Ao medir-se o potencial quando todas as espécies estão em seu estado padrão, tem-se o potencial-padrão da célula, que pode ser o potencial-padrão de redução ou de oxidação. 
A medida do potencial-padrão de um eletrodo isolado é impossível, no entanto, os químicos atribuem a um determinado eletrodo o potencial zero. Como a pilha galvânica é a combinação dos dois eletrodos para o potencial global da pilha, a diferença do outro eletrodo em relação a este zero convencional determina o potencial dos outros eletrodos. O eletrodo tomado como referência é o eletrodo-padrão de hidrogênio. Na medida do outro par faz-se a montagem de uma pilha em que o eletrodo de interesse é o da direita e o eletrodo-padrão de hidrogênio é o eletrodo da esquerda. (ATKINS e PAULA, 2012)

Há uma convenção para escrever a estrutura dos compartimentos dos eletrodos de células galvânicas. À esquerda da notação tem-se o ânodo, e na direita o cátodo. Uma linha vertical representa uma interface entre fases. A interface entre as fases pode ser de diferentes tipos, o mais comum é o uso de uma ponte salina, utilizada para unir os dois compartimentos de eletrodo e permitir o fluxo de elétrons, completando o circuito elétrico. Um exemplo de notação das células galvânicas é:

$$
\mathrm{Zn}_{(\mathrm{s})}\left|\mathrm{Zn}_{(\mathrm{aq})}^{+2}, \mathrm{Cl}_{(\mathrm{aq})}^{-}\right| \mathrm{Cu}_{(\mathrm{s})}
$$

Esta notação é particularmente importante pois o sinal do potencial de célula, de acordo com o diagrama montado, é igual ao do eletrodo que está à direita. Um potencial de célula positivo indica que o eletrodo que está à direita no diagrama é o cátodo, já um potencial negativo indica que o eletrodo à direita é o ânodo. Além disso, quanto mais negativo for o potencial-padrão de um eletrodo, maior será sua força como redutor. E as muitas diferenças entre as forças dos redutores determinam a série eletroquímica, e proporcionam a construção dos diferentes tipos de pilhas e baterias existentes. (CASTELLAN, 1986)

Os tipos de pilhas mais trabalhados no ensino médio são as pilhas secas ácidas, pilhas secas alcalinas (que diferem entre si pelo reagente da pasta úmida), as pilhas de zinco/óxido de prata, as pilhas de lítio/iodo ou de lítio/dióxido de manganês. Já as baterias, que são dispositivos construídos pela associação de duas ou mais pilhas conectadas em série ou paralelo, os tipos mais trabalhados são: "Nobreak" bateria de chumbo/água, bateria de níquel/cádmio, bateria de níquel/hidreto metálico, baterias de íon lítio, baterias de automóveis e células combustível.

Sobre a história das pilhas, Leicester (1971) aponta que a Pilha de Volta foi o primeiro gerador eletroquímico conhecido. Para sua construção, Alessandro Volta empilhou discos de metais diferentes tais como $\mathrm{Cu} / \mathrm{Sn}$ ou $\mathrm{Zn} / \mathrm{Ag}$, separou-os por pedaços de papel ou tecido umedecidos com água salgada. Mesmo desconhecendo o papel que a água salgada desempenhava no experimento, foi estabelecido evidências para a existência 
da eletricidade metálica através da construção da "pilha" voltaica. Já em 1836, John Frederic Daniell desenvolveu a primeira bateria que produzia uma corrente elétrica constante durante um longo período de tempo. (RIBEIRO, 2013) A pilha da Daniell, como ficou conhecida, tem dois fluidos em compartimentos separados ligados por uma ponte salina que fecha o circuito. A utilização de dois eletrólitos, e não um, permitiu a inovação da pilha. Outra pilha que também se tornou famosa é a Pilha de Leclanché, também chamada de pilha seca ou pilha comum. Ela é um dispositivo formado por um cilindro de zinco metálico que funciona como ânodo separado por um papel poroso. $\mathrm{O}$ cátodo é o eletrodo central formado por grafite, camada de dióxido de manganês, carvão em pó e uma pasta úmida de cloreto de amônio/cloreto de zinco. Esta pilha tem esse nome pois foi inventada em 1865 por Georges Leclanché. (RIBEIRO, 2013)

A eletrólise faz parte da área de eletroquímica pela semelhança com os estudos sobre as pilhas e baterias, mas os fenômenos são fundamentalmente diferentes. Uma eletrólise é uma reação redox não espontânea, para que ela ocorra é necessário fornecer energia na forma de corrente elétrica.

O fenômeno da eletrólise ocorre em uma célula eletrolítica. Como o intuito é fornecer corrente elétrica para que ela ocorra, o arranjo de uma célula eletrolítica é diferente de uma célula galvânica:

Em geral, os dois eletrodos ficam no mesmo compartimento, só existe um tipo de eletrólito e as concentrações e pressões estão longe das condições padrões. Como em todas as células eletroquímicas, a corrente passa pelo eletrólito, carregada pelos íons presentes. (ATKINS e JONES, p.542-543, 2012)

A oxidação em uma eletrólise ocorre no ânodo e redução no cátodo, os elétrons passam do ânodo para o cátodo por intermédio de um fio externo, os cátions movem-se pelo eletrólito na direção do cátodo e, os ânions, na direção do ânodo; assim como em uma célula galvânica. No entanto, é necessário fornecer corrente para que os elétrons passem pelo fio em uma determinada direção. O fornecimento de corrente em uma eletrólise pode ser por uma célula galvânica, como uma bateria recarregável.

Para forçar uma reação no sentido não espontâneo a fonte externa deve gerar uma diferença de potencial maior do que a diferença de potencial que seria produzida pela reação espontânea. Esta diferença a mais é chamada de sobrepotencial. Se existe na solução mais de uma espécie que pode ser reduzida/oxidada, as espécies com maiores potenciais são, preferencialmente, reduzidas/oxidadas. (ATKINS e PAULA, 2012)

Pode-se estabelecer uma relação estequiométrica entre as espécies reduzidas ou oxidadas e a quantidade de elétrons fornecida na reação. Nesse caso, o número de elétrons 
necessários para reduzir uma espécie está relacionado aos coeficientes estequiométricos da meia-reação de redução e pode ser determinada pela corrente e o tempo de fluxo da corrente. (ATKINS e PAULA, 2012)

Fornecer corrente para a ocorrência da eletrólise é viável devido às inúmeras aplicações do processo. As principais aplicações são a extração eletrolítica do alumínio e magnésio, o refino do cobre, a produção de metais a partir de seus sais, a eletrodeposição para proteção de materiais, a preparação do cloro, flúor e hidróxido de sódio, a proteção catódica, a galvanização para evitar corrosão, entre outros.

Nos cálculos relacionados à eletrólise também é possível prever a massa das substâncias que serão formadas, partindo da relação entre a quantidade de eletricidade que percorre o sistema eletrolítico e a massa molar das substâncias envolvidas. Esta relação é calculada pelas leis de Faraday. (ATKINS e PAULA, 2008)

A abordagem da história da eletrólise entrelaça-se com a das pilhas e baterias à medida que os estudos sobre a eletricidade levaram às descobertas da pilha elétrica de Volta, e o uso dessa fonte de energia levaram à decomposição da água nos gases hidrogênio e oxigênio, realizada por Anthony Carlisle (1768-1840) e William Nicholson (1753-1815). (RIBEIRO, 2013)

A utilização da eletricidade para decomposição da água aperfeiçoou o método de análise da eletrólise, no entanto, como os cientistas ainda não conheciam as causas do fenômeno da eletricidade, isso levou a um considerável aumento dos estudos sobre a natureza elétrica da matéria. Humphry Davy (1778-1829), também utilizou a eletricidade como um novo meio de estudo da matéria, e conseguiu decompor em 1807 a potassa e a soda (álcalis cáusticos) fundidas, que levaram à descoberta do potássio e do sódio, metais que não tinham ainda sido isolados, principalmente, devido à alta reatividade química que os caracteriza. (RIBEIRO, 2013) Com o mesmo método da eletrólise, o cientista ainda conseguiu obter o magnésio, o cálcio, o estrôncio e o bário. Segundo Oki (p. 36, 2000), "a partir deste período, esta forma de energia passou a ser usada para cindir espécies químicas até então difíceis de serem decompostas, iniciando uma grande transformação na química”.

\subsubsection{Modelos de reações redox}

Os modelos científicos, ou seja, aqueles usados na ciência, são criados por cientistas em busca da explicação de fenômenos. Em geral, eles são teóricos ou matemáticos e supõem que exista uma relação entre sistemas distintos, nesse sentido eles 
devem satisfazer dois critérios: serem conceitualmente compreensíveis e produtivos. Em virtude disso eles são submetidos a críticas. Por vezes eles são revisados, ampliados e ganham aceitação e disseminação, ou são descartados. Mas um modelo apenas "capta elementos, selecionados por quem o constrói, daquilo que ele representa e, portanto, é da natureza dos modelos serem incompletos.” (BORGES, 1999, p. 66-67).

Os modelos científicos são ferramentas que ajudam na interpretação dos dados, geram previsões e consequentemente desenvolvem a ciência. Muitas vezes, de acordo com o objeto de pesquisa, os modelos podem ser simplificados e aspectos podem ser descartados. Assim, os modelos aparecem sob diferentes formas. (GILBERT; BOULTER 1998).

A educação científica por vezes utiliza um modelo diferente daquele proposto pelos cientistas na tentativa de tornar a ciência compreensível (JUSTI; GILBERT, 2002). Sem esse procedimento seria quase impossível ensinar entidades não observáveis, como fluxo de elétrons ou processos químicos. (HARRISON, 2000; HARRISON; TREAGUST, 1998). Esses modelos são definidos como modelos didáticos e são muito presentes nos LD.

Diversas pesquisas apontam, no entanto, que os estudantes têm muitas dificuldades em compreender completamente o uso dos modelos para explicar um fenômeno (BORGES, 1997; PIETROCOLA, 1999; BOULTER; BUCKLEY, 2000). Isso pode ser decorrente do fato de que não é explicado o porquê criou-se aquele modelo, nem como ele explica o fenômeno estudado, nem como os modelos conectam-se entre si (BOULTER; BUCKLEY, 2000). Assim, a introdução de um novo modelo deve vir acompanhada de uma explicação sobre a forma como ele difere do anterior e da justificativa para a mudança. (CARR, 1984).

A literatura apresenta que são utilizados diferentes modelos didáticos para explicar as reações redox. Porém, os autores de livros didáticos e professores não explicam a transição entre esses modelos, nem porque um modelo melhor se encaixa em determinado contexto (ÖSTERLUND, BERG e EKBORG 2010; RINGNES, 1995).

Os diferentes modelos redox a serem apresentados são um instrumento hermenêutico que, portanto, têm limites e um campo de validade circunscrito. Tal campo de validade é distinto, mas com sobreposições que permitem interpretar um mesmo fenômeno por mais de um modelo. Assim, entende-se que cada modelo não é a extensão um do outro. (GHIBAUD, et al. 2015). 
Ringnes (1995) sistematizou os modelos nos quais os conceitos de oxidação e redução estão relacionados, são eles: modelo de oxigênio, modelo de hidrogênio, modelo de transferência eletrônica e o modelo de número de oxidação. Eles são descritos a seguir.

\subsubsection{O modelo de oxigênio}

O modelo de oxigênio aparece no desenvolvimento da química junto com o primeiro exemplo de diferenciação de uma reação de oxirredução de outros fenômenos observados na época. Em contraposição à teoria do flogisto, Lavoisier cunha o termo oxidação e o define como sendo o conjunto de reações que envolvem o oxigênio. Nestas reações a oxidação do ferro pela água ou de metais pelos ácidos seriam reações diretamente relacionadas à ação do oxigênio. Nesse sentido uma redução seria a separação do oxigênio de um corpo. (GHIBAUDI, et al., 2015).

Embora esse seja um simples critério de classificação de reações químicas e não necessariamente um modelo interpretativo, este foi o primeiro exemplo da definição de reações redox como fenômenos substancialmente distintos de outros tipos de transformações químicas. (GHIBAUDI, et al., 2015).

O uso desse modelo é bastante destacado na química orgânica juntamente ao modelo de hidrogênio, conforme explica Vollhardt e Schore, 2013, p. 297:

\footnotetext{
Reconhecemos de imediato os processos inorgânicos de oxidação e redução como correspondentes à perda e ao ganho de elétrons, respectivamente. No caso dos compostos orgânicos, nem sempre é claro se elétrons estão sendo ganhos ou perdidos em uma reação. Por isso, os químicos orgânicos acham mais útil definir a oxidação e a redução com outros termos. Um processo que adiciona átomos eletronegativos, como halogênio ou oxigênio, ou remove hidrogênio a partir de uma molécula é uma oxidação. Por outro lado, a remoção de halogênio ou oxigênio ou a adição de hidrogênio é definida como redução. (grifo nosso)
}

Exemplos em que o modelo de oxigênio é utilizado para definição das reações redox são:

a) a conversão do ácido carboxílico a um aldeído: uma redução à medida que o teor de oxigênio diminui; (ÖSTERLUND, 2010)

b) a conversão de um aldeído a um álcool: uma redução porque o teor de hidrogênio aumenta; (ÖSTERLUND, 2010)

c) oxidação do metano a dióxido de carbono: têm-se adição de oxigênio nas etapas distintas (VOLLHARDT; SCHORE, 2013)

d) relação entre os álcoois aos aldeídos e cetonas, conforme a figura 1: 


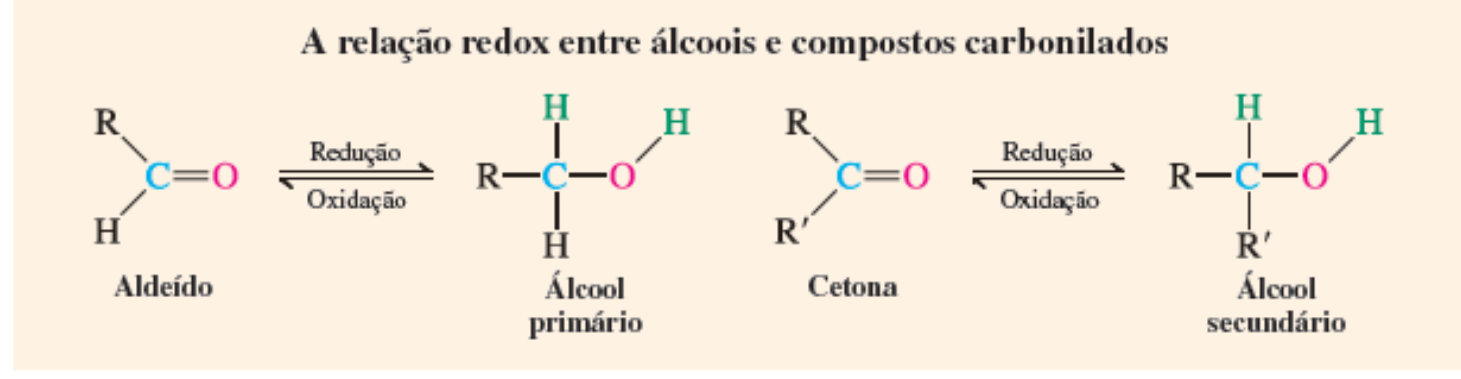

Figura 1 - Exemplo do uso do modelo de oxigênio

Fonte: Vollhardt; Schore, 2013, p. 297

No entanto, a utilização desse modelo tem duas limitações principais, a primeira: há inúmeras reações redox que não envolvem oxigênio. A segunda, reações ácido-base, apesar de envolverem transferência de oxigênio entre espécies, não podem ser consideradas como reações redox. (PAIK, et al., 2017). Um exemplo de reação que envolve oxigênio, mas não é considerado redox:

$$
\mathrm{CH}_{2} \mathrm{O}+\mathrm{NH}_{3} \rightarrow \mathrm{CH}_{2} \mathrm{NH}+\mathrm{H}_{2} \mathrm{O}
$$

Aqui a porção de carbono carbonílico $(\mathrm{C}=\mathrm{O})$ no formaldeído perde um átomo de oxigênio, mas não reduz, está é uma reação ácido-base, em que o formaldeído reage como um ácido e a amônia reage como base. (PAIK, et al., 2017).

\subsubsection{O modelo de hidrogênio}

Os estudos de Justus Von Liebig, na década de 30, levaram-no a propor uma definição alternativa para a oxidação. Em seus estudos, ele observou que um composto orgânico foi reduzido por meio da ação do hidrogênio, a perda do hidrogênio, nesse caso, levou a uma oxidação da substância. (RINGNES, 1995 apud ÖSTERLUND, 2010).

O modelo do hidrogênio é particularmente utilizado nas reações bioquímicas, como é observado em Nelson e Cox (2004) que descrevem reações bioquímicas redox com o modelo de hidrogênio, isto é, uma oxidação é uma perda de hidrogênio e uma redução é um ganho de hidrogênio. O conceito de desidrogenação é usado de forma sinônima com oxidação. Tal como destacado por Vollhardt e Shore (2013), se reconhece que os elétrons sejam a força motriz do trabalho biológico.

Os exemplos de reações nas quais se utiliza o modelo de hidrogênio são aquelas em que um substrato cede dois átomos de hidrogênio, como em:

a) Moléculas como $\mathrm{NAD}^{+}, \mathrm{NADP}^{+}, \mathrm{FMN}$ ou FAD ganham elétrons e sofrem uma redução: O FAD sendo reduzido em: $\mathrm{FAD}+2 \mathrm{e}^{-}+2 \mathrm{H}^{+} \rightarrow \mathrm{FADH}_{2}$ 
Assim como o modelo de oxigênio, as limitações desse modelo referem-se àquelas reações redox em que não há presença de hidrogênio e as reações ácido-base, como, por exemplo, em:

$$
\mathrm{NH}_{3}+\mathrm{B}(\mathrm{OH})_{3} \rightarrow \mathrm{NB}+3 \mathrm{H}_{2} \mathrm{O}
$$

O nitrogênio perde hidrogênio, mas não oxida, esta é uma reação ácido-base, na qual a amônia reage como um ácido e o hidróxido reage como base. (PAIK, et al., 2017).

\subsubsection{O modelo de transferência eletrônica}

Com a evolução da eletroquímica processos que ocorrem em células eletrolíticas puderam ser associados aos processos de transferência eletrônica particularmente com a identificação do elétron.

A identificação do elétron levou a um novo conceito de variação da valência, nesse caso "o aparecimento de uma valência positiva por um átomo corresponde à oxidação. Um átomo no qual um valor negativo aparece é reduzido" (FRY, 1915).

Gilbert Newton Lewis (1875-1946) quando na elaboração de sua teoria das ligações interpreta as interações entre átomos em uma molécula em termos de transferência ou compartilhamento de elétrons. Nos postulados que ele formulou, a redução significaria um aumento no número de elétrons na eletrosfera exterior do elemento e, por conseguinte, a oxidação implica uma diminuição. (GHIBAUDI, et al., 2015).

A mutualidade das reações de oxidação e de redução é explicitada na teoria de Lewis quando afirma que "Um elétron pode ser parte da camada de dois átomos diferentes e não pode ser dito pertencer a um ou a outro. Em geral, é impossível dizer que um elemento em um composto durante uma reação química foi oxidado ou reduzido enquanto outro elemento não sofreu mudanças; é somente quando lidamos com substâncias completamente polares que essa distinção se torna menos ambígua" (LEWIS, 1916).

Em geral, as reações redox que utilizam o modelo de transferência de elétrons são mais abundantes na química inorgânica:

\footnotetext{
Podemos considerar que existe uma classe muito grande de reações que ocorrem por transferência de elétrons de uma espécie para outra. O ganho de elétrons é chamado de redução e a sua perda é denominada oxidação; o processo em comum é chamado de reação redox. (SRHIVER; ATKINS, 2003, p. 203)

A transferência de elétrons de uma espécie para outra é hoje reconhecida como etapa essencial da oxidação e os químicos definem oxidação como sendo a perda de elétrons, desconsiderando as espécies para as quais os elétrons migram"; "em uma redução um átomo ganha elétrons de outra espécie"; "A
} 
oxidação é a perda de elétrons; A redução é o ganho de elétrons. A reação redox é a combinação de oxidação e redução (ATKINS; JONES, 2012, p. 99100)

Todas as reações de oxirredução podem ser explicadas pelo fato de que elas ocorrem através da transferência de elétrons entre substâncias. [. . .] (KOTZ et al., 2011, p. 138)

São inúmeros exemplos que utilizam a transferência de elétrons entre espécies para explicar o processo que está ocorrendo:

a) Reações de combustão

b) Reações de dismutação

c) Reações bioquímicas

d) Reações em células eletrolíticas (pilhas, baterias)

Porém há vários estudos que indicam problemas quanto à utilização desse modelo, segundo Paik et al. (2017):

Isto é parcialmente o caso porque o modelo eletrônico tem validade limitada em reações que envolvem apenas elementos e íons simples ou compostos iónicos. Além disso, muitos pesquisadores apontaram que os elétrons nem sempre são trocados literalmente em reações redox, resultando em confusão adicional (PAIK, et al., 2017, p. 2, tradução nossa)

A reação que exemplifica a limitação desse modelo seria:

$$
\mathrm{HCl}(\mathrm{aq})+\mathrm{H}_{2} \mathrm{O}(\mathrm{l}) \rightarrow \mathrm{H}_{3} \mathrm{O}^{+}(\mathrm{aq})+\mathrm{Cl}^{-}(\mathrm{aq})
$$

Aqui, um par compartilhado de elétrons é movido completamente para o átomo de cloro; no entanto, esta reação é ácido-base e não uma reação redox.

Além disso, em química orgânica este modelo parece ainda menos aplicável pois as reações são geralmente descritas em termos de interações entre eletrófilos e nucleófilos e quase nunca é correto para a hipótese de transferência de carga líquida entre átomos (GHIBAUDI et al., 2015).

\subsubsection{O modelo do número de oxidação}

Em 1938, Wendell Mitchell Latimer (1893-1955) definiu regras para atribuir o número de oxidação partindo da suposição arbitrária de que todas as ligações são puramente iônicas. Esta definição é o conceito moderno de número de oxidação. (GHIBAUDI et al., 2015).

Para Latimer, o número de oxidação é a carga que um átomo adquire se os elétrons de ligação forem atribuídos para cada ligação. Aqui as regras dividem-se na ligação em que os dois átomos possuem a mesma eletronegatividade, e aqueles em que a eletronegatividade difere entre os átomos. Para o primeiro processo, os elétrons seriam 
atribuídos igualmente, já para o segundo caso, os elétrons seriam atribuídos ao elemento de maior eletronegatividade. (GHIBAUDI et al., 2015).

Esta nova definição descreve que as reações redox seriam aquelas em que o número de oxidação de pelo menos um dos elementos participantes, varia. Dessa forma, este modelo seria puramente formal e teórico, e assim inclui e amplia os outros três modelos apresentados.

Alguns livros de química de ensino superior utilizam o modelo de número de oxidação, como em:

A oxidação corresponde ao aumento do número de oxidação. A redução corresponde à diminuição do número de oxidação. Uma reação redox, portanto, é qualquer reação na qual os números de oxidação se alteram. (ATKINS; JONES, 2012, p. 100)

[...] a oxidação corresponde a um aumento no número de oxidação de um elemento, e a redução corresponde a um decréscimo no número de oxidação. Uma reação redox é uma reação química na qual há mudança no número de oxidação de no mínimo um dos elementos envolvidos. (SHRIVER; ATKINS, 2004, p. 203)

Aqui é importante salientar que muitos livros não identificam o modelo de número de oxidação como um modelo que descreve uma reação redox, mas sim como um artificio para "acompanhar de onde os elétrons vem e para onde os elétrons vão" (SHRIVER; ATKINS, 2004, p. 203) ou "seguir o caminho dos elétrons" (ATKINS; JONES, 2012, p.100). Além disso, o modelo de número de oxidação prova-se mais utilizado no processo de balanceamento de uma equação química redox.

Österlund (2010) aponta que para equilibrar as reações de oxidação e de redução utiliza-se o modelo de nox, especialmente nas reações redox que formam ligações covalentes. Se há reações em solução aquosa utiliza-se o método das semirreações, mas este difere se há soluções básicas ou ácidas participantes da reação.

No entanto, esta nova classificação, segundo Ghibaudi et al. (2015), envolve a renúncia em associar a variação do número de oxidação com um processo de transferência de elétrons real de um átomo para outro. Segundo o autor:

[...] o conceito de n.o. é um artifício formal projetado para designar um determinado estado de um átomo em um composto e destacar sua variação durante uma transformação redox; isso não fornece nenhuma indicação da localização real dos elétrons no composto. Portanto, é completamente errado atribuir ao n.o., que é definido como carga hipotética e, portanto, é um conceito formal, um significado físico, ou identificá-lo com uma carga real. O único caso em que o n.o. coincide com uma carga real é a dos íons monoatômicos. (GHIBAUDI et al., 2015, p. 18, tradução nossa). 
Além disso, o modelo de número de oxidação é determinado pelo conceito de estado de oxidação, que pode ocasionar dificuldades de ser determinado visto que os métodos de cálculos não são unificados.

Salienta-se ainda que o modelo de Nox é baseado em um conceito puramente convencional, o número de oxidação, cujo cálculo se baseia no pressuposto (arbitrário e fictício) de que todas as ligações químicas são iônicas e a suposição de que os elétrons de ligação podem ser atribuídos em qualquer caso ao átomo mais eletronegativo. (GHIBAUDI, et al., 2015).

\subsubsection{Recapitulando}

Na medida que o desenvolvimento da química levou às investigações sobre a estrutura atômica, os modelos passaram do nível microscópico atômico para o nível microscópico eletrônico. Nesse sentido, os modelos redox foram expandindo-se e incluindo as novas descobertas realizadas. Um modelo abrange o anterior, conforme observa-se no resumo dos modelos redox, no quadro 2.

Quadro 2 - Os modelos redox descritos na literatura

\begin{tabular}{|l|l|l|l|}
\hline \multicolumn{1}{|c|}{ Modelo } & \multicolumn{1}{|c|}{ Descrição } & \multicolumn{1}{c|}{ Exemplo } & \multicolumn{1}{c|}{ Limitações } \\
\hline Oxigênio & $\begin{array}{l}\text { Processos em que se } \\
\text { produz uma transferência } \\
\text { de oxigênio }\end{array}$ & $2 \mathrm{Al}+\mathrm{Fe}_{2} \mathrm{O}_{3} \rightarrow \mathrm{Al}_{2} \mathrm{O}_{3}+2 \mathrm{Fe}$ & $\mathrm{CH}_{2} \mathrm{O}+\mathrm{NH}_{3} \rightarrow \mathrm{CH}_{2} \mathrm{NH}+\mathrm{H}_{2} \mathrm{O}$ \\
\hline Hidrogênio & $\begin{array}{l}\text { Processos em que se } \\
\text { produz uma transferência } \\
\text { de hidrogênio }\end{array}$ & $\mathrm{CH}_{4}+\mathrm{Cl}_{2} \rightarrow \mathrm{CH}_{3} \mathrm{Cl}+\mathrm{HCl}$ & $\mathrm{NH}_{3}+\mathrm{B}(\mathrm{OH})_{3} \rightarrow \mathrm{NB}^{2} 3 \mathrm{H}_{2} \mathrm{O}$ \\
\hline $\begin{array}{l}\text { Transferência } \\
\text { de elétrons }\end{array}$ & $\begin{array}{l}\text { Processos em que se } \\
\text { produz uma transferência } \\
\text { de elétrons }\end{array}$ & $\mathrm{Zn}+\mathrm{Cu}^{2+} \rightarrow \mathrm{Zn}^{2+}+\mathrm{Cu}$ & $\mathrm{HCl}+\mathrm{H}_{2} \mathrm{O} \rightarrow \mathrm{H}_{3} \mathrm{O}^{+}+\mathrm{Cl}^{-}$ \\
\hline $\begin{array}{l}\text { Número de } \\
\text { oxidação }\end{array}$ & $\begin{array}{l}\text { Processos em que o } \\
\text { número de oxidação de um } \\
\text { ou mais elementos varia }\end{array}$ & Todos os anteriores & - \\
\hline
\end{tabular}

Fonte: Ghibaudi et al. (2015)

As definições dadas pela IUPAC (IUPAC. Compendium of Chemical Terminology, 1997) evidencia que todos os modelos coexistem e que há distinção entre os processos redox inorgânicos e orgânicos, conforme os trechos que descrevem uma oxidação: "Remoção completa e clara de um ou mais elétrons de uma entidade molecular" (modelo de Transferência Eletrônica); "Um aumento de n.o. de qualquer átomo dentro de qualquer substrato"(modelo de Número de Oxidação) e "Aquisição de oxigênio [modelo Oxigênio] e/ou perda de hidrogênio [modelo Hidrogênio] de um substrato orgânico". (IUPAC, 1997, apud GHIBALDI et al, 2015, p. 18). 
Os modelos diferenciam-se quanto ao nível a que se relacionam, os modelos de Oxigênio e Hidrogênio localizam-se no nível macroscópico, enquanto que o modelo de Transferência Eletrônica num nível microscópico. Além disso, eles têm caráter empírico e associam-se a um significado físico direto.

Além das limitações expostas, um mesmo fenômeno pode ser descrito como oxidativo em um modelo, mas não em outro. Como é o caso das reações:

$$
\begin{gathered}
2 \mathrm{Li}(\mathrm{s})+\mathrm{H}_{2}(\mathrm{~g}) \rightarrow 2\left(\mathrm{Li}^{+} \mathrm{H}^{-}\right) \\
2 \mathrm{Na}(\mathrm{s})+\mathrm{H}_{2}(\mathrm{~g}) \rightarrow 2\left(\mathrm{Na}^{+} \mathrm{H}^{-}\right)
\end{gathered}
$$

No modelo de Hidrogênio, a oxidação corresponde a uma perda de hidrogênio. Por outro lado, de acordo com o modelo de Transferência Eletrônica, a captura de hidrogênio corresponde à oxidação e o di-hidrogênio desempenha o papel de oxidante e não redutor.

Daves (1991) apresenta um outro exemplo que demonstra uma incompatibilidade com todos os modelos apresentados:

$$
5 \mathrm{Fe}^{2+}(\mathrm{aq})+\mathrm{MnO}^{4-}(\mathrm{aq})+8 \mathrm{H}^{+}(\mathrm{aq}) \rightarrow 5 \mathrm{Fe}^{3+}(\mathrm{aq})+\mathrm{Mn}^{2+}(\mathrm{aq})+4 \mathrm{H}_{2} \mathrm{O}(\mathrm{l})
$$

Considerando apenas o íon de hidrogênio $\left(\mathrm{H}^{+}\right)$: a) No modelo de oxigênio, ocorreu uma oxidação ao ganhar oxigênio e uma molécula de água é formada; b) No modelo eletrônico, os íons de hidrogênio foram reduzidos pela atração de elétrons dos íons óxidos, e uma molécula de água é formada; c) No modelo de número de oxidação nem a oxidação nem a redução ocorreram. O número de oxidação é +1 antes e depois da reação.

Nesse sentido, desconsiderar a confusão conceitual que pode ser ocasionada com a utilização desses diferentes modelos, pode levar a dificuldades de aprendizagem. (DAVES, 1991).

Em virtude disso, enfatiza-se a importância do estudo aqui relatado, investigar o uso desses diferentes modelos nos livros didáticos, à medida que se consideram os livros como recurso importantíssimo na sala de aula. O livro é mediador do saber cientifico ao saber escolar. Por vezes ele norteia o trabalho do professor: quando é considerado como currículo, quando se utiliza em atividades extraclasse, quando se utiliza no planejamento do professor, entre outros.

Caracterizar como os livros didáticos brasileiros consideram os diferentes modelos - se há utilização de mais de um e, ainda, se na mudança entre os modelos o motivo é claramente definido - é justificado tanto pela importância dos livros didáticos e 
do ensino de reações redox, como pela melhoria no processo de ensino-aprendizagem das reações redox que esse estudo poderia trazer. E esta análise é um dos focos desta pesquisa.

\subsubsection{Concepções alternativas no ensino de reações redox}

Apesar da variedade de reações redox presentes no cotidiano, e das diferentes abordagens utilizadas no ensino dos conceitos (KLEIN, BRAIBANTE, 2017), as pesquisas da área de ensino de ciências têm relatado vários problemas no ensino desses conceitos (DE JONG, ACAMPO, VERDONIK 1985; ALLSOP, GEORGE, 1982; SUMFLETH, TODTENHAUPT, 1988; BARRAL, FERNANDEZ, OTERO, 1992) que podem acarretar em diversas dificuldades de aprendizagem, concepções alternativas e equívocos nos alunos, sistematizadas e listadas no quadro 3.

Garnett e colaboradores (1995) descrevem as principais causas das dificuldades relacionadas ao ensino das reações redox. Segundo os autores elas podem ser devidas a compartimentalização e não relação das disciplinas de química e física. Uso de terminologias inconsistentes entre a química e a física, por exemplo, a não relação entre os termos potencial-padrão de redução e Força Eletromotriz de uma célula. A diferença na conceituação dos termos nas disciplinas de química e física, como por exemplo, na definição de corrente elétrica ou ainda, falta de conhecimento prévio sobre o assunto. A diferença entre a linguagem científica e a linguagem cotidiana, por exemplo, carregar elétrons, e generalização das declarações e aplicação além do pretendido. Schmidt e Volke (2003) acrescentam que a causa das dificuldades no entendimento dos conceitos pode ser resultado, também, das variadas definições que um mesmo termo pode ter.

Como consequência para o ensino, os professores devem fazer um esforço para apresentarem a química e física como uma visão de mundo e não como disciplinas isoladas, apresentar exemplos comuns no cotidiano do aluno, e justificar o uso das diferentes terminologias no ensino. Para os autores deve-se adotar um único conceito nas disciplinas que os diferenciam, conhecer o que o aluno sabe sobre o tema, selecionar uma linguagem com significados que não diferem do científico e ensinar para que os alunos aprendam o conceito e não decorem um procedimento algorítmico (GARNETT, GARNETT, HACKLING, 1995). Outra implicação para o ensino que pode ser citada é a abordagem da limitação que os modelos têm, tratando-se de diferentes disciplinas (SCHMIDT, VOLKE, 2003). 


\section{Quadro 3 - Principais concepções/equívocos/dificuldades dos alunos referentes aos conceitos de} oxirredução e eletroquímica

(continua)

\begin{tabular}{|c|c|}
\hline \multicolumn{2}{|l|}{ OXIRREDUÇÃO } \\
\hline Concepções/equívocos/dificuldades dos alunos & Fonte \\
\hline $\begin{array}{l}\text { Se numa equação química não estiverem visíveis os elétrons e/ou íons } \\
\text { não é uma reação redox }\end{array}$ & $\begin{array}{l}\text { Sisler e VanderWerf, (1980); } \\
\text { Allsop e George, (1982); } \\
\text { Horton (2004); }\end{array}$ \\
\hline $\begin{array}{l}\text { Confusão entre os conceitos de agente redutor sofrendo redução e } \\
\text { agente oxidante sofrendo oxidação }\end{array}$ & $\begin{array}{l}\text { Sumfleth e Todtenhaupt (1988); } \\
\text { Schmidt e Volke (2003); }\end{array}$ \\
\hline $\begin{array}{l}\text { A carga de uma espécie poliatômica indica o estado de oxidação da } \\
\text { molécula ou íon }\end{array}$ & $\begin{array}{l}\text { Garnett e Treagust, (1992a); } \\
\text { Schmidt e Volke (2003); }\end{array}$ \\
\hline $\begin{array}{l}\text { Reação redox entendida como transferência de oxigênio } \\
\text { Em todas as reações químicas, se ocorrer recebimento de oxigênio } \\
\text { então a reação é de oxidação; se ocorrer doação de oxigênio então a } \\
\text { reação é de redução }\end{array}$ & $\begin{array}{l}\text { Garnett e Treagust, (1992a); } \\
\text { Bueso, Furió e Mans (1988); } \\
\text { Freire et al., (2011); } \\
\text { Klein e Braibante (2015); } \\
\text { Goes, Fernandez e Agostinho } \\
\text { (2016); } \\
\text { Sumfleth e Todtenhaupt (1988); } \\
\text { Schmidt, (1997); }\end{array}$ \\
\hline $\begin{array}{l}\text { Os processos de oxidação e redução podem ocorrer de forma } \\
\text { independente }\end{array}$ & $\begin{array}{l}\text { Garnett e Treagust, (1992a); } \\
\text { Caamaño (2007); } \\
\text { Freire et al. (2011); } \\
\text { Klein e Braibante (2015); }\end{array}$ \\
\hline $\begin{array}{l}\text { O estado de oxidação de um elemento é o mesmo que a carga do íon } \\
\text { monoatômico desse elemento, quando deveria ser zero }\end{array}$ & \multirow[t]{2}{*}{ Garnett e Treagust, (1992a) } \\
\hline $\begin{array}{l}\text { Números ou estados de oxidação podem ser atribuídos a moléculas } \\
\text { poliatômicas e/ou íons poliatômicos. }\end{array}$ & \\
\hline $\begin{array}{l}\text { Em uma equação, as mudanças nas cargas de espécies poliatômicas } \\
\text { podem ser usadas para identificar equações redox }\end{array}$ & \multirow[t]{2}{*}{ Garnett e Treagust, (1992a) } \\
\hline $\begin{array}{l}\text { Em uma equação, as mudanças nas cargas de espécies poliatômicas } \\
\text { podem ser usadas para determinar o número de elétrons removidos ou } \\
\text { ganhos na reação }\end{array}$ & \\
\hline Reações redox ocorrem apenas em células eletroquímicas & Ogude e Bradley (1996) \\
\hline Visualização de uma reação ácido-base como redox, e vice e versa. & Schmidt e Volke (2003) \\
\hline $\begin{array}{l}\text { As reações de oxirredução incluem a oxidação de um reagente seguido } \\
\text { da redução de um produto }\end{array}$ & \multirow[t]{2}{*}{ Horton (2004) } \\
\hline Em todas as reações de oxirredução há transferência de elétrons & \\
\hline O número de oxidação é um número fixo, não varia & \multirow[t]{2}{*}{ Barke, Hazari e Yitbarek (2009) } \\
\hline $\begin{array}{l}\text { O número de oxidação é o número de substâncias oxidadas ou quantas } \\
\text { vezes uma substância pode ser oxidada }\end{array}$ & \\
\hline $\begin{array}{l}\text { Quando as equações de oxidação e de redução são somadas, há } \\
\text { ausência de conservação das cargas, ou seja, o total de cargas das } \\
\text { espécies iniciais difere do total de cargas das espécies transformadas }\end{array}$ & Caramel e Pacca (2011) \\
\hline Ganhar ou perder elétrons não alterará o tamanho de um átomo ou íon & \multirow[t]{3}{*}{ Rosenthal e Sanger (2012) } \\
\hline Os íons em solução formam pares/moléculas de íons neutros & \\
\hline A água impulsiona uma reação de oxirredu & \\
\hline
\end{tabular}




\section{Quadro 3 - Principais concepções/equívocos/dificuldades dos alunos referentes aos conceitos de oxirredução e eletroquímica}

(continuação)

\begin{tabular}{|l|}
\hline \multicolumn{1}{|c|}{ CXncepções/equívocos/dificuldades dos alunos } \\
\hline $\begin{array}{l}\text { O número de oxidação de um elemento num íon poliatômico calcula- } \\
\text { se multiplicando o número de átomos de oxigénio pela carga elétrica } \\
\text { desse íon }\end{array}$ \\
\hline $\begin{array}{l}\text { Se um átomo ganhar elétrons forma um íon positivo, se perder elétrons } \\
\text { forma um íon negativo }\end{array}$ \\
\hline $\begin{array}{l}\text { O número de oxidação de um elemento em um íon poliatômico é igual } \\
\text { ao número de átomos de oxigénio presentes nesse íon. }\end{array}$ \\
\hline
\end{tabular}

\section{PILHAS E BATERIAS}

Em uma célula os ânions e cátions se atraem mutuamente e isso afeta o movimento dos íons para os eletrodos

Os elétrons se movem através da solução sem o auxílio de íons

Ribeiro (2013)

\section{Fonte}

Garnett e Treagust, (1992a);

Ogude e Bradley (1996)

Garnett e Treagust, (1992a);

Ogude e Bradley (1994);

Ogude e Bradley (1996);

Sanger e Greenbowe (1997);

Os elétrons se movem através de eletrólitos sendo atraídos por íons positivos em solução

Fluxo de elétrons em eletrólitos. E fluxo de prótons em eletrólitos, sem considerar se a solução é ácida básica ou neutra.

Os elétrons entram no eletrólito no cátodo, movem-se através do eletrólito e emergem no ânodo

A ponte salina fornece elétrons para completar o circuito

Garnett e Treagust, (1992a);

Ogude e Bradley (1994);

Garnett e Treagust, (1992b);

Schmidt, Marohn e Harrison (2007);

Garnett e Treagust, (1992b);

Sanger e Greenbowe (1997);

Lin et al. (2002);

Velleca et al. (2005);

Acar e Tarhan (2007);

Caamano (2007);

Freire et al. (2011);

Klein e Baibrante (2015);

O conceito de eletricidade para a química e física é diferente porque a

Garnett e Treagust, (1992a)

corrente flui em direções opostas

Corrente convencional é o fluxo de cargas positivas (geralmente prótons)

Em condutores metálicos há fluxo de prótons

Prótons e elétrons fluem em direções opostas em um eletrólito

Uma diferença de potencial entre dois pontos é unicamente devida a diferença na concentração de cargas nos pontos

Os elétrons saem do ânodo, onde há uma alta concentração de elétrons,

e passam pelo circuito externo até o cátodo, onde há uma baixa concentração de elétrons

Na tabela de potencial-padrão de redução, as espécies com o maior valor de $\mathrm{E}^{\circ}$ são sempre o ânodo

Em uma célula eletroquímica os ânions e cátions se movem até que a sua concentração em ambas as meia-células seja igual

Tabelas de potencial-padrão de redução colocam os metais em ordem decrescente de reatividade de cima para baixo 


\section{Quadro 3 - Principais concepções/equívocos/dificuldades dos alunos referentes aos conceitos de} oxirredução e eletroquímica

(continuação)

\begin{tabular}{|c|c|}
\hline \multicolumn{2}{|l|}{ PILHAS E BATERIAS } \\
\hline Concepções/equívocos/dificuldades dos alunos & Fonte \\
\hline $\begin{array}{l}\text { Não é necessária uma meia-célula padrão para caracterizar uma } \\
\text { oxirredução }\end{array}$ & \multirow[t]{4}{*}{$\begin{array}{l}\text { Garnett e Treagust, (1992b); } \\
\text { Acar e Tarhan (2007) }\end{array}$} \\
\hline $\begin{array}{l}\text { A ponte salina ajuda o fluxo de corrente (elétrons) porque os íons } \\
\text { positivos na ponte atraem elétrons de uma meia-célula para a outra } \\
\text { célula }\end{array}$ & \\
\hline $\begin{array}{l}\text { O ânodo está carregado negativamente e por isso atrai cátions. O } \\
\text { cátodo é carregado positivamente e por isso atrai ânions. }\end{array}$ & \\
\hline $\begin{array}{l}\text { Quando um eletrólito conduz uma corrente, os elétrons se movem para } \\
\text { um íon no cátodo e são transportados por esse íon para o ânodo }\end{array}$ & \\
\hline $\begin{array}{l}\text { Identificar o ânodo e o cátodo depende do posicionamento físico das } \\
\text { meia-células }\end{array}$ & \multirow[t]{2}{*}{$\begin{array}{l}\text { Sanger e Greenbowe (1997); } \\
\text { Acar e Tarhan (2007) }\end{array}$} \\
\hline $\begin{array}{l}\text { Os ânodos são carregados negativamente como os ânions. Os cátodos } \\
\text { são carregados positivamente como os cátions }\end{array}$ & \\
\hline $\begin{array}{l}\text { Íons carregados negativamente constituem apenas uma passagem de } \\
\text { corrente no eletrólito e ponte salina }\end{array}$ & Sanger e Greenbowe (1997) \\
\hline $\begin{array}{l}\text { Em uma célula galvânica, os elétrons se movem de uma região de alto } \\
\text { potencial para uma região de menor potencial. }\end{array}$ & \multirow[t]{9}{*}{ Özkaya (2002) } \\
\hline $\begin{array}{l}\text { Um voltímetro comum pode ser usado para medir a fem de uma célula } \\
\text { galvânica com precisão }\end{array}$ & \\
\hline $\begin{array}{l}\text { Não há relação entre a fem de uma célula galvânica e a capacidade } \\
\text { máxima da célula para realizar trabalho elétrico. }\end{array}$ & \\
\hline $\begin{array}{l}\text { Quando um eletrodo é imerso em um eletrólito, uma dupla camada } \\
\text { elétrica não se forma na interface entre o eletrólito e o eletrodo imerso } \\
\text { nele }\end{array}$ & \\
\hline $\begin{array}{l}\text { Não há nenhuma diferença entre o equilíbrio químico e eletroquímico } \\
\text { estabelecido em uma célula galvânica }\end{array}$ & \\
\hline $\begin{array}{l}\text { Um fluxo de corrente pode ser permitido através de uma célula } \\
\text { galvânica em que um par de meia-célula é conectado por um } \\
\text { potenciômetro }\end{array}$ & \\
\hline $\begin{array}{l}\text { Quando um par de meia-célula é conectado por um voltímetro de alta } \\
\text { resistência, estabelece-se um equilíbrio químico entre as espécies } \\
\text { envolvidas na reação celular }\end{array}$ & \\
\hline $\begin{array}{l}\text { Os valores de } \mathrm{E}^{\circ} \text { dados na tabela de potenciais de redução padrão não } \\
\text { se referem a um equilíbrio eletroquímico }\end{array}$ & \\
\hline Não existe qualquer relação entre o equilíbrio químico e eletroquímico & \\
\hline A corrente elétrica se estabelece sem um circuito fechado & \multirow[t]{3}{*}{ Caramel e Pacca (2004) } \\
\hline $\begin{array}{l}\text { Corrente elétrica existe somente quando há movimentação de cargas } \\
\text { entre dois pontos num campo elétrico }\end{array}$ & \\
\hline $\begin{array}{l}\text { Tendência em transferir as cargas dos eletrodos para a solução, } \\
\text { ignorando totalmente as cargas inicialmente aí existentes provenientes } \\
\text { da dissociação do eletrólito }\end{array}$ & \\
\hline $\begin{array}{l}\text { Não há relação entre a somatória das semirreações ocorridas na pilha } \\
\text { com a somatória dos potencias de redução e oxidação }\end{array}$ & Velleca et al. (2005) \\
\hline $\begin{array}{l}\text { O movimento de íons em solução não constitui uma corrente elétrica, } \\
\text { pois consideram a condução no eletrólito como movimento de elétrons }\end{array}$ & $\begin{array}{l}\text { Acar e Tarhan (2007); } \\
\text { Caramel e Pacca (2011) }\end{array}$ \\
\hline
\end{tabular}


Quadro 3 - Principais concepções/equívocos/dificuldades dos alunos referentes aos conceitos de oxirredução e eletroquímica

(continuação)

\section{Concepções/equívocos/dificuldades dos alunos}

Uma corrente elétrica é constituída com prótons e elétrons fluindo em direções opostas

Os eletrodos inertes podem ser oxidados ou reduzidos

Prótons e elétrons fluindo em direções opostas causam uma diferença de potencial entre as duas extremidades do fio

As placas metálicas só atuam como um transportador de elétrons durante a reação redox, por isso não há alteração na estrutura física dos eletrodos

As forças de atração entre cátions e ânions afetam a velocidade dos íons para o eletrodo, por isso diferentes potenciais são lidos quando soluções diferentes são utilizadas nas células

Uma bateria contém água

Uma bateria contém bloco de ferro, pó de ferro e partículas magnéticas

Uma bateria é composta de muitos pequenos fios ou bobinas

Além do ar, o espaço oco da bateria é preenchido com eletricidade invisível

As polaridades de uma bateria podem ser reconhecidas de acordo com sua forma; a extremidade convexa é positiva e a extremidade côncava ou plana é negativa

Uma haste no meio da bateria é o lugar onde a eletricidade é armazenada

Existem dois íons diferentes em uma bateria e os íons colidem uns com os outros resultantes na geração de eletricidade

A origem da eletricidade é do terminal "+" de uma bateria progredindo nos circuitos e eventualmente retorna à polaridade "-" da bateria

A eletricidade flui de uma bateria das polaridades "+" e "-". Uma lâmpada em um circuito com uma bateria brilhará se as duas correntes elétricas estiverem correndo umas para as outras

A corrente positiva vem da polaridade "+" de uma bateria e a corrente negativa vem de polaridade "-" de uma bateria. Ambas as correntes se encontram em uma lâmpada e permitem que a lâmpada acenda

Uma célula seca está seca no interior

As polaridades "+" e "-" de uma bateria recarregável podem permitir a entrada de eletricidade, mas a eletricidade não pode ser obtida na bateria não recarregável

A recarga significa reabastecimento de eletricidade em uma bateria vazia

Se um circuito composto por uma lâmpada e duas baterias está conectado em série ou em paralelo não faz diferença na intensidade incandescente da lâmpada Se duas baterias estiverem conectadas em paralelo com uma lâmpada e uma das baterias quebrar, a lâmpada não brilhará

Uma lâmpada tem o mesmo período de incandescência, seja alimentada por uma única bateria ou por duas baterias, independentemente dos recursos de conexão As pilhas alcalinas são as mais potentes do mercado

A eletricidade de uma bateria origina sua polaridade "+". A eletricidade pode ser transformada em luz dentro da lâmpada e posteriormente consumida.

Eletricidade em uma bateria é semelhante à gasolina em um carro, portanto, a eletricidade pode ser consumida durante a aplicação

A bateria pode ser reciclada em bateria de segunda mão, assim como o papel pode ser reciclado e transformado em novos produtos de papel

\section{Fonte}

Acar e Tarhan (2007)

Lee (2007) 


\section{Quadro 3 - Principais concepções/equívocos/dificuldades dos alunos referentes aos} conceitos de oxirredução e eletroquímica

\begin{tabular}{|c|c|}
\hline \multicolumn{2}{|l|}{ PILHAS E BATERIAS } \\
\hline Concepções/equívocos/dificuldades dos alunos & Fonte \\
\hline $\begin{array}{l}\text { As cargas são movimentadas sem atenção ao desequilíbrio elétrico que ocorre } \\
\text { simultaneamente nas soluções. }\end{array}$ & \multirow[t]{7}{*}{ Caramel e Pacca (2011) } \\
\hline $\begin{array}{l}\text { A perda de elétrons é acompanhada da consequente diminuição da carga da } \\
\text { espécie química envolvida }\end{array}$ & \\
\hline $\begin{array}{l}\text { As cargas que saem de um, entram no outro para atender a uma simetria } \\
\text { matemática e não ao equilíbrio das cargas no conjunto }\end{array}$ & \\
\hline $\begin{array}{l}\text { A corrente elétrica circula devido às diferenças de carga, que é normalmente (e } \\
\text { problematicamente) atribuída ao cátodo e ao ânodo. }\end{array}$ & \\
\hline $\begin{array}{l}\text { A corrente é unicamente de natureza iônica localizada tanto na solução, quanto } \\
\text { nos fios. }\end{array}$ & \\
\hline $\begin{array}{l}\text { A "energia" do sistema flui em dois sentidos, ou seja, o movimento de íons e } \\
\text { elétrons está associado à carga do eletrodo e, assim, as espécies químicas são } \\
\text { atraídas para os eletrodos }\end{array}$ & \\
\hline $\begin{array}{l}\text { Descaracterização do circuito fechado, pois a movimentação das cargas está } \\
\text { limitada ao eletrólito e o circuito externo parece não ter função }\end{array}$ & \\
\hline \multicolumn{2}{|l|}{ ELETRÓLISE } \\
\hline $\begin{array}{l}\text { Numa célula eletrolítica, a polaridade dos terminais da tensão aplicada não tem } \\
\text { efeito no local do ânodo e do cátodo }\end{array}$ & \multirow{4}{*}{$\begin{array}{l}\text { Garnett e Treagust, } \\
\text { (1992b); } \\
\text { Acar e Tarhan (2007) }\end{array}$} \\
\hline Não ocorrerá nenhuma reação na superfície de eletrodos inertes & \\
\hline A água não reage durante a eletrólise de soluções aquosas & \\
\hline $\begin{array}{l}\text { Os processos no ânodo e no cátodo são invertidos em células eletroquímicas e } \\
\text { eletrolíticas. Em células eletroquímicas ocorre oxidação no ânodo e redução no } \\
\text { cátodo, enquanto que em células eletrolíticas ocorre oxidação no cátodo e } \\
\text { redução no ânodo }\end{array}$ & \\
\hline $\begin{array}{l}\text { Não há associação entre a fem calculada de uma célula eletrolítica e a magnitude } \\
\text { da tensão aplicada }\end{array}$ & $\begin{array}{l}\text { Garnett e Treagust } \\
(1992 b) ; \\
\text { Lin et al. (2002); } \\
\text { Caamaño (2007); } \\
\text { Acar e Tarhan (2007); } \\
\text { Freire et al. (2011) }\end{array}$ \\
\hline $\begin{array}{l}\text { Quando se preveem reações de células eletrolíticas, as semirreações de oxidação } \\
\text { e redução das tabelas de potencial de redução padrão são invertidas antes de } \\
\text { combiná-las }\end{array}$ & $\begin{array}{lll}\text { Garnett } \\
(1992 b)\end{array}$ \\
\hline Polos positivo e negativo carregam cargas eletrônicas líquidas & \multirow{2}{*}{$\begin{array}{l}\text { Ogude e Bradley } \\
\text { (1996); } \\
\text { Schmidt, Marohn e } \\
\text { Harrison (2007) }\end{array}$} \\
\hline $\begin{array}{l}\text { Durante a eletrólise, a corrente eléctrica produz íons, ou seja, eles são vistos } \\
\text { como intermediários ou como produtos finais da eletrólise }\end{array}$ & \\
\hline Não há relação entre o potencial da célula e a concentração dos íons & $\begin{array}{l}\text { Sanger e Greenbowe } \\
(1997) \text {; } \\
\text { Freire et al. (2011) }\end{array}$ \\
\hline Íons transportam elétrons através da solução & $\begin{array}{l}\text { Huddle e White (2000); } \\
\text { Schmidt, Marohn e } \\
\text { Harrison (2007) }\end{array}$ \\
\hline $\begin{array}{l}\text { As células eletrolíticas podem forçar a ocorrência de reações não espontâneas } \\
\text { mesmo aquelas que não envolvem a transferência de elétrons }\end{array}$ & Horton (2004) \\
\hline $\begin{array}{l}\text { A polaridade dos terminais não tem efeito no ânodo e no cátodo. Na superfície } \\
\text { dos eletrodos inertes não ocorre nenhuma reação }\end{array}$ & $\begin{array}{l}\text { Caamanö (2007); } \\
\text { Freire et al. (2011) }\end{array}$ \\
\hline $\begin{array}{l}\text { Os mesmos produtos são produzidos na situação da eletrólise do sal fundido e } \\
\text { em solução aquosa }\end{array}$ & \multirow[t]{3}{*}{ Acar e Tarhan (2007) } \\
\hline $\begin{array}{l}\text { Em células eletrolíticas com eletrodos idênticos conectados à bateria, as mesmas } \\
\text { reações ocorrerão em cada eletrodo }\end{array}$ & \\
\hline $\begin{array}{l}\text { Não é importante quais lados da bateria estão conectados aos eletrodos, uma vez } \\
\text { que as mesmas reações ocorrerão nos eletrodos }\end{array}$ & \\
\hline
\end{tabular}


Quadro 3 - Principais concepções/equívocos/dificuldades dos alunos referentes aos conceitos de oxirredução e eletroquímica

(conclusão)

\begin{tabular}{|c|c|}
\hline \multicolumn{2}{|l|}{ ELETRÓLISE } \\
\hline Concepções/equívocos/dificuldades dos alunos & Fonte \\
\hline Elétrons livres são atraídos para o polo positivo e repelidos pelo polo negativo & Schmidt, Marohn e \\
\hline Elétrons são transferidos de um íon para outro & Harrison (2007) \\
\hline $\begin{array}{l}\text { O cátodo e o ânodo são identificados olhando para a direção em que os íons } \\
\text { migram }\end{array}$ & \\
\hline Um metal depositado sobre o outro é obtido por banho de imersão & Barreto, Batista e Cruz \\
\hline $\begin{array}{l}\text { Não consideração da corrente de elétrons e o circuito fechado, acreditando que } \\
\text { para a reação ocorrer é necessário apenas uma fonte externa de energia e um fio } \\
\text { ligado à solução. }\end{array}$ & (2017) \\
\hline $\begin{array}{l}\text { Para a reação ocorrer é necessário apenas uma fonte externa de energia e um fio } \\
\text { ligado à solução }\end{array}$ & \\
\hline Células eletrolíticas são as que possuem energia elétrica & \\
\hline
\end{tabular}

Analisando atentamente as concepções alternativas, equívocos e dificuldades mapeadas percebe-se que existem muitas relações entre elas. Por exemplo, o aluno que compreende uma reação de oxidação como ganho de oxigênio, e uma reação de redução como perda de oxigênio, não relaciona a simultaneidade das reações justamente pela necessidade de movimentação do átomo ou molécula de oxigênio. A simultaneidade das reações surge apenas quando introduzimos o conceito de transferência eletrônica.

Além disso, o termo oxidação, iniciando por 'oxi' é enganador, sendo facilmente associado à presença do oxigênio. Em contrapartida, o termo transferência de elétrons lembra transporte de elétrons, um conceito familiar para muitos alunos devido a lições anteriores de física. A maneira pela qual as equações de semirreação estão escritas sugere que a transferência de elétrons é o mesmo que o transporte de elétrons de um "lugar" (redutor) para outro "lugar" (oxidante) (De JONG, TREAGUST, 2002).

A dificuldade em ministrar os conceitos sobre as pilhas e baterias são as mesmas para as reações redox, principalmente a não relação entre os conceitos da física e da química, como corrente e potencial elétrico.

\subsection{O Projeto 2061}

Nada é menos parecido com um livro, do que um livro didático.

Barbara Freitag

Dada a importância do livro didático no processo de ensino-aprendizagem dos conceitos químicos, várias iniciativas procuraram avaliar a qualidade dos mesmos em diferentes países, tais como a Nigéria (WILLIANS, 1983; OMIKO, 2011), Grécia 
(GKITZIA et al., 2011), Paquistão (MAHMOOD, 2011), Turquia (KAHVECI, 2010), Corea do Sul (LITZ, 2000), Irã (HASANI, 2016), entre outros. Uma iniciativa que merece destaque é o Projeto 2061 desenvolvido pela Associação Americana para o Avanço da Ciência (AAAS, da sigla em inglês American Association for The Advancement of Science).

O Projeto 2061 é uma iniciativa que pesquisa e desenvolve ações para melhorar a educação científica nos Estados Unidos. O foco do projeto é todo o sistema educacional envolvendo os pesquisadores, professores, alunos, recursos didáticos e formuladores de políticas públicas e tem o objetivo ambicioso de que todos os cidadãos norte-americanos sejam alfabetizados em ciência, matemática e tecnologia. Vale ressaltar que esse é um projeto de longo prazo, recebendo esse nome pois o seu objetivo é alfabetizar todos os cidadãos até o ano de 2061 (ano em que da Terra será possível observar novamente a passagem do cometa Halley).

O projeto 2061 desenvolve ações e, portanto, é especializado em três áreas: Objetivos de Aprendizagem e Currículo de Ciências; Desenvolvimento de Professores e Avaliação. Na área de "Objetivos de Aprendizagem e Currículo de Ciências" o projeto segue as orientações destacadas no Science for All Americans para construir os objetivos do K-12 (currículo oficial dos EUA), que devem ser cumpridos a cada etapa de alfabetização científica. Na área "Desenvolvimento de Professores", o projeto oferece oficinas de desenvolvimento profissional e cursos on-line que buscam formar os educadores na aplicação, instrução e avaliação dos objetivos de aprendizagem definidos. Na área de "Avaliação" são desenvolvidos instrumentos de diagnóstico da compreensão e concepção dos alunos, de avaliação do alcance dos objetivos de aprendizagem, e também, de avaliação dos recursos utilizados no ensino, tais como os livros didáticos.

Objetivando-se compreender como os livros didáticos apoiam, ou fornecem suporte para a aprendizagem dos conceitos de oxirredução no contexto brasileiro, utilizase uma das ferramentas criadas pelo Projeto 2061 para avaliação dos livros didáticos: O Middle Grades Science Textbooks: A Benchmarks-Based Evaluation. Esse instrumento foi desenvolvido por vários especialistas ao longo de muitos anos para examinar quanto os livros didáticos mais utilizados ajudam os alunos na compreensão das ideias científicas e quais são os pontos fortes e fracos dos LD.

O método do instrumento de avaliação foi validado (KULM; GRIER, 1998) e consiste em 6 fases principais. Na primeira fase foram convidados professores de ensino médio experientes e professores pesquisadores da educação para serem os revisores e 
analistas dos livros. Todos os revisores foram treinados para garantir que eles entendessem e seguissem consistentemente os critérios de avaliação e, o treinamento consistiu na participação em oficinas, treino e comparação dos resultados. A etapa seguinte foi de avaliação das três coleções didáticas mais utilizadas no ensino médio, de acordo com os objetivos de aprendizagem. Cada avaliação resultou em um relatório específico que foi posteriormente divulgado na página do projeto.

$\mathrm{O}$ procedimento de avaliação consiste em responder perguntas que visam relacionar sete aspectos específicos do processo educacional. Os aspectos considerados foram: I. Identificando e mantendo um sentido de propósito, II. Levando em conta as ideias dos estudantes, III. Envolvendo os alunos com fenômenos relevantes, IV. Desenvolvendo e Usando Ideias Científicas, V. Promovendo o pensamento dos estudantes sobre fenômenos, experiências e conhecimento, VI. Avaliando o progresso e VII. Melhorando o ambiente de aprendizagem da ciência. Cada um dos aspectos contém 2 a 4 categorias que buscam identificar o quanto o livro atende ou não aquele aspecto de aprendizagem específico. O instrumento de avaliação ainda descreve indicadores de cumprimento das categorias que classificam o quanto o livro atende ao aspecto de forma excelente, satisfatória ou pobre.

$\mathrm{O}$ aspecto I. Identificando e mantendo um sentido de propósito, determina se o material curricular tenta tornar seus propósitos explícitos e significativos para os alunos, seja no próprio texto de apresentação do conteúdo ou através de sugestões feitas ao professor. Esse aspecto específico vai identificar se o objetivo de aprendizagem é claro para o aluno, ou seja, tenta identificar se o livro responde à pergunta constantemente ouvida nas salas de aulas: "Pra que eu vou usar/preciso entender isso?"

Esse aspecto é subdividido nas categorias:

a) Transmitindo o propósito da unidade. $\mathrm{O}$ material transmite um sentido geral de propósito e direção que seja compreensível e motivador para os estudantes?

b) Transmitindo o propósito da atividade. O material transmite o objetivo de cada atividade e estabelece relações com as demais atividades?

c) Justificando a sequência de atividade. O material inclui uma sequência lógica ou estratégica de atividades (versus apenas uma coleção de atividades)?

O aspecto II. Levando em conta as ideias dos estudantes, determina se os livros contêm sugestões específicas para identificar e abordar as ideias mais comuns dos alunos. Assim sendo, através dessa categoria é possível determinar o quanto o livro leva em consideração as concepções prévias e/ou alternativas dos alunos.

Esse aspecto é subdividido nas categorias: 
d) Atendendo aos conhecimentos e habilidades prévias. O material especifica conhecimentos ou habilidades prévias que são necessários para a aprendizagem do programa?

e) Alertando o professor sobre as ideias comuns dos estudantes. O material alerta aos professores sobre as ideias mais comuns dos estudantes relacionadas ao conteúdo?

f) Ajudando o professor a identificar as ideias dos alunos. O material inclui sugestões para os professores identificarem o que seus alunos pensam sobre fenômenos familiares relacionados ao conteúdo antes que as ideias científicas sejam introduzidas?

g) Abordando ideias comuns. O material aborda explicitamente ideias comuns presentes nos alunos relacionadas ao conteúdo?

Segundo os criadores do sistema de avaliação a ciência deve ser capaz de explicar vários fenômenos em termos de um pequeno número de ideias. O aspecto III. Envolvendo os alunos com fenômenos relevantes, visa identificar se o LD relaciona as ideias a uma variedade de fenômenos relevantes. Nesse aspecto ainda é identificado se a apresentação dos fenômenos oferece uma experiência "mão-na-massa" (firsthand) ou inteligível. Aqui entendemos a experiência "mão-na-massa" como aquelas propostas experimentais em que o aluno é responsável por conduzir a atividade, ou seja, um experimento com ou sem roteiro em que o aluno é protagonista, e não o professor demonstrando. Esse aspecto é subdividido nas categorias:

h) Fornecendo variedade de fenômenos. O material fornece fenômenos múltiplos e variados para apoiar a ideia de referência?

i) Fornecendo experiências reais. O material inclui experiências do tipo "mão-namassa" com fenômenos (quando experimentais) e proporciona aos alunos um sentido inteligível do fenômeno quando as experiências não podem ser de "mão-na-massa"?

A alfabetização científica exige que os alunos compreendam o vínculo entre as ideias científicas e os fenômenos que podem explicar. Além disso, eles devem compreender a utilidade das ideias e tornarem-se hábeis na sua aplicação. O aspecto IV.

Desenvolvendo e Usando Ideias Científicas consiste em critérios para determinar se o material expressa e desenvolve as ideias-chave de maneiras acessíveis e inteligíveis para os alunos, e se demonstram a utilidade das ideias-chave e fornecem práticas em contextos variados. Esse aspecto é subdividido nas categorias:

j) Introduzindo termos de forma significativa. O material introduz termos técnicos apenas em conjunto com a experiência, com as ideias ou processos e apenas conforme necessário para facilitar o pensamento e promover uma comunicação eficaz?

k) Representando ideias efetivamente. $\mathrm{O}$ material inclui representações apropriadas das ideias de referência?

l) Demonstrando o uso do conhecimento. O material demonstra/modela ou inclui sugestões para professores sobre como demonstrar/modelar habilidades ou o uso do conhecimento? 
m) Fornecendo prática. O material fornece tarefas/perguntas para os alunos praticarem habilidades ou uso do conhecimento em uma variedade de situações?

Os aspectos III, relacionar as experiências aos fenômenos, e IV, apresentar as ideias científicas, não levarão a uma aprendizagem efetiva, a menos que os alunos tenham tempo, oportunidades e orientação para dar sentido às experiências e ideias. Nesse sentido, o aspecto V. Promovendo o Pensamento dos Estudantes sobre Fenômenos, Experiências e Conhecimento consiste em critérios para determinar se o material oferece aos alunos oportunidades para expressar, pensar e remodelar suas ideias, bem como orientações sobre o desenvolvimento de uma compreensão do que experimentam. As categorias que dividem esse aspecto são:

n) Incentivando os alunos a explicar suas ideias. O material inclui rotineiramente sugestões para que cada aluno possa expressar, esclarecer, justificar e representar suas ideias? São feitas sugestões para quando e como os alunos receberão comentários dos colegas e do professor?

o) Orientando o raciocínio dos alunos. O material inclui tarefas e / ou sequências de perguntas para orientar a interpretação e o raciocínio dos alunos sobre experiências com fenômenos e leituras?

p) Incentivando os alunos a pensarem sobre o que aprenderam. O material sugere maneiras para que os alunos verifiquem o seu próprio progresso?

O aspecto VI. Avaliando o progresso consiste em critérios para avaliar se o material inclui uma variedade de avaliações alinhadas, que aplicam as ideias-chave ensinadas no material, e tem como categorias:

q) Alinhando-se aos objetivos. Assumindo uma correspondência de conteúdo entre o material curricular e o programa, os itens de avaliação incluídos se relacionam com o programa?

r) Testando a compreensão. O material avalia a compreensão de ideias do programa e evita permitir aos alunos uma saída trivial, como repetir um termo ou frase memorizada do texto sem entender?

s) Informando a instrução. Algumas avaliações estão inseridas no currículo ao longo do caminho, com conselhos aos professores sobre como eles podem usar os resultados para escolher ou modificar atividades?

Por fim o último aspecto VII. Melhorando o ambiente de aprendizagem da ciência, proporciona analisar os recursos que aprimoram o uso e a implementação do material por todos os alunos. Os critérios são:

t) Fornecendo o suporte de conteúdo ao professor. O material promove ajuda aos professores a melhorar suas compreensões da ciência, da matemática e da tecnologia necessárias para o ensino do conteúdo?

u) Incentivando curiosidades e questionamentos. O material ajuda professores a criar um ambiente de sala de aula que acolhe a curiosidade dos alunos, recompensa a criatividade, encoraja um espírito de questionamento saudável e evita o dogmatismo?

v) Apoiando todos os alunos. O material ajuda os professores a criar uma 
comunidade de sala de aula que encoraja expectativas elevadas para todos os alunos, que permite que todos os estudantes experimentem sucesso e que proporciona a todos os alunos um sentimento de pertencimento na sala de aula de ciências?

Para cada categoria o instrumento de avaliação ainda define indicadores de cumprimento dos critérios. Os indicadores são perguntas que devem ser respondidas ao longo da análise para determinar o quão bem o material atende a categoria específica. De acordo com o número de indicadores atendidos o LD é classificado em excelente, satisfatório ou pobre. A lista de indicadores e esquema de classificação é destacado no anexo A. 


\section{ASPECTOS METODOLÓGICOS}

Querem que vos ensine o modo de chegar à ciência verdadeira? Aquilo que se sabe, saber que se sabe; aquilo que não se sabe, saber que não se sabe; na verdade é este o saber.

Confúcio

Esse estudo se caracteriza como uma pesquisa qualitativa. Segundo Minayo (2007) a pesquisa qualitativa proporciona um entendimento profundo das ligações que podem ser estabelecidas entre diversos elementos, e direciona-se à compreensão de um objeto de estudo pouco conhecido. A abordagem qualitativa numa pesquisa propicia a criação de novas abordagens, revisão e criação de novos conceitos e categorias durante a investigação. Sua característica principal é a sistematização progressiva do conhecimento até a compreensão lógica interna do grupo ou do processo estudado (TURATO, 2005).

Ao posicionar esse estudo numa abordagem qualitativa deve-se ter a clareza de que ela é fundamentalmente interpretativa. Nesse sentido, ela inclui a descrição do objeto de estudo, análise dos dados para identificar temas ou categorias e, por fim, interpretação ou conclusões sobre seu significado, pessoal e teoricamente, mencionando as lições aprendidas e oferecendo mais perguntas a serem feitas (WOLCOTT, 1994).

Além disso, essa pesquisa tem caráter descritivo, buscou-se explorar e descrever como o conteúdo de reações redox é apresentado nos livros didáticos brasileiros, e como tal apresentação pode estar relacionada às concepções alternativas de estudantes.

Para descrever como o conteúdo redox é apresentado ao longo dos livros de escolarização básica, realizou-se duas análises principais. Na primeira análise buscou-se identificar ao longo dos LD de nível fundamental e médio onde o conteúdo aparece, como os exemplos de reações redox são abordados e quais as diferenças entre as coleções de nível médio. Essa análise é descrita em duas seções, no tópico de resultados e discussão, uma para o nível fundamental e outra para o ensino médio.

Na segunda análise identificou-se quais os modelos de oxirredução são utilizados para definir essas reações e na aplicabilidade desses modelos (como resolução de exercícios). Essa análise é descrita para os capítulos em que a reação redox é diretamente abordada, ou seja, nos LD de química do ensino médio, diferentemente da primeira análise em que os exemplos redox são abordados de forma tangencial.

Com os resultados obtidos nessas duas análises, pôde-se descrever a evolução do conteúdo em livros didáticos do PNLD e fazer inferências sobre como a apresentação do 
conteúdo pode influenciar as concepções alternativas mapeadas na literatura. Concomitantemente, percebeu-se a necessidade de verificar de qual forma o livro fornece suporte ao professor no ensino dessas reações e na elucidação das concepções. Nesse caso, utilizou-se um instrumento de análise da qualidade de LD.

A figura 2 resume o procedimento metodológico empregado nesta dissertação.

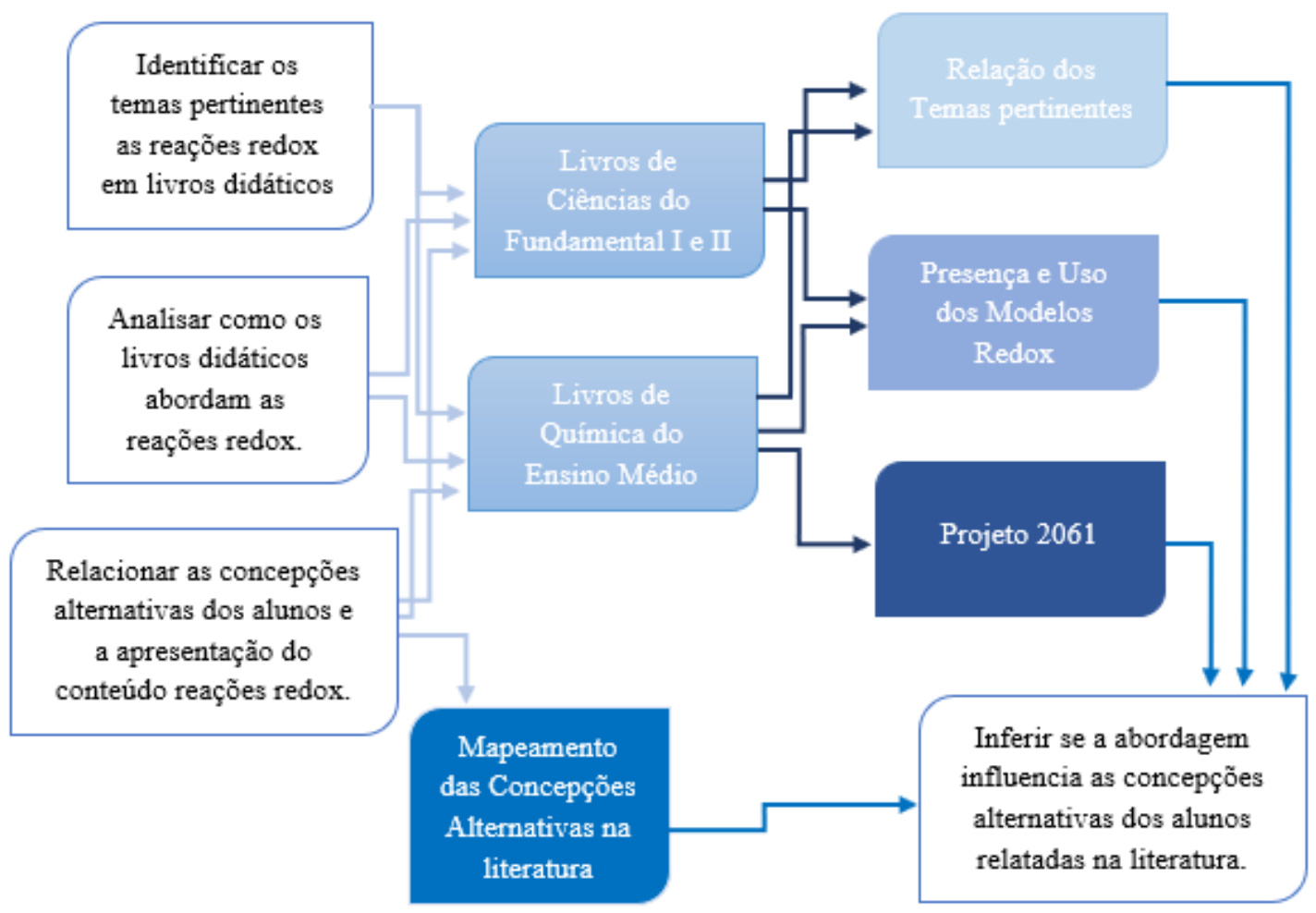

Legenda:

Objetivos

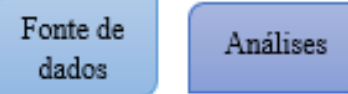

Figura 2 - Esquema resumo dos aspectos metodológicos.

$\mathrm{O}$ caminho metodológico inicialmente prescrito buscava responder à primeira questão de pesquisa: como os conceitos de reações redox vão sendo construídos nos textos dos livros didáticos de ciências do ensino fundamental I e II e de química do ensino médio? Para isso, identifica-se os temas pertinentes às reações redox em livros de nível fundamental e médio; e quais os modelos redox estão presentes na descrição destas reações. Essas análises estão presentes nas seções 2 e 3 dos resultados e discussão.

Posteriormente, objetivou-se responder à segunda questão: como esses textos podem se relacionar às concepções alternativas dos estudantes relatadas na literatura? Para isso, interpretou-se como a forma de apresentação do conteúdo pode influenciar as 
concepções alternativas e criou-se esquemas que demonstram a evolução do conteúdo nos LDs. Esta análise está presente na seção 4 dos resultados e discussão.

Ao inferir a influência da abordagem utilizada nos LD nas concepções alternativas mapeadas na literatura, percebeu-se a necessidade de identificar se os livros fornecem suporte ao professor no trabalho e confronto às concepções dos alunos. Para isso, incluiuse no planejamento metodológico a análise da qualidade dos livros, utilizando um instrumento criado pelo projeto 2061. Essa análise está presente na seção 5 dos resultados e discussão.

Para todas as análises descritas utilizou-se como metodologia de análise dos dados a análise de conteúdo. Moraes (1999) define a análise de conteúdo como uma metodologia utilizada para descrever e interpretar o conteúdo de documentos e textos. Tal análise permite a reinterpretação de mensagens para atingir uma compreensão de seus significados além de uma leitura comum. Bardin (2011) acrescenta que a análise de conteúdo é composta por procedimentos sistemáticos que proporcionam o levantamento de indicadores permitindo a realização de inferência de conhecimentos.

A análise de conteúdo, segundo Moraes (1999), consiste na realização de 5 etapas principais, sendo elas: 1) Preparação das informações; 2) Unitarização ou transformação do conteúdo em unidades; 3) Categorização ou classificação das unidades em categorias; 4) Descrição e 5) Interpretação. Detalha-se, na sequência, como procedeu-se tais etapas nas análises apresentadas neste trabalho.

\subsection{Etapa de preparação das informações}

Essa etapa consiste em selecionar quais documentos irão compor o estudo. Neste trabalho as obras a serem analisadas são as aprovadas nos editais do PNLD 2016, 2017e 2018. O PNLD 2016 corresponde ao Edital de Convocação 02/2014 da CoordenaçãoGeral dos Programas do Livro. O PNLD 2017 corresponde ao Edital de Convocação 02/2015 da Coordenação-Geral dos Programas do Livro. O PNLD 2018 corresponde ao corresponde ao Edital de Convocação 04/2015 da Coordenação-Geral dos Programas do Livro e 04/2015 do PNLD. Todas as coleções de química do PNLD 2018 foram analisadas, enquanto que para as obras de ciências da natureza do ensino fundamental I e II selecionou-se as três coleções mais distribuídas na rede pública de ensino ${ }^{7}$. A listagem das obras se encontra no quadro 4.

\footnotetext{
${ }^{7}$ Dados disponíveis em: https://www.fnde.gov.br/programas/programas-do-livro/pnld/dados-estatisticos
} 
Quadro 4 - Coleções aprovadas no PNLD

\begin{tabular}{|c|c|c|c|}
\hline & Coleção & Autores & Editora \\
\hline \multirow{3}{*}{ 象 } & Ligados.Com & Silvana Rossi Júlio. & Saraiva \\
\hline & Porta Aberta & $\begin{array}{l}\text { Denise Mendes, Margarete Artacho, Mônica } \\
\text { Jakievicius e Roberto Giansanti. }\end{array}$ & FTD \\
\hline & Projeto Buriti & $\begin{array}{l}\text { Lina Youssef Jomaa, Lucimara Regina de Souza } \\
\text { Vasconcelos e Maissa Salah Bakri. }\end{array}$ & Moderna \\
\hline \multirow{3}{*}{ 承 } & $\begin{array}{l}\text { Investigar e Conhecer: } \\
\text { Ciências da Natureza }\end{array}$ & Sônia Lopes. & $\begin{array}{l}\text { Saraiva } \\
\text { Educação }\end{array}$ \\
\hline & Projeto Teláris & Fernando Gewandsznajder. & Editora Ática \\
\hline & Projeto Araribá & Maíra Rosa Carnevalle. & Moderna \\
\hline \multirow{6}{*}{ 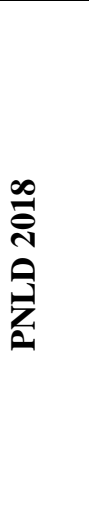 } & Vivá- Química & Vera Lucia D. de Novais e Murilo T. Antunes. & Positivo \\
\hline & Química & Eduardo F. Mortimer e Andréa Horta Machado & Scipione \\
\hline & $\begin{array}{l}\text { Química - Ciscato, } \\
\text { Pereira, Chemello e } \\
\text { Proti }\end{array}$ & $\begin{array}{l}\text { Carlos Alberto M. Ciscato, Luis Fernando Pereira, } \\
\text { Emiliano Chemello e Patricia Barrientos Proti. }\end{array}$ & Moderna \\
\hline & Ser Protagonista & $\begin{array}{l}\text { Lia M. Bezerra; Julio Cezar F. Lisboa, Aline Thaís } \\
\text { Bruni, Ana Luiza P. Nery, Rodrigo M. Liegel e Vera } \\
\text { Lúcia M. Aoki. }\end{array}$ & SM \\
\hline & Química Cidadã & $\begin{array}{l}\text { Wildson Luiz P. dos Santos, Gerson de S. Mól, } \\
\text { Siland M. F. Dib, Roseli T. Matsunaga, Sandra } \\
\text { Maria de O. Santos, Eliane N. F. de Castro, Gentil } \\
\text { de S. Silva e Salvia B. Farias. }\end{array}$ & AJS \\
\hline & Química & Martha Reis. & Ática \\
\hline
\end{tabular}

Fonte: Secretaria de Educação Básica. Portaria no 30, de 11 de agosto de 2015; Secretaria de Educação Básica. Portaria n 13, de 23 de junho de 2016; Secretaria de Educação Básica. Portaria $n^{\circ} 62$, de $1^{\circ}$ de agosto de 2017

A etapa de preparação das informações consiste, também, em estabelecer um código que possibilite identificar rapidamente cada documento a ser analisado. Nesse caso, estabeleceu-se códigos de acordo com o nome mais facilmente associável ao livro em questão. O quadro 5 descreve como os livros serão referenciados nas análises.

Quadro 5 - Descritores das coleções aprovadas no PNLD

\begin{tabular}{|c|c|c|}
\hline & Coleção & Código \\
\hline \multirow{3}{*}{ 至 } & Ligados.Com & $\mathrm{LC}$ \\
\hline & Porta Aberta & PA \\
\hline & Projeto Buriti & PB \\
\hline \multirow{3}{*}{ 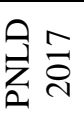 } & Investigar e Conhecer: Ciências da Natureza & $\mathrm{IC}$ \\
\hline & Projeto Teláris & $\mathrm{TL}$ \\
\hline & Projeto Araribá & AR \\
\hline \multirow{6}{*}{ 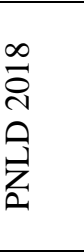 } & Vivá- Química & VV \\
\hline & Química & MM \\
\hline & Química - Ciscato, Pereira, Chemello e Proti & $\mathrm{CP}$ \\
\hline & Ser Protagonista & SP \\
\hline & Química Cidadã & $\mathrm{QC}$ \\
\hline & Química & MR \\
\hline
\end{tabular}

Os descritores foram escolhidos para melhor facilitar a identificação da coleção, assim o descritor "SP" refere-se às duas primeiras letras do nome composto da coleção (Ser Protagonista), o mesmo para a segunda e terceira coleção. Das coleções que não há um nome específico utiliza-se a inicial do sobrenome do primeiro e último autor, assim a 
coleção 4, Química-Ciscato, Pereira, Chemello e Proti tem descritor ' $\mathrm{CP}$ ' que corresponde à inicial de Ciscato e Proti (inicial do último sobrenome do primeiro e último autor). Os números correspondem ao ano escolar.

É de suma importância ressaltar que esta pesquisa, apesar de envolver apenas documentos no corpus de pesquisa, não se trata de uma análise documental. Segundo Bardin (2011) a análise documental refere-se a um procedimento muito utilizado na historiografia, e demais área de pesquisa da história, definida como um procedimento metodológico que visa representar um documento de forma diferente do original. Nesse sentido, transformam-se as informações contidas nos documentos para facilitar sua consulta ou referenciação. Bardin (2011) ainda destaca que:

[...] o propósito a atingir é o armazenamento sob uma forma variável e a facilitação do acesso ao observador, de tal forma que este obtenha o máximo de informação (aspecto quantitativo), com o máximo de pertinência (aspecto qualitativo). A análise documental é, portanto, uma fase preliminar da constituição de um serviço de documentação ou de um banco de dados. (BARDIN, 2011, p. 51).

Bardin (2011, p.52) ainda destaca as principais diferenças entre a análise documental e a análise de conteúdo, que são:

A documentação trabalha somente com documentos, enquanto que a análise de conteúdo com mensagens em diferentes meios.

A análise documental faz-se por classificação-indexação, enquanto que a categorização é somente uma das técnicas da análise de conteúdo.

A análise documental objetiva representar condensadamente a informação para posterior consulta ou armazenamento, enquanto que o objetivo da análise de conteúdo é a manipulação de uma mensagem para evidenciar os indicadores que permitam inferir sobre uma outra realidade que não a da mensagem.

\subsection{Etapa de unitarização}

Essa etapa tem a finalidade de definir a unidade de análise, ou seja, o elemento unitário de conteúdo a ser submetido posteriormente à classificação. Cada uma das análises possui uma unidade diferenciada, o procedimento de escolha das unidades é destacado na sequência.

\subsubsection{A evolução do conteúdo redox em livros do ensino fundamental I e II e do ensino médio}

Nessa investigação todas as páginas de todos os livros foram lidas. Dessa leitura depreendeu-se quais temas com ligação direta ou indireta às reações redox aparecem nos 
livros. Todas as informações relacionadas ao tema compõem a unidade de análise desse estudo.

Os trechos em que constam as informações variam para cada tema. Temas mais explorados, como a fotossíntese, são mais desenvolvidos e, portanto, a unidade de análise é composta de um texto inteiro. Já para os temas que aparecem timidamente nos livros os trechos correspondem a parágrafos de quatro a sete linhas.

Já na caracterização das obras analisadas, optou-se por fazê-la apenas para as obras do PNLD 2018, por tratar das coleções que mais abordam o conteúdo de reações redox. Na caracterização das obras, utilizou-se trechos de todas as partes dos livros, textos explicativos, legendas, exercícios, notas de memória ao professor, etc. que foram catalogados e totalizados.

Inicialmente catalogou-se o total de ocorrências das palavras que se referem aos conceitos de reações redox. Utilizou-se o mecanismo de busca na procura dos trechos específicos. Para isso utilizou-se as palavras-chaves: a) oxida, b) redu, c) redox, d) oxirredução, e) oxido-redução. Salienta-se que foram utilizadas as palavras 'oxida' e 'redu' de forma incompleta para que a busca abrangesse também outros termos que se referem às reações redox, tais como: oxidação, oxidada, agente oxidante, antioxidante, processo oxidativo, e etc. Dos trechos encontrados pelo mecanismo de busca para a palavra-chave 'redu' foram selecionados apenas aqueles que faziam referência explícita ao conteúdo redox, dessa forma, aqueles em que a palavra redução indicava uma diminuição de um número/objeto/fator, tais como nas frases "redução da camada de ozônio", "redução do lixo gerado", entre outras, não foram catalogados.

Os dados obtidos foram sistematizados em tabelas para cada livro das 6 coleções (apêndice A). Descreve-se também o contexto em que a palavra aparece e a página. Essa sistematização foi feita para aquelas palavras que aparecem fora dos capítulos cujo objetivo era a abordagem do conteúdo redox. Por exemplo, a coleção QC traz um capítulo único no terceiro livro da coleção, no entanto, as palavras oxidação, oxida, oxidada e outras aparecem nos dois primeiros livros; não sendo desenvolvida nenhuma explicação para esses conceitos. Assim, para os capítulos que abordam o conteúdo das reações redox é feita uma análise separada.

Salienta-se que as partes de organização dos livros como a capa, as páginas de apresentação, sumário e o caderno de apoio pedagógico também foram retiradas dessa análise. 
$\mathrm{Na}$ análise direta dos capítulos que abordam as reações redox, utilizou-se textos completos que se remetiam a um determinado aspecto. Por exemplo, para quantificação dos experimentos presentes nos livros utilizou-se como unidade de análise todo o texto em que a proposta experimental foi descrita, apesar de ser contabilizada uma única vez. O mesmo ocorreu para determinação dos outros aspectos, tais como, presença de elementos da história da ciência, contextualização, descrição do conteúdo e etc.

\subsubsection{Os modelos redox nos livros didáticos brasileiros}

Para compreender quais modelos redox estão presentes nos livros didáticos brasileiros utiliza-se como unidade de análise o trecho onde a definição de uma reação redox é apresentada e trechos em que um modelo redox é utilizado (por exemplo, na resolução de exercícios).

O trecho de definição de uma reação é destacado no início dos capítulos específicos, na página introdutória do capítulo, ou até em mais de um livro da coleção. Em determinadas coleções a definição de uma reação redox é apresentada superficialmente no primeiro livro da coleção, é abordada com maior profundidade no livro correspondente ao segundo ano e, posteriormente, é retomada no terceiro livro. Nesse caso, todas as definições apresentadas na coleção são consideradas na análise e subsidiam a discussão dos dados.

O trecho corresponde, em geral, a uma ou duas linhas com informações sobre o que é uma reação redox, uma reação de oxidação ou redução. Em alguns casos, o trecho é antecedido de uma frase que busca chamar atenção do leitor, como: “Que tipo de reação acontece em uma pilha?" (VV, 2, p. 224); "Há muitos exemplos desses tipos de reações disponíveis para nossos estudos” (MM, 2, p. 194).

Já os trechos que utilizam um modelo diferente daquele em que se define as reações foram selecionados de acordo com a leitura aprofundada de todo o capítulo do livro. Em geral, esses trechos podem estar alocados anteriormente ao trecho de definição das reações, numa inclusão de elementos históricos, ou ainda, na realização de exercícios e cálculos envolvendo o conteúdo.

Cada trecho é exposto na forma de citação direta separado por coleção do PNLD. 


\subsubsection{Os livros como suporte ao ensino das reações redox}

Buscando compreender se os livros aprovados pelo PNLD dão suporte ao processo de ensino-aprendizagem das reações redox utiliza-se um instrumento criado e validado por pesquisadores participantes do Projeto 2061.

O projeto 2061 fornece um instrumento de análise que permite compreender se os livros apresentam, ou não, sete aspectos definidos como essenciais na aprendizagem do conteúdo. Os setes aspectos são: I) Identificando e mantendo um sentido de propósito, II) Levando em conta as ideias dos estudantes, III) Envolvendo os alunos com fenômenos relevantes, IV) Desenvolvendo e usando ideias científicas, V) Promovendo o Pensamento dos Estudantes sobre Fenômenos, Experiências e Conhecimento, VI) Avaliando o progresso e VII) Melhorando o ambiente de aprendizagem da ciência.

Cada um dos aspectos apresenta determinadas categorias. Cada uma das categorias conta com um sistema de classificação e indicadores de cumprimento de categoria. Esse esquema é apresentado no anexo A.

Para identificação da presença dos sete aspectos percorre-se o capítulo específico destinado à abordagem aprofundada do conteúdo redox, e o capítulo localizado ao final do livro do professor geralmente denominado como Caderno de Apoio Pedagógico. Dentro destes capítulos procurou-se trechos que permitiam identificar a presença das categorias.

Nesta análise os trechos são bastante variados, pois, cada aspecto determina o objeto a ser identificado. Por exemplo, o aspecto I procura diagnosticar se o objetivo do estudo do conteúdo é apresentado aos alunos, nesse caso o objetivo deve ser apresentado ao iniciar a abordagem e ser retomado posteriormente, não parece fazer sentido que o objetivo seja expressado ao final do capítulo. Portanto, para o aspecto I utiliza-se um trecho de até um parágrafo, destacado no início do capítulo.

No aspecto IV identifica-se o quanto o livro aproxima os alunos aos fenômenos relevantes diretamente ligados ao conteúdo estudado. Para tal, analisa-se as proposições experimentais dadas pelos livros e, portanto, a unidade de análise é um texto de até duas páginas. Para os demais aspectos a unidade de análise permanece um parágrafo de no máximo 4 linhas, distribuídos ao longo do capítulo.

Como para cada coleção há uma distinção entre o volume e o número de páginas destinadas à abordagem do assunto, explicitamos na tabela 1 quais páginas e volumes foram considerados. 
Tabela 1 - Páginas dos livros correspondentes à abordagem das reações redox

\begin{tabular}{c|c|c|c|c|c}
\hline \multirow{2}{*}{ Coleção } & \multicolumn{5}{|c}{ Páginas } \\
\cline { 2 - 6 } & \multirow{2}{*}{ Livro 1 } & \multirow{2}{*}{ Livro 2 } & \multirow{2}{*}{ Livro 3 } & \multicolumn{2}{|c}{ Manual Professor } \\
\cline { 5 - 6 } & & $114-169$ & & 2 & $316-324$ \\
CP & & $192-245$ & & 2 & $350-364$ \\
MM & & $237-286$ & $184-196$ & 2 & $358-365$ \\
MR & $278-285$ & & $185-242$ & 3 & $325-327$ \\
QC & & $182-245$ & $165-180$ & \multicolumn{2}{|c|}{ Não divulgado } \\
SP & $185-186$ & $216-284$ & $202-211$ & 2 & $365-375$ \\
VV & $206-231$ & & & 2 & \multicolumn{2}{|c}{ Páginas } \\
\hline
\end{tabular}

Como o Manual do Professor da coleção SP não foi divulgado no período de seleção das obras do PNLD 2018, este não pôde ser analisado. Como existem categorias que questionam sobre as sugestões e orientações fornecidas ao professor, essas não foram julgadas. O mesmo ocorreu para as demais categorias em que as informações estejam contidas no Manual do Professor da coleção.

Neste momento é necessário acrescentar algumas considerações sobre como a análise foi realizada. Primeiro, toda a avaliação proposta pelo projeto 2061 é baseada nas ideias-chaves do conteúdo. As ideias-chaves são definidas pelas 'referências' que são o documento de orientação que define os objetivos de aprendizagem visando a alfabetização científica. Como o objetivo definido neste trabalho é analisar o conteúdo de reações redox nos livros didáticos, optou-se por descrever quais as ideias-chaves para esse conteúdo na seção de fundamentação teórica.

É preciso destacar, também, que para a análise do quanto os livros fornecem suporte ao processo de ensino-aprendizagem, a apresentação dos dados diverge da apresentação realizada pelo projeto 2061. Os resultados da análise realizada pelos revisores foram apresentados em forma de relatório para cada uma das coleções escolhidas. Os relatórios são divididos em duas seções, a primeira é denominada 'Análise de conteúdo' dividida em cinco partes: a) alinhamento, b) construindo um caso, c) coerência, d) além da alfabetização e e) precisão. Nessa seção os avaliadores examinam se o conteúdo se alinha com as ideias-chaves, se são apresentadas evidências que apoiam as ideias-chave, se as ideias-chave se relacionam entre si, se fornece informações mais avançadas do que o conjunto de ideias e ainda se o livro apresenta qualquer informação errada ou que reforçam concepções dos alunos. A segunda seção é denominada 'Análise de instrução' onde são agrupados os dados das categorias apresentadas aqui.

Neste trabalho considerações sobre a primeira seção são acrescentadas junto aos dados agrupados nas categorias citadas. Esse processo é necessário pois a análise foi 
realizada apenas no capítulo de reações redox, para que sejam produzidos relatórios de acordo com o projeto 2061, a análise deve considerar todo o livro didático, o que foge aos objetivos dessa dissertação.

\subsection{Etapa de categorização}

A etapa de categorização consiste no procedimento de agrupar dados considerando a parte comum existente entre eles. Moraes (1999) aponta que o estabelecimento de categorias precisa obedecer a alguns critérios, as categorias devem ser válidas, exaustivas e homogêneas, ser mutuamente exclusivas e consistentes. As categorias utilizadas são descritas na sequência.

\subsubsection{A evolução do conteúdo redox em livros do ensino fundamental I e II e ensino médio}

Como essa análise trata da evolução do conteúdo em livros do ensino fundamental, os temas emergem à medida que a análise é realizada. Dessa forma, considera-se que as categorias são definidas a posteriori e são caracterizadas pelos temas encontrados.

Os temas encontrados foram: Air Bag, Bafômetro, Combustão, Decomposição, Eletrólise, Escurecimento da maçãa, Extração de Metais, Fermentação, Ferrugem, Fotossíntese, Oxirredução, Pilhas e Baterias, Proteção Solar, Radicais Livres e Antioxidantes, Respiração Celular e Ozônio. Cada um desses temas corresponde a um exemplo de reação redox que é apresentado nos livros.

Os exemplos foram considerados mesmo que não haja indicação direta nos LD de ser uma reação redox. Isso acontece frequentemente para os livros de ensino fundamental, uma vez que as reações de oxirredução são definidas pela primeira vez no livro correspondente ao nono ano.

As categorias são válidas, uma vez que correspondem a exemplos de reações redox úteis na identificação da evolução do conteúdo, e considera-se que reproduzem adequadamente como o conteúdo vai sendo apresentado nos LD. As categorias também são exaustivas à medida que enquadram todo o conteúdo redox em livros de ensino fundamental e médio. Além disso, elas possuem exclusividade por tratar-se de exemplos de reações que tem mecanismos próprios e não se confundem com outros exemplos. 


\subsubsection{Os modelos redox nos livros didáticos brasileiros}

Para análise da presença dos modelos redox nos livros didáticos utiliza-se categorias definidas a priori, descritas por Ringnes (1995) e Österlund, Berg e Ekborg (2010). As categorias nada mais são que os próprios modelos redox descritos na literatura, que são: modelo de oxigênio, modelo de hidrogênio, modelo de transferência eletrônica e modelo de número de oxidação.

Conforme já apresentado na fundamentação teórica, o modelo de oxigênio define que reações redox são processos em que há uma transferência de oxigênio, enquanto que o modelo de hidrogênio descreve que a reação redox é aquela em que ocorre uma transferência de hidrogênio. O modelo de transferência eletrônica define que os processos que envolvem uma transferência de elétrons entre as espécies sejam caracterizados como processos redox. Por fim, o modelo de número de oxidação determina que uma reação redox é aquela em que o número de oxidação de um ou mais elementos varia.

Os modelos redox são categorias válidas, por tratar de modelos que explicam uma reação e se repetem ao longo da abordagem do conteúdo. Tratam de categorias exaustivas pois permitem sistematizar todo o conteúdo abordado nos $\mathrm{LD}$ de química e são mutuamente exclusivas uma vez que cada modelo é circundado por um mecanismo próprio que não se repete nos outros modelos.

\subsubsection{Os livros como suporte ao ensino das reações redox}

Para essa análise utilizam-se as categorias provenientes do Projeto 2061 para avaliação dos livros didáticos: O Middle Grades Science Textbooks: A BenchmarksBased Evaluation. O instrumento de avaliação consiste em determinar se o livro apresenta os setes aspectos, já apresentados. Cada um dos aspectos contém 2 a 4 categorias que buscam identificar o quanto o livro atende ou não aquele aspecto de aprendizagem específico. Os aspectos são descritos no quadro 6. 
Quadro 6 - Categorias provenientes do Projeto 2061

\begin{tabular}{|c|c|}
\hline Aspecto & Categoria \\
\hline $\begin{array}{l}\text { I. Identificando e } \\
\text { mantendo um sentido de } \\
\text { propósito }\end{array}$ & $\begin{array}{l}\text { a) Transmitindo o propósito da unidade. } \\
\text { b) Transmitindo o propósito da atividade. } \\
\text { c) Justificando a sequência de atividade. }\end{array}$ \\
\hline $\begin{array}{l}\text { II. Levando em conta as } \\
\text { ideias dos estudantes }\end{array}$ & $\begin{array}{l}\text { d) Atendendo aos conhecimentos e habilidades prévias. } \\
\text { e) Alertando o professor sobre as ideias comuns dos estudantes. } \\
\text { f) Ajudando o professor a identificar as ideias dos alunos. } \\
\text { g) Abordando ideias comuns. }\end{array}$ \\
\hline $\begin{array}{l}\text { III. Envolvendo os alunos } \\
\text { com fenômenos relevantes }\end{array}$ & $\begin{array}{l}\text { h) Fornecendo variedade de fenômenos. } \\
\text { i) Fornecendo experiências reais. }\end{array}$ \\
\hline $\begin{array}{l}\text { IV. Desenvolvendo e } \\
\text { Usando Ideias Científicas }\end{array}$ & $\begin{array}{l}\text { j) Introduzindo termos de forma significativa. } \\
\text { k) Representando ideias efetivamente. } \\
\text { l) Demonstrando o uso do conhecimento. } \\
\text { m) Fornecendo prática. }\end{array}$ \\
\hline $\begin{array}{c}\text { V. Promovendo o } \\
\text { Pensamento dos } \\
\text { Estudantes sobre } \\
\text { Fenômenos, Experiências } \\
\text { e Conhecimento }\end{array}$ & $\begin{array}{l}\text { n) Incentivando os alunos a explicar suas ideias. } \\
\text { o) Orientando o raciocínio dos alunos. } \\
\text { p) Incentivando os alunos a pensarem sobre o que aprenderam. }\end{array}$ \\
\hline VI. Avaliando o progresso & $\begin{array}{l}\text { q) Alinhando-se aos objetivos. } \\
\text { r) Testando a compreensão. } \\
\text { s) Informando a instrução. }\end{array}$ \\
\hline $\begin{array}{l}\text { VII. Melhorando o } \\
\text { ambiente de aprendizagem } \\
\text { da ciência }\end{array}$ & $\begin{array}{l}\text { t) Fornecendo o suporte de conteúdo ao professor. } \\
\text { u) Incentivando curiosidades e questionamentos. } \\
\text { v) Apoiando todos os alunos. }\end{array}$ \\
\hline
\end{tabular}

Ressalta-se que o instrumento de análise, nas categorias b e c, refere-se às atividades presentes no material didático. Considera-se que estejam presentes nos livros didáticos três tipos de atividades, os exercícios, as atividades experimentais e as atividades em grupos (também denominadas atividades de discussão). Procurou-se identificar para cada tipo de atividade quais atendiam as categorias.

\subsection{Etapa de descrição}

A etapa de descrição dos resultados foi destacada junto à constituição das unidades de análise dos estudos apresentados neste trabalho. Para cada uma das análises são apresentados os dados descritos em forma de texto resumido que também contam com imagens e citações diretas.

Na primeira análise, utilizam-se quadros que resumem a presença do conteúdo ao longo dos livros. Esses quadros permitem identificar como o conteúdo está presente, em quais anos e em quais livros. Nessa análise também é utilizado esquemas para caracterizar os livros de química do nível médio. 
Na segunda análise utiliza-se texto resumo da presença dos modelos nos livros. Enquanto que na terceira análise são utilizados textos, citações diretas e imagens, que são resumidos na forma de quadro a ser interpretado.

\subsection{Etapa de interpretação}

$\mathrm{Na}$ etapa de interpretação procurou-se responder à questão de pesquisa, de acordo com os resultados obtidos. Essa etapa consiste na discussão dos resultados de cada estudo extrapolando para um objetivo mais amplo. Serão consideradas as inferências de cada uma das etapas anteriores para traçar possíveis implicações dessa investigação.

A seção denominada "A evolução do conteúdo de reações redox nos livros didáticos da educação básica" é fundamentalmente interpretativa e busca destacar como as duas análises anteriores podem elucidar a questão de pesquisa. A seção seguinte traz as etapas de descrição e interpretação juntas e permite discorrer sobre a questão de pesquisa de forma mais ampla.

Na seção de conclusão a etapa de interpretação também pode ser encontrada, uma vez que se faz um resumo sobre a fundamentação teórica, os dados obtidos e análises realizadas. 


\section{RESULTADOS E DISCUSSÃO}

A ciência nunca resolve um problema sem criar pelo menos outros dez.

George Bernard Shaw

\subsection{A evolução das reações redox nos livros didáticos}

Os currículos de ensino fundamental e médio são construídos de forma que se garanta a progressão do conhecimento, ou seja, partindo do mais básico para o mais difícil e que demanda vários conhecimentos prévios. Um exemplo dessa evolução é o conteúdo de reações redox cuja base para o entendimento, ou seja, os conhecimentos prévios, em geral são tratados no ano anterior.

Além disso, alguns exemplos de reações redox são abordados em anos anteriores ao nível médio, na forma de citação ou como um conteúdo que se estende por vários anos, de diferentes formas. Esses exemplos, em geral, fazem parte do conteúdo programado para a disciplina de ciências no nível fundamental. Contudo, não se encontram pesquisas que avaliem a presença do conteúdo redox no ensino fundamental.

Em virtude disso, objetivou-se conhecer como o conteúdo redox evolui ao longo dos livros da educação básica. A ideia de evolução utilizada se trata da apresentação progressiva dos temas pertinentes à essas reações, ou seja, como os temas aparecem e são esmiuçados nos anos posteriores e retomados no nível médio.

Para isso, utiliza-se como fonte de pesquisa os livros aprovados pelo PNLD 2016, 2017 para o nível fundamental, ou seja, as coleções de ciências do fundamental I e II e as coleções de química aprovadas pelo PNLD 2018 do ensino médio.

Devido à dificuldade em encontrar os livros de ensino fundamental, já que esses não podem ser comprados pois só são vendidos para o governo federal, optou-se por analisar as seis coleções de ciências da natureza mais utilizadas em todo o território nacional, sendo elas 3 de fundamental I e 3 de fundamental II.

A informação sobre as coleções mais vendidas, e, portanto, aquelas que mais alunos têm contato nas escolas básicas, está disponível no site oficial do $\mathrm{FNDE}^{8}$, juntamente com outras informações do Programa do Livro.

A análise consistiu em percorrer as páginas dos livros identificando temas, ou exemplos de reações, que pudessem ser atreladas ao conteúdo de reações redox. Alguns temas encontrados nas coleções foram: fotossíntese, respiração celular, combustão, pilhas

\footnotetext{
${ }^{8}$ Dados disponíveis em: https://www.fnde.gov.br/programas/programas-do-livro/pnld/dados-estatisticos
} 
e o próprio tema de oxirredução, sendo que muitos repetiam ao longo dos anos escolares e dos livros.

Os resultados são apresentados de acordo com a série escolar, primeiramente para o ensino fundamental, e posteriormente completando-se com a oxirredução abordada no ensino médio. A análise do nível médio é descrita na seção seguinte, após a caracterização das coleções de química do PNLD 2018.

\section{$I^{o}$ ano do ensino fundamental I}

No currículo comum brasileiro, no primeiro ano do ensino fundamental, abordase a relação do aluno consigo e com as pessoas ao seu redor. Esse conteúdo é conhecido como "entendimento do eu e do outro", ou seja, serve para que as crianças conheçam seu corpo, sua escola, sua família, a comunidade e município em que vive. Alguns livros trazem também uma contextualização sobre os indígenas e a história dos negros no Brasil. Como os alunos que frequentam esse nível de ensino são muito novos, é comum que a ciência abordada seja mais branda e mais simplificada, dessa forma não há um tema pertinente ao conteúdo de reações redox nesse ano escolar. Ou seja, em nenhuma das três coleções investigadas foi encontrado um tema especifico.

\section{$2^{\circ}$ ano do ensino fundamental $I$}

O primeiro tema pertinente ao conteúdo de reações redox que aparece nos livros didáticos da educação básica é o de respiração atrelado ao tema de fotossíntese. Esse tema é apresentado em apenas uma das três coleções aqui investigadas e representa a primeira introdução à química, relatando a importância do gás oxigênio para as plantas e animais. Entretanto, devido ao nível de ensino, a abordagem é simplificada e não retrata a respiração celular e a troca gasosa realizada nesses organismos, conforme pode-se observar na figura 3 .

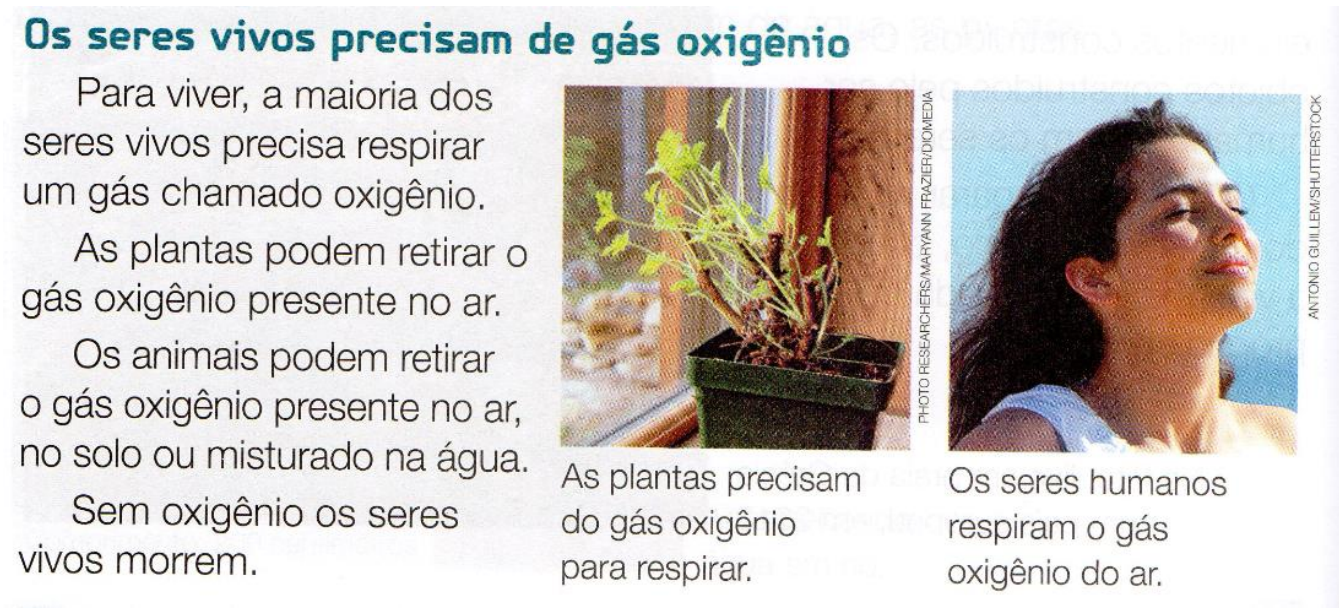

Figura 3 - Tema Respiração no livro 2 da coleção PB

Fonte: PB, 2, p.118 


\section{$3^{\circ}$ ano do ensino fundamental I}

A fotossíntese é o segundo tema que aparece nas coleções investigadas e é retratado nas três coleções. O que difere na apresentação desse tema nas coleções são as abordagens utilizadas, mas todas apresentam uma representação esquemática sobre o processo.

Na coleção PB (Projeto Buriti) é destacado que "as plantas transformam gás carbônico, água e luz em alimentos para si mesmas" (PB, 3, p. 13), que esse processo ocorre nas folhas e é denominado fotossíntese. O esquema utilizado é:

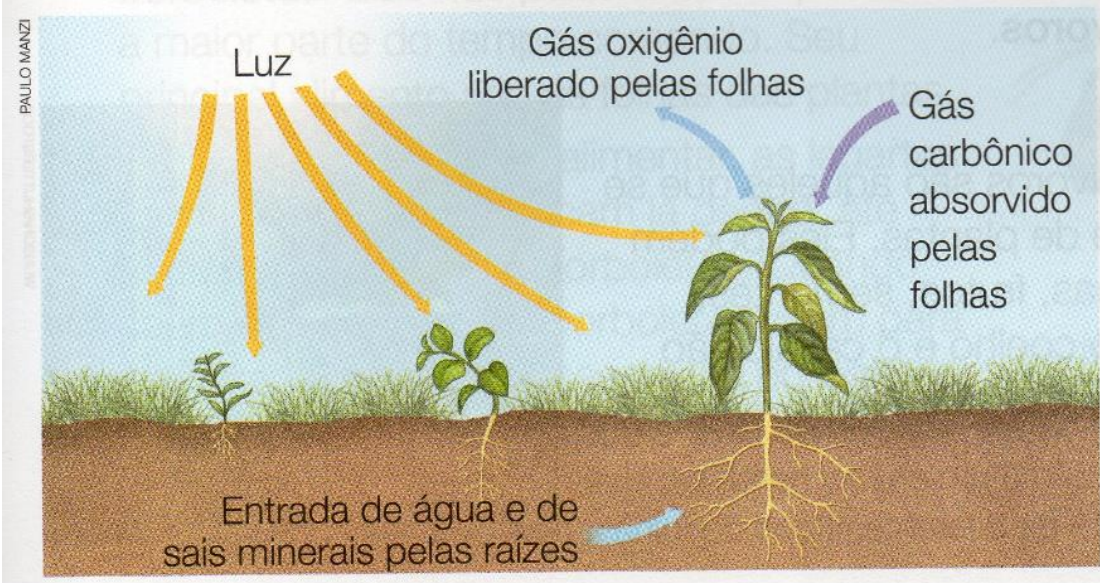

\section{Esquema simplificado representando o modo como a planta produz o próprio alimento.}

Figura 4 - Tema fotossíntese no livro 3 da coleção PB

Fonte: PB, 3, p.13

Na coleção PA (Porta Aberta) ao falar da fotossíntese são introduzidos novos termos como glicose e gás carbônico. O livro traz que "com água, luz e gás carbônico, as plantas conseguem produzir o próprio alimento, que é chamado glicose.” (PA, 3, p.220). A representação esquemática utilizada é:

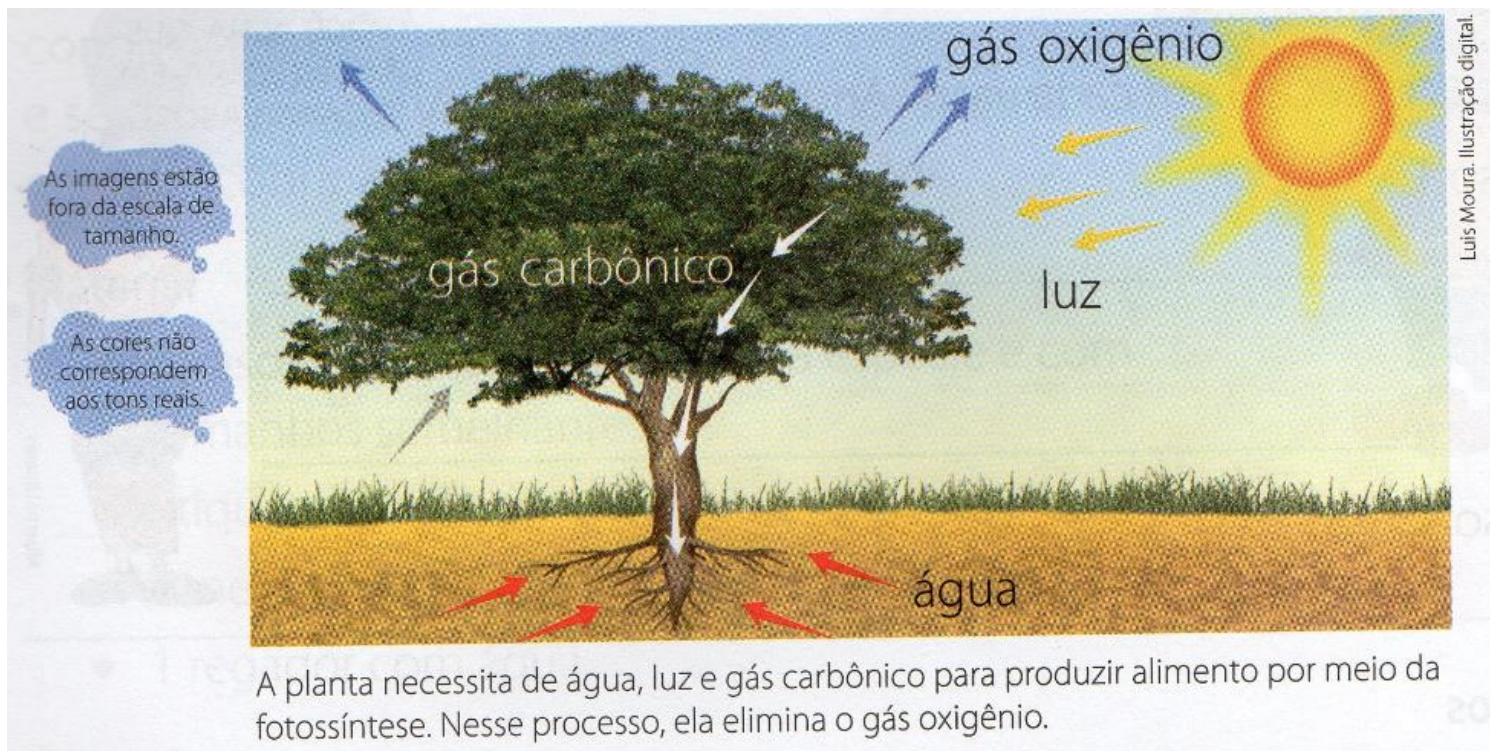

Figura 5 - Tema fotossíntese no livro 3 da coleção PA Fonte: PA, 3, p. 220 
Já na coleção LC (Ligados.com), a diferença consiste na denominação que se dá para o alimento da planta ao final da fotossíntese, utilizando a palavra açúcares, e que "Esses açúcares combinados com os sais minerais formam outros nutrientes (proteínas, vitaminas e gorduras).” (LC, 3, p.89). A representação é também mais simplificada.

\section{0 que as plantas absorvem do ambiente}

Luz solar

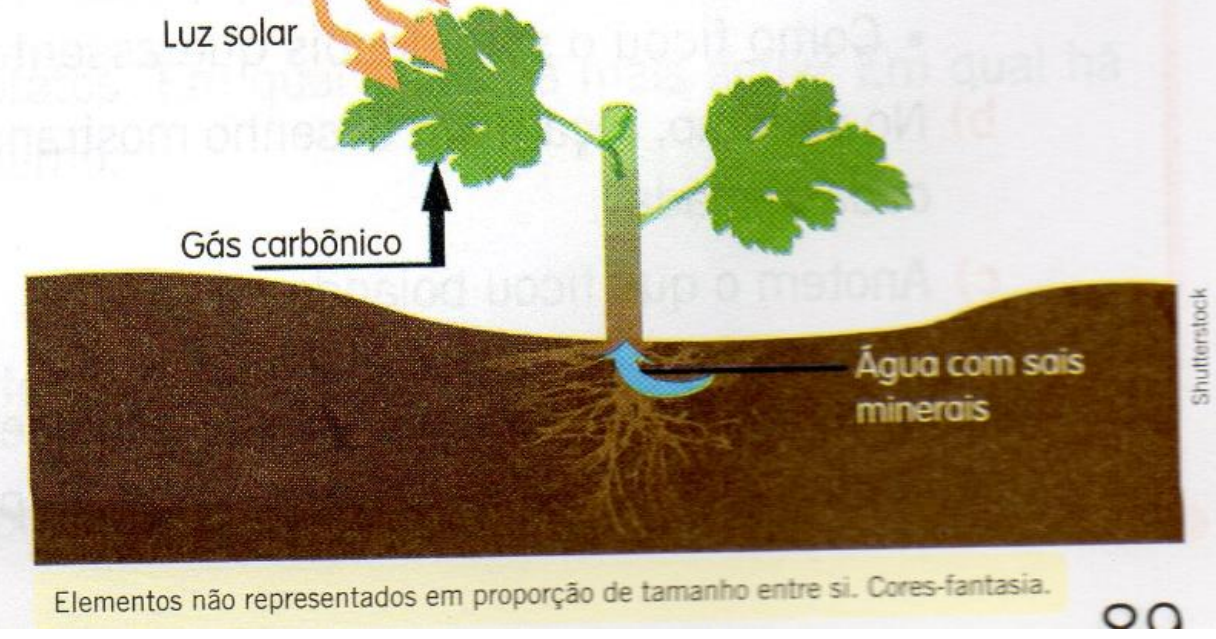

Figura 6 - Tema fotossíntese no livro 3 da coleção LC

$4^{\circ}$ ano do ensino fundamental I

Fonte: LC, 3, p.89

O tema fotossíntese também aparece no quarto ano nas coleções LC e PB. Além disso, os temas Respiração e Pilhas também aparecem nesse ano, mas somente na coleção PB.

Para o tema fotossíntese, na coleção LC, os alunos são convidados a responderem alguns exercícios que envolvem a fotossíntese e o processo de respiração das plantas. $\mathrm{O}$ primeiro exercício traz algumas folhas plantadas em diferentes condições e os alunos precisam indicar quais das folhas se desenvolverão; os exercícios seguintes questionam como ocorre a fotossíntese e utilizam outra representação que introduz a função da clorofila (figura 7). Além disso, nesse nível, aparece a primeira equação representativa do processo, de forma simplificada, os autores colocam que o esquema de resumo da fotossíntese seria: água + gás carbônico $\rightarrow$ glicose + gás oxigênio e água. 


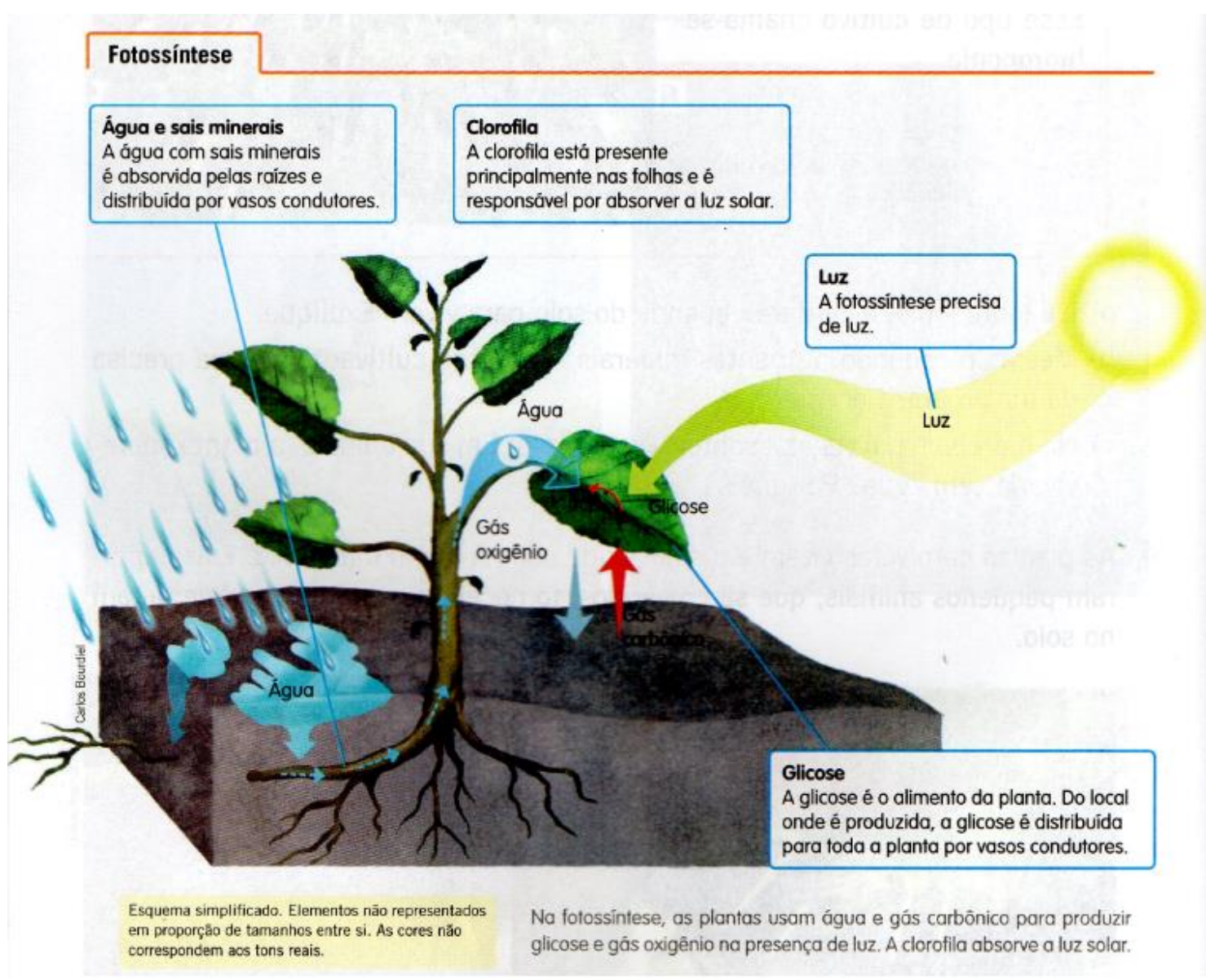

Figura 7 - Tema fotossíntese no livro 4 da coleção LC.

Fonte: LC, 4, p.44

A coleção PB aborda a fotossíntese em um box de uma página onde descreve o processo, ressaltando os participantes da reação e introduzindo o termo clorofila. Outro termo introduzindo na coleção é carboidratos e os autores colocam que: "Na presença de luz, a clorofila combina água com gás carbônico para formar carboidratos, como açúcar e amido, que são a principal fonte de energia dos seres vivos." (PB, 4, p.133). Além disso, o livro também utiliza um esquema mais simplificado, bem ilustrado, mas que não traz informações novas se comparado ao ano anterior.

Outro tema que aparece no livro da coleção PB é o de energia elétrica e nele utiliza-se as Pilhas e Baterias como exemplos de dispositivos geradores de energia. Ao introduzir a energia elétrica do ponto de vista físico, os autores colocam que:

Quando ligamos os aparelhos elétricos a uma tomada conectada à rede elétrica ou a uma pilha, permitimos que cargas elétricas se movimentam através do fio. Esse movimento das cargas forma uma corrente elétrica. A passagem da corrente elétrica pelos componentes internos de um aparelho faz com que ele funcione. (PB, 4, p.226)

Nesse caso, ao introduzir a energia elétrica a partir da física, não se utilizam os termos elétrons e ou eletrodos para explicação da pilha, apenas cargas elétricas. Isso é 
pertinente, uma vez que os alunos não tiveram contato com o conteúdo de partículas e átomos e, possivelmente, não compreenderiam os termos utilizados.

A coleção ainda acrescenta imagens de pilhas e baterias de forma macroscópica:
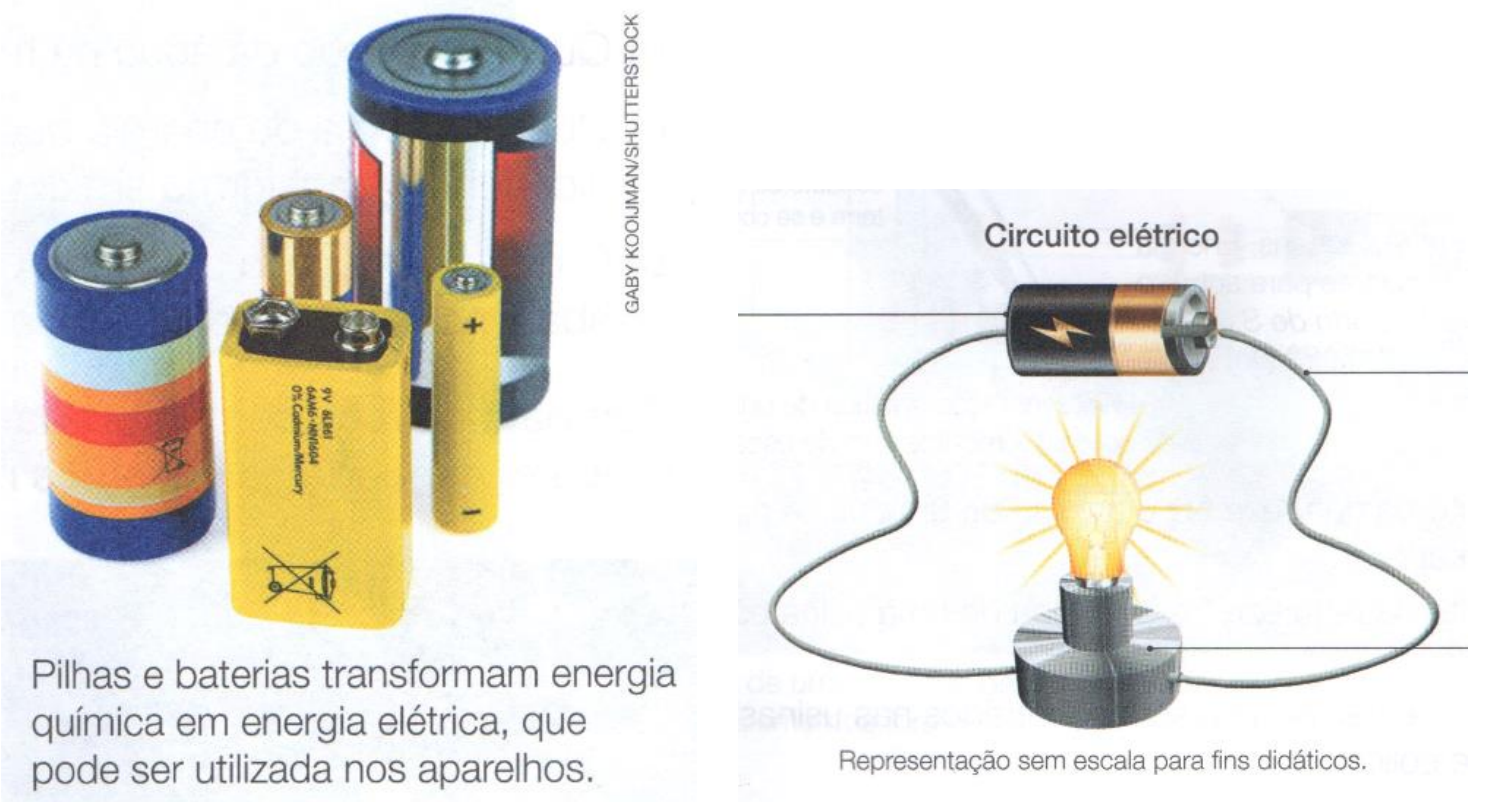

Figura 8 - Tema Pilhas no livro 4 da coleção PB.

Fonte: PB, 4, p.226

O outro tema presente na coleção $\mathrm{PB}$ é o de respiração, onde a respiração de seres humanos e de animais são exemplificadas. Ao introduzir a respiração dos humanos, o livro explica que na respiração "os seres vivos transformam as substâncias obtidas na alimentação em energia para o nosso corpo, usando o gás oxigênio presente no ar." (PB, 4, p.42) e também introduz termos relacionados ao processo, como inspiração, expiração, alvéolos e etc. Já ao abordar a respiração dos animais o livro traz mais informações químicas e coloca que:

A maior parte dos seres vivos precisa de gás oxigênio para sobreviver. O gás oxigênio é absorvido pelas células e, depois, uma série de reações com os nutrientes fornecidos pelos alimentos libera energia. Nesse processo, as células produzem e eliminam gás carbônico. (PB, 4, p. 131)

\section{$5^{\circ}$ ano do ensino fundamental I}

Nesse ano dois temas pertinentes às reações redox aparecem em duas coleções distintas. Fotossíntese é um tema que aparece na coleção PA e é citado na coleção PB, enquanto Pilhas aparece timidamente na coleção PA.

Na coleção PB a palavra fotossíntese é citada ao abordar a história da vida na Terra e parte da evolução, os autores colocam que as cianobactérias eram capazes de realizar o processo numa atmosfera sem oxigênio. 
Na coleção PA aborda-se a fotossíntese por meio de um experimento em que os alunos irão verificar se as plantas precisam de luz para sobreviver ou não. Após a apresentação do roteiro experimental, faz-se a explicação do processo de fotossíntese de forma simplificada, utilizando-se como representação um esquema também simplificado com setas mostrando o caminho da água, do gás oxigênio e do gás carbônico, muitíssimo semelhante ao utilizado no livro do terceiro ano.

O tema de Pilhas aparece timidamente na coleção PA pois, está dentro do tema Energia e Tecnologia, em que é abordado como os dispositivos funcionam. Na página de introdução do assunto há uma imagem de um chuveiro, um tablet, um fogão e um ônibus e os alunos são incentivados a listarem outros objetos. Em seguida, os alunos devem classificar qual o tipo de energia utilizada para cada um dos objetos listados, e dentre os tipos de energia são destacadas as pilhas e baterias.

\section{$6^{\circ}$ ano do ensino fundamental II}

Mesmo com a mudança de coleções o tema fotossíntese ainda aparece no $6^{\circ}$ ano do fundamental II, na coleção TL (Telaris). O livro 1 da coleção explica e exemplifica o processo de fotossíntese junto ao da respiração celular, porém, de forma introdutória, uma vez que destaca que o aluno irá saber mais no livro do sétimo da coleção. O livro descreve o processo e a participação da clorofila e dos gases, mas apenas para classificar as plantas como produtores e dar andamento no conteúdo. Para explicação do conteúdo utiliza-se uma representação demonstrada na figura 9. 


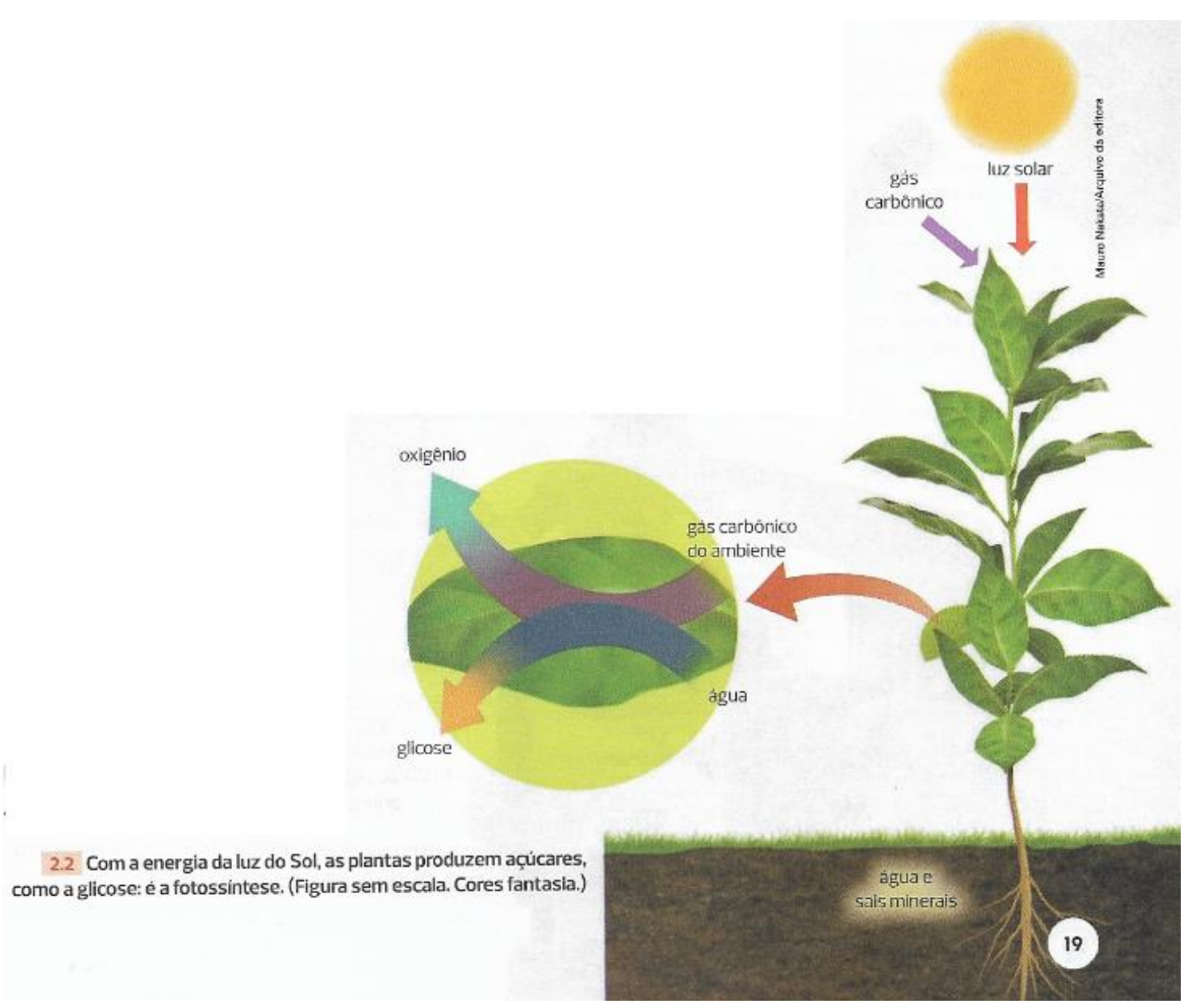

Figura 9 - O tema Fotossíntese no livro 1 da coleção TL

Fonte: TL, 1, p.19

Já para o tema Respiração Celular, a coleção TL coloca que o gás oxigênio é muito importante para as plantas e para os animais "que o usam para retirar energia dos alimentos." (TL, 1, p.19), e acrescenta que esse tema será mais trabalhado no $7^{\circ}$ ano. Na sequência do conteúdo a Respiração Celular volta a aparecer trazendo a interdependência entre os processos de fotossíntese e respiração, uma vez que "o gás oxigênio, que é liberado pelas plantas e algas na fotossíntese, é utilizado na respiração celular. Já o gás carbônico, que é liberado pela respiração celular, é utilizado na fotossíntese" (TL, 1, p.22). Ainda mais adiante no conteúdo, a coleção traz a relação entre o oxigênio e a respiração aeróbia e a importância desse processo para manutenção da vida. Nesse momento é utilizado um esquema simplificado que resume o processo apresentado, tratase da reação entre: glicose + oxigênio $\rightarrow$ gás carbônico e água. Em seguida o mesmo esquema invertido é utilizado para representar o processo de fotossíntese comentado anteriormente. Para apresentação do conteúdo é também mostrado uma imagem representativa do ciclo do oxigênio na natureza: 
11.8 Esquema simplificado do ciclo do oxigênio. Enquanto a respiração, a decomposição e a combustão consomem oxigênio, a fotossintese repõe o gás na atmosfera. (Os elementos da figura não estão na mesma escala. Cores fantasia.)

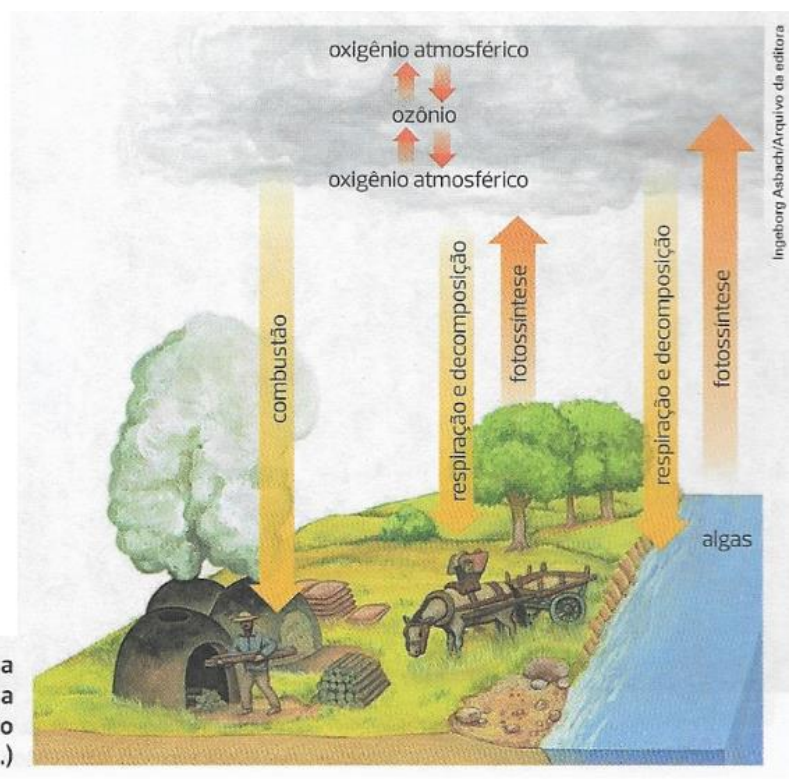

Figura 10 - O tema Respiração Celular no livro 1 da coleção TL. Fonte: TL, 1, p. 163

A Decomposição dos alimentos é também um tema encontrado no livro do $6^{\circ}$ ano da coleção TL. Os autores colocam que quando um alimento cai no chão ou um animal morre "as bactérias e os fungos atacam os açúcares, as gorduras e as proteínas que formavam o corpo daqueles organismos e transformam essas substâncias em gás carbônico, água e sais minerais" (TL, 1, p.21)

O tema Combustão aparece junto ao tema Respiração e Ferrugem na coleção IC (Investigar e Conhecer). Ao trazer a importância do gás oxigênio e as reações em que ele participa, é colocado que “A ferrugem, por exemplo, é o resultado da reação entre o gás oxigênio presente no ar e o ferro" (IC, 1, p. 283) e a Combustão aparece como outro exemplo de reação em que o oxigênio é um participante: "Durante a combustão, combustível e comburente reagem e se transformam em outras substâncias, liberando também certa quantidade de energia" (IC, 1, p.283). A Respiração também aparece como exemplo de uma reação envolvendo oxigênio, ao destacar que o alimento é o combustível da respiração, o livro coloca que: "Essa queima é lenta, ocorre em diversas etapas e envolve a participação de muitas substâncias que controlam o processo. Com a energia liberada, o organismo realiza suas atividades. (IC, 1, p.248)

Outro tema que aparece em livros do sexto ano da educação básica, na coleção AR (Araribá), é o de extração dos minerais, especificamente extração da bauxita para fabricação de alumínio. Mas, esse processo aparece apenas para ressaltar a importância da reciclagem das latinhas de alumínio, uma vez que o processo de extração do mineral é caro e poluente. Não há aprofundamento de como é feito o processo. 


\section{$7^{\circ}$ ano do ensino fundamental II}

O tema Fotossíntese aparece também no sétimo da escolarização básica, junto ao tema Respiração, as coleções se diferenciam quanto a abordagem utilizada, IC e AR unem os dois temas para falar da Respiração Celular das plantas e do processo de obtenção de alimentos, enquanto que na coleção TL o tema Respiração Celular trata daquele que o nosso organismo realiza.

A abordagem utilizada na coleção IC reúne informações sobre a fotossíntese utilizando novos termos para os alunos desse nível de ensino:

\section{“Com as substâncias necessárias, as células clorofiladas da planta podem realizar a fotossíntese. A água chega às células conduzida pelo xilema e o gás carbônico entra pelos estômatos. A célula já contém clorofila e é necessária a presença de energia luminosa" (IC, 2, p. 240). (grifo nosso)}

No livro, ainda é utilizada uma equação simplificada para representar o processo (figura 11). Em seguida, a coleção IC aborda a utilização da energia presente nos carboidratos pela planta através do processo de respiração celular, utilizando o mesmo tipo de equação simplificada.

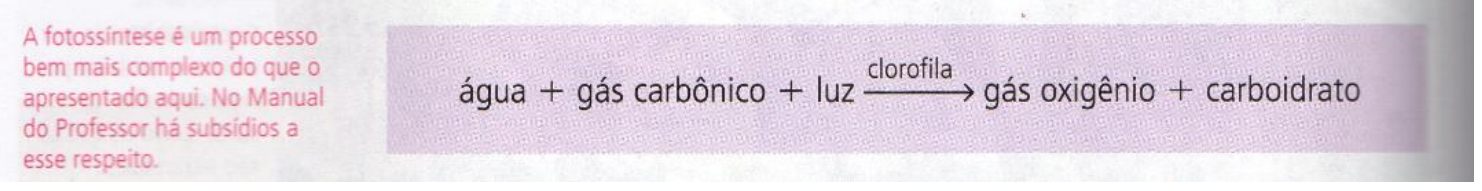

Figura 11 - O tema Fotossíntese no livro 2 da coleção IC.

Fonte: IC, 2, p.240

O tema Fotossíntese no livro de sétimo ano da coleção AR é descrito no tópico de Características das Plantas, tópico que também descreve a importância do gás oxigênio para respiração inclusive dos próprios seres fotossintetizantes. Em um primeiro momento é feita uma introdução sobre o processo, acrescentando a importância do oxigênio para a manutenção dos seres vivos, utilizando-se uma equação simplificada destacada num esquema geral que aborda várias características das plantas:

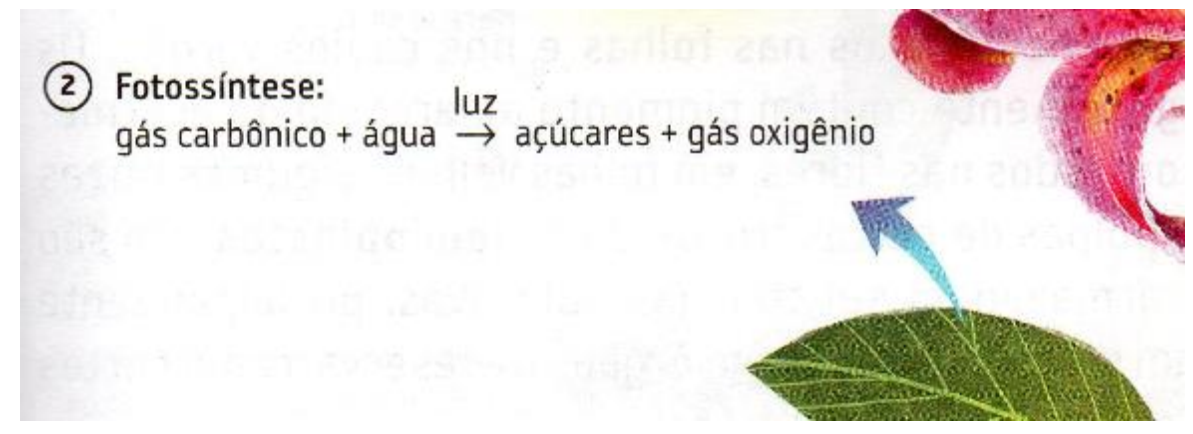

Figura 12 - O tema Fotossíntese no livro 2 da coleção IC Fonte: IC, 2, p.97

Ainda na coleção IC, algumas páginas adiante, é ressaltada a fonte de energia das plantas proveniente da fotossíntese que: 
[...] ocorre no interior dos cloroplastos presentes nas células das folhas e dos caules verdes. Para realizar a fotossíntese, as plantas necessitam de água, gás carbônico $\left(\mathrm{CO}_{2}\right)$ e energia luminosa. A água é absorvida pelas raízes e o gás carbônico, presente no ar, entra na planta pelos estômatos. (IC, 2, p. 102)

$\mathrm{Na}$ sequência do texto é acrescentado que "os açúcares produzidos pela fotossíntese são aproveitados como fonte de energia para a planta durante o processo de respiração. Esse processo ocorre em organóides denominados mitocôndrias." (IC, 2, p.103). Utiliza-se, também, um esquema que representa a ocorrência dos dois processos, destacado na figura 13.

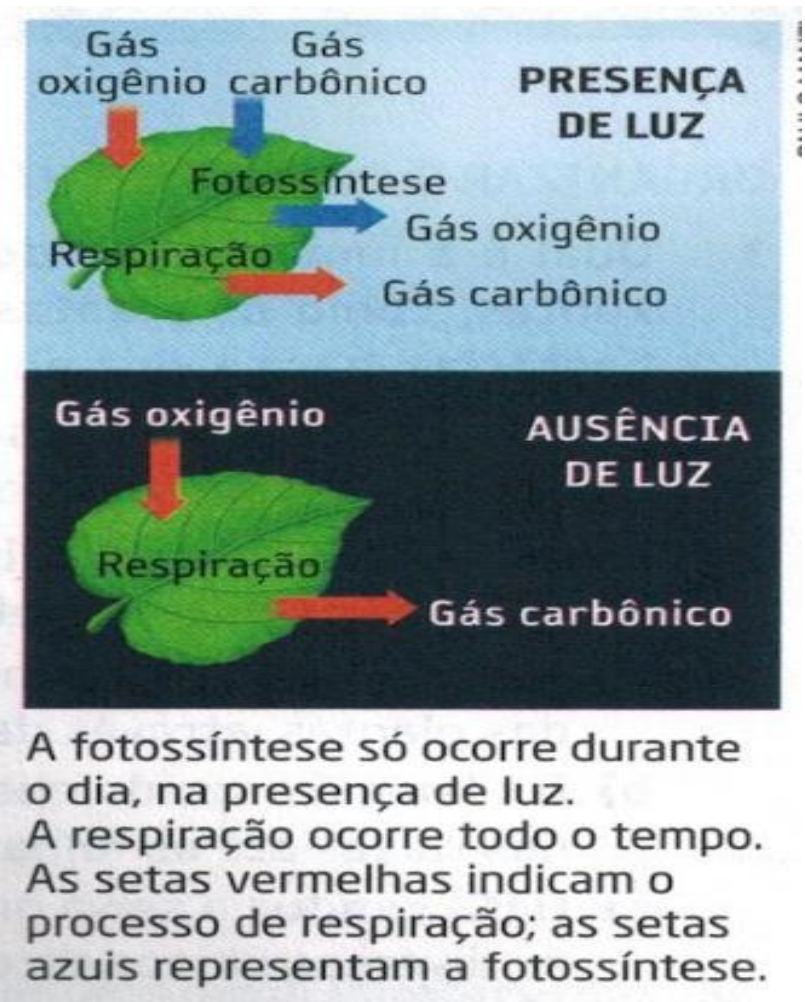

Figura 13 - O tema Respiração Celular no livro 2 da coleção IC Fonte: IC, 2, p. 103

A abordagem utilizada pela coleção TL insere os temas Respiração Celular e Fotossíntese dentro do capítulo denominado "Em busca de matéria e energia", cujo foco é principalmente falar dos diferentes processos de obtenção de energia nos seres vivos. Como o foco do capítulo é diferente do das coleções anteriores, o livro começa trazendo a importância da respiração celular para obtenção de energia, explicando o processo como:

A partir da digestão de alguns alimentos, o nosso organismo consegue obter um açúcar conhecido como glicose. No interior das células, essa substância se combina com o gás oxigênio retirado do ambiente, transformando-se em gás carbônico e água. Esse processo libera energia, que passa a ser utilizada pelo ser vivo. (TL, 2, p. 22) 
Na sequência do conteúdo, o livro apresenta a fotossíntese comparando com o processo que ocorre nos seres vivos, colocando que: “Ao contrário dos animais, as plantas são capazes de produzir matéria orgânica a partir da água e do gás carbônico que retiram do ambiente por meio da fotossíntese.” (TL, 2, p.22). Em seguida explica as etapas do processo de fotossíntese com uma representação simplificada do processo.

Mais adiante na coleção TL, há uma unidade que traz as características das plantas e o ambiente onde é colocado um box com o título 'Luz e Fotossíntese'. Nesse box é discutido a absorção e emissão de luz por diferentes objetos, dentre eles é abordada a cor verde apresentada pela clorofila que é resultado da absorção das luzes vermelhas, laranja, azul e violeta.

A formação de Ferrugem, o Escurecimento da maçã e a Combustão, são outros temas que aparecem no livro do sétimo ano da coleção TL, porém, o aparecimento desse tema é apenas na forma de citação de exemplos de transformações químicas e é acompanhado da citação da respiração celular também. No trecho que menciona tais reações é colocado que:

Depois de a fruta ser descascada, sua superfície fica escura. Você sabe porque isso acontece? Isso ocorre devido ao contato de certas substâncias presentes na maçã com o oxigênio do ar. Trata-se de uma transformação química. Também ocorrem transformações químicas quando a gasolina é usada como combustível, quando o leite é transformado em iogurte, quando uma fruta verve amadurece e na formação de ferrugem. (TL, 2, p. 24)

$8^{\circ}$ ano do ensino fundamental II

No oitavo ano do ensino fundamental II dois temas principais aparecem nas coleções, a Respiração Celular aparece nas três coleções, e a reação de Escurecimento da maçã aparece na coleção IC.

A Respiração Celular é abordada na coleção IC ao explicar o uso da energia pelos seres vivos, trazendo que:

Na respiração celular, a matéria orgânica é quebrada na presença do gás oxigênio, resultando gás carbônico e água; parte da energia liberada sob a forma de calor, enquanto parte fica armazenada em outras moléculas e pode ser utilizada em outras reações do metabolismo. (IC, 3, p. 52).

Em seguida apresenta que o mesmo não ocorre com as plantas. Já em outro capítulo que aborda as partes do corpo humano, o livro traz um resumo da respiração celular ressaltando a liberação de energia do processo e, também, uma equação simplificada observada na figura 14 . 
Podemos resumir o processo de respiração celular aeróbia da seguinte maneira, considerando que a fonte de energia seja uma molécula de glicose:

\section{Glicose + gás oxigênio $\rightarrow$ Gás carbônico + água + energia}

Figura 14 - O tema Respiração Celular no livro 3 da coleção IC Fonte: IC, 3, p. 114

A coleção AR também traz de forma bem resumida o processo de Respiração Celular aeróbia ao abordar as partes do corpo humano, especificamente do pulmão e tronco. A coleção destaca que a maior parte desse processo ocorre nas mitocôndrias.

A coleção TL também apresenta o tema da Respiração Celular ao trazer as partes do corpo humano, mas agora especificamente ao falar das partes que compõem a célula. Ao trazer as mitocôndrias o livro relembra que nelas ocorrem as reações que compõem a respiração aeróbia e a produção de energia a partir dos alimentos. Porém, a coleção também aborda o tema em outro capítulo ao tratar os tipos e funções dos alimentos. Inicialmente traz a importância da nutrição adequada para produção de energia, e que esse processo ocorre por meio da respiração celular, e posteriormente ao trazer os carboidratos, especifica que o amido é transformado em energia pela respiração.

Outro tema presente na coleção do IC no livro destinado ao oitavo ano é a reação de escurecimento da maçã e outras frutas. A coleção aborda que os alimentos possuem enzimas que provocam a deterioração natural da matéria orgânica e que elas:

[..] ficam armazenadas dentro das células. Quando uma fruta é cortada, as células são rompidas e as enzimas entram em contato com substâncias que se localizam fora das células. As enzimas promovem, então, a reação química entre essas substâncias e o gás oxigênio do ar. O resultado é o escurecimento da fruta, como vemos na fotografia abaixo. (IC, 3, p. 80)

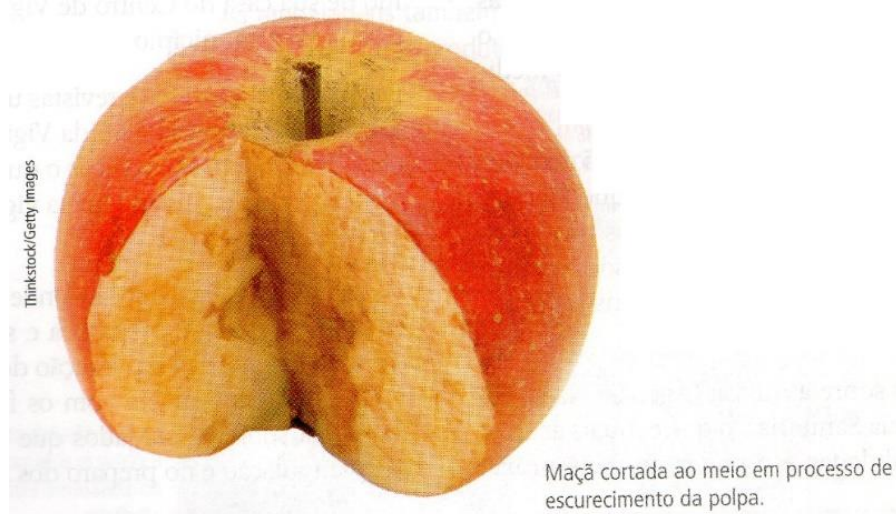

Figura 15 - O tema Escurecimento da Maçã no livro 3 da coleção IC Fonte: IC, 3, p. 80 


\section{$9^{\circ}$ do ensino fundamental II}

Para o último ano do ensino fundamental, os temas encontrados foram Air Bag, Combustão, Eletrólise, Ferrugem, Fotossíntese, Oxirredução, Pilhas e Baterias, Protetor Solar e Respiração Celular. A presença dos temas varia em cada coleção.

A reação que propicia o funcionamento do Air Bag é uma reação de oxirredução e aparece timidamente na coleção TL ao abordar-se a lei das proporções das massas. Está inserida num box ao fim da página que fala sobre os cálculos físicos e químicos para que ele funcione corretamente, além de trazer a equação que ocasiona a reação.

O tema Combustão aparece em duas das três coleções de ensino fundamental II, nas coleções TL e AR. Na coleção AR as reações de oxirredução são abordadas dentro do capítulo de Reações Químicas, como um tipo de reação de oxirredução. O trecho de introdução ao tema é:

\footnotetext{
Algumas reações de oxirredução podem produzir calor e luz na forma de chama. Quando um material produz chamas, dizemos que ele entrou em combustão, ou seja, está ocorrendo reação de combustão. A maioria delas se dá na presença do gás oxigênio. (AR, 4, p.92)
}

Esse trecho é seguido de uma apresentação da equação simplificada da combustão do butano (o gás de cozinha): $2 \mathrm{C}_{4} \mathrm{H}_{10}(\mathrm{~g})+13 \mathrm{O}_{2}(\mathrm{~g}) \rightarrow 8 \mathrm{CO}_{2}(\mathrm{~g})+10 \mathrm{H}_{2} \mathrm{O}(\mathrm{g})$.

Na coleção TL, o tema Combustão aparece em dois momentos. Primeiramente, a reação de combustão do metano é utilizada como exemplo no conteúdo de estequiometria, ou seja, trata-se apenas de uma reação usada para calcular os coeficientes estequiométricos e realizar o balanceamento. $\mathrm{O}$ mesmo acontece no segundo momento onde a combustão de um dos componentes da gasolina é utilizada como exemplo na explicação do conteúdo de lei da conservação das massas. Nesses exemplos a reação não é discutida como sendo de oxirredução.

A Eletrólise é um tema presente apenas na coleção TL, na introdução aos tipos de reações químicas. O livro inicia a abordagem dos tipos de reações trazendo dois exemplos diferentes, o primeiro trata da eletrólise, cujo trecho é:

Uma reação feita em laboratório que consiste em fazer a decomposição da água utilizando um aparelho que permite a passagem da corrente elétrica (figura 7.7). Esse processo é chamado de eletrólise e, para que ele ocorra, é necessário adicionar à água um pouco de ácido. Veja a equação que representa esse processo: $2 \mathrm{H}_{2} \mathrm{O}(\mathrm{l}) \rightarrow 2 \mathrm{H}_{2}(\mathrm{~g})+\mathrm{O}_{2}(\mathrm{~g})$. (TL, 4, p.102)

A figura que o livro se refere é: 


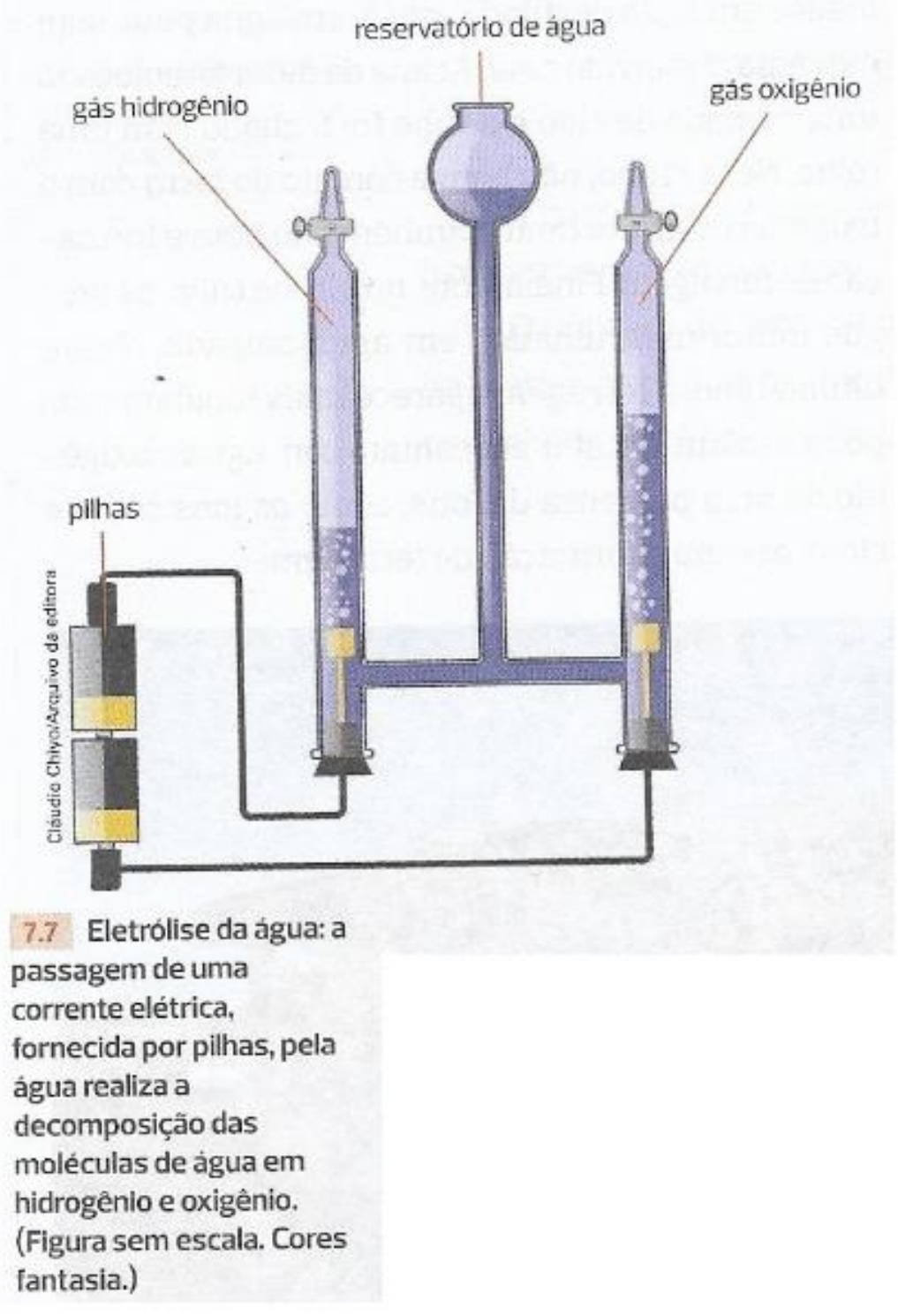

Figura 16 - O tema Eletrólise no livro 4 da coleção TL

Fonte: TL, 4, p. 102

O tema Ferrugem aparece na coleção TL em dois momentos, o primeiro, como o tema de Combustão, aparece como exemplo no conteúdo de estequiometria. Os alunos são desafiados a ajustar a equação de formação da ferrugem: $\mathrm{Fe}+\mathrm{O}_{2} \rightarrow \mathrm{Fe}_{2} \mathrm{O}_{3}$ (equação não balanceada). Após apresentar o procedimento para balanceamento da equação, o livro apresenta um box com um experimento de visualização da formação da ferrugem com a ação do oxigênio. Também são apresentadas duas imagens, uma delas é uma foto de um trem completamente enferrujado, a outra é a figura 17. 


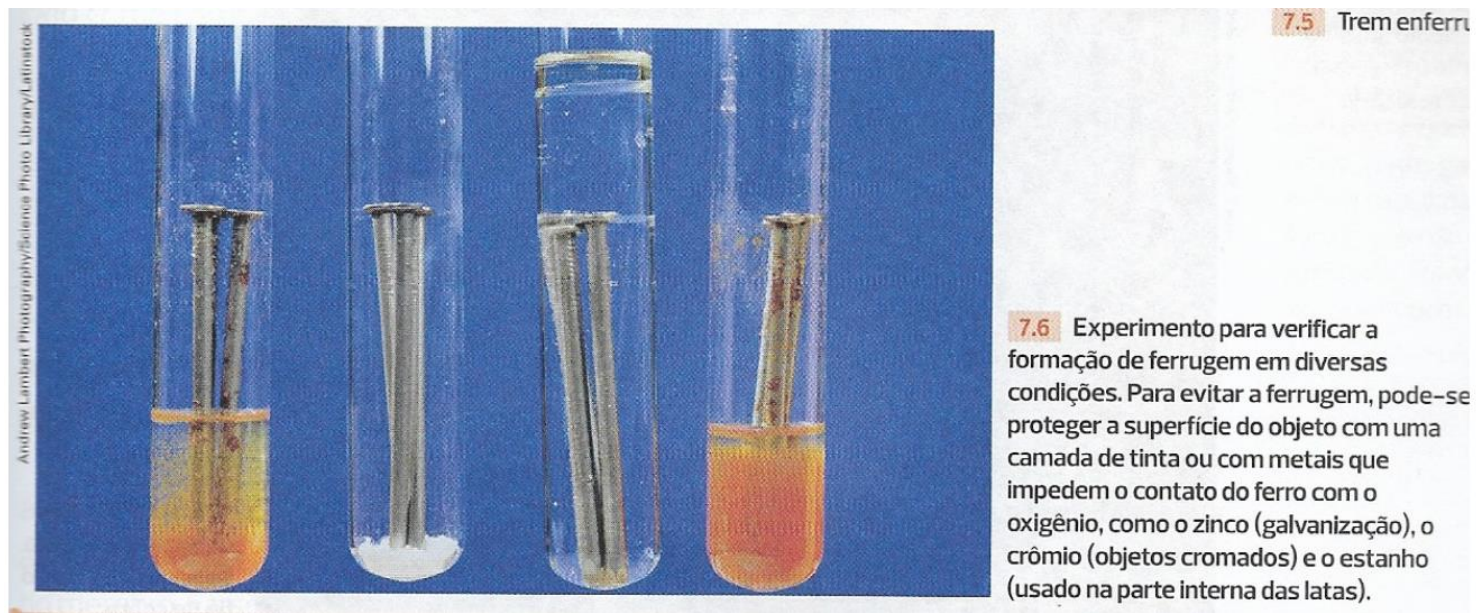

Figura 17 - O tema Ferrugem no livro 4 da coleção TL

Fonte: TL, 4, p. 101

Esse tema também aparece na coleção AR durante a abordagem do tipo de reação redox, a ferrugem é um exemplo desse tipo de reação que está presente no dia-a-dia. Utiliza-se uma foto de pregos enferrujados para exemplificar o exposto:

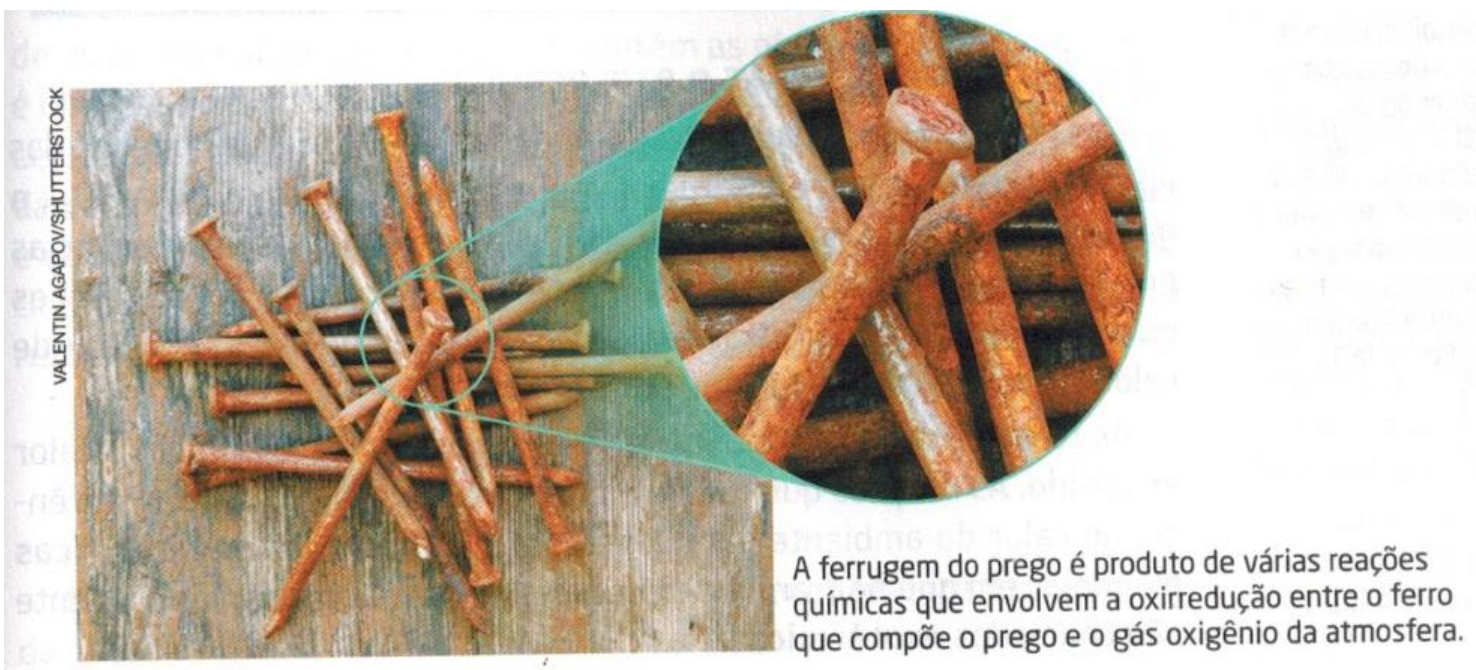

Figura 18 - O tema Ferrugem no livro 4 da coleção AR.

Fonte: AR, 4, p. 91

A Fotossíntese aparece novamente na coleção IC no nono ano de ensino fundamental. O processo de fotossíntese é apresentado como um exemplo de uma reação química que acontece o dia-a-dia. O mesmo acontece com o tema Respiração Celular nessa coleção. Os processos são apresentados de forma simplificada, sendo que o livro justifica que essas são reações complexas e que serão estudadas posteriormente no nível médio de ensino. Além disso, o tema Respiração Celular aparece também na coleção TL, num box ao final dos exercícios. Nesse box, de forma resumida, explica-se a reação da glicose com o gás oxigênio, utilizando-se também uma equação: $\mathrm{C}_{6} \mathrm{H}_{12} \mathrm{O}_{6}+6 \mathrm{O}_{2} \rightarrow 6 \mathrm{CO}_{2}$ $+6 \mathrm{H}_{2} \mathrm{O}+$ energia. No parágrafo após essa equação, é explicado os termos oxidação e redução. 
Conforme exposto, o tema Oxirredução - aqui o tema Oxirredução de forma geral, trata dos trechos em que os livros explicam o que é a reação de oxidação e redução aparece na coleção TL num box ao abordar os tipos de reações. Nesse box o trecho que explica as reações de oxidação é:

Tanto a respiração celular como a combustão são reações químicas que envolvem oxidações. Mas, em Química, o termo oxidação tem um sentido mais geral do que simplesmente reagir com o oxigênio. Uma molécula ou um átomo se oxida quando perde um ou mais elétrons para outro átomo ou molécula. Quando um átomo ou uma molécula ganha elétrons, dizemos que ele se reduz (sofre uma redução). (TL, 7, p. 110)

Esse é, também, um tema que aparece na coleção AR, pois a mesma discute que os tipos de reações existentes são de precipitação, oxirredução, exotérmica e endotérmica. Nessa abordagem os termos que envolvem as reações de oxirredução são apresentados aos alunos:

Quando uma espécie química sofre oxidação, significa que ela transferiu elétrons para outra. A espécie que recebeu elétrons passou por uma reação de redução. Quando uma espécie é oxidada, a outra necessariamente é reduzida; por isso, essas reações recebem o nome de oxirredução. As reações de oxirredução são muito comuns, em função da abundância de gás oxigênio na atmosfera e da facilidade com que ele reage com outros materiais, formando óxidos. (AR, 4, p. 91)

Outro tema abordado no ensino fundamental II que tem ligação direta com o ensino das reações redox é o de Pilhas e Baterias. Nas coleções ele é apresentado de três modos diferentes. O primeiro, apresentado nas três coleções do fundamental II, traz as pilhas e baterias como um exemplo de um tipo de energia que é utilizado nos dias atuais, essa abordagem é descrita junto ao conteúdo de física que explora os tipos de energia existente e as conversões entre eles. Para a coleção IC, conceitua-se o termo circuito elétrico: "Um circuito simples é um sistema elétrico composto de uma bateria, que gera energia elétrica, um material condutor, por onde passa uma corrente elétrica (fios metálicos), e algum componente que utiliza ou transforma essa energia elétrica em outra forma de energia" (IC, 4, p.311). Utiliza-se, também, uma imagem de um circuito montado, representado na figura 19. 


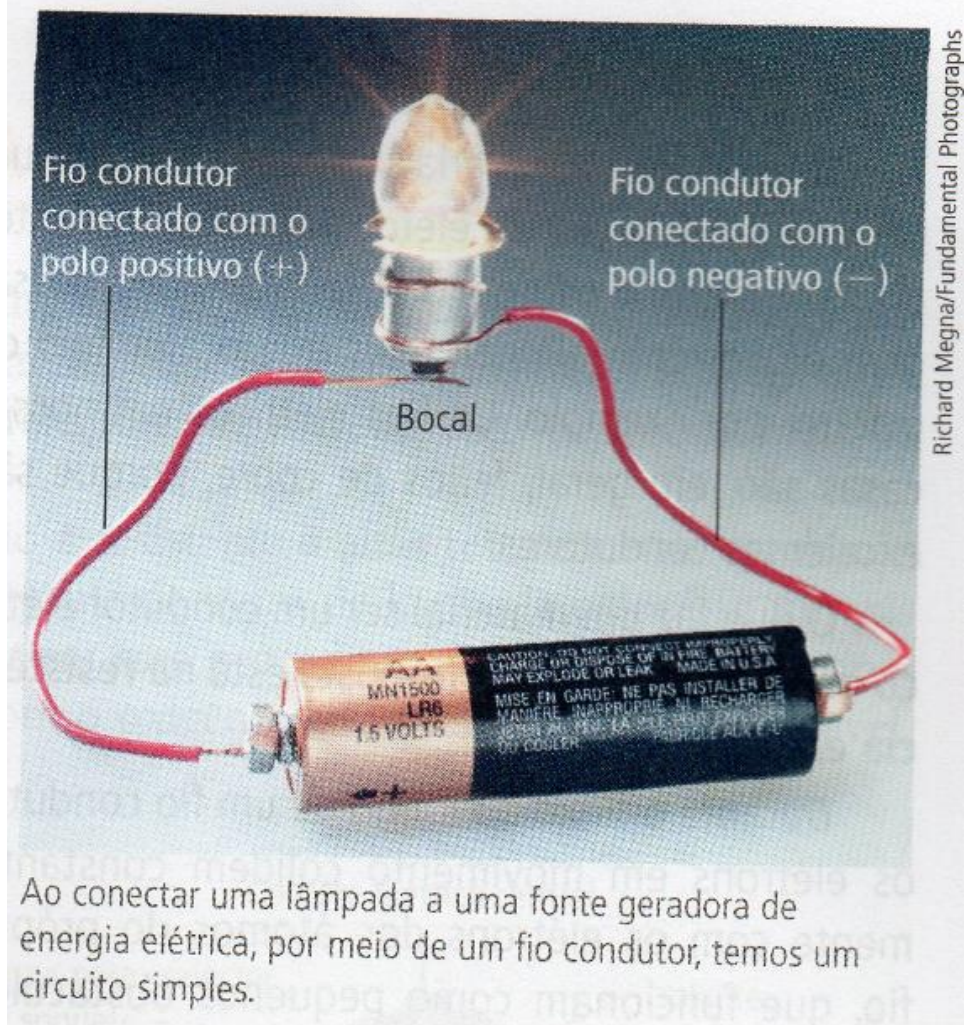

Figura 19 - O tema Pilhas e Baterias no livro 4 da coleção IC.

Fonte: IC, 4, p. 311

A mesma abordagem exposta acima é utilizada, também, na coleção TL. O livro explica o porquê uma lâmpada acende com uma corrente elétrica, e conceitua corrente elétrica como:

Normalmente, os elétrons dos metais movem-se de forma desorganizada em todas as direções. Quando ligamos os fios metálicos a uma pilha, o movimento fica mais organizado: o fluxo de elétrons segue em determinado sentido. Esse fluxo ordenado de elétrons forma a corrente elétrica. (TL, 4, p.249)

A imagem utilizada para representar o conteúdo é:
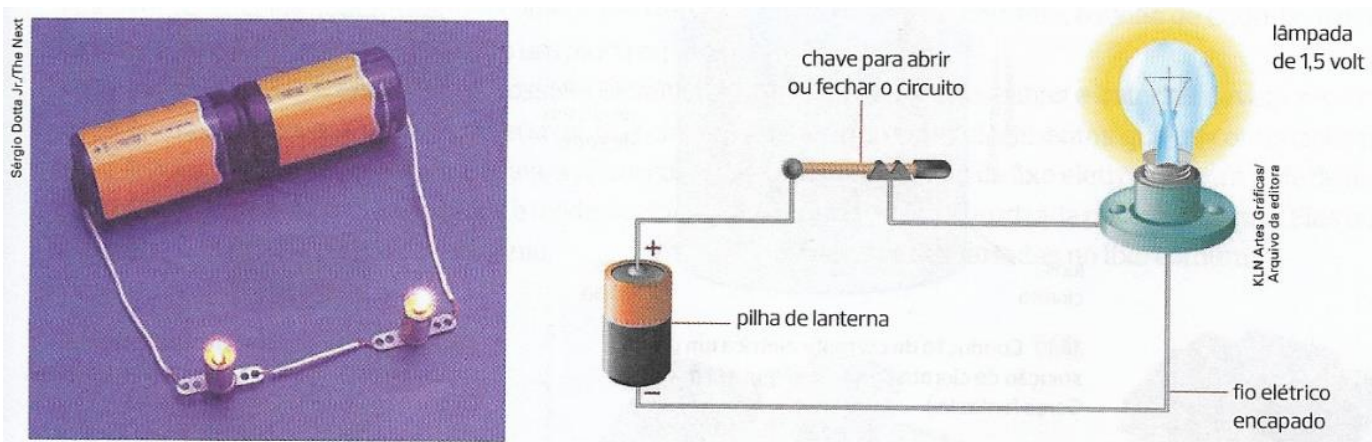

15.9 A lâmpada acende porque uma corrente elétrica passa pelo fio. Na foto, um circuito com duas pilhas ligadas por fio a duas lâmpadas de lanterna. (llustração sem escala. Cores fantasia. A marca comercial foi apagada para evitar entendimento de publicidade.)

Figura 20 - O tema Pilhas e Baterias no livro 4 da coleção TL.

Fonte: TL, 4, p. 249

Na coleção AR essa abordagem junto ao conteúdo de física também aparece ao conceituar os tipos de energias utilizadas no cotidiano, sendo que o trecho em que o tema 
aparece é: "Em pilhas e baterias, a energia elétrica é gerada por reações químicas em que há transferência de elétrons (reações de oxirredução)" (AR, 4, p.133). Não são utilizadas imagens representativas.

O segundo modo que o tema Pilhas é apresentado é de forma experimental e aparece na coleção AR. No final do livro há várias propostas de atividades experimentais ligadas ao conteúdo de química e de física, dentre essas propostas há uma intitulada “Batatas geram energia elétrica?". Nessa proposta os alunos devem construir uma pilha com batatas e eletrodos de zinco e cobre e responder algumas atividades ao final do experimento. Os alunos devem montar e testar o experimento conforme a figura 21.

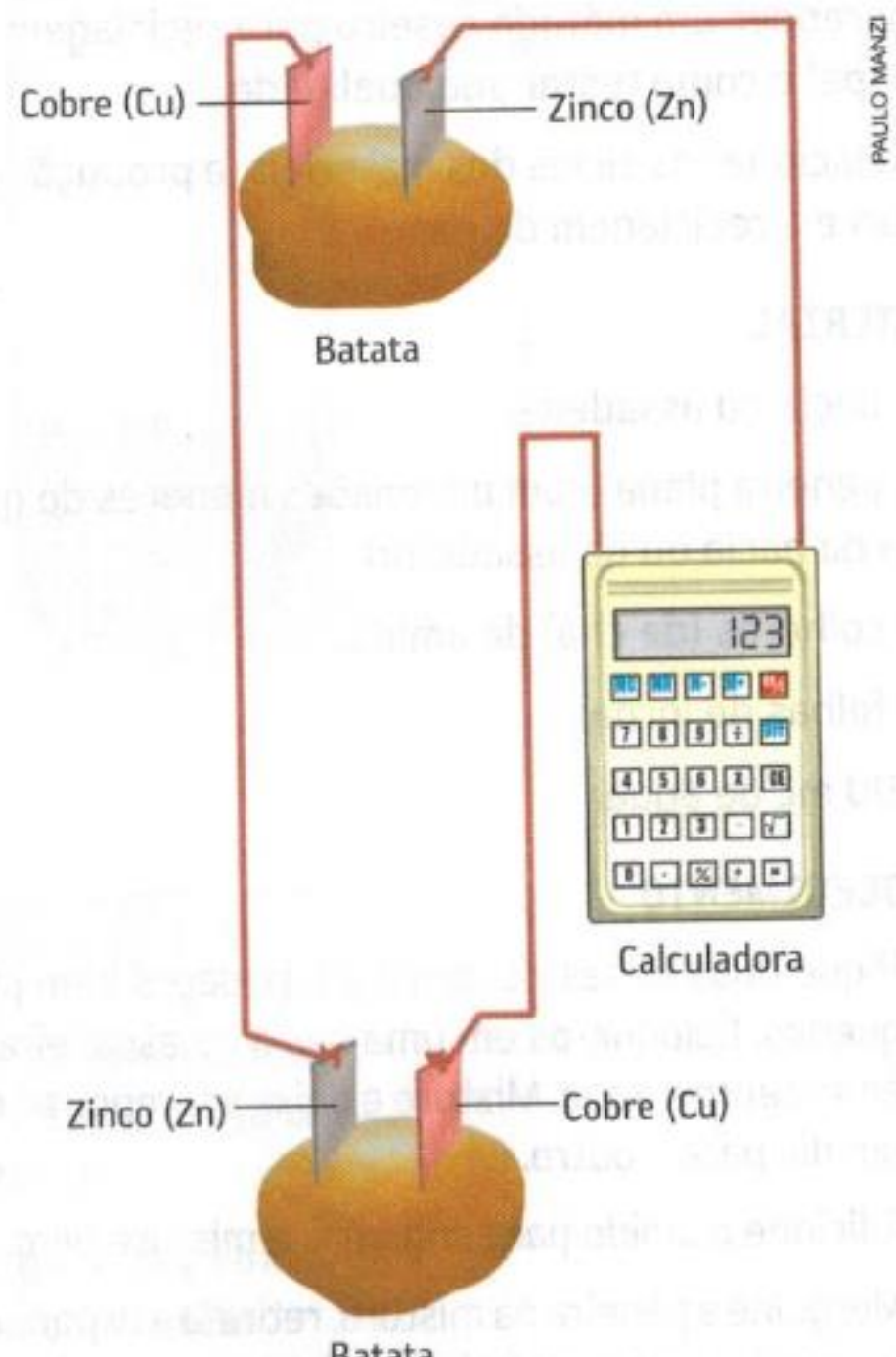

Batata

(Imagem sem escala: cores-fantasia.)

Figura 21 - O tema Pilhas e Baterias no livro 4 da coleção AR Fonte: AR, 4, p. 238

O outro modo de apresentação do tema nas coleções está presente na coleção TL e trata-se de um box que aborda o funcionamento, os tipos e como é feito o descarte das 
Pilhas e Baterias. O texto inicia abordando a transferência de elétrons: "O princípio de funcionamento de toda bateria ou pilha é uma transferência entre duas substâncias químicas.” (TL, 4, p. 251) e conclui apontando a forma correta de descarte:

Após o uso, pilhas e baterias devem ser entregues aos estabelecimentos que as comercializam, a postos de coleta de lixo eletrônico, ou à rede de assistência técnica autorizada pelas indústrias. Elas nunca devem ser descartadas no lixo comum. (TL, 4, p.251)

Algumas imagens ilustrativas são utilizadas, duas delas trazem um esquema representativo de uma pilha e uma bateria abertas e são expostas na figura 22 .

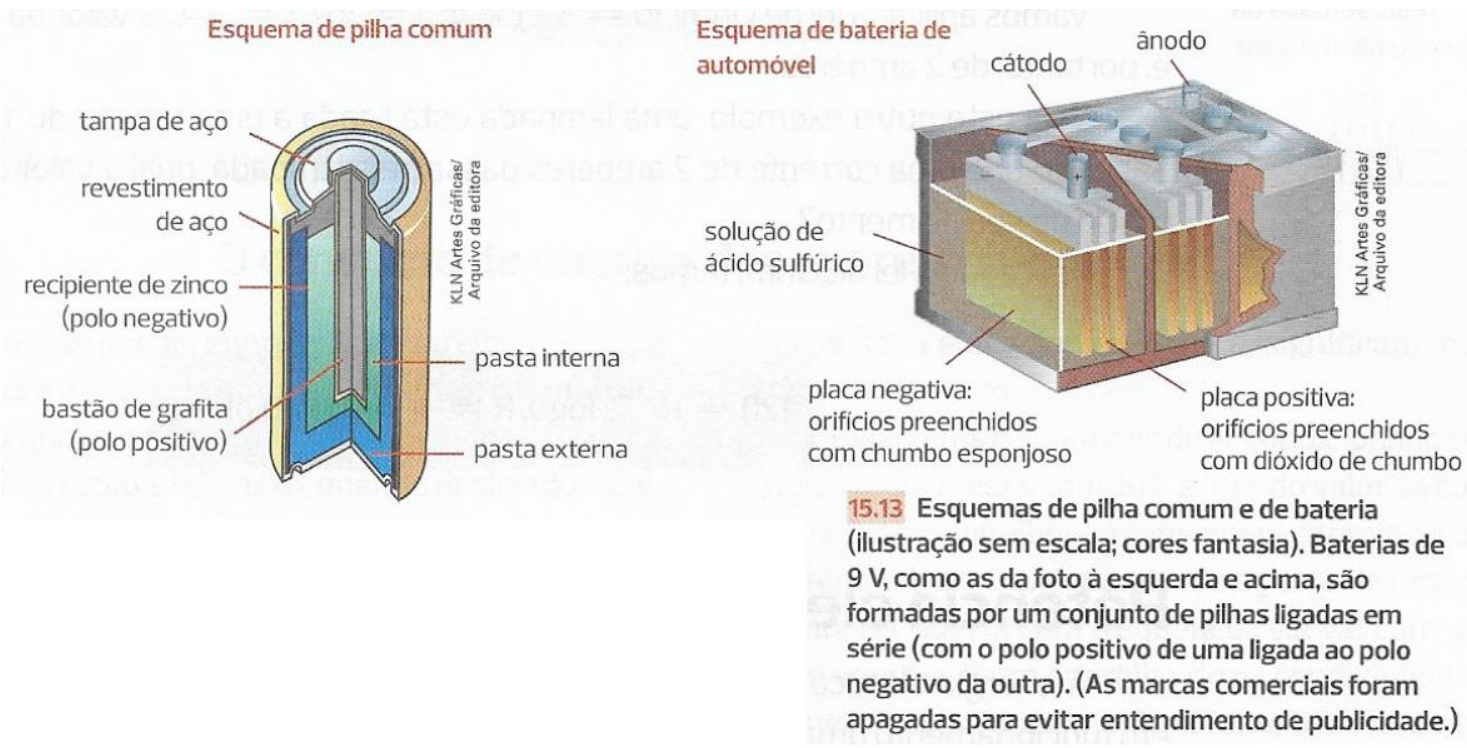

Figura 22 - O tema Pilhas e Baterias no livro 4 da coleção TL

Fonte: TL, 4, p.251

O último tema que se relaciona às reações redox é o de Proteção Solar e aparece num box na coleção IC. Esse tema aparece de forma tímida junto ao conteúdo de física ao mostrar as ondas eletromagnéticas.

\subsubsection{Distribuição dos temas ao longo do ensino fundamental}

De acordo com os resultados apresentados é possível compreender como os temas se distribuem ao longo do ensino fundamental I e II e em quais coleções eles estão presentes. Isso pode ser visualizado no quadro 7. 
Quadro 7 - A distribuição dos temas Redox nas coleções investigadas ao longo do ensino fundamental

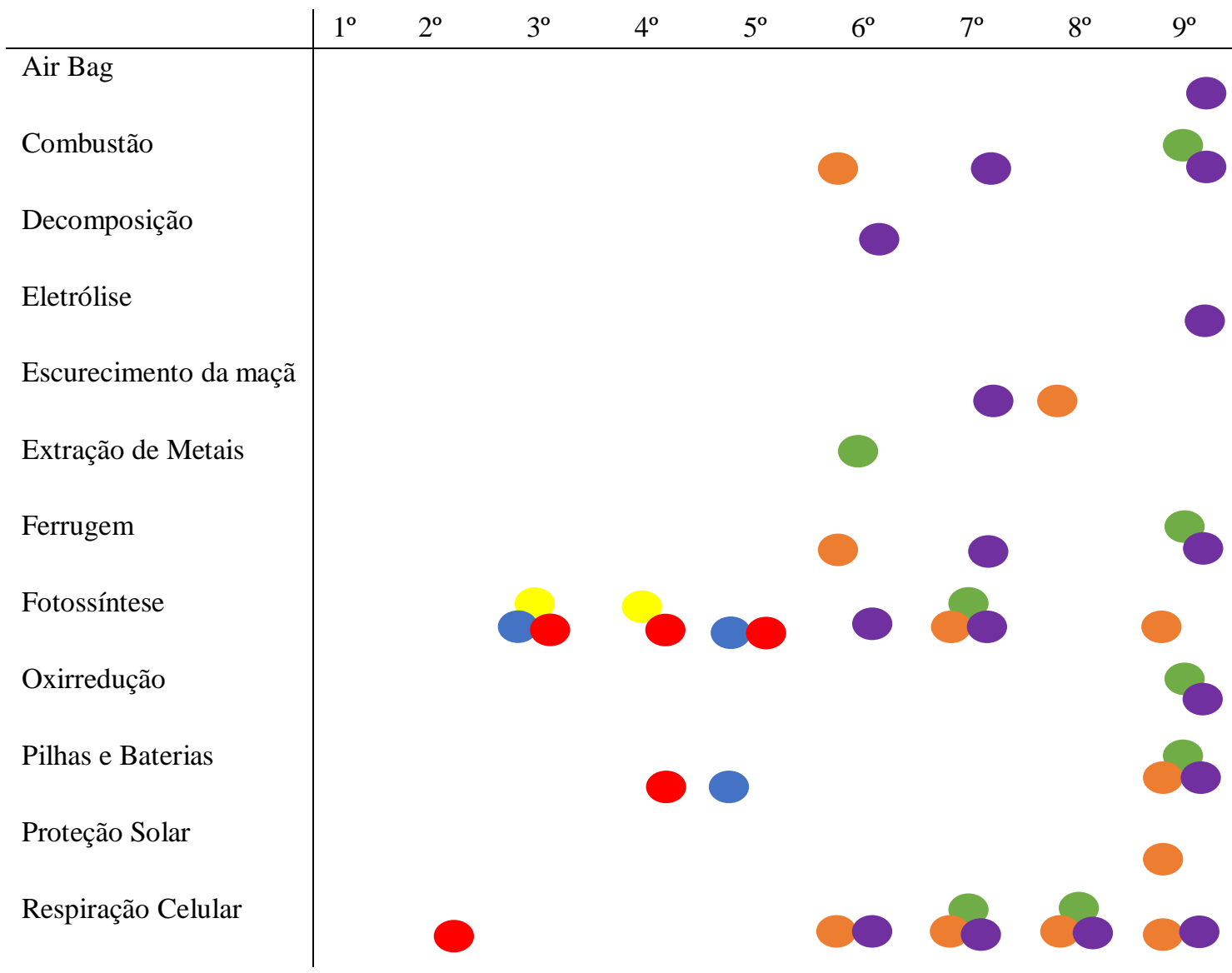

Fonte: A autora

Legenda

$\begin{array}{ll}\text { Coleção LC } & \text { Coleção AR } \\ \text { Coleção PA } & \text { Coleção IC } \\ \text { Coleção PB } & \text { Coleção TL }\end{array}$

A leitura do quadro 7 nos indica que no último ano do ensino fundamental abordase a maior quantidade de temas pertinentes às reações redox. Isso já era esperado visto que nesse ano as disciplinas de química e física são introduzidas e, normalmente, os livros são divididos ao meio explorando-se as duas disciplinas.

Ainda no $9^{\circ}$ ano o tema de oxirredução já é introduzido, ou seja, alguns termos exclusivos desse conteúdo são conceituados e explicados, como os termos oxidação, redução e transferência de elétrons. Porém, o tema que é mais explorado nas três coleções, nesse ano, é o de Pilhas e Baterias, isso devido á abordagem física sobre a geração de corrente elétrica em circuitos fechados.

Salienta-se que o tema Fotossíntese é o que mais aparece ao longo de todo o ensino fundamental, I e II. Ele aparece no $3^{\circ}$ ano (nas três coleções investigadas), no $4^{\circ}$ e $5^{\circ}$ ano (em duas das três coleções), no $6^{\circ}$ (em uma coleção), no $7^{\circ}$ ano (nas três coleções 
investigadas) e no $9^{\circ}$ novamente (em uma coleção). Ele é distribuído nos primeiros anos da escolarização básica com diferentes enfoques. Primeiramente ele aparece de forma simples, trazendo figuras ilustradas e bem coloridas sobre como as plantas se alimentam, que buscam chamar a atenção do aluno. No $4^{\circ}$ ano, ainda no fundamental I, é introduzido um esquema com os componentes da reação traduzidos numa linguagem química, simplificada, mas que fornece uma noção de como se descreve tal reação na química. Trata-se do esquema: água + gás carbônico $\rightarrow$ glicose + gás oxigênio e água. É interessante notar que a equação em que os elementos estão descritos em suas fórmulas químicas não aparece em nenhuma das coleções investigadas.

O segundo tema que mais aparece ao longo do nível fundamental é o de Respiração Celular. Esse tema aparece nas três coleções investigadas no $7^{\circ}$ e $8^{\circ}$ ano, em duas coleções no $6^{\circ}$ e $9^{\circ}$ ano e em uma coleção no $2^{\circ}$ do fundamental I. Para esse tema, a abordagem inicia utilizando-se imagens ilustrativas sobre o processo que ocorre nas plantas, com o decorrer dos conteúdos é introduzido como os seres vivos obtém energia por esse processo; no $8^{\circ}$ ano é apresentada a reação simplificada: Glicose + gás oxigênio $\rightarrow$ Gás carbônico + água + energia; enquanto que no $9^{\circ}$ a equação com os componentes em suas fórmulas químicas e balanceada é demonstrada aos alunos: $\mathrm{C}_{6} \mathrm{H}_{12} \mathrm{O}_{6}+6 \mathrm{O}_{2} \rightarrow$ $6 \mathrm{CO}_{2}+6 \mathrm{H}_{2} \mathrm{O}+$ energia.

Outros temas que tem uma distribuição no ensino fundamental II é o de Combustão e Ferrugem, e em ambos os casos a explicação é atrelada a uma equação química. Por outro lado, os temas reação do Air Bag, Eletrólise, Extração de Metais e Proteção Solar aparecem uma única vez ao longo dos nove anos do ensino fundamental, sendo que cada um aparece em uma coleção específica.

Um fato a ser ressaltado é que a maior parte dos temas presentes está atrelado à importância do gás oxigênio. Os temas Fotossíntese e Respiração Celular, que são os que mais aparecem, são exemplos. Mesmo após conceituar as reações de oxirredução no livro correspondente ao nono ano, é ressaltada a importância desse gás e a grande presença dele nas reações do cotidiano.

Posteriormente apresenta-se esta análise para os livros de ensino médio, e na sequência, discute-se como a evolução do conteúdo ao longo desses livros influencia as concepções alternativas dos alunos. Porém, é necessário explicitar como as coleções do PNLD 2018 abordam o conteúdo para, principalmente, diferenciá-las e apresentar as variadas formas em que o conteúdo é articulado nos livros. 


\subsection{Apresentação das coleções de química do PNLD 2018}

Os livros que circulam nas escolas brasileiras são distribuídos pelo Programa Nacional do Livro Didático. Esse programa conta com um edital que especifica algumas características que devem compor os livros que serão utilizados por alunos em todo território nacional. Entretanto, essa especificação está longe de padronizar a forma de abordagem dos conteúdos nas coleções. Isso implica em coleções com perfis diferentes, apresentando e articulando os conteúdos de forma única e característica das concepções de ensino de cada autor.

Devido a isso, optou-se por, nesta seção, descrever como o conteúdo redox é apresentado em cada um dos livros das coleções do ensino médio aprovadas no PNLD 2018. Optou-se por descrever apenas as coleções do ensino médio, e não as de ensino fundamental, pois, no nível médio de ensino as reações redox são abordadas de forma mais explícita.

Para essa análise, inicialmente catalogou-se o total de ocorrências das palavras que se referem aos conceitos de reações redox e com os dados obtidos para todos os livros foi possível criar uma 'nuvem de palavras' representada na figura 23.

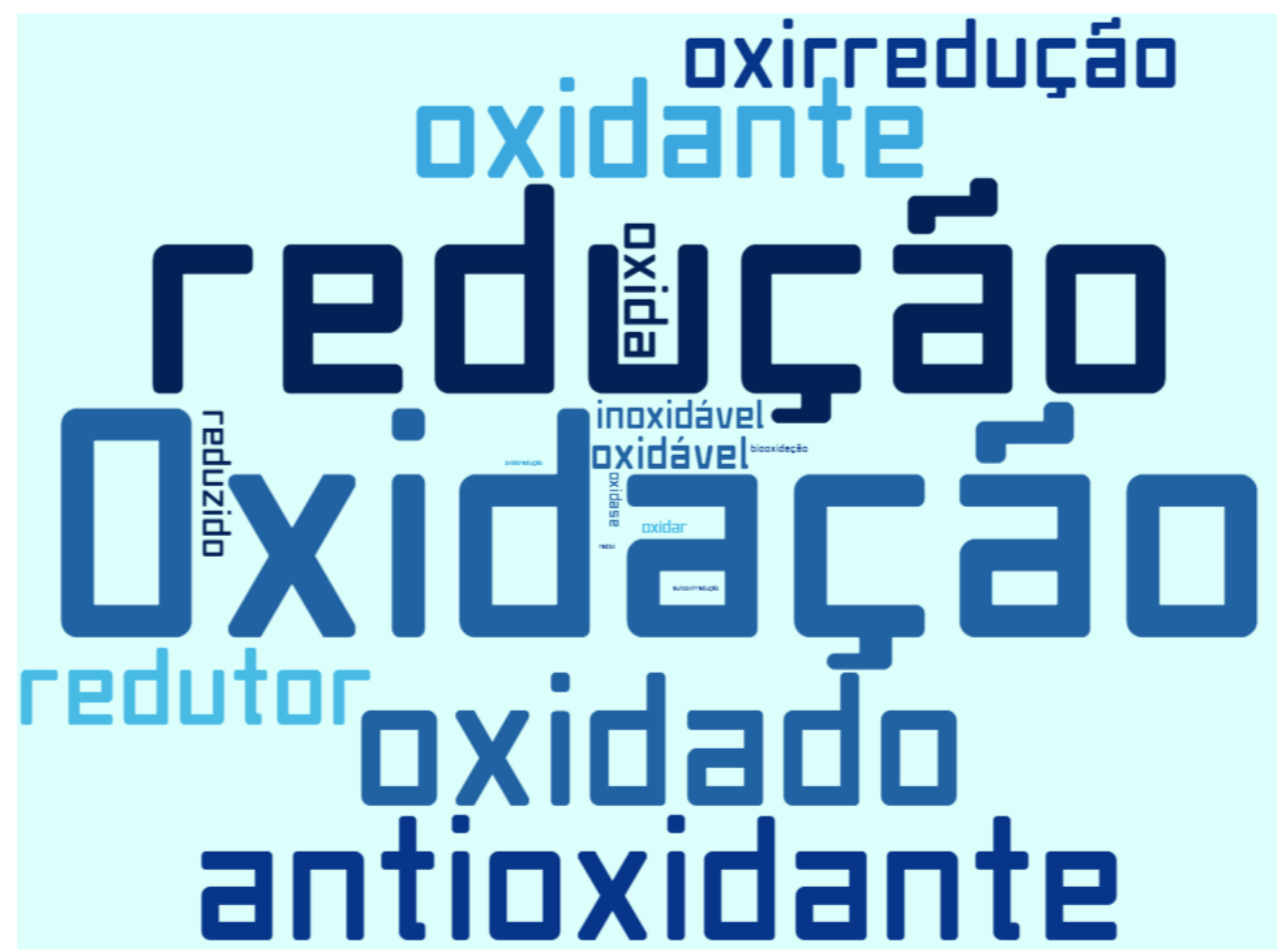

Figura 23 - Nuvem de palavras referentes ao conteúdo de reações redox 
A nuvem de palavras é um recurso que permite visualizar o grau de frequência que uma palavra aparece em um determinado texto. Para criar a nuvem de palavras utilizou-se os termos de todos os livros juntos, neste recurso as palavras em destaque, de tamanho maior, são aquelas que tem maior ocorrência no texto em questão. Na análise realizada, as palavras que apresentaram maior ocorrência foram: oxidação (92 ocorrências), redução (52), antioxidante (31) e oxidante (25). Assim pode-se afirmar que a palavra que remete ao conteúdo de oxirredução, mais utilizada nos livros didáticos brasileiros é oxidação.

Esse recurso permite evidenciar que, ao se referir às reações de oxirredução, a reação de redução é menos abordada em relação à reação de oxidação. O próprio desenvolvimento da química pode justificar a falta de uso desse termo, pois, os primeiros estudos sobre as reações de transferência eletrônica foram associados à presença do oxigênio, logo o termo oxidação foi cunhado primeiro. No entanto, trazer uma reação de oxidação sem associar a ela uma reação de redução, ou enfatizar a simultaneidade dos processos, pode causar dificuldades de aprendizagem para aquele aluno que não compreende que a transferência eletrônica deve acontecer entre espécies que tenham tendência em doar e perder elétrons. Além disso, isso pode contribuir para a concepção alternativa de que os processos não são simultâneos, uma vez que uma reação de oxidação pode aparecer "sozinha" sem outro reagente para receber os elétrons da reação.

Destaca-se também a frequência com que a palavra antioxidante aparece nos livros didáticos: 37,5\% das vezes em que ela aparece são anteriores à abordagem do conteúdo de reações redox. Somente nas coleções VV e MM a palavra aparece após a abordagem do conteúdo. Evidente que ao chegar na escola o aluno já tenha concepções sobre esse conceito, tão presente na mídia. No entanto, a ocorrência da palavra não é associada ao seu significado em nenhuma das vezes, servindo somente como citação. Isso pode contribuir para não significar a palavra para o aluno, que concluirá o período escolar sem, de fato, conhecer seu significado. Nesse sentido, seria importante que o professor atentasse para a conceituação da palavra de acordo com o conteúdo abordado.

Das palavras relacionadas aos conceitos das reações de oxirredução grande parte delas encontra-se nos exercícios propostos. Na coleção MM, tem-se, 50\%; na coleção QC, 47\%; na coleção SP, 48\%; na coleção VV, 34\%; na coleção CP, 29\%; e por fim, na coleção MR, 25\% das palavras são citadas em exercícios. Ressalta-se que as palavras foram catalogadas fora dos capítulos específicos para abordagem do conteúdo. É interessante notar que as coleções questionam os alunos sobre conceitos referentes às 
reações redox antes mesmo de abordar o conteúdo no livro didático. Para a coleção QC, das 20 citações nos exercícios, 12 delas são anteriores à abordagem do conteúdo. A coleção SP apresenta 8 citações, em exercícios anteriores ao capítulo específico, de um total de 15. A coleção MM tem 7 ocorrências anteriores (total 17), a coleção MR tem 2 num total de 12, e a coleção CP tem somente 1 citação, para 5 ao todo. A única coleção que não apresenta nenhuma citação anteriormente ao abordar o conteúdo no livro didático é a coleção VV.

Uma análise mais aprofundada nos capítulos exclusivamente destinados ao ensino das reações redox permite fazer maiores inferências sobre a importância desse conteúdo para os autores dos livros analisados.

\subsubsection{Os capítulos para ensino de reações redox}

Todas as coleções abordam a maior parte do conteúdo de reações redox em um capítulo específico. No entanto, as coleções diferem quanto ao ano que este conteúdo é abordado. Nas coleções VV, MR e SP, o conteúdo é distribuído ao longo dos três livros, com ênfase maior no livro do segundo ano. As coleções MM e CP abordam, exclusivamente, no livro do segundo ano, enquanto que na coleção QC o conteúdo é alocado no livro do terceiro ano.

Apontamos que seria importante o professor estar ciente dessa escolha dos autores para que a utilização deste importante recurso didático se adeque ao plano de trabalho docente. Se na proposta pedagógica do professor o conteúdo é ministrado no primeiro ano do ensino médio será preciso considerar que a maioria das coleções aborda esse conteúdo nos livros dos anos posteriores. Isso não impede a utilização da coleção nas salas de aulas, mas torna-se necessário articular qual livro os alunos devem utilizar e em que momento.

Todos os autores utilizam a mesma definição para as reações redox, para as reações de oxidação e redução, e agente oxidantes e redutores, mas, a ênfase dada no conteúdo difere entre eles. Isso é perceptível à medida que quantificamos o número de páginas destinadas ao conteúdo em cada coleção e, por conseguinte, no livro específico. Esses dados são apontados na tabela 2 que relaciona o número de páginas nos LD. 
Tabela 2 - Relação de páginas e do conteúdo redox

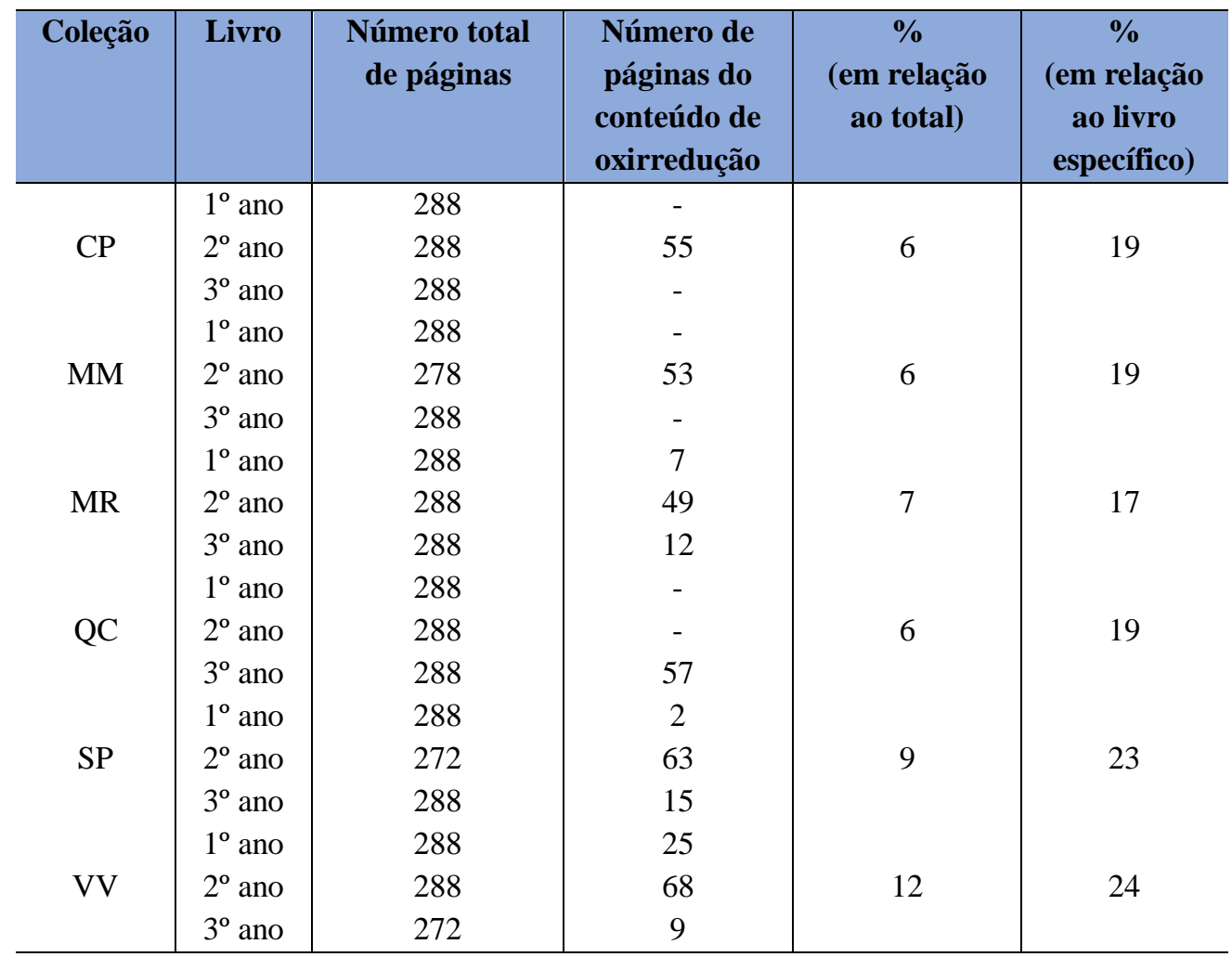

A relação percentual destacada na tabela 3 permite inferir que a importância dada ao conteúdo oxirredução varia para cada coleção. As coleções que apresentaram maior número de páginas na abordagem do conteúdo são a coleção VV, que destina $24 \%$ do total de páginas do livro do segundo ano, e a coleção SP, também com $23 \%$. À primeira vista poderíamos dizer que a coleção que menos aborda o conteúdo é a MR com 17\%, no entanto, esse percentual considera apenas o livro específico, se selecionarmos a porcentagem relativa ao conteúdo dentro de toda a coleção o total chega à $8 \%$, maior que as outras três coleções. As outras coleções mantêm-se na média de páginas.

A distribuição do conteúdo ao longo das coleções também fica clara na análise da tabela 3. A coleção VV distribui o conteúdo ao longo dos três livros de forma mais uniforme que a coleção SP (segunda posição quanto ao número de páginas). Nesse quesito a coleção MR seria a segunda que melhor distribui o conteúdo. Todos os livros que permaneceram na média de páginas destinam apenas um livro para abordagem do conteúdo.

A distinção entre o número de páginas reflete-se também na abordagem do conteúdo entre as coleções. Procura-se destacar na sequência como o conteúdo é abordado, nos capítulos específicos, de cada livro. Assim pode-se relacionar a importância dada pelos autores aos conceitos das reações redox. 


\section{Coleção Química Cidadã (QC)}

A proposta da coleção QC é contextualizar o ensino para desenvolver habilidade argumentativa, formação crítica e atitudes positivas para o engajamento em sociedade, conforme destacam os autores. No Manual do Professor da coleção podem ser observados que, durante os textos, os autores buscaram incluir temas sociocientíficos na contextualização histórica, social e cultural, e tal proposta deve nortear todos os livros.

A coleção QC aborda as reações redox no livro do terceiro ano, primeiramente no capítulo 4 que aborda a "Síntese Orgânica: transformação de funções orgânicas", e posteriormente no capítulo 5 que é denominado 'Oxirredução e Eletroquímica'. Na capa de introdução ao capítulo 5 são listados os conceitos que serão abordados: 1) metais, sociedade e ambiente; 2) propriedades dos metais; 3) ligas metálicas; 4) oxirredução; 5) número de oxidação; 6) balanceamento de equações de reações de oxirredução; 7) pilhas eletroquímicas; 8) a pilha de Daniell; 9) potencial elétrico das pilhas; 10) tipos de pilhas e baterias; 11) eletrólise; 12) aspectos quantitativos da eletrólise: a lei de Faraday; 13) metais pesados e ambiente. Nessa seção introdutória é perceptível que a abordagem do conteúdo será norteada pelo conteúdo de metais e as pilhas e baterias. O quadro 8 sintetiza a forma como o conteúdo é apresentado no livro 3 da coleção QC. 
Quadro 8 - O conteúdo redox na coleção QC

\begin{tabular}{|c|c|c|c|c|}
\hline \multicolumn{5}{|c|}{$3^{\circ}$ ano - Capítulo 5: Oxirredução e eletroquímica } \\
\hline Conceitos abordac & & Exemplos & Experimentação & Outros recursos \\
\hline \multicolumn{5}{|c|}{$\begin{array}{l}\text { Metais (sociedade, propriedades e } \\
\text { ligas) }\end{array}$} \\
\hline \multicolumn{2}{|c|}{ Oxirredução (gerais) } & Ferro e oxigênio & & \\
\hline \multicolumn{2}{|c|}{$\begin{array}{l}\text { Número de oxidação e regras para sua } \\
\text { determinação }\end{array}$} & $\begin{array}{l}\text { Formação do } \\
\text { cloreto de sódio }\end{array}$ & & \\
\hline \multicolumn{2}{|c|}{ Balanceamento de equações redox } & $\begin{array}{l}\text { Obtenção do } \\
\text { manganês }\end{array}$ & & \\
\hline \multicolumn{2}{|c|}{ Pilhas eletroquímicas } & $\begin{array}{l}\text { Oxidação da } \\
\text { palha de aço e } \\
\text { do clipe }\end{array}$ & $\begin{array}{l}\text { Líquidos podem } \\
\text { atacar metais? }\end{array}$ & \\
\hline Pilha de Daniell & $\begin{array}{l}\text { Representação de } \\
\text { células } \\
\text { eletroquímicas }\end{array}$ & Zinco e cobre & & \\
\hline \multirow[t]{4}{*}{$\begin{array}{l}\text { Tipos de pilhas e } \\
\text { baterias }\end{array}$} & $\begin{array}{l}\text { Potencial elétrico } \\
\text { das pilhas } \\
\text { Pilha seca de zinco } \\
\text { carbono }\end{array}$ & & & \\
\hline & $\begin{array}{l}\text { Pilhas alcalinas } \\
\text { recarregáveis }\end{array}$ & $\begin{array}{l}\text { Pilha de níquel- } \\
\text { cádmio }\end{array}$ & & \\
\hline & Pilhas miniaturas & $\begin{array}{l}\text { Pilha de níquel- } \\
\text { metal-hidreto } \\
\text { Pilha de íon lítio } \\
\text { Bateria de } \\
\text { mercúrio e de } \\
\text { óxido de prata }\end{array}$ & & \\
\hline & $\begin{array}{l}\text { Baterias de } \\
\text { chumbo-ácido } \\
\text { Células de } \\
\text { combustível }\end{array}$ & $\begin{array}{l}\text { Combustível a } \\
\text { hidrogênio }\end{array}$ & & \\
\hline Eletrólise & & & $\begin{array}{l}\text { O que acontece } \\
\text { quando uma } \\
\text { corrente elétrica } \\
\text { passa por um } \\
\text { líquido? }\end{array}$ & \\
\hline $\begin{array}{l}\text { Aplicações da } \\
\text { eletrólise }\end{array}$ & $\begin{array}{l}\text { Eletrodeposição } \\
\text { Proteção catódica } \\
\text { contra a corrosão } \\
\text { Purificação de } \\
\text { metais }\end{array}$ & $\begin{array}{l}\text { Oxidação do } \\
\text { ferro }\end{array}$ & & \\
\hline \multicolumn{5}{|c|}{$\begin{array}{l}\text { A lei de Faraday e os aspectos } \\
\text { quantitativos da eletrólise }\end{array}$} \\
\hline \multicolumn{2}{|c|}{$\begin{array}{l}\text { Metais pesados, meio ambiente e o } \\
\text { descarte de pilhas e baterias }\end{array}$} & & & $\begin{array}{l}\text { Box Atitude } \\
\text { Sustentável - Como } \\
\text { fazer o descarte de } \\
\text { pilhas e baterias }\end{array}$ \\
\hline
\end{tabular}

Ao final do livro 3 os autores da coleção QC reúnem uma série de informações que buscam dar suporte ao professor no uso do LD. Nesse capítulo, primeiro são 
fornecidas informações gerais sobre a proposta pedagógica do livro e como os documentos orientadores de ensino foram articulados no LD. Em um tópico específico os autores listam sugestões de atividades adicionais que podem auxiliar o professor no processo de ensino-aprendizagem.

No tópico de sugestões de atividades adicionais, chama-se atenção para um experimento de oxidação de metais sugerida. Segundo os autores a atividade experimental ilustra o fenômeno de oxidação e permite que os alunos assimilem os conteúdos de reatividade, oxidação do ferro, cobre e outros metais.

Nas linhas seguintes do quadro de atividades são sugeridos dois filmes ("A história dos eletrônicos" e "Metais pesados"), uma série de seis videoaulas cujos temas são “Tudo se transforma, Metais”, "Conversa periódica - pilhas e baterias, reações espontâneas de oxirredução", "Conversa periódica - pilhas e baterias, reações não espontâneas de oxirredução", "Tudo se Transforma, Pilhas e Baterias", "Conversa Periódica - Pilhas e baterias, corrosão" e a última videoaula seria "Metais pesados". No mesmo quadro ainda são apresentados dois objetos de aprendizagem: um simulador virtual para balanceamento de equações e um para representar o processo de oxirredução.

\section{Coleção Ser protagonista (SP)}

Os autores da coleção SP distribuem o conteúdo de reações redox ao longo dos três livros, com diferentes enfoques. No livro do primeiro ano são apresentados os tipos de reações químicas, dentro desse capítulo há uma seção específica para as reações de oxirredução. O livro 2 contém a maior parte dos conceitos referentes às reações redox. Neste livro há uma unidade inteira, dividida em quatro capítulos, denominada 'Transformações da matéria e energia elétrica'. Somente três, dos quatro capítulos abordam as reações de oxirredução, e são intitulados 'Número de oxidação e balanceamento de reações', 'Oxidação de metais: produção de energia e corrosão' e 'Eletrólise: Energia elétrica gerando transformações químicas'. No livro 3 a ênfase no conteúdo dá-se na apresentação das reações dos compostos orgânicos, na unidade 3 (reações orgânicas), capítulo 9 (reações envolvendo hidrocarbonetos), conforme apresentado no quadro 9. 
Quadro 9 - O conteúdo redox na coleção SP

(continua)

$1^{\circ}$ ano - Unidade 3: Comportamento das substâncias

Capítulo 10: Reações químicas

Conceitos abordados

Exemplos

Experimentação

Outros recursos

Oxirredução (geral) Ferro e oxigênio

Box Química tem

história - A

descoberta do

oxigênio

Box Você se

lembra? -

Reatividade

Box Química tem

história - Caso do

Celobar

$2^{\circ}$ ano - Unidade 4: Transformações da matéria e energia elétrica

Capítulo 10: Número de oxidação e balanceamento de reações

Capítulo 11: Oxidação em metais: produção de energia e corrosão

Capítulo 12: Eletrólise: energia elétrica gerando transformações químicas

Conceitos abordados

Reações que

envolvem

transferência de

elétrons

Número de

oxidação

Eletronegatividade

e Nox

Identificação de

Vinho e vinagre

reações redox pelo

Nox

Regras para

determinação do

Nox

Balanceamento de $\quad \mathrm{KMnO}_{4}+\mathrm{H}_{2} \mathrm{SO}_{4}$

equações redox $\quad+\mathrm{H}_{2} \mathrm{O}_{2}$

Condições que

interferem na

corrosão do ferro

Exemplos

Vinho e vinagre
Experimentação

Outros recursos

Box Saiba mais -

Sobre a definição de Nox

Box Você se lembra? -

Eletronegatividade: uma propriedade periódica

Box Saiba mais Oxidação e redução: processos concomitantes

Box Saiba mais A química dos airbags

Box química e biologia -

Oxidantes de uso doméstico

Estudo

comparativo da corrosão do ferro
Box Ciência, tecnologia e sociedade Estresse oxidativo e envelhecimento 
Quadro 9 - O conteúdo redox na coleção SP

(continuação)

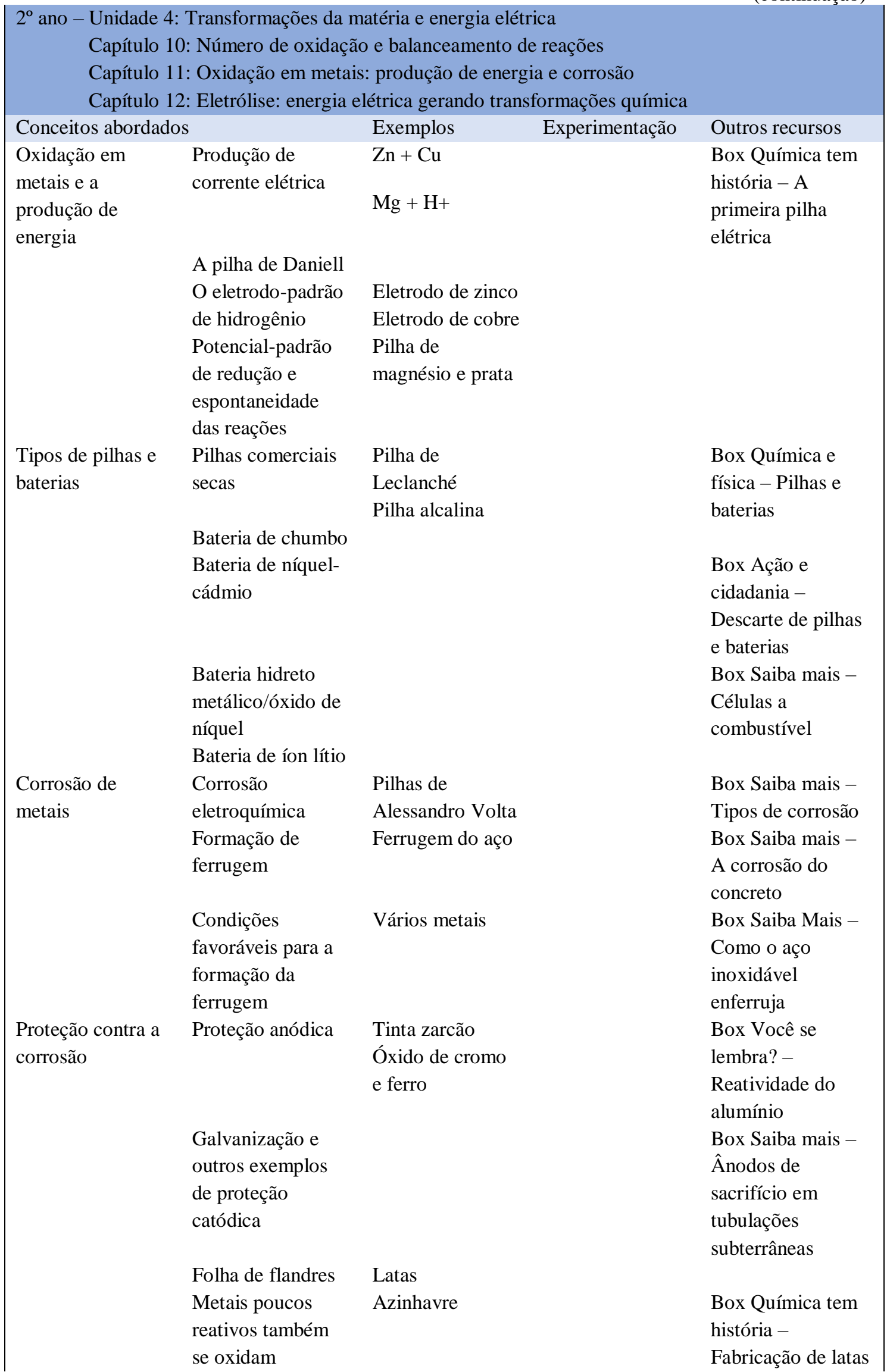




\section{Quadro 9 - O conteúdo redox na coleção SP}

(continuação)

\begin{tabular}{|c|c|c|c|c|}
\hline $\begin{array}{r}2^{\circ} \text { ano - Unidade 4: } \\
\text { Capítulo } 11 \\
\text { Capítulo } 11 \\
\text { Capítulo } 12\end{array}$ & $\begin{array}{l}\text { Transformações da } \mathrm{n} \\
\text { : Número de oxidaçã } \\
\text { : Oxidação em metai } \\
\text { : Eletrólise: energia e }\end{array}$ & $\begin{array}{l}\text { atéria e energia elét } \\
\text { e balanceamento d } \\
\text { produção de energ } \\
\text { étrica gerando tran }\end{array}$ & $\begin{array}{l}\text { ca } \\
\text { reações } \\
\text { a e corrosão } \\
\text { ormações química }\end{array}$ & \\
\hline Conceitos abordado & & Exemplos & Experimentação & Outros recursos \\
\hline Construir pilha de li & mão & & Pilha de limão & \\
\hline Outros tipos de bate & rias & & & $\begin{array}{l}\text { Box Ciência, } \\
\text { tecnologia e } \\
\text { sociedade - A } \\
\text { bateria de ar-lítio } \\
\text { em automóveis }\end{array}$ \\
\hline Tipos de eletrólise & $\begin{array}{l}\text { Eletrólise ígnea e } \\
\text { eletrólise em } \\
\text { solução aquosa }\end{array}$ & $\begin{array}{l}\text { Bateria de } \\
\text { chumbo }\end{array}$ & & $\begin{array}{l}\text { Box Química tem } \\
\text { história - Pilha } \\
\text { elétrica, eletrólise e } \\
\text { a descoberta dos } \\
\text { elementos }\end{array}$ \\
\hline & Eletrólise ígnea & $\begin{array}{l}\text { Fluoreto de } \\
\text { potássio }\end{array}$ & & $\begin{array}{l}\text { Box Ação e } \\
\text { cidadania - } \\
\text { Produção versus } \\
\text { reciclagem do } \\
\text { alumínio }\end{array}$ \\
\hline & $\begin{array}{l}\text { Eletrólise e } \\
\text { solução aquosa }\end{array}$ & $\begin{array}{l}\text { Solução de } \mathrm{NaCl} \\
\text { e eletrodo de } \\
\text { platina }\end{array}$ & & $\begin{array}{l}\text { Box Saiba mais - } \\
\text { Produção industrial } \\
\text { de cloro e soda } \\
\text { cáustica }\end{array}$ \\
\hline & Eletrólise da água & & & $\begin{array}{l}\text { Box Saiba mais - } \\
\text { Lixo eletrônico }\end{array}$ \\
\hline & $\begin{array}{l}\text { Comparação entre } \\
\text { eletrólise e } \\
\text { funcionamento das } \\
\text { pilhas }\end{array}$ & & & \\
\hline $\begin{array}{l}\text { Principais } \\
\text { aplicações da } \\
\text { eletrólise }\end{array}$ & $\begin{array}{l}\text { Obtenção de } \\
\text { metais por } \\
\text { eletrólise ígnea }\end{array}$ & Alumínio & & $\begin{array}{l}\text { Box Saiba mais - } \\
\text { Alumínio metálico } \\
\text { e compostos de } \\
\text { alumínio }\end{array}$ \\
\hline & & Magnésio e sódio & & $\begin{array}{l}\text { Box Química tem } \\
\text { história - Humphry } \\
\text { Davy e a pilha de } \\
\text { Volta }\end{array}$ \\
\hline & Galvanoplastia & $\begin{array}{l}\text { Cromo e potássio } \\
\text { Ouro }\end{array}$ & & $\begin{array}{l}\text { Box Saiba mais - } \\
\text { A galvanoplastia e } \\
\text { seu potencial } \\
\text { poluidor }\end{array}$ \\
\hline & Anodização & Alumínio e água & & $\begin{array}{l}\text { Box Saiba mais - } \\
\text { Eletrodeposição de } \\
\text { metais }\end{array}$ \\
\hline & $\begin{array}{l}\text { Refino eletrolítico } \\
\text { do cobre }\end{array}$ & & & \\
\hline
\end{tabular}


Quadro 9 - O conteúdo redox na coleção SP

(continuação)

$2^{\circ}$ ano - Unidade 4: Transformações da matéria e energia elétrica

Capítulo 10: Número de oxidação e balanceamento de reações

Capítulo 11: Oxidação em metais: produção de energia e corrosão

Capítulo 12: Eletrólise: energia elétrica gerando transformações química

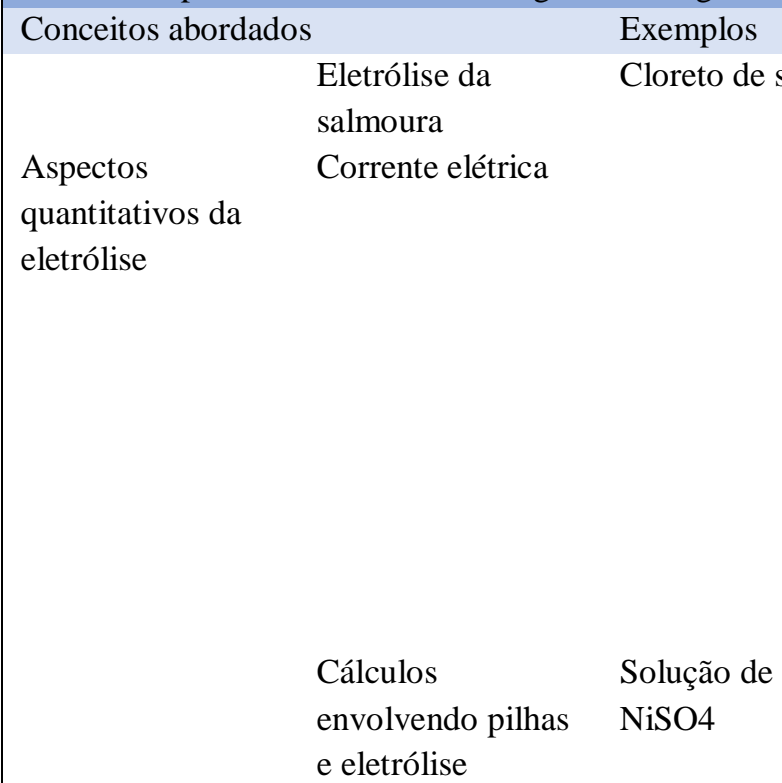

Efeito da corrente elétrica em uma

Cobreação de um

reação química

objeto metálico

Outros recursos

Box Saiba mais -

Pintura eletrolítica

Box Química tem

história - Lei de

Faraday

Box Saiba mais -

Unidades de

medida no Sistema

Internacional

Box Química e

Física - Trabalho e potência em um dispositivo elétrico

Box Saiba mais-

Carga total de uma bateria

Box Química e

Física - Choques

elétricos

Box Química tem história - Seriam o sódio e o potássio metais?

Box Ciência, tecnologia e sociedade - Será a vez do hidrogênio?

$3^{\circ}$ ano - Unidade 3: Reações orgânicas Capítulo 9: Reações envolvendo hidrocarbonetos

Conceitos abordados

Reações de

Combustão

Exemplos

Experimentação

Outros recursos

alcanos

completa

Metano e iso-

Box Saiba mais -

Queimadas e emissões atmosféricas

Combustão
incompleta
Reação de
substituição com
halogênio
Reação de
substituição com
ácido nítrico


Quadro 9 - O conteúdo redox na coleção SP

(conclusão)

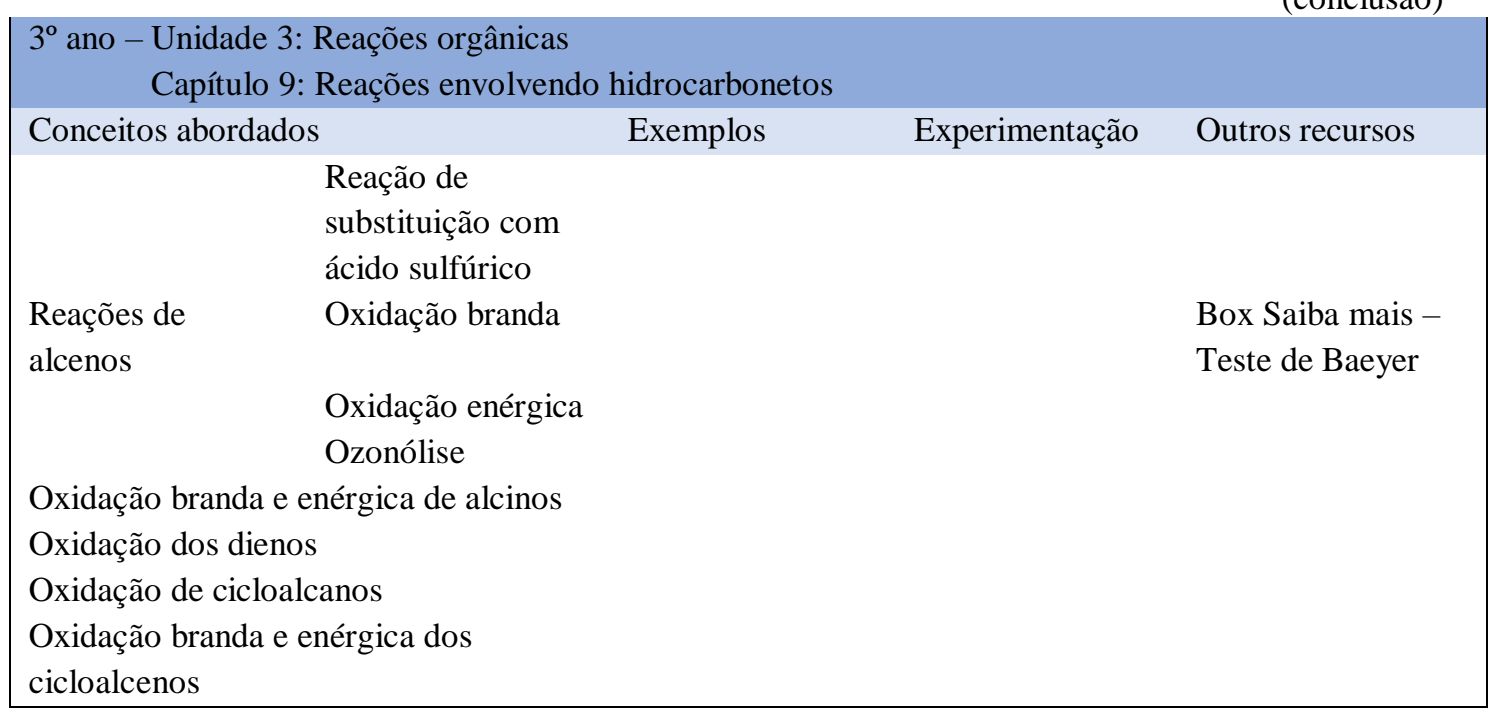

\section{Coleção Vivá (VV)}

Segundo os autores, a proposta da coleção é de relacionar os objetivos das Diretrizes Curriculares para o Ensino Médio (DCNEM) e Parâmetros Curriculares Nacionais (PCN) para fornecer ao professor atividades que o auxiliará a desenvolver tais habilidades e competências nos alunos. Para isso é relacionado no Manual do Professor as competências e habilidades promulgadas nos documentos e os princípios que norteiam as atividades descritas na coleção, sendo elas a contextualização, interdisciplinaridade, uso de Tecnologias da Informação e Comunicação (TIC's) e experimentação.

A coleção VV aborda as reações redox ao longo dos três livros que compõem a coleção. O livro destinado ao primeiro ano do ensino médio é dividido em quatro unidades principais, destas quatro unidades, o conteúdo de reações redox engloba um capitulo na unidade 3, "Eletrólitos e reações químicas: fundamentos qualitativos e quantitativos". A abordagem do conteúdo continua no livro 2 onde há uma unidade denominada Reação Química e Eletricidade composta de dois capítulos "Pilhas e Baterias" e "Transformação Química por ação da eletricidade e cálculos eletroquímicos”. Na capa que introduz a unidade os autores destacam uma peça cromada enfatizando que serão estudadas reações como aquela. A abordagem das reações de oxirredução continua no terceiro livro com as reações químicas orgânicas, há um tópico específico para as reações de oxirredução que se inicia com a descrição das reações de combustão. O quadro 10 ilustra a abordagem na coleção VV. 
Quadro 10 - O conteúdo redox na coleção VV

(continua)

$1^{\circ}$ ano - Unidade 4: Eletrólitos e reações químicas: fundamentos qualitativos e quantitativos Capítulo 10: Reações de oxirredução

Conceitos abordados

Oxirredução (geral)

Generalizações

sobre Nox

Agente oxidante e redutor

Reações com

substâncias simples

com eletrólitos em

solução

Substância simples $\mathrm{Zn}+\mathrm{AgNO}_{3}$ metal

Substância simples

não metal

Balanceamento das

reações

Equações no geral

$\mathrm{KI}+\mathrm{MnO}_{4}+$

$\mathrm{H}_{2} \mathrm{O}$

$\mathrm{K}_{2} \mathrm{Cr}_{2} \mathrm{O}_{7}+$

$\mathrm{H}_{2} \mathrm{SO}_{4}+$

$\mathrm{FeSO}_{4}$

Equações na forma $\mathrm{KI}+\mathrm{MnO}_{4}+$ iônica
Box Conexões -

Algumas reações de oxirredução presentes no cotidiano
Reatividade dos metais
Box Conexões - Os bafômetros e as reações de oxirredução

$2^{\circ}$ ano - Unidade 4: Reação química e eletricidade

Capítulo 10: Pilhas e Baterias

Capitulo 11: Transformação Química por ação da eletricidade e cálculos eletroquímicos

Conceitos abordados

Construção das primeiras pilhas

Geração de eletricidade
Pilha de

Volta,

Galvani e

Daniell

Exemplos Experimentação Outros recursos

Box Viagem no Tempo - Como surgiram as pilhas elétricas?
Geração de

eletricidade 


\section{Quadro 10 - O conteúdo redox na coleção VV}

(continuação)

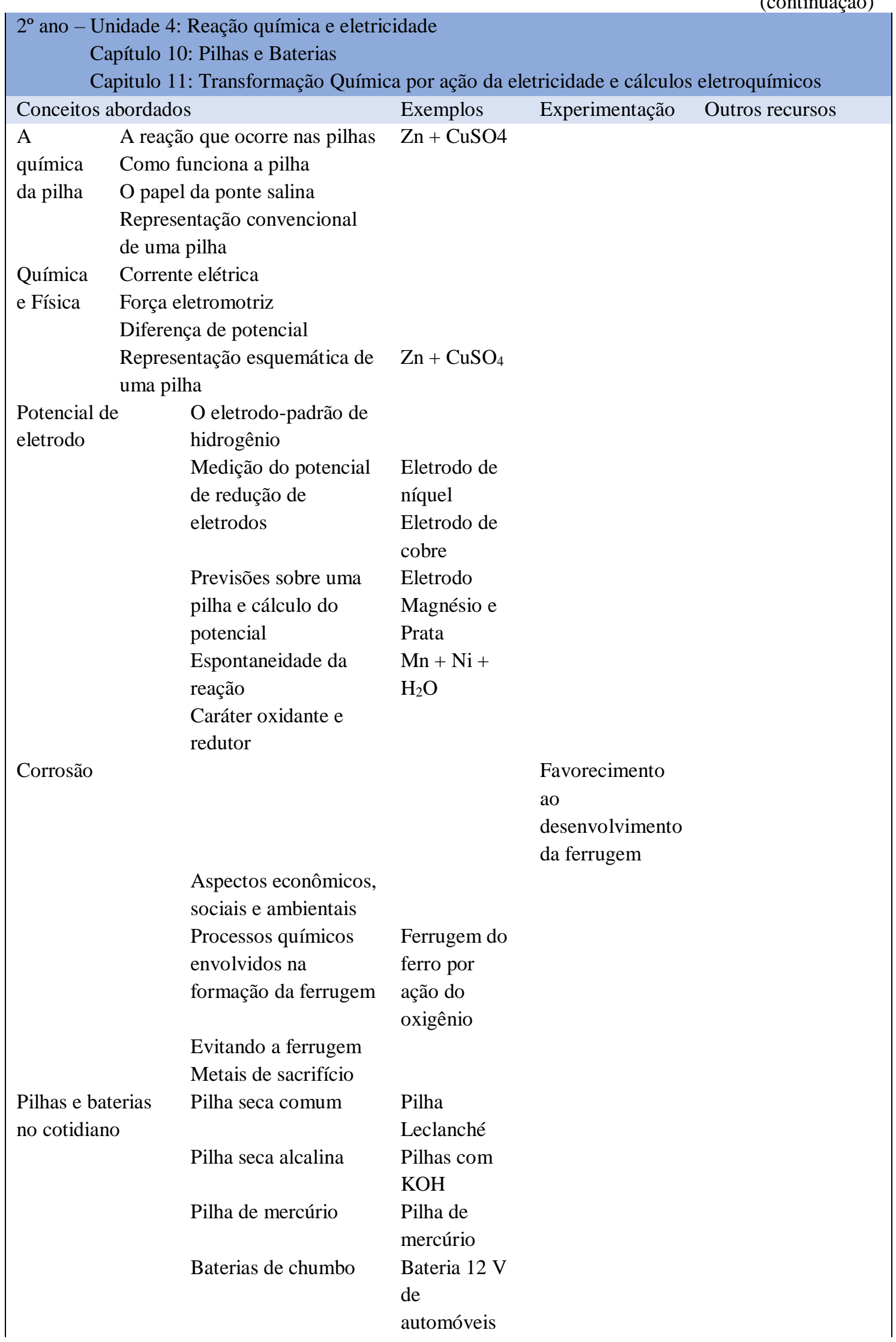




\section{Quadro 10 - O conteúdo redox na coleção VV}

(continuação)

\begin{tabular}{|c|c|c|c|c|}
\hline \multicolumn{5}{|c|}{$\begin{array}{l}\text { Capítulo 10: Pilhas e Baterias } \\
\text { Canitulo 11. Transformacão Ouí }\end{array}$} \\
\hline \multicolumn{2}{|c|}{ Conceitos abordados } & Exemplos & Experimentação & Outros recursos \\
\hline \multirow{2}{*}{\multicolumn{2}{|c|}{$\begin{array}{l}\text { Baterias de níquel- } \\
\text { cádmio }\end{array}$}} & $\begin{array}{l}\text { Baterias de } \\
\text { níquel- } \\
\text { cádmio }\end{array}$ & & $\begin{array}{l}\text { Box Conexões - } \\
\text { Química e meio } \\
\text { ambiente: Os } \\
\text { perigosos íons de } \\
\text { metais pesados }\end{array}$ \\
\hline & & $\begin{array}{l}\text { Célula de } \\
\text { oxidação do } \\
\text { hidrogênio }\end{array}$ & & $\begin{array}{l}\text { Box Conexões - } \\
\text { Química e Meio } \\
\text { Ambiente- Pilhas e } \\
\text { Baterias de celulares } \\
\text { e notebooks: o que } \\
\text { fazer com elas? }\end{array}$ \\
\hline \multicolumn{2}{|c|}{ Como funciona a eletrólise } & $\mathrm{Ni}+\mathrm{Cl}$ & & \\
\hline $\begin{array}{l}\text { Tipos de } \\
\text { eletrólise }\end{array}$ & Eletrólise ígnea & $\begin{array}{l}\text { Cloreto de } \\
\text { sódio }\end{array}$ & & \\
\hline & $\begin{array}{l}\text { Eletrólise em solução } \\
\text { aquosa } \\
\text { Eletrólise em solução } \\
\text { aquosa diluída de } \\
\text { nitrato de prata }\end{array}$ & Água & & \\
\hline & $\begin{array}{l}\text { Eletrólise em solução } \\
\text { aquosa diluída de } \\
\text { ácido sulfúrico }\end{array}$ & & $\begin{array}{l}\text { É possível } \\
\text { montar uma } \\
\text { pilha e com ela } \\
\text { fazer uma } \\
\text { eletrólise em } \\
\text { meio aquoso? }\end{array}$ & $\begin{array}{l}\text { Box Viagem no } \\
\text { tempo - A história } \\
\text { da eletrólise e suas } \\
\text { implicações para os } \\
\text { avanços da Química }\end{array}$ \\
\hline \multirow[t]{2}{*}{$\begin{array}{l}\text { Aplicações de } \\
\text { eletrólise }\end{array}$} & Galvanização & $\begin{array}{l}\text { Cromo e } \\
\text { Níquel }\end{array}$ & & \\
\hline & $\begin{array}{l}\text { Purificação do cobre } \\
\text { Obtenção de } \\
\text { substâncias por } \\
\text { eletrólise }\end{array}$ & & & $\begin{array}{l}\text { Box Viagem no } \\
\text { tempo - Edison, a } \\
\text { lâmpada ... e muito } \\
\text { mais }\end{array}$ \\
\hline \multicolumn{2}{|c|}{$\begin{array}{l}\text { Relação da quantidade de carga elétrica } \\
\text { produzida em uma pilha e a quantidade de } \\
\text { matéria das substâncias participantes }\end{array}$} & & & $\begin{array}{l}\text { Box Viagem no } \\
\text { tempo - Faraday: } \\
\text { grandes } \\
\text { contribuições à } \\
\text { ciência } \\
\text { Box Conexões - } \\
\text { Química e indústria: } \\
\text { A produção de } \\
\text { alumínio }\end{array}$ \\
\hline
\end{tabular}


Quadro 10 - O conteúdo redox na coleção VV

(conclusão)

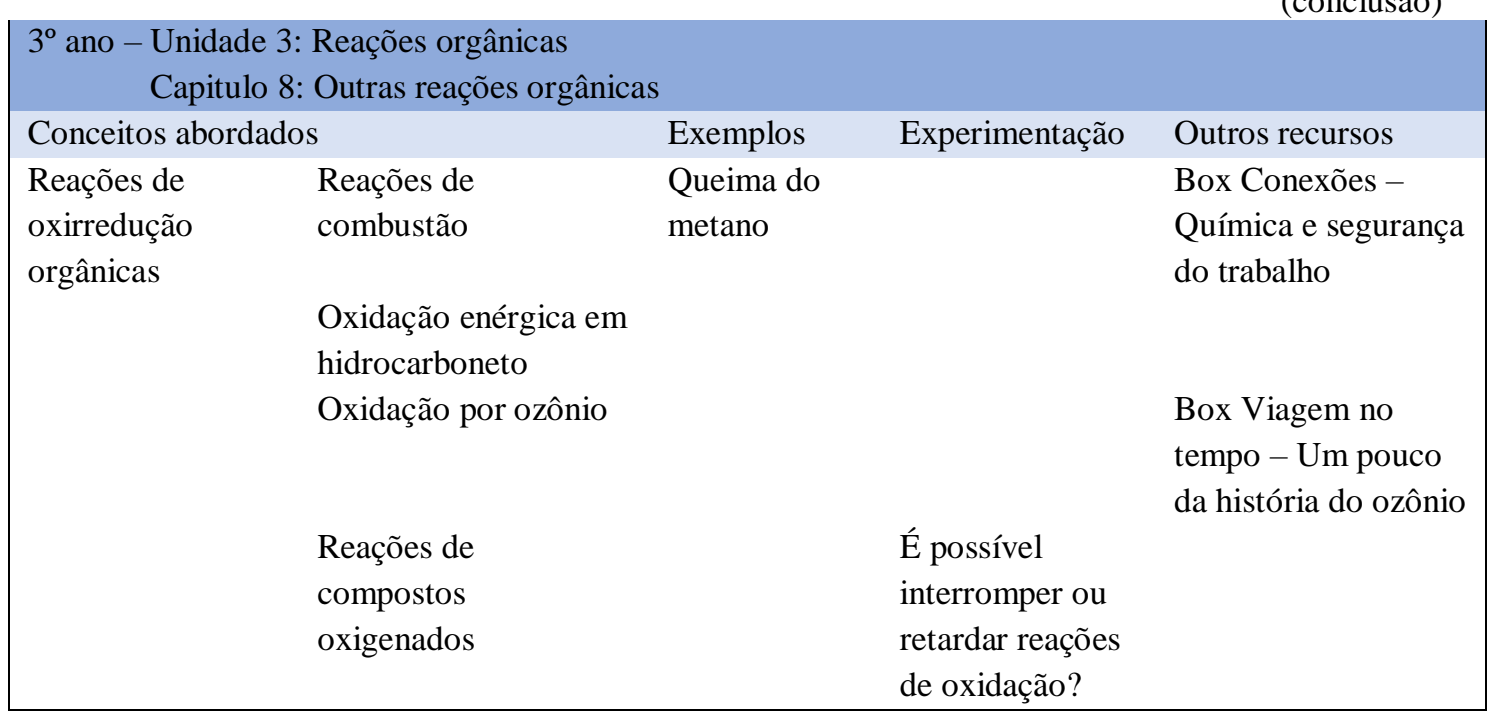

No Manual do Professor do primeiro ano da coleção VV observa-se a apresentação de diversos aspectos que permeiam a abordagem das reações redox, tais como as considerações que são tecidas em relação aos documentos orientadores de ensino, aos aspectos da História da Ciência, Ciência Tecnologia e Sociedade, e às Tecnologias da Informação. Das partes específicas do conteúdo de reações redox a primeira menção é feita quando se aponta a importância da retomada e expansão gradativa de conceitos. Nesse ponto cita-se as reações redox, sendo:

[...] introduzidas no volume 1 , que têm tratamento mais aprofundado no 2, onde elas são abordadas como parte integrante de geradores e receptores de energia elétrica, e, no volume 3, como participantes das reações de oxirredução de compostos orgânicos; em todos os casos sempre há retomada e aprofundamento de conceitos inicialmente abordados. (VV, 1, p. 310).

Por isso, sugere-se que o professor retome com a classe os conceitos que fazem parte e têm ligação direta com o assunto.

Na unidade de reações redox, do Manual do Professor do segundo livro, são destacadas as competências e habilidades a serem desenvolvidas, segundo os PCN. Os autores descrevem que, ao introduzir a unidade, o professor faça referência à legenda de uma foto cujo objeto tem um processo de cromação envolvido, assim seriam levantadas as concepções prévias dos alunos sobre o assunto.

Para o capítulo específico de Pilhas e Baterias os autores destacam o 'Tema de Cidadania' que pode ser trabalhado de forma mais aprofundada; e que é necessário retomar conceitos da física para que o conteúdo seja melhor trabalhado. São apresentados um simulador, um texto sobre carros movidos a hidrogênio, 8 experimentos diferenciados, sugestões de leituras e explicação dos principais exercícios da unidade. 


\section{Coleção Química: Ensino Médio (MM)}

Segundo os autores da coleção MM o livro tem uma abordagem construtivista. Os autores definem o construtivismo como o ensino onde "O conhecimento não é transmitido, mas construído ativamente pelos indivíduos; e aquilo que o sujeito já sabe influencia na sua aprendizagem" (MM, 2, p. 285). Essa ideia, é explicitada quando os alunos são estimulados a comunicar suas ideias e confrontar seu pensamento com a forma de pensar ciência, na proposição de atividades experimentais, discussões em grupos e conduzidas pelo professor. Além disso, os autores descrevem que o enfoque conceitual sugerido nos livros da coleção busca privilegiar a resolução de problemas abertos, que pretende que os alunos utilizem aspectos técnicos, sociais, políticos, econômicos e ambientais em sua resolução, portanto, isso resultaria numa demanda por abordagens interdisciplinares no ensino médio. Os autores ainda enfatizam que a linguagem presente nas obras é organizada para possibilitar uma interação entre os discursos científico e cotidiano.

O conteúdo de reações redox na coleção MM é abordado de forma explícita no segundo livro da coleção. São citadas as palavras oxidação e oxirredução no livro destinado ao primeiro ano, mas sem apresentar uma definição. No livro 2 o conteúdo é abordado predominantemente no capítulo 5 denominado "Movimento de elétrons: uma introdução ao estudo da eletroquímica”, conforme apresentado no quadro 11. 


\section{Quadro 11 - O conteúdo redox na coleção MM}

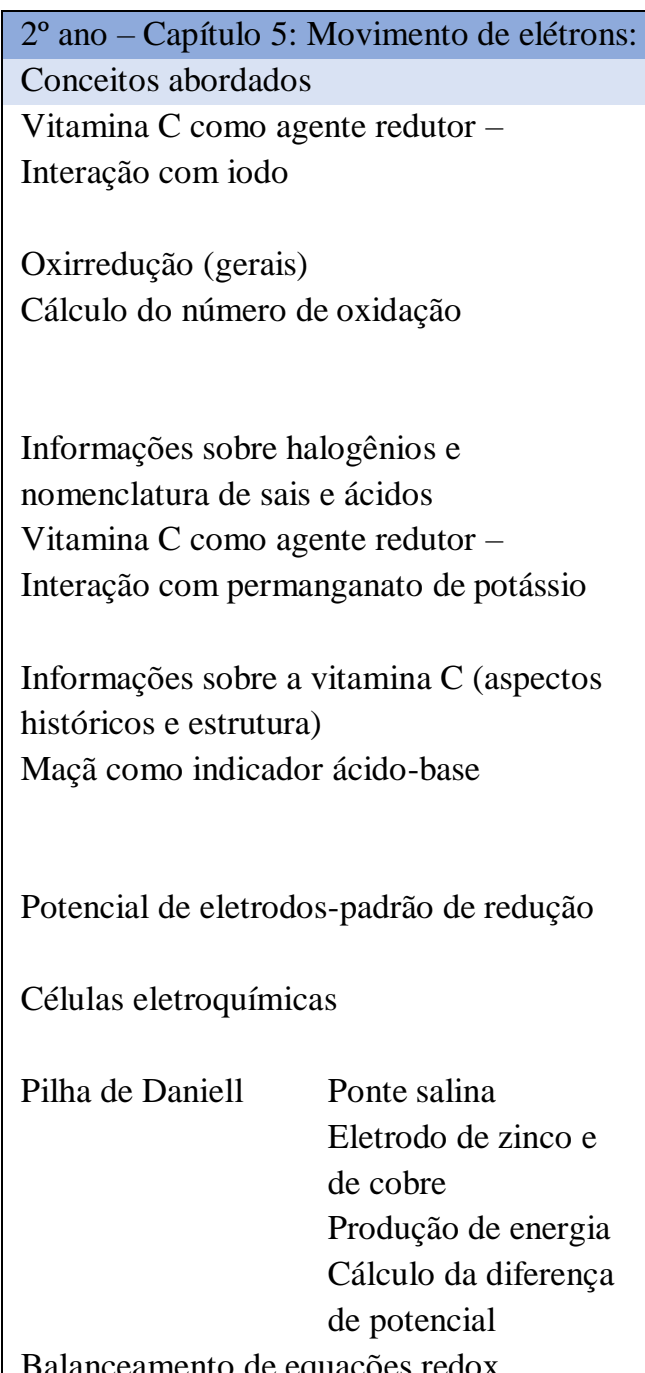

Balanceamento de equações redox

$\begin{array}{llll}\text { Pilha comum } & \begin{array}{l}\text { Componentes de } \\ \text { uma pilha }\end{array} & \begin{array}{l}\text { Pilha de } \\ \text { Leclanché }\end{array} & \begin{array}{l}\text { Abrindo uma } \\ \text { pilha }\end{array} \\ & \text { Pilha alcalina } & & \end{array}$

Eletrólise

Aplicações da

Obtenção de

eletrólise

materiais

Corrosão do ferro

\section{Reação entre}

Iodo e vitamina $\mathrm{C}$

Permanganato de potássio e ácido clorídrico
Maçãs e pregos

Eletrodo-padrão de zinco

Reação entre

alumínio e cobre
Experimentação Outros recursos

Investigação

sobre a vitamina

C

Investigação

sobre a vitamina

C

Evidência de transformações na maçã

Reatividade dos metais

Box Além da química - Descarte de pilhas

Projeto - Pesquisa sobre baterias

Investigação da eletrólise aquosa de iodeto de potássio

Peças de automóveis, chips de computadores, e produção de alumínio

Investigação sobre a corrosão em pregos 
O Manual do Professor da coleção MM apresenta diversos aspectos que visam auxiliar o trabalho do professor, dentre eles, propostas interdisciplinares, comentários sobre o ensino de química, sua relação com o ensino tradicional, a linguagem a ser utilizada, os aspectos a serem trabalhados nos três níveis, entre outros. Para o conteúdo redox relaciona-se orientações que descrevem o objetivo do capítulo, sugestões para organizar o trabalho com os alunos que explicitam o objetivo das atividades propostas no texto, uma sugestão de atividade adicional onde os alunos fariam entrevistas na comunidade sobre a relação dos elementos químicos e o organismo humano, as respostas de todos os exercícios do capítulo, uma lista de sugestões de leituras para formação do professor e sugestões de outros materiais didáticos como dois simuladores sobre eletrólise e quatro vídeos sobre pilhas, baterias e corrosão.

\section{Coleção Química- Ciscato, Pereira, Chemello e Proti (CP)}

Os autores da coleção CP enfatizam que o livro tem uma proposta de divisão dos conceitos em temas centrais que têm caráter significativo em sua aplicação/intervenção efetiva na sociedade.

O conteúdo de reações redox é abordado majoritariamente no segundo livro da coleção CP. No livro 1, destinado ao primeiro ano, são citadas algumas reações redox, mas sem uma abordagem aprofundada e sem citar a transferência eletrônica entre espécies. As reações redox, abordadas no livro 2, são enfatizadas no capítulo 3, intitulado “As transformações químicas e a energia elétrica". Este capítulo é dividido em 4 temas principais denominados: Ocorrência de fenômenos espontâneos de oxidação e redução; Potenciais padrão de redução; Funcionamento das pilhas e baterias e maneiras de evitar ou retardar a corrosão e; Eletrólise. O livro 3 da coleção também aborda as reações redox, porém com ênfase nas reações orgânicas. Neste livro há um tema denominado "Fermentação alcoólica e oxidação alcoólica" que aborda especificamente as reações que ocorrem no processo de fermentação e produção do vinho principalmente no tópico “Oxidação de álcoois e problemas ambientais decorrentes do uso de etanol como combustível". A abordagem do conteúdo na coleção CP é ilustrada no quadro 12, abaixo. 


\section{Quadro 12 - O conteúdo redox na coleção $\mathrm{CP}$}

(continua)

$2^{\circ}$ ano - Unidade 3: As transformações químicas e a energia elétrica

Tema 1: Ocorrência de fenômenos espontâneos de oxidação e redução

Tema 2: Potenciais padrão de redução

Tema 3: Funcionamento das pilhas e baterias e maneiras de evitar a corrosão

Tema 4: Eletrólise

Conceitos abordados

A invenção da pilha e a produção de alumínio por eletrólise

Usos, descartes e problemas associados as pilhas e baterias

Produção de alumínio por eletrólise e o consumo de energia elétrica e impacto ambiental

Oxirredução (geral)

Número de

Revisão de

oxidação

Potenciais padrão

de redução

eletronegatividade

e caráter polar

Determinação do

Nox

Eletrodo padrão

de hidrogênio

Prevendo a

ocorrência de uma

reação redox

Reação redox e a maresia

Funcionamento

Pilha de Volta

das pilhas e

Ponte Salina

baterias

Tipos de pilhas e Pilhas alcalinas baterias

Pilha botão

Baterias de

chumbo

Baterias de íons

lítio

Célula a

combustível

Como evitar ou Galvanização

retardar a corrosão

Anodização por

anodos de

sacrifício

Revestimentos

protetores
Exemplos

Experimentação Outros recursos

Luigi Galvani,

Alessandro Volta e

a primeira pilha

Resolução 401 do

CONAMA

Cobre metálico em uma solução de nitrato de prata

Ferro e hipoclorito

de sódio

Box -

Autopreservação química
Zinco metálico em

sulfato de cobre

Ferro e água

Zinco metálico em sulfato de cobre

Pilhas com

hidróxido de sódio

Zinco e oxigênio

Zinco oxidado

Zinco em cascos de navios

Tinta de zarcão
Construção e associação de pilhas em série e em paralelo 
Quadro 12 - O conteúdo redox na coleção CP

(conclusão)

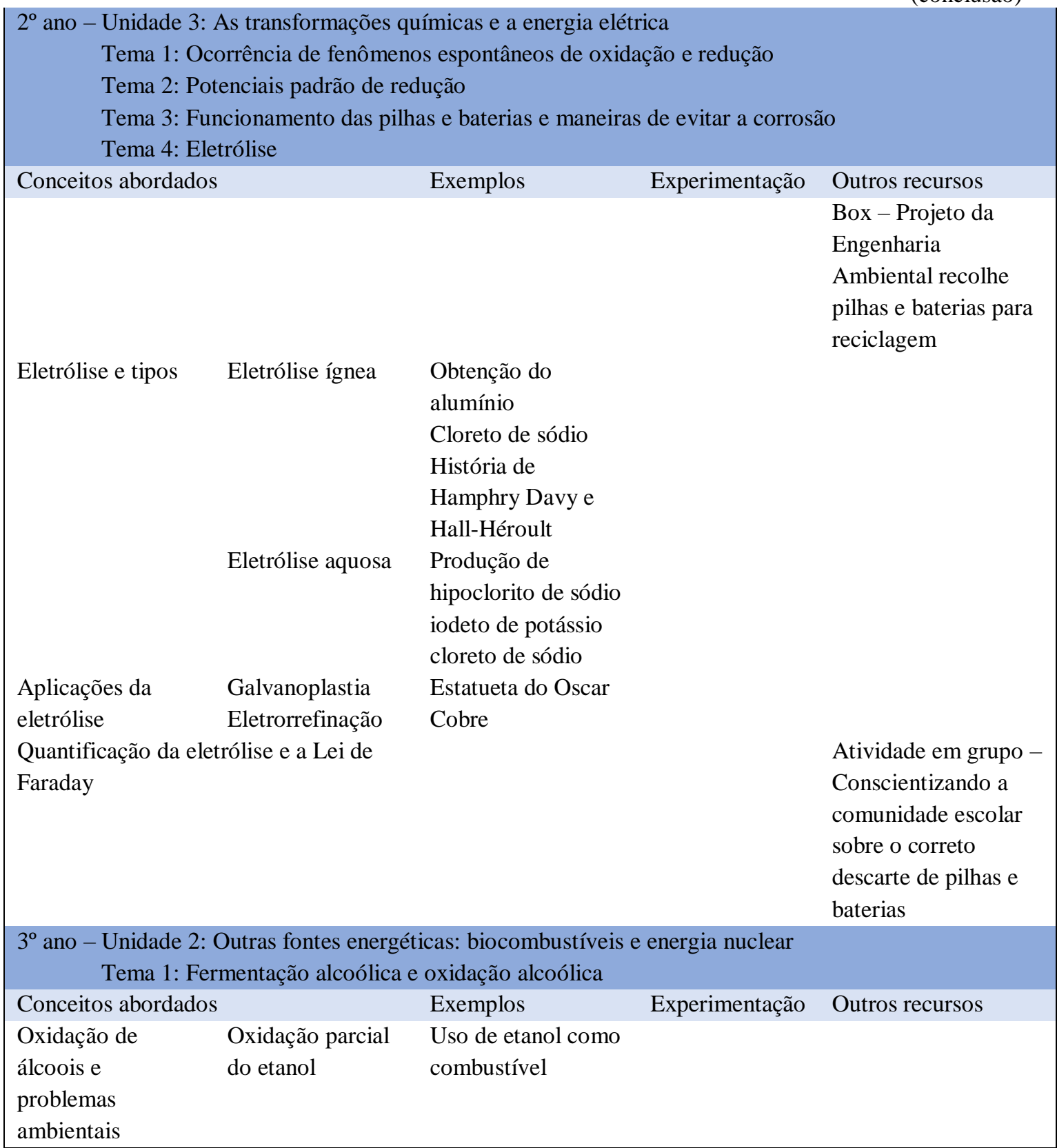

O Manual do Professor da coleção é dividido em aspectos pedagógicos gerais, em que são definidas as orientações do ensino de química presentes nos livros, e aspectos pedagógicos específicos dos capítulos. No que se refere ao conteúdo de reações redox os autores definem os objetivos do ensino dos conceitos e destacam que o tema escolhido é o estudo da obtenção de energia elétrica. São selecionados diversos estudos da área de ensino para complementar as propostas de atividades ao longo do capítulo, por exemplo, ao relembrar uma atividade de reação entre íons prata e cobre metálico é citado um artigo que destaca uma concepção alternativa de que os processos de oxidação e redução podem ocorrer de maneira independente. 
São tecidos comentários sobre cada tema, atividade experimental e quadros espalhados no capítulo de reações redox para ampliar a abordagem do professor, bem como é acrescentada uma sequência didática diferenciada sobre formação de ferrugem que inclui 3 experimentos.

Os autores listam diversos artigos sobre o conteúdo para formação complementar do professor e listam sites que podem ser consultados. Nesses sites são destacados um vídeo sobre o funcionamento da pilha, uma matéria sobre acidente de Mariana (ocorrido na cidade de Minas Gerais, em 2015), uma sobre a carga e descarga das pilhas e baterias, e por último, uma simulação da reação entre cobre metálico e nitrato de prata.

\section{Coleção Martha Reis (MR)}

Os autores da coleção MR destacam, no Manual do Professor do livro 1, que o objetivo da coleção é ajudar o aluno a entender o mundo à sua volta utilizando para isso a Química apreendida. Em busca desse objetivo os autores descrevem que em cada unidade:

[...] foram escolhidos temas ambientais ou sociais que são os assunto-chave para o estudo dos conceitos químicos expostos na coleção. Dessa forma, à medida que vão sendo abordadas e discutidas questões pertinentes ao meio ambiente, à cidadania e à tecnologia, o conteúdo é desenvolvido. (MR, 1, p. 291).

A coleção MR distribui o conteúdo redox ao longo dos três livros destinados ao ensino médio. No primeiro livro, o conteúdo é alocado no capítulo que aborda as reações químicas em geral, sendo a oxirredução vista como um tipo específico de reação. No livro do segundo ano, o conteúdo é quase todo desenvolvido na unidade 5 cujo tema é lixo eletrônico, onde são destacados os conceitos referentes às pilhas e baterias e à eletrólise. No terceiro livro, várias reações orgânicas de oxirredução são descritas na unidade 3 sobre consumismo. 
Quadro 13 - O conteúdo redox na coleção MR

(continua)

$1^{\circ}$ ano - Unidade 5: Chuva ácida

Capítulo 11: Metais e oxirredução

Conceitos abordados

Oxirredução (geral)

Cálculo do Nox

Deslocamento Entre metais

simples

Entre ametais
Lixo Eletrônico
Pilhas e baterias

\section{Conceitos abordados}

Introdução a unidade

Revisão dos conceitos de oxirredução, ordem de reatividade dos metais e diferenciação entre processo espontâneo e não espontâneo

$\begin{array}{ll}\begin{array}{l}\text { Força } \\ \text { eletromotriz }\end{array} & \text { Potencial-padrão de } \\ & \text { redução } \\ & \text { Potencial-padrão de } \\ & \text { oxidação } \\ & \text { Concentração da } \\ & \text { solução } \\ & \text { Temperatura variando } \\ & \text { o potencial-padrão } \\ & \text { Medida do potencial- } \\ & \text { padrão de um eletrodo } \\ & \text { Cálculo da força } \\ & \text { eletromotriz } \\ & \text { Pilha seca ácida }\end{array}$

Tipos de pilhas e

Pilha seca ácida

baterias

$2^{\circ}$ ano - Unidade 5: Lixo Eletrônico

Capítulo 10: Pilhas e baterias

$\begin{array}{lll}\text { Exemplos } & \text { Experimentação } & \text { Outros recursos } \\ \text { Reação de } & & \text { Box -Nox e IUPAC } \\ \text { formação do } & & \\ \text { cloreto de } & & \\ \text { sódio } & & \end{array}$

Box com procedimentos matemáticos de cálculo Box com tabela de reatividade dos metais
Sódio

metálico e

cloreto de

prata

coloidal

Flúor

gasoso e

cloreto de

sódio sólido

\section{Exemplos Experimentação Outros recursos}

Box Foi notícia! -

Gerenciamento de lixo eletrônico no Brasil

\section{Zinco e}

cobre

Pilha de

Leclanché

Pilha

comum

ácida 
Quadro 13 - O conteúdo redox na coleção MR

(continuação)

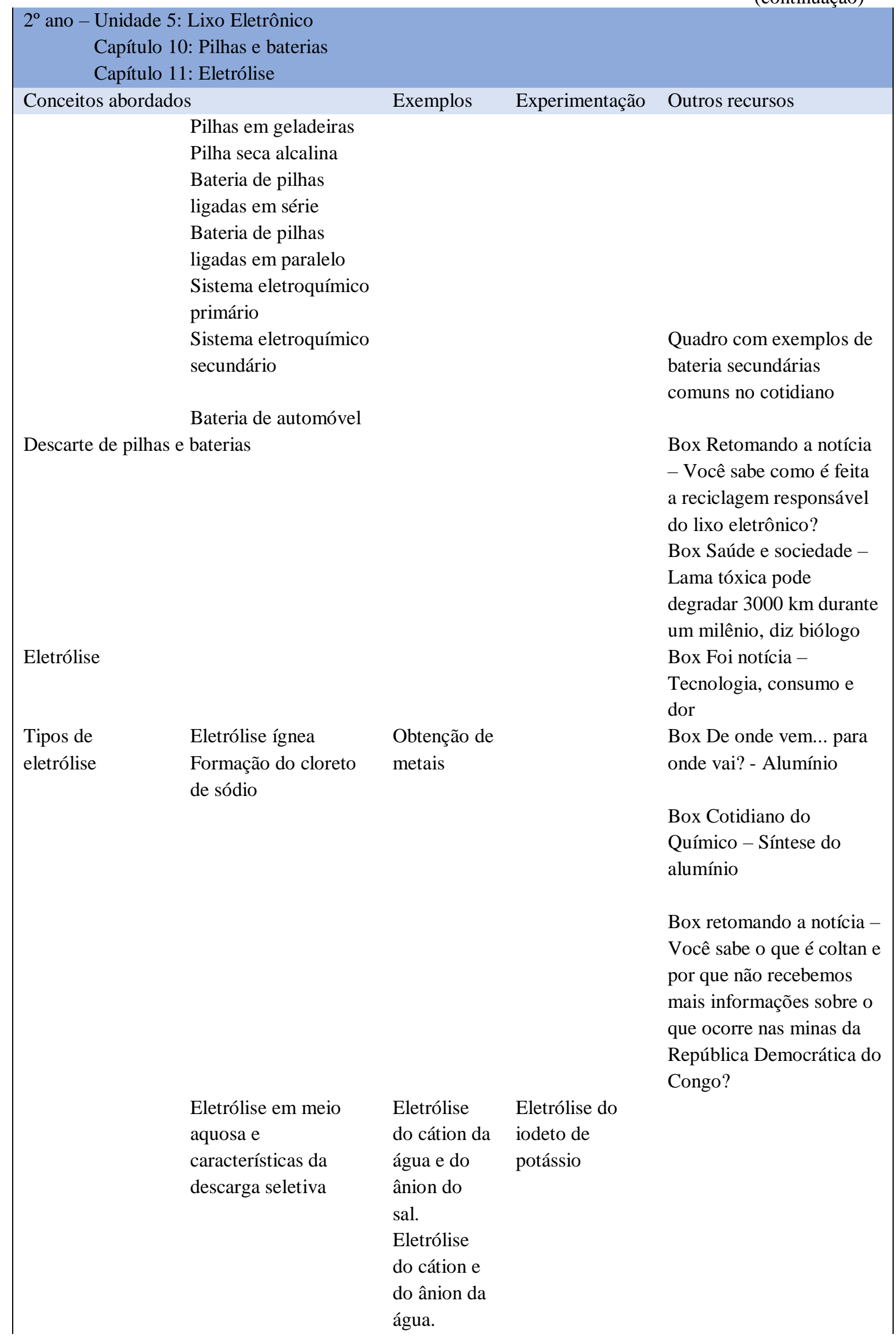


Quadro 13 - O conteúdo redox na coleção MR

(conclusão)

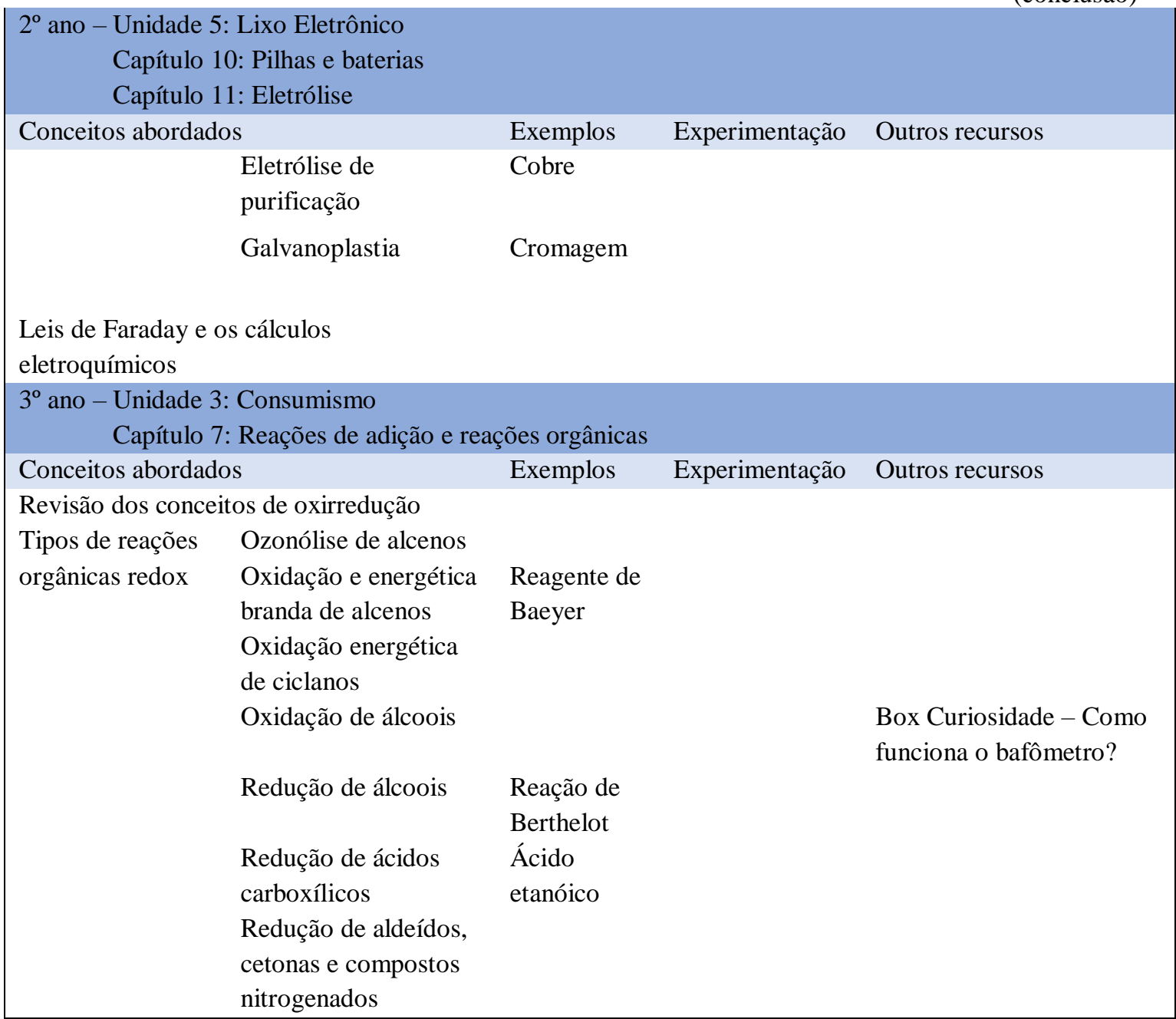

No Manual do Professor da coleção MR a intenção dos autores de que os livros possam ser orientadores do planejamento anual do professor é explicitada em um quadro de sugestão de distribuição do conteúdo. As reações redox, de acordo com o quadro, poderiam ser ministradas no primeiro ano no mês de novembro junto aos metais, no segundo ano nos meses de outubro e novembro para pilhas, baterias e eletrólise, e no terceiro ano no mês de agosto junto a abordagem das reações orgânicas.

No Manual do Professor é apresentado também, uma proposta de como conduzir as aulas utilizando-se cada capítulo do livro. Chama atenção no livro do primeiro ano, dentro da unidade 2 que aborda as transformações da matéria com o tema 'Oxigênio e Ozônio', uma proposta de experimento sobre eletrólise da água. Nesta proposta o objetivo principal é que os alunos entendam a proporcionalidade dos volumes gasosos com os coeficientes de uma reação. 
A justificativa para introdução dos conceitos de oxirredução no livro do primeiro ano também é encontrada no Manual do Professor quando os autores enfatizam que as reações, apesar de ocorrerem com praticamente todos os elementos, são mais facilmente observáveis nos metais. Os autores baseiam-se na publicação "Química - um tratamento moderno de Pimentel e Spratley, Bookman”, para justificar a não utilização do termo transferência de elétrons ao abordar as ligações iônicas, o que também foi extrapolado para as reações redox nesta publicação. No livro 3, a justificativa de introdução das reações orgânicas é a presença desses fenômenos no cotidiano, tais como a reação do bafômetro, tintura de cabelos, etc.

Exclusivamente para o capítulo que aborda as reações de oxirredução no livro 1, os autores acrescentam uma sugestão de atividade interdisciplinar sobre o papel dos metais na sociedade. No livro 2, sugere-se uma reportagem sobre lixo eletrônico do Brasil, na introdução da unidade e um texto a mais que aborda as aplicações da eletrólise.

\subsubsection{Diferenças e semelhanças das coleções de química}

A leitura dos quadros 8-13 permite comparar a abordagem escolhida entre os autores das coleções de química aprovadas pelo PNLD. Primeiro aponta-se a escolha da inclusão do conteúdo nos últimos capítulos de todas as coleções, esse fator pode contribuir para que o conteúdo seja deixado por último no ano letivo arriscando não ser ministrado por falta de tempo. Coadunando com esse fator, Sanjuan e colaboradores (2009) apontam que muitos professores, por saberem que ao final do ano letivo muitas vezes não há tempo para ministrá-lo, deixam o conteúdo para os últimos meses, a grande causa desse fator seria a dificuldade em trabalhar esse assunto. Além disso, mesmo que um professor mapeie e se preocupe em confrontar as concepções alternativas de seus alunos, alocar o conteúdo no final do semestre pode resultar na não retomada dessas concepções e discussão se essas foram sanadas.

Outra diferença entre as coleções é a quantia de atividades experimentais distribuídas ao longo dos capítulos. A coleção MM lidera o número de propostas experimentais com 7, seguido pela coleção VV com 6. Porém, é valido destacar que as propostas da coleção VV são distribuídas pelos três livros enquanto que na coleção MM estão presentes num único capítulo. Isso é justificado pelo perfil da coleção MM que valoriza a experimentação para "promover uma integração entre teoria e prática usando os experimentos como forma de interrogar a natureza e gerar discussões sobre os 
fenômenos de interesse da química" (MM, 1, p. 3). As coleções que menos apresentam propostas experimentais são a CP, com 1, a QC e MR com 2 e SP com 3.

Outro aspecto que deve ser considerado nos livros didáticos é a inclusão de fatos da história da ciência. O próprio edital do PNLD coloca como critério eliminatório a presença da história da ciência, além de nomes ou datas, portanto, devem ser explorados o contexto social, cultural, econômico e político em que ocorreu a produção científica. As coleções VV e SP apresentam esses aspectos em boxes separados da abordagem principal no capítulo, no entanto, na coleção VV são destinadas 2 a 3 páginas para fatos históricos enquanto que nas outras, esse aspecto aparece de forma tímida, com frases curtas aparecendo esporadicamente. A coleção CP e QC introduz esses elementos junto ao texto principal, mas também com uma grande diferença entre a escolha da abordagem.

Além desses fatores, pode-se apontar a presença de discussão sobre as reações orgânicas de oxirredução nas coleções. Tais reações são abordadas nas coleções VV, SP e MR com exemplificação, e nas coleções QC, CP e MM são pouquíssimas destacadas e sem discussão profunda sobre o que as torna reações de oxidação ou redução. Entretanto, deveria haver um esforço para discutir, entre as pesquisas da área, a importância da abordagem dessas reações nesse nível de ensino. Até que ponto discutir essas reações ajuda na formação do aluno crítico e consciente que é o objetivo no ensino médio, para além disso, se são muito importantes, como a abordagem que vem sendo realizada auxilia no alcance desse objetivo.

Por outro lado, outro tipo de reação de oxirredução está sendo deixada de lado no ensino médio: as reações de oxirredução biológicas. Dos exemplos mais utilizados nos livros pouco são aqueles que destacam as reações de manutenção da vida que vem sendo trabalhadas ao longo de todo o ensino fundamental, como a fotossíntese, a combustão, a produção de energia no organismo vivo, entre outras. Com exceção da coleção MM que utiliza a vitamina $\mathrm{C}$ como norteadora do capítulo, as coleções comentam de forma bastante acanhada o processo redox envolvido nessas transformações.

Além disso, a literatura ressalta a importância de outras temáticas ao abordar os conteúdos químicos, especificamente temas mais modernos e que contemplem a geração presente hoje nas escolas. Nesse sentido, trazemos como exemplo a coleção MR que se diferencia no PNLD 2018 por trazer as reações redox junto a uma abordagem mais ampla sobre lixo eletrônico. Essa abordagem é interessante e intrigante porque mais que relatar a importância dos metais para a produção de tecnologia absolutamente presente no nosso 
cotidiano, é preciso, também, apontar os malefícios que o consumo desenfreado e o descarte inadequado podem causar.

\subsubsection{Dos conceitos redox apresentados}

Segundo a orientação dos documentos de ensino (BRASIL, 2000, 2006) na abordagem das reações de oxirredução é importante que se alinhem às ideias sobre estrutura da matéria. Segundo essa análise, relacionar as ideias de estrutura da matéria significa associar o tipo de ligação química envolvida no processo (as reações podem ocorrer resultando de ligações iônicas ou covalentes), a eletronegatividade dos reagentes envolvidos (elementos mais eletronegativos tendem a atrair os elétrons da ligação para si). Nesse sentido, o conceito de número de oxidação seria associado à densidade eletrônica dos participantes da reação, não podendo ser associada à carga elétrica.

Segundo a orientação dos documentos (BRASIL, 2000, 2006) uma reação de oxidação deveria ser entendida como:

Reações de oxidação, que envolve ligação iônica entre os participantes, resulta num aumento do Nox dos reagentes para os produtos. Reações de oxidação, em que há envolvimento de substâncias covalentes, resulta em elementos com caráter parcial cuja carga seja positiva ou negativa, dependendo da eletronegatividade entre os átomos. Portanto, o caráter redutor ou oxidante de um elemento depende da eletronegatividade de todos os átomos envolvidos no processo. Assim sendo, um mesmo elemento pode sofrer redução ou oxidação dependendo do outro elemento.

Esta seria a definição mais completa, de acordo com os documentos, e também segue as recomendações das pesquisas da área (SISLER, WANDERWERF, 1980; GHIBAUDI et al. 2015, GARNETT, GARNETT, TREAGUST, 1990). Ressalta-se, no entanto, que esse tipo de abordagem está presente em apenas três das seis coleções de química aprovadas pelo PNLD, as coleções SP, MR e CP são as únicas em que as ideias sobre estrutura da matéria são utilizadas para abordagem das reações redox.

Os documentos oficiais de ensino (BRASIL, 2000, 2006) definem que ao final do estudo de eletroquímica os alunos devem compreender o conceito de potencial-padrão de eletrodo, a evolução das pilhas e eletrólise e ainda relacionar e prever a energia elétrica envolvida nos processos de oxidação e de redução. 
Apesar de apresentar o conceito de eletrodo-padrão de redução de forma não tão detalhada conforme exposto acima, todas as coleções aprovadas pelo PNLD abordam o conceito. $\mathrm{Na}$ maior parte das coleções o conceito é tratado de forma simplificada, o destaque é da coleção VV que apresenta a relação entre os conceitos da química e da física e esclarece os conceitos que podem causar dificuldades de interpretação. Com relação aos cálculos para prever a energia elétrica envolvida nos processos, somente a coleção MM não traz procedimentos de cálculo da diferença de potencial das células.

Outro ponto que deve ser abordado nos livros didáticos é a evolução das pilhas. A abordagem histórica dos três tipos de pilhas descritos seria importante para contemplar a evolução das pilhas e baterias, conforme orientam os documentos oficiais. Esta abordagem histórica poderia considerar as contribuições de Galvani e o estudo da eletricidade animal anteriormente à proposição da primeira pilha. Além disso, os editais do PNLD apontam como critério específicos a importância de os livros apresentarem "A história da ciência muito além de nomes ou datas, explorando o contexto social, cultural, econômico e político em ocorreu a produção científica” (BRASIL, p.45, 2015)

No entanto, não é isso que se observa nos livros didáticos. A abordagem histórica aparece de diferentes formas, na coleção VV um box em duas páginas no início do capítulo apresenta os estudos de Galvani, Volta e Daniell, enquanto que Leclanché é somente citado. Na coleção MR são dedicados 2 parágrafos para contar um pouco da história de Daniell e apenas cita Volta, Galvani não é citado, e Leclanché tem uma abordagem um pouco mais ampla. A coleção CP é a que mais apresenta os fatos históricos que levaram à construção da pilha, inclusive citando outros cientistas que contribuíram para seu desenvolvimento, porém, o nome de Leclanché não aparece uma única vez no livro. Em contraste com as outras coleções, na coleção MM o único cientista pouco citado é Daniell, sem referência a nenhum outro. Galvani, Volta e Daniell são bastante lembrados na coleção QC, enquanto que Leclanché é apenas citado uma vez. As contribuições de Galvani e Volta para evolução da pilha são citadas timidamente na coleção SP, em um box no canto da página, surpreendentemente os autores referem-se a pilha o tempo todo como pilha de Daniell, mas em nenhum momento relatam o motivo desse nome ou falam sobre Daniell, Leclanché é apenas citado.

Pode-se inferir que a história da evolução das pilhas e baterias em todas as coleções do PNLD não seguem os pressupostos determinados pelos documentos oficiais que embasam essas coleções. As únicas coleções que parecem atribuir algum significado 
à abordagem histórica é a coleção $\mathrm{CP}$ e VV. Vale ressaltar que em todas elas a história da construção da pilha de Leclanché não está de acordo com os documentos.

Para o conteúdo de eletrólise não se observa a presença da história da construção dos dispositivos eletrolíticos nas coleções de química do PNLD. As coleções MR, MM e QC não fazem nenhuma menção aos estudos de nenhum dos cientistas citados na fundamentação teórica desta dissertação. A coleção SP detalha em um box ao final do capítulo os estudos que levaram a caracterização dos elementos sódio e potássio envolvendo as descobertas de Nicholson, Carlisle e Davy. A coleção CP aborda brevemente a história da eletrólise, explicando junto ao texto como os estudos levaram à decomposição e obtenção dos elementos conhecidos. E a coleção VV é a que mais apresenta a evolução do método da eletrólise, porém, em um texto ao final do capítulo.

\subsubsection{Os temas de oxirredução presentes nas coleções de ensino médio}

Observou-se na seção 1 os vários exemplos de reações redox que aparecem ao longo dos livros do ensino fundamental I e II. Foi perceptível como os temas vão surgindo nos primeiros anos e deixando de aparecer nos últimos anos, enquanto que há temas que só são destacados no fundamental II.

Uma investigação nos livros de ensino médio pode revelar se os temas continuam aparecendo em tal nível de ensino e como isso se dá. Essa investigação é importante para definir como é a evolução do conteúdo de reações redox nos livros da educação básica e, então, buscar uma resposta à questão de pesquisa.

Para isso, buscou-se nas coleções de química do PNLD 2018 a presença desses temas pertinentes e a evolução que se dá ao abordar estes temas. Essa análise é explicitada na sequência para cada um dos três anos do nível médio de ensino.

\section{$1^{\circ}$ ano do ensino médio}

Três das seis coleções investigadas abordam o conteúdo de reações redox no primeiro ano do ensino médio, sendo elas as coleções SP, MR e VV. Nas três coleções, as reações redox são definidas e relacionadas aos processos envolvendo metais.

$\mathrm{Na}$ coleção SP, define-se reação redox, oxidação, redução, número de oxidação e agente oxidante e redutor, para então, apresentar a fila de reatividade dos metais. $\mathrm{Na}$ apresentação do conteúdo a reação da Ferrugem é utilizada como exemplo e algumas outras envolvendo metais como o cálcio e o magnésio. Além disso, o livro traz um box 
relatando a importância da descoberta do gás oxigênio para entendimento das reações redox.

No livro 1 da coleção MR são definidos os termos: reações redox, número de oxidação, agentes oxidantes e redutores. Nesse ano, também, são explicadas as regras para determinação do número de oxidação, utilizando as reações de formação do metano e do gás carbônico para isso. Na sequência do conteúdo são discutidas as reações envolvendo metais como agentes redutores e ametais como agentes oxidantes. As Pilhas e Baterias são destacadas como exemplos de reação redox (figura 24).

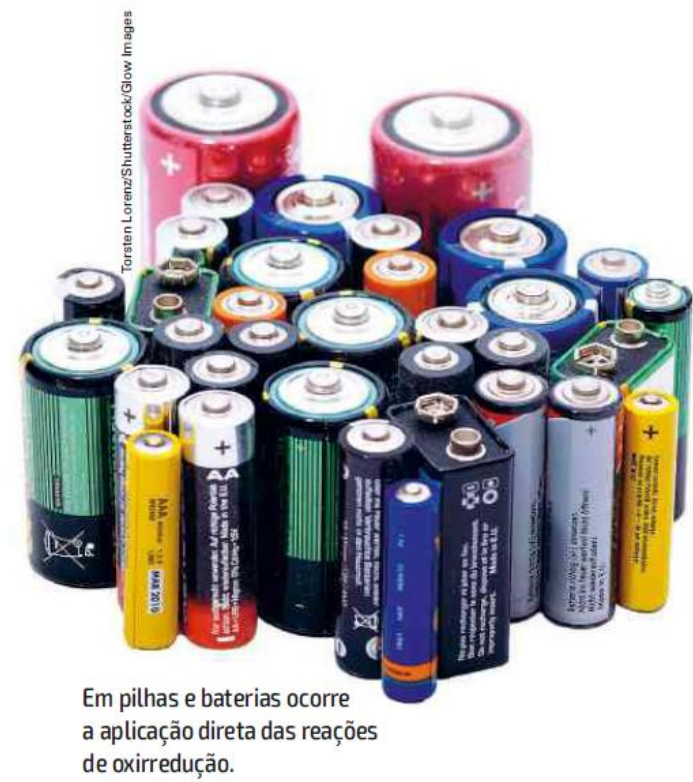

Figura 24 - O tema Pilhas e Baterias no livro 1 da coleção MR.

Fonte: MR, 1, p. 278

Na coleção VV, o capítulo que trata das reações redox está inserido dentro de uma unidade denominada "Eletrólitos e reações químicas: fundamentos qualitativos e quantitativos" e nesse capítulo também se define reações redox, número de oxidação e agentes oxidantes e redutores. As regras para determinação do número de oxidação também são explicadas, e na sequência discute-se o balanceamento e equações redox. Nessa abordagem são utilizados vários exemplos de reações redox, iniciando-se pelas reações envolvendo o ferro em seus diversos estados de oxidação e com um box intitulado "Algumas reações de oxirredução presentes no cotidiano" trazendo a Ferrugem, o Ozônio na atmosfera terrestre, a Combustão de compostos orgânicos (figura 25), a Fermentação, a Respiração Celular para obtenção de energia, a Decomposição de alimentos e as Pilhas e Baterias, em outro box a reação do Bafômetro é discutida. A coleção também traz o caso das reações com eletrólitos em solução que são substâncias simples, metais e 
ametais, para construção da fila de reatividade, e também apresenta como descrever as equações em sua forma iônica.

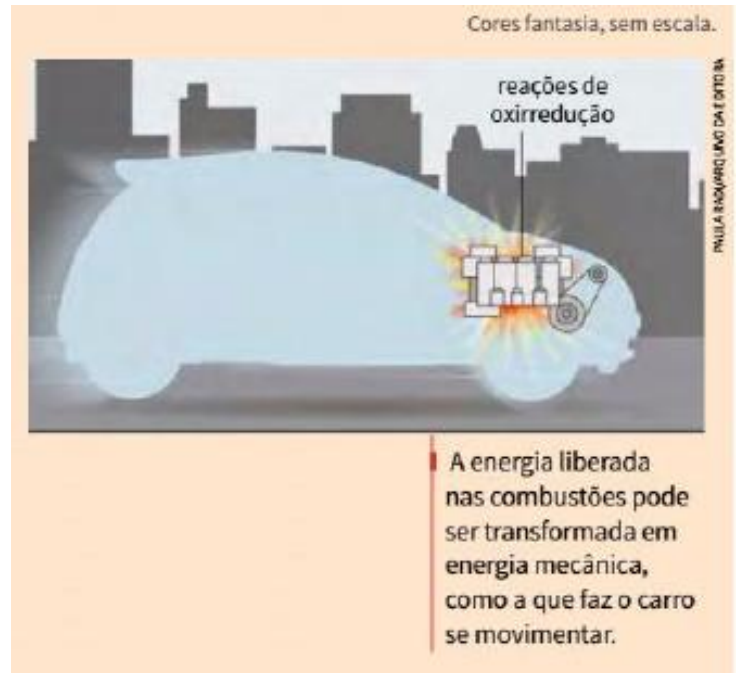

Figura 25 - O tema Combustão no livro 1 da coleção VV

\section{$2^{\circ}$ ano do ensino médio}

Fonte: VV, 1, p.218

Com exceção da coleção QC, todas as coleções abordam as reações redox no segundo livro, principalmente ao abordar a eletroquímica das Pilhas e Baterias e Eletrólise. Todas as coleções utilizam o dispositivo didático da Pilha de Daniell para abordar o funcionamento das pilhas.

A coleção CP inicia a abordagem do conteúdo trazendo a história da eletroquímica e como as primeiras Pilhas evoluíram até chegar nas Pilhas atuais. A coleção contempla todo o conteúdo de Pilhas, explicando quais os principais usos, como é seu funcionamento, quais os tipos mais comuns e como eles são utilizados, além de trazer um box sobre o descarte das pilhas e baterias (figura 26). O mesmo acontece para o tema Eletrólise próximo ao final do capítulo, no livro é explicado o funcionamento e usos desses processos atualmente. Os conceitos envolvendo oxirredução, e principalmente número de oxidação, são explicados utilizando-se a formação de Ferrugem como exemplo, que também é abordada em outro momento do capítulo trazendo a ferrugem no contexto do fenômeno da maresia. De forma simplificada, a coleção também traz o processo de Extração e Purificação do Alumínio e um box que relaciona os produtos naturais antioxidantes e a ação dos Radicais Livres. Além dos temas apontados, no capítulo de oxirredução também são abordados o potencial-padrão de redução e os cálculos de massa das pilhas e da eletrólise. 

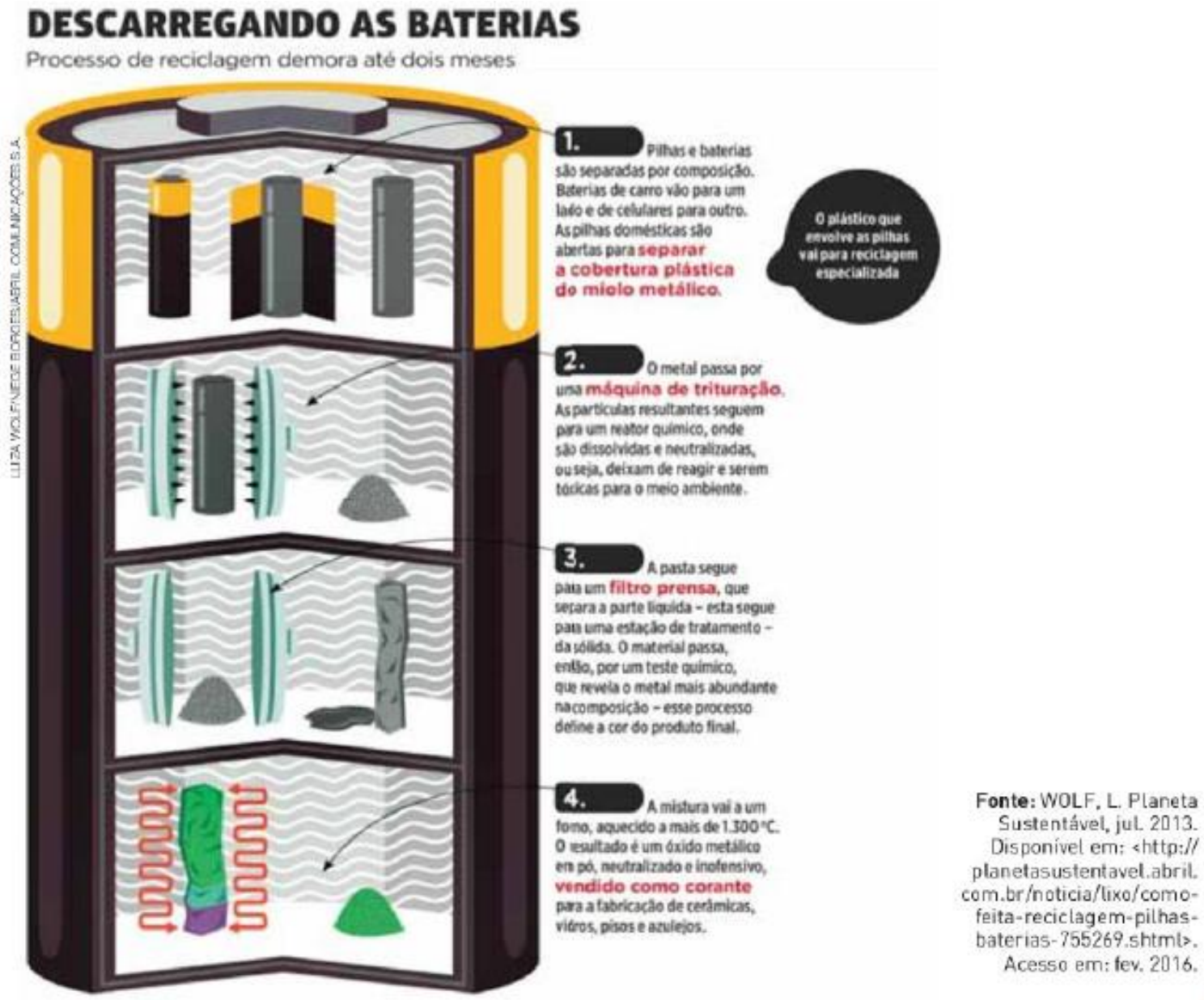

Figura 26 - O tema Pilhas e Baterias no livro 2 da coleção $\mathrm{CP}$ Fonte: CP, 2, p.147

Na coleção MR retoma-se os conceitos trabalhados no primeiro ano para falar, principalmente, do tema Pilhas, Baterias e Eletrólise. Esses temas são abordados no contexto da unidade que é sobre Lixo Eletrônico. No capítulo específico faz-se uma revisão dos conceitos de oxirredução e número de oxidação para apresentar os cálculos de balanceamento das equações, de força eletromotriz, potencial-padrão de redução e outros cálculos junto à física. Nesse livro, são explicadas o funcionamento, características, aplicações das pilhas, baterias e eletrólise, além de trazer algumas dúvidas comuns sobre as pilhas, como "Se uma pilha ficar na geladeira, ela volta a funcionar?" e “Porque uma pilha vaza?", figuras 27 e 28, respectivamente. Outro tema que aparece como um dos usos da eletrólise é a Extração e processamento do Alumínio, relacionado ao consumo nos aparelhos eletrônicos e uma crítica ao consumo excessivo desses dispositivos. 


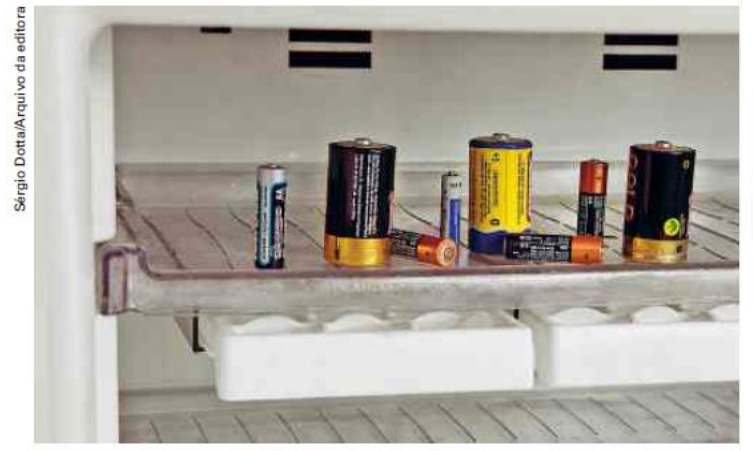

Pilhas guardadas em geladeira.

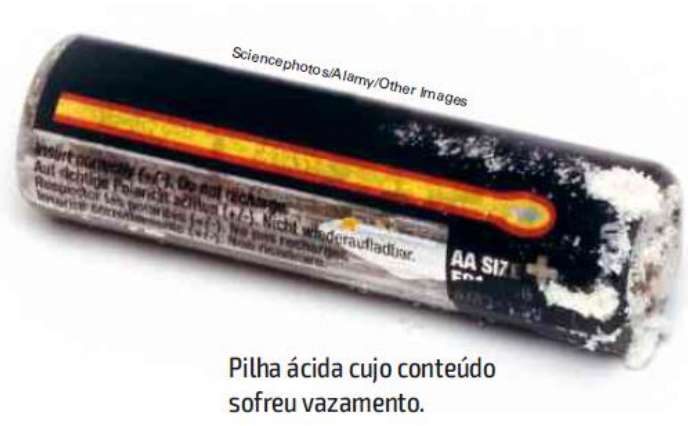

sofreu vazamento.

Figura 27 e 28 - O tema Pilhas e Baterias no livro 2 da coleção MR Fonte: MR, 2, p. 251

Na coleção MM aborda-se a oxirredução de forma diferenciada das demais, isso porque na definição das reações redox, da oxidação, redução, número de oxidação, agentes oxidantes e redutores, utiliza-se reações bioquímicas com a vitamina $\mathrm{C}$ sendo oxidante e redutora. A imagem que abre o capítulo no livro trata da reação de transformação do minério de ferro a ferro metálico, que posteriormente se desdobrará no tema Extração do Alumínio. As Pilhas, Baterias e a Eletrólise ocupam a maior parte do capítulo, sendo que as pilhas são utilizadas na introdução como exemplos das reações e mais adiante ao falar do funcionamento, usos e descarte desses dispositivos. Outro tema que aparece na coleção, no livro do segundo ano, é a reação de escurecimento da maçã propondo-se um experimento em que é possível visualizar a fruta também como um agente oxidante (figura 29). A abordagem das reações redox ainda traz os cálculos que envolvem o balanceamento das equações químicas, o potencial-padrão de redução, entre outros. O capítulo é concluído trazendo a possibilidade de evitar a Ferrugem como uma das aplicações da eletrólise.

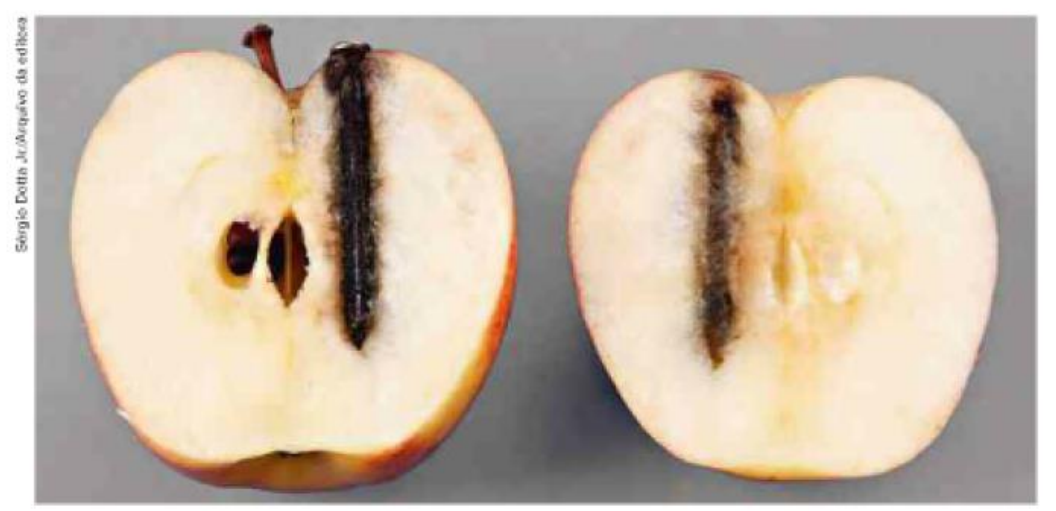

Figura 5.22

Após alguns dias observa-se 0 escurecimento da maçã onde o prego foi fincado.

Figura 29 - O tema Escurecimento da Maçã no livro 2 da coleção MM

Fonte: MM, 2, p. 209 
Para o segundo ano do ensino médio, a abordagem na coleção SP já inicia trazendo vários exemplos do cotidiano com reações redox, inclusive com uma imagem de abertura da reação de fermentação (figura 30) e outros temas destacados em negrito no trecho:

A fermentação é um fenômeno causado por microrganismos vivos - sejam bactérias, fungos ou leveduras -, que decompõem e transformam o meio em que eles se desenvolvem e do qual se alimentam. Os processos utilizados pelos seres vivos para a obtenção de energia, seja a respiração aeróbica, seja a fermentação, seja a quimiossíntese, também envolvem transferência de elétrons. Essas reações são chamadas de reações de oxirredução. Além de estarem presentes nas reações químicas utilizadas para a obtenção de energia, as reações de oxirredução são observadas na corrosão de metais e na fotossíntese, e explicam o funcionamento do bafômetro, o escurecimento de lentes fotossensíveis em presença de luz solar, bem como a ação antioxidante da vitamina C. (SP, 2, p. 184) (grifo nosso)

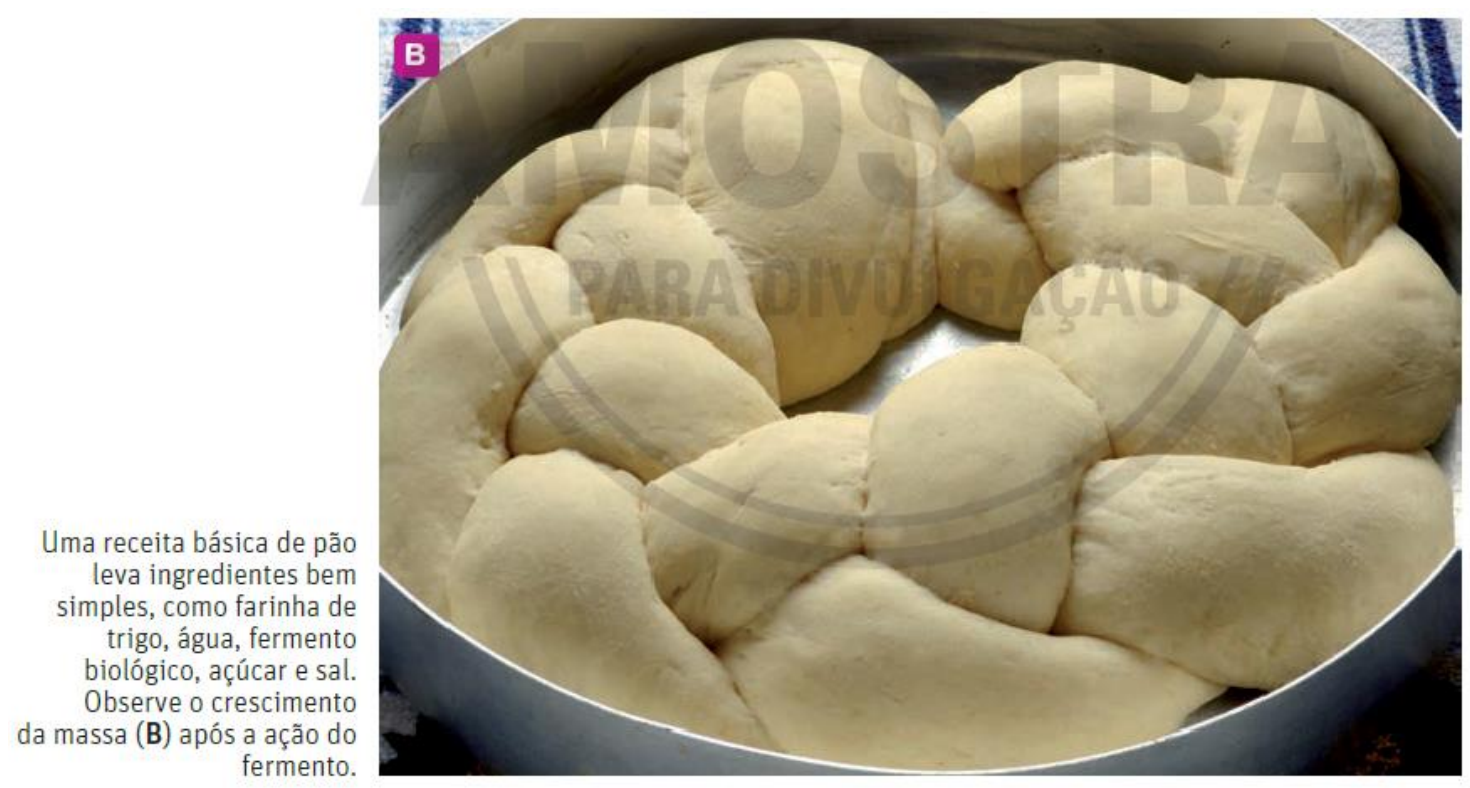

Figura 30 - O tema Fermentação no livro 2 da coleção SP

Fonte: SP, 2, p. 184

$\mathrm{Na}$ coleção são retomados os conceitos abordados no primeiro livro, reconceituando-os, e utilizando como exemplo a reação de Combustão do etanol. As Pilhas, Baterias e a Eletrólise ocupam a maior parte do capítulo e são interligadas pela formação de Ferrugem e se conclui com o processo de Extração do Alumínio como um dos usos da eletrólise. Quatro boxes chamam atenção no capítulo redox do livro da coleção SP. O primeiro traz a reação que ocorre no Air Bag, relacionando a velocidade com os reagentes da reação; o segundo fala sobre os Oxidantes de uso doméstico e cita alguns produtores que são utilizados como branqueadores e produtos de limpeza; o terceiro relaciona a ação dos Radicais Livres com a qualidade de vida e traz a importância da atividade física no envelhecimento; por fim, o quarto traz parte da história da 
eletroquímica e como o desenvolvimento dos processos eletrolíticos ajudaram na identificação de alguns elementos químicos.

A abordagem do conteúdo na coleção VV segue o mesmo padrão percebido para as coleções apresentadas anteriormente, a abordagem é relacionada, principalmente, às Pilhas, Baterias e à Eletrólise. Para o caso da coleção VV, vários boxes trazendo a história da evolução das pilhas, da eletrólise e suas implicações na química, estão distribuídos ao longo do livro. A diferença nessa coleção também se dá pela relação estabelecida com o cotidiano, por exemplo, o tema Ferrugem aparece como um tipo de reação redox, mas os aspectos sociais e ambientais buscando evitar prejuízos ao prédios e obras públicas também são comentados, conforme pode ser observado na figura 31. A importância do descarte correto das pilhas e baterias também é outro tema que se relaciona com o cotidiano à medida que retoma um box anterior que traz a problemática da contaminação com metais pesados e o efeito na saúde humana e no meio ambiente. O livro também traz o tema da Extração e Produção do Alumínio para o desenvolvimento da sociedade. Além disso, todo o conteúdo de cálculos eletroquímicos, número de oxidação e potencialpadrão de redução, também são abordados na coleção.

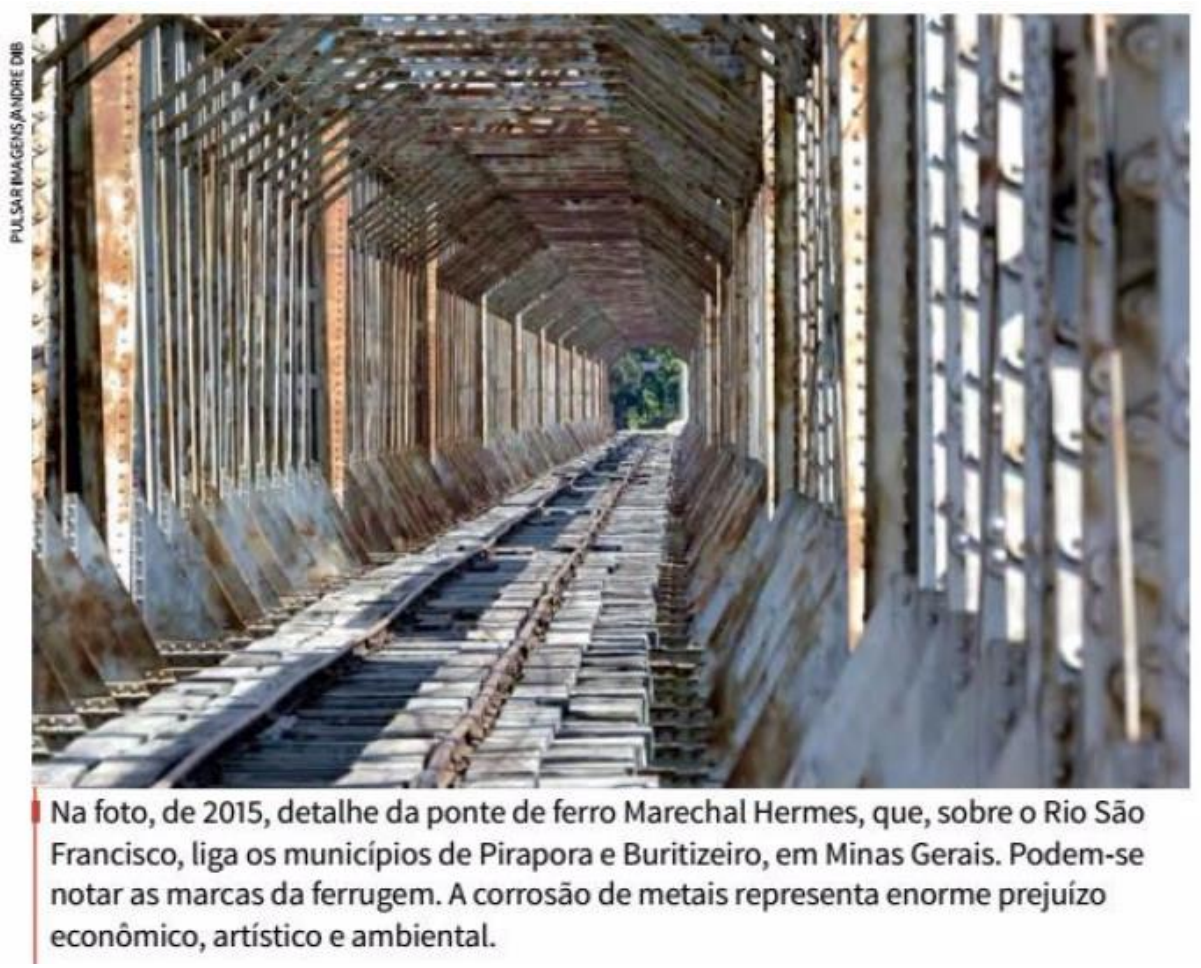

Figura 31 - O tema Ferrugem no livro 2 da coleção VV Fonte: VV, 2, p. 238 


\section{$3^{\circ}$ ano do ensino médio}

No último ano do ensino médio e, portanto, último ano da escolarização básica, as reações redox aparecem de duas maneiras diferentes. Primeiramente, na coleção QC são abordadas as reações redox e sua relação com os metais, como nos livros do segundo ano, e também algumas reações orgânicas. Já em outras três coleções (MR, SP e VV) apresentam-se somente as reações redox orgânicas.

$\mathrm{Na}$ coleção QC, a primeira abordagem traz as reações orgânicas como de formação do vinho em vinagre, a oxidação de alcenos, a oxidação de álcoois e Fermentação. O tema da Fermentação é abordado do ponto de vista do "azedamento" de um alimento: "Sabe-se que esse sabor decorre da formação de ácidos pela oxidação dos alimentos. A oxidação que leva o alimento a "azedar" é causada pela presença de oxigênio e pode ser acelerada por algumas substâncias químicas, naturais ou não.” (QC, 3, p. 161), e também da produção de alimentos como as bebidas, queijos e etc.

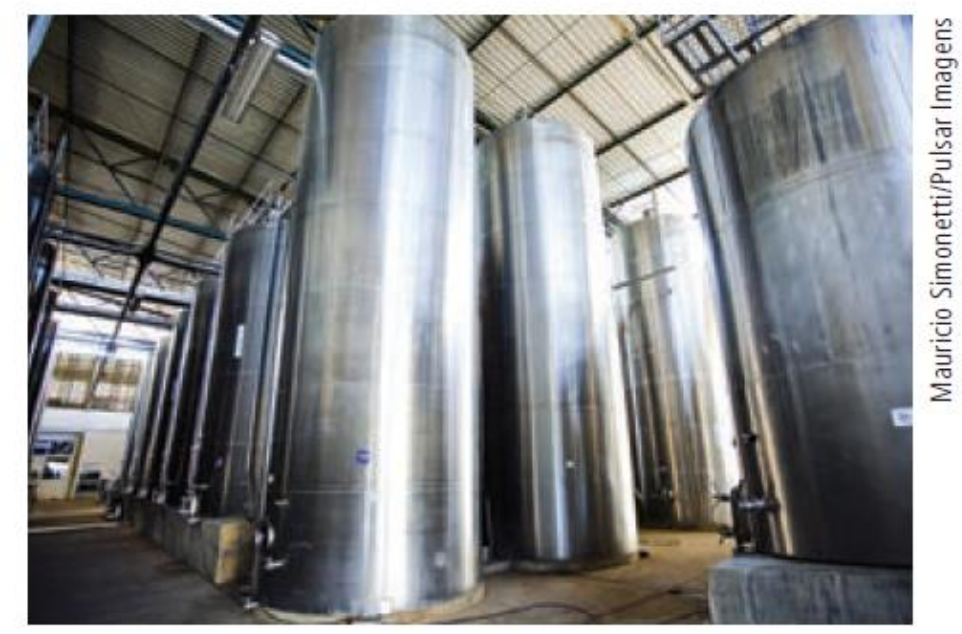

\section{A f fermentação é uma das transformações mais antigas realizadas pelo ser humano, como a fermentação de bebidas alcoólicas.}

Figura 32 - O tema Fermentação no livro 3 da coleção QC. Fonte: QC, 3, p. 161

A abordagem das reações redox no próximo capítulo do livro, se remete sempre a ação de um metal, dentro desse capítulo são exploradas, inclusive, as propriedades, reciclagem, história e formação de ligas com os metais. Os primeiros exemplos de reações redox abordados no livro referem-se às reações envolvendo o ferro, seja ele reagindo com o oxigênio, seja no processo de extração e transformação do minério a metal. Nesse livro 
também são discutidas as Pilhas, Baterias e Eletrólise, sempre relacionando ao uso dos metais na nossa sociedade e suas consequências para a própria evolução da sociedade, isso se dá, por exemplo, ao trazer o funcionamento das pilhas e como elas propiciaram o desenvolvimento dos mais diversos dispositivos utilizados atualmente. Os temas Extração do Alumínio e a formação de Ferrugem também são abordados. Um dos únicos exemplos citados no livro, que não tem relação direta com as pilhas, baterias ou eletrólise, está presente em um box que fala sobre as lentes fotossensíveis, conforme pode ser observado na figura 33.
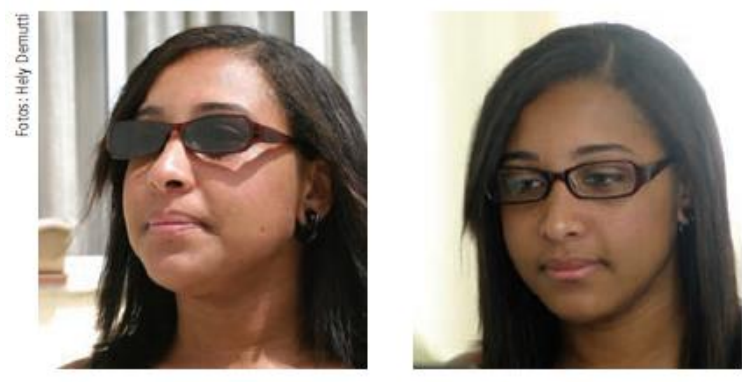

As lentes de alguns óculos fotossensiveis são confeccionadas com cristais de cloreto de prata e cristais de cloreto de cobre. Quando essas lentes são submetidas à luz solar, ocorre uma reação de oxidação e redução entre os íons cloreto e os de prata, fazendo com que a lente fique escurecida. Essa reação pode ser revertida se as lentes forem retiradas da exposição direta à luz.

Figura 33 - O tema Lentes Fotossensíveis no livro 3 da coleção QC.

Fonte: QC, 3, p. 197

No terceiro livro da coleção VV as reações redox são citadas em um tópico específico dentro do conteúdo de reações orgânicas. Inicialmente as reações de Combustão, e especificamente de combustão do metano, são abordadas. Seguindo o discutido no primeiro livro da coleção, neste livro abordam-se as reações com o ozônio e os prejuízos para a camada que envolve a Terra, trazendo, inclusive, um box que apresenta a história da caracterização desse elemento. Outras reações orgânicas também são abordadas, como a oxidação enérgica e a oxidação e redução de compostos oxigenados.

Na coleção MR são abordadas várias reações orgânicas que são de oxirredução sempre do ponto de vista químico, ou seja, as reações de formação do metano e gás carbônico e aquelas envolvendo o Ozônio, as de introdução do conteúdo, não são contextualizadas, apenas mostram a transferência de elétrons entre as espécies. $\mathrm{O}$ mesmo acontece para as outras reações abordadas, que são: as reações de oxidação branda de alcenos, oxidação energética de alcenos, oxidação energética de ciclanos, oxidação de álcoois, redução de álcoois, redução de ácidos carboxílicos, redução de aldeídos, redução de cetonas e a reação de redução de compostos nitrogenados. A contextualização fica por conta de pequenos boxes distribuídos ao longo do conteúdo que trazem a decomposição do lixo, o vinagre de vinho, e os antioxidantes. Um box mais extenso traz, também, as reações redox orgânicas aplicadas no funcionamento do bafômetro. 


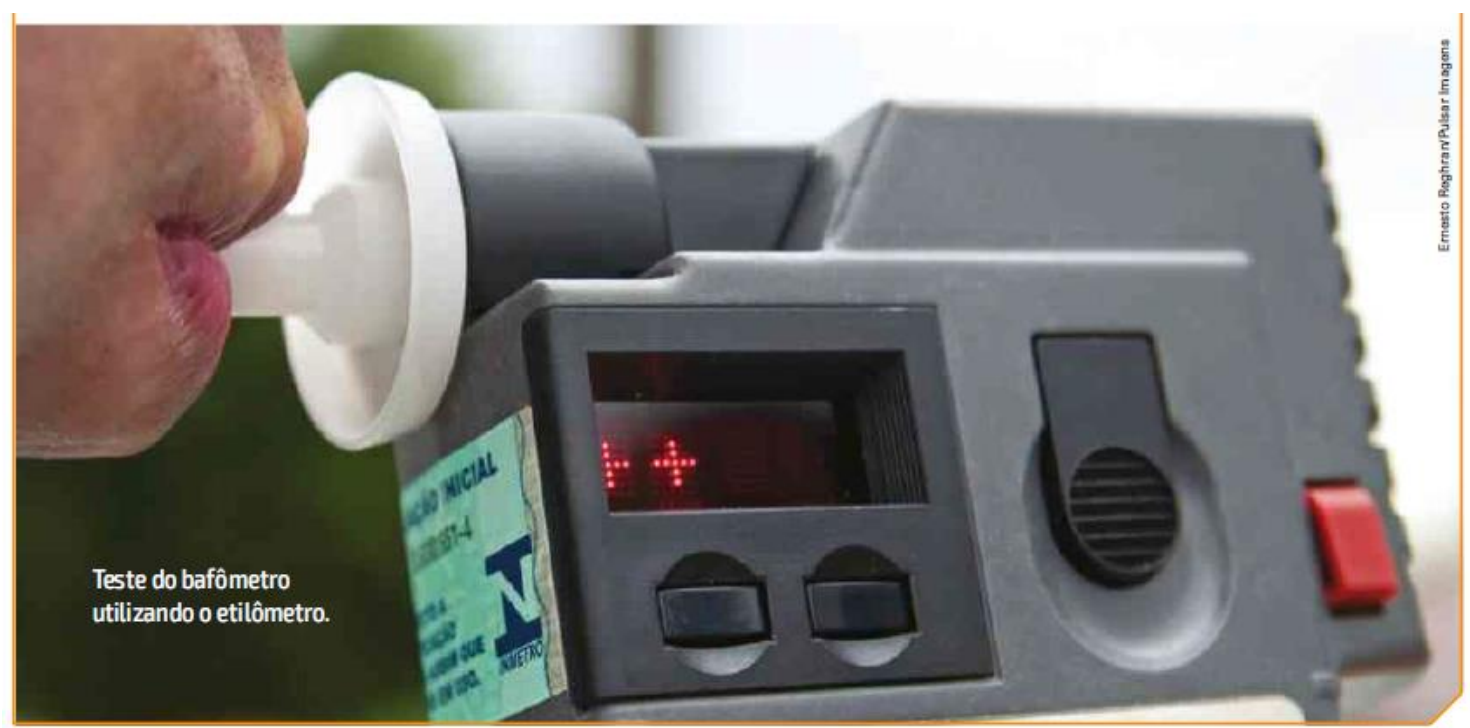

Figura 34 - O tema Bafômetro no livro 3 da coleção MR Fonte: MR, 3, p. 193

A coleção SP segue a mesma abordagem da coleção MR, apresenta as reações do ponto de vista químico e contextualiza por meio de pequenos boxes ao longo do texto, a diferença está no número de reações abordadas. São discutidas as reações: combustão, substituição nos alcanos, com alcenos, com alcinos, com dienos, com cicloalcanos e com cicloalcenos. A contextualização é feita trazendo pequenas imagens com produtos obtidos das reações citadas (figuras 35 e 36). Além disso, um box mais extenso traz as alternativas para o uso do CFC, abordando a problemática desse gás no meio ambiente.

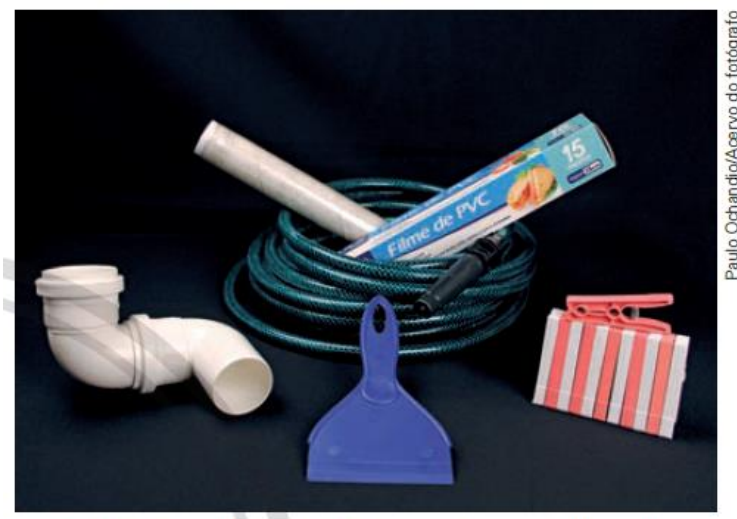

Objetos feitos de PVC: tubulações, mangueiras, filmes de PVC, espátulas de pedreiro e pregadores.

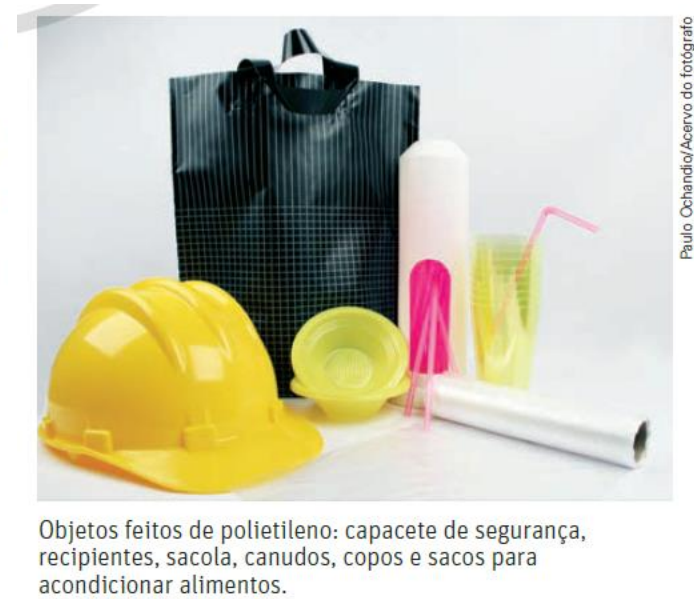

acondicionar alimentos.

Figuras 35 e 36 - A contextualização presente no livro 3 da coleção SP Fonte: SP, 3, p.167

Com os resultados da investigação detalhada acima, é possível incluir a etapa do ensino médio no quadro 7 e traçar a evolução dos temas redox ao longo de todo o ensino básico. Essa análise pode ser visualizada no quadro 14 e inclui os outros temas que foram destacados no ensino médio. 


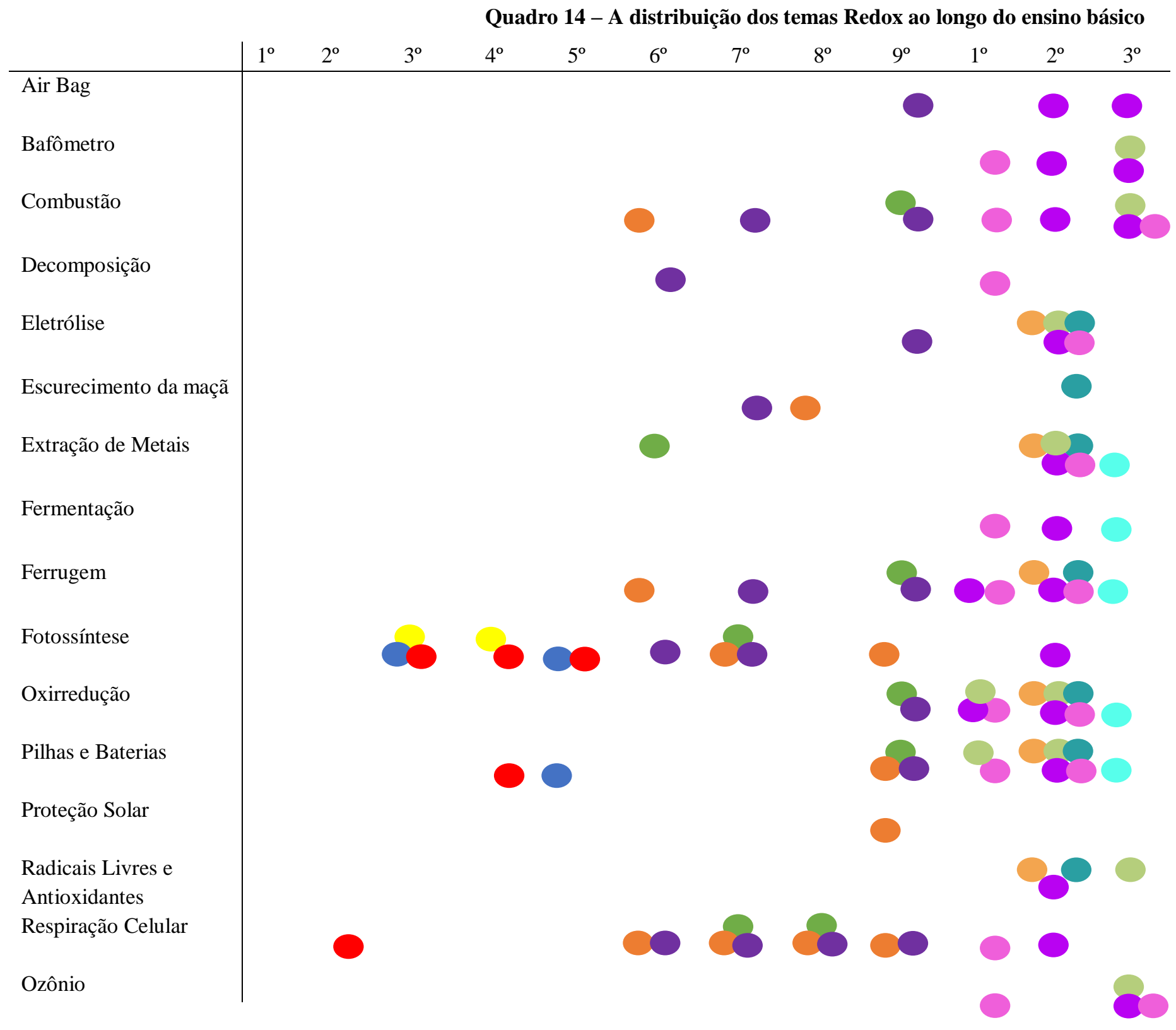

Legenda

Coleção LC

Coleção PA

Coleção PB

Coleção AR

Coleção IC

Coleção TL

Coleção CP

Coleção MR

Coleção MM

Coleção QC

Coleção SP

Coleção VV 
A leitura do quadro 14 permite destacar que a maior quantidade de temas que se referem às reações redox é abordada nos livros do segundo ano do ensino médio, seguidos pelo $9^{\circ}, 1^{\circ}$ e $3^{\circ}$ ano. Entretanto, foi encontrado um tema que é abordado no ensino fundamental e não é citado no ensino médio, é o caso do tema proteção solar. Contudo, 4 temas aparecem apenas no nível médio de ensino: Fermentação, Radicais Livres e Antioxidantes, reações do Ozônio e do Bafômetro.

No $1^{\circ}$ ano do ensino médio, a abordagem é vinculada ao conteúdo de metais e serve como princípio para construção da tabela de reatividade dos metais. Além disso, nesse ano, os cálculos referentes ao conteúdo são introduzidos, mas apenas os cálculos para encontrar o número de oxidação das substâncias e de balanceamento das equações redox em uma coleção.

No $2^{\circ}$ ano do ensino médio, discute-se e explica-se as reações redox para aplicá-las no conteúdo de pilhas e baterias e posteriormente da eletrólise. São introduzidos novos cálculos, mas concomitantes à abordagem das células galvânicas e eletrolíticas e do ponto de vista da energia produzida por esses dispositivos. Em apenas uma coleção apresenta-se os agentes oxidantes e redutores sem ser do ponto de vista das pilhas.

No $3^{\circ}$ ano do ensino médio a ênfase está nas reações orgânicas, com exceção de uma coleção. As reações orgânicas são vistas do ponto de vista químico, em que se apresenta a distribuição dos elétrons, os elementos oxidados e reduzidos na reação e os produtos obtidos. A contextualização é pouca e feita com imagens ou em boxes separados do conteúdo principal.

Esta análise permite esboçar a linha do tempo que apresenta a evolução do conteúdo redox ao longo dos livros da educação básica analisados nesta dissertação. Posteriormente, discute-se como a abordagem pode influenciar nas concepções alternativas mapeadas na literatura. Esta sistematização está presente na seção 5.4. 


\subsection{Os modelos redox nos livros didáticos brasileiros}

As reações de oxirredução além de estarem presentes no cotidiano das sociedades tecnológicas, fazem parte dos conteúdos a serem ensinados na educação básica e, portanto, estão presentes nos livros didáticos do sistema de ensino brasileiro. A presen

ça desse conteúdo é observada nos livros de ensino fundamental (conforme apontado na primeira análise descrita na seção de resultados e discussão) e nos livros de ensino médio.

Porém, observa-se que a primeira definição apresentada aos alunos é destacada no livro correspondente ao nono ano do ensino fundamental II e posteriormente retomada nos livros de química do ensino médio. A literatura aponta que podem ser utilizados diferentes modelos redox para definir estas reações e o uso de diferentes modelos podem, também, dificultar o aprendizado desse conteúdo.

Nesse sentido, objetivando-se investigar quais modelos redox estão presentes nos livros didáticos selecionados no PNLD 2017 e 2018, selecionou-se os trechos correspondentes à definição das reações redox. Os trechos selecionados permitiram inferir se há utilização de mais de um modelo e como é explicado tal modificação. Além disso, para explicitar se há discrepância entre o modelo utilizado na definição e outros usados na discussão e resolução dos exercícios, observou-se a apresentação do conteúdo como um todo. Na sequência apresenta-se os modelos utilizados nas coleções analisadas.

\section{Coleção Telaris (TL)}

A coleção Telaris apresenta a primeira definição das reações redox no livro correspondente ao último ano do nível fundamental de ensino. Nesse livro, a definição aparece em um box dentro do capítulo denominado "Reações Químicas". Este box é destacado após a discussão sobre o consumo de energia em reações como a respiração celular e a combustão. Após apresentar a reação envolvendo o gás oxigênio e a molécula de glicose, é destacado que:

\footnotetext{
Tanto a respiração celular como a combustão são reações químicas que envolvem oxidações. Mas, em Química, o termo oxidação tem um sentido mais geral do que simplesmente reagir com o oxigênio. Uma molécula ou um átomo se oxida quando perde um ou mais elétrons para outro átomo ou molécula. Quando um átomo ou uma molécula ganha elétrons, dizemos que ele se reduz (sofre uma redução). (TL, 4, p. 110).
}

Em outro box, ao abordar as pilhas e baterias, inicia-se comentando que "o princípio de funcionamento de toda bateria ou pilha é uma transferência de elétrons entre duas substâncias químicas" (TL, 4, p. 251). Na sequência do texto são comentados vários tipos de pilhas e baterias, mas sem discutir que nestes dispositivos ocorrem reações de 
oxirredução.

\section{Coleção Araribá (AR)}

Na coleção Araribá a definição de uma reação redox também aparece ao abordar os tipos de reações químicas. Entretanto, diferentemente da coleção TL, a abordagem está dentro da discussão do conteúdo, e não em um box a parte.

As reações redox aparecem como um tipo de reações químicas, sendo os outros tipos mencionados a reação de precipitação, de combustão, endotérmicas e exotérmicas. Na parte de reações redox, a definição descrita é:

Quando uma espécie química sofre oxidação, significa que ela transferiu elétrons para outra. A espécie que recebeu elétrons passou por uma reação de redução. Quando uma espécie química é oxidada, a outra necessariamente é reduzida; por isso, essas reações recebem o nome de oxirredução. (AR, 4, p.91, grifo do autor)

$\mathrm{Na}$ sequência do texto é abordada a frequência dessas reações em função "da abundância de gás oxigênio na atmosfera e da facilidade com que ele reage com outros materiais, formando óxidos" (AR, 4, p. 91). O texto é concluído explicando a reação de formação de ferrugem envolvendo um prego metálico e o gás oxigênio.

\section{Coleção Ciscato, Pereira, Chemello e Proti (CP)}

A definição das reações redox na coleção CP é descrita no segundo livro. O primeiro livro, apesar de referenciar e citar exemplos de reações redox, tais como a combustão; não define os termos oxidação e redução. No segundo livro a definição é dada no capítulo "Ocorrência de fenômenos espontâneos de oxidação e redução", que é uma sequência da história da invenção das pilhas e baterias. A definição observada é:

Quando uma espécie química perde um ou mais elétrons em uma reação química, diz-se que ocorreu a oxidação dessa espécie. Quando uma espécie química ganha um ou mais elétrons em uma reação química, diz-se que ocorreu a redução dessa espécie. Reações que envolvem os fenômenos de oxidação e de redução são chamadas de óxido-redução, oxirredução ou, simplesmente, redox. (CP, 2, p. 119-120, grifo do autor).

No terceiro livro, na abordagem das reações orgânicas, utiliza-se a noção de oxidação para determinar a oxidação parcial do etanol formando etanal. Assim, os autores representam a reação que está sendo abordada e na sequência afirmam que:

Observe que o nox do átomo de carbono em que estava ligado ao grupo hidroxila passa de -1 para +1 . O aumento do nox é característica no processo de oxidação, nesse caso, do álcool, acompanhado da redução do oxigênio: na molécula de gás $\mathrm{O}_{2}$ os átomos de oxigênio têm nox igual a zero e, na molécula de água, igual a -2. (CP, 3, p. 87). 
Numa coluna separada, caracterizada por apresentar anotações ao professor que auxiliem no trabalho didático pedagógico, é solicitado que o professor "Retome o procedimento para determinar o número de oxidação [...] relembre os alunos de que a oxidação de uma espécie sempre ocorre simultaneamente à redução de outra.” (CP, 3, p. 87).

\section{Coleção Martha Reis (MR)}

A coleção MR distribui o conteúdo de reações redox ao longo dos livros dos três anos. No livro do primeiro ano a definição é apresentada na seção 'Metais e oxirredução'. O foco dessa seção é discutir as propriedades dos metais, a ligação metálica e as reações de oxirredução associadas aos processos de corrosão, pilhas e baterias, entre outros. A definição inicial dada é:

Reação de oxirredução é aquela em que ocorre variação no Nox dos elementos dos reagentes para os produtos. O elemento que sofre oxidação é aquele que "perde" elétrons, cujo Nox aumenta dos reagentes para os produtos. O elemento que sofre redução é aquele que "ganha" elétrons, cujo Nox diminui dos reagentes para os produtos. (MR, 1, p. 278, grifo do autor).

Como o foco do capítulo é a explicação das reações envolvendo metais, a seção continua no procedimento de cálculo do Nox e das reações de deslocamento de metais.

No segundo livro da coleção, a unidade 5 'Lixo Eletrônico' traz em sua primeira seção uma discussão sobre as pilhas e baterias, retomando os conceitos apresentados no primeiro livro. A definição apresentada trata de uma revisão dos conceitos envolvidos, os autores destacam que "Toda reação de oxirredução está relacionada a uma transferência de elétrons entre os átomos e/ou íons das substâncias reagentes” (MR, 2, p. 238). Para relacionar os participantes de uma reação de oxirredução define-se que:

\footnotetext{
Átomo ou íon que doa elétrons, portanto sofre oxidação: é denominado redutor (ou agente redutor) porque provoca o ganho de elétrons (redução) de outro átomo ou íon. Átomo ou íon que recebe elétrons, portanto sofre redução: é denominado oxidante (ou agente oxidante) porque provoca a perda de elétrons (oxidação) de outro átomo ou íon. (MR, 2, p. 238, grifo do autor)
}

O terceiro livro também traz reações redox, mas no contexto das reações orgânicas. No início da seção específica das reações redox orgânicas, os autores apresentam que "quando numa reação um mesmo elemento químico aparece com Nox diferente no reagente e no produto, significa que ocorreu uma transferência de elétrons, ou seja, a reação é de oxirredução.” (MR, 3, p. 184). Os autores exemplificam a reação de formação do gás carbônico em que carbono sofre oxidação pela ação do oxigênio, e a reação de formação do metano onde o carbono reduz por ação do hidrogênio. Esses exemplos são particularmente 
importantes, pois, na sequência do texto "estudaremos as reações de oxirredução provocadas especificamente pelo oxigênio (oxidação) e pelo hidrogênio (redução).” (MR, 3, p.184).

\title{
V. Coleção Mortimer e Machado (MM)
}

Os autores da coleção MM apresentam a definição das reações redox principalmente no segundo livro da coleção. Neste livro, há um capitulo 'Movimento de elétrons: Uma introdução ao estudo da eletroquímica' em que são apresentadas diversas reações que ocorrem no dia-a-dia e que são classificadas como reações de oxirredução. Na primeira seção do capítulo já é esboçada uma definição de reação redox nos trechos:

\begin{abstract}
O estudo das transformações ou reações químicas é, sem dúvida, um dos grandes eixos da química. Há uma grande variedade de transformações, químicas e bioquímicas, que ocorrem como consequência da interação entre eletricidade e materiais. Essas reações envolvem mudanças no número de elétrons de valência de átomos ou de íons. Isso é possível porque átomos e íons podem perder ou ganhar elétrons. Quando isso acontece, o átomo ou o íon muda o seu estado de oxidação. (MM, 2, p. 194, grifo do autor)
\end{abstract}

Os autores ainda acrescentam que algumas reações citadas "são conhecidas por reações de oxirredução, ou redox. Isso significa que essas reações envolvem a oxidação de uma substância e a redução de outra" (MM, 2, p. 194, grifo do autor). Essa definição, um pouco simplificada, é expandida na sequência do texto à medida que os autores acrescentam alguns termos. A definição a ser utilizada nas próximas seções é dada por:

\begin{abstract}
As substâncias químicas, em certas reações químicas, podem se comportar como oxidantes ou redutoras. Uma substância que atua como redutora transfere elétrons para outra substância que atua como oxidante. Nesse processo, a espécie redutora tem seu número de elétrons reduzido, e a espécie oxidante tem seu número de elétrons aumentado. (MM, 2, p. 197, grifo do autor).
\end{abstract}

Os autores continuam a discussão apresentada, acrescentando que:

Quando uma substancia se comporta como oxidante, em geral um ou mais de seus átomos ou íons ganham elétrons. $\mathrm{O}$ mesmo acontece em relação às substâncias que se comportam como redutoras, mas nesse caso um ou mais de seus átomos ou íons perdem elétrons. (MM, 2, p. 197, grifo do autor)

Na sequência do texto os autores fazem uma abordagem completa sobre o número de oxidação e os procedimentos/regras para o cálculo. No livro 1 e 3 são apresentados exemplos de reações redox, mas não há uma definição, nem abordagem dessas reações.

\section{Coleção Química Cidadã (QC)}

A coleção Química Cidadã apesar de fazer inúmeras referências aos processos redox, inclusive citando processos em que a espécie se oxida, no livro destinado ao primeiro ano não traz nenhuma definição clara do que seriam os processos redox. $\mathrm{O}$ mesmo acontece no 
livro do segundo ano, onde são destacadas reações de combustão, de formação de ferrugem, mas nenhuma definição é dada.

A primeira menção à reação de oxidação está na seção 4: síntese orgânica: transformações de funções orgânicas, do terceiro livro. Nesta seção, as reações são explicadas como:

\begin{abstract}
Reações de oxidação são aquelas nas quais espécies químicas - átomos, íons ou moléculas - perdem elétrons. Embora seja comum em Química Orgânica falarmos de reações de oxidação - porque espécies orgânicas são oxidadas -, não podemos nos esquecer de que, sempre que uma espécie é oxidada, outra espécie é reduzida - ou seja, ganha elétrons. (QC, 3, p. 157).
\end{abstract}

Ainda nessa seção, na parte introdutória, os autores pontuam que "Em Química Orgânica, em geral, a oxidação ocorre com a adição de átomos de oxigênio ou com a retirada de átomos de hidrogênio da molécula.” (QC, 3, p. 157). Na sequência do capítulo os autores explicam que a maioria das reações orgânicas que envolvem o processo de oxidação.

No livro 3 da coleção QC há uma seção específica apenas para as reações redox no capitulo 5: oxirredução e eletroquímica. Aqui define-se as reações redox como:

\begin{abstract}
As reações químicas, nas quais o oxigênio é um dos reagentes, são historicamente denominadas reações de oxidação. Já as reações inversas, de perda de oxigênio, são denominadas reações de redução. Atualmente, considera-se que as reações de oxidação são aquelas nas quais a espécie química perde elétrons e as reações de redução, aquelas nas quais a espécie química ganha elétrons. As reações de oxidação e de redução sempre acontecem simultaneamente: enquanto uma espécie ganha elétrons, outra espécie cede. Denomina-se oxidação, o processo químico no qual espécies químicas doam elétrons e redução, o processo no qual espécies químicas recebem elétrons. Reação de oxirredução é um tipo de reação em que ocorre transferência de elétrons entre as espécies envolvidas. (QC, 3, p. 195, grifo do autor).
\end{abstract}

\title{
VII. Coleção Ser Protagonista (SP)
}

A coleção Ser Protagonista aborda o conceito de oxidação e de redução nos três livros. No livro do primeiro ano as reações de oxirredução são especialmente destacadas concluindo a classificação das reações químicas expostas anteriormente. Assim os autores apresentam a classificação das reações químicas, adição, decomposição, simples e dupla troca e por fim as reações redox.

No início da seção os autores já apresentam que "Algumas reações químicas ocorrem com transferência de elétrons entre os elementos das substâncias reagentes" (SP, 1, p. 185). Na sequência do texto é apresentado um exemplo de reação redox. A definição é encontrada no segundo parágrafo e diz que:

O ganho e a perda de elétrons sempre ocorrem juntos. Assim, nas reações de oxirredução ocorre a transferência de elétrons. Oxidação é o nome utilizado para designar processos que envolvem perda de elétrons. A substância que se oxida é 
o agente redutor. Redução é o termo usado para denominar processos que envolvem ganho de elétrons. A substância que se reduz é o agente oxidante. (SP, 1, p. 185 , grifo do autor)

No livro do segundo ano, as reações redox são abordadas com maior profundidade na unidade 4: transformações da matéria e energia elétrica. No início da unidade já é explicitado que "serão estudadas as transformações químicas que resultam de um processo de transferência de elétrons, denominada reações de oxirredução" (SP, 2, p. 182)

A definição de oxidação e redução é acompanhada de um exemplo em que o ferro sofre oxidação:

O ferro é um metal mais reativo do que o cobre e, portanto, apresenta maior tendência a formar cátions. Sendo assim, o ferro (Fe) sofre oxidação, ou seja, perde elétrons, enquanto o cátion $\mathrm{Cu}^{2+}$ sofre redução, isto é, recebe elétrons. Os processos de oxidação e de redução sempre ocorrem associados, e pode-se dizer que a reação ocorre mediante uma transferência de elétrons. Nesse caso, a transferência ocorre do metal ferro $(\mathrm{Fe})$ para os íons $\mathrm{Cu}^{2+}$ em solução aquosa. (SP, 2 , p. 185, grifo do autor)

No livro 3, a reação que envolve um processo redox é destacada na unidade 3: reações orgânicas. Dentro dessa unidade o primeiro capítulo de reações de hidrocarbonetos tem a primeira seção destinada ao estudo das reações de alcanos. Os autores iniciam a seção apontando que "Uma das principais reações de alcanos é a combustão, uma reação de oxirredução na qual os átomos de carbono de um hidrocarboneto se oxidam e os de oxigênio presentes no $\mathrm{O}_{2}$ se reduzem" (SP, 3, p. 165, grifo do autor). Na sequência são explicadas e exemplificadas as reações de combustão completa e incompleta que trazem várias reações redox. Entretanto, os esquemas utilizados remetem a mudança no número de oxidação, uma vez que aponta as espécies que vão oxidando e reduzindo de acordo com o número de oxidação que apresentam, isso também é ressaltado ao explicar um número de oxidação fracionário, como em:

O valor representado abaixo do símbolo do carbono no iso-octano corresponde ao Nox médio dos átomos de carbono na substância. $\mathrm{O}$ valor fracionário indica a média entre os diferentes valores de Nox dos átomos de carbono na molécula. $\mathrm{Na}$ combustão completa, todos os átomos de carbono atingem seu Nox máximo, ou seja, +4 , ao se transformarem em $\mathrm{CO}_{2}$. (SP, 3, p. 165)

\section{Coleção Vivá (VV)}

Na coleção VV o termo oxirredução é introduzido no livro do primeiro ano num capítulo separado. O título do capítulo 'Reações de oxirredução' já especifica que as reações redox terão um destaque maior, não apenas uma seção que exemplifica as reações. A primeira definição presente descreve que a palavra oxidação: 
um metal a perder o brilho e outras características metálicas. O significado químico do termo, porém, se ampliou, como veremos mais adiante (VV, 1, p. 208).

Os autores abordam as reações redox por meio da combustão do magnésio e definem as reações redox como:

Chamamos de reações de oxirredução as transformações em que há transferência de elétrons, como a que vimos acima. O termo oxirredução deriva de dois processos que ocorrem na transformação: a oxidação (que envolve a perda de elétrons) e a redução (que envolve o ganho de elétrons). (VV, 1, p. 208, grifo do autor).

O segundo livro faz uma ampla abordagem das reações envolvendo as pilhas e baterias e os processos de eletrólise. Neste livro algumas perguntas no início do capítulo buscam relembrar o conteúdo trabalhado no primeiro ano. A definição do livro diz que nas pilhas e baterias "acontecem processos que envolvem a transferência de elétrons, isto é, tratase de reações de oxirredução. Essas reações de oxirredução são espontâneas e, por isso, pilhas e baterias são capazes de gerar energia elétrica." (VV, 2, p. 224, grifo do autor).

O terceiro livro, do conteúdo de orgânica especifica as reações que envolvem os compostos orgânicos e nesse contexto abre uma seção para as reações de oxirredução. Nesta parte do texto os autores definem que "Reações de oxirredução são reações que envolvem a transferência de elétrons. A combustão de qualquer material é um exemplo de reação de oxirredução" (VV, 3, p. 202). Os autores ainda trazem uma nota lembrete sobre os termos redução e oxidação, no lembrete utiliza-se como exemplo uma reação apresentada anteriormente que a espécie química que perde elétrons sofre oxidação e a que ganha elétrons sofre redução.

\subsubsection{Os modelos redox mais utilizados}

Os trechos destacados permitem inferir quais modelos são utilizados nos 20 livros didáticos analisados. Nas coleções percebe-se uma variação da abordagem dos conceitos de reações redox. As coleções TL e AR, de ciências do ensino fundamental, apresentam a definição das reações redox nos livros correspondentes ao nono ano.

Na coleção SP os autores destacam as reações redox nos livros dos três anos com maior destaque para os livros do primeiro e segundo ano. No livro do terceiro ano não se tem uma definição clara do conceito de oxirredução, mas reações redox são exemplificadas.

A coleção QC aborda explicitamente o conteúdo de reações redox somente no livro referente ao terceiro ano. Nos outros anos os conceitos de oxidação e redução até aparecem, mas uma definição clara só é dada no último livro da coleção. Na coleção VV as reações redox são profundamente abordadas no livro do primeiro ano. Nos livros do segundo e 
terceiro são feitas menções às reações redox, porém, não é feita uma descrição clara do conceito.

A coleção CP traz exemplos de reações redox no primeiro livro da coleção, porém, o conceito só é definido no segundo livro. A definição do conceito é parte integrante de um capítulo inteiro. O livro do terceiro ano traz exemplos de reações orgânicas que envolvem processos redox, mas a definição é colocada apenas como "nota de memória" para o professor.

Na coleção MM é destinado um capítulo inteiro, no segundo livro, para o ensino dos conceitos das reações de oxirredução. Nos livros do primeiro e segundo ano os autores exemplificam reações redox, mas sem destacar uma definição dos conceitos abordados.

Já nas coleções MR e VV os conceitos referentes às reações redox aparecem nos livros dos três anos, seja na apresentação ou revisão. O livro do primeiro ano traz a abordagem principal, enquanto os outros fazem uma retomada do conceito abordado anteriormente.

Em média, os conceitos de reações redox são abordados no segundo livro das coleções do ensino médio, mas são feitas menções e exemplificações das reações nos livros dos três anos. Apenas três coleções definem o que é uma oxidação nos três livros.

Dos modelos redox utilizados na explicação dos conceitos de oxidação e redução é perceptível que todos os autores utilizam o modelo de transferência eletrônica. Mesmo nas reações em que a ação do oxigênio é destaque, os autores definem as reações como transferência de elétrons entre as espécies.

Um livro, da coleção QC, traz os modelos de Oxigênio e Hidrogênio no capítulo referente aos estudos das reações orgânicas redox. Neste livro destaca-se que "a oxidação ocorre com a adição de átomos de oxigênio ou com a retirada de átomos de hidrogênio da molécula.” (QC, 3, p. 157). Um caso parecido acontece no livro 3 da coleção MR onde os autores descrevem que os alunos estudarão, especificamente, as reações em que o oxigênio atua como oxidante e o hidrogênio como redutor.

Apesar de na sequência do texto os autores definirem as reações redox como transferência eletrônica, há um exemplo do uso de diferentes modelos sem que seja explicado ao aluno o motivo da mudança. Não é explicado o porquê na química orgânica a oxidação referir-se à adição/retirada de átomos de hidrogênio e oxigênio. Tampouco isso é trabalhado no conteúdo de química orgânica. Ressalta-se que a alternância entre os modelos, desacompanhada de uma justificativa para tal, pode ser fonte de confusão e dificuldade de compreensão pelos alunos (ÖSTERLUND, 2010; GHIBALDI et al. 2015). 
Em outro trecho os autores da coleção QC destacam que:

As reações químicas, nas quais o oxigênio é um dos reagentes, são historicamente denominadas reações de oxidação. Já as reações inversas, de perda de oxigênio, são denominadas reações de redução. Atualmente, considera-se que [...]. (QC, 3, p. 195).

Um livro da coleção VV também destaca o modelo de oxigênio em:

[...] a palavra oxidação era empregada originalmente para designar reações em que uma substância interage com o oxigênio $\left(\mathrm{O}_{2}\right)$ e até hoje é usada para indicar o processo que leva um metal a perder o brilho e outras características metálicas. O significado químico do termo, porém, se ampliou [...]. (VV, 1, p. 208).

Nesses exemplos o modelo de oxigênio não é utilizado para definir as reações redox, mas sim utilizado para discutir história da ciência e a evolução dos conceitos. O exemplo refere-se às primeiras reações de oxirredução na qual Lavoisier cunhou o termo oxidação. A utilização de dois modelos explicativos, nesse caso, não parece causar confusão conceitual, pois, os próprios autores destacam que o significado do termo se ampliou, tal como a história da química evidencia.

Destaca-se a inclusão de elementos da história da ciência como um aspecto positivo no ensino dos conceitos da química, conforme apontam diversos autores da área de ensino de ciências. (GUERRA; QUINTAL, 2009, PRESTES; CALDEIRA, 2009; SILVA, 2013).

Identificou-se, também, que os livros do ensino médio fazem alusão explícita ao modelo de número de oxidação. Mas os resultados encontrados diferem daqueles apontados por Österlund (2010) em sua tese de doutoramento. Faz-se considerações aos trechos referentes ao modelo Nox na seção seguinte.

\subsubsection{O número de oxidação}

Após a definição dos conceitos de oxirredução, oxidação, redução, agente oxidante e agente redutor, em todas as coleções, aborda-se o número de oxidação. A literatura aponta que o modelo do número de oxidação é um modelo único e diferente dos outros modelos (oxigênio, hidrogênio e elétrons). O modelo define as reações de oxirredução como aquelas em que há mudança no estado de oxidação de um ou mais elementos participantes da reação.

Nas coleções analisadas este não parece ser um modelo que justifica uma reação redox, mas sim uma consequência da transferência eletrônica entre as espécies. Trechos de todas as coleções podem ser destacados para apoiar essa conclusão, por exemplo, na coleção SP o conceito de número de oxidação é dado em:

[...] por não envolver a formação de íons, entretanto, a transferência de elétrons entre as espécies não é facilmente percebida ou verificada. Para reconhecer uma 
reação de oxirredução, basta determinar o número de oxidação (Nox) dos átomos dos elementos envolvidos no processo. O número de oxidação permite a identificação de reações de oxirredução, sendo essa a sua principal aplicação. A diminuição no Nox de um átomo presente em determinada espécie química indica a sua redução; o aumento do Nox indica uma oxidação. (SP, 2, p. 185 - 187, grifo do autor).

Na coleção QC o conceito de número de oxidação também é dado no livro 3 da coleção, e é definido como: "O conceito de número de oxidação é fundamental para a compreensão das reações de oxidação-redução, por indicar como se deu a transferência de elétrons na reação química." (QC, 3, p. 197). Outro trecho do livro descreve como a quantidade de elétrons cedidos ou recebidos durante as ligações químicas:

Nas ligações iônicas, esse número indica a quantidade de elétrons que o átomo cedeu ou ganhou. No caso de ligações covalentes, essa é a quantidade de elétrons que seria cedida ou recebida pelos átomos, se as ligações fossem rompidas e os elétrons ficassem com os átomos mais eletronegativos. (QC, 3, p. 197).

Na coleção CP a abordagem do Nox é presente em dois momentos, primeiramente descreve-se que o conceito de Nox seria responsável por responder à questão de quais átomos recebem os elétrons de uma reação. Para isso os autores retomam conceitos de eletronegatividade e distribuição de cargas, para, então, definir o número de oxidação como "a carga que um átomo teria se houvesse a transferência completa de elétrons" (CP, 2, p.122)

A coleção MM, por outro lado, conceitua o Nox logo após a abordagem do modelo de transferência eletrônica, onde é colocado que "Os átomos ou íons que perdem ou ganham elétrons sofrem uma variação em sua carga. A carga elétrica resultante desse processo é definida como o número de oxidação (nox) do átomo.” (MM, 2, p. 197, grifo do autor).

A coleção MR é a única que faz referência explícita ao modelo do número de oxidação, anteriormente à apresentação do conceito de transferência eletrônica. Na abordagem do primeiro ano, as reações redox são definidas como aquelas em que ocorre variação do Nox dos elementos dos reagentes para os produtos. A conceituação do número de oxidação seria então "a carga elétrica real que ele [o elemento] adquire quando faz uma ligação iônica ou o caráter parcial (ß) que ele adquire quando faz uma ligação predominantemente covalente." (MR, 1, p. 278).

Apesar de apontar inicialmente o modelo de número de oxidação, na coleção MR isso é feito de modo introdutório ao modelo de transferência eletrônica. Isso é perceptível quando há no livro do terceiro ano uma associação entre os modelos de número de oxidação e de transferência eletrônica, sendo o primeiro uma consequência do segundo, e não um modelo em si. 
É perceptível que em todas as coleções os autores descrevem que o número de oxidação serve para 'perceber/verificar/identificar/reconhecer' (coleção SP); indicar como se deu (coleção QC); e é uma característica (coleção CP), das reações redox. Ainda se percebe uma clara utilização deste modelo para realizar o balanceamento das equações químicas. O modelo de Nox não é definido sem que haja referência explícita à transferência eletrônica.

Contudo, é perceptível que as coleções analisadas utilizam majoritariamente o modelo de número de oxidação na abordagem do conteúdo redox. Apesar do modelo utilizado para definir uma reação redox ser o de elétrons, ou seja, a transferência eletrônica, o número de oxidação é utilizado no balanceamento das reações, na abordagem das células eletroquímicas e da eletrólise.

Ghibaudi et al. (2015) apontam que no processo de ensino-aprendizagem o professor deve ter clareza da existência desses modelos e das relações estabelecidas entre eles. Os autores ainda afirmam que "no que diz respeito ao modelo mais amplo, o modelo NO, sua natureza formal e abstrata requer uma consciência clara das operações de modelagem que o precedem e constituem sua justificativa lógica." (GHIBALDI et al., 2015, p. 20, tradução nossa). As relações entre os modelos são especialmente problemáticas quando se aborda a sobreposição dos modelos de elétrons e de Nox pois, em geral, atribui-se um significado físico ao número de oxidação que não pertence a ele.

Sisler e Wanderwerf (1980), Vitz (2002) e Sima (2013) criticam os livros didáticos que descrevem os processos redox como consequência da troca de elétrons entre as espécies, pois, essa afirmação implica uma relação de causa (transferir elétrons) e efeito (modificar o Nox) que não se sustenta à medida que há processos que não podem ser representados como fruto da transferência eletrônica real entre os átomos. Os autores são enfáticos ao afirmar que a única definição logicamente consistente de reações redox é aquela em que se define em termos de mudança do número de oxidação.

Segundo os autores, sobrepor os modelos de elétrons e de Nox não deve ser realizado pois não há necessidade de hipotetizar uma transferência de elétrons para equilibrar uma reação redox. $\mathrm{O}$ equilíbrio das equações químicas redox tem uma base matemática que depende unicamente da regra de números de oxidação das espécies: a soma de Nox em uma molécula deve equivaler-se à carga da molécula. Assim o equilíbrio das reações redox não precisa supor que haja equivalência entre o ganho e a perda de elétrons. (SISLER, WANDERWERF, 1980) 
Porém, tal definiç̧ão apresenta alguns problemas do ponto de vista didático. Primeiro, os estados de oxidação são definidos com base em regras amplamente reconhecidas como "arbitrárias" (GHIBAUDI et al. 2015). Segundo, os métodos mais comuns e aceitos para calcular o número de espécies de oxidação são as regras propostas pela IUPAC e por Pauling que apresentam inúmeras limitações (entre elas: procedimento de cálculo complexo, muitas exceções às regras, dificuldade no cálculo com compostos que não tem $\mathrm{H}$ ou $\mathrm{O}$ na molécula). (PAIK et al., 2017).

Apesar disso, salienta-se que generalizar toda e qualquer reação redox como uma transferência de elétrons entre átomos apresenta as mesmas limitações que podem ser descritas para os modelos de oxigênio e hidrogênio. Esta definição é aceitável em inúmeros casos, mas não pode ser extrapolada para reações redox que envolvem espécies poliatômicas em solução (por exemplo, redução de íons de permanganato) ou para muitas reações entre espécies orgânicas, que também são reconhecidos como redox com base nas variações de Nox.

\subsubsection{Consequências do uso dos modelos no ensino de redox}

A seleção dos trechos que definem as reações redox, as reações de oxidação e de redução, os agentes oxidantes e redutores, permitiu inferir que todos os autores das coleções aprovadas no PNLD utilizam o modelo de elétrons. Dois livros também descrevem o modelo de oxigênio, no entanto, nestes trechos esse modelo é substituído na sequência pelo modelo de elétrons.

Quando utilizam o modelo de elétrons, os autores, na sequência, definem o número de oxidação e os procedimentos para o seu cálculo. A única exceção é a coleção MR que utiliza o modelo de Nox no primeiro livro da coleção, mas nos dois outros livros utiliza-se o modelo de transferência eletrônica. Isso indica que os autores não assumem o modelo de Nox como um modelo único e distinto dos outros três apresentados, mas sim como uma consequência da transferência de elétrons. Apontamos ser incorreta essa associação entre os modelos de elétrons e de Nox, uma vez que nem sempre uma variação do número de oxidação é resultado de uma transferência eletrônica real entre os átomos. Os dois processos não necessariamente estão vinculados.

Em virtude das críticas apontadas nessa sobreposição, e algumas dificuldades e limitações do modelo de Nox, Paik e colaboradores (2017) propõem que haja uma nova definição dos processos redox baseadas nas proposições feitas por Goodstein. 
Goodstein ao propor uma nova definição para o conceito de reação redox afirma que ela deve ser definida "como uma reação em que uma mudança na ordem relativa de eletronegatividades atômicas ocorre entre um determinado átomo e os átomos aos quais está ligado antes e após a reação " (GOODSTEIN, 1970, p. 455).

Isso implica em afirmar que a ordem relativa das eletronegatividades atômicas na ligação muda durante a reação. Paik et al. (2017) descrevem que esta nova definição pode ser interpretada com três tipos de relacionamento para a ligação de um átomo:

(I) Vinculação com um átomo de maior eletronegatividade

(II) Ligação com um átomo de igual eletronegatividade

(III) Ligação com um átomo de eletronegatividade inferior (incluindo elétrons de pares isolados)

Assim, os átomos em qualquer reação podem pertencer a uma das seguintes combinações: (I) $\rightleftarrows$ (I), (I) $\rightleftarrows$ (II), (I) $\rightleftarrows$ (III), (II) $\rightleftarrows$ (II), (II) $\rightleftarrows$ (III), ou (III) $\rightleftarrows$ (III). Segundo o autor, essas combinações podem então ser classificadas em dois tipos: na primeira, não há alteração na ordem relativa das eletronegatividades atômicas na ligação (tipo A) e, no segundo, há uma alteração na ordem relativa das eletronegatividades atômicas na união (tipo B). (PAIK et al., 2017)

As reações da forma (I) $\rightleftarrows$ (I), (II) $\rightleftarrows$ (II) e (III) $\rightleftarrows$ (III) seriam classificadas como tipo A, enquanto as da forma (I) $\rightleftarrows$ (II), (I) $\rightleftarrows$ (III) e (II) $\rightleftarrows$ (III) seriam classificadas como tipo B. Somente as reações de tipo B são reações redox de acordo com Goodstein (1970). Por fim, os autores enfatizam que o modelo de Goodstein tem o benefício de definir facilmente reações de redox sem exceções. (PAIK et al., 2017).

No entanto, essa nova definição também apresenta uma série de limitações, primeiro seria complicado definir quais são os agentes oxidantes e redutores na reação. Segundo, ainda há necessidade de utilizar-se as regras da IUPAC e de Pauling que também apresentam suas limitações. Terceiro, deve-se reconhecer a conectividade dos átomos em uma molécula para aplicar o método, que implica na clareza de muitos outros conceitos químicos que muitas vezes não são claros pelos alunos. Por último, esse modelo não se aplica às reações redox na química orgânica. (PAIK et al., 2017).

Além disso, não parece ser possível que se faça uma alteração drástica no conteúdo dos livros didáticos, ao menos não para os próximos três anos (período em que as coleções aqui analisadas serão utilizadas). Nos cabe aqui apontar a melhor mediação que o professor pode fazer com o recurso disponibilizado.

Nesse sentido, apoia-se a proposta de Ghibaldi et al. (2015) no que diz respeito à utilização do modelo de Nox. Para isso salientamos que o professor deve ter clareza na 
especificidade da natureza formal deste modelo, ou seja, ele é um modelo teórico e matemático, dessa forma não pode ser atribuído a ele um significado físico, tal como acontece nos livros didáticos.

Segundo os autores (GHIBALDI et al. 2015) o modelo de Nox representa uma ferramenta prática, útil para:

1) escrever as fórmulas compostas e dar nome às espécies na química inorgânica

2) identificar reações de oxirredução, à medida que padroniza o conceito tanto na química orgânica quanto na inorgânica

3) balancear as reações químicas, pois permite aplicar procedimentos de balanceamento simples e imediatos

Assim reitera-se que é importante que o professor tenha clareza de que os modelos têm uma distinção entre a realidade física dos processos redox. Isso implica considerar que o modelo tenta descrever os processos macroscópicos observados, mas por ser um modelo tem limitações intrínsecas. 


\subsection{A evolução do conteúdo de reações redox nos livros didáticos da educação básica}

As reações de oxirredução são apontadas na literatura como difíceis de ensinar (SOUDANI, et al., 2000), difíceis de aprender (De JONG, O.; ACAMPO, J.; VERDONK, 1995) e podem resultar em várias concepções alternativas. Essas concepções alternativas podem advir de outros momentos da escolarização básica, e não somente na discussão do conteúdo no nível médio. Isso pode ocorrer, por exemplo, ao exemplificar estas reações no ensino fundamental e retomá-las, ou não, nos últimos anos da educação básica.

Alguns exemplos de reações redox estão presentes no ensino fundamental I e II, conforme apresentado na sessão 5.1. Dentre esses exemplos, os mais discutidos são a Fotossíntese e Respiração Celular. Estes temas são citados em apenas duas coleções ao longo do ensino médio. Isso pode indicar que mesmo os alunos tendo um extensivo contato com essas reações ao longo do ensino básico, eles podem concluir o ensino médio sem saber que se tratam de reações redox.

Além disso, no ensino fundamental, com exceção do $9^{\circ}$ ano, não se conceitua reações redox, de forma que os temas encontrados são apenas exemplos das reações que são discutidas nas coleções. A primeira conceituação do conteúdo está presente no livro do $9^{\circ}$ ano que utiliza o modelo de transferência eletrônica para definir uma reação de oxirredução.

Já no ensino médio (análise apresentada na sessão 5.2) os exemplos de reações redox se voltam mais para a definição dos termos envolvendo estas reações, e as Pilhas e Baterias. Nas definições redox utiliza-se majoritariamente o modelo de transferência eletrônica, embora nos exercícios e cálculos envolvendo esse conteúdo, faz-se o uso do modelo de número de oxidação.

Comparando-se como os principais temas vão aparecendo ao longo de todos os livros analisados é possível apontar como se dá a evolução desse conteúdo nas coleções do PNLD. Utilizando-se os temas Fotossíntese, Respiração Celular, Pilhas e Baterias e a conceituação de Oxirredução, traça-se o caminho percorrido por esse conteúdo até a conclusão da escolarização básica. Este "caminho" é destacado nas figuras 37, 38, 39 e 40 que descrevem de que forma os conteúdos são abordados. 


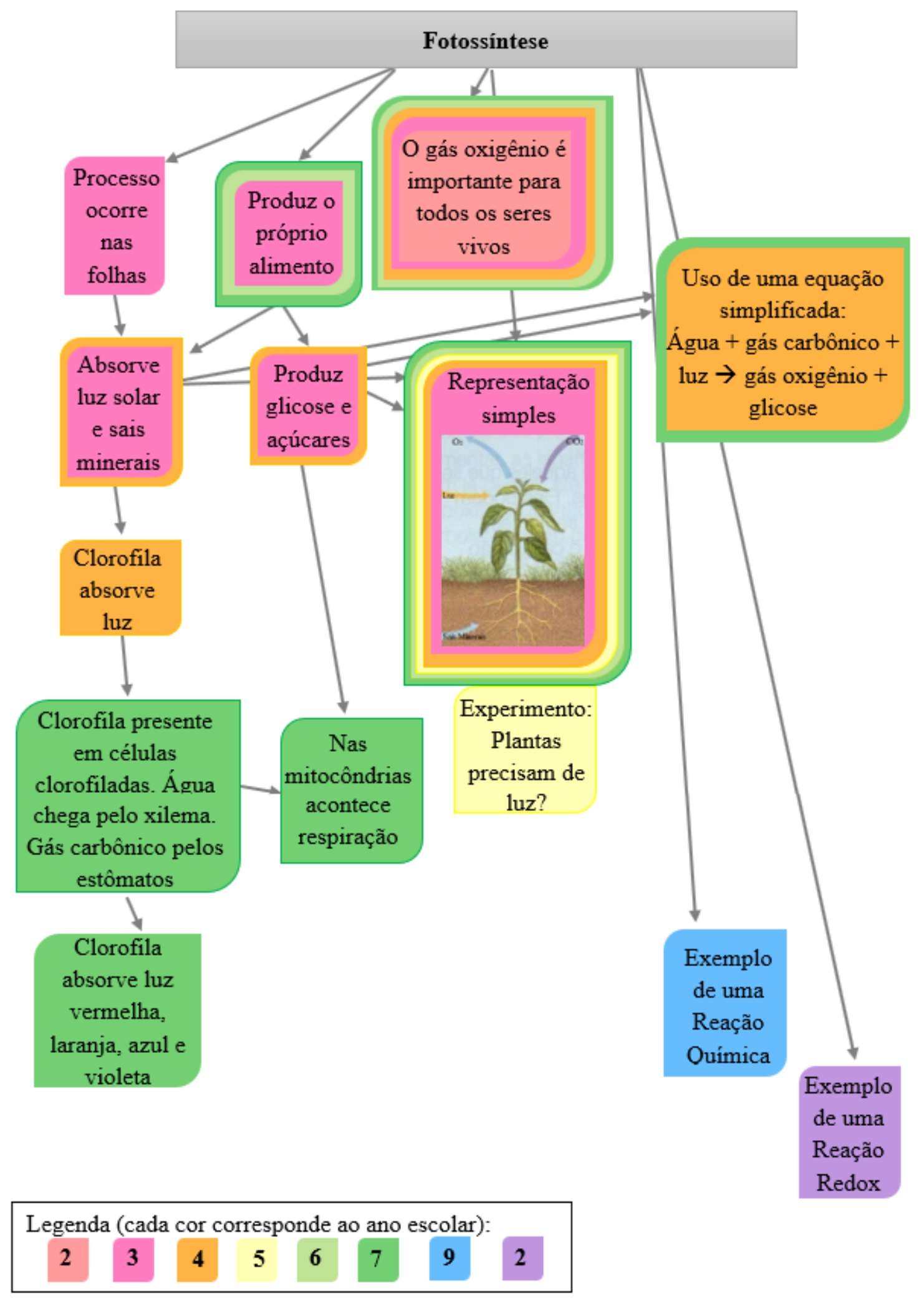

Figura 37 - A evolução do tema Fotossíntese ao longo dos livros de educação básica.

É importante tecer algumas considerações sobre o esquema de evolução do tema Fotossíntese nos LD. Primeiro, do lado esquerdo da figura têm-se ideias mais relacionadas à biologia, tratando das partes das plantas e do mecanismo para produção de alimento. Do 
lado direito estão representadas as ideias que tem a ver com a química, trazendo o uso de equações simplificadas e ideias diretamente relacionadas com o conteúdo redox nos finais da educação básica. Entre o lado esquerdo e direito são representadas ideias que podem se relacionar com ambas as ciências química e biologia, e também, aquelas que mais se repetem ao longo dos livros.

Cada caixa representa uma ideia, sendo que cada cor se refere ao ano em que a ideia está presente. No centro da caixa é destacada em qual ano estas ideias aparecem inicialmente, sendo que as cores ao redor representam onde elas são repetidas.

Percebe-se que a ideia mais presente ao longo do ensino fundamental é a de que o oxigênio é importante para os seres vivos, e a fotossíntese é um exemplo em que este gás reage. $\mathrm{O}$ uso de representações simples com um desenho de plantas e setas indicando a entrada do gás carbônico e sais minerais, e saída do gás oxigênio, também é recorrente.

Outro ponto que merece destaque é que a equação química que representa o mecanismo de Fotossíntese não é presente em nenhum dos níveis de ensino. Dada a complexidade da reação e da compreensão do mecanismo envolvido na fotossíntese, é compreensível que esta reação não seja discutida em sua forma química no nível fundamental. Contudo, poderia haver uma citação desta reação em nível médio, mesmo que seja para demonstrar o processo envolvido na transferência eletrônica e não para abordagem explicita do mecanismo da reação. 


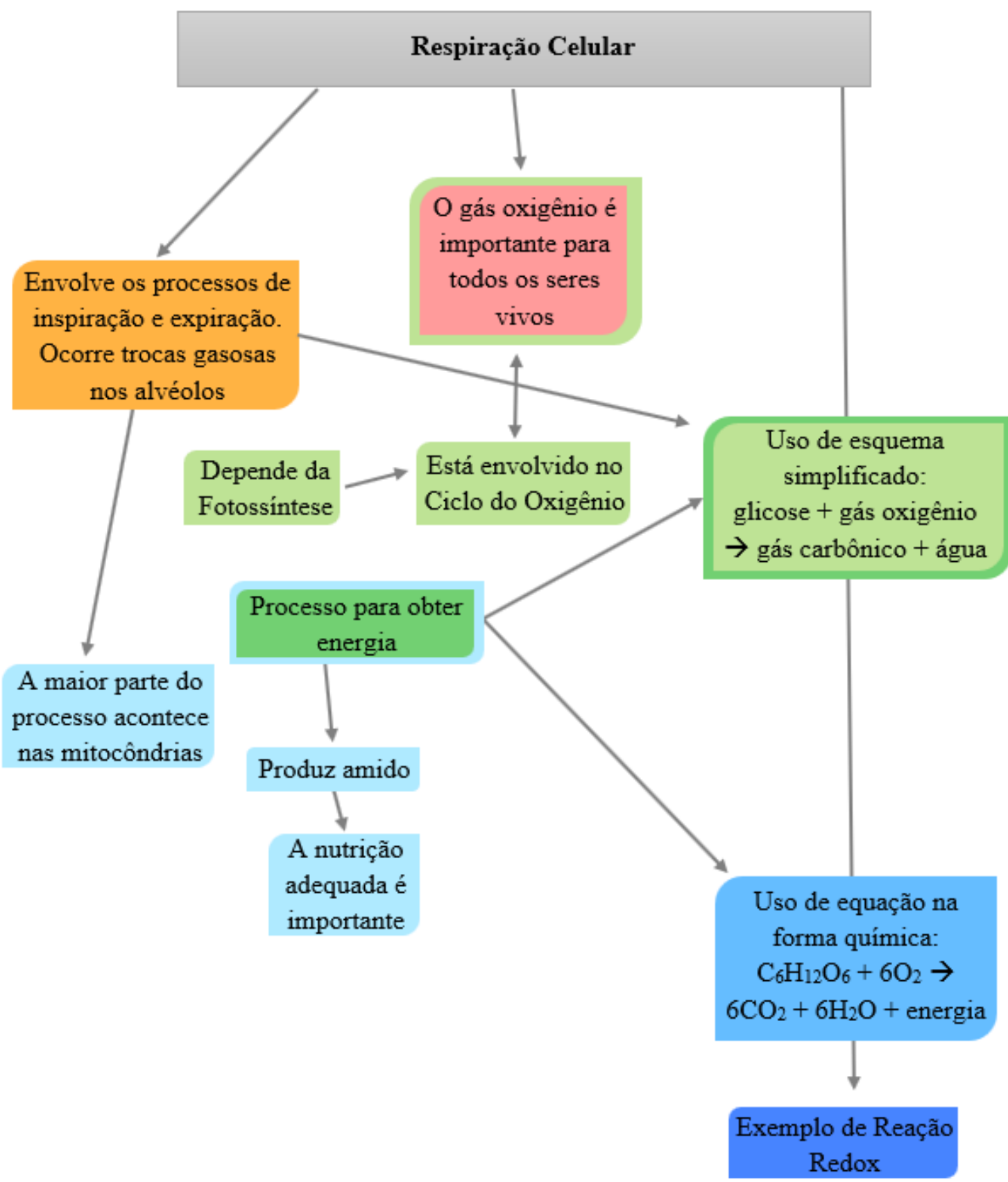

Legenda (cada cor corresponde ao ano escolar):
\begin{tabular}{ll|l|l|l|l|l}
2 & 4 & 6 & 7 & 8 & 9 & 1
\end{tabular}

Figura 38 - A evolução do tema Respiração Celular ao longo dos livros de educação básica.

Na figura 38 também se representam as ideias relacionadas à biologia do lado esquerdo, enquanto que as que envolvem a química estão do lado direito. 
É perceptível que a associação do tema Respiração Celular à ideia de que o gás oxigênio é fundamental aos seres vivos, também aparece em mais de um ano do ensino fundamental I e II. Nesse caso, esta ideia é a que mais se repete.

Para esse tema não é frequente o uso de representações esquemáticas. Contudo, uma equação em sua forma química aparece a primeira vez e pode ser um meio de trabalhar, ou citar, essas reações em nível fundamental.

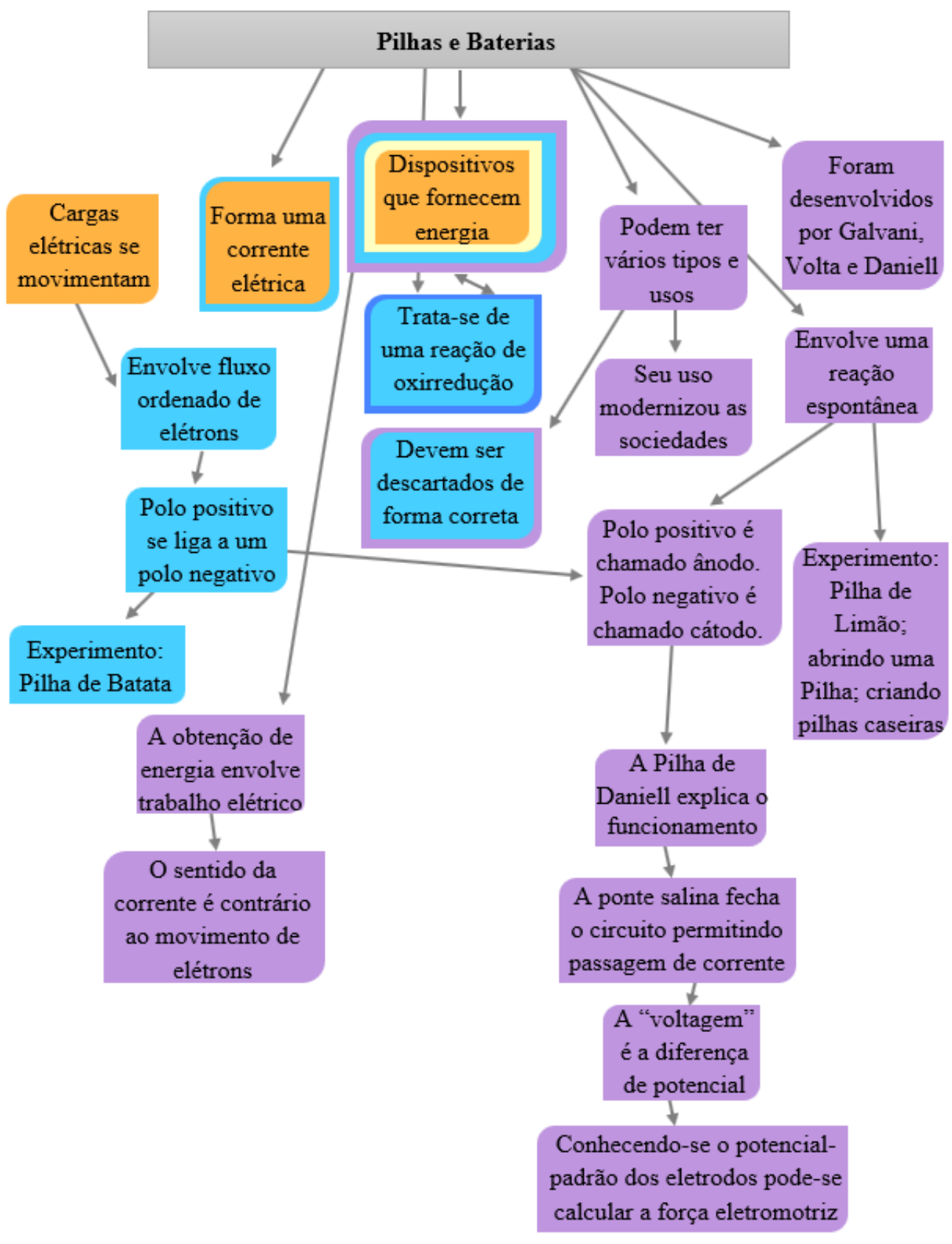

Legenda (cada cor corresponde ao ano escolar):

\begin{tabular}{l|l|l|l|l|}
4 & 5 & 9 & 1 & 2
\end{tabular}

Figura 39 - A evolução do tema Pilhas e Baterias ao longo dos livros de educação básica. 
O tema Pilhas e Baterias pouco se relaciona às temáticas biológicas, mas é citado ao abordar esses dispositivos do ponto de vista físico. Na figura 39 no lado esquerdo estão representadas ideias que se referem mais à física e do lado direito à química. Porém, a ideia envolvida nas duas abordagens é a de que tratam de dispositivos que fornecem energia.

Diferentemente das temáticas de Fotossíntese e Respiração Celular, a temática de Pilhas é mais presente nos últimos anos do ensino fundamental e abordada extensamente nos livros do ensino médio.

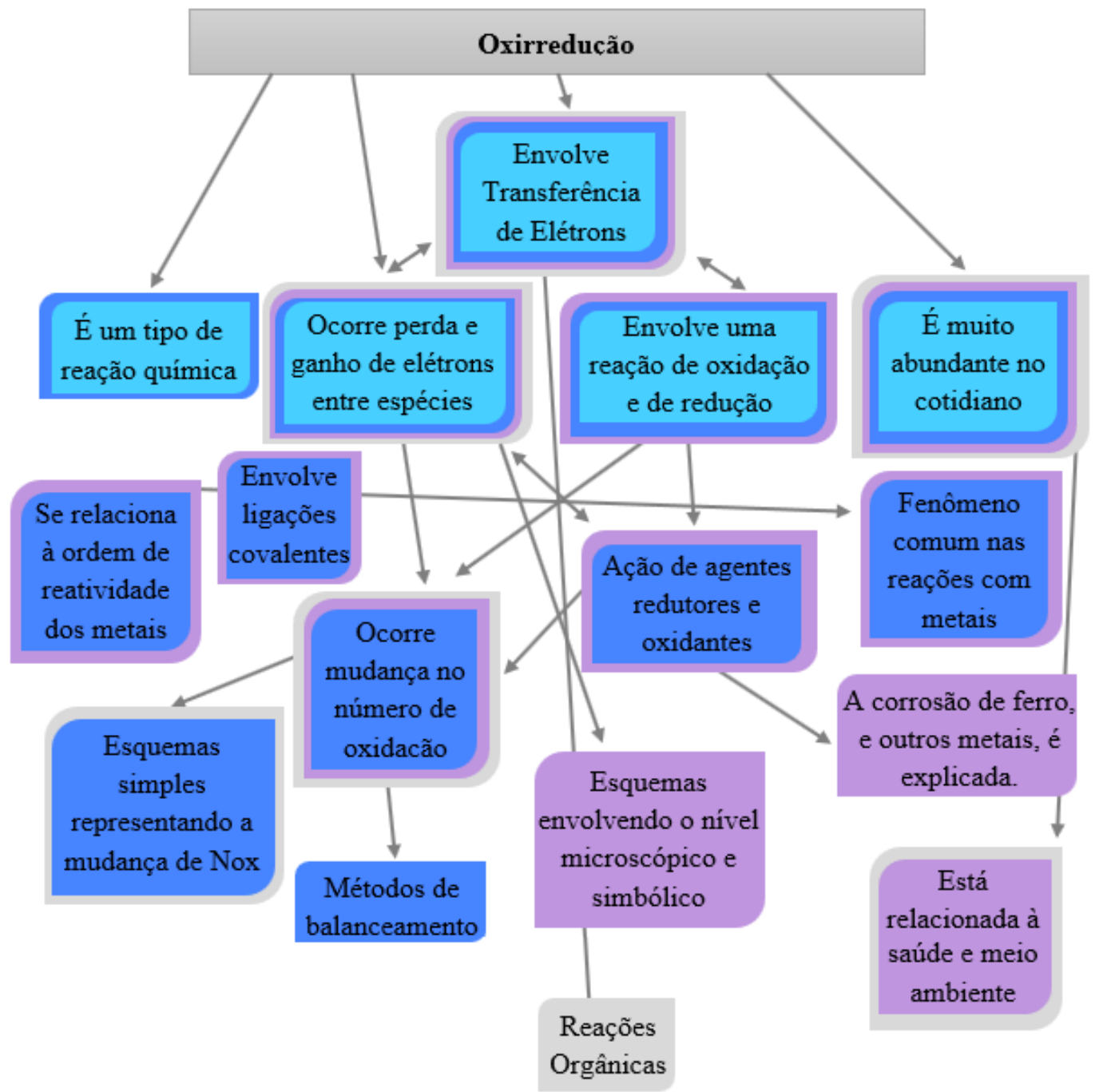

Legenda (cada cor corresponde ao ano escolar):

$\begin{array}{llllll}9 & 1 & 2 & 3\end{array}$

Figura 40 - A evolução do tema Oxirredução ao longo dos livros de educação básica.

$\mathrm{Na}$ leitura da figura 40 percebe-se que as ideias que envolvem definições de uma reação de oxirredução são mais abordadas nos anos finais da escolarização básica, 
aparecendo pela primeira vez no livro correspondente ao nono ano e sendo mais abordadas no segundo ano do nível médio.

Retomando as discussões apresentadas nas seções 5.1, 5.2 e 5.3 pode-se inferir como a apresentação do conteúdo nos livros da educação básica podem influenciar as concepções alternativas mapeadas na literatura.

Primeiramente, ao abordar os temas pertinentes às reações redox nos livros de ensino fundamental evidencia-se que os temas presentes nesse nível podem influenciar a concepção alternativa de que é necessária a presença do oxigênio para que as reações redox ocorram. Isso porque, com exceção das pilhas e baterias, todas as reações redox abordadas ao longo do ensino fundamental têm o oxigênio como participante da reação. Isso acontece inclusive para aquelas que mais se repetem como a fotossíntese e respiração celular.

Além disso, no nível fundamental de ensino os temas abordados eram, muitas vezes, interligados à importância do gás oxigênio para os seres vivos, destacando a importância desse gás em reações que serão retomadas no ensino médio.

Com relação às concepções que se referem às pilhas, baterias e eletrólise, o que se observou é que elas devem advir da discussão do conteúdo no nível médio. Isso porque a pilha de Daniell, principal dispositivo didático utilizado para explicar o funcionamento das pilhas, só aparece no segundo ano do ensino médio, não aparecendo nos livros de ensino fundamental. Isso indica que é difícil que o aluno tenha conhecimentos prévios sobre o fluxo de elétrons, a função da ponte salina e outros, antes da abordagem do conteúdo. Ou seja, é importante pesquisar essas concepções durante a apresentação das reações redox.

Além disso, é importante destacar que o modelo de transferência eletrônica tem sido o mais utilizado para definir as reações redox e, isso pode contribuir para a concepção alternativa de que os processos redox não são simultâneos. Nesse caso, a definição não atende aos documentos orientadores e a transferência pode estar sendo vista como uma transferência real entre os reagentes. Ora, para que uma transferência realmente ocorra é preciso que alguma coisa deixe algum lugar e se desloque para outro. Nesse sentido, pode haver um entendimento que os elétrons precisam primeiro deixar o átomo oxidado para chegar ao átomo reduzido. Ou seja, os alunos podem entender equivocadamente que o processo não é simultâneo.

É perceptível que os livros podem estar influenciando principalmente as concepções mais presentes na literatura, sendo aquelas citadas em três ou mais estudos. Isso reforça a ideia comum na área de ensino de ciências e química de que é necessário discutir e planejar intervenções que busquem confrontar essas concepções alternativas. 
Acrescenta-se que ainda é necessário realizar novos estudos que busquem identificar possíveis novas concepções alternativas e, também, realizar ações para que os professores conheçam ao menos as mais relatadas na literatura e que são persistentes.

Com os resultados obtidos é possível descrever, de forma resumida, uma linha do tempo (figura 41) com a evolução dos temas e do conteúdo de reações redox ao longo dos livros didáticos. A linha do tempo criada busca trazer como a complexidade do conteúdo vai aumentando ao longo da educação básica e resumir como os principais temas vão sendo abordados.

Aponta-se que a discussão sem mediação do conteúdo abordado nos livros pode causar as concepções alternativas citadas. Entretanto, é preciso salientar que o livro didático é um recurso que auxilia o professor no processo de ensino-aprendizagem, e como recurso sua utilização é sempre de alguma forma mediada.

Com isso, faz-se necessário analisar se os livros de ensino médio auxiliam nessa mediação do professor com seus alunos, alertando sobre as possíveis concepções alternativas dos estudantes. Essa investigação é descrita na seção 5.5 destacando as principais concepções da literatura e como estes aspectos, considerados essenciais para o processo de ensino, estão presentes nos livros analisados nesta dissertação. 


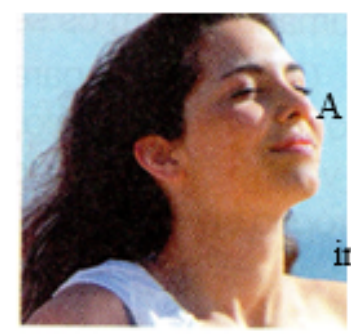

Os seres humanos

respiram o gás

oxigênio do ar.

Equações químicas simplificadas são introduzidas nos temas

Respiração Celular e Fotossintese: água + gás carbônico $\rightarrow$ glicose + gás oxigênio e água

Pilhas e Baterias aparecem como fontes de energia

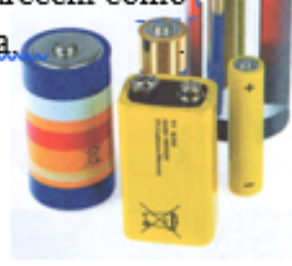

Importância do oxigênio para Respiração e

Fotossintese, que liberam energia. A Ferrugem, o Escurecimento da maçã e a Combustão são citadas como exemplos de Transformações Químicas.

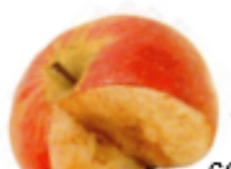

A respiração celular converte alimentos em energia para nosso corpo.

Definição e explicação das Reações Redox

$O$ funcionamento, características, tipos e descarte das Pilhas, Baterias e Eletrólise são! extensamente abordados. O esquema da Pilha de Daniell explicando o funcionamento das pilhas.

Alguns exemplos do Fundamental são

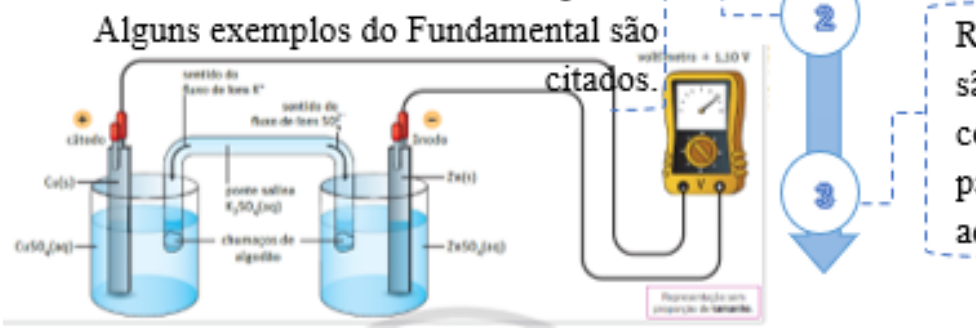

A Fotossintese surge como um processo que gera alimento por meio da absorção de luz e sais minerais. Uso de esquemas simples.

Experimento sobre fotossintese.

Pilhas e Baterias citadas como fonte de energia.
Respiração Celular fornece energia.

A Combustão, Ferrugem e Respiração são exemplos de reações em que o oxigênio participa, daí sua importância.

Figura 41 - Linha de evolução dos temas redox em livros da educação básica 


\subsection{Os livros didáticos como suporte ao processo de aprendizagem}

Os resultados obtidos até aqui permitem inferir que a abordagem presente nos livros pode influenciar as concepções alternativas mapeadas na literatura, de diferentes formas. Primeiro, identificou-se que ao longo do nível fundamental de ensino a maior parte dos exemplos redox que aparecem são relacionados à importância do gás oxigênio, ou tem o oxigênio como um dos participantes da reação. Embora não se negue a importância do gás oxigênio e dos processos em que ele participa, especialmente nesse nível de ensino, cabe salientar a possível influência na concepção alternativa de que o oxigênio é necessário para que se ocorra uma reação redox.

Ao longo dos livros de ensino médio a maior parte das vezes em que uma reação de oxidação é demonstrada não se associa a ela uma reação de redução. Isso pode contribuir para a ideia de que os processos de oxidação e redução não são dependentes.

A abordagem da Pilha de Daniell, desde o arranjo dos elementos nas representações, até a explicação das semirreações, pode influenciar a concepção de que a ponte salina fornece elétrons para o sistema ou que os elétrons circulam na solução livremente.

Entretanto, é preciso considerar a limitação deste recurso didático em causar tais concepções, uma vez que ele pode ser apenas um auxiliar ao trabalho do professor. Em virtude disso, considerou-se importante investigar se o livro fornece auxilio ao professor para que o mesmo trabalhe tais concepções em sala de aula. Para isso, utilizou-se o instrumento criado e validado pelo projeto 2061. Esse instrumento consiste em verificar se os livros contemplam 7 aspectos do processo de ensino, e como isso se dá.

Além disso, no desenho metodológico proposto percebeu-se a necessidade de investigar se as concepções alternativas estão sendo diretamente trabalhadas, ou seja, como o conteúdo do livro trabalha algumas concepções alternativas mapeadas na literatura. Para isso, optou-se por selecionar as quatro concepções alternativas mais relatadas na literatura e identificar nos livros se: a) há uma abordagem explícita para explicar essa concepção; b) o conteúdo pode ajudar ou dificultar o entendimento dessas concepções e c) o livro fornece suporte ao professor para tratamento específico dessas concepções.

Nesse quesito foram analisadas as categorias do projeto 2061: e) Alerta aos professores sobre as ideias mais comuns dos estudantes relacionadas ao conteúdo? e g) Aborda explicitamente ideias comuns presentes nos alunos relacionadas ao conteúdo? Optou-se por expandir os resultados e trazer mais detalhes para essas categorias pois, 
acredita-se que elas ajudarão a evidenciar resultados que subsidiem uma afirmação que atenda à questão de pesquisa.

Quanto às concepções alternativas mais relatadas na literatura, extraiu-se do quadro 3 aquelas que foram relatadas em 4 ou mais pesquisas. A listagem das concepções selecionadas para esse estudo é:
A. Reação redox entendida como transferência de oxigênio.
B. Os processos de oxidação e redução podem ocorrer de forma independente.
C. Os elétrons se movem através da solução sem o auxílio de íons.
D. A ponte salina fornece elétrons para completar o circuito.

No quadro 3 é possível identificar uma concepção que atende aos critérios de seleção das concepções alternativas a serem consideradas, mas que não foi utilizada. Trata-se da concepção alternativa: "Não há associação entre a Força Eletromotriz (fem) calculada de uma célula eletrolítica e a magnitude da tensão aplicada". Esta concepção, apesar de ser citada em mais de 4 publicações, não foi utilizada pois é um tema que não é trabalhado no nível médio de ensino. Em geral, as ideias de tensão e sua relação com a força eletromotriz calculada são abordadas no ensino superior.

Os resultados obtidos estão resumidos no quadro 15 e serão apresentados e discutidos na sequência. 
Quadro 15 - As categorias do projeto 2061 presentes nas coleç̃es brasileiras

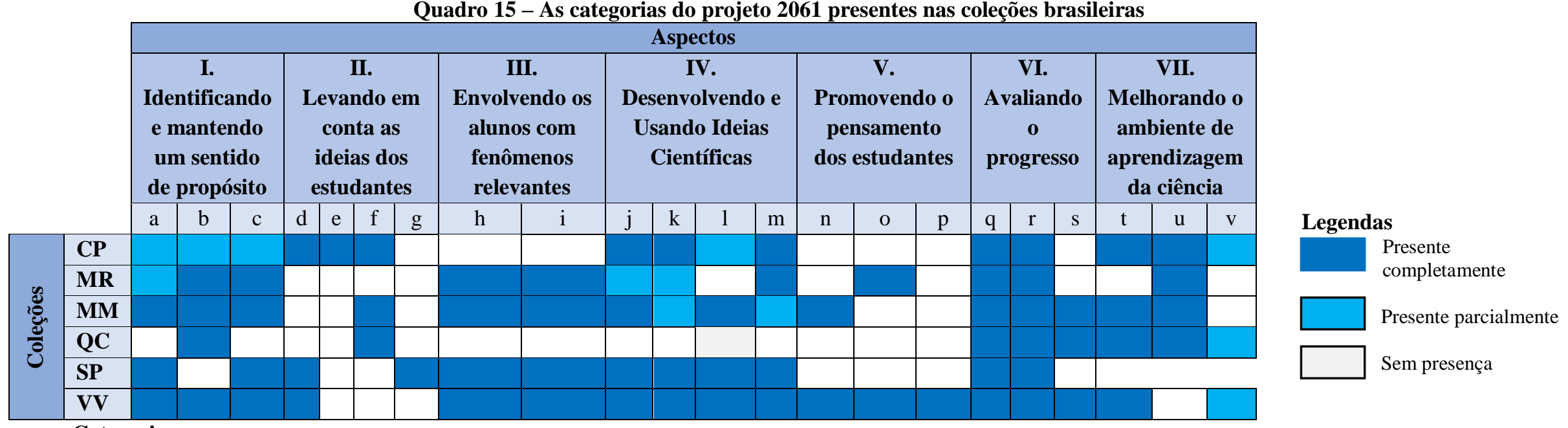

\section{Categorias:}

a) Transmite um sentido geral de propósito e direção que seja compreensível e motivador para os estudantes?

b) Transmite o objetivo de cada atividade e estabelece relações com as demais atividades?

c) Inclui uma sequência lógica ou estratégica de atividades (versus apenas uma coleção de atividades)?

d) Especifica conhecimentos ou habilidades prévias que são necessários para a aprendizagem do programa?

e) Alerta aos professores sobre as ideias mais comuns dos estudantes relacionadas ao conteúdo? f) O material inclui sugestões para os professores identificarem o que seus alunos pensam sobre fenômenos familiares relacionados ao conteúdo antes que as ideias científicas sejam introduzidas?

g) Aborda explicitamente ideias comuns presentes nos alunos relacionadas ao conteúdo?

h) Fornece fenômenos múltiplos e variados para apoiar a ideia de referência?

i) Inclui experiências do tipo "mão-na-massa" com fenômenos (quando experimentais) e proporciona aos alunos um sentido inteligível do fenômeno quando as experiências não podem ser de "mão-na-massa"?

j) Introduz termos técnicos apenas em conjunto com a experiência, com as ideias ou processos e apenas conforme necessário para facilitar o pensamento e promover uma comunicação eficaz? k) Inclui representações apropriadas das ideias de referência?

1) Demonstra/modela ou inclui sugestões para professores sobre como demonstrar/modelar habilidades ou o uso do conhecimento?

m) Fornece tarefas/perguntas para os alunos praticarem habilidades ou uso do conhecimento em uma variedade de situações? n) Inclui rotineiramente sugestões para que cada aluno possa expressar, esclarecer, justificar e representar suas ideias?

o) Inclui tarefas e/ou sequências de perguntas para orientar a interpretação e o raciocínio dos alunos sobre experiências com fenômenos e leituras?

p) Sugere maneiras para que os alunos verifiquem o seu próprio progresso?

q) Os itens de avaliação incluídos se relacionam com o programa?

r) Avalia a compreensão de ideias do programa e evita permitir aos alunos uma saída trivial, como repetir um termo ou frase memorizada do texto sem entender?

s) Algumas avaliações estão inseridas no currículo ao longo do caminho, com conselhos aos professores sobre como eles podem usar os resultados para escolher ou modificar atividades?

t) Ajuda aos professores a melhorar suas compreensões da ciência, da matemática e da tecnologia necessárias para o ensino do conteúdo?

u) Ajuda professores a criar um ambiente de sala de aula que acolhe a curiosidade dos alunos, recompensa a criatividade, encoraja um espírito de questionamento saudável e evita o dogmatismo?

v) Ajuda os professores a criar uma comunidade de sala de aula que encoraja expectativas elevadas para todos os alunos, que permite que todos os estudantes experimentem sucesso e que proporciona a todos os alunos um sentimento de pertencimento na sala de aula de ciências? 


\section{Coleção Ciscato, Pereira, Chemello e Proti (CP)}

Na seção introdutória ao capítulo a coleção CP apresenta:

Neste capítulo serão estudados os fenômenos relacionados ao funcionamento de pilhas e baterias, alguns processos eletroquímicos, mais especificamente os modelos submicroscópicos que os explicam, e os impactos ambientais associados ao seu uso. Para isso, serão abordados os conceitos de oxidação, redução [...] (CP, $2, \mathrm{p} .114)$

O parágrafo apresenta o que será estudado, de forma compreensível, porém, a abordagem escolhida pelos autores não é muito motivadora ou interessante. $\mathrm{O}$ espaço escolhido para inclusão do parágrafo é um box ao lado da página principal, que apesar de estar destacado de cor azul, pode passar despercebido pelos alunos.

Não é fornecido nenhum objetivo para resolução de exercícios, servindo apenas como conclusão do tema e intervalo entre um tema e outro. Quanto à única atividade experimental o objetivo é declarado e relacionado com o conteúdo abordado anteriormente, como por exemplo "Com base nesse princípio [retomada dos princípios abordados no capítulo], nesta atividade serão construídas pilhas utilizando materiais não convencionais" (CP, 2, p. 139). Já na atividade em grupo, destaca-se o objetivo em forma de pergunta: "Mas será que a população está devidamente informada a respeito do descarte de pilhas e baterias e dos perigos do descarte incorreto?" (CP, 2, p.169)

A sequência escolhida para abordagem do conteúdo é lógica e os assuntos destacados no início do capítulo são retomados posteriormente, como por exemplo, a eletrólise do alumínio onde os aspectos ambientais são apresentados e depois retomados ao contextualizar o método de eletrólise. Porém, o raciocínio para a sequência não é deixado claro aos alunos e nem é perceptível de forma implícita.

Quanto às concepções dos alunos que são abordadas na coleção CP as mesmas encontradas no livro destinado ao aluno, são destacados no livro do professor. Os conhecimentos relacionados às ligações iônicas e covalentes são retomados no texto principal, além de serem destacados em notas de cores diferenciadas e em espaços fora do texto principal (presentes somente no livro do professor). Em uma dessas notas é sugerido ao professor que:

Revise, de forma resumida, os conceitos de eletronegatividade, ligação iônica e covalente, utilizando como exemplos as substâncias $\mathrm{NaCl}, \mathrm{H}_{2}$ e $\mathrm{HCl}$. Essa revisão orientará as determinações de nox dos átomos nas espécies químicas (moléculas, compostos iônicos, íons polinucleares etc.) (CP, 2, p. 121)

Em uma das notas destacadas, é especificado ao professor que no Caderno de Apoio Pedagógico "são mostrados possíveis conhecimentos prévios que podem ser apresentados pelos alunos em relação a esses tópicos e, ao longo do capítulo, são indicados os momentos 
em que essas questões devem ser retomadas." (CP, 2. P. 117). Além dessa nota o livro ainda traz notas como: "Retome as discussões da questão "O que acontece com o ferro quando ele enferruja?”, proposta no início do capítulo para levantamento dos conhecimentos prévios dos alunos." (CP, 2, p. 120). As notas destacadas atendem coerentemente as categorias d, e e f.

\section{As concepções alternativas}

No Caderno de Apoio ao Professor há, na discussão de cada capítulo, uma seção de Orientações onde são descritos conhecimentos prévios que os alunos deveriam apresentar e uma Apoio ao seu trabalho onde as referências bibliográficas citadas ao longo do Manual do Professor são reunidas. Especificamente para o capítulo de reações redox (capítulo 3 da referida coleção) apresenta-se a concepção alternativa "processos de oxidação e redução ocorrendo de maneira independente", a dificuldade em resolução e problemas que requerem conhecimento conceitual aprofundado e as dificuldades de aprendizagem nos tópicos: oxidação, redução, corrente elétrica, condutibilidade elétrica em soluções, representação das reações e potencial-padrão de redução.

No decorrer dessa seção, o livro didático ainda apresenta outras concepções alternativas como "A pilha transmite energia para a lâmpada acender", "As baterias, assim como as pilhas, são também dispositivos que geram eletricidade" e também "Na superfície dos eletrodos inertes não ocorre reação". Todas as concepções apresentadas são referenciadas, caso o professor tenha interesse em ler os trabalhos na íntegra. Para as concepções selecionadas têm-se que:

A. Reação redox entendida como transferência de oxigênio

O Manual do Professor da coleção não apresenta ao professor essa concepção alternativa, nem a cita como uma das possivelmente apresentadas pelos alunos.

O capítulo é iniciado com uma abordagem histórica, depois é apresentado os problemas atuais associados ao uso das pilhas e baterias e a produção de alumínio por eletrólise. A reação escolhida para introduzir os conceitos de oxidação e redução foi a reação do cobre metálico em uma solução de nitrato de prata:

$$
\mathrm{Cu}(\mathrm{s})+2 \mathrm{AgNO}_{3}(\mathrm{aq}) \leftrightarrows 2 \mathrm{Ag}(\mathrm{s})+\mathrm{Cu}\left(\mathrm{NO}_{3}\right)_{2}(\mathrm{aq})
$$

Apesar da presença do oxigênio nessa reação, considera-se que o uso dela pode ajudar a compreender que a presença do oxigênio não é condição necessária para que reações de oxirredução ocorram porque o oxigênio não reduz nem oxida nessa reação. Isso também é ressaltado pelos autores que acrescentam: "Uma vez que os íons nitrato $\left(\mathrm{NO}_{3}{ }^{-}(\mathrm{aq})\right)$ não 
participam efetivamente da reação de oxirredução nem perdendo nem recebendo elétrons (...)” (CP, 2, p. 120). No livro ainda é acrescentado a forma reduzida da equação:

$$
\mathrm{Cu}(\mathrm{s})+2 \mathrm{Ag}^{+}(\mathrm{aq}) \leftrightarrows \mathrm{Cu}^{2+}(\mathrm{aq})+2 \mathrm{Ag}(\mathrm{s})
$$

Além disso, das 15 reações de oxirredução apresentadas ao longo de todo o capítulo, em apenas 5 delas o oxigênio é um agente oxidante ou redutor da reação.

B. Os processos de oxidação e redução podem ocorrer de forma independente.

Conforme explicitado anteriormente, essa é uma das concepções alternativas destacadas no Manual do Professor da coleção CP, o que demonstra uma preocupação em elucidá-la ao longo do livro. Isso também é perceptível pois ao descrever os objetivos de aprendizagem é destacado que os alunos deverão "perceber a simultaneidade dos processos de oxidação e redução em uma reação redox" (CP, 2, p.316). Ao retomar o texto proposto no capítulo, os autores da coleção ainda destacam ao professor que "além de definir os conceitos de oxidação e redução, evidenciar a simultaneidade em que esses dois processos ocorrem em uma reação de oxirredução" (CP, 2, p.317), retomando a referência que traz essa concepção alternativa.

Na apresentação do conteúdo essa concepção é abordada ainda na introdução, quando é colocado que:

A oxidação dos átomos de cobre e a redução dos íons $\mathrm{Ag}^{+}(\mathrm{aq})$ ocorrem simultaneamente. Assim, para cada íon $\mathrm{Cu}^{2+}(\mathrm{aq})$ formado, dois elétrons são cedidos a dois íons $\mathrm{Ag}^{+}(\mathrm{aq})$, gerando dois átomos de prata metálica. (CP, 2, p.119)

Outro fator que pode contribuir para elucidar essa concepção alternativa é o fato de que as reações de oxidação e redução são apresentadas juntas, bem como as semirreações, um exemplo é:

$$
\begin{array}{lll}
\text { Semirreação de oxidação: } \mathrm{H}_{2}(\mathrm{~g}) \rightleftarrows 2 \mathrm{H}^{+}(\mathrm{aq})+2 \mathrm{e}^{-} & E_{\text {axl }}^{\circ}=0,00 \mathrm{~V} \\
\text { Semirreação de redução: } 2 \mathrm{H}^{+}(\mathrm{aq})+2 \mathrm{e}^{-} \rightleftarrows \mathrm{H}_{2}(\mathrm{~g}) & E_{\text {red }}^{\circ}=0,00 \mathrm{~V}
\end{array}
$$

Figura 42 - Semirreações de oxidação e redução Fonte: CP, 2, p.129

C. Os elétrons se movem através da solução sem o auxílio de íons.

Para essa concepção analisou-se duas abordagens possíveis, a primeira diz respeito ao fluxo de elétrons no fio metálico do circuito externo, e a segunda nos íons presentes em solução aquosa. Com relação ao Manual do Professor, a coleção destaca que um vídeo pode ser utilizado para explicar como as pilhas funcionam destacando ao final o fluxo de elétrons no fio elétrico. Enquanto que no capítulo específico é descrito que "um fio condutor elétrico conecta os dois polos e permite o fluxo espontâneo de elétrons do polo negativo para o polo positivo da pilha" (CP, 2, p.137). 
As representações didáticas do livro também utilizam legendas para cada uma das partes que compõem a pilha e o sentido do fluxo é demonstrado por meio de setas:

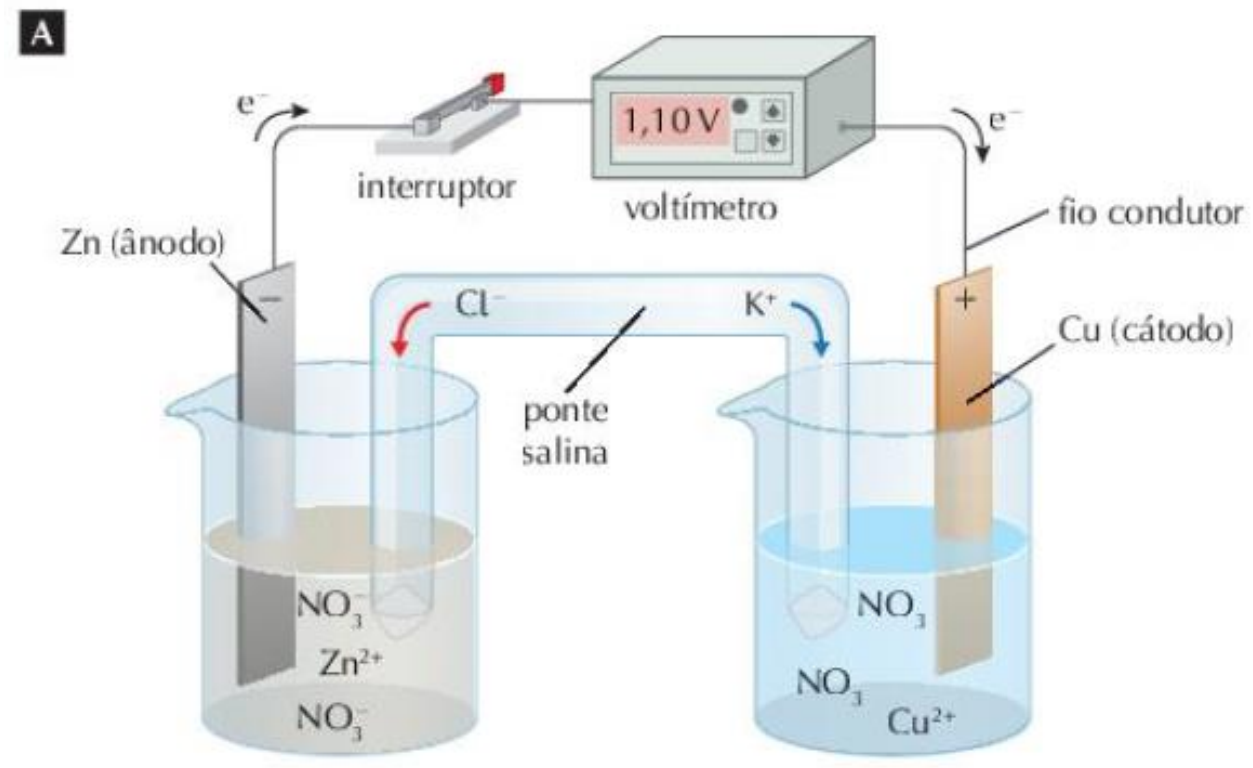

Figura 43 - Representação da pilha na coleção CP.

Fonte: CP, 2, p. 137.

Apesar da representação do fluxo de elétrons no circuito externo, o livro não aborda diretamente essa concepção alternativa, mas explica a função da ponte salina para fechar o circuito elétrico e garantir a neutralidade elétrica das soluções. Nesse caso, os cátions e ânions da ponte salina "migram para essa solução e a neutralizam - do ponto de vista das cargas elétricas." (CP, 2, p.138)

D. A ponte salina fornece elétrons para completar o circuito.

O papel da ponte salina não é enfatizado no Manual do Professor da coleção, nem essa concepção é detalhada. Já a abordagem no livro destaca as duas funções da ponte salina, mas nas representações das pilhas utilizadas não é explicitado como se dá o fluxo de íons nessa representação.

Além disso, é importante atentar que na descrição da função da ponte salina colocase que é garantir a neutralidade elétrica da solução e a movimentação dos íons nas soluções catódicas e anódicas, do ponto de vista das cargas elétricas. Entretanto, essa expressão 'cargas elétricas' aparece a primeira vez ao tratar desse conteúdo e a diferença entre esse termo e o número e oxidação não é explicado, ou seja, pode ajudar a não significar e dificultar o entendimento da função da ponte salina.

Há uma variedade de fenômenos que podem ser explicados pelo processo de oxidação e redução, tais como a corrosão, a fotossíntese, os antioxidantes no nosso 
organismo, os alvejantes e outros produtos de limpeza, a revelação fotográfica, produção industrial de elementos químicos, na respiração e geração de energia, entre outros.

Os fenômenos mais abordados na coleção CP são: os tipos de corrosão, reatividade dos metais, a maresia, produção de alumínio por eletrólise, e a proteção de metais. Outros exemplos são citados, mas com pouca ou nenhuma ênfase, sem relação direta com o conteúdo. Mesmo ao demonstrar a variedade dos tipos de corrosão, todos os exemplos se aplicam a reações envolvendo metais. Um único box, em separado ao final da página, apresenta o conteúdo relacionado a substâncias antioxidantes e radicais livres. No entanto, essa não seria a abordagem ideal e, portanto, a coleção não atende as categorias $\mathrm{h}$ e i. Isso significa que a coleção não envolve os alunos com uma variedade de fenômenos relevantes.

A única atividade experimental proposta pelo livro também não atende as categorias por não fornecer uma experiência "mão-na-massa". Na atividade prática de construção de uma pilha, além dos materiais serem difíceis de encontrar fora do ambiente escolar, a sugestão é de que parte do experimento de corte nos limões seja executada pelo professor (apesar de ser possível que o aluno o faça).

A apresentação dos conceitos de oxidação e redução é diretamente relacionada ao fenômeno de corrosão, as pilhas e baterias são definidas a partir da pilha de Volta, enquanto que a eletrólise trata principalmente da eletrólise do alumínio. Nesse sentido a categoria j é bem atendida pois a experiência, entendidas aqui como os exemplos, são o guia de toda a apresentação do conteúdo.

O capítulo ainda apresenta várias ilustrações que representam o conteúdo abordado. Todas as representações apresentam os três níveis representacionais da química, o nível simbólico, macroscópico e microscópico. A figura 44 apresenta uma das representações presentes no livro.

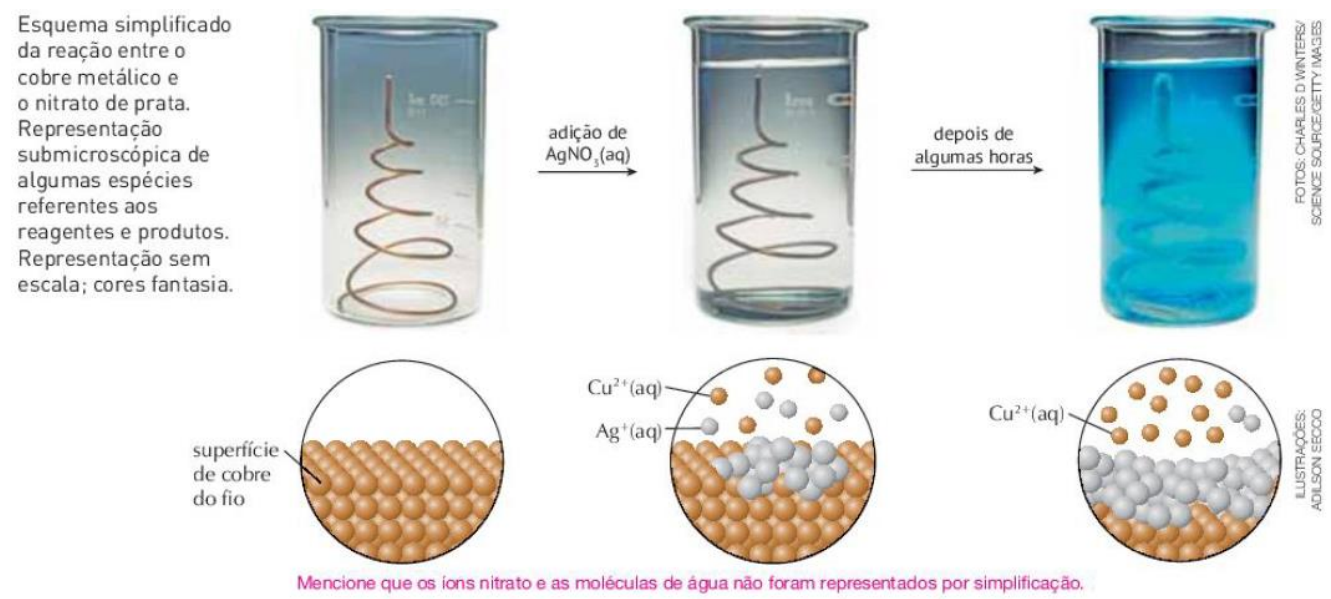

Figura 44 - Representação esquemática presente na coleção CP Fonte: Coleção CP, 2, p. 120 
A principal aplicação dos conceitos redox que pode ser citada, é no descarte das pilhas e baterias usadas. Nesse sentido, o livro deve orientar o procedimento correto, tal como é descrito na última página do capítulo. Essa é a única demonstração direta do conteúdo presente na coleção CP. No entanto, alguns exemplos práticos de aplicação no cotidiano podem ser obtidos nos exercícios propostos, como em:

[...] Para recuperar o brilho original de objetos de prata, basta aquecer cerca de um
litro de água contendo uma colher de sopa de sal de cozinha dissolvido. Após
aquecimento, deve-se embalar o objeto de prata em papel alumínio, mergulhá-lo
no recipiente com a água salgada (uma panela, por exemplo) e deixar em repouso
por uns 5 minutos. Desse modo, o brilho da prata é recuperado. Acompanhe a
seguir as semirreações de oxidação e redução que ocorrem. (CP, 2, p. 135)

Isso indica uma tentativa de demonstração de prática das habilidades adquiridas, ou uso do conhecimento. Porém, é necessário acrescentar que tais aplicações práticas poderiam estar presentes ao longo de todo o capítulo, uma vez que há professores que não utilizam os exercícios dos livros em seu planejamento.

A variedade de situações apresentadas nos exercícios são muitas, desde a inserção de quantias pequenas de ferro nos alimentos, o peróxido de hidrogênio como bactericida, a forma certa de realização da reciclagem de latinhas de alumínio, e outras. Apesar de serem incluídas apenas nos exercícios, considera-se que o livro atende a categoria m.

A coleção CP apresenta um box denominado 'Reflita sobre os tópicos abordados neste capítulo', nesse box é sugerido que os alunos discutam com seus colegas sobre questões como: O que acontece com o ferro quando ele enferruja, porque o ouro não se degrada como o ferro ao longo do tempo, como funciona uma pilha, porque em regiões litorâneas a corrosão ocorre com maior intensidade e como são produzidas as joias folheadas a ouro. As perguntas presentes neste box relacionam-se à maior parte dos conceitos presentes no capítulo, porém, ele é apresentado uma única vez após o texto de introdução. A maior parte das sugestões feitas ao professor são para identificar as concepções alternativas dos alunos, retomando as questões apresentadas no box citado.

As categorias n, o e p permitem identificar se o material oportuniza que o aluno expresse, justifique e represente as ideias que estão sendo construídas ao longo da abordagem do conteúdo. Para isso, box como o apresentado na introdução, deve ser acrescentado ao longo de todo o capítulo, para que o aluno seja sempre estimulado a expressar suas ideias. Por isso, considera-se que o material não atenda a nenhuma dessas categorias.

A única forma do próprio aluno avaliar seu progresso é a realização dos exercícios propostos. Na coleção CP existem três seções de exercícios, a primeira e mais frequente é denominada 'Questões para fechamento do tema' que traz exercícios gerais sobre o que foi 
exposto anteriormente, a segunda seção são perguntas sobre um texto específico ou atividade experimental, em que o aluno deve responder ao final da leitura, e por fim os 'Exercícios finais' que corresponde a quatro páginas com exercícios sobre todo o capítulo. Porém, sem o gabarito com as respostas isso fica dificultado.

O suplemento do professor da coleção CP possui algumas sugestões de avaliação, mas que também se referem ao uso dos exercícios, como em:

Se julgar apropriado, volte a esse exercício após o estudo sobre o funcionamento da pilha, destacando aos alunos que, nos pares metálicos aqui propostos, o eletrodo de prata funciona como um eletrodo inerte (afinal, não existem íons $\mathrm{Ag}^{+}$nos fluidos corporais de uma rã) $(\mathrm{CP}, 2, \mathrm{p} .134)$

Se um professor escolher utilizar os exercícios propostos como forma de avaliação, pode-se afirmar que, com exceção de alguns exercícios pontuais, a resolução dos mesmos necessita de uma habilidade e domínio do conteúdo. Ou seja, na maioria dos exercícios não se utiliza uma fórmula ou repetição de um termo memorizado, tal como a categoria $r$ indica.

Uma outra forma de avaliação que pode ser destacada no Manual do Professor é a utilização da atividade em grupo, ao final da unidade. Nesse sentido, os professores deveriam avaliar não somente a produção do vídeo ou material impresso, mas também, o desenvolvimento e envolvimento em toda a atividade.

As indicações do Manual do Professor da coleção CP se referem, em sua grande maioria, ao ensino dos conceitos redox. Não foram encontradas recomendações sobre recursos que o professor pode utilizar para melhorar seu próprio conhecimento em ciência. No entanto, no apoio pedagógico é possível encontrar algumas respostas mais detalhadas às possíveis perguntas dos alunos. Como, por exemplo, em:

Para a quinta questão, é possível que os alunos questionem a diferença entre bijuterias banhadas e folheadas com algum metal precioso, como ouro. Folhear (ou chapar) consiste simplesmente em aplicar, por meio de compressão, uma fina camada de ouro sobre o metal usado como base. Banhar a ouro implica uso de eletrólise, em que o metal será mergulhado em uma solução com presença de cátions de ouro. O ouro será, então, depositado sobre a peça por meio da aplicação de corrente elétrica. (CP, 2 p. 318)

Nesse sentido, o material fornece suporte ao professor e também incentiva curiosidade dos alunos, atendendo as categorias $\mathrm{t}$ e $\mathrm{u}$.

A categoria $v$ é a mais difícil de ser identificada no livro. De acordo com os indicadores de cumprimento, o material deve evitar estereótipos, ilustrar o contributo das mulheres e das minorias para a ciência, sugerir formatos alternativos para que os alunos expressem suas ideias, sugerir formas específicas para modificar atividades para estudantes com necessidades especiais e ainda validar as experiências pessoais e sociais dos alunos. 
O material evita estereótipos ou linguagem que possa ser ofensivo. Além desse nenhum dos outros indicadores foram encontrados na coleção CP. O que pode ser ressaltado é a preocupação dos autores em transmitir ao professor que considere na avaliação da última atividade (atividade de pesquisa em grupo) "a postura e o respeito aos colegas durante todas as etapas, especialmente durante as apresentações dos vídeos publicitários" (CP, 2, p. 321)

\section{Coleção Martha Reis (MR)}

Como o conteúdo redox está distribuído ao longo dos três livros da coleção MR, a análise inicia-se no livro do primeiro ano. No capítulo destinado à apresentação das reações de oxirredução não é apresentado nenhum objetivo explícito ao aluno. O Manual do Professor da coleção apresenta o objetivo da unidade e do capítulo, mas sem especificar a relação da abordagem redox com o tema principal.

As reações redox são introduzidas em um capítulo que aborda os metais, suas propriedades, modelos de ligação e ligas formadas. Esse capítulo está localizado dentro de uma unidade cujo objetivo é abordar a chuva ácida e seus impactos ambientais. Nenhuma citação é feita ao objetivo de se trabalhar a oxirredução nessa temática, e dessa forma não é compreensível nem motivador o sentido da abordagem. Além disso, também não são destacados nenhum objetivo para os exercícios da unidade, e nenhuma justificativa para a sequência adotada.

Já o livro do segundo ano aborda a temática lixo eletrônico na apresentação do conteúdo redox. A primeira página da unidade destaca o problema ambiental acarretado pelo excesso de consumo de aparelhos eletrônicos e acrescenta:

\footnotetext{
Tomar consciência do problema, discutir alternativas de descarte e reciclagem e, principalmente, frear a febre consumista que acompanha o ciclo intermitente de aquisição e descarte desses produtos pode ser o primeiro passo para chegar a uma solução definitiva para o problema. (MR, 2, p. 236)
}

A leitura dessa seção introdutória indica que o principal objetivo do capítulo é que o aluno compreenda o problema e procure alternativas. No entanto, a relação entre a abordagem da temática e do conteúdo redox só fica explícito ao final da unidade, sem estabelecer um objetivo principal para o estudo. Uma vez que a temática também pode ser discutida sem relação direta com as reações de oxirredução, esse não é um objetivo compreensível e motivador para os estudantes. O objetivo e relação das atividades (experimentação, exercícios e atividade em grupo) com a abordagem principal também não são claros. 
Todavia, o Manual do Professor do livro do segundo ano torna mais esclarecedor ao professor o motivo dessa abordagem. O Manual do Professor acrescenta, também, uma seção cujo título é: “Como justificar para o aluno a importância do que ele irá aprender agora?”. Nessa seção é descrito que:

O estudo da eletroquímica se baseia em muitos fenômenos que já foram estudados no Volume 1 como transferência de elétrons, oxidação e redução e reatividade de metais. Vamos recordar esses fenômenos e mostrar as aplicações que eles proporcionam como as pilhas e as baterias tão incorporadas atualmente em nosso dia a dia. Falaremos também sobre a eletrólise, um processo de obtenção de substâncias que constitui a chamada indústria de base, aquela que fornece a matéria-prima utilizada em todas as outras indústrias químicas. Por fim, veremos os processos de obtenção de cobre eletrolítico (com 99,9\% de pureza) sem o qual não teríamos acesso a eletricidade em larga escala, e a galvanoplastia, ou seja, o processo que nos permite usar uma corrente folheada a ouro ou comprar torneiras cromadas e brilhantes para nossa casa. Aliás, como tudo na vida, exibir peças brilhantes em casa ou folheadas a metais preciosos no pescoço tem seu custo, na verdade um alto custo ambiental e social que devemos mostrar ao aluno para leválo a refletir: Será que vale a pena? (MR, 2, p. 357)

$\mathrm{Na}$ sequência é explicitado como foi desenvolvido o conteúdo, primeiramente recordando os fenômenos desenvolvidos no primeiro livro, depois desenvolvendo os conceitos novos como as diferenças entre as pilhas e questões relativas ao uso desses dispositivos, e por fim, enfatizando a importância do processo de eletrólise para obtenção de matérias-primas. É ainda acrescentado todos os objetivos específicos para cada um dos capítulos. As informações contidas no Manual do Professor permitem considerar que o livro do segundo ano atende as categorias $\mathrm{a}, \mathrm{b}$ e $\mathrm{c}$.

O livro do terceiro ano só traz informações sobre a abordagem das reações redox orgânicas no Manual do Professor da coleção. É descrito que serão tratadas as reações de oxidação e de redução orgânicas, pois:

Essas reações, além de muito importantes industrialmente, costumam despertar grande interesse nos alunos por estarem relacionadas a fenômenos cotidianos, como uso do bafômetro, tintura de cabelos, mudança de coloração de frutos expostos às condições ambientes, etc. (MR, 3, p. 337)

Como no desenvolvimento do conteúdo são abordados todos os fenômenos citados, considera-se que o livro 3 também apresenta as três categorias, a, b e c.

\section{As concepções alternativas}

No Manual do Professor da coleção MR não é feita menção a nenhuma concepção alternativa no conteúdo de reações redox. Mesmo nas sugestões de leitura do Manual do Professor do livro 1, 2 e 3 não há menção a nenhum livro ou publicação que verse sobre as concepções alternativas dos alunos, isso também não aparece para os outros tópicos da química. Para as concepções alternativas selecionadas têm-se que: 
A. Reação redox entendida como transferência de oxigênio.

A reação que apresenta as reações redox, no livro 1 da coleção MR, é a de formação do cloreto de sódio e, portanto, não há presença do oxigênio nessa reação. O mesmo ocorre no início do capítulo de pilhas e baterias no livro do $2^{\circ}$ ano, a primeira reação é entre zinco metálico e solução aquosa com cátion cobre II. Já no livro 3, na primeira reação apresentada um dos reagentes é o oxigênio, porém isso já seria esperado à medida que nas reações redox orgânicas, em sua maioria, o oxigênio participa da reação.

Com relação às reações utilizadas, em 10 delas o oxigênio não é agente redutor nem oxidante e em outras 8 ele está presente. Contudo, uma única reação está presente no livro do primeiro ano, sendo que essa é a de formação do gás carbônico, posteriormente trabalhado no livro do terceiro ano onde abordam-se as reações orgânicas. Isso indica que apesar do Manual do Professor da coleção não relatar essa concepção alternativa, a abordagem escolhida pode auxiliar no tratamento dessa concepção em específico.

B. Os processos de oxidação e redução podem ocorrer de forma independente

Com relação aos processos de oxidação e redução simultâneos, a coleção aborda essa concepção explicitamente ao abordar a concentração e temperatura nas pilhas: "a reação de oxirredução é reversível e tende a entrar em equilíbrio químico, ou seja, a partir de certo momento as reações direta (de oxidação) e inversa (de redução) ocorrem simultaneamente com a mesma taxa de desenvolvimento." (MR, 2, p. 246) e:

\footnotetext{
Note apenas que, como as reações de oxidação e redução ocorrem simultaneamente e o aumento de temperatura aumenta a rapidez das reações nos dois sentidos, não podemos prever qual a influência exata da temperatura em uma pilha genérica. (MR, 2, p. 246)
}

Além disso, no capítulo de pilhas e baterias, apresentam-se as reações de oxidação e redução que ocorrem num eletrodo de zinco e então é acrescentado que se "trata de um processo contínuo e ininterrupto" (MR, 2, p. 241). Entretanto, na reação apresentada, os reagentes presentes são o eletrodo de zinco e a placa de zinco, essa mesma abordagem não é utilizada ao tratar-se de reações com outros elementos como na Pilha de Daniell.

Nas outras reações abordadas apresenta-se sempre uma semirreação e depois da outra, e por fim soma-se as duas numa reação global. Considera-se que essa abordagem não necessariamente auxilia na compreensão da simultaneidade do processo, uma vez que mesmo as semirreações são apresentadas em tópicos diferentes no livro. Essa abordagem permanece no livro de orgânica quando são colocadas apenas as reduções ou oxidações envolvendo átomos de carbono. 
C. Os elétrons se movem através da solução sem o auxílio de íons.

Para essa concepção identificou-se como as células galvânicas são abordadas e quais as funções dos componentes são descritas. Com relação ao circuito externo, esse é mencionado duas vezes, a primeira é encontrada ao detalhar o esquema de funcionamento da pilha onde coloca-se que o cátion cobre "recebe os 2 elétrons doados pelo zinco que vieram pelo fio condutor até a placa de cobre" (MR, 2, p.242). A segunda, mais adiante no livro, traz a relação entre o circuito externo e a ponte salina: "Por convenção, denominamos o fio condutor por onde "caminham" os elétrons de circuito externo." (MR, 2, p. 243). Em ambas as abordagens há um esclarecimento sobre a condução dos elétrons no circuito externo.

D. A ponte salina fornece elétrons para completar o circuito.

O papel da ponte salina é destacado ao abordar as pilhas no segundo livro da coleção. Após apresentar um esquema da pilha de zinco e cobre é acrescentado que: “A função da ponte salina é permitir a migração de íons de uma solução para a outra, de modo que o número de íons positivos e negativos na solução de cada eletrodo permaneça em equilíbrio. (MR, 2, p. 242)"

Segundo o livro, isso é necessário para que as soluções de ambos os eletrodos não percam a neutralidade elétrica e assim a pilha funcione por mais tempo. Com isso, faz-se uma analogia com o papel do circuito externo, onde acrescenta-se: "denominamos a ponte salina da pilha por onde "caminham" os íons de circuito interno" (MR, 2, p. 243).

Apesar da abordagem escolhida, à primeira vista, não causar essa concepção alternativa, ela também não parece explicar como se dá a neutralidade elétrica. O esquema utilizado (figura 45) não demonstra a migração dos íons na ponte salina, dos elétrons no circuito externo e nem o processo de eletrodeposição.

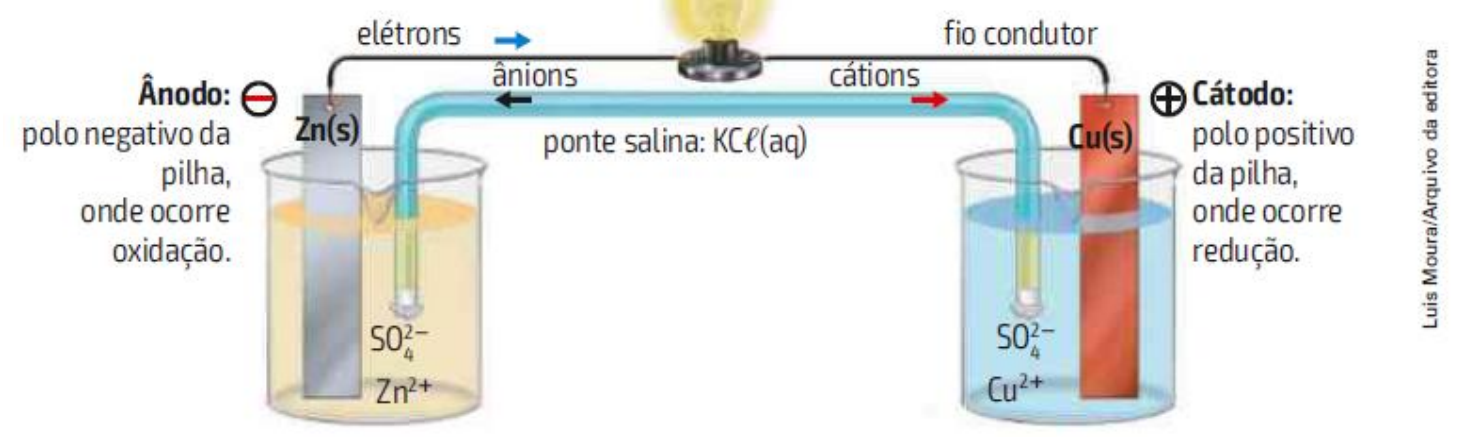

Figura 45 - Esquema de representação de uma pilha na coleção MR.

Fonte: MR, 2, p.242 
Os fenômenos que são envolvidos na abordagem redox são: formação de cloreto de sódio, formação do metano, formação de gás carbônico, metais, pilhas e baterias, produção de elementos químicos, decomposição de lixo orgânico, antioxidantes em alimentos, tintura de cabelo e o bafômetro. É importante salientar que os únicos fenômenos que são envolvidos na explicação do conteúdo é a formação do cloreto de sódio, metano e do gás carbônico, no livro do primeiro ano, as pilhas e baterias, no segundo ano. Os outros fenômenos são apenas apresentados como exemplos de reações redox presentes no cotidiano.

São propostas duas atividades experimentais no desenvolvimento do capítulo no livro 2. A primeira é de construção de uma pilha caseira com a função de observação da transferência de elétrons. Essa atividade é dividida em duas partes, a parte 1 é a construção de uma pilha de limão, enquanto que a parte 2 de uma pilha voltaica. A parte 1 requer materiais encontrados, em sua maioria, em laboratórios de ciências, porém a parte 2 pode ser realizada com materiais de baixo custo e facilmente encontrados. Nesse sentido, considera-se que a atividade fornece uma experiência do tipo "mão-na-massa", à medida que pode ser reproduzida em casa. A segunda atividade é a realização da eletrólise do iodeto de potássio, realizada somente em laboratório por conter materiais e reagentes de difícil acesso. Em virtude disso, a coleção MR atende as categorias h e i do instrumento de avaliação utilizado.

A apresentação dos conceitos de oxidação e redução são envolvidos com as reações de formação do cloreto de sódio, do metano e do gás carbônico no primeiro ano. No segundo ano com as reações envolvidas nas pilhas e baterias. Contudo, alguns conceitos são apresentados sem serem associados a nenhum fenômeno específico, é o caso dos conceitos de força eletromotriz, potencial-padrão de redução e de oxidação e das leis de Faraday.

Quanto às representações do conteúdo, os autores utilizam uma figura visual para compreensão dos fenômenos de oxidação e redução em todos os capítulos:

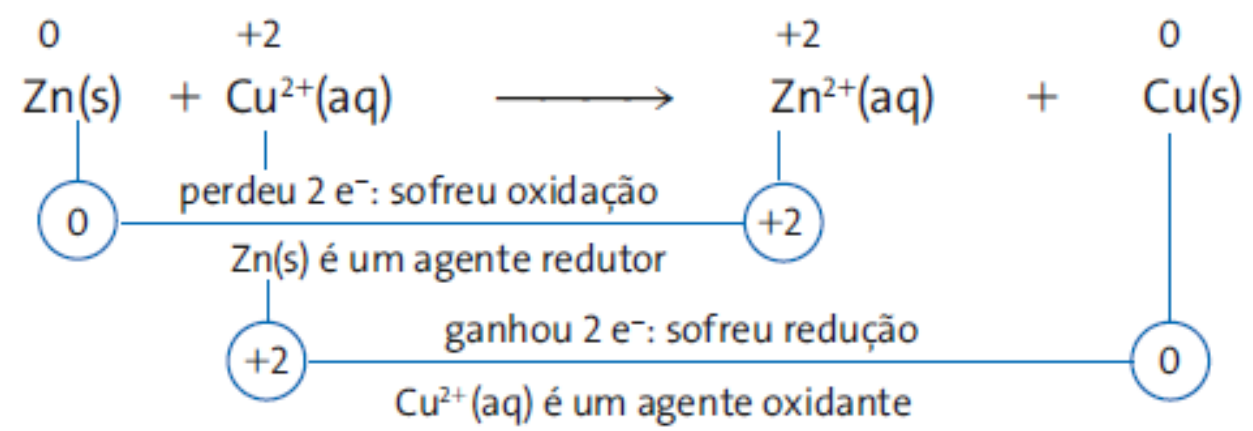

Figura 46 - Representação esquemática presente na coleção MR

Fonte: MR, 2, p. 238 
O uso dessa representação pode causar confusão pois não são usadas setas que poderiam indicar quais as reações de oxidação e redução, a distribuição do texto é infeliz à medida que frases como "perdeu $2 \mathrm{e}^{-}$: sofreu oxidação" parecem relacionar-se tanto com o $\mathrm{Cu}^{2+}$ quanto ao $\mathrm{Zn}(\mathrm{s})$.

Além disso, em geral não há uma representação que contemple os três níveis representacionais da química, não apresentando o nível macro e micro. O nível macroscópico é mais contemplado em imagens, enquanto que não foram encontradas representações do nível microscópico. A representação esquemática para a pilha é mais adequada, conforme observado na figura 6 , acima.

Quanto ao uso do conhecimento, conforme apontado, a principal aplicação é na orientação ao descarte correto de pilhas e baterias, a abordagem da coleção também apresenta problemas. No livro 2 há uma seção específica denominada 'Descarte de pilhas e baterias' cujo objetivo é apresentar o caminho percorrido por esses dispositivos quando descartados no lixo doméstico.

Na sequência é apresentada uma notícia para tratar da reciclagem responsável do lixo eletrônico, nela é apresentado que: "alguns tipos de pilhas - como as alcalinas - [...] podem ser descartadas diretamente no lixo doméstico para serem encaminhadas, segundo consta no artigo, a aterros sanitários licenciados". Em outra citação é apontado que "O problema é que apenas $10 \%$ dos aterros brasileiros, segundo estimativa do Instituto Brasileiro do Meio Ambiente e dos Recursos Naturais Renováveis (Ibama), atendem a esse quesito.”; e que "Também é preciso considerar que nem todas as pilhas que compramos estão de acordo com o padrão". Outros pontos abordados são que "a reciclagem responsável de pilhas e outros tipos de baterias é um processo mais difícil e complexo" e que "Existe apenas uma empresa em operação no Brasil, que recicla cerca de 6 milhões de pilhas e baterias por ano, menos de $1 \%$ do total comercializado" (MR, 2, p. 260). A leitura completa da seção só acrescenta mais dúvidas ao processo de descarte desses materiais e não apresenta nenhuma solução ou fonte de informação.

O Manual do Professor da coleção sugere outra abordagem para esse tema indicando a visualização de dois vídeos que mostram o processo de reciclagem em uma usina, uma entrevista sobre logística reversa e troca de eletrodomésticos para economia de energia, e ainda o descarte e destino dos metais presentes nos celulares. Considera-se que essa abordagem seja a mais correta para o nível médio, e, portanto, a categoria 1 não é contemplada. 
Os exercícios da coleção apresentam uma variedade de exemplos, como: óxidos de nitrogênio, iodo para tratamento radioterápicos, peróxido de zinco como antisséptico bucal, escurecimento de objetos de prata, latas para conservação de alimentos, restauração dentária por amálgamas, toxicidade dos metais, entre outros. Estando presentes nos exercícios, a coleção MR inclui elementos da categoria m.

Não foram encontradas no material oportunidades oferecidas aos alunos de expressarem suas ideias. É necessário ressaltar que algumas perguntas são feitas após textos de introdução, que são respondidas na sequência do texto, porém, essas não foram consideradas como incentivo ao aluno expressar, representar, ou justificar suas ideias, mas sim como constatação da leitura do texto. Contudo, no Manual do Professor da coleção são sugeridos alguns encaminhamentos ao professor para oportunizar aos alunos fala na sala de aula, como por exemplo: "Proponha que os exercícios sejam feitos em grupos de três componentes, e cada integrante fará a resolução em seu caderno. Resolva alguns exercícios na lousa, valorizando a participação oral dos seus alunos.” (MR, 2, p. 359)

A orientação do raciocínio dos alunos, também, só é contemplada no Manual do Professor da coleção. São feitas algumas sugestões nesse sentido:

Recorde com seus alunos os conceitos de oxirredução. Escreva na lousa algumas reações e peça que copiem no caderno identificando a substância que sofreu redução, a substância que sofreu oxidação e os agentes redutor e oxidante. (MR, 2, p. 359)

Outro trecho também expressa essa preocupação:

Inicie uma discussão com seus alunos para relembrar as características das pilhas e baterias. Peça aos alunos que expressem de forma oral os conceitos das aulas anteriores. Considerando as respostas dos alunos sobre conceitos que foram relembrados, aborde a eletrólise ígnea. (MR, 2, p. 361)

Porém, a categoria p não foi encontrada, à medida que requer orientações diretamente aos alunos, sem a condução do professor.

As formas de avaliação presentes nos capítulos dedicam-se somente à resolução de exercícios. A resolução de todos eles implica a utilização de conceitos recém apreendidos. Além disso, o Manual do Professor também apresenta sugestões de avaliação com a realização de atividades em grupos, apresentações orais sobre pesquisas, e respostas a um texto específico.

Como grande parte dos exercícios são de resolução de cálculos, considera-se que o material contempla a categoria r. Entretanto, as sugestões feitas aos professores não incentivam a modificação ou escolha de atividades baseadas nas respostas dos alunos, portanto, a categoria s não está presente nessa coleção. 
O último aspecto é contemplado apenas em sua categoria u. As ideias sobre ciência e tecnologia - do próprio professor- não são abordadas em nenhum espaço da coleção. E, apesar de incentivar que os professores considerem as respostas dos alunos, os indicadores de cumprimento da categoria $\mathrm{v}$, também não se fazem presentes.

\section{Coleção Mortimer e Machado (MM)}

O texto introdutório, do capítulo que aborda as reações redox, descreve a importância do estudo dessas reações. Já no primeiro contato com o conteúdo, o aluno conhece algumas das reações presentes no cotidiano que são compreendidas pelos processos redox. O Manual do Professor da coleção, também, torna claro a escolha do texto destacando que: "Como o texto pretende estimular os alunos à aprendizagem de novas ideias há alguns fatos anunciados sobre situações do cotidiano de todos nós, com o intuito de instigar o questionamento da turma sobre muitos aspectos desses fatos.” (MM, 2, p. 352)

O objetivo das atividades experimentais também é apresentado. Antecedendo ao experimento, os autores descrevem o objetivo da atividade como, por exemplo, na primeira atividade será estudado a ação do ácido ascórbico sobre o iodo. O Manual do Professor do livro destaca que o experimento foi "planejado para que o aluno tenha condição de observar um fenômeno envolvendo mudanças visuais muito nítidas e bonitas” (MM, 2, p.352). Entretanto, o objetivo dos exercícios não é declarado.

A justificativa da escolha dos textos também tem destaque no Manual do Professor da coleção. Um exemplo é o texto "Algumas informações sobre o grupo do iodo - os halogênios", os autores da coleção destacam que o texto atende a vários propósitos:

\footnotetext{
Como propósito central, apresentar a possibilidade da existência de vários valores para o estado de oxidação de uma espécie química, fato que ocorre com muita frequência, para vários elementos. [...]

Apresentar informações sobre o iodo e seus parceiros na tabela periódica, suas propriedades e seus estados físicos. [...]

Favorecer o uso e a aplicação da tabela periódica. (MM, 2, p. 353)
}

Dessa forma, o capítulo de reações redox atende satisfatoriamente às categorias do aspecto I. Já o aspecto II é parcialmente atendido. As habilidades prévias necessárias não são comentadas durante a exposição do conteúdo, nem no Manual do Professor da coleção. Quanto a auxiliar o professor na busca das ideias dos alunos, o Manual do Professor estimula que o professor colete essas informações, por meio de perguntas no início e durante a atividade "utilizando uma conversa ou uma apresentação com espaço para manifestações espontâneas ou solicitadas da turma" (MM, 2, p. 352). 
O Manual do Professor da coleção MM não destaca essa concepção, nem nenhuma outra para o professor. Isso também ocorre para os outros conteúdos da química presentes no livro.

A. Reação redox entendida como transferência de oxigênio.

A introdução aos conceitos redox é feita no segundo livro e a reação utilizada para exemplificar e conceituar as reações redox é uma experimentação com vitamina $C$, que não tem o oxigênio como agente da reação. Das reações utilizadas na explicação do conteúdo em apenas 3 delas o oxigênio é um dos agentes oxidante ou redutor, enquanto em outras 8 o oxigênio não está diretamente ligado. Nesse sentido, a abordagem da coleção MM, apesar de não abordar diretamente essa concepção, permite que o aluno expanda seus conhecimentos para explicar tal concepção.

B. Os processos de oxidação e redução podem ocorrer de forma independente.

Com relação a essa concepção, mesmo que a coleção apresente que as reações redox envolvem "a oxidação de uma substância e a redução de outra" (MM, 2, p.194), a simultaneidade do processo não é destacada. Entretanto, a interação entre as substâncias participantes das reações redox é ressaltada várias vezes durante o capítulo, a própria abordagem reforça isso ao trazer uma substância como redutora e oxidante, a depender do meio que se encontra.

$\mathrm{Na}$ introdução dos conceitos das células eletroquímicas é descrito que: "Um sistema no qual ocorre uma reação de oxidação e outra de redução, simultaneamente, é chamado de célula eletroquímica.” (MM, 2, p. 216). Porém, as reações são representadas e trabalhadas separadamente, na própria pilha a reação de oxidação é explicada de forma separada à reação de redução. As semirreações também não são compreendidas para formação de uma reação global, mas sim como fenômenos separados.

C. Os elétrons se movem através da solução sem o auxílio de íons.

A abordagem do livro traz a explicação da pilha de Daniell inicialmente sem a presença do fio elétrico e depois é explicado como funciona a pilha conectando-se o fio. Nessa abordagem os eletrodos de zinco e cobre são conectados por um fio condutor e,

[...] assim que a conexão é feita se estabelece a passagem de corrente elétrica pelo fio condutor e o voltímetro marca uma diferença de potencial de 1,1V. Ao fecharse o circuito, haverá passagem de elétrons do eletrodo de zinco para o eletrodo de cobre. (MM, 2, p. 219)

Em seguida, a representação utilizada para o circuito fechado é: 


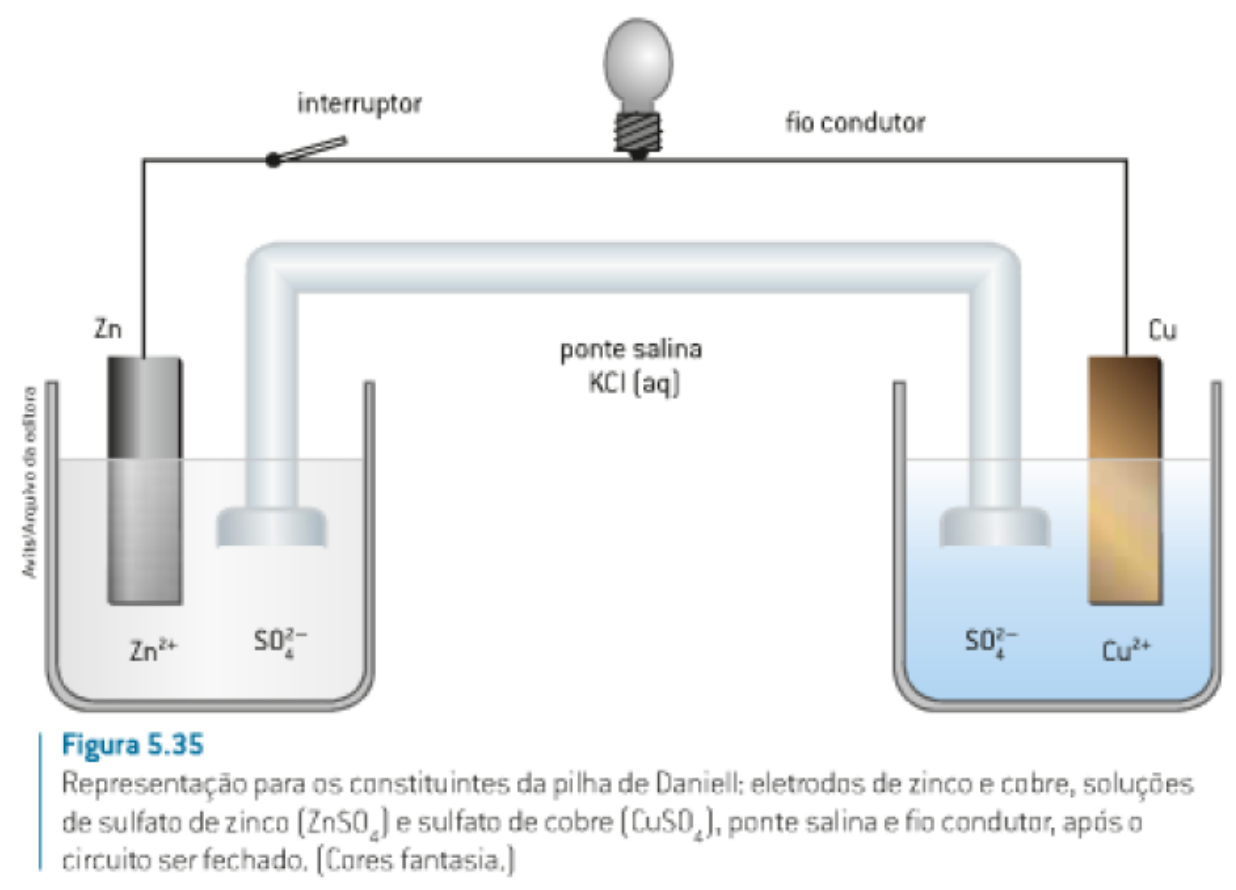

Figura 47 - Representação da pilha de Daniell na coleção MM Fonte: MM, 2, p. 219

Nesse caso não é possível interpretar onde os elétrons estão, qual caminho eles fazem e o papel deles para o funcionamento da pilha. A presença da lâmpada ainda pode causar confusão conceitual nos alunos pois o circuito não fornece energia suficiente para que uma lâmpada se acenda. Outro fator importante é que o papel dos íons nas soluções aquosas não é explicado.

D. A ponte salina fornece elétrons para completar o circuito.

O papel da ponte salina não é destacado na abordagem das pilhas, a única menção a ela refere-se à sua constituição, em: "Na pilha de Daniell, a ponte salina é um tubo em forma de "U", preenchido com algodão embebido em uma solução de cloreto de potássio $(\mathrm{KCl})$ " (MM, 2, p.217)

A variedade de fenômenos associada às reações redox é o diferencial da coleção MM. O texto de introdução destaca que as reações que serão trabalhadas são referentes às pilhas e baterias, as que ocorrem no nosso organismo e a eletrólise. O fenômeno que introduz os conceitos redox é relacionado à vitamina $\mathrm{C}$, ela é apresentada como agente redutor $\mathrm{e}$ oxidante. Posteriormente o exemplo da maçã como redutora e oxidante também é explicitado.

Outro diferencial são as atividades experimentais presentes no capítulo. Toda a conceituação é precedida por uma atividade que ilustra as reações e é utilizada na explicação do conteúdo. Além disso, das 9 atividades experimentais sugeridas, apenas 2 necessitam de 
materiais encontrados somente em laboratórios de ciências, as outras podem ser realizadas em casa sendo que o procedimento é bem claro. Nesse sentido, ambas as categorias h e i estão muito presentes no capítulo sobre reações de oxirredução.

As atividades experimentais também auxiliam na introdução de termos de forma significativa e estimulante ao aluno. Já as representações presentes são de três tipos, na primeira parte do conteúdo a representação utilizada é mais simplificada e introduz apenas o nível simbólico:

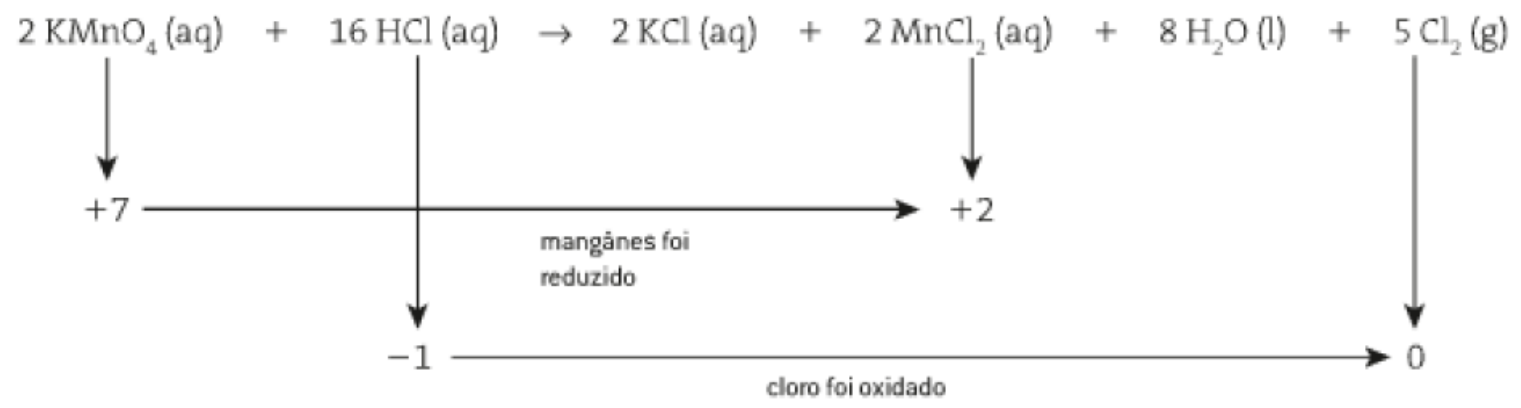

Figura 48 - Representação esquemática '1' presente na coleção MM Fonte: MM, 2, p. 199

$\mathrm{Na}$ abordagem das pilhas e eletrólise as representações escolhidas incluem os níveis macroscópicos e microscópico de duas formas diferentes:

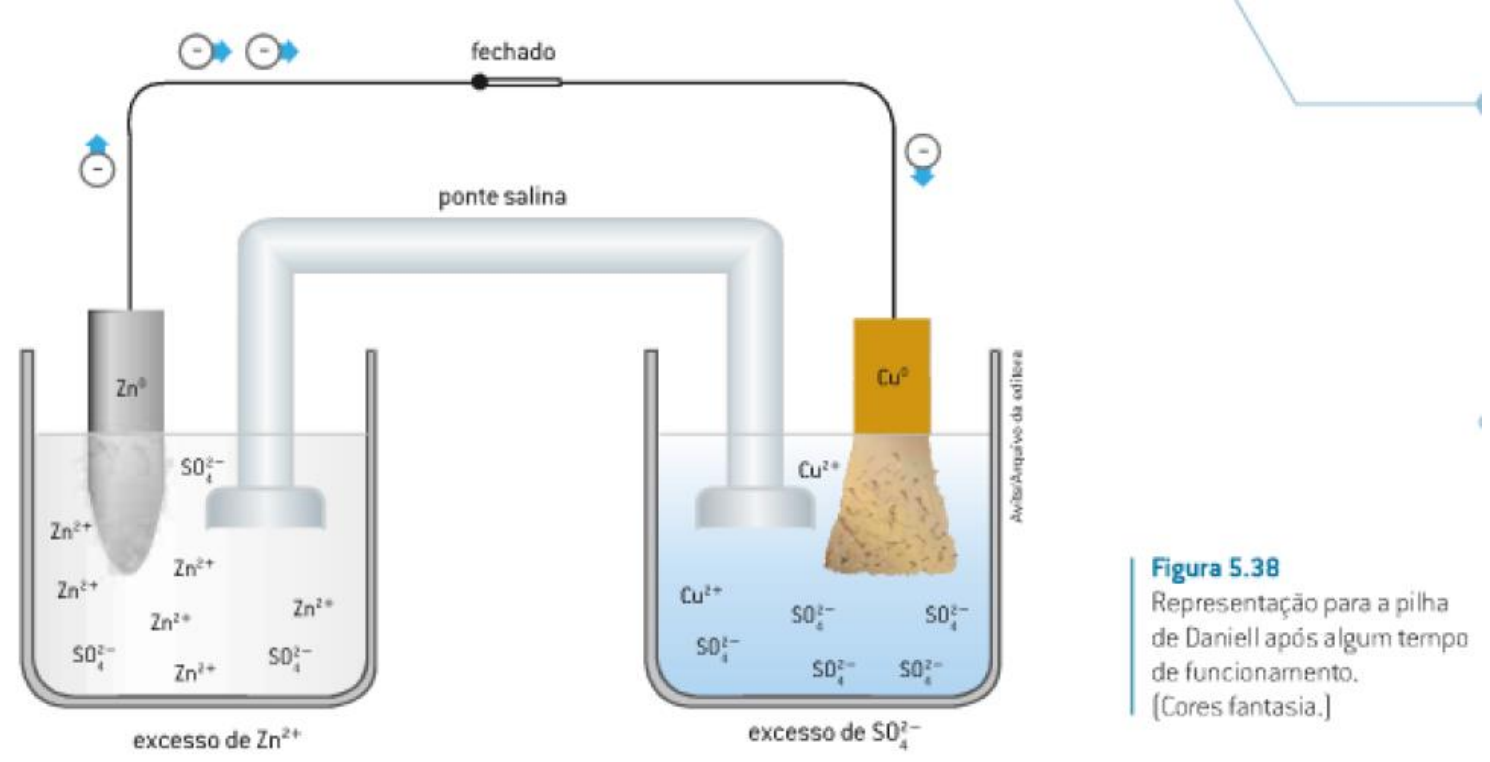

Figura 49 - Representação esquemática '2' presente na coleção MM Fonte: MM, 2, p. 221

E quanto ao nível microscópico é contemplado em representações do tipo: 


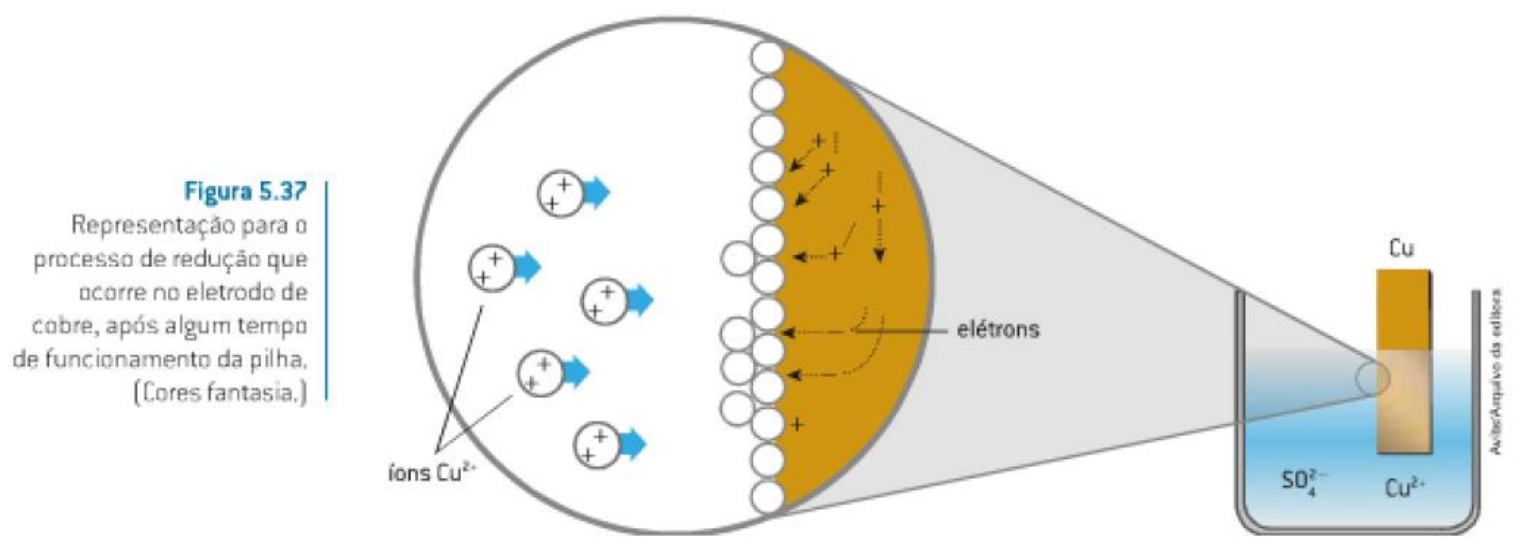

Figura 50 - Representação esquemática '3' presente na coleção MM Fonte: MM, 2, p. 220

É importante salientar que a representação da figura 49 apresenta alguns problemas. Por exemplo, o papel da ponte salina é desconsiderado e a informação 'fechado' no fio que conecta as placas de zinco e cobre pode não significar nada ao aluno. Ambas as representações não podem ser utilizadas sem mediação do professor.

O descarte de pilhas é tema de um box específico apresentado após a explicação dos constituintes das pilhas. Esse tema também é destacado no Manual do Professor da coleção quando os autores afirmam que: "Além disso, não podemos deixar de alertar os alunos para os cuidados no descarte dos materiais da pilha” (MM, 2, p.355). Há, no final do Manual do Professor uma sugestão de vídeo que também aborda o descarte e reciclagem desses materiais.

Os autores também têm a intenção que os alunos desenvolvam habilidades em outros aspectos. Isso é destacado nos trechos:

Depois da atividade a seguir, esperamos estabelecer critérios adequados para decidir como guardar uma maçã depois de partida. Além disso, acreditamos que você tomará iniciativas para fazer outras experiências relacionas à conservação de alimentos. (MM, 2, p. 207)

Outro trecho é:

Não é fácil alcançar o equilíbrio entre o conforto, a qualidade de vida e as implicações das interferências do homem na natureza. Mas é importante refletirmos sempre sobre como cada um de nós pode contribuir para esse equilíbrio. Como consumidores, por exemplo, podemos mudar nossos hábitos, responsabilizando-nos pelo descarte dos materiais, por meio da reciclagem, e diminuindo o consumo de embalagens descartáveis. (MM, 2, p. 234)

Os fenômenos, diferentes daqueles utilizados na abordagem principal, presente nos exercícios são: transformação do hipoclorito em cloreto, as baterias de marca passos, o escurecimento de objetos de prata e o uso da calda bordalesa no combate a doenças de plantas. O livro traz vários exemplos na abordagem principal, mas isso não se repete nos exercícios. A grande maioria deles é repetitiva, cujas respostas necessitam apenas 
memorização e repetição. Poucos são os exercícios que fazem relação os diversos assuntos trabalhados.

A maior parte das oportunidades que o capítulo oferece para os alunos expressarem suas ideias está logo após as atividades experimentais. Há sempre um box denominado 'Reflexão', que contém perguntas que o grupo de alunos deve refletir, escrever, ou produzir um texto. Além disso, o Manual do Professor da coleção sugere ao professor que promova uma exposição enfatizando os conceitos fundamentais abordados. Essas questões seriam importantes, também, para "verificar como estão estabelecendo relações entre os conceitos novos e os fenômenos observados" (MM, 2, p. 353)

Dessa forma, considera-se que apenas a categoria n é presente no livro, enquanto que as categorias o e p, não estão.

O material não apresenta um instrumento de avaliação único. A coleção MM segue as outras apresentadas, ou seja, a avaliação se dá na resolução dos exercícios. Todavia, os exercícios contemplam as categorias q e r. Quanto à categoria s, essa é melhor observada no Manual do Professor da coleção, em um dos trechos a preocupação com o surgimento de questões que o professor não está habituado é ressaltada:

[...] Para trabalhar com mais dados, solicite à turma, previamente, que traga pilhas usadas para a escola e incorpore pilhas diferentes (comuns e alcalinas, grandes e pequenas) aos materiais necessários. Como já prevenimos, podem surgir questões cujas soluções não serão encontradas facilmente. Instigue os alunos a procurar respostas, conversar com pessoas especializadas. (MM, 2, p. 355)

Por fim, quanto ao último aspecto, o Manual do Professor da coleção encoraja os professores a tornarem o ambiente da sala de aula mais inclusivo às experiências pessoais dos alunos e da comunidade. Um dos trechos em que isso torna-se claro é:

Esse tema envolve muitos conteúdos aos quais nós, professores, não temos acesso pelos meios tradicionais. Nossa sugestão é que você, professor dessa disciplina que envolve tanta transformação, confie na capacidade dos alunos e, com eles, mergulhe em atividades diferentes, divertidas e bonitas, transformando as aulas comuns em momentos de grande envolvimento.

[...] Assim, ao sentirem que sua participação está sendo relevante e suas ideias consideradas, uma atmosfera de respeito mútuo e de animação tem condições de se formar. (MM, 2, p. 352)

No Manual do Professor ainda podem ser encontradas várias sugestões de leitura para formação do professor que trazem outras atividades experimentais, outras abordagens e contexto para o ensino das reações redox. O material traz ainda uma lista de cursos de pósgraduação na área de ensino de ciências e química para aqueles professores que queiram complementar a formação. Apesar de não estarem diretamente relacionados à compreensão 
de ciência, tecnologia e matemática, considera-se que as informações presentes no Manual do Professor contemplam a categoria t e u.

A categoria $\mathrm{v}$ não está presente na coleção $\mathrm{MM}$, pois, não foram encontradas informações que ressaltem o contributo das mulheres e das minorias para a ciência, nem formatos alternativos para que os alunos expressem suas ideias ou sugestões de modificações para alunos com necessidades especiais.

\title{
IV. Coleção Química Cidadã (QC)
}

No capítulo dedicado ao estudo das reações redox não é transmitido nenhum objetivo ao aluno, isto é, não fica explícito a importância da aprendizagem dos conceitos e a relação com a temática escolhida. No Manual do Professor da coleção também não se encontra nenhuma orientação ao professor de como apresentar o objetivo do estudo desse conteúdo ao aluno.

Entretanto, o objetivo das outras atividades e dos recursos adicionais são escritos no Manual do Professor do terceiro livro. Para os exercícios os autores destacam que o objetivo principal é a avaliação da compreensão conceitual. O texto continua apontando que:

\begin{abstract}
Inicialmente, a ênfase está em remeter os estudantes à revisão dos conceitos mais fundamentais que foram abordados, de modo que, para a resolução, eles voltem propositadamente ao texto, para identificar os tópicos centrais. Em seguida, vêm as questões que envolvem a resolução de problemas convencionais de Química. Incluímos esses exercícios para que o aluno desenvolva a capacidade de resolver problemas, usando a linguagem da Química e interpretando os processos comuns à área. (QC, 3, p. 315)
\end{abstract}

Orientações como essas também são fornecidas para as atividades experimentais, os textos sobre história da ciência, as atividades de pesquisa e atividades em grupo. A justificativa para introdução do conteúdo redox no terceiro livro da coleção, segundo os autores, é para consolidar os estudos sobre eletricidade estudados na física e que o aluno seja capaz de compreender a complexidade dos sistemas em aplicações tecnológicas. Contudo, esse objetivo não é declarado ao aluno em nenhum momento do capítulo. Dessa forma, considerou-se que a única categoria, do aspecto I, contemplada na coleção QC é a b. Enquanto que as categorias a e c não são desenvolvidas.

As habilidades e conceitos prévios necessários ao entendimento das reações redox, não estão explícitos em nenhuma seção do capítulo, e nem aparecem no Manual do Professor da coleção.

As concepções alternativas 
Apesar de instigar o professor a conhecer e trabalhar as concepções prévias dos alunos o Manual do Professor da coleção não se refere às concepções alternativas e nem cita nenhuma em potencial para o conteúdo de reações redox.

A. Reação redox entendida como transferência de oxigênio.

A introdução do conteúdo já apresenta que historicamente as reações químicas em que o oxigênio é um dos reagentes eram denominadas reações de oxidação, e na sequência apresenta o significado do termo atualmente. Entretanto, o primeiro exemplo utilizado para abordar essas reações é a do ferro com o oxigênio, justificado pela presença desse conteúdo junto a abordagem dos metais.

Das 17 reações químicas apresentadas, em 13 delas a reação não conta com o oxigênio sendo um doador/receptor de elétrons, das 4 em que esse participa da reação, 3 delas estão concentradas no início do capítulo, na apresentação dos conceitos redox.

B. Os processos de oxidação e redução podem ocorrer de forma independente.

Apesar de não explicitar que essa é uma ideia comum, a abordagem do conteúdo auxilia na desconstrução dessa concepção alternativa, uma vez que aponta: “As reações de oxidação e de redução sempre acontecem simultaneamente: enquanto uma espécie ganha elétrons, outra espécie cede.” (QC, 3, p. 195). Essa informação também é reforçada ao trabalhar as pilhas e baterias:

Como já vimos, essas reações de oxirredução ocorrem simultaneamente, ou seja, à medida que alguns átomos se oxidam, outros se reduzem. Por isso, cada uma das reações indicadas anteriormente é denominada semirreação. (QC, 3, p. 205)

Além disso, sempre que uma semirreação é apresentada associa-se a ela a semirreação correspondente para formação da equação completa, como é o caso da formação do cloreto de sódio:

$$
\begin{gathered}
\mathrm{Na} \rightarrow \mathrm{Na}^{+}+\mathrm{e}^{-} \\
\frac{1 / 2 \mathrm{Cl}_{2}+\mathrm{e}^{-} \rightarrow \mathrm{Cl}^{-}}{\mathrm{Na}(\mathrm{s})+1 / 2 \mathrm{Cl}_{2}(\mathrm{~g}) \rightarrow \mathrm{NaCl}(\mathrm{s})}
\end{gathered}
$$

Figura 51 - Semirreações de oxidação e redução na formação do $\mathrm{NaCl}$ Fonte: QC, 3, p. 197

C. Os elétrons se movem através da solução sem o auxílio de íons.

$\mathrm{Na}$ abordagem das células eletroquímicas o fluxo de elétrons é retomado em vários momentos para justificar a formação de energia elétrica em uma pilha. Primeiramente aborda-se o fluxo de elétrons que ocorre nas soluções por meio dos íons: 
As soluções, que contém íons, também permitem a movimentação de elétrons. Quando isso acontece, íons de $\mathrm{Cu}^{2+}$, presentes na solução, recebem elétrons - são reduzidos - e depositam-se na chapa de cobre. Consequentemente, a massa de cobre metálico $(\mathrm{Cu})$ aumenta e a concentração de íons $\mathrm{Cu}^{2+}$ diminui na solução. Simultaneamente, átomos de zinco (Zn) da chapa perdem elétrons - são oxidados - e transformam-se em íons $\mathrm{Zn}^{2+}$. Consequentemente, a placa de zinco é desgastada (corroída) e a concentração de íons $\mathrm{Zn}^{2+}$ aumenta. (QC, 3, p. 206)

Logo em seguida o papel do fio metálico é trabalhado:

No processo global, os elétrons de átomos de zinco de uma cela unitária são transferidos, através do fio de cobre que une as duas placas, para os íons de cobre da outra cela unitária. A passagem de elétrons de uma cela para a outra, pelo fio de cobre, produz uma corrente elétrica que pode, por exemplo, acender uma lâmpada. (QC, 3, p. 207)

Dessa forma, a movimentação dos elétrons com os íons em solução pode ajudar a esclarecer essa concepção alternativa.

D. A ponte salina fornece elétrons para completar o circuito.

O papel da ponte salina é elucidado ao abordar o funcionamento das pilhas. Os elétrons não são citados quando na explicação da ponte salina, mas sim os íons, onde descreve-se que:

Para evitar que isso ocorra [desequilíbrio de cargas], é preciso que haja um movimento de íons entre as soluções de forma a mantê-las sempre neutras. Isso é resolvido conectando as duas soluções por meio de uma solução (...). Esse tubo, chamado de ponte salina, permite que íons migrem de uma solução para a outra, mantendo-as neutras e possibilitando a continuidade das reações de oxirredução dos metais. (QC, 3, p. 207)

Além disso, ao trabalhar com as cargas da ponte salina é sempre remetido a um íon, por exemplo, num resumo junto à representação da célula eletroquímica destaca-se que o excesso de cargas é controlado pelos íons da ponte salina: "Excesso de cargas negativas dos ânions $\mathrm{SO}_{4}{ }^{2-}$, da semicela da direita, migram pela ponte salina para a semicela da esquerda, em que há excesso de cátions $\mathrm{Zn}^{2+}$." (QC, 3, p. 207)

Em virtude do exposto no Manual do Professor da coleção, considera-se que apenas a categoria fé presente. Dessa forma, o aspecto II é parcialmente atendido.

Já as categorias que indicam a presença do aspecto III, nem estão presentes. Toda a abordagem dos conceitos é relacionada aos metais, enquanto que os únicos exemplos diferenciados fornecidos são: As lentes fotossensíveis e formação do cloreto de sódio. E esses ainda não estão ligados diretamente às ideias-chave, são somente exemplificações.

Quanto às duas atividades experimentais presentes, a lista de materiais necessários é encontrada somente em laboratório de química, e é necessária a condução do professor para realização da atividade. É muito difícil considerá-las como experiências "mão-na-massa" à medida que só ilustram os fenômenos. 
Como todo o conteúdo é apresentado e posteriormente exemplificado com os fenômenos, ou seja, as ideias e experiências, não se considera que a categoria $\mathrm{j}$ esteja presente. Para que a mesma seja considerada é necessário que os termos científicos sejam apresentados conjuntamente ao fenômeno que se aplica, mas isso não acontece. Todos os termos são conceituados e depois relacionados a um fenômeno específico.

As representações distribuídas ao longo do capítulo são diferentes para cada seção. $\mathrm{Na}$ primeira parte uma única representação tenta demonstrar microscopicamente a transferência eletrônica, conforme a figura 52:

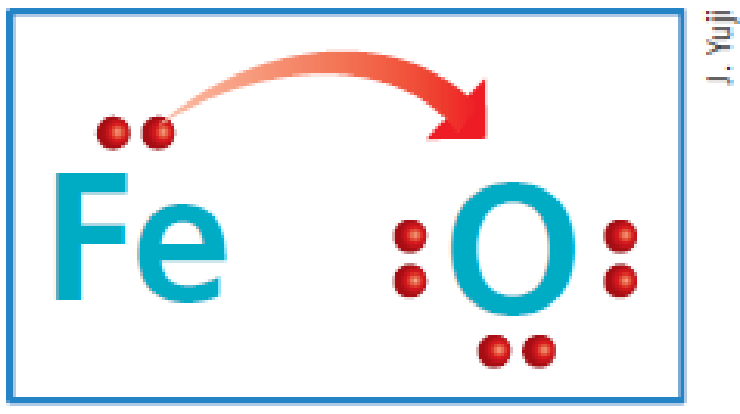

\section{$\Delta$ Quando o ferro reage com o oxigênio do ar, há transferência de elétrons de átomos de ferro para átomos de oxigênio.}

Figura 52 - Representação esquemática '1' presente na coleção QC

Fonte: QC, 3, p. 195

Essa representação pode ser confusa para o aluno e deve ser utilizada somente com mediação do professor. A outra representação para o conteúdo de pilhas é destacada na figura 53:

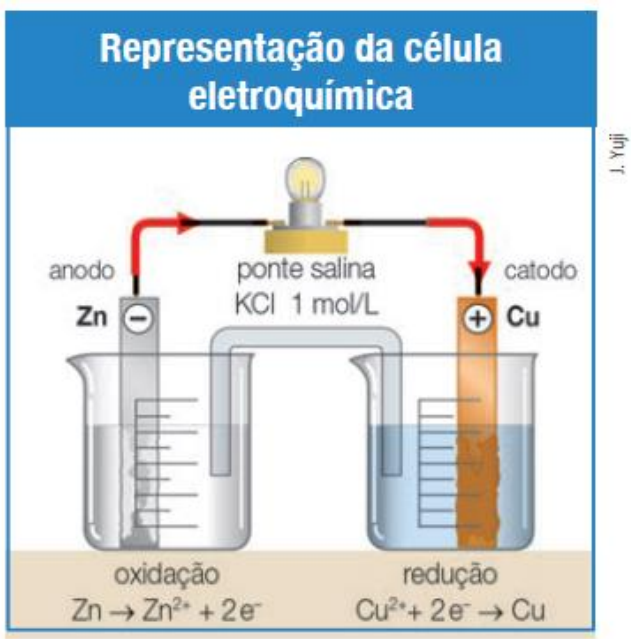

- Em uma célula eletroquímica, ocorrem reações de oxirredução, ou seja, as chamadas semirreações ou semicelas, compostas por uma placa do metal mergulhada em sua solução. $\mathrm{Na}$ semicela de zinco, há a oxidação do Zn, e na semicela de cobre, ocorre a redução dos íons $\mathrm{Cu}^{2+}$. Excesso de cargas negativas dos ânions $\mathrm{SO}_{4}^{2-}$, da semicela da direita, migram pela ponte salina para a semicela da esquerda, em que há excesso de cátions $\mathrm{Zn}^{2+}$. Esse movimento de cargas pela ponte salina fecha o circuito elétrico. 
Figura 53 - Representação esquemática '2' presente na coleção QC

Fonte: QC, 3, p. 207

Essa representação também pode dificultar a compreensão dos conceitos, por exemplo, ao abordar o papel da ponte salina. Na figura é difícil identificar o que é a ponte salina, e porque ela é constituída de $\mathrm{KCl}$, ou seja, qual a função dos íons potássio e cloreto. A abordagem do texto também não traz nenhuma informação que possa sanar essas possíveis dúvidas, segundo o texto a ponte salina "permite que íons migrem de uma solução para a outra, mantendo-as neutras e possibilitando a continuidade das reações de oxirredução dos metais." (QC, 3, p. 207). Os íons em solução também são desconsiderados nesse tipo de representação.

Quanto ao uso dos conceitos redox, procurou-se a temática de descarte das pilhas e baterias. Essa é contemplada em um box intitulado 'Atitude Sustentável', que ainda apresenta questões que objetivam a formação cidadã dos alunos. Dois exemplos das questões apresentadas são: "Como a indústria de pilhas e baterias pode contribuir para eliminar ou diminuir a quantidade de metais pesados presentes nesses produtos?" e "Proponha uma maneira viável de recolhimento de pilhas e baterias para não jogar esses materiais diretamente no lixo.” (QC, 3, p. 237). Nenhuma outra aplicação direta do conteúdo foi identificada.

A abordagem do conteúdo segue a temática dos metais durante todo o capítulo. $\mathrm{Na}$ grande maioria dos exercícios isso se repete, os fenômenos diferentes apresentados são: a fotossíntese, oxidação do metanol e o bafômetro. Entretanto, são só três exemplos que fogem da temática contra 117 que apresentam os metais.

Todos os dados permitem inferir que as categorias $\mathrm{j}, \mathrm{k} 1 \mathrm{e}$ m não estejam presentes no capítulo redox da coleção QC. Isso indica que o aspecto IV não é considerado, e a forma de apresentação do conteúdo não seria a mais adequada.

As perguntas do box "Pare e Pense" são sugestões para que o aluno expresse suas ideias, no entanto, o uso das perguntas é útil somente no início da abordagem do conteúdo. Isso porque as perguntas, além de serem muito simples, são respondidas na sequência da apresentação do conteúdo, e podem ser facilmente ignoradas sem a mediação do professor. Nenhuma informação também indica que as categorias o e p estejam presentes no livro. Dessa forma, o aspecto $\mathrm{V}$ também não é contemplado na coleção QC.

Os exercícios refletem o conteúdo abordado e estão alinhados com as ideias-chaves. A avaliação também é destaque no Manual do Professor da coleção que descreve qual a concepção de avaliação dos autores e acrescentam: 
O ideal é que o estudante seja avaliado não apenas pela entrega de relatórios dos experimentos, das respostas dos exercícios ou da realização de trabalhos escolares sobre os temas abordados, mas também pelo seu engajamento nos debates em sala de aula, pela sua participação nas atividades. Trata-se de uma incumbência talvez trabalhosa para o professor, mas a adoção de instrumentos de autoavaliação de forma participativa da turma, com discussão reflexiva e orientada, poderá auxiliar no processo. (QC, 3, p. 294)

Ainda segundo o Manual do Professor da coleção, a sugestão de direcionamento para modificação das atividades é estabelecer um diálogo com os alunos. Os autores colocam que, a partir do que os alunos pensam o professor "poderá intervir para dar suporte para o entendimento em conjunto do conceito em questão" (QC, 3, p. 312). Portanto, as categorias do aspecto VI são encontradas.

Quanto ao último aspecto, o suporte ao conteúdo do professor é apresentado sob diferentes formas. Os autores trazem uma obra didática que orienta os princípios didáticopedagógicos orientadores da coleção, na seção 'Atualização do professor'. Essa seção traz ainda uma lista de eventos da área de ensino de química. No apoio à compreensão de ciência, matemática e tecnologia dos professores, o Manual do Professor da coleção traz uma lista enorme de leituras complementares tanto sobre o ensino de química, quanto sobre a química.

A preocupação em buscar um ambiente com mais participação dos alunos é nítida em vários trechos do Manual do Professor da coleção:

As propostas mais avançadas de ensino de Química têm como um dos pressupostos a necessidade do envolvimento ativo dos alunos nas aulas, gerando um processo interativo professor/estudante, em que os horizontes conceituais dos estudantes sejam contemplados. Isso significa criar oportunidades para que eles expressem como veem o mundo, o que pensam, como entendem os conceitos, quais são as suas dificuldades etc. Pensando dessa maneira, procuramos incorporar, ao nosso material, atividades de ensino que estimulem o estudante a manifestar as suas ideias, o que, por sua vez, permitirá ao professor tomar conhecimento de suas concepções sobre o tema em estudo. A própria abordagem temática tem também esse papel, uma vez que ela traz, para a sala de aula, temas da vivência do aluno, nos quais o professor pode explorar seus conhecimentos prévios e suas experiências culturais. (QC, 3, p. 300)

As atividades citadas são adoção de dinâmicas, vídeos, visitas técnicas e atividades em grupo de conscientização cidadã e ambiental. No próprio capítulo de reações redox as atividades de participação cidadã e atitude sustentável são bastante presentes. Apesar da maioria dos indicadores da categoria v não estarem presentes e, portanto, a categoria não é contemplada, considera-se que o aspecto VII é um dos mais presentes no capítulo de reações redox da coleção QC. 


\section{Coleção Ser Protagonista (SP)}

As duas páginas referentes ao conteúdo redox, no primeiro livro da coleção, não descrevem qual o objetivo do estudo dessas reações. Já no segundo livro da coleção, na página de introdução os autores destacam as reações que serão estudadas, exemplificando pela geração de energia nas pilhas e baterias, propriedades antioxidantes da vitamina $C$, corrosão e obtenção de metais. Os autores ainda acrescentam que essas reações estão relacionadas aos carros elétricos, o que traria mais motivação no estudo das reações. Por fim, o objetivo é declarado em: "Neste capítulo, você vai saber como reconhecer reações de oxirredução, balancear as equações que as representam e investigar alguns exemplos delas em seu dia a dia." (SP, 2, p.184)

A relação entre as atividades e exercícios, bem como os objetivos deles, não são apresentados. A justificativa da sequência de aulas também não se destaca, porém, é coerente com as ideias-chave. Portanto, conjectura-se que as categorias a e c estejam presentes.

Os conhecimentos prévios não são explicitados. Entretanto, são incluídos box que discorrem sobre os conhecimentos prévios, como é o caso do conceito de eletronegatividade presente em um box denominado 'Você se lembra?'. Nesse box o conceito de eletronegatividade é retomado e destacado na tabela periódica.

As concepções alternativas

A. Reação redox entendida como transferência de oxigênio.

A presença do oxigênio nas reações redox não é destacada no livro 1 da coleção SP, entretanto, um box, na página em que se apresenta as reações de oxirredução, relaciona a importância da descoberta desse elemento com a evolução do entendimento das reações redox. No livro 2, livro que abrange a maior parte do conteúdo redox, a primeira reação envolvendo a transferência de elétrons que é apresentada é a reação entre o ferro e o cobre. Utilizando-se essa reação como exemplo define-se os termos oxidação, redução, transferência de elétrons, agente redutor e oxidante. Porém, a apresentação dos conceitos de número de oxidação e sua relação com a transferência eletrônica, é desenvolvida utilizandose a reação de formação do ácido acético como exemplo, reação essa que envolve o oxigênio.

Além disso, das 40 equações apresentadas ao longo dos três livros, em apenas 15 delas o oxigênio é protagonista na reação. Mesmo nas reações redox orgânicas, onde esperase que o oxigênio esteja muito presente, as oxidações por meio do oxigênio são menos presentes que aquelas que este não participa.

B. Os processos de oxidação e redução podem ocorrer de forma independente. 
Na coleção essa concepção é abordada em um box na introdução do conteúdo, no livro 2. O título do box já é bastante claro e traz: "Oxidação e redução: processos concomitantes", e contextualiza a reação de formação da ferrugem explicitando que "Se houve oxidação, entretanto, necessariamente ocorreu também uma redução.” (SP, 2, p. 187).

Outro ponto a acrescentar é que as semirreações de oxidação são sempre trabalhadas juntas, quando se traz uma reação de oxidação esta é acompanhada da reação de redução, conforme observado na figura 54.

\section{Ânodo (-): $\mathrm{Zn}(\mathrm{s}) \longrightarrow \mathrm{Zn}^{2+}(\mathrm{aq})+2 \mathrm{e}^{-} \quad$ (semirreação de oxidação) \\ Cátodo (+): $\mathrm{Cu}^{2+}(\mathrm{aq})+2 \mathrm{e}^{-} \rightarrow \mathrm{Cu}(\mathrm{s})$ (semirreação de redução)}

Figura 54 - Semirreações de oxidação e redução na coleção SP Fonte: SP, 2, p. 200

Em geral, a abordagem do conteúdo trabalha sobre a equação global da reação, sendo as semirreações explicativas da reação global. Apenas na abordagem dos diferentes tipos de pilhas existentes que há uma exemplificação do tipo de reação que ocorre em cada um dos polos da pilha.

Além disso, na abordagem das pilhas, especificamente da Pilha de Daniell, ao explicar como ocorre a transferência eletrônica nas duas semicélulas, retoma-se a simultaneidade do processo, conforme observado em:

No eletrodo negativo (ânodo) da pilha, ocorre o processo de oxidação do zinco, liberando elétrons que são transferidos pelo fio metálico para o eletrodo positivo (cátodo). Esses elétrons participam do processo de redução dos cátions $\mathrm{Cu}^{2+}$, depositando o cobre metálico no polo positivo. Os dois processos são simultâneos. (SP, 2, p. 200) (grifo nosso)

C. Os elétrons se movem através da solução sem o auxílio de íons.

O livro não aborda de forma especifica essa concepção alternativa. As pilhas são abordadas num tópico que trata sobre as reações e a geração de corrente elétrica, sendo o papel do fio condutor é primeiramente definido como um dos meios para fazer com que as duas semicélulas estejam em contato e possibilitar que os elétrons circulem.

Na primeira representação da Pilha de Daniell utilizada (figura 55), o fluxo dos elétrons não é demonstrado, apenas o sentido dos íons na ponte salina. Contudo, ao explicar o funcionamento do eletrodo padrão de hidrogênio o sentido dos elétrons no fio é destacado por meio de uma seta: 


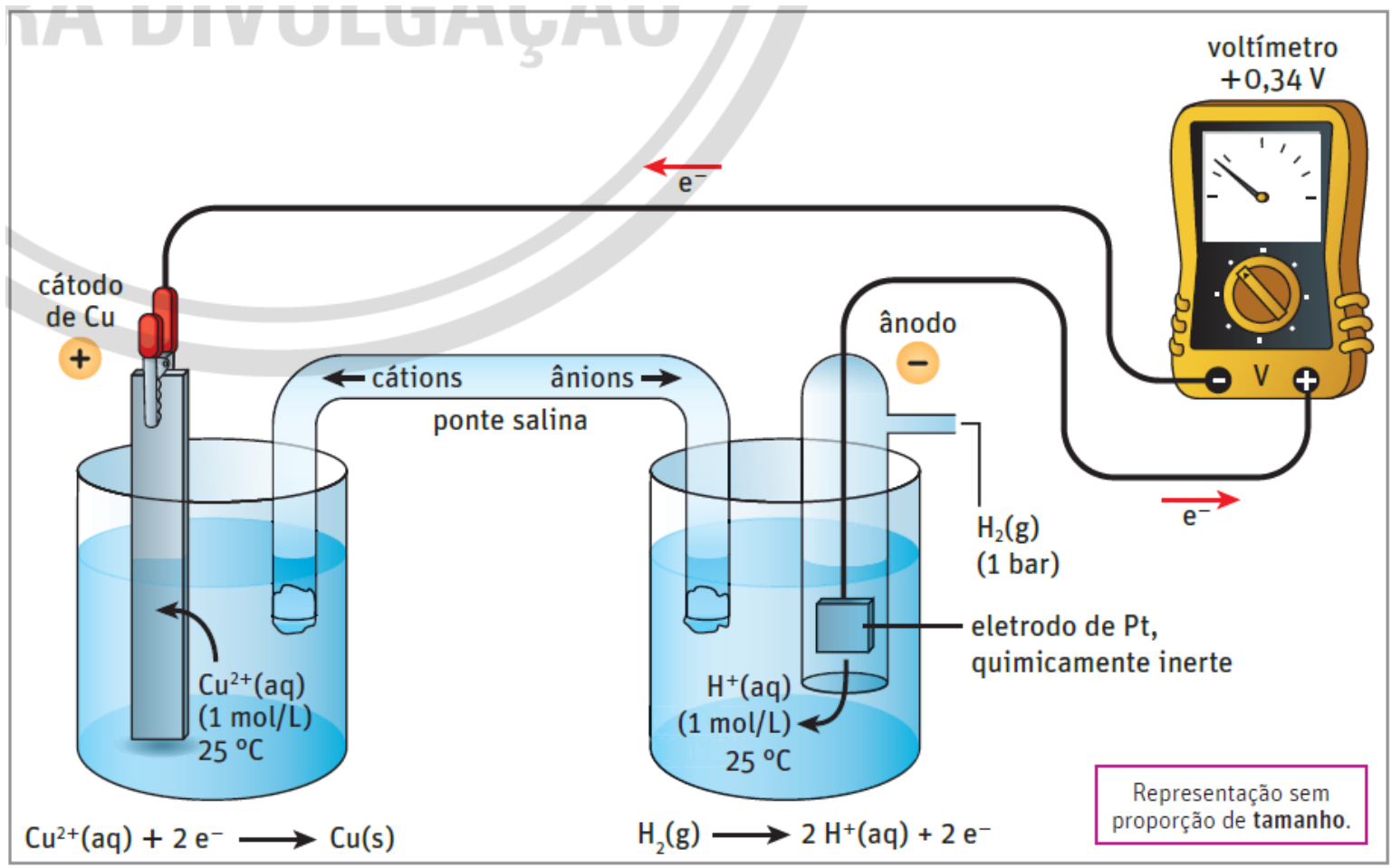

Figura 55 - Representação da Pilha de Daniell na coleção SP

(SP, 2, p. 201)

A circulação dos elétrons pelo fio externo é explicada especificamente para a reação da Pilha de Daniell, onde é abordado que: "No eletrodo negativo (ânodo) da pilha, ocorre o processo de oxidação do zinco, liberando elétrons que são transferidos pelo fio metálico para o eletrodo positivo (cátodo)"(SP, 2, p. 200) e retomado em: “os elétrons liberados pelo zinco circulam pelo fio elétrico, antes de serem incorporados pelos cátions $\mathrm{Cu}^{2+}(\mathrm{aq})$ " ( $\mathrm{SP}, 2, \mathrm{p}$. 200)

D. A ponte salina fornece elétrons para completar o circuito.

A ponte salina como componente da pilha é trazida como um dispositivo que permite o contato elétrico entre as semicélulas e que permite a circulação de íons, garantindo a neutralidade de carga elétrica em cada uma das células. A forma como a ponte salina atua é também retomada após a representação da pilha, onde descreve-se que:

Os íons presentes na ponte salina mantêm a neutralidade das soluções. No ânodo, o aumento da concentração de cátions $\mathrm{Zn}^{2+}(\mathrm{aq})$ requer um fluxo de ânions $\mathrm{SO}_{4}{ }^{2-}$ (aq). No cátodo, a diminuição da concentração de $\mathrm{Cu}^{2+}(\mathrm{aq})$ requer um fluxo de cátions, $\mathrm{K}^{+}(\mathrm{aq})$. Dessa forma, o circuito elétrico está fechado. (SP, 2, p. 200)

Nas demais representações utilizadas coloca-se uma seta para indicar o sentido do fluxo de íons na ponte salina e o papel desse dispositivo não é retomado.

A variedade de fenômenos explicados pelo processo de oxirredução é destacada já na apresentação do capítulo no livro 2, conforme apontado. $\mathrm{O}$ texto introdutório ainda exibe outros fenômenos, como, por exemplo, a fermentação, respiração aeróbia, bafômetro, lentes 
fotossensíveis e ação antioxidante da vitamina C. Essa variedade também é demonstrada em todo o capítulo, seja na explicação dos conceitos, ou em box distribuídos ao longo do texto. Os livros 1 e 3 seguem a mesma orientação, apresentando os fenômenos de corrosão, combustão, fabricação e reciclagem de plásticos, e o processo de fumigação.

Das três atividades experimentais, duas delas são experiências "mão-na-massa", enquanto que a de eletrólise necessita de materiais disponíveis em laboratório. No entanto, todas elas são de fácil entendimento e não necessitam de mediação do professor na condução da atividade. Isso indica que as categorias h e i são abrangidas nos três livros em que as reações redox são abordadas.

Os conceitos apresentados são todos ligados a um fenômeno específico, e em alguns casos mais de um exemplo é apresentado. Por exemplo, na conceituação das reações de oxidação utiliza-se como experiência a reação de formação da ferrugem, na sequência do texto a oxidação do cálcio e magnésio concluem o raciocínio apresentado. Essa abordagem auxilia na significação do conceito.

Os tipos de representações presentes no livro são muito variados. Inicialmente no livro 1 da coleção a representação utilizada é demonstrada na figura 56.

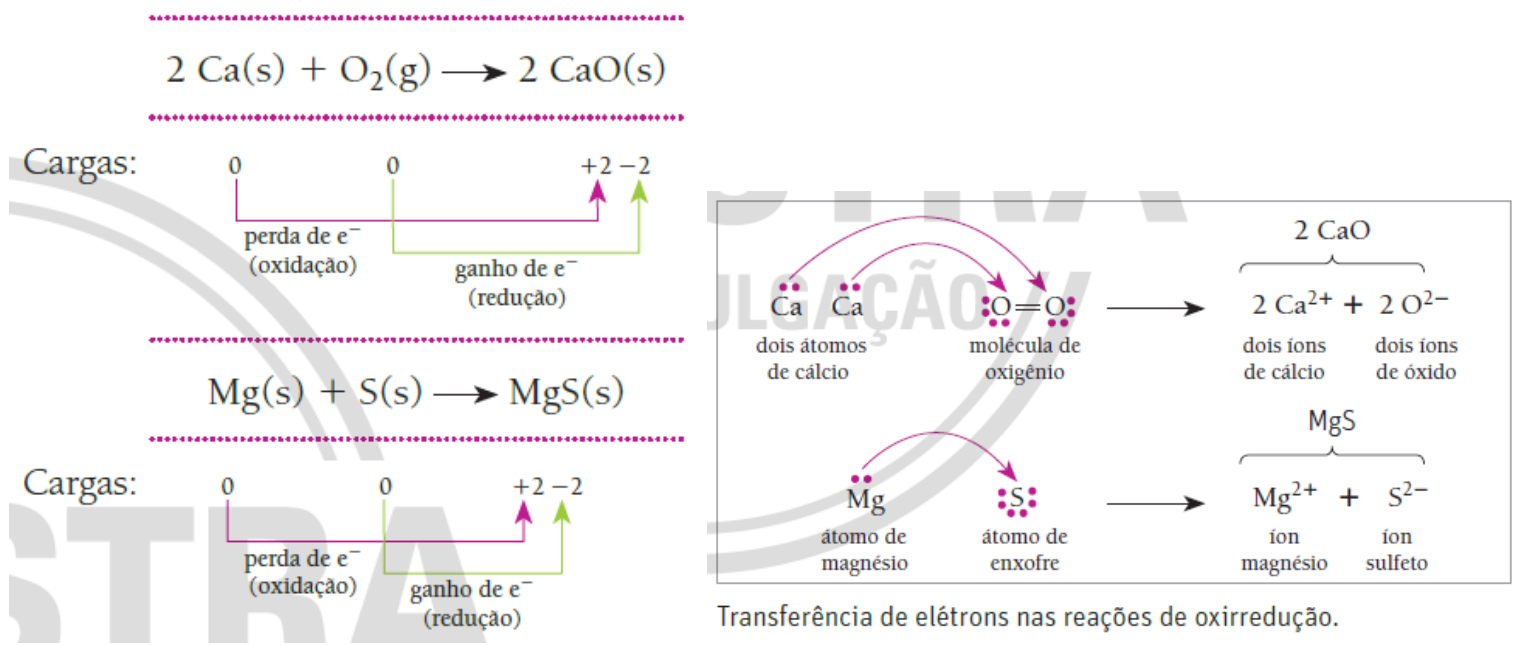

Figura 56 - Representação esquemática ' 1 ' presente na coleção SP

Fonte: SP, 1, p. 185.

No livro 2 da coleção as representações incluem a variação do Nox da reação redox, conforme observa-se na figura 57. 


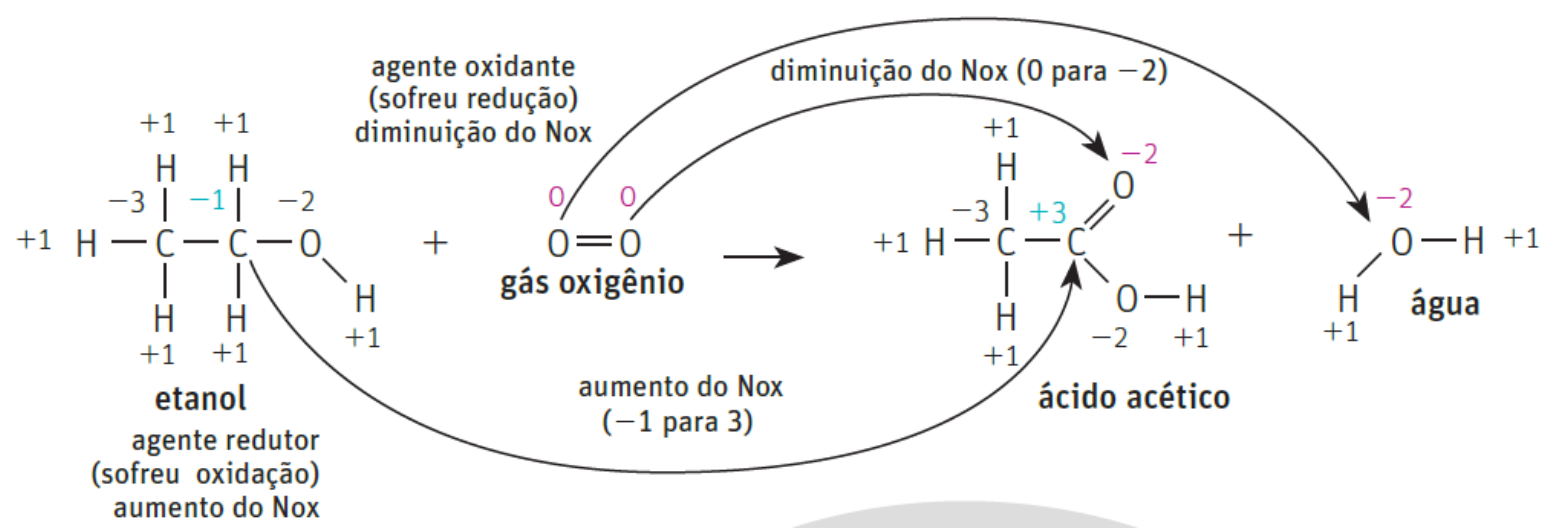

Figura 57 - Representação esquemática '2' presente na coleção SP

Fonte: SP, 2, p. 187.

No caso das pilhas também são incluídas representações específicas:

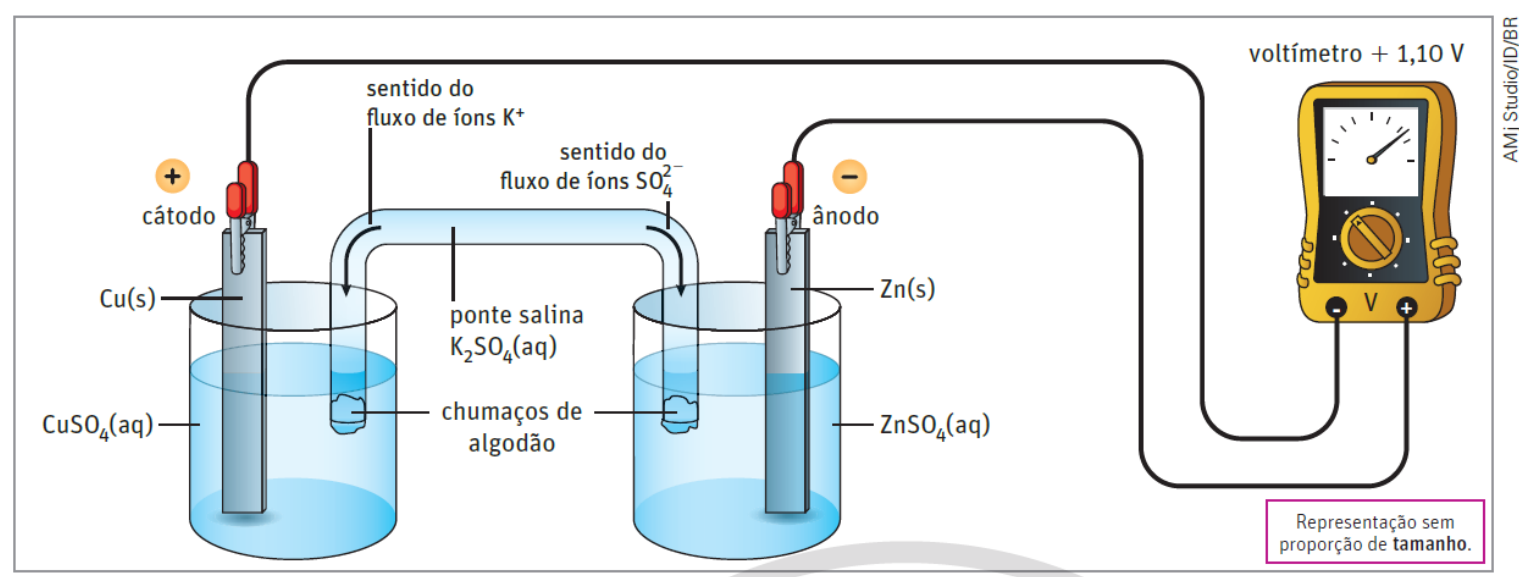

Esquema da pilha de Daniell. Representação em cores-fantasia.

Figura 58 - Representação esquemática '3' presente na coleção SP Fonte: SP, 2, p. 200.

Esse tipo de representação pode causar algumas dificuldades conceituais nos livros, pois: ambos os eletrodos de zinco e cobre são representados com a mesma coloração e os íons em solução não são considerados. A primeira representação microscópica aparece na abordagem da eletrólise, apresentada na figura 59. 


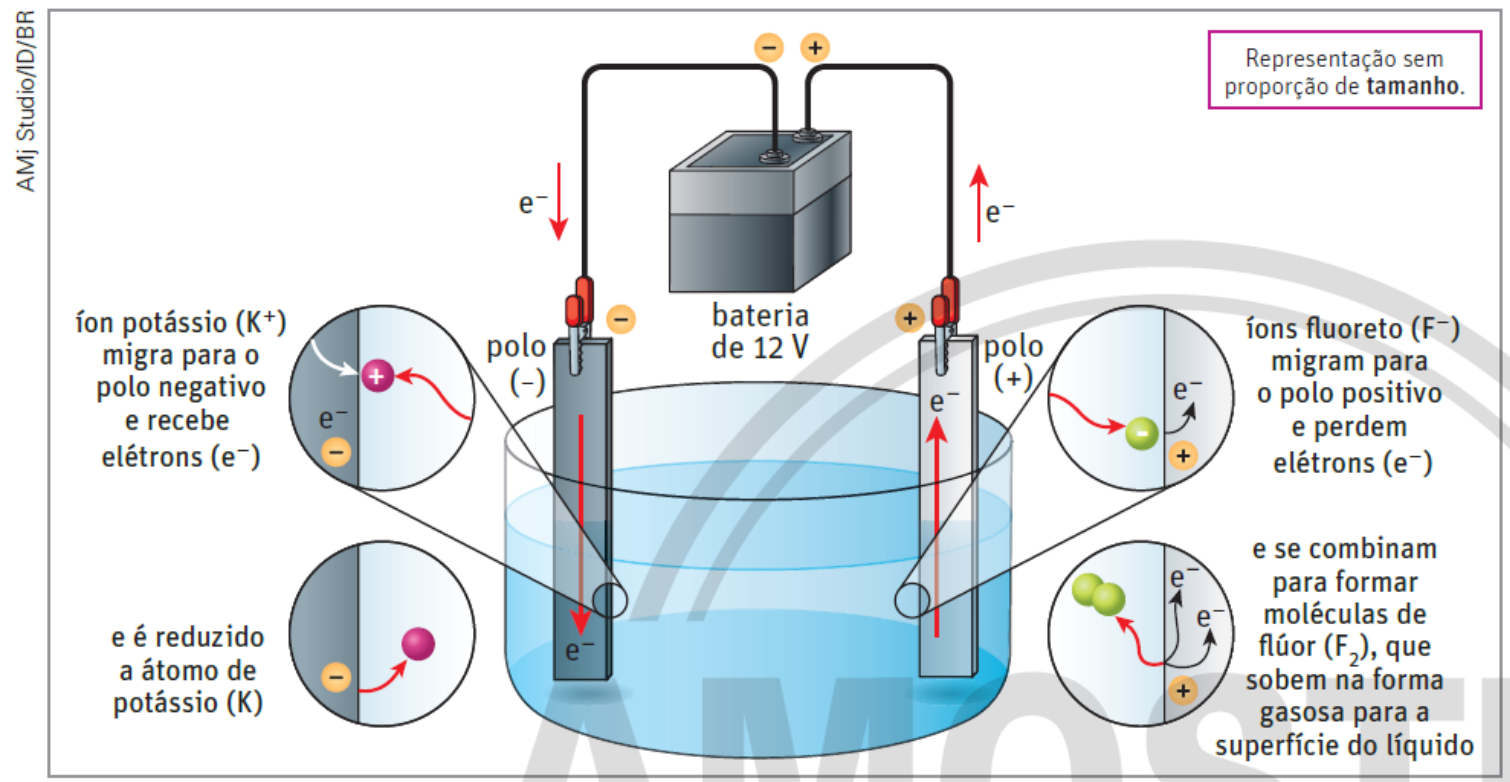

Esquema da eletrólise ígnea do KF. em cores-fantasia.

Figura 59 - Representação esquemática '4' presente na coleção SP

Fonte: SP, 2, p. 222.

No livro 3 da coleção, que aborda as reações orgânicas, as representações são mais simplificadas, se comparadas às utilizadas nos outros capítulos, conforme pode ser observado na figura 60.

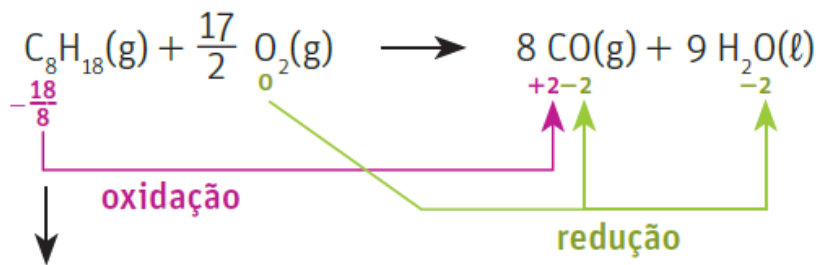

oxidante: $\mathrm{O}_{2}$ redutor: $\mathrm{C}_{8} \mathrm{H}_{18}^{2}$

Nox médio do carbono no iso-octano.

Figura 60 - Representação esquemática '5' presente na coleção SP Fonte: SP, 3, p. 165.

Quanto ao uso do conhecimento, o descarte das pilhas e baterias é abordado em um box específico denominado 'Ação e Cidadania'. Alguns outros exemplos também podem demonstrar a utilidade dos conceitos trabalhados, como nos trechos:

As pilhas e baterias comerciais devem apresentar tamanho, formato, massa e desempenho adequados para o equipamento específico. Deve-se estar atento para evitar acidentes, danos ao ambiente ou ao aparelho. (SP, 2, p.204)

Portanto, em latas amassadas, é possível encontrar ferrugem no produto que ela contiver, comprometendo sua qualidade. (SP, 2, p. 213)

Para limpar objetos de cobre ou prata pode-se colocá-los em uma panela com solução de bicarbonato de sódio e papel-alumínio, aquecendo-os levemente. (SP, 2, p. 213)

As situações presentes nos exercícios da coleção são tão variadas quanto às utilizadas na abordagem do conteúdo. O livro 1 não apresenta exercício, mas nos livros 2 e 3 os fenômenos citados são: titulação do permanganato de potássio, obtenção de metais, 
enchimento de airbag, combustíveis para veículos espaciais, calda bordalesa no combate a doenças em plantas, produção de cloreto de sódio, utilização do formol, chuva ácida, entre outros.

Portanto, pode-se afirmar que as categorias j, k, 1 e m estão presentes e são bem desenvolvidas na coleção. Com isso, apontamos que o aspecto IV é muito promovido, ou seja, a coleção aborda as ideias-chaves de maneira acessível e inteligível.

As categorias $n$, o e p, determinam o quanto o material promove a evolução do pensamento dos estudantes. Para isso, os livros da coleção deveriam incentivar os alunos a expressar suas ideias sobre o assunto, orientar o raciocínio dos alunos à construção do conhecimento e incentivar a reflexão sobre o que aprenderam. Nenhum desses aspectos foi observado nos livros da coleção SP.

No início do capítulo redox do segundo livro da coleção, há questões que intentam a reflexão sobre os carros elétricos. Essas são: “1. Existem incentivos no Brasil para o desenvolvimento e comercialização de carros híbridos e elétricos? Discuta a relevância de incentivos nesse setor.”, “2. Que limitações existem para a comercialização massiva de carros elétricos atualmente?” e "3. Quais são as vantagens do carro elétrico, em comparação com o carro de combustão interna, em termos de emissão de poluentes?”. Entretanto, questões como essa não se repetem ao longo da abordagem do conteúdo e não se referem diretamente aos conceitos redox. Em virtude disso, não se pode afirmar que estejam presentes as categorias $\mathrm{n}, \mathrm{o}$ e $\mathrm{p}$.

A avaliação do aprendizado dos alunos se dá mediante resolução de exercícios. Ao final das seções principais do capítulo, há uma seção denominada 'Vestibular e Enem' que faz um recorte das principais questões presentes nos vestibulares nacionais. Para resolução dessas questões é necessária uma retomada de todo o conteúdo apreendido ao longo do capítulo, sendo um meio de avaliação. Como as questões retomam o conteúdo e refletem as ideias-chaves, considera-se que a categoria q está presente. Como a dificuldade das questões é aumentada ao longo do capítulo, considera-se que esteja presente a categoria r.

O aspecto VII. Melhorando o ambiente de aprendizagem da ciência, não pôde ser avaliado durante a escrita desse trabalho, pois está diretamente relacionado ao conteúdo presente no Manual do Professor da coleção.

\section{Coleção Vivá (VV)}

A coleção VV distribui o conteúdo redox ao longo dos livros dos três anos. No livro do primeiro ano um quadro destaca que o capítulo irá ajudar o aluno a compreender: 
oxidação e redução, número de oxidação, e outros. Após o texto de introdução um trecho declara o objetivo de forma mais clara:

Neste capítulo, vamos estudar processos químicos semelhantes aos que ocorrem quando o ferro enferruja ou quando objetos de cobre se alteram, na cozinha ou em outros ambientes. Tais processos têm muita relevância, tanto do ponto de vista de nossa saúde quanto econômico e ambiental (VV, 1, p. 207)

Já no livro do segundo ano, o objetivo declarado é especificado no texto introdutório como: "Nesta unidade, vamos estudar os aspectos envolvidos na relação entre reações químicas que produzem energia elétrica e o processo inverso, isto é, a energia elétrica propiciando reações químicas.” (VV, 2, p. 216). O mesmo quadro destaque do livro 1, também está presente no livro 2. O propósito também é declarado num trecho após o texto de introdução, e de forma mais motivadora ao aluno:

\begin{abstract}
Neste capítulo, vamos ver como pilhas e baterias são construídas para entender de que modo os processos em que há transferência de elétrons podem gerar energia elétrica para múltiplas finalidades. Também vamos explorar questões eletroquímicas de importância socioeconômica e ambiental, como o fato de, à beira-mar, ser mais fácil a formação de ferrugem e os recursos para evitar que estruturas metálicas sejam danificadas por esse processo (VV, 2, p.219)
\end{abstract}

No livro referente ao terceiro ano só é declarado que serão estudadas com detalhes alguns tipos de reações orgânicas de oxirredução. Além disso, no Manual do Professor de todos os livros as competências e habilidades desenvolvidas são expostas.

Os objetivos dos exercícios não são expostos. Em comparação, o objetivo das atividades experimentais é exposto sempre em forma de pergunta a ser respondida. Já as questões de pesquisa, ou as questões que estão presentes ao fim de um texto específico, não são relacionadas com as outras atividades e nem tem um objetivo explícito.

A sequência escolhida para evolução do conteúdo é lógica, ainda mais considerando a distribuição do conteúdo ao longo dos três anos. Em virtude disso, julgou-se que as categorias a, b e c estejam presentes na coleção VV. Sendo a categoria b presente parcialmente.

Os conhecimentos prévios que os alunos necessitam para o entendimento das reações redox são explicitados apenas no Manual do Professor da coleção. No entanto, os autores da coleção demonstram consideração com o conhecimento que o aluno já possui, isso é presente nos parágrafos introdutórios dos capítulos, como, por exemplo: "Vamos aproveitar uma série de conhecimentos que você já tem e o que observa em seu cotidiano para identificar processos químicos que envolvem oxidação e redução." (VV, 1, p. 208) e em "Vale relembrar como ocorrem as transformações em que os elétrons são transferidos de uma espécie para outra." (VV 2, p. 219). 
No Manual do Professor da coleção, nas orientações pedagógicas de cada capítulo, a primeira seção é denominada 'pressupostos'. Para o livro 1 os pressupostos necessários seriam:

Matemática básica: operações com números racionais e média aritmética. Substâncias (simples e compostas); metais e não metais.

Fórmulas de compostos iônicos e moleculares; estrutural e de Lewis. Reações químicas básicas: equações.

Eletronegatividade: conceito, uso da tabela de Pauling. Conceito operacional de solubilidade. (VV, 1, p. 362)

Os pressupostos especificados para a abordagem no livro 2, são:

Física: noções de eletrodinâmica, geradores, receptores, circuitos elétricos. Eletrólitos e não eletrólitos.

Oxirredução: conceito, oxidante, redutor, semiequação de oxidação e de redução, reações na forma iônica. (VV, 2, p. 366)

Além disso, os autores incentivam os professores a relembrarem com os alunos conceitos anteriores trabalhados, ressaltando um estudo em que é apontado a importância de mapear os conhecimentos prévios dos alunos antes da introdução de novos conceitos. Isso é particularmente importante, pois, o conteúdo é iniciado no livro 1 da coleção, sendo aprofundado no livro 2. Nesse sentido, o Manual do Professor explicita que "pode ser necessário que o professor faça uma revisão desses conceitos e proponha perguntas aos alunos, ao longo das aulas, de modo que esses conceitos de tornem claros.” (VV, 2, p. 366)

As concepções alternativas

O Caderno de Apoio Pedagógico da coleção VV aborda diretamente as dificuldades dos alunos nos vários conceitos da eletroquímica. O Manual do Professor do primeiro livro da coleção traz poucas informações sobre as reações redox visto que essas reações estão inseridas num capítulo maior que trata todos os tipos de reações químicas. A dificuldade associada à terminologia química é citada, mas sem relação direta com as concepções alternativas aqui investigadas. O mesmo acontece no Manual do Professor do terceiro livro da coleção, que não aborda diretamente essas concepções alternativas.

No Manual do Professor do segundo livro da coleção outras dificuldades são apresentadas e que envolvem os conceitos trabalhadas na disciplina de física, como a corrente elétrica. Segundo o Manual do Professor da coleção os alunos podem ter dificuldade em: associar a necessidade da presença de cargas elétricas em movimento para que um material possa conduzir corrente elétrica; levarem em conta a carga negativa associada ao elétron; diferenciar uma substância simples e o íon do mesmo metal em solução aquosa, e ainda, como constituinte de um composto iônico. 
A. Reação redox entendida como transferência de oxigênio.

O livro 1 da coleção traz essa concepção numa abordagem histórica, é citado que originalmente empregava-se a palavra oxidação para se referir ao oxigênio participando da reação, mas acrescenta que o significado do termo é outro atualmente. Ao apresentar o número de oxidação o livro também retoma a participação do oxigênio do ar, e que essas reações infelizmente são bastante comuns em grandes centros urbanos. Isso pode indicar uma tentativa de elucidar essa concepção alternativa. Contudo, a primeira reação utilizada para exemplificar a reação e conceituar os termos é a queima do magnésio metálico em que o oxigênio participa diretamente da reação.

No segundo livro da coleção, após apresentar elementos da história da ciência e do desenvolvimento da eletroquímica, o livro traz a reação da Pilha de Daniell para introduzir os conceitos. Essa mesma reação é trabalhada ao longo da maior parte do capítulo.

No livro três, 3 das 5 reações apresentadas envolvem diretamente a presença do oxigênio. Mas se considerarmos que a maior parte das reações orgânicas tem como agente oxidante o oxigênio é esperado que elas fossem a maior parte das reações. Já em toda a coleção 27 exemplos de reações redox são apresentados, dessas 6 envolvem o oxigênio participando diretamente da reação.

B. Os processos de oxidação e redução podem ocorrer de forma independente.

A interdependência das reações de oxidação e de redução e a simultaneidade da transferência eletrônica é abordada no primeiro livro da coleção ao conceituar os termos agente redutor e agente oxidante. Utilizando-se o exemplo da reação entre o Zinco metálico e o cobre em solução, o livro destaca que “(...) sem a presença de espécie que se oxide, no caso o $\mathrm{Zn}^{0}$, não haveria redução do $\mathrm{Cu}^{2+}$.(...) Por outro lado, sem a presença de espécie que se reduza, no caso os íons $\mathrm{Cu}^{2+}$, o zinco não teria como se oxidar.”(VV, 1, p.216). Todavia, destacar a necessidade da presença dos eletrodos não necessariamente garante o entendimento da simultaneidade do processo, dado que o aluno pode entender que ocorre primeiramente um processo e em seguida o outro, como a concepção descreve. Entretanto, nas representações utilizadas que trazem as equações das reações redox ambos os processos aparecem e são destacados na mesma equação.

No segundo livro da coleção não há nenhum destaque, explicação, ou menção a essa concepção alternativa. Contudo, nas representações, as reações de oxidação e de redução estão sempre juntas e próximas da equação global. Esse mesmo padrão é utilizado na apresentação das semirreações. O mesmo ocorre no terceiro livro da coleção. 
C. Os elétrons se movem através da solução sem o auxílio de íons.

A movimentação dos elétrons nas pilhas já é destacada no Manual do Professor do segundo livro da coleção, principalmente pela transposição do conceito de corrente elétrica da física para a química e da confusão que as cargas positivas e negativas podem causar.

O livro 2 trabalha diretamente com as pilhas e a geração de energia elétrica ao utilizar-se esses dispositivos. No capítulo especifico, após uma abordagem histórica, os componentes da pilha de Daniell são abordados e descreve-se a função de cada um para geração de energia. $\mathrm{Na}$ introdução é descrito que para obter energia elétrica que seja capaz de realizar trabalho é "necessário separar fisicamente o processo de oxidação do de redução, de modo que os elétrons provenientes da oxidação circulem por um fio(...)" (VV, 2, p.224). Em seguida acrescenta-se: "Para que a corrente elétrica circule, é necessário que o circuito esteja fechado. Pelo fio metálico que une as duas placas metálicas, movimenta-se os elétrons e, pela ponte salina, os íons" (VV, 2, p.225)

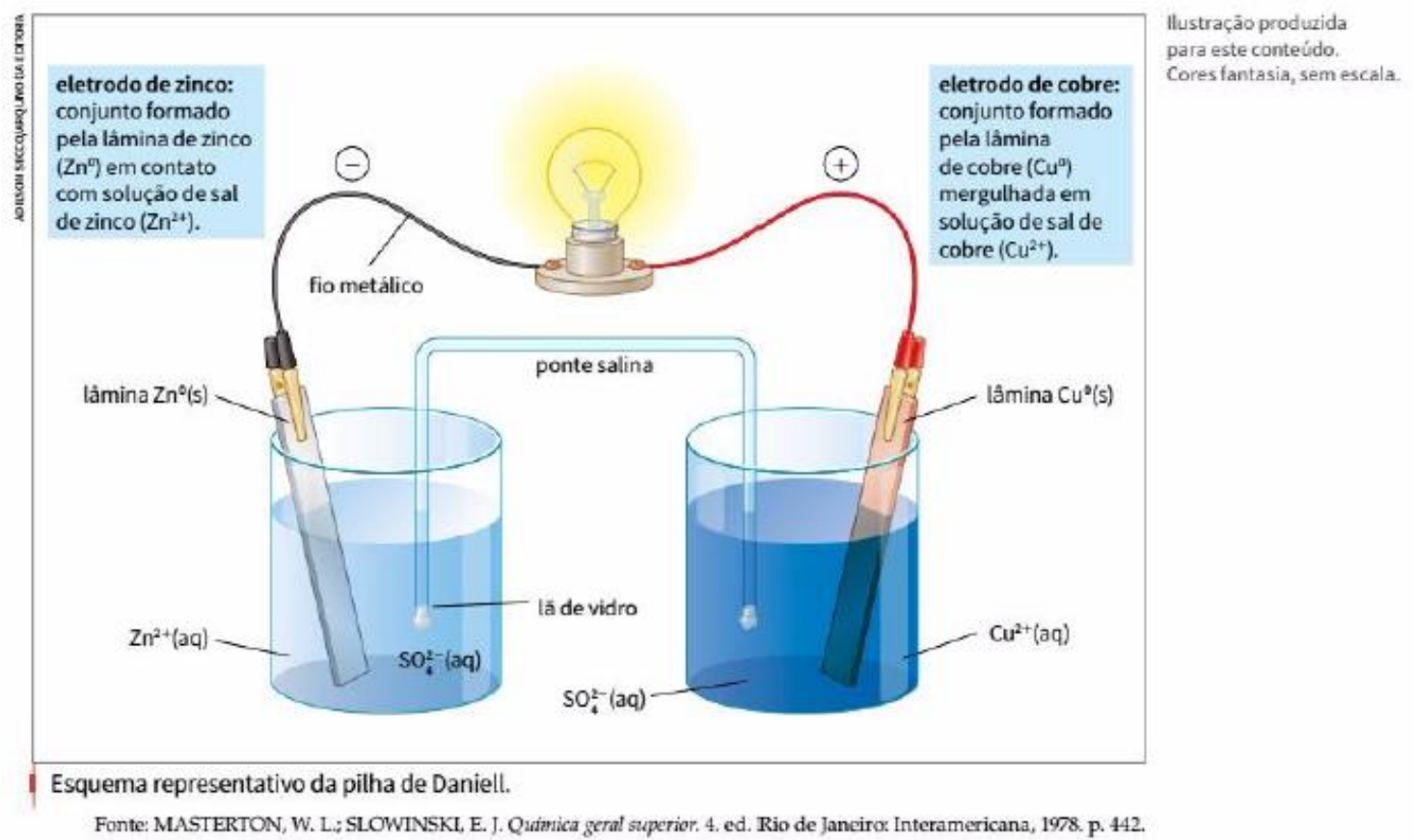

Figura 61 - A Pilha de Daniell na coleção VV Fonte: VV, 2, p.226

Todavia, a representação utilizada no livro pode causar confusão quanto ao movimento de elétrons no fio, uma vez que é colocado o sinal - e + próximo ao fio, o que pode dar a impressão que o elétron "entra negativo" na lâmpada e "sai positivo" da lâmpada.

D. A ponte salina fornece elétrons para completar o circuito.

No livro 2 da coleção, há uma seção só para abordar o papel da ponte salina na pilha eletroquímica. Essa seção está contida no tópico que explica como funciona a pilha e cita inclusive o papel do fio metálico: 
Para manter a neutralidade de cargas, ocorre um movimento organizado de íons: de cátions em direção à solução do sal de $\mathrm{Cu}^{2+}$ e/ou de ânions em direção à solução de $\mathrm{Zn}^{2+}$. Dessa corrente iônica participam inclusive os íons da ponte saline: cátions potássio $\left(\mathrm{K}^{+}\right)$dirigem-se à semicélula de cobre, e ânions nitrato $\left(\mathrm{NO}_{3}{ }^{-}\right)$, à de zinco . Tudo isso ocorre ao mesmo tempo que os elétrons fluem no fio metálico, graças à reação de oxirredução. (VV, 2, p.226)

Os fenômenos exibidos e desenvolvidos nos capítulos, para o livro 1 são: os estados de oxidação do ferro, antigos flashes de máquinas fotográficas, chuva ácida, combustão do metano, fermentação acética do etanol, e por fim as reações envolvidas no bafômetro.

Um box específico ainda aborda algumas reações de oxirredução presentes no cotidiano, como o escurecimento de objetos de prata, ferros enferrujados nas canalizações, ozônio como poluente urbano gerado pela combustão da gasolina, fermentações e combustões na produção de etanol, fermentação na produção de bebidas alcoólicas, respiração celular, putrefação de alimentos e antioxidantes que previnem a degradação dos alimentos. Esse tipo de abordagem é presente unicamente na coleção VV e representa o ideal ao detalhar os processos redox mais complexos envolvidos no nosso cotidiano.

No livro 2 há um capítulo onde são incluídas as reações envolvendo as pilhas, as baterias e a eletrólise. O livro também traz um box que discute o perigo dos íons de metais pesados livres no meio ambiente. No livro 3, as reações de oxirredução de cada uma das funções orgânicas estão presentes.

Quanto às atividades experimentais, elas são: uma para o livro 1, considerada "mãona-massa"; três para o livro 2, sendo duas consideradas "mão-na-massa", e uma para o livro 3, também considerada "mão-na-massa". Portanto, as categorias h e i são totalmente contempladas na coleção VV.

Todos os termos abordados ao longo da coleção são relacionados a um fenômeno, um exemplo e, portanto, a uma experiência. É importante enfatizar que o conteúdo também é relacionado com outras disciplinas, como a física e a biologia, isso é particularmente importante pois a literatura aponta que os alunos têm dificuldades em conceituá-los e verificarem as similaridades e diferenças entre as disciplinas. Principalmente no caso da física e da química. Isso indica que a categoria j é apropriadamente abordada.

As representações se diferenciam com relação ao ano a qual o livro se destina, e ao longo do capítulo. As primeiras representações, em todos os capítulos, apresentam uma semelhança, conforme pode ser observado nas figuras 62, 63 e 64. 


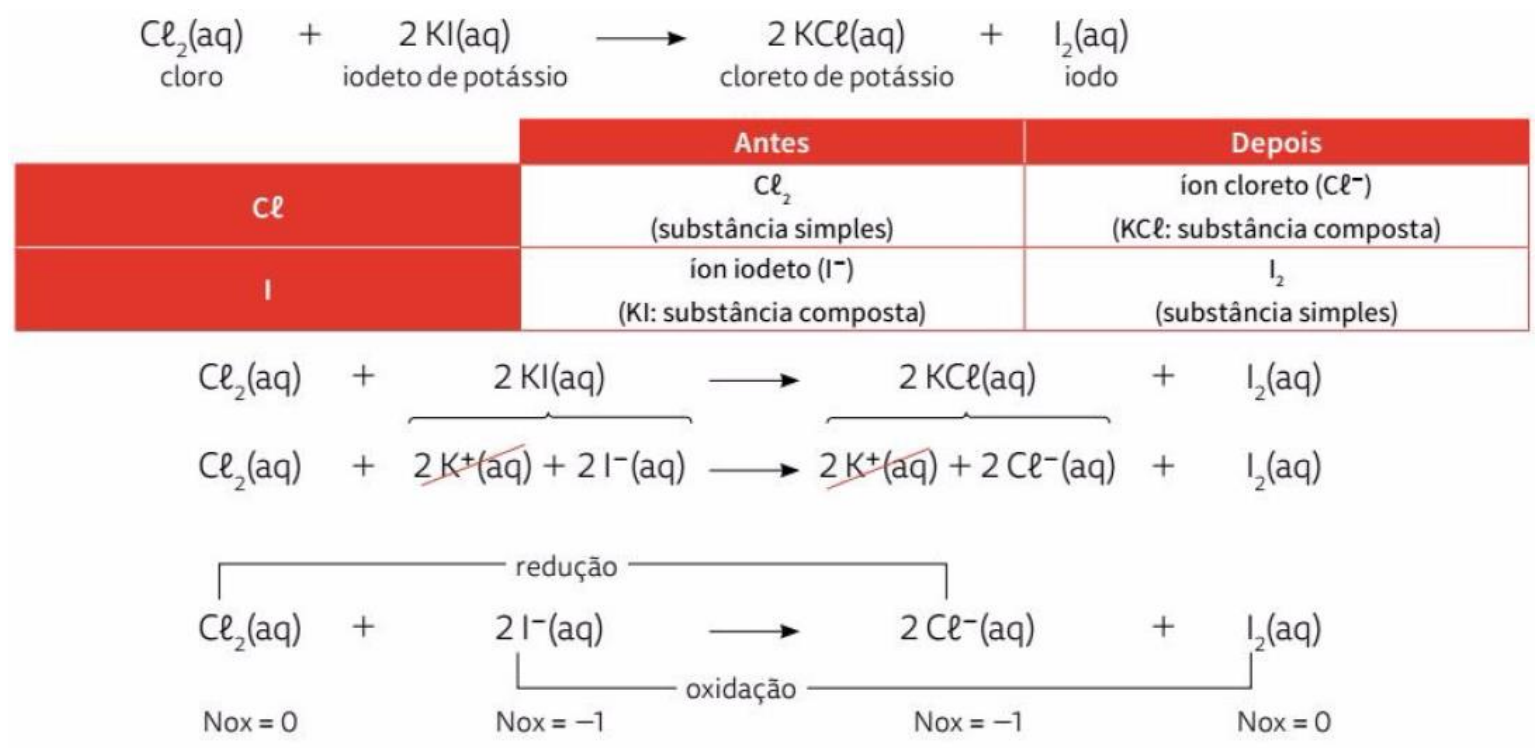

Figura 62 - Representação esquemática ' 1 ' presente na coleção VV Fonte: VV, 1, p. 220.

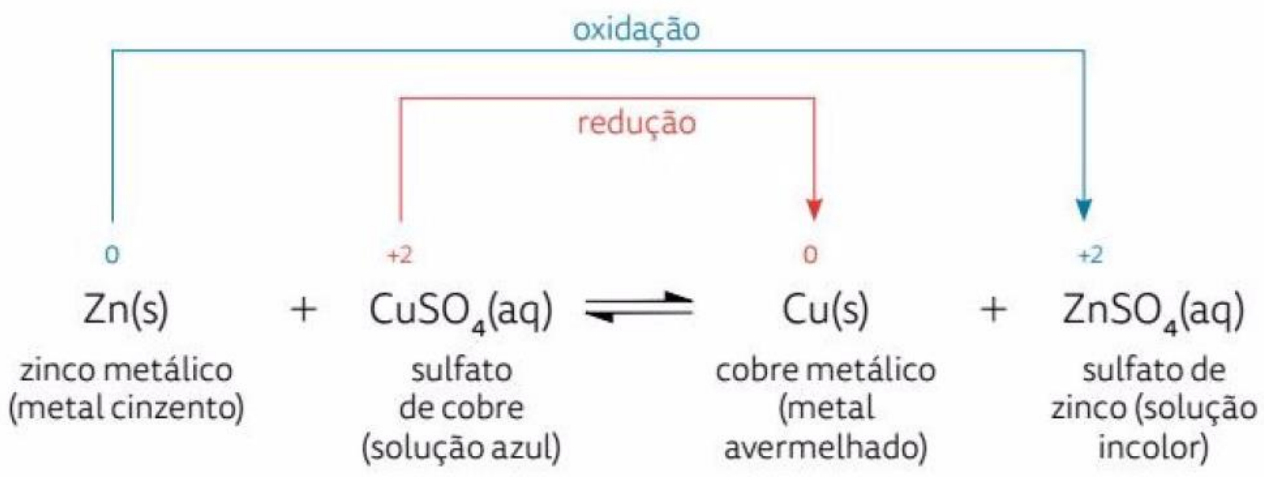

Figura 63 - Representação esquemática '2' presente na coleção VV Fonte: VV, 2, p. 224.

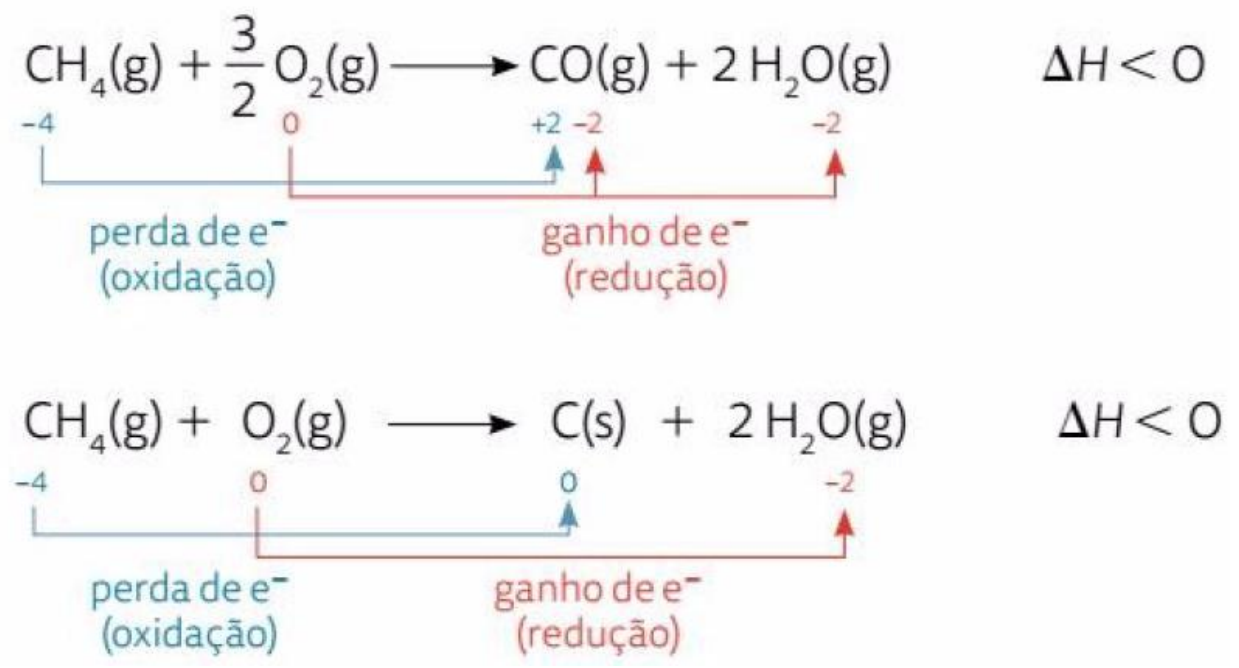

Figura 64 - Representação esquemática '3' presente na coleção VV Fonte: VV, 3, p. 203. 
As representações no livro do primeiro ano são mais detalhadas que as reações presentes nos livros do segundo e terceiro ano, pois nesse as reações são apresentadas, sendo posteriormente relembradas. Mas é perceptível que o padrão de especificar as cargas acima dos elementos e a mudança do Nox, mantem-se na coleção.

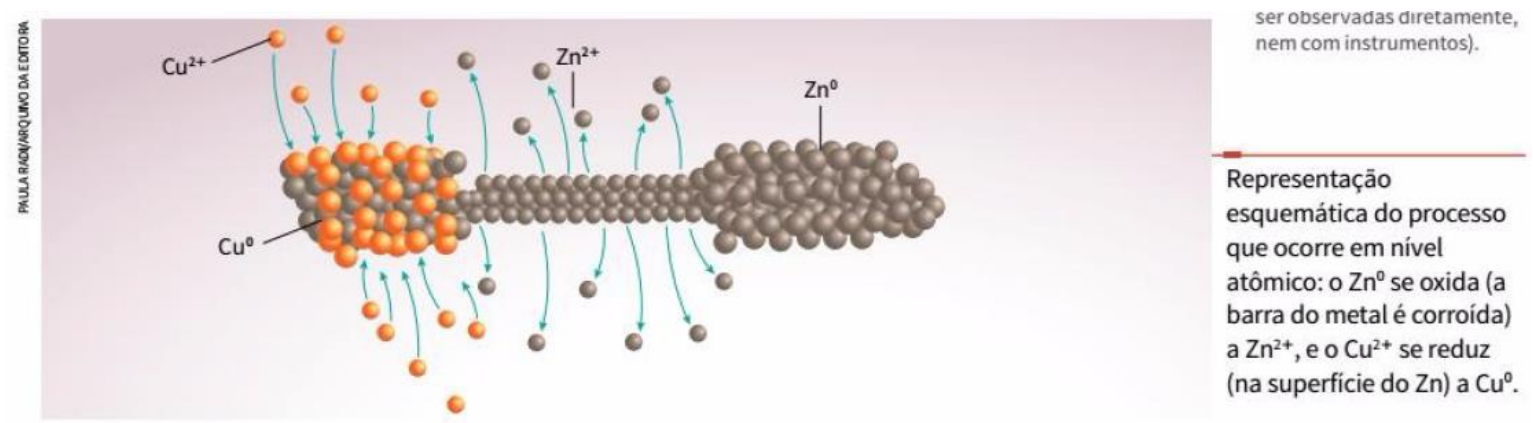

Figura 65 - Representação esquemática '4' presente na coleção VV Fonte: VV, 1, p. 215.

A representação destacada na figura 65 foi a única encontrada que busca exibir o nível microscópico, no livro 1. No livro 2 encontrou-se apenas uma, mas que não possuía relação direta com o conteúdo, e no livro 3 nenhuma das representações exibem o nível microscópico.

A demonstração do uso do conhecimento, no caso dos descartes das pilhas e baterias, é apresentada em mais de um parágrafo ao longo do capítulo de eletroquímica no livro 2. Inicialmente aborda-se a contaminação do mercúrio presente nas pilhas, onde os autores especificam que: “[...] é importante que os cidadãos adquiram a consciência e o hábito de não descartá-las no lixo, sob pena de contaminar o solo e os mananciais com metal pesado." (VV, 2, p. 247). Esse assunto é expandido em um box que aborda os casos de contaminação por mercúrio no Brasil.

A questão do descarte das pilhas é profundamente abordada em um box intitulado 'Química e Meio Ambiente - Pilhas e baterias de celulares e notebooks: o que fazer com elas?', nesse box a abordagem discute sobre o que é legal, e o que seria ideal a ser feito. Outros exemplos não foram encontrados, a não ser a utilização prática comentadas nos enunciados dos exercícios, como por exemplo para as pilhas:

Quando os gases $\mathrm{H}_{2}$ e $\mathrm{NH}_{3}$ se acumulam ao redor do cátodo de grafita da pilha de Leclanché, podemos resolver o problema, temporariamente, de duas maneiras:

- Retirando a pilha do equipamento em que está sendo usada;

- Utilizando algum sistema que impeça o aquecimento das substâncias químicas à medida que a pilha é usada. (VV, 2, p. 245)

O número de fenômenos demonstrados nos exercícios, também varia na coleção. Para o livro do primeiro ano, os exercícios que contextualizam os conceitos redox demonstram 
os fenômenos: oxidação de utensílios de cobre, corrosão de cimento e estruturas metálicas de pilares, oxidações do etanol, avaliação da qualidade da água, escurecimento de objetos de prata, tratamento de resíduos industriais e propelentes de satélites e sondas espaciais. No livro do segundo ano, os fenômenos que não se relacionam diretamente às pilhas, baterias e eletrólise são as reações envolvidas no bafômetro. No terceiro livro, os fenômenos presentes nas questões são: grisu em minas de carvão, álcool isopropílico utilizado em limpeza de equipamentos eletrônicos delicados, feromônios, a cobrança da água em centros urbanos.

Os dados apresentados indicam que, na coleção VV, há presença do aspecto IV de maneira acessível e inteligível. Considerou-se que apesar da coleção apresentar poucas representações do nível microscópico, a categoria k está presente. As categorias j, 1 e m são abundantes e a forma como são expostas na coleção é pertinente.

No aspecto $\mathrm{V}$, identifica-se o quanto a coleção incentiva e orienta pensamento dos estudantes. Das três categorias, cujos critérios constatam a presença do aspecto, todas elas foram encontradas na coleção VV.

Após a leitura de textos, geralmente nos boxes que se encontram destacados da abordagem principal, são colocadas questões que incentivam o aluno a expressar suas ideias. Um dos exemplos é após o texto que trata o descarte de pilhas e baterias, em que o aluno é questionado: "Você concorda com a opinião do promotor público expressa nos dois primeiros parágrafos? Justifique.” (VV, 2, p. 253). No caso da categoria n, as sugestões são feitas em forma de perguntas, mas estão distribuídas ao longo dos três livros.

A forma como o conteúdo é apresentado tem uma relação direta com o aluno, ou seja, é sempre dito "você deve", "analise", "compare", entre outras. A escolha dessa abordagem orienta o raciocínio dos alunos e motiva o estudo dos conceitos. Alguns trechos permitem concluir que a categoria esteja muito presente na coleção, como no caso da abordagem do caráter oxidante e redutor:

\footnotetext{
Analise as espécies que constam na tabela de potenciais-padrão de redução, no final do livro, e verifique: qual tem maior tendência a reduzir-se?

$\mathrm{O} \mathrm{F}_{2}$ tem o maior $\mathrm{E}^{\mathrm{o}}$ de redução: $+2,87 \mathrm{~V}$.

$\mathrm{O} \mathrm{F}_{2}$, ao reduzir-se, necessariamente oxida outra espécie, portanto, $\mathrm{F}_{2}$ é a espécie com maior caráter oxidante entre as que constam na tabela de $\mathrm{E}^{\mathbf{o}}$.

Analogamente, podemos verificar: qual tem maior tendência a oxidar-se?

$\mathrm{O} \mathrm{Li}$, cujo $\mathrm{E}^{\mathrm{o}}$ de oxidação é o maior, $+3,05 \mathrm{~V}$, tem como correspondente inverso o $\mathrm{E}^{\mathrm{o}}$ de redução do $\mathrm{Li}$. $\mathrm{O} \mathrm{Li}^{0}$ é a espécie com maior caráter redutor. Fazendo um raciocínio semelhante a esse, é possível comparar o caráter oxidante ou redutor de diferentes espécies químicas. (VV, 2, p. 236)
}

A coleção VV contempla a categoria $p$ de duas diferentes formas. A primeira, mais presente ao longo dos capítulos, é na introdução a um novo conteúdo. Um exemplo pode ser observado antes da abordagem do conteúdo de eletrólise, onde é exposto: “Antes da 
introdução de novos conceitos, reflita com base no que você já conhece e responda às questões a seguir." (VV, 2, p.258). As questões retomam alguns conceitos, inclusive trabalhados em anos anteriores, e quando respondidas servem para que o aluno avalie o conhecimento apreendido.

A outra forma expressa, é ao final de cada capítulo em que consta um box denominado 'Resgatando o que foi visto'. Para o capítulo final de eletrólise no livro 2, o box apresenta:

\begin{abstract}
Nesta unidade, vimos que certas reações químicas geram energia elétrica e, inversamente, a energia elétrica propicia uma série de reações químicas. Vimos também que há uma relação entre a quantidade de eletricidade produzida ou recebida por um sistema químico e a massa de substâncias produzidas e consumidas. Responda novamente às questões propostas no início da unidade $4 \mathrm{e}$ no início dos capítulos 10 e 11, incorporando os novos conhecimentos. Esperamos que agora você seja capaz de avaliar a eficiência no consumo de energia de diversos dispositivos de seu cotidiano e de discutir criticamente as formas de descarte de pilhas e baterias. (VV, 2, p. 282)
\end{abstract}

A avaliação do progresso do aluno, ou do entendimento dos conceitos trabalhados, pode ser realizada ao fim da sequência didática utilizando-se os exercícios da seção 'Testando seus conhecimentos'. Essa seção retoma os conceitos abordados em questões de complexidade moderada, mas está presente apenas na unidade do livro 2.

Contudo, o Manual do Professor da coleção faz uma ampla discussão sobre o processo de avaliação, os tipos de avaliação e fornece atividades extras que, segundo os autores, podem ser aproveitadas para a avaliação da aprendizagem em diferentes momentos do ensino.

Como os itens solicitados nos exercícios correspondem às ideias-chaves, e o Manual do Professor da coleção apresenta outros métodos, que também se alinham aos objetivos, considera-se que a coleção atenda à categoria q.

Algumas instruções sobre como modificar as atividades são introduzidas ao longo do Manual do Professor, baseando-se não somente na aprendizagem dos alunos, mas, também, na disponibilidade de materiais. No caso das atividades experimentais isso é nítido em trechos como:

\footnotetext{
No primeiro experimento proposto no capítulo, na p. 222, um dos materiais necessários são 6 placas de cobre medindo cerca de $2 \mathrm{~cm} \mathrm{X} 2 \mathrm{~cm}$. Caso o professor não consiga encontrar placas de cobre, elas podem ser substituídas por pedaços de papel-alumínio (de preferência do tipo mais grosso, como de embalagens de pratos prontos). [...] (VV, 2, p.366)
}

As demais orientações referem-se ao conceito que deve ser retomado, caso os alunos apresentem dúvidas em algum contexto. Como por exemplo em: 
É possível, por exemplo, que os alunos não tenham clareza quanto à necessidade da presença de cargas elétricas em movimento para que um material possa conduzir corrente elétrica ou quanto à diferenciação entre um gerador e um receptor (por isso, na realização de experimentos envolvendo fontes de energia elétrica, o professor deve chamar a atenção dos alunos para a origem da corrente elétrica e/ou para os efeitos que ela provoca, o que deve ser feito desde o primeiro ano do Ensino Médio). (VV, 2, p. 365)

Portanto, em virtude do apresentado, considera-se que o aspecto de avaliação esteja presente na coleção. $\mathrm{O}$ mesmo acontece para o último aspecto que verifica o ambiente que a coleção tenta criar, para o aprendizado da ciência. Nesse aspecto, a categoria té presente no Manual do Professor da coleção, onde são incluídos textos teóricos para o professor sobre áreas do ensino de química, que buscam "contribuir com a atualização teórica do professor e enriquecer sua prática pedagógica" (VV, 2, p. 318).

Já as categorias u e v estão presentes tanto durante os capítulos que abordam o conteúdo redox, quanto no Manual do Professor da coleção. Isso é observado, principalmente, em questões localizados abaixo de textos em destaque. A maioria dos exemplos que se observa tenta trazer o contexto do aluno para a sala de aula, valendo-se de questões como: "O problema relatado trouxe custos à prefeitura de Salvador. De que forma problemas como esse poderiam ser evitados nas cidades brasileiras? No município em que você mora há algum tipo de problema semelhante?” (VV, 1, p. 212), e também em: “Alguma dessas propostas está sendo colocada em prática na cidade ou região onde você mora?” (VV, 1, p. 219). 


\subsubsection{Coleções brasileiras e o ensino de reações redox}

A análise do quadro 15 permite extrair algumas conclusões sobre o quanto as coleções didáticas brasileiras fornecem suporte ao ensino das reações redox. Primeiramente é preciso destacar que a coleção que contempla o maior número de aspectos é a VV. Tal coleção expressa os objetivos do estudo, aborda o conteúdo abrangendo o maior número de fenômenos, desenvolve os termos utilizando artifícios adequados, oferece oportunidades para que professores e alunos avaliem suas ideias num ambiente de respeito ao contexto do aluno.

Em comparação, há coleções que não apresentaram nenhuma categoria de alguns aspectos. É o caso da coleção QC que desenvolve todo o conteúdo por meio de fenômenos relacionados somente aos metais, utiliza representações e introduz os termos de forma incoerente e não promove o pensamento dos estudantes. A coleção CP também apresenta os conceitos relacionando-os somente aos metais e não sugere que o aluno expresse suas ideias e avalie seu progresso. Enquanto que na coleção MR não são explicitados os conhecimentos e habilidades prévias dos alunos.

Destaca-se, ainda, que as categorias h e m relacionam-se entre si, à medida que buscam identificar quais fenômenos redox são apresentados nos livros. Observa-se que, com exceção de duas coleções, a maioria dos livros didáticos brasileiros apresentam uma variedade de fenômenos redox. Entretanto, é importante salientar que apenas uma delas aborda reações redox mais complexas, ou mesmo cita quais delas estão presentes no cotidiano.

Somente a coleção VV cita reações complexas, como a fotossíntese, em seu livro. Isso pode indicar que reações abordadas ao longo do ensino fundamental não estão sendo retomadas no ensino médio. Deve-se ressaltar que não se tem a intenção de que elas sejam abordadas com profundidade durante o nível médio, justamente por tratar-se de reações complexas que são melhor explicadas em níveis superiores. No entanto, como as aplicações práticas do conteúdo também são pouco explicitadas, em todas as coleções, é importante que o aluno consiga ao menos reconhecer quais reações envoltas em seu cotidiano são explicadas pelos processos redox.

Os dois aspectos do processo de ensino-aprendizagem menos presentes nas coleções brasileiras são: V. Promovendo o pensamento dos alunos, e II. Considerando as ideias dos estudantes. $\mathrm{O}$ aspecto II é particularmente importante nessa pesquisa, pois tenta 
identificar diretamente a relação que os LD brasileiros estabelecem com as concepções alternativas. Enquanto que o aspecto $\mathrm{V}$ é também importante pois incentiva os alunos a expressarem-se, a observarem sua evolução na aprendizagem dos conceitos e constatarem o quanto aprenderam.

Quanto ao aspecto II, uma leitura dos dados identifica que apenas uma coleção ressalta a importância das concepções alternativas, citando inclusive outras que não fizeram parte diretamente desse estudo. Trata-se da coleção CP que apresenta concepções alternativas no Manual do Professor do livro 2 e ainda desenvolve algumas delas na abordagem principal do livro. Contudo, a coleção SP, desenvolve as quatro concepções alternativas selecionadas da literatura, durante a abordagem das reações redox no livro 2.

Esse fator pode indicar que as concepções alternativas dos alunos não estão sendo discutidas. Isso pode ser devido à confusão existente entre o conceito de concepção prévia e concepção alternativa, ou a falta de interesse em abordá-las no nível básico. Fato é que elas continuam sendo retratadas na literatura e são um aspecto importante para entender a dificuldade de aprender e ensinar o conteúdo redox.

Destaca-se também a categoria $v$ que não foi atendida completamente em nenhuma das coleções. A categoria $\mathrm{v}$ determina o quanto o material fornece auxílio ao professor em três pontos importantes: incentivar expectativas elevadas nos alunos quanto à aprendizagem dos conceitos; permitir que os alunos experimentem sucesso, e ainda oferecer suporte ao professor para que o mesmo consiga estabelecer uma relação onde todos os alunos sintam-se pertencentes à sala de aula.

Retomamos os indicadores de cumprimento da categoria $\mathrm{v}$, no anexo A, para esclarecer os motivos pelos quais não consideramos que as coleções atendiam a essa categoria completamente. São eles:

1. O material evita estereótipos ou linguagem que possam ser ofensivos para um grupo particular.

2. O material ilustra o contributo das mulheres e das minorias para a ciência. E traz modelos a seguir.

3. O material sugere formatos alternativos para que os alunos expressem suas ideias durante a instrução e avaliação.

4. O material inclui sugestões específicas sobre como os professores podem modificar atividades para estudantes com necessidades especiais.

5. O material fornece estratégias para validar as experiências pessoais e sociais relevantes dos alunos com ideias científicas.

Quanto ao indicador 1 é nítido que todas as coleções o atendam, à medida que os documentos orientadores (BRASIL, 2000, 2006) são explícitos ao quanto essa prática deve ser presente. Os revisores e avaliadores das coleções devem garantir que nenhum livro chegue aos alunos com linguagem ofensiva. 
O indicador 2, de todos desse procedimento de avaliação, é o único não presente em nenhuma das coleções. Contudo é importante destacar que nem mesmo as pesquisas da área de ensino e história das ciências saberia dizer quais foram os contributos das mulheres e minorias para a evolução dos conceitos redox. A literatura brasileira e estrangeira carece de fontes para que esses fatores sejam incluídos nos livros e materiais didáticos. Vale lembrar que as vozes das mulheres e minorias foram caladas por longos anos, sendo que esse indicador poderia nem ser considerado em épocas anteriores.

No indicador 4 entende-se que os formatos alternativos que podem ser sugeridos são diferentes das formas orais e escritas. Percebe-se que o intento do instrumento é proporcionar que todos os diferentes tipos de alunos participem e expressem suas ideias no ambiente escolar. Para atender a todos os diferentes tipos de alunos é necessário incluir práticas e recomendações ao ensino para portadores de necessidades especiais também.

Os diferentes tipos de alunos são enfatizados no indicador 4. Percebe-se o quanto as atividades experimentais propostas em todas as coleções desconsideram totalmente fatores como esse. Inúmeras práticas não podem ser realizadas com alunos cegos, surdos ou com dificuldade de locomoção. Em virtude disso vale o questionamento: quanto o ensino de ciências e química aproxima-se das discussões sobre inclusão do cenário acadêmico?

$\mathrm{O}$ indicador 5 foi encontrado nas coleções do PNLD. Validar as experiências pessoais e sociais dos alunos é, além de chamar a atenção do aluno para os fenômenos a sua volta, trazer sua experiência com eles para a sala de aula. Formar um cidadão crítico e consciente do seu papel em sociedade passa essencialmente por esse processo. Os livros didáticos não deveriam distanciar-se disso jamais.

Com relação a abordagem das concepções alternativas os resultados encontrados permitem inferir que somente a coleção CP discute e apresenta possíveis concepções alternativas redox aos professores. Entretanto, somente a coleção SP apresenta o conteúdo de forma que auxilie o professor a discutir todas as concepções alternativas selecionadas.

Porém, a concepção alternativa que é o oxigênio é necessária para que ocorra uma reação redox pode ser elucidada ao trabalhar-se com cinco das seis coleções investigadas.

Outro fator importante a ser destacado é que somente uma coleção preocupa-se em discutir como o conteúdo redox, principalmente no cálculo de potencial-padrão de redução e força eletromotriz, se relaciona ao conteúdo abordado na disciplina de física. Isso é muito importante, pois na disciplina de física termos como circuito elétrico, cargas elétricos e fluxo de elétrons são conceituadas, muitas vezes de forma diferente da química. 


\section{CONCLUSÕES}

A maioria dos professores gasta seu tempo fazendo perguntas que têm como objetivo descobrir se o aluno não sabe sobre algo, enquanto a verdadeira arte de fazer perguntas é para descobrir o que o aluno sabe ou o que ele é capaz de saber.

Albert Einstein

O caminho percorrido durante a pesquisa e escrita desta dissertação foi árduo, esclarecedor e gratificante. Inicialmente traçou-se o objetivo de conhecer como os conceitos de reações redox vão sendo construídos nos livros didáticos de ciências do ensino fundamental I e II e de química do ensino médio, e relacionar esta construção às concepções alternativas dos estudantes relatadas na literatura.

Em busca desse objetivo realizaram-se três análises nos livros de ciências do fundamental I e II e de química do ensino médio.

A primeira análise realizada permitiu traçar a evolução do conteúdo nos livros didáticos da educação básica. Para isso, quantificou-se os temas pertinentes às reações redox nesses livros. Vários temas foram encontrados, entre eles aqueles que mais se repetem ao longo dos livros são o de Pilhas e Baterias, Fotossíntese e Respiração Celular. Alguns temas aparecem no ensino fundamental e não são citados no ensino médio, enquanto o contrário também foi encontrado.

Ressalta-se que as reações redox começam a ser abordadas já no livro do $9^{\circ}$ ano no ensino fundamental II e não somente no $2^{\circ}$ ano do ensino médio. A ênfase no tema de Pilhas e Baterias no ensino fundamental é muito ligada à abordagem física e como fonte de energia, enquanto que no ensino médio é mais relacionada às reações que os metais participam. No $1^{\mathrm{o}}$ ano pode-se definir as reações redox junto à classificação das reações químicas, enquanto que no $3^{\circ}$ ano trata-se as reações redox orgânicas e a fabricação de produtos.

Desta análise percebeu-se que os temas podem influenciar a concepção alternativa de que o oxigênio precisa estar presente em toda e qualquer reação redox. Isto porque ao longo do ensino fundamental os principais exemplos relacionados às reações de oxirredução envolvem o gás oxigênio. Esta abordagem, inclusive, tenta reforçar a ideia da essencialidade deste gás para vida no nosso ambiente.

Outra concepção alternativa que pode ser influenciada é a de que os processos de oxidação e redução são independentes. Ao quantificar-se como as palavras oxidação e redução aparecem fora do contexto específico de ensino destas reações, notou-se que a 
reação de oxidação aparece mais vezes e sem associar a ela uma reação de redução. Isso pode contribuir com a ideia de que pode haver uma oxidação independente de um reagente que receba os elétrons da reação.

Ao analisar os temas pertinentes nos livros de química percebeu-se outras conclusões importantes. Concluiu-se que os livros contextualizam diversas palavras que tem relação com o conteúdo de reações redox, sem necessariamente conceituá-las. É o caso das palavras inoxidável e antioxidante que aparecem em outros momentos do livro, mas não são definidas. Será que os alunos realmente compreendem esses conceitos tão presentes no dia-a-dia?

Outra conclusão importante é a de que as coleções contextualizam muito pouco as reações redox orgânicas. Nas quatro coleções, as reações redox orgânicas presentes no cotidiano são apenas citadas, às vezes em boxes deslocados no canto da página que mal chamam a atenção dos alunos.

Concluiu-se, também, que as definições dadas para as reações redox nos livros de química podem causar confusão e dificuldade de entendimento destas reações. Dado que a ênfase na definição das reações redox está no processo de transferência de elétrons, não se faz a discussão de que não existe uma transferência real e concreta entre os átomos. Segundo as ideias de estrutura da matéria, pode-se ressaltar o caráter parcial de um elemento cuja carga pode ser negativa ou positiva, dependendo da eletronegatividade entre os átomos, isso implica em abordar as reações do ponto de vista da eletronegatividade, o que é presente em apenas três coleções analisadas.

A segunda análise realizada buscou identificar como o conteúdo é construído nos livros didáticos, revelando quais os modelos mais utilizados e se a utilização de mais de um destes é acompanhada de justificativa. Observou-se que todos os livros didáticos definem as reações redox em termos da transferência de elétrons entre espécies, o que se encaixaria no modelo de transferência eletrônica. Uma única coleção apresentou uma variação entre esse modelo e o de número de oxidação, a coleção MR. Nesta, o modelo de número de oxidação é apresentado no livro do primeiro ano, enquanto que nos outros dois utiliza-se mais frequentemente a abordagem eletrônica, porém não se percebeu uma justificativa para essa abordagem.

O uso do modelo de transferência eletrônica em todos os livros, e da forma como é discutido (relacionando-se à ideia de uma transferência real entre os átomos), também pode influenciar a concepção de que os processos não são dependentes. Uma vez que a reação for entendida como uma transferência concreta, pode haver a compreensão de que 
um átomo necessita apenas doar ou apenas receber elétrons de outro, sem que a força da eletronegatividade atue sobre estes em conjunto.

Uma conclusão também importante deste estudo é a falta de clareza de que os modelos têm limitações intrínsecas e, portanto, podem causar dificuldades no entendimento desse conteúdo. É importante que os modelos sejam usados com cautela, discutindo seus limites e como eles tentam descrever os processos macroscópicos observados.

Desses dois estudos também se percebeu que as concepções alternativas relacionadas ao conteúdo de pilhas, baterias e eletrólise podem estar surgindo no momento da abordagem deste conteúdo em nível médio. Isso devido ao fato de que a Pilha de Daniell só é abordada neste nível de ensino, reforçando a necessidade de se pesquisar as concepções alternativas dos alunos durante o processo de ensinoaprendizagem destas reações.

Com o resultado das duas análises citadas foi perceptível que a forma como o conteúdo vai sendo construído nos livros didáticos da educação básica pode influenciar as concepções alternativas dos alunos, ao menos aquelas mais citadas na literatura. Esse fator motivou a análise sobre a qualidade dos livros e como eles poderiam fornecer suporte ao ensino e confronto destas reações.

Assim, para a terceira análise utilizou-se o instrumento criado pelo projeto 2061 da AAAS. Esse instrumento de avaliação permite classificar o quanto os livros atendem a sete aspectos do processo de ensino-aprendizagem. Identificou-se uma clara diferença entre as abordagens para o conteúdo redox escolhida pelos autores. Enquanto há uma coleção que contempla cinco dos aspectos integralmente, a coleção VV, há uma coleção que contempla apenas um aspecto na íntegra, a coleção QC. Nesse sentido, as coleções diferenciam-se desde a variedade de fenômenos apresentados, até a apresentação ou não do objetivo do estudo das reações de oxirredução.

Os resultados encontrados explicitam que apenas uma coleção discute e apresenta possíveis concepções alternativas do conteúdo aos professores, a coleção CP. Enquanto que apenas a coleção SP tem uma abordagem que permite elucidar todas as concepções alternativas selecionadas. Isso é alarmante pois os livros são ferramentas que auxiliam o professor na construção do conteúdo e mesmo esses estão desconsiderando esse aspecto que tem influência direta no ensino dos conceitos químicos.

Outro fator importante a ser destacado é que somente uma coleção dedica uma seção do livro para "acertar os ponteiros entre a física e a química" o que seria 
recomendado para diminuir e elucidar essas concepções alternativas. Com exceção da coleção VV, as coleções desconsideram a dificuldade no entendimento do conteúdo ocasionada pela confusão entre os termos apresentados na física e na química.

Além disso, as coleções também não cumprem as recomendações de autores da área quanto à construção do conteúdo. Seria importante evitar simplificações e declarações breves, porém, percebe-se muitas vezes as definições redox sendo destacadas em quadros coloridos com frases breves com intuito de memorização. Seria importante, também, evitar argumentos simplistas na previsão de fluxo de íons, contudo não é perceptível nem mesmo uma abordagem buscando esclarecer o movimento dos íons em solução à medida que apenas três coleções explicam a movimentação de elétrons e íons de forma ampla e esclarecedora.

Este estudo apontou a relação entre como o conteúdo de reações redox é construído nos livros didáticos da educação básica e a influência que eles podem estar tendo nas concepções alternativas dos alunos. Contudo, é importante citar algumas implicações para o ensino de reações redox emergentes deste estudo.

Primeiramente, pontua-se o instrumento criado pela AAAS como uma nova ferramenta para análise na etapa de escolha dos livros do PNLD. Segundo, ressalta-se a importância de que o professor conheça as concepções alternativas mapeadas na literatura, e a de seus alunos, uma vez que estas têm forte influência sobre o processo de ensino-aprendizagem. Terceiro, destaca-se a abordagem interdisciplinar com a biologia e física que pode auxiliar no confronto a estas concepções alternativas.

Por fim, aponta-se que esse estudo não se finda aqui e, como todo processo de pesquisa científica, levanta novas questões e a importância de novas pesquisas que investiguem: Como é feita a mediação do livro no ensino dessas reações? Quais as melhores formas de investigar e trabalhar com as concepções dos alunos? Como o conteúdo do livro pode auxiliar na elucidação dessas concepções? 


\section{REFERÊNCIAS}

ACAR, B.; TARHAN, L. Effect of cooperative learning strategies on students' understanding of concepts in electrochemistry. International Journal of Science and Mathematics Education, 5, p.349-376, 2007.

AHTEE, M.; ASUNTA, T.; PALM, H. Student Teachers Problems in teaching electrolysis with a key demonstration. Chemistry Education: Research and Practice in Europe. v.3, n.3, p. 317-326, 2002.

ALLSOP, R.T., GEORGE, N.H. Redox in Nuffield advanced chemistry. Education in Chemistry, v. 19, p. 57-59, 1982.

AMARAL, I. A. et al. Algumas tendências de concepções fundamentais presentes em coleções didáticas de Ciências de $5^{\text {a }}$ a $8^{\text {a }}$ séries. In: Encontro nacional de pesquisadores em educação em ciências, 2., 1999, Valinhos. Atas... Valinhos: ABRAPEC, 1999. 1 CD-ROM.

AMARAL, I. A.; MEGID NETO, J. Qualidade do livro didático de Ciências: o que define e quem define? Ciência \& Ensino, Campinas, n.2, p. 13-14, jun.1997.

ASSUDE, T., MAOLINAS, C. Aperçu sur les rôles des manuels dans la recherche en didactique des mathématiques. In Eric Bruillard (dir), Manuels scolaires, regards croisés: Documents, actes e rapports, pour la éducation. Scérén / CRDP Basse - Normandie, p. 231-241, 2005.

ATKINS, P., JONES, L. Princípios de Química: Questionando a vida moderna. Bookman, $5^{\text {a }}$ edição, Porto Alegre, 2012.

ATKINS, P., PAULA, J. Físico-Química - Volume I. LTC, 9a edição, Rio de Janeiro, 2012.

ATKINS, P., PAULA, J. Físico-Química - Volume II. LTC, $8^{\text {a }}$ edição, Rio de Janeiro, 2008.

AYDIN, S. Examination of Chemistry teachers' topic-specific nature of pedagogical content knowledge in electrochemistry and radioactivity. Tese ( $\mathrm{PhD}$ in Secondary Science and Mathematical Education). Ankara, Turkey: Middle East Technical University, 2012.

AYDIN, S.; BOZ, Y. The nature of integration among PCK components: A case study of two experienced chemistry teachers. Chemistry Education Research and Practice, v. 14, n. 4, p. 615-24, 2013.

BAGANHA, D. E. O Papel e o uso do Livro Didático de Ciências nos anos finais do Ensino Fundamental. 123p. Dissertação (Mestrado em Educação - Programa de Pós-Graduação em Educação, Universidade Federal do Paraná, Curitiba, 2010.

BARDIN, L. Análise de conteúdo. São Paulo: Edições 70 Ltda, 2011.

BARKE, H. D.; HAZARI, A.; YITBAREK, S. (org.) Misconceptions in Chemistry: Addressing Perceptions in Chemical Education. Berlin: Springer, 2009.

BARRAL, F. L.; FERNÁNDEZ, E. G. R.; OTERO, J. R. G. Secondary students' interpretation of the process occurring in an electrochemical cell. Journal of Chemical Education, v. 69, n. 8, p. 655-7, 1992.

BARRETO, B. S. J., BATISTA, C. H., CRUZ, M. C. P., Células Eletroquímicas, Cotidiano e Concepções dos Educandos. Química Nova na Escola, v. 39, n. 1, p. 52-58, 2017

BATISTA, A. A. G. Um objeto variável e instável: textos, impressos e livros didáticos. In: ABREU, Márcia (org): Leitura, história e história da leitura. Campinas/São Paulo: Associação de leitura do Brasil/FAPESP, 2002.

BITTENCOURT, C. M. F. Em foco: história, produção e memória do livro didático. Revista Educação e Pesquisa. v. 30, nº 3, 2004. 
BOCANEGRA, C. H. Aspectos conceituais e epistemológicos do tema eletroquímica nos livros didáticos de química aprovados pelo Programa Nacional do Livro Didático para o Ensino Médio - PNLEM (2007). Dissertação (mestrado) Universidade Estadual Paulista, Instituto de Biociências de Rio Claro, 2010.

BORGES, T. Como evoluem os modelos mentais. Ensaio, v.01, n.01, p.66-92, 1999.

BORGES, T. Um estudo de modelos mentais. Investigações em Ensino de Ciências, v. 02, n. 03, p. 207-226, 1997.

BOUlabiar, A., BOURAOUI, K., CHAStretTe, M., ABDERRABBA, M. A historical analysis of the Daniell cell and electrochemistry teaching in French and Tunisian Textbooks. Journal of Chemical Education, v. 81, n. 5, p. 754-757, 2004.

BOULTER C. J., BUCKLEY B. C. Constructing a typology of models for science education. In J. K. Gilbert \& C. J. Boulter (Eds.), Developing Models in Science Education, p. 41-57, 2000.

BRASIL. Ministério da Educação. Secretaria da Educação Média e Tecnológica. Parâmetros Curriculares Nacionais + $(\mathrm{PCN}+)$ - Ciências da Natureza e suas Tecnologias. Brasília: MEC, 2002.

BRASIL. Ministério da Educação. Secretaria de Educação Média e Tecnológica. Parâmetros Curriculares Nacionais (Ensino Médio). Brasília: MEC, 2000.

BRASIL; Ministério da Educação. Secretaria de Educação Básica. Ciências da Natureza, Matemática e suas tecnologias (Orientações Curriculares para o Ensino Médio, v. 2). 2006.2 Disponível em: http://portal.mec.gov.br/seb/arquivos/pdf/book_volume_02_internet.pdf. Acesso em: 14 ago. 2017.

BRUILLARD, E. Les manuels scolaires questionnés par la recherche. In Eric Bruillard (dir), Manuels scolaires, regards croisés. Documents, actes e rapports, pour la éducation. Scérén / CRDP Basse - Normandie, p.13-36, 2005

BUESO, A.; FURIÓ, C.; MANS, C. Interpretación de las reacciones de oxidaciónreducción por los estudiantes. Primeros resultados. Enseñanza de las ciências, v. 6, n. 3, p. 244-250, 1988.

BUZEN, C. Reapresentação de objetos de ensino em livros didáticos de língua portuguesa: um estudo exploratório. In: SIGNORINI I. (Org.). Significados da Inovação no ensino de Língua Portuguesa e na Formação de Professores. 1ed. Campinas: Mercado de Letras, 2007.

CAAMAÑN, A. La enseñanza y el aprendizaje de la química. In: JIMÉNEZ ALEIXANDRE, M. P. (Coord.) et al. Enseñar Ciencias. Barcelona: GRAÓ, p. 95$118,2007$.

CARAMEL, N. J. C.; PACCA, J. L. A. Concepções alternativas em eletroquímica e circulação da corrente elétrica. Caderno Brasileiro de Ensino de Física, v. 28, n. 1, p.7-26, 2011.

CARAMEL, N. J. C.; PACCA; J. L. A. As concepções da condução elétrica e o funcionamento da pilha. In: Atas do IX Encontro nacional de pesquisa em ensino de física (IX ENPEF), 2004.

CARR M. Model confusion in chemistry. Research in Science Education, v. 14, p. 97103, 1984.

CASTEllan, G. W. Fundamentos de Físico-química. Tradução Cristina Maria Pereira, Roberto de Barros Faria. LTC, $4^{\text {a }}$ edição, Rio de Janeiro, 1986.

CHOPPIN, A. História dos livros e das edições didáticas: sobre o estado da arte. Educação e Pesquisa, vol. 30, nº. 3, p. 549 - 566. Set/dez. 2004. 
CISCATO, C. A. M., PEREIRA, L. F., CHEMELLO, E., PROTI, P. B. Coleção Química - Ciscato, Pereira, Chemello e Proti, Química Ensino Médio I. Moderna, $1^{\text {a }}$ edição, São Paulo, 2016.

CISCATO, C. A. M., PEREIRA, L. F., CHEMELLO, E., PROTI, P. B. Coleção Química - Ciscato, Pereira, Chemello e Proti, Química Ensino Médio II. Moderna, $1^{\text {a }}$ edição, São Paulo, 2016.

CISCATO, C. A. M., PEREIRA, L. F., CHEMELLO, E., PROTI, P. B. Coleção Química - Ciscato, Pereira, Chemello e Proti, Química Ensino Médio III. Moderna, $1^{\text {a }}$ edição, São Paulo, 2016.

CORDEIRO, D. S., CÁSSIO, F. L., CORIO, P., FERNANDEZ, C. O papel dos íons nas transformações químicas em solução segundo os livros didáticos: Protagonista?. In: Atas da $33^{\text {a }}$ Reunião Anual da Sociedade Brasileira de Química- 33 ${ }^{\text {a }}$ ASBQ, 2010

COSTA, R. A. M. Contribuições do uso do livro didático digital nas práticas docentes no ensino de química. Dissertação (Mestrado Profissional em Ensino de Ciências e Matemática) - Instituto Federal de Educação, Ciência e Tecnologia de São Paulo, IFSP, 2016.

DAVIES, A. J. A model approach to teaching redox. Education in Chemistry, v. 9, p. 135-37, 1991

De JONG, O.; ACAMPO, J.; VERDONK, A. Problems in teaching the topic of redox reactions: actions and conceptions of chemistry teachers. Journal of Research in Science Teaching, v. 33, n. 10, p. 1097-1110, 1995.

De JONG, O.; TREAGUST, D. F. The teaching and learning of electrochemistry. In: GILBERT, J. K.; DE JONG, O.; JUSTI, R.; TREAGUST, D. F.; VAN DRIEL, J. H. (org.) Chemical Education: Towards Research-Based Practice. Dordrecht: Kluwer Academic Publishers, p. 317-38, 2002.

DENZIN, N., LINCOLN, Y. O planejamento da pesquisa qualitativa: teorias e abordagens. Bookman, São Paulo, 2006.

EMMEL, R., ARAÚJO, M. C. P., A pesquisa sobre o livro didático no Brasil: Contexto, caracterização e referenciais de análise no período 1999-2010. In: Atas do IX Seminário de Pesquisa em Educação da Região Sul. Caxias do Sul, 2012.

FERNANDES, J. P., GOUVÊA, G. Levantamento da produção científica sobre a análise do Livro Didático de Ciências nas revistas nacionais no período de 2005 à 2010. In.: Atas do VIII Encontro Nacional de Pesquisa em Educação em Ciências. Campinas, 2011.

FERREIRA, P.M.F.; JUSTI, R.S. A abordagem do DNA nos livros de Biologia e Química do ensino médio: uma análise crítica. Ensaio: Pesquisa e Educação em Ciências, v.6, n.1, p.35-48, 2004.

FIGUEIREDO, M. C. de O. O livro didático na sala de aula: os modos de uso de um livro de ciências por uma professora do ensino fundamental. 2017. 173f. Dissertação (Mestrado em Ensino de Ciências) - Instituto de Ciências Exatas e Biológicas, Universidade Federal de Ouro Preto, Ouro Preto, 2017.

FONSECA, M. R. M. da. Química: ensino médio/Martha Reis I. Ática, $2^{a}$ edição, São Paulo, 2016

FONSECA, M. R. M. da. Química: ensino médio/Martha Reis II. Ática, $2^{\text {a }}$ edição, São Paulo, 2016

FONSECA, M. R. M. da. Química: ensino médio/Martha Reis III. Ática, $2^{\mathrm{a}}$ edição, São Paulo, 2016

FONTES, A. M., LOURENÇO, M. F. de P., MESSEDER, J. C., A representação experimental da pilha de Daniell nos Livros didáticos: um erro questionado. In: 
atas do XVI Encontro Nacional de Ensino de Química (XVI ENEQ) e X Encontro de Educação Química da Bahia (X EDUQUI) Salvador, 2012.

FRACALANZA, H. O que sabemos sobre os livros didáticos para o ensino de Ciências no Brasil. 1993. Tese (Doutorado) - Faculdade de Educação, UNICAMP, Campinas, 1993.

FRANCISCO, C. A.; QUEIROZ, S. L. Análise de Dissertações Produzidas sobre Livros Didáticos de Química em Programas de Pós-Graduação em Ensino de Ciências e Matemática. In: atas do XV Encontro Nacional de Ensino de Química. Brasília, 2010.

FREIRE, L. I. F.; FERNANDEZ, C. Professores novatos de química e o desenvolvimento do PCK de oxidorredução: influências da formação inicial. Educación Química, v. XXV, p. 312-324, 2014.

FREIRE, M. da S.; SILVA JÚNIOR, C. N. da; SILVA, M. G. L. da. Dificuldades de aprendizagem no ensino de eletroquímica segundo licenciandos de química. VIII Encontro Nacional de Pesquisa em Educação em Ciências, Campinas, 2011.

FREITAG, B. MOTTA, V. R., COSTA, W. F. da. O livro didático em questão. 2. ed. São Paulo: Cortez, 1993.

FRY, H.S. The electronic conception of positive and negative valences. Journal American Chemical Society. v. 37, p. 2368-2373, 1915.

FUNDO NACIONAL DE DESENVOLVIMENTO DA EDUCAÇÃO. Funcionamento do PNLD. Disponível em: <http://www.fnde.gov.br/programas/programas-dolivro/livro-didatico/funcionamento $>$. Acesso em 8 de agosto de 2017

GARNETT, P. J., GARNETT, P. J., HACKLING, M. W., Students' Alternative Conceptions in Chemistry: A review of Research and Implications for Teaching and Learning. Studies in Science Education, v.25, p. 69-95, 1995

GARNETT, P. J.; GARNETT, P. J., TREAGUST, D. F. Implications of research on students' understanding of electrochemistry for improving science curricula and classroom practice. International Journal of Science Education, v. 12, p. 147-56, 1990.

GARNETT, P. J.; TREAGUST, D. F. Conceptual difficulties experienced by senior high school students of electrochemistry: Electric circuits and oxidation-reduction equations. Journal of Research in Science Teaching, v. 12, p. 121-42, 1992a.

GARNETT, P. J.; TREAGUST, D. F. Conceptual difficulties experienced by senior high school students of electrochemistry: Electrochemical (galvanic) and electrolytic cells. Journal of Research in Science Teaching, v. 29, n. 10, p. 1079-99, 1992 b.

GERARD, F-M., ROEGIERS, X. Conceber e avaliar manuais escolares. Porto Portugal. Porto Editora, 1998.

GHIBAUDI, E., REGIS, A., ROLETTO, E. Le reazioni redox: um pasticcio concettuale?. Perspectives in Science, v. 5, p. 14-24, 2015.

GILBERT, J. K., BOULTER, C. J. Learning science through models and modeling. In B. J. Fraser, K. G. Tobin (Eds.), International Handbook of Science Education, p. 67-80, 1998.

GKITZIA, V., SALTA, K., TZOUGRAKI, C. Development and application of suitable criteria for the evaluation of chemical representations in school textbooks. Chemistry Education Research and Pratice, v. 12, p. 5-14, 2011.

GOES, L. F.; FERNANDEZ, C.; AGOSTINHO, S. M. L. Concepções e dificuldades de um grupo de professores de química sobre conceitos fundamentais de eletroquímica. In: atas do XVIII Encontro Nacional de Ensino de Química (XVIII ENEQ) Florianópolis, SC, 2016. 
GOES, L. F.; NOGUEIRA, K. S. C.; FERNANDEZ, C. A representação das reações redox através das imagens em livros didáticos brasileiros de química. Revista Acta Scientiae, v. 20, p. 135-153, 2018.

GOODSTEIN, M. P. Interpretation of Oxidation-Reduction. Journal of Chemical Education, v. 47, p. 452-457, 1970.

GUERRA, A, QUINTAL, J. R. A história da ciência no processo ensino-aprendizagem. Física na Escola, v. 10, n. 1, 2009.

HARRISON, A. G. A typology of school science models. International Journal of Science Education, v. 22, n.9, p. 1011-1026, 2000.

HARRISON, A. G., TREAGUST, D. F. Modelling in science lessons. Are there better ways to learn with models?. School Science and Mathematics, v. 98, n.8, p. 420429, 1998.

HASANI, A. S. An Investigation over Iranian Middle School English Textbook. Journal of Studies in Social Sciences and Humanities, v. 2, n. 1, p. 12-16, 2016.

HASLAM, A.; SAAD, J. A.; ROSSI FILHO, S. O livro e o designer II: como criar e produzir livros. Rosari, 2007.

HORTON, C. Student preconceptions and misconceptions in Chemistry. Assumption College, Worcester, USA, 2004.

HUDDLE, P. A., WHITE, M. D. Using a Teaching Model to Correct Known Misconceptions in Electrochemical. Journal of Chemical Education, v. 77, n. 1, p. 104-111, 2000

HUME, A. CoRes as tools for promoting pedagogical content knowledge of novice science teachers. Chemistry Education in New Zealand, v. 118, p. 13-9, 2010.

JOAQUIM, M. G. de G., Imagens na comunicação do conhecimento em livros didáticos de química e física: uma análise à luz da semiótica Peirceana. Dissertação (mestrado) Universidade de São Paulo, Faculdade de educação, Instituto de Física, Instituto de Química, Instituto de Biociências, São Paulo, 2017.

JUNIOR, C. G. S., REGNIER, J-C. Livros didáticos e suas funções para o professor de matemática no Brasil e na França. In: Atas do $2^{\circ}$ SIPEMAT: Simpósio Internacional de Pesquisa em Educação Matemática, p.63, 2008.

JUSTI, R. S., GILBERT J. K. Modelling, teachers' views on the nature of modelling, and implications for the education modellers. International Journal of Science Education, v. 24, n.4, p. 369-387, 2002.

KAHVECI, A. Quantitative Analysis of Science and Chemistry Textbooks for Indicators of Reform: A complementary perspective. International Journal of Science Education, v. 32, n. 11, p. 1495-1519, 2010.

KLEIN, S. G., BRAIBANTE, M. E. F. Reações de oxidação-redução: Concepções conceituais de estudantes do nível médio, In: Atas do X Encontro Nacional de Pesquisa em Educação em Ciências (X ENPEC), 2015.

KLEIN, S. G., BRAIBANTE, M. E. F., Reações de oxi-redução e suas diferentes abordagens. Química Nova na Escola, v. 39, n. 1, p. 35-45, 2017.

KOTZ, J.C., TREICHEL, P.M., Química e reações químicas. LTC, $4^{a}$ edição, Rio de Janeiro, 2002.

KULM, G., GRIER, L. Mathematics curriculum materials reliability study. Washington, DC: Project 2061, American Association for the Advancement of Science, 1998.

LAJOLO, M. Livro didático: um (quase) manual de usuário. Em aberto, n. 69, p. 3-9, 1996 
LEE, S. J. Exploring students' understanding concerning batteries - Theories and practices. International Journal of Science Education, v. 29, n. 4, p. 497-516, 2007.

LEICESTER, H. M. The Historical Background of Chemistry. Courier Dover Publications, New York, 1971.

LEITE, Á. E., GARCIA, N. M. D., ROCHA, M. Tendências de pesquisa sobre os livros didáticos de ciências e física. In: Atas do X Congresso Nacional de Educação e I Seminário Internacional de Representações Sociais, Subjetividade e Educação. Curitiba, 2011.

LIN, H. S.; YANG, T. C.; CHIU, H. L.; CHOU, C. Y. Students' Difficulties in Learning Electrochemistry. Proceedings of the National Science Council, v. 12, n. 3, p. 100-105, 2002.

LISBOA, J. C. F. Coleção Ser Protagonista. Química $1^{\circ}$ ano: ensino médio. Edições SM, $3^{a}$ edição, São Paulo, 2016.

LISBOA, J. C. F. Coleção Ser Protagonista. Química $2^{\circ}$ ano: ensino médio. Edições SM, $3^{\text {a }}$ edição, São Paulo, 2016.

LISBOA, J. C. F. Coleção Ser Protagonista. Química $3^{\circ}$ ano: ensino médio. Edições SM, $3^{\text {a }}$ edição, São Paulo, 2016.

LITZ, D. R. A. Textbook Evaluation and ELT Management: A South Korean Case Study. Asian EFL Journal, v.53, p. 1-51, 2000

LOPES, A.R.C.. Livros didáticos: obstáculos ao aprendizado da ciência química 1obstáculos animistas e realistas. Química Nova, v.15, n.3, p. 254-261,1992.

MACHADO, A. L., SANTOS, A. V. Da pilha de Daniell ao eletrodo de vidro no livro de Análise Química Instrumental: Uma abordagem didática?. In: Atas do $7^{\circ}$ Simpósio Brasileiro de Pesquisa em Ensino de Química - 7 SIMPEQUIM, 2009.

MAHMOOD. K. Conformity to Quality Characteristics of Textbooks: The Illusion of Textbook Evaluation in Pakistan. Journal of Research and Reflections in Education, v. 5, n.2, p. 170-190, 2011.

MAIA, J. O., VILLANI, A. O Livro Didático e os Cadernos do Estado de São Paulo nas práticas pedagógicas dos professores de Química. In.: Atas do IX Encontro Nacional de Pesquisa em Educação em Ciências. Águas de Lindóia, 2013.

MARPICA, N. S.; LOGAREZZI, A. J. M. Um panorama das pesquisas sobre livro didático e educação ambiental. Ciência \& Educação, v. 16, n. 1, p. 115-130, 2010.

MARTINS, A. L. S., SOARES, E. C., SILVA, D. R., VAlENTIM, J. A. Análise do conceito de Eletrólise nos livros didáticos de Química do PNLD-2015 e periódicos. In: Atas do XVIII Encontro Nacional de Ensino de Química (XVIII ENEQ), Florianópolis, 2016a

MARTINS, A. L. S., SOARES, E. C., SILVA, D. R., VALENTIM, J. A. O conceito de Eletrólise nos livros didáticos de Química do PNLD-2015. In: Atas do XVIII Encontro Nacional de Ensino de Química (XVIII ENEQ), Florianópolis, 2016b

MARTINS, A. N. A. Abordagem da problemática do descarte de pilhas e baterias nos livros didáticos de química do PNLD 2015 para o conteúdo de eletroquímica. Monografia (graduação) - Universidade Estadual da Paraíba, 2015.

MEGID NETO, J.; FRACALANZA, H. O livro didático de ciências: problemas e soluções. Ciência \& Educação, v. 9, n. 2, p. 147-157, 2003.

MENDONÇA, R. J.; CAMPOS, A. F.; JÓFILI, Z. M. S. O conceito de oxidação-redução nos livros didáticos de química orgânica do Ensino Médio. Química Nova na Escola, v. 20, p. 45-8, 2004.

MINAYO, M.C.S. O Desafio do Conhecimento: Pesquisa Qualitativa em Saúde. HUCITEC, 10. ed., São Paulo, 2007. 
MONTEIRO, I. G.; JUSTI, R. S. Analogias em livros didáticos de química brasileiros destinados ao ensino médio. Investigações em Ensino de Ciências. v.5, n.2, p. 6791, 2000.

MORAES, R. Análise de conteúdo. Revista Educação, Porto Alegre, v. 22, n. 37, p. 732, 1999

MOREIRA, K. H. Livros didáticos como fonte de pesquisa: um mapeamento da produção acadêmica em história da educação. Educação e Fronteiras On-Line, v.2, n.4, p.129-142, 2012.

MOREIRA, W. A., MOREIRA, C. M. G, TRETIN, P. H. Cálculo da ddp: uma análise dos conceitos presentes nos livros didáticos. In: atas do XIV Encontro Nacional de Ensino de Química (XIV ENEQ) - UFPR, 2008.

MORTIMER, E. F. A evolução dos livros didáticos de química destinados ao ensino secundário. Em Aberto. v.7, n.40, p. 25-41, 1988.

MORTIMER, E. F., MACHADO, A. H. Coleção Química: Ensino Médio. Química Ensino Médio I. Scipione, $3^{\text {a }}$ edição, São Paulo, 2016.

MORTIMER, E. F., MACHADO, A. H. Coleção Química: Ensino Médio. Química Ensino Médio II. Scipione, $3^{\text {a }}$ edição, São Paulo, 2016.

MORTIMER, E. F., MACHADO, A. H. Coleção Química: Ensino Médio. Química Ensino Médio III. Scipione, $3^{\text {a }}$ edição, São Paulo, 2016.

NELSON, D. L., COX, M. M. Lehninger principles of biochemistry. Freeman, $4^{\text {a }}$ edição, New York, 2004.

NIAZ, M. Faciliting conceptual change in student's understanding of electrochemistry. International Journal of Science Education, v.24, n.4, p.425-439, 2002.

NIAZ, M.; CHACÓN, E. A conceptual change teaching strategy to facilitate high school students' understanding of electrochemistry. Journal of Science Education and Technology, v. 12, n. 2, p. 129-34, 2003.

NOGUEIRA, K. S. C., GOES, L. F., FERNANDEZ, C. O estado da arte sobre o ensino de reações redox nos principais eventos na área de educação no Brasil. Revista Electrónica de Enseñanza de las Ciencias, v. 16, n. 3, p. 410-434, 2017.

NOVAIS, V. L. D., ANTUNES, M. T. Coleção Vivá. Química: volume I: Ensino médio. Positivo, $1^{\mathrm{a}}$ edição, Curitiba, 2016.

NOVAIS, V. L. D., ANTUNES, M. T. Coleção Vivá. Química: volume II: Ensino médio. Positivo, $1^{\mathrm{a}}$ edição, Curitiba, 2016.

NOVAIS, V. L. D., ANTUNES, M. T. Coleção Vivá. Química: volume III: Ensino médio. Positivo, $1^{\mathrm{a}}$ edição, Curitiba, 2016.

NÚÑEZ, I. B.; RAMALHO, B. L.; SILVA, I. K. P.; CAMPOS, A. P. N. A seleção dos livros didáticos: um saber necessário ao professor. O caso do ensino de Ciências. Revista Iberoamericana de Educación, p. 1-12, 2003.

OCOTERO, V. M., CASAS, C. P., VÁZQUEZ, S. M., ESPINAL, M. de J. M. Los procesos redox y su relevancia en la vida. In OCOTERO, V. M. (coord.) Lecturas de apoyo para comprender mejor la Química. Facultad de Ciencias, Universidad Nacional Autónoma de México, $1^{\text {a }}$ ed., 2015.

OGUDE, A. N.; BRADLEY, J. D. Ionic conduction and electrical neutrality in operating electrochemical cells. Journal of Chemical Education, v. 71, n. 1, p. 29-34, 1994.

OGUDE, N. A., BRADLEY, J. D. Electrode Processes and Aspects Relating to Cell EMF, Current, and Cell Components in Operating Electrochemical Cells. Journal of Chemical Education, v.73, n.12, p.1145-1149, 1996.

OKI, M. C. M. A eletricidade e a Química. Química Nova na Escola, v. 12, 2000.

OLIVEIRA, D.C. Análise de Conteúdo Temático- Categorial: Uma proposta de sistematização. Revista Enfermagem - UERJ, v. 16, n. 4, p.569-576, 2008. 
OLIVEIRA, W. TIEDEMANN, P. W., CECCHINI, R. G., OSORIO, V. K. L. Eletrodo de hidrogênio $-\mathrm{O}$ que há nos livros didáticos além de $\mathrm{Eq}=0 \mathrm{~V}$ ?. In: Atas da 30 ${ }^{\mathbf{a}}$ Reunião Anual da Sociedade Brasileira de Química - 30ª RASBQ. 2007.

OLIVEIRA, W. TIEDEMANN, P. W., CECCHINI, R. G., OSORIO, V. K. L. Eletrodo de hidrogênio - $\mathrm{O}$ que há nos livros didáticos além de $\mathrm{E}^{\mathrm{O}}=0$ ?. Química Nova, v. 32, n. 4, p. 1064-1068, 2015.

OMIKO, A. Evaluation of Chemistry textbooks in use in Secondary Schools in Ebonyi State of Nigeria. Tese Ph.D apresentado ao Department of Science Education, Faculty of Education, Ebonyi State University Abakaliki, 2011.

ÖSKAYA, A. R. Conceptual difficulties experienced by prospective teachers in electrochemistry: Half-cell potential, cell potential, and chemical and electrochemical equilibrium in galvanic cells. Journal of Chemical Education, v. 79, n. 6, p. 735-8, 2002.

ÖSTERLUND, L. L.; BERG, A.; EKBORG, M. Redox models in chemistry textbooks for the upper secondary school: friend or foe? Chemical Education Research and Practice, v. 11, p. 182-192, 2010.

PAIK, S-H, KIM, S., KIM, K. Suggestion of a Viewpoint Change for the Classification Criteria of Redox Reactions. Journal of Chemical Education, v. 95, n. 5, p. 563568, 2017

PEDREIRA, A. J., CARNEIRO, M. H. S., Livro didático de Biologia: um levantamento bibliográfico. In: Atas do XI Encontro Nacional de Pesquisa em Educação em Ciências, Florianópolis, 2017.

PIETROCOLA, M. Construção e realidade: O realismo cientifico de Mário Bunge e o ensino de ciências através de modelos. Investigações em Ensino de Ciências, v. 04, n. 03, p. 213-227, 1999.

PITANGA, A. F., SANTOS, H. B. dos, GUEDES, J. T., FERREIRA, W. M., SANTOS, L. D. dos. História da Ciência nos Livros Didáticos de Química: Eletroquímica como Objeto de Investigação. Química Nova na Escola, São Paulo, Vol. 36, N 1 , p. 11-17, 2014.

PRESTES, M. E. B., CALDEIRA, A. M. de A. Introdução. A importância da história da ciência na educação científica. Filosofia e História da Biologia, v. 4, p. 1-16, 2009.

PRETTO, Nelson de Luca. A ciência nos livros didáticos. Campinas-SP: Ed. Da UNICAMP; Salvador: CED/UFBA, 1985. 95 p.

PULIDO, M. D., O dualismo eletroquímico de Berzelius: sua caracterização e presença em livros didáticos de química. Dissertação (mestrado) - Universidade de São Paulo, Faculdade de Educação, Instituto de física, Instituto de Química e Instituto de Biociências, São Paulo, 2016.

QUESADO, M. O livro didático e as demandas atuais da educação em Ciências. In: Martins, I; Gouvêa, G; Vilanova, O livro didático de Ciências: contextos de exigência, critérios de seleção, práticas de leitura e uso em sala de aula. $1^{\mathrm{a}}$. ed. Rio de Janeiro: Copyright, 2012. P. 89-102.

REIS, T. O., GOES, L. F., FERNANDEZ, C. A representação do conteúdo de oxirredução por meio de imagens nos livros didáticos de química para o Ensino Médio. In: Atas do XVIII Encontro Nacional de Ensino de Química (XVIII ENEQ), Florianópolis, 2016a

REIS, T. O., GOES, L. F., FERNANDEZ, C. Reações redox e livros didáticos: um mapeamento do conteúdo de oxirredução em livros de química para o Ensino Médio. In: Atas do XVIII Encontro Nacional de Ensino de Química (XVIII ENEQ), Florianópolis, 2016b 
RIBEIRO, V. M. M. Mudança Conceptual relativa a reações de oxidação-redução: um estudo exploratório. Dissertação de mestrado. Faculdade de engenharia, Universidade Lusófona de Humanidades e Tecnologias, Lisboa, 2013

RICARDO, E. C. Competências, interdisciplinaridade e contextualização: dos Parâmetros Curriculares Nacionais a uma compreensão para o ensino das Ciências. Tese (Doutorado em Educação Científica e Tecnológica). Universidade Federal de Santa Catarina, Florianópolis: UFSC, 2005.

RICARDO, E. C.; ZYLBERSZTAJN, A. Os Parâmetros Curriculares Nacionais para as Ciências do Ensino Médio: uma análise a partir da visão de seus elaboradores. Investigações em Ensino de Ciências, Porto Alegre, v.13, n.3, p. 257-274, 2008.

RINGNES, V. Oxidation-reduction - learning difficulties and choice of redox models. School Science Review, v.77, $\mathrm{n}^{\mathbf{o}}$ 279, p. 74-78, 1995.

ROJO, Roxane. Materiais didáticos: escolha e uso. In: BRASIL. MEC. Salto para o Futuro. TV Escola: Materiais didáticos: escolha e uso. Boletim 14, agosto 2005.

ROSENTHAL, D. P., SANGER, M. J. Students misinterpretations and misconceptions based on their explanations of two computer animations of varying complexity depicting the same oxidation-reduction reaction. Chemistry Education Research and Practice, v. 13, p. 471-483, 2012.

SANGER, M. J.; GREENBOWE, T. J. An analysis of college Chemistry textbooks as sources of misconceptions and errors in electrochemistry. Journal of Chemical Education, v. 76, n. 6, p. 853-60, 1999.

SANGER, M. J.; GREENBOWE, T. J. Common student misconceptions in electrochemistry: Galvanic, electrolytic, and concentration cells. Journal of Research in Science Teaching, v. 34, n. 4, p. 377-98, 1997a.

SANGER, M. J.; GREENBOWE, T. J. Students' misconceptions in electrochemistry: Current flow in electrolyte solutions and the salt bridge. Journal of Chemical Education, v. 74, n. 7, p. 819-23, 1997 b.

SANGER, M.; GREENBOWE, T. Addressing student misconceptions concerning electron flow in aqueous solutions with instruction including computer animations and conceptual change strategies. International Journal of Science Education, v.22, n.5, p.521-537, 2000.

SANJUAN, M. E. C.; DOS SANTOS, C. V.; MAIA, J. O.; DA SILVA, A. F. A.; WARTHA, E. J. Maresia: Uma Proposta para o Ensino de Eletroquímica. Química Nova na Escola, v.31, n.3, p.190-197, 2009.

SANTOS, J. E., SALES, L. L. M., DA SILVA, F. J. S. Uma análise dos livros didáticos de química usando a epistemologia de Bachelard a partir dos conceitos de oxidação e redução. In: atas do $8^{\circ}$ Simpósio Brasileiro de Educação Química ( ${ }^{\circ}$ SIMPEQUIM) - Natal, 2010.

SANTOS, V. W., AIRES, J. A. A abordagem CTS em livros didáticos de química: uma análise do conteúdo Pilhas. In: Atas do XVIII Encontro Nacional de Ensino de Química (XVIII ENEQ), Florianópolis, 2016.

SANTOS, W. L. P. dos (coord.). Coleção Química Cidadã. Química cidadã: volume I. AJS, $3^{\text {a }}$ edição, São Paulo, 2016.

SANTOS, W. L. P. dos (coord.). Coleção Química Cidadã. Química cidadã: volume II. AJS, $3^{\text {a }}$ edição, São Paulo, 2016.

SANTOS, W. L. P. dos (coord.). Coleção Química Cidadã. Química cidadã: volume III. AJS, $3^{\text {a }}$ edição, São Paulo, 2016.

SANTOS, W. L.; CARNEIRO, M. H. S. Livro Didático de Ciências: Fonte de Informação ou Apostila de Exercícios? Contexto e Educação: Ano 21. Ijuí: Editora Unijuí. p. 201 - 222. n. 75, 2006. 
SCHIMER, S. B., SAUERWEIN, I. P. S, Livros didáticos em publicações na área de ensino: contribuições para análise e escolha. Investigações em Ensino de Ciências, v.22, n. 1, p. 23-41, 2017.

SCHMIDT, H. J. Students' misconceptions - looking for a pattern. Science Education, v.81, p. 123-135, 1997

SCHMIDT, H. J., VOLKE, D. Shift of meaning and students' alternative concepts. International Journal of Science Education., v. 25, p. 1409-1424, 2003

SCHMIDT, H. J.; MAROHN, A.; HARRISON, A. G. Factors that prevent learning in electrochemistry. Journal of Research in Science Teaching, v. 44, n. 2, p. 25883, 2007.

SCHNETZLER, R. P. Alternativas didáticas para a formação docente em química. In: DALBEN, A. et al. (Coords.). Coleção didática e prática de ensino. Belo Horizonte: Autêntica, 2010.

SCHNETZLER, R. P. Um estudo sobre o tratamento do conhecimento químico em livros didáticos brasileiros dirigidos ao ensino secundário de química de 1875 a 1978. Química Nova, v.4, n.1, p.6-15, 1981.

SEGUIN, R. The elaboration of schooltextebooks - Methodological guide. Unesco. Divison of Educational Sciences, Contents and Methods of Education. p.163, 1989.

SELLES, S. E., FERREIRA, M. S. Influências histórico-culturais nas representações sobre as estações do ano em livros didáticos de ciências. Ciência \& Educação, v.10, n.1, p.101-110, 2004.

SESEN, B. A.; TARHAN, L. Inquiry-based laboratory activities in electrochemistry: High school students' achievements and attitudes. Research in Science Education, v. 43, p. 413-35, 2013.

SHIBLEY JR., I. A., AMARAL, K. E., DAVID, J. A. e MCCAULLY, R. J. Oxidation and Reduction Reactions in Organic Chemistry. Journal of Chemical Education, v. 87, n. 12, p. 1351-1354, 2010.

SHRIVER, D. F., ATKINS, P. W. Química Inorgânica. Bookman, $3^{a}$ edição, Porto Alegre, 2003.

SILVA JUNIOR, C. G. Critérios de adoção e utilização do livro didático de matemática no ensino fundamental, e a participação do professor na adoção: o caso do Agreste de Pernambuco. Dissertação de mestrado em Ensino das ciências, UFRPE. Recife - PE, 2005.

SILVA, G. R., História da Ciência e experimentação: perspectivas de uma abordagem para os anos iniciais do Ensino Fundamental. Revista Brasileira de História da Ciência, v. 6, n. 1, p. 121-132, Rio de Janeiro, 2013.

SILVA, L. A. da, SILVA, F. C. V. da, A contextualização do conteúdo de eletroquímica: um olhar para o livro didático e para concepções de professores de química. In: atas do XVIII Encontro Nacional de Ensino de Química (XVIII ENEQ), Florianópolis, 2016

SILVA, L. L. M., SARAH, A. T., CORRÊA, C. N., RIBEIRO, F. V. P., SANTOS, K. R. dos, NEVES, P. A. P. F. G. das, COSTA, F. M. P funcionamento da pilha de Daniell em três livros didáticos de química. In: Atas do $\mathbf{5 7}^{\circ}$ Congresso Brasileiro de Química, Rio Grande do Sul, 2017.

SILVA, M. C. G., MARQUES, C. V. V. C. O. O livro didático de ciências: concepções de seleção e utilização por professores da zona urbana da cidade de Codó-MA. Pesquisa em Foco, São Luís, vol. 21, n. 1, p. 46-66. 2016.

SILVA, R. C. Diálogo entre os critérios de avaliação do PNLD e o tratamento didático em livro didático. Dissertação de mestrado em Ensino de Língua e 
Literatura, Programa de Pós-Graduação em Letras da Universidade Federal do Tocantins, 2015.

SIMA, J. Redox reactions: inconsistencies in their descriptions. Foundations of Chemistry, v. 15, n. 1, p. 57-64, 2013.

SISLER, H., VANDERWERF, C., Oxidation-reduction: an example of chemical sophistry. Journal of Chemical Education, v. 57, p. 42, 1980.

SOUDANI, M.; SIVADE, A.; CROS, D.; MÉDIMAGH, M. S. Transfering knowledge from the classroom to the real world: redox concepts. School Science Review, v. 82, n. 298, 2000.

SUMFLETH, E., TODTENHAUPT, S. Zum redox-verständnis der schüler beim ubergang von der sekundarstufe I zur Sekundarstufe II. (About students' understanding of redox reaction at the interface of lower and upper secondary school level). Chimica Didactica, v. 14, p. 43-68, 1988

TURATO, E. R. Métodos qualitativos e quantitativos na área da saúde: definições, diferenças e seus objetos de pesquisa. Revista Saúde Pública, São Paulo, v. 39, n.3, p. 507-514, 2005.

VERA, G.W.G., FERNANDES, A.C., VANZELER, E.P.B. Avaliação dos conteúdos de eletroquímica em livros didáticos para o ensino médio. In: atas do $\mathbf{1 2}^{\circ}$ Simpósio Brasileiro de Educação Química (12 SIMPEQUIM), Fortaleza, 2014.

VIDAL, P. H. O., PORTO, P. A. A pilha de Volta em livros didáticos de química: algumas considerações. In: Atas da 32 ${ }^{\mathbf{a}}$ Reunião Anual da Sociedade Brasileira de Química - 32a RASBQ. 2009.

VITZ, E. Redox Redux: Recommendations for Improving Textbook and IUPAC Definitions. Journal of Chemical Education, v. 79, n. 3, p. 397-400, 2002.

VOLLHARDT, P. Química orgânica: estrutura e função. Tradução: Flavia Martins da Silva ... [et al.], Bookman, 6. ed., Porto Alegre, 2013.

WILLIAMS, D. Developing criteria for textbook evaluation. ELT Journal, v. 37, n. 3, p. 251-255, 1983

WOLCOTT, H. T. Transforming qualitative data: Description. Thousand Oaks, CA: Sage, 1994.

WUO, W. O ensino de física: saber científico, livros e prática docente. In: BUENO, J. G. S. (org). Escolarização, práticas didáticas, controle e organização do ensino. $1^{\text {a }}$ ed., Araraquara: J.M. Editores, 2002. 


\section{APÊNDICE}

APÊNDICE A - Trechos referentes ao conteúdo de reações redox Coleção QC - livro 1

\begin{tabular}{|c|c|c|}
\hline \multicolumn{3}{|c|}{ Coleção QC - livro 1} \\
\hline Contexto & Trecho & Pag. \\
\hline \multicolumn{3}{|c|}{ Oxida } \\
\hline $\begin{array}{l}\text { Introdução a } \\
\text { Transformação } \\
\text { Química }\end{array}$ & $\begin{array}{l}\text { Ela será oxidada, ou seja, enferrujará. A ferrugem é uma substância } \\
\text { que tem propriedades bem diferentes do metal original. }\end{array}$ & 13 \\
\hline $\begin{array}{l}\text { Propriedades } \\
\text { químicas }\end{array}$ & $\begin{array}{l}\text { Oxidável - uma barra de ferro oxida em contato com a umidade; } \\
\text { muitas frutas oxidam ao contato com o ar. Uma joia de ouro } \\
\text { praticamente não oxida; }\end{array}$ & 21 \\
\hline $\begin{array}{l}\text { Exercício sobre } \\
\text { transformação }\end{array}$ & $\begin{array}{l}\text { Mas, se a lata for de ferro, sem pintura e ficar alguns dias em } \\
\text { ambiente úmido, ela será oxidada, ou seja, enferrujará. }\end{array}$ & 37 \\
\hline $\begin{array}{l}\text { Exercício sobre } \\
\text { propriedades } \\
\text { químicas }\end{array}$ & Componente 1 - Oxida em contato umidade. & 38 \\
\hline $\begin{array}{l}\text { Exercício Forças } \\
\text { Intermoleculares }\end{array}$ & $\begin{array}{l}\text { I - Suas mãos ficam limpas imediatamente, pois a graxa ou a } \\
\text { manteiga se dissolve na presença de um oxidante, no caso a água. }\end{array}$ & 267 \\
\hline $\begin{array}{l}\text { Resposta exercício } \\
\text { TQ }\end{array}$ & $\begin{array}{l}\text { 1) Errado - As reações químicas podem ocorrer tanto em processos } \\
\text { artificiais como naturais, como a oxidação e a respiração animal ou } \\
\text { vegetal. }\end{array}$ & 332 \\
\hline $\begin{array}{l}\text { Resposta exercício } \\
\text { PQ }\end{array}$ & $\begin{array}{l}\text { O gás de cozinha (GLP) - um ótimo combustível; a } \\
\text { palha de aço - sofre oxidação ou corrosão (ferrugem); }\end{array}$ & 333 \\
\hline \multicolumn{3}{|c|}{ Oxirredução/ Redox/ Óxido-redução } \\
\hline & Não houve & \\
\hline \multicolumn{3}{|c|}{ Reduz } \\
\hline & Não houve & \\
\hline \multicolumn{3}{|c|}{ Coleção QC - livro 2} \\
\hline Contexto & Trecho & Pag \\
\hline \multicolumn{3}{|c|}{ Oxida } \\
\hline $\begin{array}{l}\text { Exercícios } \\
\text { unidades de } \\
\text { medida da química }\end{array}$ & $\begin{array}{l}\text { O cravo-da-índia, por exemplo, contém uma substância conservante, } \\
\text { denominada eugenol [C3H5C6H3(OH)OCH3], que possui ação } \\
\text { antioxidante, prevenindo o ranço (produto da reação entre o oxigênio e } \\
\text { a gordura da carne) e evitando o aparecimento de bolor. } \\
\text { Com os seus conhecimentos, julgue os itens considerando } \\
\text { C para os corretos e E para os errados. } \\
\text { 1) Os conservantes e antioxidantes naturais são menos propensos a } \\
\text { causar doenças, como o câncer, no ser humano. } \\
\text { 4) Normalmente, reações provocadas pela ação do ar, da luz, do } \\
\text { contato com metais etc. deixam o alimento com cheiro ruim } \\
\text { característico e impróprio para o consumo. O antioxidante serve para } \\
\text { retardar essa reação. }\end{array}$ & 27 \\
\hline $\begin{array}{l}\text { Classes de } \\
\text { substancias: } \\
\text { funções orgânicas, } \\
\text { ácidos, bases e sais }\end{array}$ & $\begin{array}{l}\text { Com aspecto líquido incolor e viscoso, o ácido sulfúrico }\left(\mathrm{H}_{2} \mathrm{SO}_{4}\right) \text { é um } \\
\text { forte oxidante e desidratante }\end{array}$ & 115 \\
\hline Cinética química & $\begin{array}{l}\text { Combustível é todo material oxidável (sólido, líquido ou gasoso) capaz } \\
\text { de reagir com o gás oxigênio, denominado comburente }\end{array}$ & 140 \\
\hline
\end{tabular}




\begin{tabular}{|c|c|c|}
\hline $\begin{array}{l}\text { Rapidez de uma } \\
\text { reação }\end{array}$ & $\begin{array}{l}\text { A unidade de tempo a ser usada deve levar em conta a reação em } \\
\text { estudo. Assim, pode-se usar [...] anos para a oxidação espontânea da } \\
\text { celulose de um papel }\end{array}$ & 142 \\
\hline $\begin{array}{l}\text { Aplicação dos } \\
\text { catalisadores }\end{array}$ & $\begin{array}{l}\text { A vantagem da conversão de álcool em gasolina está no fato de que o } \\
\text { poder energético (entalpia de combustão) da gasolina é maior que o do } \\
\text { álcool. Isso ocorre porque o álcool é um hidrocarboneto parcialmente } \\
\text { oxidado. }\end{array}$ & 164 \\
\hline $\begin{array}{l}\text { Exercícios de } \\
\text { cinética química }\end{array}$ & $\begin{array}{l}\text { [...] julgue os itens com } \mathbf{C} \text { para os corretos e } \mathbf{E} \text { para os errados. } \\
\text { 1) Combustível é todo material oxidável (sólido, líquido ou gasoso) } \\
\text { capaz de reagir com o gás oxigênio. }\end{array}$ & 173 \\
\hline $\begin{array}{l}\text { Exercícios de } \\
\text { cinética química }\end{array}$ & $\begin{array}{l}\text { o apodrecimento da madeira, demora anos, assim como a oxidação } \\
\text { espontânea do papel. }\end{array}$ & 173 \\
\hline Equilíbrio químico & $\begin{array}{l}\text { Uma solução é o uso de detergente biodegradável, aquele que se } \\
\text { decompõe por ação bacteriana, ou seja, é oxidado por colônias de } \\
\text { bactérias presentes na água dos rios, produzindo gás carbônico. }\end{array}$ & 187 \\
\hline $\begin{array}{l}\text { Reações químicas e } \\
\text { sua reversibilidade- } \\
\text { Experimento: } \\
\text { Porque a cor vai e } \\
\text { volta? }\end{array}$ & $\begin{array}{l}\text { O hidróxido de sódio torna o meio alcalino, favorecendo a oxidação da } \\
\text { glicose pelo oxigênio do ar dissolvido em solução, produzindo o ácido } \\
\text { glicólico, conforme descreve a equação: } \\
\mathrm{H}(\mathrm{CHOH})_{5} \mathrm{CHO}_{(\mathrm{aq})}+1 / 2 \mathrm{O}_{2(\mathrm{aq})} \rightarrow \mathrm{H}(\mathrm{CHOH})_{5} \mathrm{COOH}_{(\mathrm{aq})}\end{array}$ & 192 \\
\hline $\begin{array}{l}\text { Reações químicas e } \\
\text { sua reversibilidade- } \\
\text { Experimento: } \\
\text { Porque a cor vai e } \\
\text { volta? }\end{array}$ & $\begin{array}{l}\text { Segundo os mecanismos propostos para a reação, o azul de metileno } \\
\text { facilita a transferência de oxigênio. Quando a glicose é oxidada, o azul } \\
\text { de metileno é reduzido a leucometileno, que é incolor. Rapidamente o } \\
\text { leucometileno é oxidado pelo oxigênio dissolvido, formando azul de } \\
\text { metileno e deixando a solução novamente azul. }\end{array}$ & 192 \\
\hline $\begin{array}{l}\text { Reações químicas e } \\
\text { sua reversibilidade- } \\
\text { Experimento: } \\
\text { Porque a cor vai e } \\
\text { volta? }\end{array}$ & azul de metileno & 192 \\
\hline $\begin{array}{l}\text { Estação de } \\
\text { Tratamento de } \\
\text { Água - } \\
\text { Desinfecção }\end{array}$ & $\begin{array}{l}\text { Por ser muito reativo, ao ser adicionado a substâncias orgânicas ou } \\
\text { inorgânicas, o cloro pode oxidá-las. Com essa oxidação, nem todo } \\
\text { cloro adicionado produzirá cloro residual livre. }\end{array}$ & 329 \\
\hline $\begin{array}{l}\text { Tipos de } \\
\text { tratamentos de } \\
\text { efluentes }\end{array}$ & Processos Avançados de Oxidação (PAOs) etc. & 330 \\
\hline $\begin{array}{l}\text { Tratamento de } \\
\text { efluente secundário }\end{array}$ & $\begin{array}{l}\text { Os sistemas aeróbicos mais utilizados para o tratamento são: lagoas } \\
\text { facultativas, lagoas aeradas, filtros biológicos aeróbicos, valos de } \\
\text { oxidação, disposição controlada no solo e lodo ativado. }\end{array}$ & 331 \\
\hline $\begin{array}{l}\text { Tratamento de } \\
\text { efluente terciário }\end{array}$ & $\begin{array}{l}\text { São processos físicos e químicos, sendo a coagulação, a floculação, a } \\
\text { decantação, a flotação, a separação por membranas, a adsorção e a } \\
\text { oxidaçâo os mais utilizados. }\end{array}$ & 331 \\
\hline $\begin{array}{l}\text { Resolução de } \\
\text { exercícios capitulo } \\
2\end{array}$ & $\begin{array}{l}\text { 5) Equação não balanceada e reação errada, falta a oxidação do } \mathrm{SO}_{2} \text {. } \\
2 \mathrm{SO}_{2}+\mathrm{O}_{2}+2 \mathrm{H}_{2} \mathrm{O} \rightarrow 2 \mathrm{H}_{2} \mathrm{SO}_{4}\end{array}$ & 344 \\
\hline $\begin{array}{l}\text { Resolução de } \\
\text { exercícios capitulo } \\
3\end{array}$ & e) Errado - A oxidação de um metal forma um óxido. & 355 \\
\hline
\end{tabular}




\begin{tabular}{|c|c|c|}
\hline \multicolumn{3}{|c|}{ Não houve } \\
\hline \multicolumn{3}{|c|}{ Redução } \\
\hline $\begin{array}{l}\text { Reações químicas e } \\
\text { sua reversibilidade- } \\
\text { Experimento: } \\
\text { Porque a cor vai e } \\
\text { volta? }\end{array}$ & $\begin{array}{l}\text { Segundo os mecanismos propostos para a reação, o azul de metileno } \\
\text { facilita a transferência de oxigênio. Quando a glicose é oxidada, o azul } \\
\text { de metileno é reduzido a leucometileno, que é incolor. }\end{array}$ & 192 \\
\hline $\begin{array}{l}\text { Reações químicas e } \\
\text { sua reversibilidade- } \\
\text { Experimento: } \\
\text { Porque a cor vai e } \\
\text { volta? }\end{array}$ & azul de metileno & 192 \\
\hline \multicolumn{3}{|c|}{ Coleção QC - livro 3} \\
\hline Contexto & Trecho & \begin{tabular}{|l|} 
Pag \\
\end{tabular} \\
\hline \multicolumn{3}{|c|}{ Oxida } \\
\hline $\begin{array}{l}\text { Introdução as } \\
\text { funções orgânicas }\end{array}$ & $\begin{array}{l}\text { São as chamadas substâncias organossintéticas, entre as quais } \\
\text { podemos citar: medicamentos } \\
\text { (ácido acetilsalicílico), aditivos de alimentos (ácido benzoico } \\
\text { [conservante] e ácido ascórbico [antioxidante]), plásticos (PVC e } \\
\text { PET), agrotóxicos (DDT, BHC) e outros. }\end{array}$ & 16 \\
\hline $\begin{array}{l}\text { Característica do } \\
\text { ácido metanoico }\end{array}$ & $\begin{array}{l}\text { É também muito utilizado na limpeza de peças de aços inoxidáveis e } \\
\text { de alumínio. }\end{array}$ & 64 \\
\hline $\begin{array}{l}\text { Introdução aos } \\
\text { aditivos químicas }\end{array}$ & $\begin{array}{l}\text { O não escurecimento da maçã no pedaço com pó do comprimido } \\
\text { deve-se à presença do ácido ascórbico (vitamina C), que se oxida } \\
\text { preferencialmente a hidroquinona. }\end{array}$ & 73 \\
\hline $\begin{array}{l}\text { Tabela de aditivos } \\
\text { alimentícios }\end{array}$ & $\begin{array}{l}\text { Aditivos/códigos - Antioxidantes/A } \\
\text { Função - Evitar a oxidação dos alimentos. }\end{array}$ & 73 \\
\hline $\begin{array}{l}\text { Exemplos de } \\
\text { aldeídos e cetonas }\end{array}$ & $\begin{array}{l}\text { Algumas substâncias com a função cetona, conhecidas como corpos } \\
\text { cetônicos, são produzidas em nossos organismos em uma das etapas } \\
\text { do metabolismo dos ácidos graxos; elas não se acumulam, pois são } \\
\text { oxidadas produzindo } \mathrm{CO}_{2} \text { e } \mathrm{H}_{2} \mathrm{O} \text {. Todavia, elas são encontradas, em } \\
\text { grande quantidade, na urina de pessoas diabéticas, uma vez que o } \\
\text { organismo dessas pessoas produz mais cetonas do que pode oxidar. }\end{array}$ & 92 \\
\hline $\begin{array}{l}\text { Características dos } \\
\text { éteres }\end{array}$ & $\begin{array}{l}\text { Além disso, como outros éteres, em contato com o ar, pode ser } \\
\text { oxidado, originando peróxidos, que são mais explosivos [...] }\end{array}$ & 93 \\
\hline $\begin{array}{l}\text { Exemplos de ácidos } \\
\text { carboxílicos }\end{array}$ & $\begin{array}{l}\text { ÁCIDO CARBOXÍLICO - Ácido acético } \\
\text { ORIGEM - Oxidação do etanol } \\
\text { ÁCIDO CARBOXÍLICO - Ácido cítrico } \\
\text { ORIGEM - Frutas cítricas } \\
\text { APLICAÇÕES - Aromatizante cítrico e antioxidante. }\end{array}$ & 93 \\
\hline $\begin{array}{l}\text { Exercícios sobre } \\
\text { funções orgânicas }\end{array}$ & $\begin{array}{l}\text { 45. (Mackenzie-SP) As substâncias } \mathrm{A}, \mathrm{B} \text { e } \mathrm{C} \text { pertencem, } \\
\text { respectivamente, às funções orgânicas: } \\
\qquad \begin{array}{l}\text { (A) } \mathrm{H}_{3} \mathrm{C}-\mathrm{CH}_{2}-\mathrm{CH}_{2} \\
\text { oxidação } \\
\text { branda } \\
\text { (B) } \mathrm{H}_{3} \mathrm{C}-\mathrm{CH}_{2}-\mathrm{C}_{\text {oxidação }}^{\text {energética }} \\
\text { (C) } \mathrm{H}_{3} \mathrm{C}-\mathrm{CH}_{2}-\mathrm{C}_{\mathrm{OH}}\end{array}\end{array}$ & 107 \\
\hline
\end{tabular}




\begin{tabular}{|c|c|c|}
\hline $\begin{array}{l}\text { Exercícios sobre } \\
\text { reações orgânicas }\end{array}$ & $\begin{array}{l}\text { 37. Observe as seguintes reações abaixo: [...] As reações que } \\
\text { ocorreram nas alternativas I, II e III são, respectivamente: } \\
\text { d) Eliminação, oxidação e hidrogenação. }\end{array}$ & 156 \\
\hline $\begin{array}{l}\text { Caderno de respostas } \\
\text { - exercício } 32\end{array}$ & $\begin{array}{l}\text { São novas substâncias produzidas a partir do rearranjo das cadeias } \\
\text { carbônicas. Exemplo: medicamentos (ácido acetilsalicílico); aditivos } \\
\text { de alimentos [ácido benzoico (conservante) e ácido ascórbico } \\
\text { (antioxidante)]; plásticos (PVC e PET); agrotóxicos (DDT, BHC) etc. }\end{array}$ & 340 \\
\hline $\begin{array}{l}\text { Caderno de respostas } \\
\text { - exercício } 60\end{array}$ & $\begin{array}{l}\text { Aditivos Códigos - Antioxidantes A } \\
\text { Ação - Evitar a oxidação dos alimentos. }\end{array}$ & 347 \\
\hline $\begin{array}{l}\text { Caderno de respostas } \\
\text { - exercício } 39\end{array}$ & Oxidação, combustão, esterificação, catálises e fermentação. & 356 \\
\hline $\begin{array}{l}\text { Caderno de respostas } \\
\text { - exercício } 40\end{array}$ & $\begin{array}{l}\text { Os vinhos devem ser guardados na horizontal, para } \\
\text { evitar a entrada de oxigênio e, consequentemente, a } \\
\text { oxidação do etanol transformando em ácido etanoico } \\
\text { (vinagre). Devem ser guardados em ambiente climatizado, para } \\
\text { diminuir a possibilidade da reação de oxidação. }\end{array}$ & 356 \\
\hline $\begin{array}{l}\text { Caderno de respostas } \\
\text { - exercício } 46\end{array}$ & 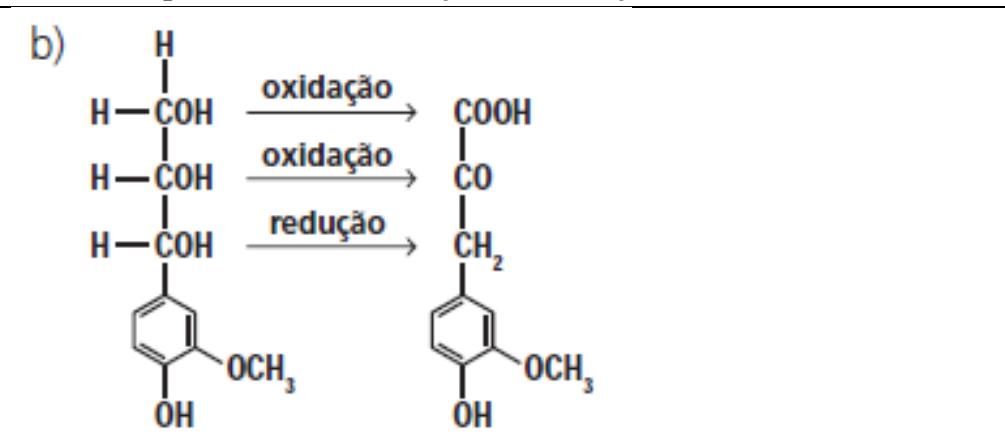 & 356 \\
\hline $\begin{array}{l}\text { Caderno de respostas } \\
\text { - exercício } 48\end{array}$ & $\begin{array}{l}\text { a) I - Desidratação intramolecular (eliminação de } \\
\mathrm{H}_{2} \mathrm{O} \text { ). } \\
\text { II - Esterificação. } \\
\text { III - Oxidação parcial. } \\
\text { IV - Substituição. }\end{array}$ & 357 \\
\hline $\begin{array}{l}\text { Caderno de respostas } \\
\text { - exercício } 8\end{array}$ & $\begin{array}{l}\text { Todas estão corretas. Em Química Orgânica, em geral, a oxidação } \\
\text { ocorre com a adição de átomos de oxigênio ou com a retirada de } \\
\text { átomos de hidrogênio da molécula. Um exemplo de oxidação é a } \\
\text { transformação de álcool em vinagre ou vinho, reações de adição de um } \\
\text { reagente com dupla ligação ou combustão completa e incompleta. }\end{array}$ & 358 \\
\hline $\begin{array}{l}\text { Caderno de respostas } \\
\text { - exercício } 7\end{array}$ & $\begin{array}{l}\text { 4) Errado, o aço inoxidável é uma mistura de ferro com crômio e } \\
\text { níquel, o que lhe dá grande resistência à corrosão. }\end{array}$ & 368 \\
\hline \multicolumn{3}{|c|}{ Oxirredução/ Redox/ Óxido-redução } \\
\hline \multicolumn{3}{|c|}{ Não houve } \\
\hline \multicolumn{3}{|c|}{ Redução } \\
\hline \multicolumn{3}{|c|}{ Não houve } \\
\hline
\end{tabular}

\begin{tabular}{|l|l|c|}
\hline \multicolumn{2}{|c|}{ Coleção SP - livro 1 } & Pag. \\
\hline Contexto & Trecho & \multicolumn{1}{|c|}{ Oxida } \\
\hline $\begin{array}{l}\text { Box - Sabesp utilizará } \\
\text { tecnologia moderna } \\
\text { para transformar água } \\
\text { de reuso em potável }\end{array}$ & $\begin{array}{l}\text { Depois das membranas, será empregado o processo de osmose por } \\
\text { foto-oxidação, que vai eliminar pequenas partículas, como bactérias } \\
\text { e vírus }\end{array}$ & 52 \\
\hline $\begin{array}{l}\text { Box - Lei das } \\
\text { proporções definidas }\end{array}$ & $\begin{array}{l}\text { Como exemplo, podemos utilizar a reação de oxidação do metal } \\
\text { titânio }[\ldots]\end{array}$ & 60 \\
\hline
\end{tabular}




\begin{tabular}{|c|c|c|}
\hline & $\begin{array}{l}\text { A massa de dióxido de titânio é mostrada no eixo da ordenada, a de } \\
\text { metal titânio oxidado, no eixo da abscissa. }\end{array}$ & \\
\hline $\begin{array}{l}\text { Características das } \\
\text { ligas metálicas }\end{array}$ & $\begin{array}{l}\text { A adição de outros metais (veja a tabela abaixo) confere ao aço } \\
\text { certas características, como dureza (aço usado em objetos de corte), } \\
\text { resistência à oxidação (aço inoxidável), resistência à tração (cabos } \\
\text { de aço) e resistência mecânica }\end{array}$ & 133 \\
\hline $\begin{array}{l}\text { Saiba mais- Aplicação } \\
\text { de metais puros }\end{array}$ & $\begin{array}{l}\text { O cobre eletrolítico possui teor de pelo menos } 99,9 \% \text { de Cu e é o } \\
\text { material mais adequado para fios de condução de eletricidade, } \\
\text { unindo baixa resistividade elétrica, alta ductibilidade e resistência à } \\
\text { oxidação. }\end{array}$ & 133 \\
\hline $\begin{array}{l}\text { Química e Biologia- } \mathrm{O} \\
\text { oxigênio dissolvido em } \\
\text { ambientes aquáticos }\end{array}$ & $\begin{array}{l}\text { [...] Nesses processos, denominados oxidativos, o oxigênio é } \\
\text { removido do sistema aquático e pode ser reposto através da } \\
\text { interface ar-água. } \\
\text { A quantidade de oxigênio necessária para promover a oxidação da } \\
\text { matéria orgânica em ambientes aquáticos é denominada demanda } \\
\text { bioquímica de oxigênio (DBO) }\end{array}$ & 152 \\
\hline $\begin{array}{l}\text { Legenda da foto de } \\
\text { introdução as reações } \\
\text { químicas }\end{array}$ & $\begin{array}{l}\text { Muitos metais, como os que compõem esse portão e outras } \\
\text { estruturas, sofrem oxidação por exposição ao ar úmido. }\end{array}$ & 178 \\
\hline $\begin{array}{l}\text { Box química e biologia } \\
\text { - A vitamina C e o } \\
\text { escorbuto }\end{array}$ & $\begin{array}{l}\text { Além do seu papel nutricional, o ácido ascórbico é comumente } \\
\text { utilizado como antioxidante para preservar o sabor e a cor natural } \\
\text { de muitos alimentos }[\ldots]\end{array}$ & 200 \\
\hline Classificação dos sais & $\begin{array}{l}\text { [...] Este é um recurso usado para retirar a umidade do meio, que } \\
\text { pode oxidar peças metálicas e danificar o equipamento. }\end{array}$ & 214 \\
\hline Exercício 37 & $\begin{array}{l}\text { Grandes fontes de emissão do gás dióxido de enxofre são as } \\
\text { indústrias de extração dos minérios sulfurados. } \\
\text { [...] } \\
\text { Por sua vez, o sulfito de cálcio formado pode ser oxidado, com o } \\
\text { auxílio do ar atmosférico, para a obtenção do sulfato de cálcio, } \\
\text { como mostrado na equação (2) }\end{array}$ & 282 \\
\hline \multicolumn{3}{|c|}{ Oxirredução/ redox/ óxido-redução } \\
\hline \multicolumn{3}{|c|}{ Não houve } \\
\hline \multicolumn{3}{|c|}{ Redu } \\
\hline \multicolumn{3}{|c|}{ Não houve } \\
\hline \multicolumn{3}{|c|}{ Coleção SP - livro 2} \\
\hline Contexto & Trecho & Pag. \\
\hline \multicolumn{3}{|c|}{ Oxida } \\
\hline $\begin{array}{l}\text { Alternativa do } \\
\text { exercício } 38\end{array}$ & Nesse caso, a gema do ovo atua como um agente: c) oxidante & 31 \\
\hline Exercício 44 & $\begin{array}{l}\text { O etanol [...] quando metabolizado pelo fígado, oxida-se a etanal } \\
{[\ldots]}\end{array}$ & 32 \\
\hline $\begin{array}{l}\text { Alternativa do } \\
\text { exercício } 36\end{array}$ & $\begin{array}{l}\text { c) Oxidação, pois a luz solar que incide sobre o tronco ativa } \\
\text { fotoquimicamente a cal, que elimina os seres vivos do } \\
\text { microambiente. }\end{array}$ & 47 \\
\hline $\begin{array}{l}\text { Introdução a rapidez } \\
\text { das reações químicas }\end{array}$ & $\begin{array}{l}\text { O processo de envelhecimento em seres vivos se dá por meio de um } \\
\text { conjunto de complexas reações de oxidação biológicas, as quais } \\
\text { envolvem a formação de radicais livres ao longo dos anos. }\end{array}$ & 74 \\
\hline $\begin{array}{l}\text { Catalisadores na } \\
\text { indústria }\end{array}$ & $\begin{array}{l}\text { Para a produção de ácido nítrico pelo processo Ostwald, por } \\
\text { exemplo, a primeira etapa é a de oxidação da amônia, catalisada por } \\
\text { platina. }\end{array}$ & 91 \\
\hline
\end{tabular}




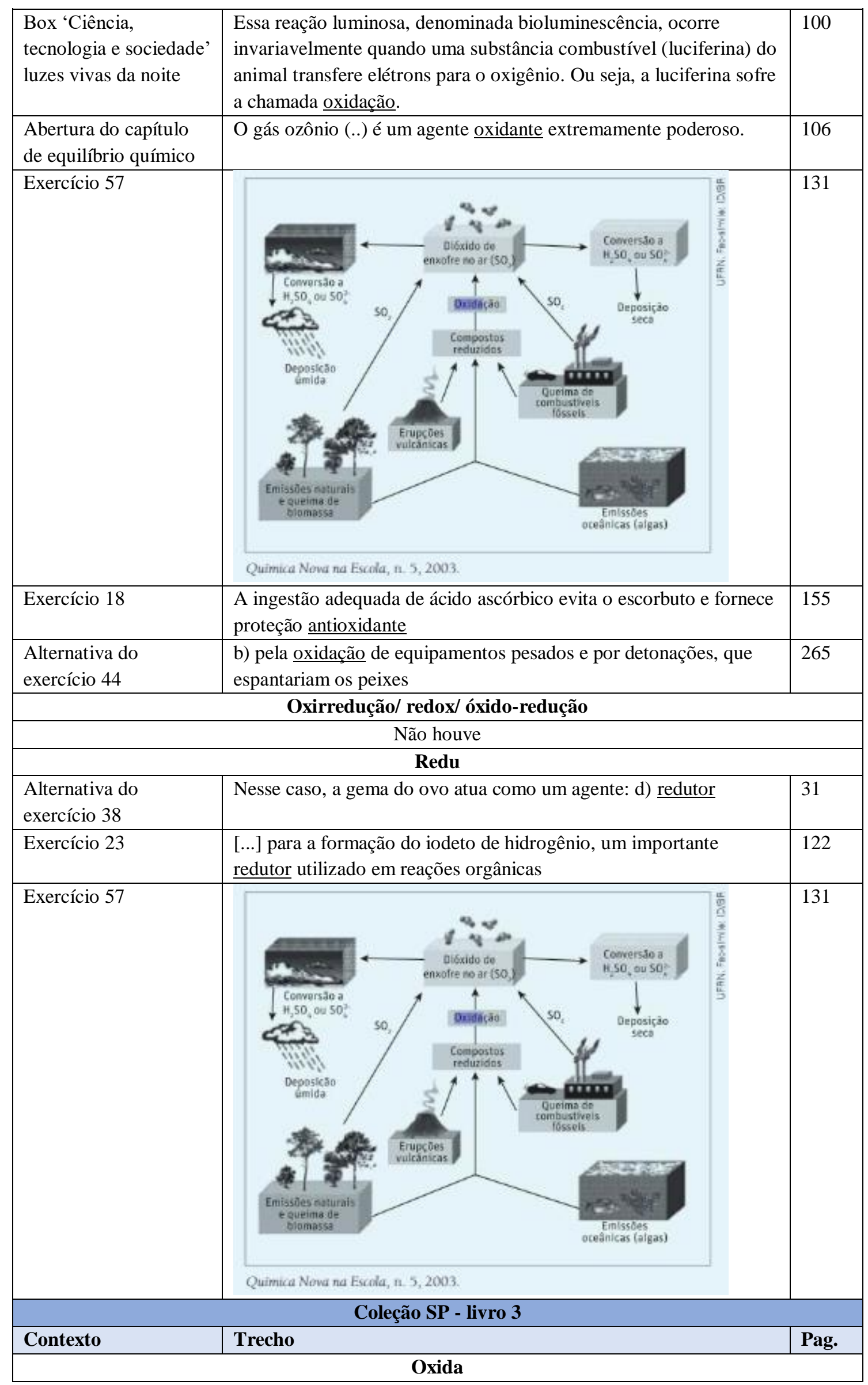




\begin{tabular}{|c|c|c|}
\hline Exercício 5 & $\begin{array}{l}\text { Quando nossa pele é exposta ao sol, o organismo produz, além de } \\
\text { outras substâncias, o ácido fumárico, que tem ação antioxidante e } \\
\text { pode reduzir os danos causados pelos radicais livres. Devido a sua } \\
\text { ação antioxidante e por não se tóxico, ele é utilizado como aditivo } \\
\text { alimentar em alguns países. }\end{array}$ & 39 \\
\hline Exercício 31 & $\begin{array}{l}\text { Quando são absorvidos por peixes, esses hidrocarbonetos são } \\
\text { metabolizados por enzimas oxidases mistas encontradas em seus } \\
\text { fígados, formando produtos altamente mutagênicos. }\end{array}$ & 77 \\
\hline $\begin{array}{l}\text { Obtenção do ácido } \\
\text { acético }\end{array}$ & $\begin{array}{l}\text { Na fermentação, o processo ocorre por ação do fungo Mycoderma } \\
\text { aceti, com auxílio da enzima álcool oxidase. }\end{array}$ & 90 \\
\hline $\begin{array}{l}\text { Box 'Química tem } \\
\text { história' - Os corantes } \\
\text { e a anilina }\end{array}$ & $\begin{array}{l}\text { [...], estudando a oxidação da fenilamina, também conhecida como } \\
\text { anilina }[\ldots]\end{array}$ & 105 \\
\hline $\begin{array}{l}\text { Exemplo de amina - } \\
\text { Vitamina B }\end{array}$ & $\begin{array}{l}\text { Este composto tem importante participação nas reações químicas do } \\
\text { nosso organismo. Ao auxiliar nas reações de oxidação dos } \\
\text { alimentos, possibilita a geração de energia química necessária ao } \\
\text { nosso organismo. }\end{array}$ & 112 \\
\hline $\begin{array}{l}\text { Polímeros, ambiente, } \\
\text { politicas públicas e } \\
\text { cidadania (incineração) }\end{array}$ & $\begin{array}{l}\text { Compostos orgânicos como madeira, papel e plásticos são oxidados } \\
\text { nos incineradores a dióxido de carbono }\left(\mathrm{CO}_{2}\right) \text {, vapor de água e } \\
\text { cinzas. }\end{array}$ & 273 \\
\hline \multicolumn{3}{|c|}{ Oxirredução/ redox/ óxido-redução } \\
\hline $\begin{array}{l}\text { Alternativa exercício } \\
20\end{array}$ & $\begin{array}{l}\text { O equilíbrio acima pode ser considerado como: } \\
\text { c) reação de oxirredução }\end{array}$ & 45 \\
\hline Exercício 13 & $\begin{array}{l}\text { "Toda reação de combustão é uma reação de oxirredução, mas o } \\
\text { contrário não é válido" } \\
\text { Explique a afirmação acima e cite um exemplo que a justifique. }\end{array}$ & 73 \\
\hline $\begin{array}{l}\text { Alternativa exercício } \\
56\end{array}$ & $\begin{array}{l}\text { É correto afirmar-se que, no bafômetro moderno: } \\
\text { a) Ocorre uma reação de óxido-redução na qual o dicromato } \\
\text { de potássio é o agente oxidante. }\end{array}$ & 221 \\
\hline \multicolumn{3}{|c|}{ Redu } \\
\hline \multicolumn{3}{|c|}{ Não houve } \\
\hline
\end{tabular}

\begin{tabular}{|c|c|c|}
\hline \multicolumn{3}{|c|}{ Coleção VV - livro 1} \\
\hline Contexto & Trecho & Pag. \\
\hline \multicolumn{3}{|c|}{ Oxida } \\
\hline Introdução a química & $\begin{array}{l}\text { Por exemplo, os aços inoxidáveis (basicamente, liga de ferro, } \\
\text { carbono e cromo) são mais resistentes à corrosão que aços comuns. }\end{array}$ & 14 \\
\hline $\begin{array}{l}\text { Características do } \\
\text { ácido nítrico }\end{array}$ & Trata-se de uma substância volátil, tóxica e oxidante. & 151 \\
\hline $\begin{array}{l}\text { Exemplos de óxidos } \\
\text { ácidos }\end{array}$ & $\begin{array}{l}\text { Note que o número de oxidação do Mn é bem elevado: }+7 \text {, e isso } \\
\text { acontece com outros óxidos ácidos metálicos, como é o caso do } \\
\mathrm{CrO}_{3} \text {, no qual o Nox do } \mathrm{Cr} \text { é }+6 \text {. }\end{array}$ & 237 \\
\hline $\begin{array}{l}\text { Box ‘Conexões’ - } \\
\text { Química e Biologia - } \\
\text { trocas gasosas na } \\
\text { respiração }\end{array}$ & $\begin{array}{l}\text { Como você sabe, em nosso organismo, o oxigênio }\left(\mathrm{O}_{2}\right) \text { do ar tem o } \\
\text { papel fundamental de oxidante capa de, em termos simplificados, } \\
\text { transformar compostos orgânicos presentes nos nutrientes em } \\
\text { dióxido de carbono }\left(\mathrm{CO}_{2}\right) \text { e água }\left(\mathrm{H}_{2} \mathrm{O}\right)\end{array}$ & 280 \\
\hline \multicolumn{3}{|c|}{ Oxirredução/ redox/ óxido-redução } \\
\hline \multicolumn{3}{|c|}{ Não houve } \\
\hline \multicolumn{3}{|c|}{ Redu } \\
\hline \multicolumn{3}{|c|}{ Não houve } \\
\hline \multicolumn{3}{|c|}{ Coleção VV - livro 2} \\
\hline Contexto & Trecho & Pag. \\
\hline
\end{tabular}




\begin{tabular}{|c|c|c|}
\hline \multicolumn{3}{|c|}{ Oxida } \\
\hline $\begin{array}{l}\text { Elementos } \\
\text { constituintes das ligas } \\
\text { metálicas }\end{array}$ & Aço inox - propriedades - inoxidável; boa aparência & 18 \\
\hline Exercício 3 & $\begin{array}{l}\text { Se, em determinadas condições, o dióxido de enxofre é oxidado } \\
\text { pelo } \mathrm{O}_{2} \text {, do ar, qual o produto formado? }\end{array}$ & 24 \\
\hline $\begin{array}{l}\text { Química e } \\
\text { comportamento - } \\
\text { tratamento dos cabelos }\end{array}$ & $\begin{array}{l}\text { Como o meio básico torna o peróxido de hidrogênio um oxidante } \\
\text { mais eficaz [...] } \\
\text { Tanto para clarear os cabelos quanto para fazer permanentes, é } \\
\text { possível recorrer à água oxigenada como agente oxidante. } \\
\text { O que acontece com o número de oxidação do } \mathrm{O} \text { no } \mathrm{H}_{2} \mathrm{O}_{2} \\
\text { nas ligações } \mathrm{S}-\mathrm{S} \text { e } \mathrm{S}-\mathrm{H} \text { ? }\end{array}$ & 48,49 \\
\hline $\begin{array}{l}\text { Introdução a cinética } \\
\text { química }\end{array}$ & $\begin{array}{l}\text { Parte dos aditivos serve para melhorar o sabor ou o aspecto do } \\
\text { alimento, mas muito têm por função evitar que ele se deteriore } \\
\text { rapidamente. Entre estes últimos, podemos citar dois grupos: os } \\
\text { antioxidantes e os conservantes. } \\
\text { Os antioxidantes, evitam, em especial, a oxidação de gorduras em } \\
\text { alimentos ricos nessas substâncias, como manteigas e maioneses. } \\
\text { Alguns desses antioxidantes são substâncias contidas em alimentos } \\
\text { naturais; é o caso do ácido cítrico, presente na laranja, no limão, na } \\
\text { mexerica e em outras frutas cítricas. }\end{array}$ & 123 \\
\hline Exercício 4 & $\begin{array}{l}\text { O monóxido de nitrogênio é oxidado por ação do oxigênio, gerando } \\
\text { dióxido de nitrogênio, } \mathrm{NO}(\mathrm{g})\end{array}$ & 180 \\
\hline Exercício 5 & $\begin{array}{l}\text { Semiequação de oxidação: } \\
2 \mathrm{Cl}^{-} \rightarrow \mathrm{Cl}_{2(\mathrm{~g})}+2 \mathrm{e}^{-}\end{array}$ & 180 \\
\hline \multicolumn{3}{|c|}{ Oxirredução/ redox/ óxido-redução } \\
\hline $\begin{array}{l}\text { Química e } \\
\text { comportamento - } \\
\text { tratamento dos cabelos }\end{array}$ & Permanente: resultado de reações de oxirredução. & 49 \\
\hline Alternativa exercício 6 & $\begin{array}{l}\text { a) Endotérmica e de oxirredução, na qual o } \mathrm{SI}^{4+} \text { é reduzido a } \\
\text { SI. }\end{array}$ & 119 \\
\hline Exercício 4 & $\begin{array}{l}\text { a) Balanceie as três equações; assinale os processos que } \\
\text { forem de oxirredução, indicando os agentes oxidantes e } \\
\text { redutor. } \\
\text { b) Explique por que a terceira equação é uma auto- } \\
\text { oxirredução. }\end{array}$ & 180 \\
\hline Exercício 5 & $\begin{array}{l}\text { Como funcionam algumas dessas lentes fotocromáticas? Nessas } \\
\text { lentes, que chegam a reduzir } 80 \% \text { a luminosidade que atinge os } \\
\text { olhos, ocorre um processo de oxirredução que é reversível, o que } \\
\text { possibilita a inversão do processo [...] }\end{array}$ & 180 \\
\hline \multicolumn{3}{|c|}{ Redu } \\
\hline & $\begin{array}{l}\text { Semi-equação de redução: } \\
2 \mathrm{Ag}^{+}+2 \mathrm{e}^{-} \rightarrow 2 \mathrm{Ag}\end{array}$ & \\
\hline \multicolumn{3}{|c|}{ Coleção VV - livro 3} \\
\hline Contexto & Trecho & Pag. \\
\hline \multicolumn{3}{|c|}{ Oxida } \\
\hline $\begin{array}{l}\text { Quadro comparativo } \\
\text { entre as reações químicas } \\
\text { e as reações nucleares }\end{array}$ & $\begin{array}{l}\text { A reatividade química de um elemento varia com o tipo de } \\
\text { ligação da qual ele participa, com seu número de oxidação, etc. }\end{array}$ & 17 \\
\hline Atividades & $\begin{array}{l}\text { 1.O betacaroteno (fórmula estrutural abaixo), presente na } \\
\text { cenoura, na manga, no mamão e no pimentão, é um importante } \\
\text { antioxidante e protege as membranas celulares. }\end{array}$ & 82 \\
\hline
\end{tabular}




\begin{tabular}{|c|c|c|}
\hline & $\begin{array}{l}\text { Outros exemplos de antioxidante são a vitamina } \mathrm{C} \text {, presente na } \\
\text { acerola, no caju e na laranja [...] }\end{array}$ & \\
\hline \multirow[t]{2}{*}{ Destilação da Hulha } & Redução do ferro & \multirow[t]{2}{*}{98} \\
\hline & $\begin{array}{r}\text { reduçăo } \\
\text { oxidaçăo } \\
\end{array}$ & \\
\hline $\begin{array}{l}\text { O etanol: um depressor } \\
\text { do sistema nervoso }\end{array}$ & $\begin{array}{l}\text { O fígado o identifica como tóxico e libera uma enzima, a álcool } \\
\text { desidrogenase (indicada pela sigla ADH), que o oxida, } \\
\text { transformando-a em etanal - um aldeído. }\end{array}$ & 107 \\
\hline Aplicação de fenóis & $\begin{array}{l}\text { A hidroquinona, que apresenta propriedades antioxidantes, é } \\
\text { usada em reveladores e como princípio de cremes para } \\
\text { clareamento de pele. }\end{array}$ & 113 \\
\hline $\begin{array}{l}\text { Exemplos de ácidos } \\
\text { carboxílicos }\end{array}$ & $\begin{array}{l}\text { Líquido incolor conhecido desde a alquimia, o ácido acético ou } \\
\text { ácido etanoico é produto da oxidação do etanol presente no vinho. }\end{array}$ & 125 \\
\hline $\begin{array}{l}\text { Box 'Química: prática e } \\
\text { reflexão' }\end{array}$ & $\begin{array}{l}\text { Nesse processo, ocorre a oxidação do álcool do vinho em ácido } \\
\text { acético. }\end{array}$ & 128 \\
\hline Exemplos de aminas & $\begin{array}{l}\text { A anilina é facilmente oxidada pelo ar e os produtos dessa } \\
\text { oxidação são coloridos (amarelados, avermelhados). }\end{array}$ & 138 \\
\hline $\begin{array}{l}\text { Como diferenciar } \\
\text { isômeros planos } \\
\text { experimentalmente }\end{array}$ & $\begin{array}{l}\text { Aldeídos podem ser oxidados a ácidos carboxílicos, o que não } \\
\text { ocorre com as cetonas. }\end{array}$ & 157 \\
\hline Alternativa questão 13 & $\begin{array}{l}\text { A combustão completa do butano, um dos principais constituintes } \\
\text { do gás natural, é um exemplo de reação de oxirredução, na qual o } \\
\text { hidrocarboneto é o agente oxidante e o gás oxigênio presente no } \\
\text { ar atmosférico é o agente redutor. }\end{array}$ & 177 \\
\hline $\begin{array}{l}\text { Legenda da figura de } \\
\text { introdução as reações de } \\
\text { adição e substituição }\end{array}$ & $\begin{array}{l}\text { A indústria alimentícia utiliza vários materiais artificialmente; é o } \\
\text { caso de aditivos como conservantes, aromatizantes e } \\
\text { antioxidantes. }\end{array}$ & 180 \\
\hline $\begin{array}{l}\text { Box 'Conexões' - Você } \\
\text { sabe como é fabricada a } \\
\text { margarina? }\end{array}$ & $\begin{array}{l}{[. . .] \text { de óleo, ele passa a ser gordura, com ponto de fusão em }} \\
\text { temperatura mais alta e com maior estabilidade no processo de } \\
\text { oxidação. }\end{array}$ & 183 \\
\hline $\begin{array}{l}\text { Introdução ao capítulo } \\
\text { Nutrição e principais } \\
\text { nutrientes }\end{array}$ & $\begin{array}{l}\text { A vitamina } \mathrm{C} \text {, ou ácido ascórbico, por exemplo, evita o } \\
\text { escorbuto, atua como antioxidante e auxilia na absorção de íons } \\
\text { de ferro. }\end{array}$ & 240 \\
\hline Açucares importantes & $\begin{array}{l}\text { A oxidação da glicose, que acontece nos organismos vivos, é uma } \\
\text { importante fonte de energia. }\end{array}$ & 256 \\
\hline Exercício 6 & $\begin{array}{l}\text { A lisina é oxidada no organismo, formando a hidroxilisina, que é } \\
\text { um componente do colágeno. }\end{array}$ & 267 \\
\hline \multicolumn{3}{|c|}{ Oxirredução/ redox/ óxido-redução } \\
\hline Exemplos de proteínas & $\begin{array}{l}\text { Citocromo C (responsável por captar e ceder elétrons em } \\
\text { oxirredução intracelular) }\end{array}$ & 243 \\
\hline Exercício 6 & $\begin{array}{l}\text { Tanto a DBO como a DQO são técnicas de determinação da } \\
\text { quantidade de matéria orgânica no corpo hídrico baseadas em } \\
\text { reações de oxirredução. }\end{array}$ & 211 \\
\hline Alternativa questão 13 & $\begin{array}{l}\text { A combustão completa do butano, um dos principais constituintes } \\
\text { do gás natural, é um exemplo de reação de oxirredução, na qual o } \\
\text { hidrocarboneto é o agente oxidante e o gás oxigênio presente no } \\
\text { ar atmosférico é o agente redutor. }\end{array}$ & 177 \\
\hline
\end{tabular}




\begin{tabular}{|l|l|l|}
\hline Destilação da Hulha & Redução do ferro & \multicolumn{1}{|c|}{98} \\
\hline Alternativa questão 13 & $\begin{array}{l}\text { A combustão completa do butano, um dos principais constituintes } \\
\text { do gás natural, é um exemplo de reação de oxirredução, na qual o } \\
\text { hidrocarboneto é o agente oxidante e o gás oxigênio presente no } \\
\text { ar atmosférico é o agente redutor. }\end{array}$ & 177 \\
\hline
\end{tabular}

\begin{tabular}{|c|c|c|}
\hline \multicolumn{3}{|c|}{ Coleção MM - livro 1} \\
\hline Contexto & Trecho & Pag. \\
\hline \multicolumn{3}{|c|}{ Oxida } \\
\hline $\begin{array}{l}\text { Alguns materiais e suas } \\
\text { propriedades }\end{array}$ & $\begin{array}{l}\text { [...] você pôde reconhecer alguns exemplos de propriedades } \\
\text { especificas dos materiais, como o estado físico, a tenacidade } \\
\text { (resistência a impactos e a alongamentos), a resistência a } \\
\text { oxidação e a solubilidade em água. }\end{array}$ & 23 \\
\hline $\begin{array}{l}\text { Como é feito o } \\
\text { tratamento da água? }\end{array}$ & $\begin{array}{l}\text { Para tratar tamanha quantidade de água, gasta-se uma média } \\
\text { diária de } 120 \text { toneladas de coagulantes (sulfato de alumínio ou } \\
\text { cloreto férrico ou ainda sulfato ferroso oxidado) }\end{array}$ & 61 \\
\hline Alternativa questão 62 & c) À oxidação do peróxido de hidrogênio & 193 \\
\hline Alternativa questão 82 & d) O número de oxidação mais comum para d é +2 & 196 \\
\hline Alternativa questão 86 & a) Atômico e ao número de oxidação & 197 \\
\hline Exercício 77 & $\begin{array}{l}\text { O prego que enferruja e o "palito de fósforo" que queima são } \\
\text { exemplos de oxidações. }\end{array}$ & 225 \\
\hline Exercício 41 & $\begin{array}{l}\text { Uma alternativa econômica para a diminuição de dióxido de } \\
\text { enxofre lançado à atmosfera é o tratamento das emissões das } \\
\text { chaminés com uma pasta úmida de calcário, } \mathrm{CaCO}_{3(\mathrm{~s})} \text {, em } \\
\text { presença de um oxidante. }\end{array}$ & 246 \\
\hline \multicolumn{3}{|c|}{ Oxirredução/ redox/ óxido-redução } \\
\hline Exercício 75 & III. uma transformação físico-química denominada oxirredução. & 54 \\
\hline \multicolumn{3}{|c|}{ Redu } \\
\hline \multicolumn{3}{|c|}{ Não houve } \\
\hline \multicolumn{3}{|c|}{ Coleção MM - livro 2} \\
\hline Contexto & Trecho & Pag. \\
\hline \multicolumn{3}{|c|}{ Oxida } \\
\hline $\begin{array}{l}\text { Reação lenta: a formação } \\
\text { de ferrugem }\end{array}$ & $\begin{array}{l}\text { Nesse caso, usa-se um material que se oxida mais facilmente do } \\
\text { que o ferro e que, dessa forma, vai se oxidar no lugar dele. } \\
\text { Trabalharemos esse assunto no capítulo } 5 \text { deste volume. }\end{array}$ & 126 \\
\hline $\begin{array}{l}\text { Reações que interessam } \\
\text { ser retardadas: } \\
\text { escurecimento de frutas }\end{array}$ & $\begin{array}{l}\text { Esse escurecimento é provocado por uma reação química iniciada } \\
\text { pela presença de uma enzima chamada polifenol oxidase (PFO) e } \\
\text { o oxigênio molecular, o que leva à formação de uma substancia } \\
\text { orgânica denominada quinona. A reação química é conhecida } \\
\text { como escurecimento enzimático e é uma reação oxidativa, pois } \\
\text { ocorre na presença de oxigênio. }\end{array}$ & 126 \\
\hline \multicolumn{3}{|c|}{ Oxirredução/ redox/ óxido-redução } \\
\hline Exercício 52 & $\begin{array}{l}\text { A corrosão é um processo irreversível, envolvendo reações do } \\
\text { tipo redox que ocorrem na interface entre um metal metálico e um } \\
\text { agente oxidante. }\end{array}$ & 159 \\
\hline \multicolumn{3}{|c|}{ Redu } \\
\hline \multicolumn{3}{|c|}{ Não houve } \\
\hline
\end{tabular}




\begin{tabular}{|c|c|c|}
\hline \multicolumn{3}{|c|}{ Coleção MM - livro 3} \\
\hline Contexto & Trecho & Pag. \\
\hline \multicolumn{3}{|c|}{ Oxida } \\
\hline $\begin{array}{l}\text { Os hidrocarbonetos } \\
\text { aromáticos e a } \\
\text { ocorrência de câncer } \\
\text { de pulmão entre } \\
\text { fumantes }\end{array}$ & $\begin{array}{l}\text { Foi somente nesse ano que cientistas descobriram que o benzopireno, } \\
\text { substância encontrada na fumaça do cigarro, é oxidado a um } \\
\text { carcinógeno - substância que transforma uma célula normal numa } \\
\text { célula cancerosa-[...] }\end{array}$ & 40 \\
\hline $\begin{array}{l}\text { Caracterizando } \\
\text { quimicamente a } \\
\text { nicotina: a função } \\
\text { amina }\end{array}$ & $\begin{array}{l}\text { Se não fosse pela oxidação da maior parte da nicotina por meio da } \\
\text { temperatura alta e do movimento rápido da fumaça que acompanha o } \\
\text { ato de fumar, nenhum fumante poderia viver o suficiente para sofrer as } \\
\text { consequências de ser fumante. }\end{array}$ & 46 \\
\hline $\begin{array}{l}\text { Bebida e direção: } \\
\text { uma mistura } \\
\text { perigosa }\end{array}$ & $\begin{array}{l}\text { O álcool é eliminado após ter sido metabolizado no fígado, onde é } \\
\text { inicialmente oxidado a aldeído acético (etanal), substância então } \\
\text { oxidada a ácido acético, o qual finalmente é transformado em gás } \\
\text { carbônico e água. } \\
\text { Os produtos parciais dessa oxidação, o aldeído e o ácido acético, } \\
\text { produzem o gosto desagradável na boca da pessoa com ressaca de } \\
\text { bebida alcoólica. }\end{array}$ & $\begin{array}{l}52 \\
53\end{array}$ \\
\hline Exercício 56 & $\begin{array}{l}\text { III. A molécula do retinal apresenta um grau de oxidação superior ao } \\
\text { do retinol. }\end{array}$ & 70 \\
\hline Exercício 63 & $\begin{array}{l}\text { IV. Os compostos citados no texto, por oxidação, produzem os álcoois } \\
\text { correspondentes. }\end{array}$ & 72 \\
\hline $\begin{array}{l}\text { Alternativa } \\
\text { Exercício } 68\end{array}$ & $\begin{array}{l}\text { b) Redutor, pois a eliminação de materiais redutores é mais } \\
\text { lenta do que a dos oxidantes. }\end{array}$ & 74 \\
\hline Definindo caloria & $\begin{array}{l}\text { Assim como os combustíveis, os alimentos que consumimos liberam } \\
\text { energia durante sua queima ( } \underline{\text { oxidação) }} \text { no organismo (metabolismo), } \\
\text { cuja quantidade é expressa em calorias. }\end{array}$ & 85 \\
\hline $\begin{array}{l}\text { Substâncias e } \\
\text { alimentos que nos } \\
\text { ajudam a manter a } \\
\text { saúde }\end{array}$ & $\begin{array}{l}\text { Alimentos expostos ao ar podem se transformar: o suco de laranja, } \\
\text { nessa condição, tem algumas de suas substâncias oxidadas; um pedaço } \\
\text { de maçã escurece; mesmo o sal e o açúcar, substâncias estáveis, } \\
\text { absorvem umidade e mudam de aspecto físico. }\end{array}$ & 93 \\
\hline $\begin{array}{l}\text { Substâncias e } \\
\text { alimentos que nos } \\
\text { ajudam a manter a } \\
\text { saúde }\end{array}$ & $\begin{array}{l}\text { Antocianinas: substâncias aromáticas presentes em frutas como amora, } \\
\text { jabuticaba e açaí, que funcionam como antioxidantes. }\end{array}$ & 95 \\
\hline $\begin{array}{l}\text { Exercício de } \\
\text { reflexão } 18\end{array}$ & $\begin{array}{l}\text { Em alguns folhetos de divulgação de revitalizantes e/ou suplementos } \\
\text { alimentares, alguns sais minerais, identificados pelo nome de } \\
\text { elementos químicos, são citados como essenciais para a incorporação } \\
\text { de vitaminas, hormônios, enzimas ou para ação antioxidante, além de } \\
\text { outras funções. }\end{array}$ & 96 \\
\hline $\begin{array}{l}\text { Função dos sais } \\
\text { minerais }\end{array}$ & $\begin{array}{l}\text { Selênio - Atua na absorção da vitamina E e no metabolismo da } \\
\text { gordura e é antioxidante. }\end{array}$ & 98 \\
\hline $\begin{array}{l}\text { Interação entre } \\
\text { vitamina } \mathrm{C} \text { e o ferro }\end{array}$ & $\begin{array}{l}\text { O ferro fica disponível para ser absorvido pelo organismo quando se } \\
\text { encontra como íon } \mathrm{Fe}^{2+} \text { ou } \mathrm{Fe}^{3+} \text {. Nos vegetais está presente em sua } \\
\text { forma mais oxidada, a forma } \mathrm{Fe}^{3+} \text {. Por sua vez, nas carnes e vísceras, o } \\
\text { ferro está como } \mathrm{Fe}^{2+} \text {, compondo o grupo de proteínas como o da } \\
\text { hemoglobina. }\end{array}$ & 100 \\
\hline $\begin{array}{l}\text { Interação entre } \\
\text { vitamina } \mathrm{C} \text { e o ferro }\end{array}$ & $\begin{array}{l}\text { A absorção do ferro pelo organismo ocorre no intestino delgado (em } \\
\text { meio básico) e ele deve estar na forma } \mathrm{Fe}^{2+} \text {. Nessas condições, o ferro } \\
\text { de origem animal está compondo a hemoglobina e, portanto, fica } \\
\text { impedido de ser oxidado. }\end{array}$ & 101 \\
\hline
\end{tabular}




\begin{tabular}{|c|c|c|c|}
\hline Exercício 79 & \multicolumn{2}{|c|}{$\begin{array}{l}\text { A equação química, não balanceada, a seguir representa a oxidação } \\
\text { completa de um mol da substância tributirina, também conhecida } \\
\text { como butirina, presente em certos alimentos." } \\
\text { [...] } \\
\text { Suponha que nos processos metabólicos toda a energia liberada na } \\
\text { oxidação da butirina seja convertida em calor. }\end{array}$} & 129 \\
\hline Exercício 94 & \multicolumn{2}{|c|}{ 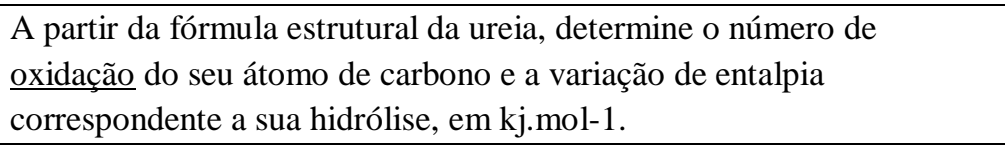 } & 132 \\
\hline $\begin{array}{l}\text { A tragédia de } \\
\text { Marian: o maior } \\
\text { desastre ambiental } \\
\text { jamais visto no } \\
\text { Brasil }\end{array}$ & \multicolumn{2}{|c|}{$\begin{array}{l}\text { Há uma grande polêmica em torno da toxicidade desse mar de lama e } \\
\text { rejeitos. }\end{array}$} & 139 \\
\hline $\begin{array}{l}\text { Importância do } \\
\text { oxigênio dissolvido } \\
\text { em ambientes } \\
\text { aquáticos }\end{array}$ & \multicolumn{2}{|l|}{$\begin{array}{r}\text { Figura 3.21 } \\
\text { Balanço do oxigênio dissolvido } \\
\text { nos sistemas aquáticos los } \\
\text { processos acelerados ou } \\
\text { aumentados pela descarga } \\
\text { de materiais orgañicos såo } \\
\text { indicados por setas azuis]. }\end{array}$} & 160 \\
\hline Exercício 71 & \multicolumn{2}{|c|}{$\begin{array}{l}\text { Escreva as fórmulas da amonia e dos íons nitrito e nitrato. Quais são } \\
\text { os números de oxidação do nitrogênio nesses compostos? }\end{array}$} & 179 \\
\hline Exercício 94 & \multicolumn{2}{|c|}{$\begin{array}{l}\text { c) Pela oxidação de equipamentos pesados e por detonações que } \\
\text { espantiram os peixes }\end{array}$} & 192 \\
\hline Exercício 40 & \multicolumn{2}{|c|}{$\begin{array}{l}\text { b) Oxidação de monóxido de cloro por átomos de oxigênio para } \\
\text { produzir átomos de cloro. }\end{array}$} & 219 \\
\hline Obtenção do pet & \multicolumn{2}{|c|}{$\begin{array}{l}\text { A presença de oxigenio induz um processo de degradação oxidativa, e } \\
\text { a degradação térmica com umidade provoca a quabra das cadeias, } \\
\text { reduzindo a massa molar do polímero. }\end{array}$} & 232 \\
\hline $\begin{array}{l}\text { Como são } \\
\text { preparados os } \\
\text { vidros? }\end{array}$ & \multicolumn{2}{|c|}{$\begin{array}{l}\text { Contudo, a cor final obtida depende do estado de oxidação do metal, } \\
\text { da sua concentração, da composição do vidro e do tratamento térmico } \\
\text { ao qual foi submetido. } \\
\text { Tabela-Estado de oxidação }\end{array}$} & 263 \\
\hline \multicolumn{4}{|c|}{ Oxirredução/ redox/ óxido-redução } \\
\hline \multicolumn{4}{|c|}{ Não houve } \\
\hline \multicolumn{4}{|c|}{ Redu } \\
\hline $\begin{array}{l}\text { Alternativa } \\
\text { Exercício } 68\end{array}$ & \multicolumn{2}{|c|}{$\begin{array}{l}\text { a) } \\
\text { Redutor, pois a eliminação de materiais redutores é mais } \\
\text { lenta que a dos oxidantes. }\end{array}$} & 74 \\
\hline
\end{tabular}

\begin{tabular}{|c|c|c|}
\hline \multicolumn{3}{|c|}{ Coleção CP - livro 1} \\
\hline Contexto & Trecho & Pag. \\
\hline \multicolumn{3}{|c|}{ Oxida } \\
\hline A ação conservante & $\begin{array}{l}\text { antioxidantes, que inibem a ação do gás oxigênio (presente } \\
\text { no ambiente) sobre o alimento. }\end{array}$ & 14 \\
\hline Exercício 2 & $\begin{array}{l}\text { No processo de oxidação do etanol é formado o ácido } \\
\text { acético. Considerando que os reagentes foram totalmente } \\
\text { consumidos, copie o quadro abaixo em seu caderno e } \\
\text { complete as três lacunas de acordo com a lei de Lavoisier. }\end{array}$ & 29 \\
\hline $\begin{array}{l}\text { Respostas as questões } 3 \text { de } \\
\text { abertura do tema }\end{array}$ & $\begin{array}{l}\text { Para a conservação de carnes, pode ser empregado o sal, } \\
\text { além de antioxidantes. }\end{array}$ & 261 \\
\hline \multicolumn{3}{|c|}{ Oxirredução/ redox/ óxido-redução } \\
\hline \multicolumn{3}{|c|}{ Não houve } \\
\hline
\end{tabular}




\begin{tabular}{|c|c|c|}
\hline \multicolumn{3}{|c|}{ Redu } \\
\hline \multicolumn{3}{|c|}{ Não houve } \\
\hline \multicolumn{3}{|c|}{ Coleção CP - livro 2} \\
\hline Contexto & Trecho & Pag. \\
\hline \multicolumn{3}{|c|}{ Oxida } \\
\hline $\begin{array}{l}\text { Rapidez das reações e o } \\
\text { cálculo estequiométrico }\end{array}$ & $\begin{array}{l}\text { Pelo seu alto potencial de redução, o que o torna um forte } \\
\text { agente oxidante, ele pode ser usado como germicida na } \\
\text { sanitização da água, do ar ou de superfícies. } \\
\text { (Se julgar necessário, retome o conceito de agente oxidante } \\
\text { estudado no capítulo } 3 \text { ) }\end{array}$ & 179 \\
\hline Exercício 1 & $\begin{array}{l}\text { Considere o esquema que representa a reação entre átomos } \\
\text { de cloro e moléculas de cloreto de nitrosila, um gás de cor } \\
\text { amarela utilizado como agente oxidante. }\end{array}$ & 188 \\
\hline $\begin{array}{l}\text { Enzimas: catalisadores } \\
\text { biológicos }\end{array}$ & $\begin{array}{l}\text { Ao sentir-se ameaçado, essa solução entra em contato com } \\
\text { as enzimas catalase e peroxidase, armazenadas } \\
\text { estrategicamente em outro compartimento de seu corpo, } \\
\text { dando início a reações exotérmicas que prosseguem } \\
\text { rapidamente. }\end{array}$ & 197 \\
\hline $\begin{array}{l}\text { A fixação do nitrogênio e a } \\
\text { nitrogenase }\end{array}$ & $\begin{array}{l}\text { Esse processo é uma redução do nitrogênio - durante a } \\
\text { reação seu estado de oxidação é reduzido de } 0 \text { em } \mathrm{N}_{2} \text { para }-3 \\
\text { em } \mathrm{NH}_{2} \text {. }\end{array}$ & 197 \\
\hline $\begin{array}{l}\text { A fixação do nitrogênio e a } \\
\text { nitrogenase }\end{array}$ & $\begin{array}{l}\text { Uma vez que os metais de transição podem variar o estado } \\
\text { de oxidação rapidamente, as metaloenzimas são } \\
\text { especialmente úteis para realizar transformações nas quais } \\
\text { os substratos são oxidados ou reduzidos. }\end{array}$ & 197 \\
\hline \multicolumn{3}{|c|}{ Oxirredução/ redox/ óxido-redução } \\
\hline \multicolumn{3}{|c|}{ Não houve } \\
\hline \multicolumn{3}{|c|}{ Redu } \\
\hline $\begin{array}{l}\text { Rapidez das reações e o } \\
\text { cálculo estequiométrico }\end{array}$ & $\begin{array}{l}\text { Pelo seu alto potencial de redução, o que o torna um forte } \\
\text { agente oxidante, ele pode ser usado como germicida na } \\
\text { sanitização da água, do ar ou de superfícies. } \\
\text { (Se julgar necessário, retome o conceito de agente oxidante } \\
\text { estudado no capítulo } 3 \text { ) }\end{array}$ & 179 \\
\hline $\begin{array}{l}\text { A fixação do nitrogênio e a } \\
\text { nitrogenase }\end{array}$ & $\begin{array}{l}\text { Esse processo é uma redução do nitrogênio - durante a } \\
\text { reação seu estado de oxidação é reduzido de } 0 \text { em } \mathrm{N}_{2} \text { para }-3 \\
\text { em } \mathrm{NH}_{2} \text {. }\end{array}$ & 197 \\
\hline $\begin{array}{l}\text { A fixação do nitrogênio e a } \\
\text { nitrogenase }\end{array}$ & $\begin{array}{l}\text { Uma vez que os metais de transição podem variar o estado } \\
\text { de oxidação rapidamente, as metaloenzimas são } \\
\text { especialmente úteis para realizar transformações nas quais } \\
\text { os substratos são oxidados ou reduzidos. }\end{array}$ & 197 \\
\hline \multicolumn{3}{|c|}{ Coleção CP - livro 3} \\
\hline Contexto & Trecho & Pag. \\
\hline \multicolumn{3}{|c|}{ Oxida } \\
\hline $\begin{array}{l}\text { Exames nos quais se } \\
\text { utiliza radioatividade }\end{array}$ & O tecnécio apresenta múltiplos estados de oxidação. & 169 \\
\hline $\begin{array}{l}\text { Um método alternativo à } \\
\text { hidrogenação na indústria } \\
\text { alimentícia: a } \\
\text { interesterificação }\end{array}$ & $\begin{array}{l}\text { Parte da LDL é metabolizada no fígado e utilizada para a } \\
\text { construção de membranas celulares, mas o excesso de } \\
\text { colesterol no sangue dificulta a captação dessa lipoproteína } \\
\text { pela célula, então ela oxida e se deposita nas paredes do } \\
\text { sistema circulatório. }\end{array}$ & 192 \\
\hline Exercício 3 & $\begin{array}{l}\text { III. A molécula do retinal apresenta um grau de oxidação } \\
\text { superior ao do retinol }\end{array}$ & 216 \\
\hline
\end{tabular}




\begin{tabular}{|c|c|c|}
\hline & $\begin{array}{l}\text { No entanto, armazenar energia nessa forma não é muito } \\
\text { eficiente, pois os carboidratos contêm alto teor de oxigênio, } \\
\text { isto é, já estão parcialmente oxidados, o que faz com que } \\
\text { eles forneçam apenas } 4 \mathrm{kcal} / \mathrm{g} \text { quando metabolizados. [...] } \\
\text { Quando oxidados, os triglicerídeos fornecem mais que o } \\
\text { dobro de energia, por grama, que os carboidratos. }\end{array}$ & \\
\hline Tipos de vitaminas & $\begin{array}{l}\text { Vitaminas hidrossolúveis, isto é, solúveis em água: são } \\
\text { polares. Costumam ser pouco resistentes a altas } \\
\text { temperaturas e também passíveis de oxidação. }\end{array}$ & 231 \\
\hline Exercício 3 & $\begin{array}{l}\text { A vitamina E é lipossolúvel e pode ser usada como } \\
\text { antioxidante em alguns alimentos com o objetivo de } \\
\text { aumentar sua validade. }\end{array}$ & 264 \\
\hline \multicolumn{3}{|c|}{ Oxirredução/ redox/ óxido-redução } \\
\hline \multicolumn{3}{|c|}{ Não houve } \\
\hline \multicolumn{3}{|c|}{ Redu } \\
\hline $\begin{array}{l}\text { A destilação seca da hulha } \\
\text { (pirólise) }\end{array}$ & $\begin{array}{l}\text { O coque exerce, nesse caso, dois papéis na fabricação do } \\
\text { ferro: de combustível, permitindo alcançar as altas } \\
\text { temperaturas (cerca de } 1500 \mathrm{C}^{\circ} \text { ) necessárias à fusão da } \\
\text { hematita, e de agente redutor da redução do óxido de ferro } \\
\text { (III) sob altas temperaturas. }\end{array}$ & 53 \\
\hline \multicolumn{3}{|c|}{ Coleção MR - livro 1} \\
\hline Contexto & Trecho & Pag. \\
\hline \multicolumn{3}{|c|}{ Oxida } \\
\hline Características dos metais & $\begin{array}{l}\text { O sódio metálico, por exemplo, é um sólido brando (que } \\
\text { cede facilmente à pressão) e pode ser cortado com uma faca } \\
\text { comum, mas é preciso tomar muito cuidado e usar luvas de } \\
\text { borracha ao manuseá-lo. É prateado, oxida rapidamente no } \\
\text { ar e reage violentamente com a água, como mostra a foto ao } \\
\text { lado. }\end{array}$ & 182 \\
\hline Exercicio 34 & $\begin{array}{l}\text { As panelas de INOX são bastante seguras, porque o material } \\
\text { não se oxida e não libera o metal na comida, dizem alguns } \\
\text { pesquisadores." } \\
\text { (Adaptado de O Globo, 14/10/2011). }\end{array}$ & 194 \\
\hline $\begin{array}{l}\text { De onde vem ... para onde } \\
\text { vai? } \\
\text { Ácido Sulfúrico }\end{array}$ & $\begin{array}{l}\text { Também é possível obter enxofre pela oxidação do gás } \\
\text { sulfídrico, } \mathrm{H}_{2} \mathrm{~S}(\mathrm{~g}) \text {, existente nos efluentes gasosos de } \\
\text { diversas instalações industriais, como refinarias de petróleo } \\
\text { e de gás natural }\end{array}$ & 254 \\
\hline $\begin{array}{l}\text { Eventos Naturais que } \\
\text { provocam chuva ácida }\end{array}$ & $\begin{array}{l}\text { Na floresta Amazônica os valores de } \mathrm{pH} \text { da chuva são } \\
\text { próximos dos observados no Rio de Janeiro e em São Paulo. } \\
\text { Esse elevado índice de acidez na floresta tem sido atribuído } \\
\text { sobretudo a dois fatores: } \\
\text { 1. Formação de ácido sulfúrico proveniente da oxidação do } \\
\text { sulfeto de hidrogênio, } \mathrm{H}_{2} \mathrm{~S}(\mathrm{~g}) \text {, que se volatiliza dos alagados } \\
\text { da região. }\end{array}$ & 258 \\
\hline $\begin{array}{l}\text { Você sabe o que é } \\
\text { corrosão? }\end{array}$ & $\begin{array}{l}\text { A resistência dos objetos de aço inoxidável à corrosão deve- } \\
\text { se à adição de pelo menos } 4 \% \text { de crômio ao aço. }\end{array}$ & 276 \\
\hline \multicolumn{3}{|c|}{ Oxirredução/ redox/ óxido-redução } \\
\hline Exercicio 5 & $\begin{array}{l}\text { É correto afirmar que a formação do orvalho resulta de: } \\
\text { I. uma mudança de estado físico chamada condensação; } \\
\text { II. uma transformação química chamada sublimação; } \\
\text { III. uma transformação físico-química chamada } \\
\text { oxirredução; }\end{array}$ & 35 \\
\hline
\end{tabular}




\begin{tabular}{|c|c|c|}
\hline \multicolumn{3}{|c|}{ Redu } \\
\hline $\begin{array}{l}\text { De onde vem ... para onde } \\
\text { vai? } \\
\text { Ferro metálico }\end{array}$ & $\begin{array}{l}\text { Na hematita, o ferro apresenta-se na forma de cátion, } \mathrm{Fe} 3 \cdot \\
\text { Assim, a obtenção de ferro metálico, } \mathrm{Fe}(\mathrm{s}) \text {, consiste, em } \\
\text { última análise, em fazer o cátion ferro receber } 3 \text { elétrons } \\
\text { (processo denominado redução). } \\
\text { O coque (carbono amorfo, } \mathrm{C}(\mathrm{s}) \text {, com mais de } 90 \% \text { de } \\
\text { pureza) é utilizado para promover a redução da hematita, } \\
\text { isto é, a transformação do cátion } \mathrm{Fe}^{3+} \text { em ferro metálico, } \\
\mathrm{Fe}(\mathrm{s}) \text {. } \\
\text { O monóxido de carbono formado irá então reduzir o ferro da } \\
\text { hematita (transformar o cátion ferro, } \mathrm{Fe}^{3+} \text { em ferro } \\
\text { metálico, } \mathrm{Fe}(\mathrm{s}) \text { ) de acordo com as seguintes etapas }\end{array}$ & 184 \\
\hline Aplicações dos aldeídos & $\begin{array}{l}\text { O etanal é utilizado na síntese de diversos compostos } \\
\text { orgânicos, na obtenção de resinas, inseticidas (DDT) e } \\
\text { também na fabricação de espelhos comuns (como redutor de } \\
\text { íons prata). }\end{array}$ & 233 \\
\hline
\end{tabular}

\begin{tabular}{|c|c|c|}
\hline \multicolumn{3}{|c|}{ Coleção MR - livro 2} \\
\hline Contexto & Trecho & Pag. \\
\hline \multicolumn{3}{|c|}{ Oxida } \\
\hline Exercicio 2 & $\begin{array}{l}\text { Um método de obtenção do ácido sulfúrico, } \mathrm{H}_{2} \mathrm{SO}_{4}(\mathrm{aq}) \text {, } \\
\text { envolve as seguintes equações não balanceadas: } \\
\text { I. combustão do enxofre a óxido sulfuroso, } \mathrm{SO}_{2}(\mathrm{~g}) \\
\mathrm{S}_{8}(\mathrm{~s})+\mathrm{O}_{2}(\mathrm{~g}) \rightarrow \mathrm{SO}_{2}(\mathrm{~g}) \\
\mathrm{II} . \text { oxidação } \\
\mathrm{SO}_{2}(\mathrm{~g})+\mathrm{O}_{2}(\mathrm{~g}) \rightarrow \mathrm{SO}_{3}(\mathrm{~g}) \text { a óxido sulfúrico, } \mathrm{SO}_{3}(\mathrm{~g})\end{array}$ & 54 \\
\hline $\begin{array}{l}\text { Uso do ozônio no } \\
\text { tratamento de água }\end{array}$ & $\begin{array}{l}\text { o ozônio é um poderoso oxidante ( } 1,5 \text { vez mais forte do } \\
\text { que o cloro); } \\
\text { O ozônio, por ser mais oxidante, age diretamente na parede } \\
\text { celular, causando sua ruptura, demandando menor tempo } \\
\text { de contato e tornando impossível sua reativação. }\end{array}$ & 92 \\
\hline Exercicio 2 & $\begin{array}{l}\text { A oxidação de } 1 \mathrm{~g} \text { de gordura num organismo humano } \\
\text { libera } 9300 \text { calorias. }\end{array}$ & 127 \\
\hline Lei de Hess & $\begin{array}{l}\text { É impossível medir com precisão o } \Delta H \text { dessa reação, pois, } \\
\text { na prática, não se consegue parar a oxidação do carbono } \\
\text { exatamente no estágio correspondente à formação do } \\
\mathrm{CO}(\mathrm{g})\end{array}$ & 143 \\
\hline Box - História de Hess & Pesquisou inicialmente a oxidação de açúcares & 143 \\
\hline $\begin{array}{l}\text { Taxa de desenvolvimento de } \\
\text { reações }\end{array}$ & $\begin{array}{l}\text { Algumas reações são muito rápidas e ocorrem quase } \\
\text { instantaneamente, como a combustão do TNT } \\
\text { (trinitrotolueno) e a oxidação da hidrazina, } \mathrm{N}_{2} \mathrm{H}_{4} \text {, pelo } \\
\text { peróxido de hidrogênio, } \mathrm{H}_{2} \mathrm{O}_{2} \text { (reação utilizada na } \\
\text { propulsão de foguetes). }\end{array}$ & 151 \\
\hline Conversor catalítico & $\begin{array}{l}\text { A colmeia é então envolta por uma manta cerâmica } \\
\text { termoexpansiva, ou seja, que isola termicamente o } \\
\text { catalisador e oferece proteção mecânica à colmeia. Em } \\
\text { seguida, todo o conjunto - denominado conversor } \\
\text { catalítico - é montado dentro de uma carcaça de aço } \\
\text { inoxidável e instalado no cano de escape do automóvel. }\end{array}$ & 166 \\
\hline
\end{tabular}




\begin{tabular}{|c|c|c|}
\hline Exercício 12 & $\begin{array}{l}\text { A reação de oxirredução que ocorre entre os íons brometo, } \\
\mathrm{Br}^{1-} \text {, e bromato, } \mathrm{BrO}^{3-} \text {, em meio ácido, formando o bromo, } \\
\mathrm{Br}_{2} \text {, é representada pela equação }\end{array}$ & 172 \\
\hline Exercício 15 & $\begin{array}{l}\text { b) A dissolução da hidroxiapatita é uma reação de } \\
\text { oxirredução, devido ao aumento do Nox do cálcio e à } \\
\text { redução do Nox do oxigênio do grupo hidroxila. }\end{array}$ & 213 \\
\hline \multicolumn{3}{|c|}{ Redu } \\
\hline Exercício 4 & $\begin{array}{l}\text { A hematita, } \mathrm{Fe}_{2} \mathrm{O}_{3}(\mathrm{~s}) \text {, é empregada na obtenção de ferro } \\
\text { metálico, } \mathrm{Fe}(\mathrm{s}) \text {. Esse processo é feito em alto-forno, } \\
\text { usando-se carvão, } \mathrm{C}(\mathrm{s}) \text {, como redutor. }\end{array}$ & 60 \\
\hline Exercício 19 & $\begin{array}{l}\text { No organismo humano, o nitrato, } \mathrm{NO}_{3}{ }^{-1}(\mathrm{aq}) \text {, sofre redução } \\
\text { transformando-se facilmente em nitrito, } \mathrm{NO}_{2}^{-1}(\mathrm{aq}) \text {. }\end{array}$ & 79 \\
\hline $\begin{array}{l}\text { Cálculos de } \Delta \mathrm{H} \text { a partir das } \\
\text { entalpias de formação }\end{array}$ & $\begin{array}{l}\text { Qual o valor da variação de entalpia da reação de redução } \\
\text { da hematita, } \mathrm{Fe}_{2} \mathrm{O}_{3}(\mathrm{~s}) \text {, com o monóxido de carbono, } \\
\mathrm{CO}(\mathrm{g}) \text {, para obtenção de ferro metálico, } \mathrm{Fe}(\mathrm{s}) \text {, e gás } \\
\text { carbônico, } \mathrm{CO}_{2}(\mathrm{~g}) \text { ? } \\
\mathrm{O} \text { valor do } \Delta \mathrm{H} \text { da reação de redução da hematita é igual a } \\
-6,6 \text { kcal. }\end{array}$ & 141 \\
\hline $\begin{array}{l}\text { Box sobre hidreto de } \\
\text { hidrogênio }\end{array}$ & $\begin{array}{l}\text { É usado como redutor, isto é, substância capaz de doar } \\
\text { elétrons em uma reação química (conhecido como redutor } \\
\text { de Berthelot), principalmente em sínteses orgânicas. }\end{array}$ & 189 \\
\hline $\begin{array}{l}\text { De onde vem ... Para onde } \\
\text { vai? } \\
\text { Amônia }\end{array}$ & $\begin{array}{l}\text { É utilizada ainda em sistemas de refrigeração (possui baixo } \\
\text { ponto de ebulição, }-33,5^{\circ} \mathrm{C} \text {, e condensação, }-77^{\circ} \mathrm{C} \text { ) e na } \\
\text { metalurgia como agente redutor. }\end{array}$ & 195 \\
\hline
\end{tabular}

\begin{tabular}{|c|c|c|}
\hline \multicolumn{3}{|c|}{ Coleção MR - livro 3} \\
\hline Contexto & Trecho & Pag \\
\hline \multicolumn{3}{|c|}{ Oxida } \\
\hline Exercício 13 & $\begin{array}{l}\text { O ácido etilenodiaminotetracético, conhecido como EDTA, } \\
\text { utilizado como antioxidante em margarinas, de fórmula... }\end{array}$ & 22 \\
\hline Exercício 19 & $\begin{array}{l}\text { A chamada Medicina ortomolecular preconiza a ingestão de } \\
\text { suplementos de vitaminas (antioxidantes) e de oligoelementos } \\
\text { (sais minerais) para combater os radicais livres. }\end{array}$ & 35 \\
\hline $\begin{array}{l}\text { Você sabe quais os } \\
\text { danos reais que um } \\
\text { vazamento de petróleo } \\
\text { causa ao meio } \\
\text { ambiente? }\end{array}$ & $\begin{array}{l}\text { Alguns componentes do petróleo são solúveis em água e se } \\
\text { dissipam nesse meio. Outros podem sofrer reações de oxidação, } \\
\text { formando, por exemplo, derivados oxigenados do alcatrão } \\
\text { (altamente tóxicos). }\end{array}$ & 43 \\
\hline Reatividade dos fenóis & $\begin{array}{l}\text { Os fenóis são compostos facilmente oxidáveis e também } \\
\text { possuem um fraco caráter ácido. }\end{array}$ & 87 \\
\hline Figura sobre vanilina & $\begin{array}{l}\text { A indústria obtém o composto 3-metóxi-4- } \\
\text { hidroxibenzenocarbaldeído (essência de vanilina ou baunilha } \\
\text { idêntica à natural) da oxidação do eugenol (4-alil-2- } \\
\text { metoxifenol) extraído do cravo-da-índia. }\end{array}$ & 93 \\
\hline $\begin{array}{l}\text { De onde vem.. Para } \\
\text { onde vai? Benzenol e } \\
\text { propanona }\end{array}$ & $\begin{array}{l}\text { O produto obtido, o cumeno, é então enviado a uma coluna de } \\
\text { contato, para reação de oxidação com oxigênio do ar. }\end{array}$ & 96 \\
\hline Exercício 3 & $\begin{array}{l}\text { A oxidação do cumeno (isopropilben zeno) é método industrial } \\
\text { de produção de fenol e acetona. } \\
\text { a) Calcule a quantidade de cumeno (em mol) que deve ser } \\
\text { oxidada para se obter } 100 \mathrm{~mL} \text { de acetona. }\end{array}$ & 97 \\
\hline
\end{tabular}




\begin{tabular}{|c|c|c|}
\hline $\begin{array}{l}\text { Propriedades dos } \\
\text { ácidos carboxílicos }\end{array}$ & $\begin{array}{l}\text { O ácido etanoico é obtido pela oxidação do etanol na presença } \\
\text { da bactéria Acetobacter aceti }\end{array}$ & 100 \\
\hline $\begin{array}{l}\text { Propriedades das } \\
\text { aminas }\end{array}$ & $\begin{array}{l}\text { As aminas aromáticas são muito tóxicas e sua absorção } \\
\text { prolongada através da pele pode ter consequências letais. Essas } \\
\text { aminas quase sempre são incolores quando puras, mas podem } \\
\text { facilmente ser oxidadas pelo ar, dando origem a compostos } \\
\text { coloridos (em geral amarelos). }\end{array}$ & 106 \\
\hline $\begin{array}{l}\text { Danos causados pelo } \\
\text { cigarro }\end{array}$ & $\begin{array}{l}\text { Nicotina } \\
\text { É uma substância de caráter básico. Quando pura se apresenta } \\
\text { na forma de um líquido oleaginoso e incolor que, em contato } \\
\text { com o ar, se oxida, tornando-se pardo-escuro, e faz parte de um } \\
\text { grupo de compostos denominados alcaloides. }\end{array}$ & 111 \\
\hline $\begin{array}{l}\text { Você sabe o que } \\
\text { significa para } \\
\text { o meio ambiente a } \\
\text { plantação de coca e a } \\
\text { produção de cocaína } \\
\text { no Amazonas? }\end{array}$ & $\begin{array}{l}\text { São necessários } 2 \mathrm{~kg} \text { de pasta de coca para produzir } 1 \mathrm{~kg} \text { de } \\
\text { pasta-base de cocaína (PBC), também conhecida como pasta } \\
\text { oxidada ou pasta lavada, no processo conhecido como refino da } \\
\text { coca. } \\
\text { Para a produção de } 1 \mathrm{~kg} \text { de cloridrato de cocaína são } \\
\text { necessários cerca de } 30 \mathrm{~L} \text { de derivados benzênicos (benzeno, } \\
\text { tolueno), } 20 \mathrm{~L} \text { de solventes orgânicos (querosene, gasolina, } \\
\text { benzina) e } 1 \mathrm{~kg} \text { de substâncias oxidantes (ácidos e bases fortes). }\end{array}$ & 125 \\
\hline $\begin{array}{l}\text { Cocaína, crack, merla } \\
\text { e oxi: semelhanças e } \\
\text { diferenças }\end{array}$ & $\begin{array}{l}\text { O oxi é uma droga mais barata e mais letal que o crack. } \\
\text { Também é obtido da pasta de coca, só que em vez da adição de } \\
\text { bicarbonato de sódio e amoníaco, é preparado com querosene e } \\
\text { cal virgem que oxidam o produto, daí o nome. }\end{array}$ & 127 \\
\hline $\begin{array}{l}\text { Atividade bioquímica } \\
\text { dos enantiômeros }\end{array}$ & $\begin{array}{l}\text { A vitamina C auxilia a absorção do ferro, aumenta a resistência } \\
\text { orgânica, fortalece os ossos, os vasos sanguíneos, as gengivas e } \\
\text { tem efeito antioxidante e antiestressante. }\end{array}$ & 141 \\
\hline Exercício 6 & $\begin{array}{l}\text { Utilização de } \mathrm{H}_{2} \mathrm{O}_{2} \text { em substituição a } \mathrm{K} 2 \mathrm{Cr} 2 \mathrm{O} 7 \text { nas reações de } \\
\text { oxidação. }\end{array}$ & 156 \\
\hline Exercício 9 & $\begin{array}{l}\text { A preparação do cloroeteno a partir do etino e do ácido } \\
\text { clorídrico é uma reação de: } \\
\text { a) adição. } \\
\text { b) eliminação. } \\
\text { c) oxidação. }\end{array}$ & 175 \\
\hline $\begin{array}{l}\text { De onde vem... para } \\
\text { onde vai? } \\
\text { Acetileno e derivados }\end{array}$ & $\begin{array}{l}\text { O etanal tende a sofrer oxidação, forma ácido etanoico e } \\
\text { provoca a redução dos íons } \mathrm{Hg}^{2+}(\mathrm{aq}) \text { a mercúrio metálico, } \\
\mathrm{Hg}(\mathrm{l}) \text {. } \\
\text { Além disso, adiciona-se sulfato de ferro III, } \mathrm{Fe}_{2}\left(\mathrm{SO}_{4}\right)_{3} \text {, à } \\
\text { solução catalítica para provocar a oxidação de qualquer resíduo } \\
\text { de mercúrio metálico que possa ter se formado e para repor os } \\
\text { íons } \mathrm{Hg}^{2+} \text { no sistema. }\end{array}$ & 176 \\
\hline $\begin{array}{l}\text { Vulcanização da } \\
\text { borracha }\end{array}$ & $\begin{array}{l}\text { Além disso, apresentam pequena resistência à tração, } \\
\text { solubilidade em solventes orgânicos e facilidade de serem } \\
\text { oxidadas. }\end{array}$ & 207 \\
\hline $\begin{array}{l}\text { Aditivos e sua Função } \\
\text { no alimento }\end{array}$ & $\begin{array}{l}\text { Antioxidantes - São substâncias que sofrem oxidação mais } \\
\text { facilmente do que aquelas que constituem o alimento ou a } \\
\text { bebida, protegendo o produto da oxidação. Usados em: sucos de } \\
\text { frutas, maioneses, margarinas, chocolates. } \\
\text { Sequestrantes - São substâncias que apresentam a propriedade } \\
\text { de prender ou inativar um íon metálico, ajudando a proteger o } \\
\text { alimento da oxidação. Usados em: maioneses, margarinas, } \\
\text { molhos, óleos vegetais, conservas. }\end{array}$ & 227 \\
\hline
\end{tabular}




\begin{tabular}{|c|c|c|}
\hline $\begin{array}{l}\text { A função dos } \\
\text { carboidratos }\end{array}$ & $\begin{array}{l}\text { Dietas com restrição de carboidratos, geralmente feitas "para } \\
\text { emagrecer", são prejudiciais, porque forçam a queima de } \\
\text { gordura para obtenção de energia. Como os carboidratos são } \\
\text { necessários para a queima da gordura, na sua ausência essa } \\
\text { queima (oxidação) é incompleta e produz toxinas que podem } \\
\text { levar à acidose (diminuição do pH do sangue), ao desequilíbrio } \\
\text { de sódio e à desidratação. Quando há necessidade, ou seja, o } \\
\text { organismo precisa de energia, o glicogênio é decomposto em } \\
\text { glicose, que é transportada pelo sangue até os tecidos para ser } \\
\text { oxidada, voltando à forma original de água, gás carbônico e } \\
\text { energia. } \\
\text { É importante frisar que o organismo humano não consegue } \\
\text { transformar a celulose, pois não tem a enzima celulase, } \\
\text { necessária para isso. Somente o amido é metabolizado (oxidado } \\
\text { ou "queimado"). }\end{array}$ & 239 \\
\hline Box sobre chocolate & $\begin{array}{l}\text { Quando for comprar um chocolate, analise o rótulo. Como os } \\
\text { ingredientes são dispostos em ordem decrescente de quantidade, } \\
\text { fuja daqueles que começam com sacarose ou manteiga de } \\
\text { cacau, pois são puro açúcar e gordura, e não fazem bem. } \\
\text { Escolha os que começam com massa de cacau, pois são mais } \\
\text { saudáveis, já que fornecem flavonoides que agem como } \\
\text { antioxidantes. Mesmo assim, coma com moderação! }\end{array}$ & 242 \\
\hline A cor da pele & $\begin{array}{l}\text { A melanina é um pigmento biológico. Quimicamente é um } \\
\text { polímero de massa e complexidades variáveis, sintetizado nos } \\
\text { melanócitos (células situadas na camada basal da pele, entre a } \\
\text { epiderme e a derme) pela oxidação progressiva do aminoácido } \\
\text { tirosina. }\end{array}$ & 251 \\
\hline Curtimento & $\begin{array}{l}\text { A óleo - Em contato com o } \mathrm{O}_{2}(\mathrm{~g}) \text { do ar, esses ácidos graxos } \\
\text { sofrem oxidação (rompimento de uma das ligações da dupla e a } \\
\text { entra da de um grupo } \mathrm{OH} \text { ), e produzem os chamados } \\
\text { hidroxiácidos graxos, que se combinam com as proteínas da } \\
\text { pele para formar agregados insolúveis. }\end{array}$ & 254 \\
\hline \multicolumn{3}{|c|}{ Oxirredução/ redox/ óxido-redução } \\
\hline Sulfonação em alcanos & $\begin{array}{l}\text { Somente alcanos com } 6 \text { ou mais carbonos reagem com ácido } \\
\text { sulfúrico. Os alcanos mais simples, de massa molar baixa, são } \\
\text { destruídos (oxirredução violenta). }\end{array}$ & 153 \\
\hline \multicolumn{3}{|c|}{ Redu } \\
\hline Aplicação dos aldeídos & $\begin{array}{l}\text { O etanal é usado na síntese de diversos compostos orgânicos, na } \\
\text { obtenção de resinas, inseticidas (DDT) e também como redutor } \\
\text { de íons prata na fabricação de espelhos comuns. }\end{array}$ & 94 \\
\hline $\begin{array}{l}\text { De onde vem... } \\
\text { para onde vai? } \\
\text { Acetileno e derivados }\end{array}$ & $\begin{array}{l}\text { O etanal tende a sofrer oxidação, forma ácido etanoico e } \\
\text { provoca a redução dos íons } \mathrm{Hg}^{2+}(\mathrm{aq}) \text { a mercúrio metálico, } \\
\mathrm{Hg}(\mathrm{l}) \text {. }\end{array}$ & 176 \\
\hline
\end{tabular}




\section{ANEXO}

ANEXO A - Indicadores de cumprimento de categoria e esquema de classificação do projeto

2061.

\begin{tabular}{|c|c|c|c|c|}
\hline \multirow{2}{*}{$\begin{array}{l}\text { Cate- } \\
\text { goria }\end{array}$} & \multirow[t]{2}{*}{ Indicadores } & \multicolumn{3}{|c|}{ Esquema de classificação } \\
\hline & & Excelente & Satisfatório & Pobre \\
\hline a) & $\begin{array}{l}\text { 1.Um problema, pergunta, representação } \\
\text { (ou propósito identificado de outra } \\
\text { forma) é apresentado aos alunos. } \\
\text { 2.O problema, a pergunta, ou a } \\
\text { representação provavelmente será } \\
\text { compreensível para os alunos. } \\
\text { 3.O problema, a pergunta, ou a } \\
\text { representação provavelmente será } \\
\text { interessante e/ou motivador para os } \\
\text { alunos. } \\
\text { 4.Os alunos têm a oportunidade de pensar } \\
\text { e discutir o problema, a questão, a } \\
\text { representação. } \\
\text { 5.A maioria das aulas é consistente com } \\
\text { o propósito declarado e aqueles que não } \\
\text { estão, são rotulados explicitamente como } \\
\text { digressões. } \\
6.0 \text { material retorna ao propósito } \\
\text { indicado no final da unidade. }\end{array}$ & $\begin{array}{l}\text { O material } \\
\text { atende aos } \\
\text { indicadores 1- } \\
\quad 6\end{array}$ & $\begin{array}{l}\text { O material } \\
\text { atende aos } \\
\text { indicadores 1- } \\
\quad 3 \text { e } 5\end{array}$ & $\begin{array}{c}\text { O material } \\
\text { cumpre o } \\
\text { indicador } 1 \text { na } \\
\text { melhor das } \\
\text { hipóteses }\end{array}$ \\
\hline b) & $\begin{array}{l}\text { 1.O material transmite ou solicita aos } \\
\text { professores que transmitam o objetivo da } \\
\text { atividade aos estudantes. } \\
2.0 \text { propósito é expresso de uma forma } \\
\text { que é susceptível de ser compreensível } \\
\text { para os alunos. } \\
\text { 3.O material incentiva cada aluno a } \\
\text { pensar sobre o propósito da atividade. } \\
\text { 4.O material transmite ou solicita aos } \\
\text { professores que transmitam aos alunos } \\
\text { como a atividade se relaciona com a } \\
\text { finalidade da unidade. } \\
\text { 5.O material envolve os alunos ao pensar } \\
\text { sobre o que aprenderam até agora e o que } \\
\text { eles precisam aprender/fazer em pontos } \\
\text { apropriados. }\end{array}$ & $\begin{array}{l}\text { O material } \\
\text { atende a todos } \\
\text { os indicadores }\end{array}$ & $\begin{array}{l}\text { O material } \\
\text { atende a três } \\
\text { dos cinco } \\
\text { indicadores }\end{array}$ & $\begin{array}{c}\text { O material não } \\
\text { atende a mais } \\
\text { de um dos } \\
\text { cinco } \\
\text { indicadores }\end{array}$ \\
\hline c) & $\begin{array}{l}\text { 1.O material inclui uma sequência lógica } \\
\text { ou estratégica de atividades. } \\
2.0 \text { material transmite o raciocínio para } \\
\text { esta sequência. }\end{array}$ & $\begin{array}{l}\text { O material } \\
\text { atende ambos } \\
\text { os indicadores }\end{array}$ & $\begin{array}{l}\text { O material } \\
\text { encontra o } \\
\text { primeiro } \\
\text { indicador }\end{array}$ & $\begin{array}{l}\text { O revisor pode } \\
\text { inferir uma } \\
\text { lógica para a } \\
\text { sequência de } \\
\text { apenas } \\
\text { algumas } \\
\text { atividades }\end{array}$ \\
\hline d) & $\begin{array}{l}\text { 1.O material alerta o professor para ideias } \\
\text { ou habilidades prévias (versus declarando } \\
\text { apenas tópicos ou termos pré-requisito). }\end{array}$ & $\begin{array}{c}\text { O material } \\
\text { atende aos } \\
\text { indicadores } 1 \text {, } \\
2,3 \text { ou } 4 \text { e } 5\end{array}$ & $\begin{array}{c}\text { O material } \\
\text { atende aos } \\
\text { indicadores } 1 \text {, } \\
2,5 \text { e } 3 \text { ou } 4\end{array}$ & $\begin{array}{l}\text { O material não } \\
\text { atende a mais } \\
\text { de um } \\
\text { indicador }\end{array}$ \\
\hline
\end{tabular}




\begin{tabular}{|c|c|c|c|c|}
\hline & $\begin{array}{l}\text { 2.O material alerta os professores para as } \\
\text { ideias específicas para as quais os pré- } \\
\text { requisitos são necessários. } \\
\text { 3.O material alerta os alunos para ideias } \\
\text { prévias ou experiências que estão sendo } \\
\text { assumidas. } \\
4 . O \text { material aborda adequadamente } \\
\text { (fornece suporte instrucional para) pré- } \\
\text { requisitos na mesma unidade ou em } \\
\text { unidades anteriores (na mesma ou em } \\
\text { outras notas). (O material não deve ser } \\
\text { responsabilizado por abordar os pré- } \\
\text { requisitos de um intervalo de } \\
\text { classificação anterior. No entanto, se um } \\
\text { material abordar esses pré-requisitos, eles } \\
\text { devem contar como evidência para esse } \\
\text { indicador.) } \\
\text { 5.O material faz conexões adequadas } \\
\text { (fornece suporte instrucional para } \\
\text { conexões) entre ideias tratadas em uma } \\
\text { unidade específica e seus pré-requisitos } \\
\text { (mesmo que os pré-requisitos sejam } \\
\text { abordados em outro lugar). }\end{array}$ & $\begin{array}{l}\text { para todos ou } \\
\text { mais pré- } \\
\text { requisitos }\end{array}$ & $\begin{array}{c}\text { para alguns } \\
\text { pré-requisitos }\end{array}$ & \\
\hline e) & $\begin{array}{l}\text { 1.O material apresenta precisamente } \\
\text { ideias específicas comuns que são } \\
\text { relevantes para as ideias-chave e } \\
\text { apareceram em publicações acadêmicas } \\
\text { (em vez de apenas declarar que os alunos } \\
\text { têm dificuldades com ideias ou tópicos } \\
\text { particulares). } \\
2.0 \text { material esclarece / explica ideias } \\
\text { comumente mantidas (em vez de apenas } \\
\text { listá-las). }\end{array}$ & $\begin{array}{c}\text { O material } \\
\text { atende aos } \\
\text { indicadores } 1 \\
\text { e } 2 \text { para uma } \\
\text { proporção } \\
\text { considerável } \\
\text { de ideias } \\
\text { comumente } \\
\text { mantidas que } \\
\text { apareceram } \\
\text { em } \\
\text { publicações } \\
\text { acadêmicas }\end{array}$ & $\begin{array}{l}\text { O material } \\
\text { atende aos } \\
\text { indicadores } 1 \\
\text { e } 2 \text { para } \\
\text { algumas ideias } \\
\text { comuns que } \\
\text { surgiram em } \\
\text { publicações } \\
\text { acadêmicas. }\end{array}$ & $\begin{array}{c}\text { O material } \\
\text { cumpre o } \\
\text { indicador } 1 \text { na } \\
\text { melhor das } \\
\text { hipóteses }\end{array}$ \\
\hline f) & $\begin{array}{l}\text { 1.O material inclui questões ou tarefas } \\
\text { específicas que podem ser usadas pelos } \\
\text { professores para identificar as ideias dos } \\
\text { alunos. } \\
\text { 2.As perguntas / tarefas provavelmente } \\
\text { serão compreensíveis para os alunos que } \\
\text { não estudaram o tópico e não estão } \\
\text { familiarizados com o vocabulário } \\
\text { científico. } \\
\text { 3.As questões / tarefas são identificadas } \\
\text { como servindo a finalidade de identificar } \\
\text { as ideias dos alunos. } \\
\text { 4.O material inclui perguntas / tarefas que } \\
\text { pedem aos alunos para fazer previsões e / } \\
\text { ou dar explicações sobre os fenômenos } \\
\text { (em vez de se concentrar principalmente }\end{array}$ & $\begin{array}{c}\text { O material } \\
\text { fornece um } \\
\text { número e uma } \\
\text { variedade } \\
\text { suficientes de } \\
\text { questões / } \\
\text { tarefas que } \\
\text { atendem aos } \\
\text { indicadores } 1 \\
\text { e } 2 \text { e atendem } \\
\text { aos } \\
\text { indicadores 3- } \\
5\end{array}$ & $\begin{array}{c}\text { O material } \\
\text { fornece alguns } \\
\text { Perguntas / } \\
\text { tarefas que } \\
\text { atendem aos } \\
\text { indicadores 1- } \\
4\end{array}$ & $\begin{array}{c}\text { O material } \\
\text { fornece } \\
\text { algumas } \\
\text { questões / } \\
\text { tarefas que } \\
\text { atendem ao } \\
\text { indicador } 1 \text { ou } \\
\text { aos } \\
\text { indicadores } 1 \mathrm{e} \\
2\end{array}$ \\
\hline
\end{tabular}




\begin{tabular}{|c|c|c|c|c|}
\hline & $\begin{array}{l}\text { na identificação dos significados dos } \\
\text { alunos para os termos). } \\
5.0 \text { material sugere como os professores } \\
\text { podem pesquisar sob as respostas iniciais } \\
\text { dos alunos às perguntas ou interpretar as } \\
\text { respostas dos alunos (por exemplo, } \\
\text { fornecendo amostras anotadas do } \\
\text { trabalho do aluno). }\end{array}$ & & & \\
\hline g) & $\begin{array}{l}\text { 1.O material aborda explicitamente as } \\
\text { ideias comuns. } \\
\text { 2.O material inclui perguntas, tarefas ou } \\
\text { atividades que provavelmente ajudarão } \\
\text { os alunos a progredir de suas ideias } \\
\text { iniciais, por exemplo, até: } \\
\text { a. Desafiando explicitamente as } \\
\text { ideias dos alunos, por exemplo, } \\
\text { comparando suas previsões sobre um } \\
\text { fenômeno com o que realmente acontece } \\
\text { b. Levando os alunos a contrastar } \\
\text { ideias comuns com as ideias } \\
\text { cientificamente corretas e a resolver as } \\
\text { diferenças entre elas costendendo as ideias corretas } \\
\text { comumente mantidas que têm escopo. } \\
\text { 3.O material inclui sugestões aos } \\
\text { professores sobre como levar em } \\
\text { consideração as ideias de seus próprios } \\
\text { alunos. }\end{array}$ & $\begin{array}{c}\text { O material } \\
\text { atende aos } \\
\text { indicadores } 1 \\
\text { e } 2 \text { para uma } \\
\text { proporção } \\
\text { considerável } \\
\text { de ideias } \\
\text { comumente } \\
\text { mantidas } \\
\text { documentadas } \\
\text { na literatura }\end{array}$ & $\begin{array}{l}\text { O material } \\
\text { atende aos } \\
\text { indicadores } 1 \\
\text { e } 2 \text { para } \\
\text { algumas ideias } \\
\text { comuns que } \\
\text { estão } \\
\text { documentadas } \\
\text { na literatura. }\end{array}$ & $\begin{array}{c}\text { O material } \\
\text { atende o } \\
\text { primeiro } \\
\text { indicador, na } \\
\text { melhor das } \\
\text { hipóteses }\end{array}$ \\
\hline h) & $\begin{array}{l}\text { 1.Os fenômenos podem ser usados para } \\
\text { apoiar as ideias-chave. } \\
\text { 2.Os fenômenos estão explicitamente } \\
\text { ligados às ideias-chave relevantes }\end{array}$ & $\begin{array}{c}\text { O material } \\
\text { fornece um } \\
\text { número } \\
\text { suficiente e } \\
\text { uma variedade } \\
\text { de fenômenos } \\
\text { que atendem } \\
\text { aos } \\
\text { indicadores } 1 \\
\text { e } 2\end{array}$ & $\begin{array}{c}\text { O material } \\
\text { fornece alguns } \\
\text { fenômenos } \\
\text { que atendem } \\
\text { aos } \\
\text { indicadores } 1 \\
\text { e } 2\end{array}$ & $\begin{array}{l}\text { O material } \\
\text { fornece, na } \\
\text { melhor das } \\
\text { hipóteses, um } \\
\text { fenômeno que } \\
\text { atende os } \\
\text { indicadores } 1 \text { e } \\
2\end{array}$ \\
\hline i) & $\begin{array}{l}\text { 1.Cada experiência "mão-na-massa" é } \\
\text { eficiente (quando comparada a outras } \\
\text { experiências de primeira mão) e, se várias } \\
\text { experiências de primeira mão visarem a } \\
\text { mesma ideia, o conjunto de experiências } \\
\text { "mão-na-massa" é eficiente. (A eficiência } \\
\text { de uma experiência é igual ao custo da } \\
\text { experiência [em tempo e dinheiro] em } \\
\text { relação ao seu valor.) } \\
\text { 2.As experiências que não são "mão-na- } \\
\text { massa" (por exemplo, texto, imagens, } \\
\text { vídeo) proporcionam aos alunos uma } \\
\text { sensação inteligível do fenômeno. (Se o } \\
\text { material fornecer apenas experiências }\end{array}$ & $\begin{array}{l}\text { O material } \\
\text { atende todos } \\
\text { os indicadores } \\
\text { ou apenas os } \\
\text { indicadores } 1 \\
\text { e } 3 \text { ou os } \\
\text { indicadores } 2 \\
\text { e 3, se as } \\
\text { experiências } \\
\text { "mão-na- } \\
\text { massa" não } \\
\text { forem } \\
\text { possíveis }\end{array}$ & $\begin{array}{c}\text { O material } \\
\text { inclui algumas } \\
\text { experiências } \\
\text { eficientes } \\
\text { "mão-na- } \\
\text { massa" } \\
\text { suficiente. }\end{array}$ & $\begin{array}{l}\text { O material } \\
\text { inclui, na } \\
\text { melhor das } \\
\text { hipóteses, } \\
\text { apenas uma } \\
\text { experiência } \\
\text { eficaz "mão- } \\
\text { na-massa" }\end{array}$ \\
\hline
\end{tabular}




\begin{tabular}{|c|c|c|c|c|}
\hline & $\begin{array}{l}\text { "mão-na-massa", este indicador não é } \\
\text { aplicável.) } \\
\text { 3.O conjunto de experiências "mão-na- } \\
\text { massa" e inteligíveis é suficiente. }\end{array}$ & & & \\
\hline j) & $\begin{array}{l}\text { 1.O material liga termos técnicos a } \\
\text { experiências relevantes que desenvolvem } \\
\text { a ideia à medida que o termo é usado (ao } \\
\text { invés de apenas aprender a aprender } \\
\text { definições de termos). } \\
2.0 \text { material restringe o uso de termos } \\
\text { técnicos aos necessários para se } \\
\text { comunicar inteligentemente sobre ideias- } \\
\text { chave. }\end{array}$ & $\begin{array}{c}\text { Material } \\
\text { atende ambos } \\
\text { os indicadores }\end{array}$ & $\begin{array}{l}\text { O material } \\
\text { atende } \\
\text { plenamente a } \\
\text { um indicador e } \\
\text { encontra } \\
\text { parcialmente o } \\
\text { outro }\end{array}$ & $\begin{array}{l}\text { O material } \\
\text { atende } \\
\text { marginalmente } \\
\text { a ambos os } \\
\text { indicadores, na } \\
\text { melhor das } \\
\text { hipóteses }\end{array}$ \\
\hline k) & $\begin{array}{l}\text { 1.A representação é precisa (ou, se não } \\
\text { precisa, é solicitado aos alunos a } \\
\text { criticarem a representação). } \\
\text { 2.É provável que a representação seja } \\
\text { compreensível para os estudantes. } \\
\text { 3.A representação está explicitamente } \\
\text { ligada à coisa real. }\end{array}$ & $\begin{array}{c}\text { O material } \\
\text { inclui um } \\
\text { número } \\
\text { suficiente e } \\
\text { uma variedade } \\
\text { de } \\
\text { representações } \\
\text { que atendem } \\
\text { aos } \\
\text { indicadores 1- } \\
3 \text { e nenhuma } \\
\text { das } \\
\text { representações } \\
\text { incluídas no } \\
\text { material é } \\
\text { imprecisa }\end{array}$ & $\begin{array}{c}\text { O material } \\
\text { inclui algumas } \\
\text { representações } \\
\text { que atendem } \\
\text { aos } \\
\text { indicadores 1- } \\
3 \text { e poucas (se } \\
\text { houver) as } \\
\text { representações } \\
\text { incluídas no } \\
\text { material são } \\
\text { imprecisas }\end{array}$ & $\begin{array}{c}\text { Mesmo que o } \\
\text { material inclua } \\
\text { algumas } \\
\text { representações } \\
\text { que atendam } \\
\text { aos } \\
\text { indicadores 1- } \\
\text { 3, poucas ou } \\
\text { nenhuma das } \\
\text { ideias-chave } \\
\text { são } \\
\text { adequadament } \\
\text { e } \\
\text { representadas }\end{array}$ \\
\hline 1) & $\begin{array}{l}\text { 1.O material executa consistentemente } \\
\text { (ou instrui os professores a realizarem) o } \\
\text { desempenho esperado (por exemplo, o } \\
\text { texto do aluno explica um fenômeno } \\
\text { particular usando a teoria molecular } \\
\text { cinética). (Os guias do professor } \\
\text { geralmente incluem respostas a perguntas } \\
\text { colocadas no texto do aluno. Se o } \\
\text { material não instruir o professor a usar as } \\
\text { respostas para modelar o uso do } \\
\text { conhecimento, tais respostas não contam } \\
\text { como instâncias de modelagem.) } \\
\text { 2.O desempenho é passo a passo. } \\
3 . O \text { desempenho é explicitamente } \\
\text { identificado como uma demonstração do } \\
\text { uso de conhecimento ou habilidade. } \\
4 . O \text { material fornece comentários de } \\
\text { execução que apontam para aspectos } \\
\text { espeć́ficos da demonstração e / ou } \\
\text { critérios para julgar a qualidade de uma } \\
\text { performance. }\end{array}$ & $\begin{array}{l}\text { O material } \\
\text { atende todos } \\
\quad \text { os } 4 \\
\text { indicadores }\end{array}$ & $\begin{array}{l}\text { O material } \\
\text { atende aos } \\
\text { indicadores } 1 \\
\text { e } 2\end{array}$ & $\begin{array}{c}\text { O material } \\
\text { cumpre o } \\
\text { indicador } 1 \text { na } \\
\text { melhor das } \\
\text { hipóteses }\end{array}$ \\
\hline m) & $\begin{array}{l}\text { 1.O material fornece um número } \\
\text { suficiente de tarefas em uma variedade de }\end{array}$ & $\begin{array}{l}\mathrm{O} \text { material } \\
\text { atende aos }\end{array}$ & $\begin{array}{c}\text { O material } \\
\text { fornece }\end{array}$ & $\begin{array}{l}\text { O material } \\
\text { fornece no }\end{array}$ \\
\hline
\end{tabular}




\begin{tabular}{|c|c|c|c|c|}
\hline & $\begin{array}{l}\text { contextos, incluindo contextos } \\
\text { cotidianos. (Para determinar se a tarefa / } \\
\text { pergunta aborda a substância real da } \\
\text { ideia-chave, os revisores precisarão } \\
\text { considerar a questão e a resposta esperada } \\
\text { no guia do professor.) } \\
2.0 \text { material inclui novas tarefas. } \\
\text { 3.O material fornece uma sequência de } \\
\text { perguntas ou tarefas em que a } \\
\text { complexidade é progressivamente } \\
\text { aumentada. } \\
\text { 4.O material fornece aos alunos primeiro } \\
\text { oportunidades para a prática guiada com } \\
\text { feedback e, em seguida, com a prática em } \\
\text { que a quantidade de suporte diminui } \\
\text { gradualmente. }\end{array}$ & $\begin{array}{c}\text { indicadores } 1 \text {, } \\
2 \text { e } 3 \text { ou } 4 .\end{array}$ & $\begin{array}{l}\text { algumas } \\
\text { tarefas/pergunt } \\
\text { as, incluindo } \\
\text { novas tarefas }\end{array}$ & $\begin{array}{c}\text { melhor } \\
\text { algumas } \\
\text { tarefas/pergunt } \\
\text { as, mas não há } \\
\text { novas tarefas }\end{array}$ \\
\hline n) & $\begin{array}{l}\text { 1.Material rotineiramente incentiva os } \\
\text { alunos a expressar suas ideias. } \\
\text { 2.Material encoraja os alunos não apenas } \\
\text { a expressar, mas também a esclarecer, } \\
\text { justificar e representar suas ideias (não se } \\
\text { espera que um material encoraje os } \\
\text { alunos a esclarecer, justificar e } \\
\text { representar ideias sempre que lhes seja } \\
\text { pedido para expressar suas ideias, no } \\
\text { entanto, no curso De ensinar uma ideia } \\
\text { chave específica, o material deve } \\
\text { proporcionar aos alunos oportunidades } \\
\text { para esclarecer, justificar e representar } \\
\text { ideias). } \\
\text { 3.Material oferece oportunidades para } \\
\text { cada aluno (em vez de apenas alguns } \\
\text { alunos) para expressar ideias. } \\
\text { 4.O material inclui sugestões específicas } \\
\text { sobre como ajudar o professor a fornecer } \\
\text { comentários explícitos aos alunos ou } \\
\text { inclui texto que fornece comentários } \\
\text { diretamente aos alunos. } \\
\text { 5.O material inclui sugestões sobre como } \\
\text { diagnosticar erros de alunos, explicações } \\
\text { sobre como esses erros podem ser } \\
\text { corrigidos e recomendações sobre como } \\
\text { as ideias dos alunos podem ser } \\
\text { desenvolvidas. }\end{array}$ & $\begin{array}{c}\text { Material } \\
\text { atende a todos } \\
\text { os indicadores }\end{array}$ & $\begin{array}{c}\text { Material } \\
\text { atende a } 3 \text { dos } \\
5 \text { indicadores }\end{array}$ & $\begin{array}{c}\text { Material não } \\
\text { atende a mais } \\
\text { de } 1 \text { em cada } 5 \\
\text { indicadores }\end{array}$ \\
\hline o) & $\begin{array}{l}\text { 1.O material inclui tarefas específicas e } \\
\text { relevantes e / ou perguntas para a } \\
\text { experiência ou a leitura. } \\
\text { 2.As perguntas ou tarefas têm } \\
\text { características úteis, como } \\
\text { a. Enquadrando questões importantes } \\
\text { b. Ajudando os alunos a relacionar } \\
\text { suas experiências com fenômenos ou }\end{array}$ & $\begin{array}{c}\text { Material } \\
\text { cumpre todos } \\
\text { os três } \\
\text { indicadores }\end{array}$ & $\begin{array}{c}\text { Material } \\
\text { cumpre os } \\
\text { indicadores } 1 \\
\text { e } 2\end{array}$ & $\begin{array}{c}\text { Material } \\
\text { atende o } \\
\text { indicador } 1 \text { na } \\
\text { melhor das } \\
\text { hipóteses }\end{array}$ \\
\hline
\end{tabular}




\begin{tabular}{|c|c|c|c|c|}
\hline & $\begin{array}{l}\text { representações com ideias científicas } \\
\text { apresentadas } \\
\text { c. Ajudando os alunos a estabelecer } \\
\text { conexões entre suas próprias ideias e os } \\
\text { fenômenos ou representações observados } \\
\text { d. Ajudando os alunos a estabelecer } \\
\text { conexões entre suas próprias ideias e as } \\
\text { ideias científicas apresentadas } \\
\text { e. Antecipando equívocos comuns de } \\
\text { estudantes } \\
\text { f. Concentrando-se nos contrastes } \\
\text { entre os equívocos dos alunos e as } \\
\text { alternativas científicas. } \\
\text { 3.Existem sequências de questões ou } \\
\text { tarefas de andaimes (em oposição a } \\
\text { perguntas ou tarefas separadas). }\end{array}$ & & & \\
\hline p) & $\begin{array}{l}\text { 1.O material oferece aos alunos a } \\
\text { oportunidade de rever suas ideias iniciais } \\
\text { com base no que aprenderam (sem pedir- } \\
\text { lhes explicitamente que pensem sobre } \\
\text { como suas ideias mudaram). } \\
2.0 \text { material envolve (ou fornece } \\
\text { sugestões específicas para que os } \\
\text { professores se envolvam) os alunos no } \\
\text { monitoramento de como suas ideias } \\
\text { mudaram, mas raramente na unidade. } \\
\text { 3.O material envolve (ou fornece } \\
\text { sugestões específicas para que os } \\
\text { professores se envolvam) os alunos no } \\
\text { monitoramento de como suas ideias } \\
\text { mudaram e faz isso periodicamente na } \\
\text { unidade. }\end{array}$ & $\begin{array}{l}\text { O material } \\
\text { encontra o } \\
\text { indicador } 3\end{array}$ & $\begin{array}{c}\mathrm{O} \text { material } \\
\text { atende o } \\
\text { indicador } 2\end{array}$ & $\begin{array}{l}\text { O material } \\
\text { cumpre o } \\
\text { indicador } 1 \text { na } \\
\text { melhor das } \\
\text { hipóteses }\end{array}$ \\
\hline q) & $\begin{array}{l}\text { 1.As ideias específicas nas ideias-chave } \\
\text { são necessárias para responder aos itens } \\
\text { de avaliação. } \\
\text { 2.As ideias específicas nas ideias-chave } \\
\text { são suficientes para responder aos itens } \\
\text { de avaliação (ou, se forem necessárias } \\
\text { outras ideias, não são mais sofisticadas do } \\
\text { que ideias-chave e foram ensinadas } \\
\text { anteriormente). }\end{array}$ & $\begin{array}{l}\text { O material } \\
\text { fornece um } \\
\text { número } \\
\text { suficiente } 9 \text { de } \\
\text { itens de } \\
\text { avaliação que } \\
\text { atendem aos } \\
\text { indicadores } 1 \\
\text { e 2. }\end{array}$ & $\begin{array}{c}\text { O material } \\
\text { fornece alguns } \\
\text { itens de } \\
\text { avaliação que } \\
\text { atendem aos } \\
\text { indicadores } 1 \\
\text { e } 2\end{array}$ & $\begin{array}{l}\text { O material não } \\
\text { fornece mais } \\
\text { do que um / } \\
\text { alguns itens de } \\
\text { avaliação que } \\
\text { atendem aos } \\
\text { indicadores } 1 \text { e } \\
2\end{array}$ \\
\hline r) & $\begin{array}{l}\text { 1.Os itens de avaliação se concentram na } \\
\text { compreensão de ideias-chave. } \\
2 . \text { Os itens de avaliação incluem tarefas } \\
\text { familiares e novas. }\end{array}$ & $\begin{array}{l}\text { O material } \\
\text { fornece um } \\
\text { número } \\
\text { suficiente de } \\
\text { itens de } \\
\text { avaliação que } \\
\text { atendem aos } \\
\text { indicadores } 1 \\
\text { e } 2\end{array}$ & $\begin{array}{c}\text { O material } \\
\text { fornece alguns } \\
\text { itens de } \\
\text { avaliação que } \\
\text { atendem aos } \\
\text { indicadores } 1 \\
\text { e } 2 \text { ou itens de } \\
\text { avaliação } \\
\text { suficientes que } \\
\text { atendem ao } \\
\text { indicador } 1\end{array}$ & $\begin{array}{l}\text { O material não } \\
\text { fornece mais } \\
\text { do que um / } \\
\text { alguns itens de } \\
\text { avaliação que } \\
\text { atendem ao } \\
\text { indicador } 1\end{array}$ \\
\hline
\end{tabular}




\begin{tabular}{|c|c|c|c|c|}
\hline s) & $\begin{array}{l}\text { 1.O material usa a avaliação embutida } \\
\text { como uma estratégia de rotina (em vez de } \\
\text { incluir apenas questões ocasionais). } \\
2.0 \text { material auxilia os professores na } \\
\text { interpretação das respostas dos alunos } \\
\text { para diagnosticar quais dificuldades de } \\
\text { aprendizagem permanecem. } \\
\text { 3.O material fornece sugestões } \\
\text { específicas aos professores sobre como } \\
\text { usar a informação das avaliações } \\
\text { incorporadas para tomar decisões de } \\
\text { instrução sobre quais ideias precisam ser } \\
\text { abordadas por outras atividades. }\end{array}$ & $\begin{array}{c}\text { O material } \\
\text { atende a todos } \\
\text { os indicadores }\end{array}$ & $\begin{array}{c}\text { O material } \\
\text { atende aos } \\
\text { indicadores } 1 \\
\text { e } 2 \text { ou } \\
\text { indicadores } 1 \\
\text { e } 3\end{array}$ & $\begin{array}{c}\text { O material } \\
\text { cumpre o } \\
\text { indicador } 1 \text { na } \\
\text { melhor das } \\
\text { hipóteses }\end{array}$ \\
\hline t) & $\begin{array}{l}\text { 1.Alerta os professores a como as ideias } \\
\text { foram simplificadas para que os alunos } \\
\text { compreendam e quais são as versões mais } \\
\text { sofisticadas (mesmo que os alunos não } \\
\text { sejam obrigados a entender as versões } \\
\text { mais sofisticadas). } \\
\text { 2.Fornece respostas suficientemente } \\
\text { detalhadas às perguntas no livro do aluno } \\
\text { para que os professores compreendam e } \\
\text { interpretem várias respostas dos alunos. } \\
\text { 3.Recomenda recursos para melhorar a } \\
\text { compreensão do professor sobre ideias- } \\
\text { chave. }\end{array}$ & \multirow{3}{*}{\multicolumn{3}{|c|}{ Mesmo que os aspectos I a VI. }} \\
\hline $\mathrm{u})$ & $\begin{array}{l}\text { 1.Inclui sugestões sobre como incentivar } \\
\text { as perguntas dos alunos e orientar a busca } \\
\text { de respostas, respeitar e valorizar as } \\
\text { ideias dos alunos, levantar questões de } \\
\text { evidência e evitar o dogmatismo. } \\
\text { 2.Fornece exemplos de interações de sala } \\
\text { de aula - por exemplo, caixas de diálogo, } \\
\text { vinhetas ou videoclipes - que ilustram } \\
\text { formas apropriadas de responder a } \\
\text { perguntas ou ideias de alunos, etc. }\end{array}$ & & & \\
\hline v) & $\begin{array}{l}\text { 1.O material evita estereótipos ou } \\
\text { linguagem que possa ser ofensivo para } \\
\text { um Grupo particular. } \\
\text { 2.O material ilustra o contributo das } \\
\text { mulheres e das minorias para a ciência. E } \\
\text { traz modelos a seguir. } \\
\text { 3.O material sugere formatos alternativos } \\
\text { para que os alunos expressem suas ideias } \\
\text { durante a instrução e avaliação. } \\
\text { 4.O material inclui sugestões específicas } \\
\text { sobre como os professores podem } \\
\text { modificar atividades para estudantes com } \\
\text { necessidades especiais. } \\
\text { 5.O material fornece estratégias para } \\
\text { validar as experiências pessoais e sociais }\end{array}$ & & & \\
\hline
\end{tabular}


